LA-14416-PR

Progress Report

Approved for public release;

distribution is unlimited.

Groundwater Level Status Report for 2009

Los Alamos National Laboratory 
Edited by Hector Hinojosa, Group IRM-CAS.

The three most recent reports in this unclassified series are LA-14331-PR, LA-14358-PR, and LA-14397-PR.

Los Alamos National Laboratory, an affirmative action/ equal opportunity employer, is operated by Los Alamos National Security, LLC, for the National Nuclear Security Administration of the U.S. Department of Energy under contract DE-AC52-06NA25396.

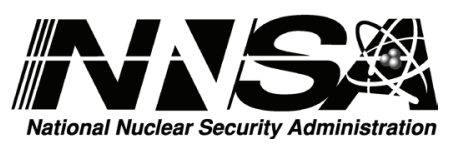

This report was prepared as an account of work sponsored by an agency of the U.S. Government. Neither Los Alamos National Security, LLC, the U.S. Government nor any agency thereof, nor any of their employees make any warranty, express or implied, or assume any legal liability or responsibility for the accuracy, completeness, or usefulness of any information, apparatus, product, or process disclosed, or represent that its use would not infringe privately owned rights. Reference herein to any specific commercial product, process, or service by trade name, trademark, manufacturer, or otherwise does not necessarily constitute or imply its endorsement, recommendation, or favoring by Los Alamos National Security, LLC, the U.S. Government, or any agency thereof. The views and opinions of authors expressed herein do not necessarily state or reflect those of Los Alamos National Security, LLC, the U.S. Government, or any agency thereof. Los Alamos National Laboratory strongly supports academic freedom and a researcher's right to publish; as an institution, however, the Laboratory does not endorse the viewpoint of a publication or guarantee its technical correctness. 
LA-14416-PR

Progress Report

Issued: March 2010

Groundwater Level Status Report for 2009

Los Alamos National Laboratory

Richard J. Koch

Sarah Schmeer

- Los Alamos 
This page left blank intentionally. 


\begin{tabular}{|c|c|c|}
\hline \multicolumn{3}{|c|}{ Contents } \\
\hline \multicolumn{3}{|c|}{ ABSTRACT } \\
\hline 1.0 & INTROI & UCTION ............... \\
\hline 0 & DESCRI & PTION OF GROUNDWATER LEVEL DATA. \\
\hline 3.0 & GROUND & DWATER LEVEL DATA FROM REGIONAL AQUIFER WELLS..................................... \\
\hline 3.1 & CDV- & …..............6 6 \\
\hline 3.2 & CDV-R & (1) \\
\hline 3.3 & $\mathrm{R}-1 \ldots \ldots$. & \\
\hline 3.4 & $\mathrm{R}-2$. & \\
\hline 3.5 & & 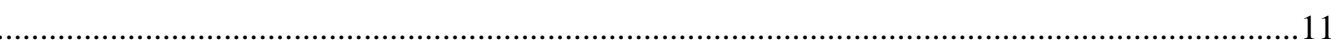 \\
\hline 3.6 & & .......12 \\
\hline 3.7 & $\mathrm{R}-6$. & $\ldots \ldots .14$ \\
\hline 3.8 & R-7. & .....15 \\
\hline 3.9 & $\mathrm{R}-8 .$. & 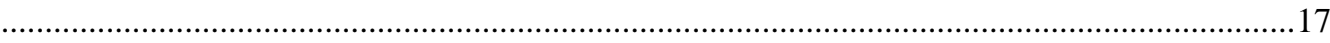 \\
\hline 3.10 & $\mathrm{R}-9$ & 18 \\
\hline 3.11 & $1 \quad \mathrm{R}-10$ & ........................ \\
\hline 3.12 & $2 \quad \mathrm{R}-10 \mathrm{~A}$ & \\
\hline 3.13 & 3 R-11 & \\
\hline 3.14 & $4 \mathrm{R}-12$ & .......22 \\
\hline 3.15 & $5 \mathrm{R}-13$ & 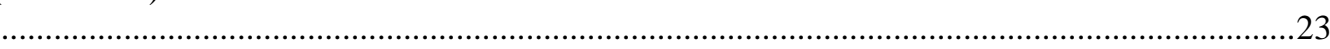 \\
\hline 3.16 & $\mathrm{R}-14$ & .....24 \\
\hline 3.17 & $7 \mathrm{R}-15$ & . \\
\hline 3.18 & $3 \mathrm{R}-16$ & 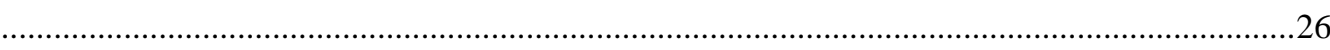 \\
\hline 3.19 & ) $\mathrm{R}-16 \mathrm{R}$ & (2) \\
\hline 3.20 & $\mathrm{R}-17$ & \\
\hline 3.21 & R-18 & ....30 \\
\hline 3.22 & -19 & 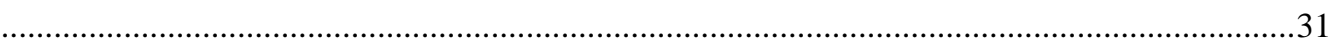 \\
\hline 3.23 & 3 R-20. & \\
\hline 3.24 & $4 \mathrm{R}-21$. & \\
\hline 3.25 & 5 R-22. & (.). \\
\hline 3.26 & j $\mathrm{R}-23$. & 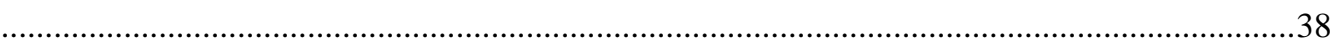 \\
\hline 3.27 & $7 \mathrm{R}-24$ & (1) \\
\hline 3.28 & $3 \mathrm{R}-2$ & .......40 \\
\hline 3.29 & $2-2+2>3$ & \\
\hline 3.30 & -2 & \\
\hline 3.31 & 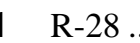 & ......47 \\
\hline 3.32 & -31 & 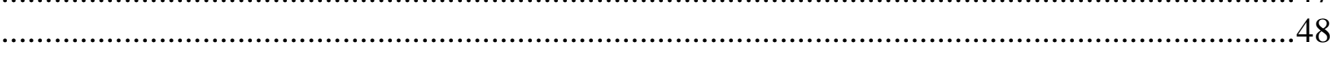 \\
\hline 3.33 & 3 R-32 & .................. \\
\hline 3.34 & R-33. & 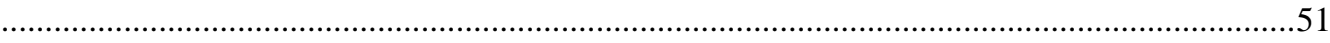 \\
\hline 3.35 & $5 \mathrm{R}-34$ & (1) \\
\hline 3.36 & R-35A & \\
\hline 3.37 & -3 & $\ldots . .54$ \\
\hline 3.38 & $\mathrm{R}-36$ & ............... \\
\hline 3.39 & & $\ldots \ldots . . . \ldots . . . . .$. \\
\hline 3.40 & $\mathrm{R}-38$ & \\
\hline 3.41 & $1 \mathrm{R}-39$. & \\
\hline 3.42 & $2 \mathrm{R}-40$. & (1) \\
\hline 3.43 & $3 \mathrm{R}-41$ & (2) \\
\hline 3.44 & 4 R-42. & 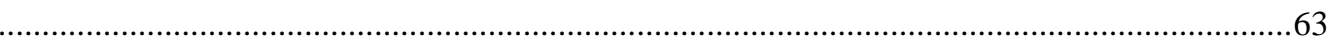 \\
\hline 3.45 & $\mathrm{R}-43$ & \\
\hline 3.46 & $\mathrm{R}-4$ & 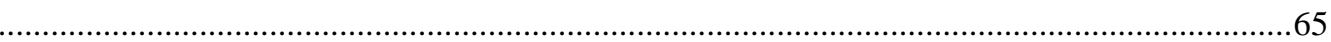 \\
\hline 47 & & \\
\hline 48 & $\mathrm{R}-46$. & \\
\hline
\end{tabular}




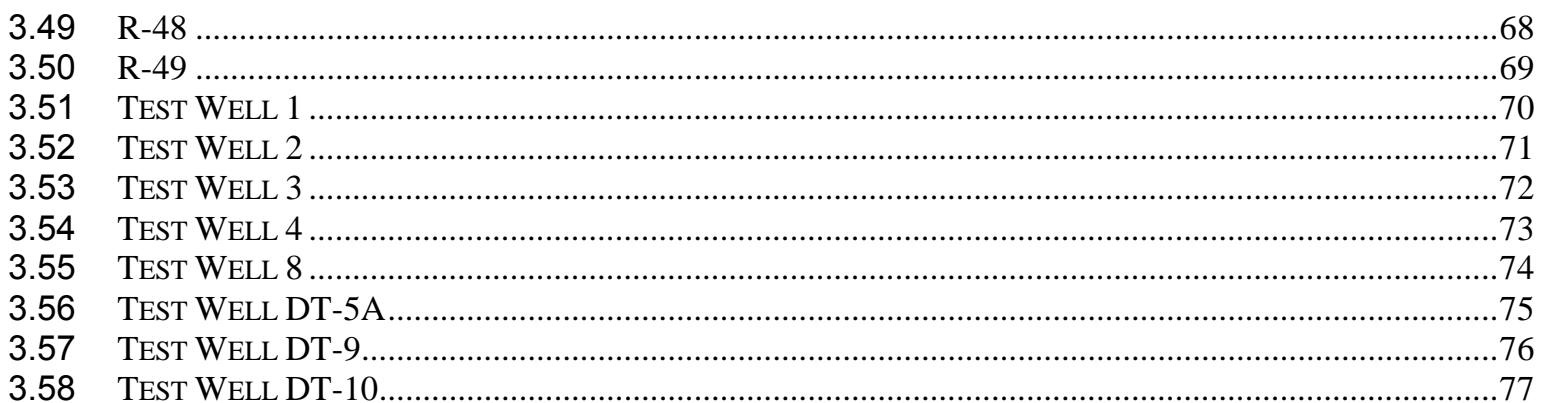

4.0 GROUNDWATER LEVEL DATA FROM INTERMEDIATE WELLS ..............................................78

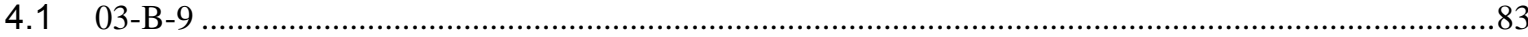

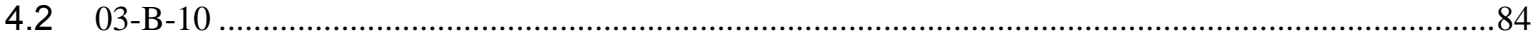

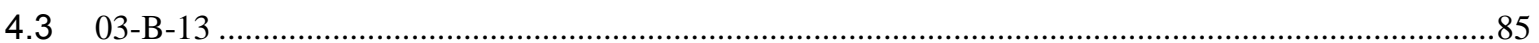

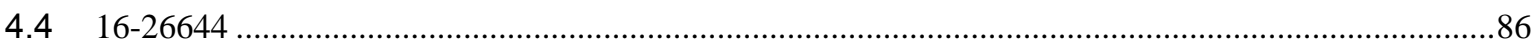

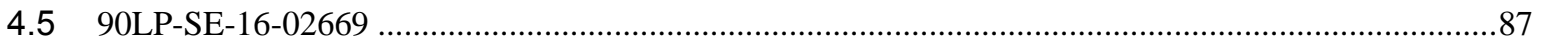

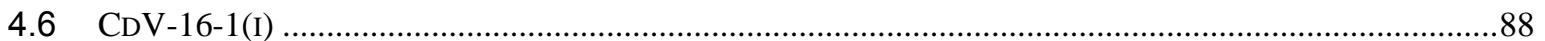

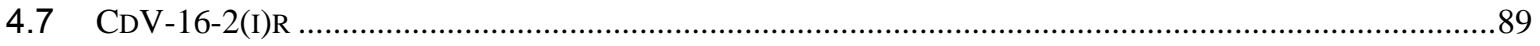

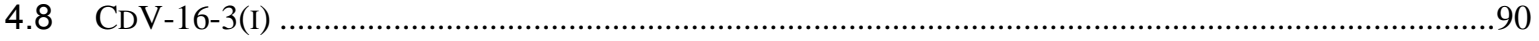

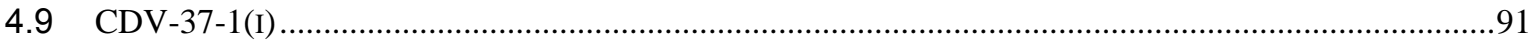

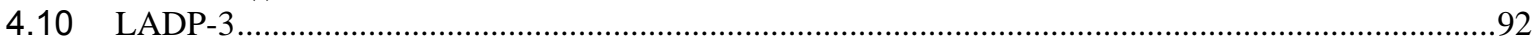

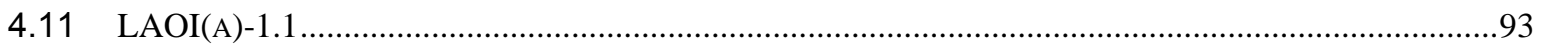

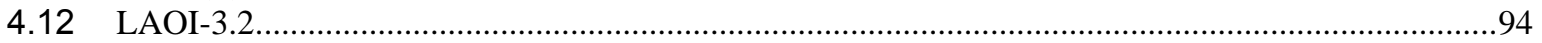

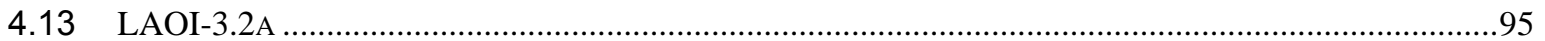

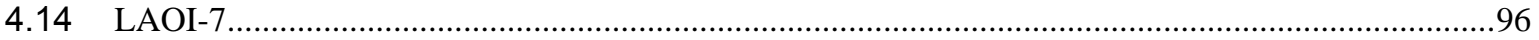

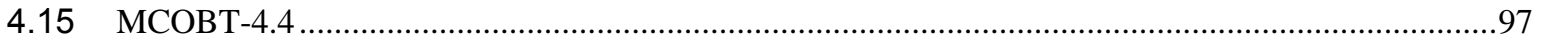

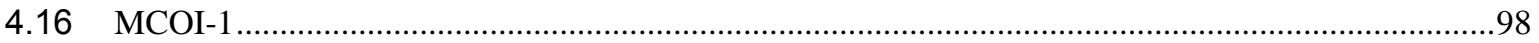

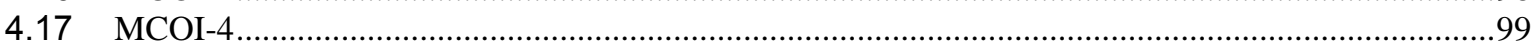

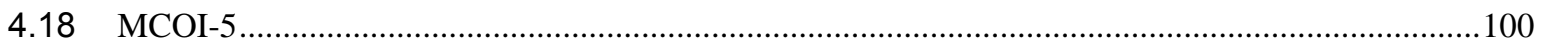

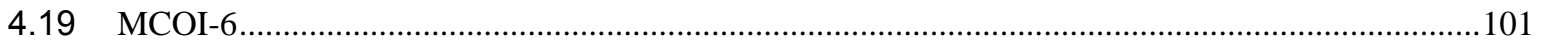

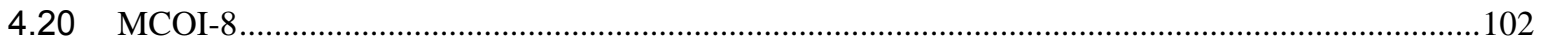

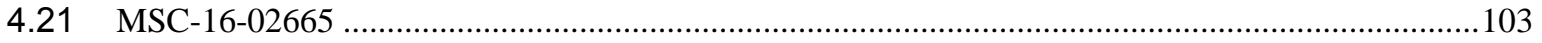

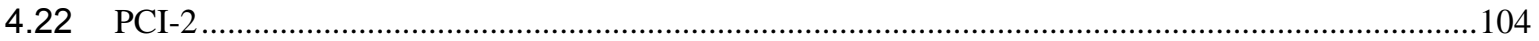

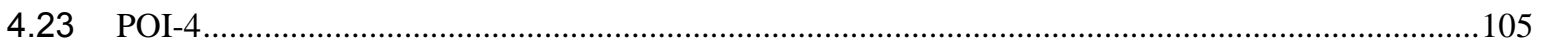

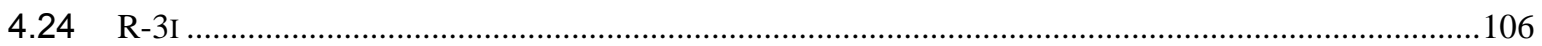

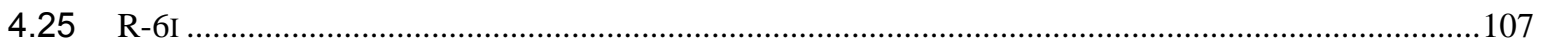

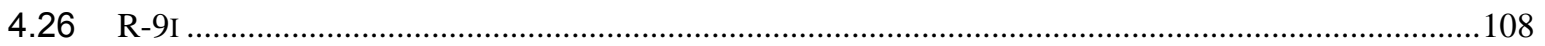

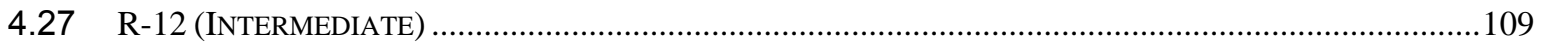

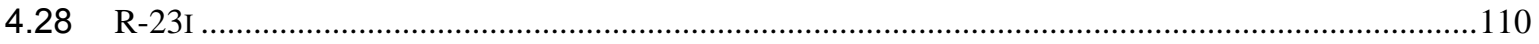

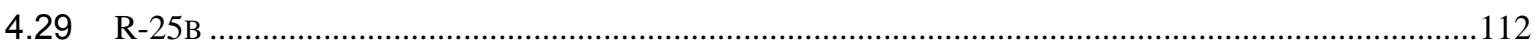

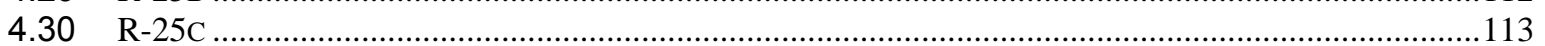

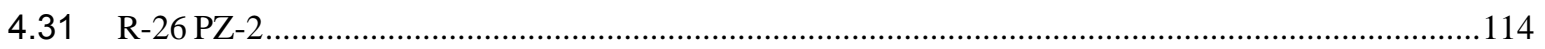

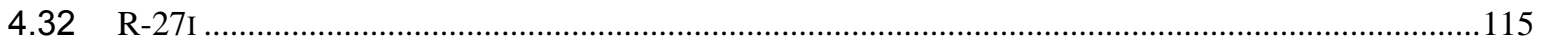

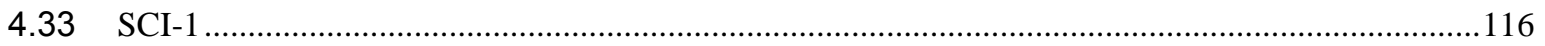

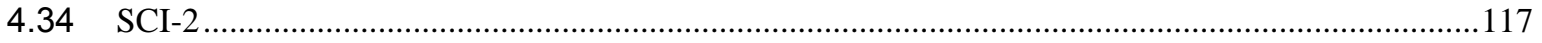

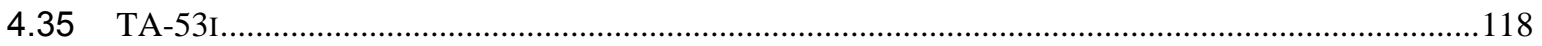

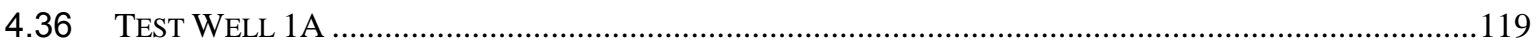

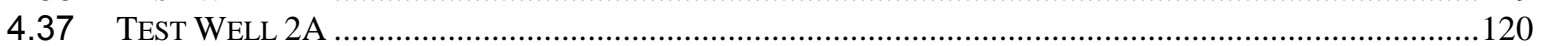

5.0 GROUNDWATER LEVEL DATA FROM ALLUVIAL WELLS..................................................121

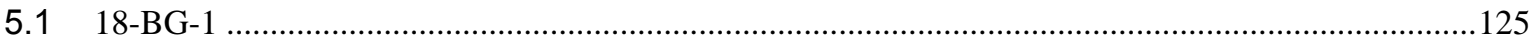

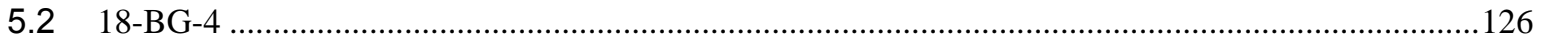

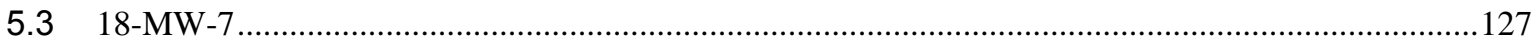

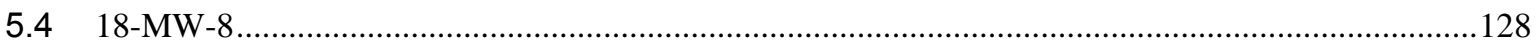

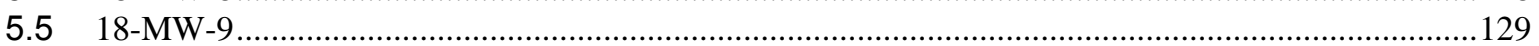




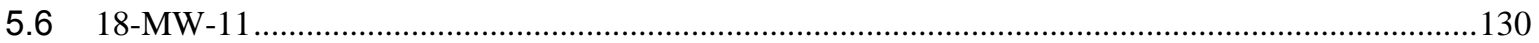

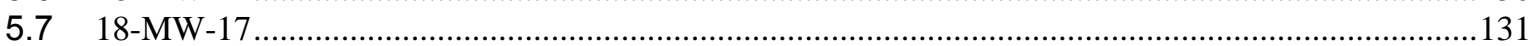

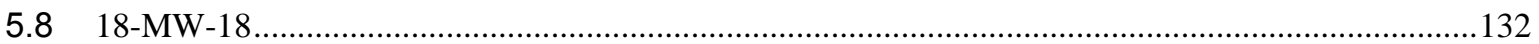

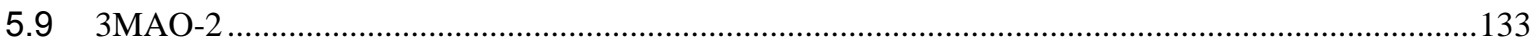

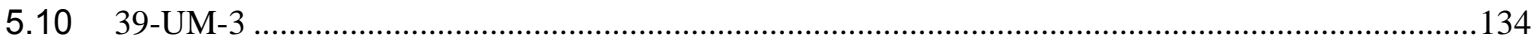

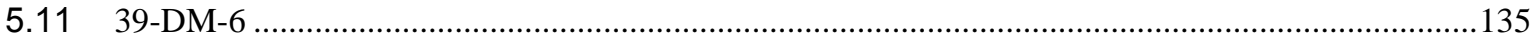

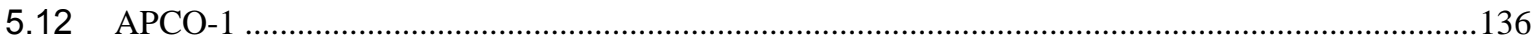

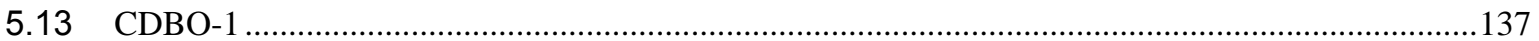

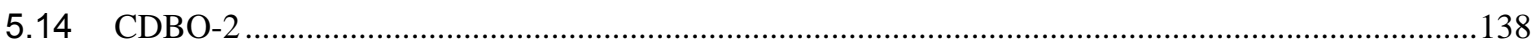

5.15 CDBO-3

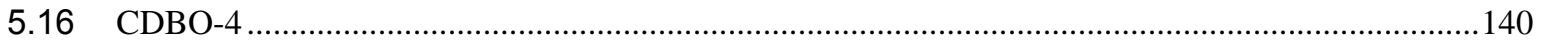

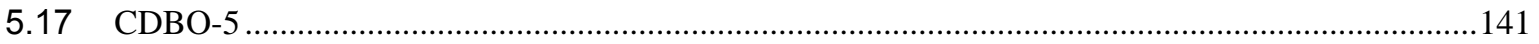

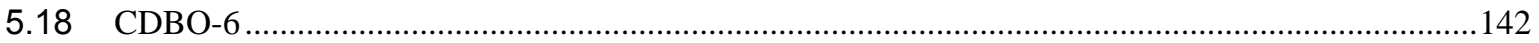

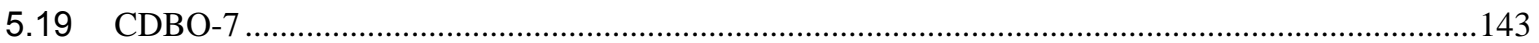

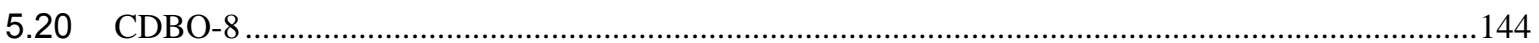

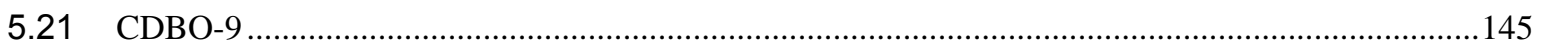

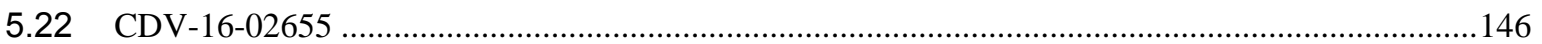

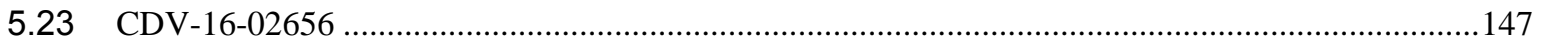

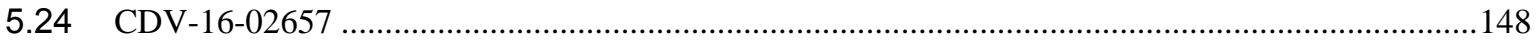

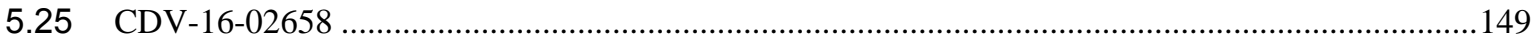

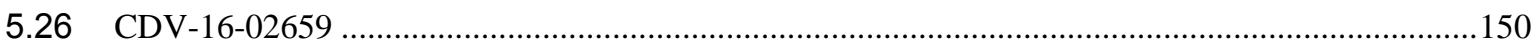

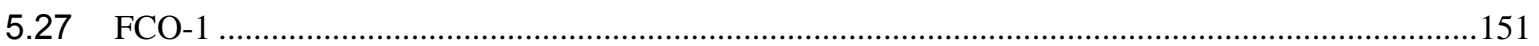

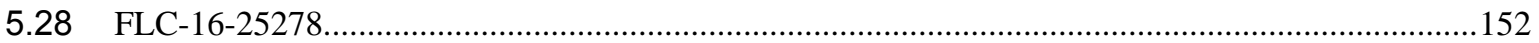

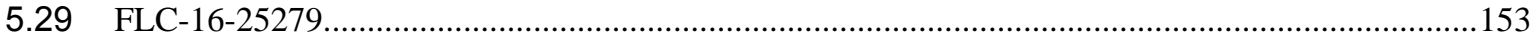

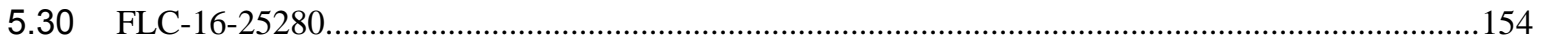

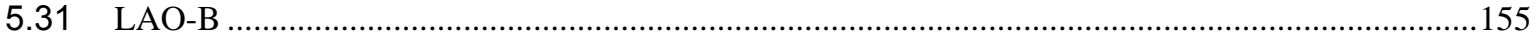

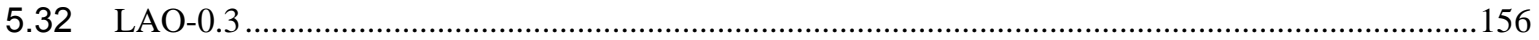

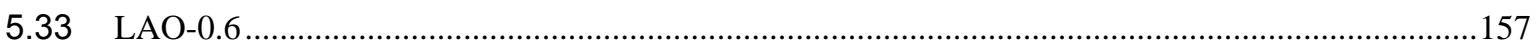

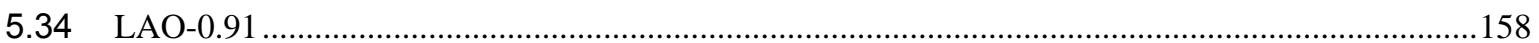

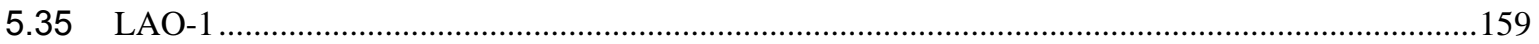

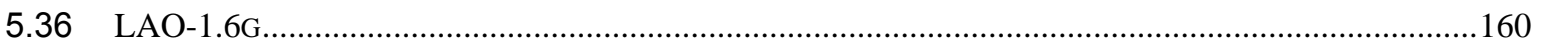

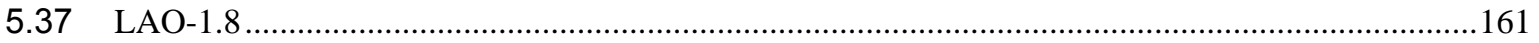

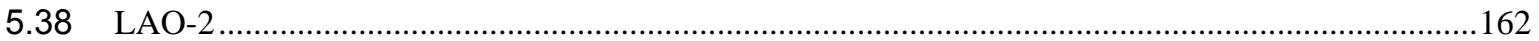

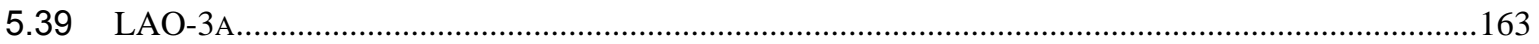

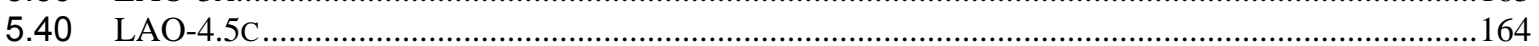

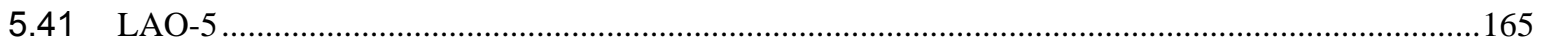

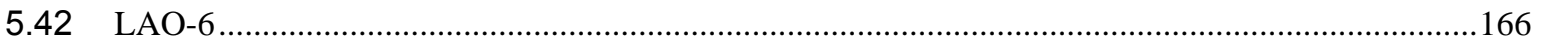

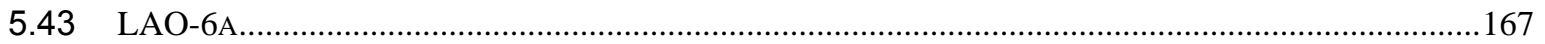

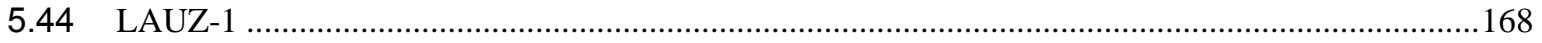

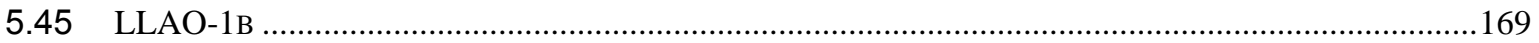

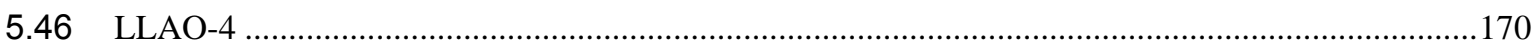

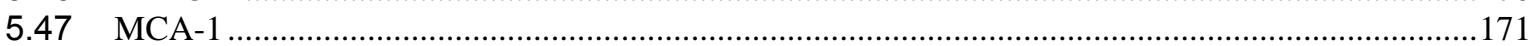

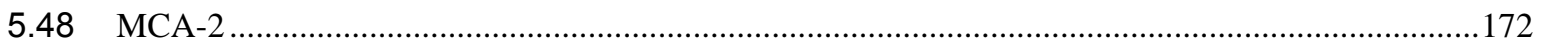

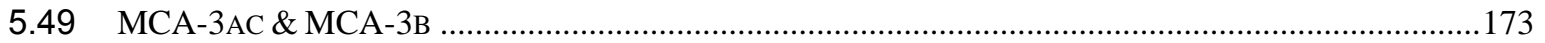

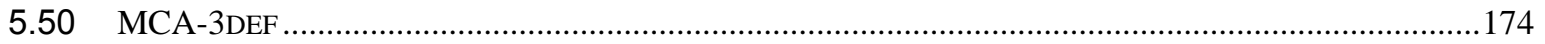

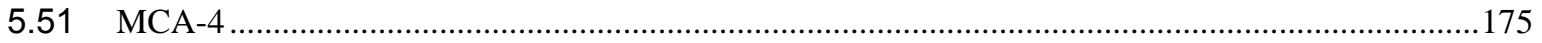

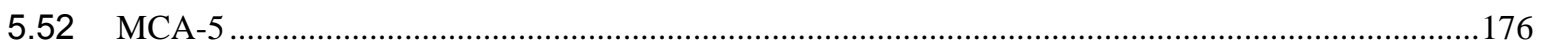

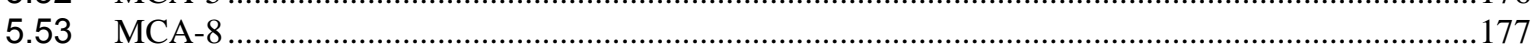

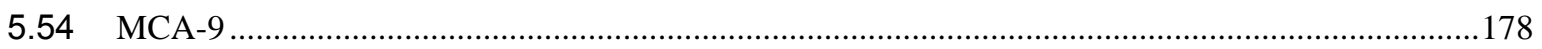

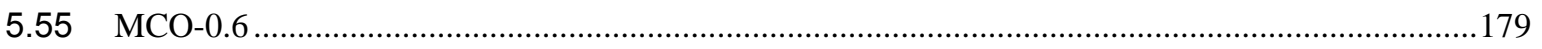

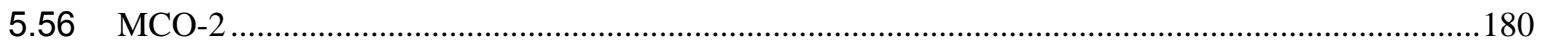

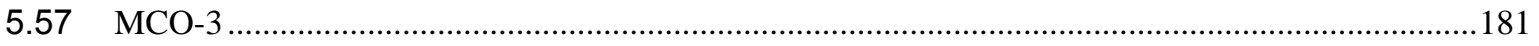

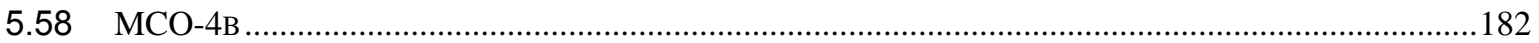

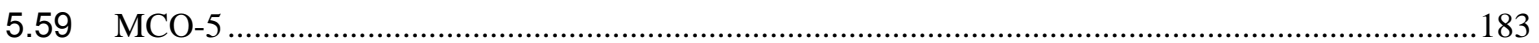

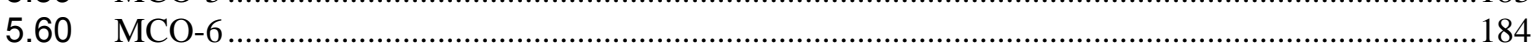

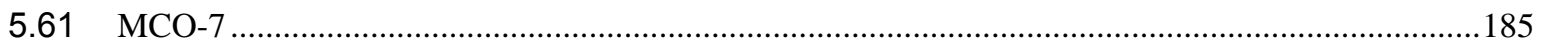




\begin{tabular}{|c|c|}
\hline & \\
\hline 63 & 187 \\
\hline 64 & .188 \\
\hline & 189 \\
\hline & \\
\hline & \\
\hline & ..192 \\
\hline & .193 \\
\hline & ............... \\
\hline 11 & (1) \\
\hline$r 2$ & 196 \\
\hline & .197 \\
\hline & 198 \\
\hline & 199 \\
\hline & ...200 \\
\hline & ..201 \\
\hline & 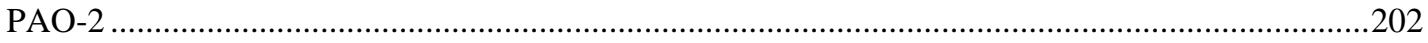 \\
\hline & 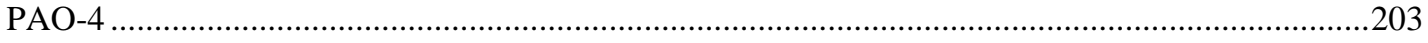 \\
\hline & 204 \\
\hline & 205 \\
\hline & ……................... \\
\hline & (2..................................... \\
\hline & ...208 \\
\hline & 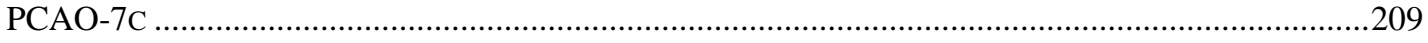 \\
\hline & 210 \\
\hline & 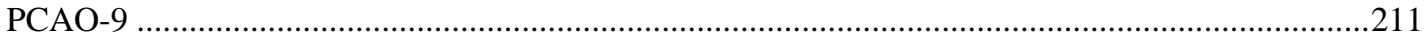 \\
\hline & - \\
\hline & 213 \\
\hline & 214 \\
\hline & 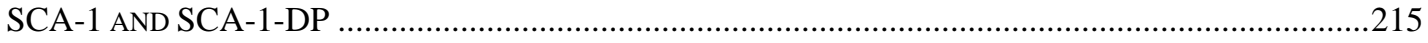 \\
\hline & ……............................. \\
\hline & ...217 \\
\hline & 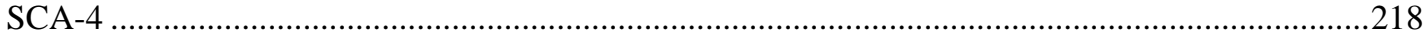 \\
\hline & 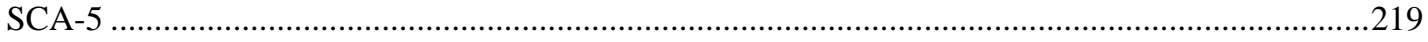 \\
\hline & 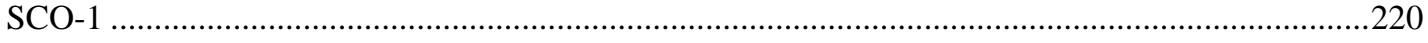 \\
\hline & ............................ \\
\hline & . \\
\hline & (2) \\
\hline & 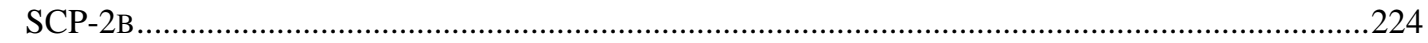 \\
\hline & .225 \\
\hline & 226 \\
\hline & (1) \\
\hline & \\
\hline & \\
\hline & \\
\hline
\end{tabular}

6.0 GROUNDWATER LEVEL DATA FROM WATER SUPPLY WELLS ..........................................231

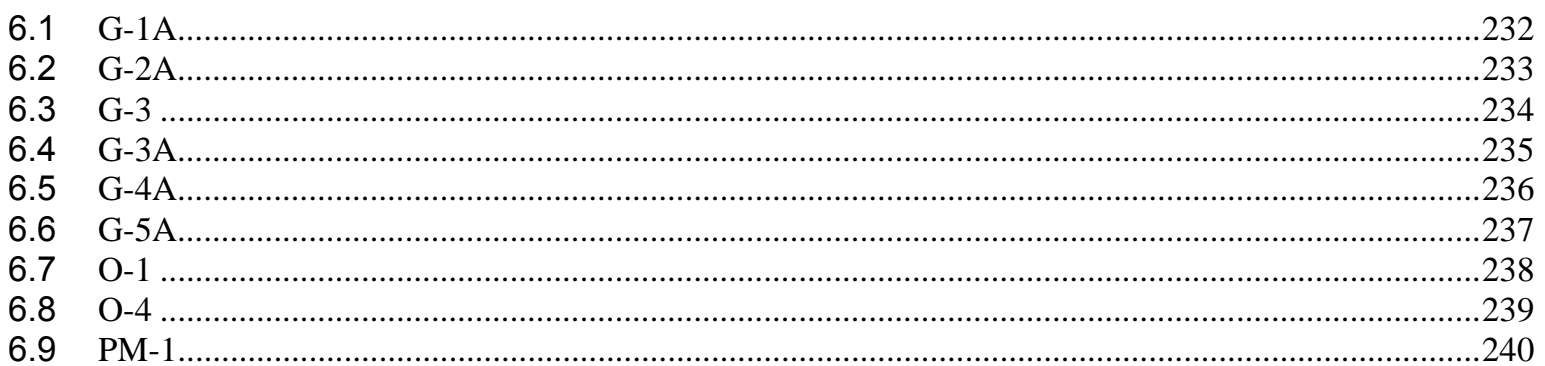




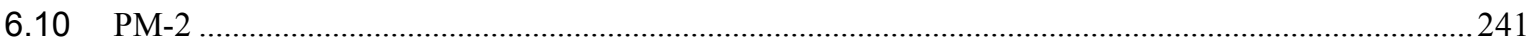

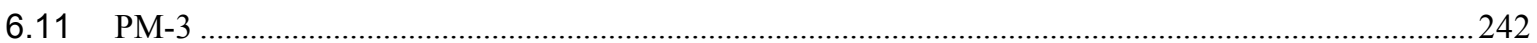

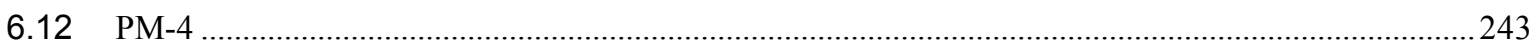

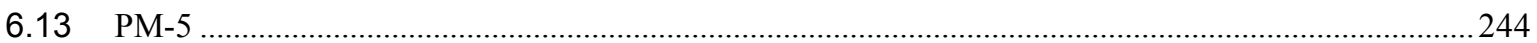

7.0 ACKNOWLEDGMENTS..................................................................................................................245

8.0 REFERENCES AND BIBLIOGRAPHY .................................................................................................245

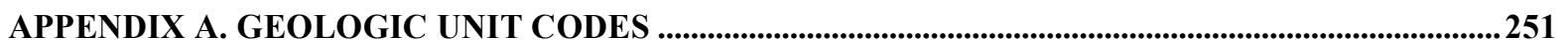

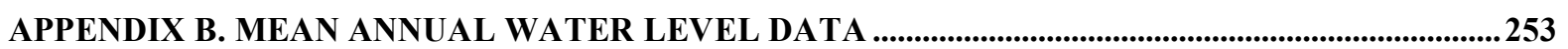

APPENDIX C. SUMMARY OF TRANSIENT RESPONSES....................................................................255

APPENDIX D. SUMMARY OF INTERMEDIATE GROUNDWATER LEVEL RESPONSES TO

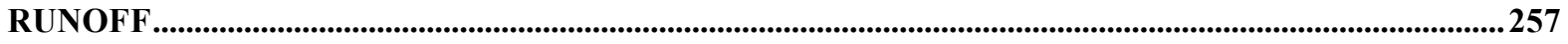

D.1. InTERMEdiate GroundWATER RESPONSES IN CERROS DEL Rio BASAlt (TB4) .................................257

D.2. INTERMEDIATE GROUNDWATER IN GUAJE PUMICE BED (QBOG) .....................................................25

D.3. INTERMEDIATE GROUNDWATER IN THE PUYE FORMATION (TP) ...................................................... 260

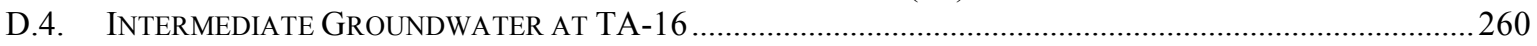

D.5. SUMMARY OF RUNOFF IMPACTS TO INTERMEDIATE PERCHED GROUNDWATER .....................................262

\section{APPENDIX E. SUMMARY OF REGIONAL AND INTERMEDIATE GROUNDWATER TEMPERATURE

\section{List of Figures}

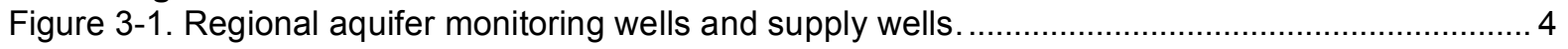

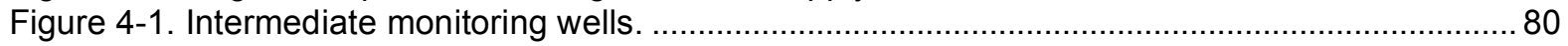

Figure 5-1. Alluvial wells monitored for groundwater levels in 2009. .......................................... 124

Figure D-1. Intermediate groundwater levels in Cerros del Rio basalt...........................................25

Figure D-2. Intermediate groundwater levels in Cerros del Rio basalt in Los Alamos and Pueblo canyons and mean daily flow at Gaging Station E042........................................................... 258

Figure D-3. Intermediate groundwater responses to snowmelt runoff in 2008 and 2009 in Cerros del

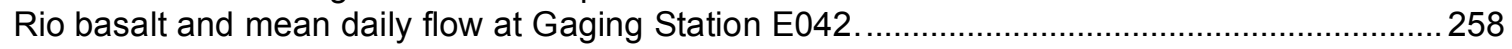

Figure D-4. Intermediate groundwater levels at R-12 and R-23i and mean daily flow at Gaging

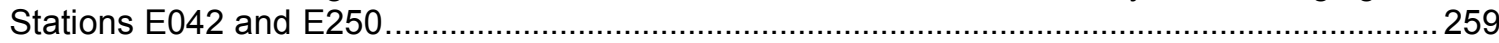

Figure D-5. Intermediate groundwater levels in the Guaje pumice bed at LAOI(A)-1.1, LADP-3, and

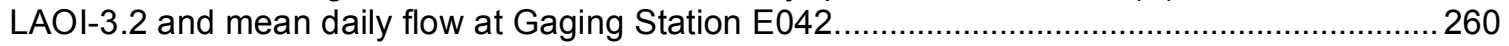

Figure D-6. Intermediate groundwater levels in TA-16 wells and mean daily flow at Gaging Station E252.

Figure E-1. Temperature of groundwater at the top of the regional aquifer.....................................264

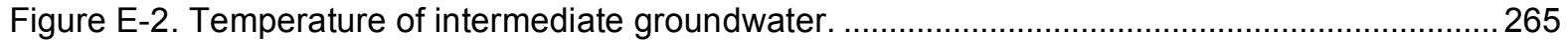

\section{List of Tables}

Table 3-1. Location Information for Regional Aquifer Monitoring Wells ............................................... 5

Table 4-1. General Information for Intermediate Wells at LANL ........................................................ 79

Table 4-2. Well Completion Information for Intermediate Wells and Screens .................................... 81

Table 5-1. Information and Location Data for Alluvial Aquifer Wells at LANL ................................... 121

Table 6-1. General Information for Los Alamos County Water Supply Wells ..................................... 231

Table A-1. Geologic Unit Codes ................................................................................................. 251

Table B-1. Mean Annual Groundwater Levels at the Top of the Regional Aquifer in 2009 ...............253

Table B-2. Mean Annual Groundwater Levels in Intermediate Wells in 2009 ..................................254

Table C-1. Summary of Transient Responses to Supply Well Pumping in LANL Monitoring Wells . 255

Table E-1. Groundwater Temperature in Regional Aquifer and Intermediate Groundwater Wells .... 263 


\title{
Groundwater Level Status Report for 2009 Los Alamos National Laboratory
}

by

Richard J. Koch and Sarah Schmeer

\begin{abstract}
The status of groundwater level monitoring at Los Alamos National Laboratory in 2009 is provided in this report. This report summarizes groundwater level data for 179 monitoring wells, including 55 regional aquifer wells (including 11 regional/intermediate wells), 26 intermediate wells, 98 alluvial wells, and 12 water supply wells. Pressure transducers were installed in 161 monitoring wells for continuous monitoring of groundwater levels. Time-series hydrographs of groundwater level data are presented along with pertinent construction and location information for each well. The report also summarizes the groundwater temperatures recorded in intermediate and regional aquifer monitoring wells.
\end{abstract}

\subsection{Introduction}

This report presents and describes groundwater level data obtained by Los Alamos National Laboratory (LANL) during Fiscal Year (FY) 2009 to provide regulatory compliance and to provide other programs at LANL with groundwater level data as a resource for groundwater modeling and data assessment. The Groundwater Level Monitoring (GWLM) Project was instituted in 2005 to meet New Mexico Environment Department Compliance Order on Consent (Consent Order) requirements to collect groundwater level data.

During 2009, 55 regional aquifer monitoring wells containing 85 regional aquifer screens, 26 intermediate wells and 11 intermediate/regional monitoring wells comprising 51 intermediate screens, 98 alluvial wells, and 12 Los Alamos County (LAC) water supply wells were monitored for groundwater levels. Seven of the multiple completion regional aquifer wells monitored one or more intermediate zones; however, at least one intermediate zone was dry in seven of these wells. Four of the multiple completion regional aquifer wells also monitored intermediate groundwater levels.

Pressure transducers were installed in 53 regional aquifer wells and 21 intermediate wells; periodic manual measurements were obtained from three intermediate wells, two of which are dry and are monitored quarterly or annually, and one of which has not yet had a transducer installed at one screen. Transducers were installed in 87 alluvial wells during 2009 and 11 alluvial wells were monitored with quarterly manual measurements. Transducers have been installed in all 12 LAC water supply wells through the cooperation and efforts of the LAC Utilities Department personnel.

This report includes groundwater level data obtained during FY 2009 (October 1, 2008, through September 30, 2009) and, where available, historical data. The groundwater level data are presented in time-series hydrographs to provide a comprehensive representation of the groundwater level characteristics, to the extent possible with available data. For the alluvial wells, the first hydrograph for each well represents the entire period of record, while the second hydrograph represents the most recent two or three years of data to provide better representation of recent and seasonal changes.

\subsection{Description of Groundwater Level Data}

The GWLM Project at LANL is conducted under the Quality Assurance Project Plan (QAPP) for Groundwater Level Monitoring (LANL 2006) to assure the quality of groundwater level data. The QAPP contains the work processes and the data quality objectives utilized in the GWLM Project. 
Groundwater level data were collected during 2009 according to the criteria outlined in the 2009 Interim Facility-Wide Groundwater Monitoring Plan (LANL 2009). Two types of groundwater level data were collected:

- manual groundwater level measurements were obtained in monitoring wells and boreholes and

- $\quad$ pressure transducers were used to measure groundwater levels in monitoring wells.

Manual groundwater level measurements were obtained according to Environmental Program Directorate (EPD) standard operating procedure (SOP) 5223 (formerly ENV-SOP-202), Manual Groundwater Level Measurements. Transducer measurements were obtained according to EPD SOP 5227 (formerly ENV-SOP-201), Pressure Transducer Installation, Removal, and Maintenance, and EPD SOP 5226 (formerly ENV-WQH-SOP-064), Westbay ${ }^{\circledR}$ Pressure Transducer Installation, Removal, and Maintenance. Groundwater level data obtained both manually and with pressure transducers were reviewed and validated according to EPD SOP 5230 (formerly ENV-WQH-SOP062), Groundwater Level Data Processing, Review, and Validation.

Wells installed with pressure transducers had measurements collected at least hourly. Where possible, manual groundwater level measurements were obtained at least semi-annually to provide quality control for the transducer measurements. In the following sections, both manual measurements and transducer measurements are shown on the time-series hydrographs. Because hourly transducer measurements are too voluminous to reproduce for most hydrographs, mean daily groundwater levels are shown on most hydrographs in this report. Some monitoring wells have significant drawdown when pumped during sampling events. Because pumping of the monitoring wells for sampling usually occurs over several hours, the mean daily water level value will not usually portray the full amount of drawdown experienced during pumping of a well. For this reason, mean daily water level data are not usually appropriate for determining well characteristics such as specific capacity, etc.

Transducers that measure pressure head in wells typically have a measurement precision of $\pm 0.1 \%$ of the full-scale measurement capability. Thus, typical measurement accuracy for a 100-psi transducer is $0.23 \mathrm{ft}$, and for a 500 -psi transducer is $1.2 \mathrm{ft}$. The higher-pressure-rated transducers are required in the deeper Westbay ${ }^{\circledR}$ installations where higher water pressures are encountered. Most shallow wells and deep wells not installed with the Westbay ${ }^{\circledR}$ sampling system are equipped with $30-$ psi transducers, with a measurement accuracy of $0.07 \mathrm{ft}$. A few of the shallow alluvial wells are equipped with 15-psi transducers. Manual groundwater level measurements typically have an accuracy of approximately $0.1 \mathrm{ft}$ per $100 \mathrm{ft}$ of measurement $(0.1 \%)$.

From 2000 through 2004, groundwater level data obtained during groundwater sampling of Westbay ${ }^{\circledR}$ wells was from a 1000-psi-rated transducer that had an accuracy of about $\pm 2.3 \mathrm{ft}$. In 2005 new sampling transducers with a 500-psi rating were obtained, which have an accuracy of about $1.2 \mathrm{ft}$. The higher accuracy of the new Westbay ${ }^{\circledR}$ sampling transducers is the cause for the apparent water level shift for sampling water levels in mid 2005, as observed on many of the accompanying hydrographs for Westbay ${ }^{\circledR}$ wells. Similarly, the apparent scatter of sampling water levels on hydrographs from Westbay ${ }^{\circledR}$ wells is the result of the higher-pressure-rated and less accurate transducers that are used for sampling.

In the following sections, acronyms used to describe groundwater level data include

$\begin{array}{ll}\text { GW } & \text { data obtained from transducers during groundwater sampling events } \\ \text { Trans } & \text { measurements from transducers installed in a well } \\ \text { MP } & \text { Measurement Port identification in multiple completion Westbay }{ }^{\circledR} \text { wells } \\ \text { RT } & \text { Regional aquifer top screen } \\ \text { RD } & \text { Regional aquifer deeper screen } \\ \text { I } & \text { Intermediate perched groundwater }\end{array}$


A Alluvial groundwater

Geologic unit codes used in the construction information tables are listed in Appendix A; Appendix B presents mean annual water level data; Appendix $C$ summarizes transient responses to supply well pumping; Appendix D summarizes intermediate groundwater level responses to runoff; and groundwater temperature data are summarized for regional and intermediate wells in Appendix E.

Previous reports of groundwater level data at LANL were compiled for the regional aquifer test wells (TWs) by Koch et al. (2004) and for all wells in a submittal to the New Mexico Environment Department in January 2005 (LANL 2005). Groundwater levels in water supply wells at Los Alamos have been summarized in the series of water supply reports for Los Alamos, e.g., Koch and Rogers (2003). The previous reports in this series are as follows: Groundwater Level Status Report for 2005, issued in May 2006 (Allen and Koch 2006); Groundwater Level Status Report for Fiscal Year 2006, issued in March 2007 (Allen and Koch 2007); Groundwater Level Status Report for Fiscal Year 2007, issued in March 2008 (Allen and Koch 2008); and Groundwater Level Status Report for 2008, issued in March 2009 (Koch and Schmeer 2009).

\subsection{Groundwater Level Data from Regional Aquifer Wells}

Figure 3-1 shows the locations of the regional aquifer monitoring wells and water supply wells in the vicinity of LANL. Table 3-1 lists the regional aquifer monitoring wells that were monitored for groundwater levels in 2009. Screen intervals and port depths for each well are shown in subsequent sections.

The Appendix B table lists the mean annual water level for 2009 for each well screen located at the top of the regional aquifer. Figure 3-1 also shows the mean annual regional aquifer groundwater elevation for monitoring wells and the mean annual non-pumping water level for supply wells. Appendix C Table $\mathrm{C}-1$ summarizes the transient responses observed in monitoring wells that result from supply well pumping at Los Alamos.

In the following sections reference is made to the barometric efficiency of some monitoring wells. Barometric efficiency is defined as the ratio of the water level change observed in a well divided by the concurrent atmospheric pressure change, expressed as a percentage. For a given change in atmospheric pressure, if the water in a well responds by an equal amount, the well is said to have $100 \%$ barometric efficiency; however, this type of response by the water in the well can occur only when the aquifer adjacent to the well does not experience the atmospheric pressure change. Thus, a well with a $100 \%$ barometric efficiency is installed into an aquifer that does not experience the atmospheric pressure fluctuations. 


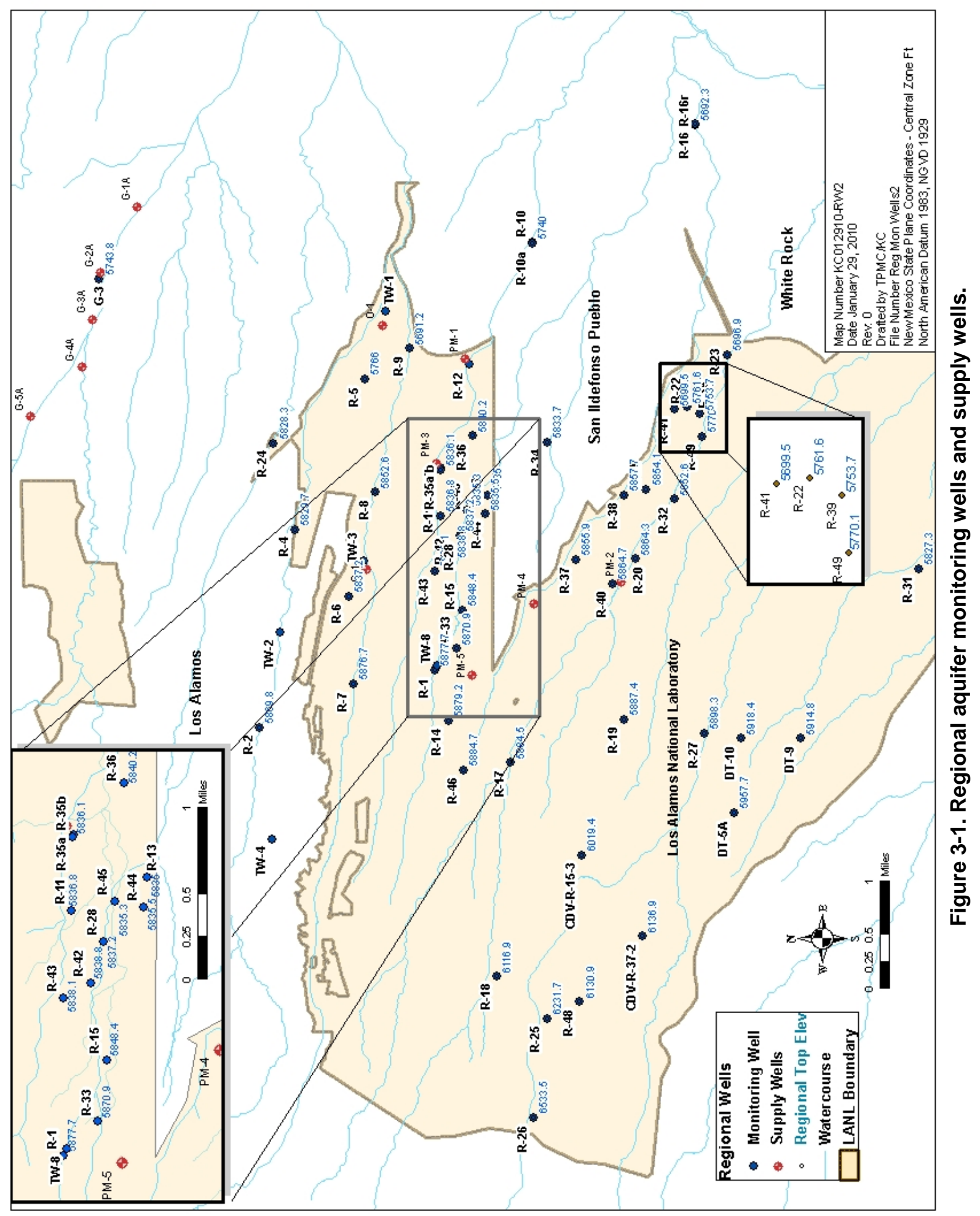


Table 3-1. Location Information for Regional Aquifer Monitoring Wells

\begin{tabular}{|c|c|c|c|c|c|}
\hline Well Name & $\begin{array}{c}\text { Date } \\
\text { Completed }\end{array}$ & $\begin{array}{l}\text { Completed } \\
\text { Depth (ft) }\end{array}$ & Easting (ft) & Northing (ft) & $\begin{array}{c}\text { Surface } \\
\text { Elevation (ft) }\end{array}$ \\
\hline CdV-R-15-3 & $05 / 03 / 00$ & 1722.0 & 1623222.30 & 1762347.50 & 7258.90 \\
\hline CdV-R-37-2 & $08 / 09 / 01$ & 1664.0 & 1619216.70 & 1759320.80 & 7330.60 \\
\hline R-1 & $11 / 10 / 03$ & 1080.1 & 1632354.13 & 1769600.84 & 6881.21 \\
\hline R-2 & $10 / 19 / 03$ & 943.3 & 1629519.57 & 1778281.56 & 6770.38 \\
\hline $\mathrm{R}-4$ & $09 / 28 / 03$ & 840.0 & 1639287.98 & 1776530.28 & 6577.49 \\
\hline$R-5$ & $05 / 22 / 01$ & 884.0 & 1646707.00 & 1773063.00 & 6472.60 \\
\hline R-6 & $11 / 16 / 04$ & 1252.0 & 1636011.02 & 1773884.07 & 6995.80 \\
\hline R-7 & $01 / 20 / 01$ & 977.0 & 1631666.00 & 1773653.00 & 6779.20 \\
\hline R-8 & $01 / 28 / 02$ & 850.0 & 1641139.01 & 1772554.62 & 6544.74 \\
\hline R-9 & $10 / 04 / 99$ & 758.0 & 1648236.50 & 1770847.10 & 6382.80 \\
\hline $\mathrm{R}-10$ & $10 / 05 / 05$ & 1079.0 & 1653465.92 & 1764766.46 & 6362.31 \\
\hline R-10a & $08 / 18 / 05$ & 706.0 & 1653411.63 & 1764782.29 & 6363.74 \\
\hline $\mathrm{R}-11$ & $10 / 08 / 04$ & 901.7 & 1639959.31 & 1769353.57 & 6673.72 \\
\hline$R-13$ & $10 / 06 / 01$ & 1029.4 & 1640991.66 & 1766994.17 & 6673.05 \\
\hline $\mathrm{R}-14$ & $07 / 04 / 02$ & 1315.6 & 1629855.01 & 1768953.12 & 7062.08 \\
\hline R-15 & $09 / 21 / 99$ & 1030.6 & 1635308.60 & 1768272.50 & 6820.00 \\
\hline R-16 & $08 / 31 / 02$ & 1276.7 & 1659283.61 & 1756710.97 & 6256.87 \\
\hline R-16r & $10 / 11 / 05$ & 631.4 & 1659289.39 & 1756730.68 & 6256.97 \\
\hline $\mathrm{R}-17$ & $01 / 04 / 06$ & 1140.9 & 1627795.96 & 1765861.23 & 6921.51 \\
\hline $\mathrm{R}-18$ & $12 / 14 / 04$ & 1405.0 & 1617254.37 & 1766545.47 & 7404.83 \\
\hline R-19 & $03 / 30 / 00$ & 1877.4 & 1629918.40 & 1760252.10 & 7066.30 \\
\hline $\mathrm{R}-20$ & $09 / 08 / 02$ & 1353.3 & 1637835.40 & 1759694.51 & 6694.35 \\
\hline $\mathrm{R}-21$ & $11 / 20 / 02$ & 941.4 & 1641284.17 & 1759143.06 & 6656.24 \\
\hline R-22 & $10 / 19 / 00$ & 1472.9 & 1645324.40 & 1757111.10 & 6650.50 \\
\hline $\mathrm{R}-23$ & $10 / 02 / 02$ & 886.3 & 1647913.60 & 1755165.37 & 6527.75 \\
\hline R-24 & $09 / 02 / 05$ & 861.0 & 1643554.46 & 1777591.35 & 6547.38 \\
\hline $\mathrm{R}-25$ & $09 / 28 / 00$ & 1934.7 & 1615178.42 & 1764060.50 & 7516.10 \\
\hline R-26 & $10 / 17 / 03$ & 1479.0 & 1610267.23 & 1764721.12 & 7641.69 \\
\hline R-27 & $11 / 07 / 05$ & 878.7 & 1629230.52 & 1756296.28 & 6713.72 \\
\hline $\mathrm{R}-28$ & $12 / 17 / 03$ & 980.3 & 1638988.73 & 1768358.57 & 6728.61 \\
\hline R-31 & $12 / 01 / 00$ & 1077.7 & 1637353.80 & 1745648.40 & 6362.50 \\
\hline R-32 & $08 / 09 / 02$ & 1002.0 & 1640797.67 & 1757730.25 & 6637.63 \\
\hline R-33 & $10 / 13 / 04$ & 1126.0 & 1633401.71 & 1768532.65 & 6853.33 \\
\hline R-34 & $08 / 20 / 04$ & 920.7 & 1643595.82 & 1764028.77 & 6629.99 \\
\hline R-35a & $06 / 21 / 07$ & 1086.2 & 1642326.53 & 1769310.85 & 6623.06 \\
\hline$R-35 b$ & $07 / 11 / 07$ & 872.2 & 1642234.75 & 1769322.98 & 6625.21 \\
\hline R-36 & $02 / 12 / 08$ & 803.7 & 1643907.07 & 1767736.64 & 6591.37 \\
\hline R-37 & $6 / 6 / 2009$ & 1068.8 & 1637828.13 & 1762616.71 & 6870.59 \\
\hline R-38 & $12 / 7 / 2008$ & 853.4 & 1640998.66 & 1760235.07 & 6668.58 \\
\hline R-39 & $12 / 1 / 2008$ & 875.6 & 1644995.98 & 1756488.99 & 6580.86 \\
\hline $\mathrm{R}-40$ & $1 / 5 / 2009$ & 895 & 1636628.23 & 1760801.14 & 6719.24 \\
\hline R-41 & $3 / 19 / 2009$ & 997.1 & 1645217.12 & 1757745.55 & 6660.53 \\
\hline$R-42$ & $8 / 27 / 2008$ & 973.5 & 1637709.96 & 1768775.73 & 6759.02 \\
\hline R-43 & $10 / 17 / 2008$ & 990.4 & 1637236.21 & 1769614.7 & 6732.65 \\
\hline R-44 & $1 / 15 / 2009$ & 1016.0 & 1640061.34 & 1767109.85 & 6714.91 \\
\hline R-45 & $1 / 24 / 2009$ & 1016.0 & 1640249.62 & 1768017.72 & 6704.02 \\
\hline $\mathrm{R}-46$ & $2 / 26 / 2009$ & 1383.8 & 1627433.85 & 1768183.02 & 7213.33 \\
\hline R-48 & 9/26/2009 & 1540.0 & 1615980.5 & 1762434.9 & 7486.78 \\
\hline$R-49$ & $6 / 1 / 2009$ & 949.3 & 1643900.9 & 1756401.85 & 6584.54 \\
\hline TW-1 & $01 / 03 / 50$ & 642.0 & 1650041.50 & 1772076.87 & 6369.19 \\
\hline TW-2 & $12 / 15 / 90$ & 834.0 & 1634231.12 & 1777267.87 & 6648.06 \\
\hline TW-3 & $11 / 20 / 49$ & 815.0 & 1637727.50 & 1773138.12 & 6626.90 \\
\hline TW-4 & $03 / 08 / 50$ & 1205.0 & 1624028.12 & 1777680.12 & 7244.56 \\
\hline TW-8 & $12 / 15 / 60$ & 1065.0 & 1632573.87 & 1769506.62 & 6873.50 \\
\hline DT-10 & $03 / 13 / 60$ & 1408.0 & 1628988.50 & 1754448.75 & 7019.90 \\
\hline DT-5A & $01 / 25 / 60$ & 1819.5 & 1625310.00 & 1754789.37 & 7143.86 \\
\hline DT-9 & $02 / 19 / 60$ & 1501.0 & 1628993.62 & 1751492.62 & 6935.00 \\
\hline
\end{tabular}




\subsection{CdV-R-15-3}

Location: CdV-R-15-3 is located on a mesa between upper Three-Mile Canyon and Cañon de Valle within the Cañon de Valle watershed.

Completion Type: Multiple completion, three screens in intermediate zones, three screens in regional zones.

Period of Record: Westbay ${ }^{\circledR}$ installed September 17, 2000; transducers installed March 1, 2001; intermittent data through 2009. The transducers were removed for several months in 2009 to rebuild the cables.

Remarks: The three intermediate screens have been dry since well installation. A transducer was never installed at screen 2 . Transducers monitoring dry screens 1 and 3 were removed in January 2006. Regional screens 4 and 5 have similar heads; screen 6 head is $35 \mathrm{ft}$ lower. Westbay monitoring port MP6B has not been operational since the system was installed (Kopp et al. 2002, p. 38). Six ft of water appeared in the screen 3 sump at port MP3C October 2006; sump water still present in October 2009. Screens 4 and 5 do not indicate a water level response to atmospheric pressure fluctuations; screen 6 indicates a $30 \%$ response to atmospheric pressure.

\begin{tabular}{|c|c|c|c|c|c|c|c|c|c|c|c|c|}
\hline \multicolumn{13}{|c|}{ Measurement and Sampling Ports in CDV-R-15-3 } \\
\hline Screen & $\begin{array}{c}\text { Screen } \\
\text { Top } \\
\text { Depth (ft) }\end{array}$ & $\begin{array}{c}\text { Screen } \\
\text { Bottom } \\
\text { Depth } \\
\text { (ft) }\end{array}$ & $\begin{array}{c}\text { Screen } \\
\text { Top } \\
\text { Elev (ft) }\end{array}$ & $\begin{array}{l}\text { Screen } \\
\text { Bottom } \\
\text { Elev (ft) }\end{array}$ & $\begin{array}{c}\text { Screen } \\
\text { Length } \\
\text { (ft) }\end{array}$ & $\begin{array}{l}\text { Hydro } \\
\text { Zone } \\
\text { Code }\end{array}$ & $\begin{array}{c}\text { Geo } \\
\text { Unit } \\
\text { Code }\end{array}$ & Port & $\begin{array}{c}\text { Port } \\
\text { Depth } \\
\text { (ft) }\end{array}$ & $\begin{array}{c}\text { Port } \\
\text { Elev }(\mathrm{ft})\end{array}$ & \begin{tabular}{|c|} 
Port \\
Distance \\
from \\
Bottom \\
of \\
Screen \\
(ft)
\end{tabular} & Comment \\
\hline \multirow{3}{*}{1} & \multirow{3}{*}{617.7} & \multirow{3}{*}{624.5} & \multirow{3}{*}{6641.2} & \multirow{3}{*}{6634.4} & \multirow{3}{*}{6.8} & \multirow{3}{*}{$\mathrm{I}$} & \multirow{3}{*}{ Qbo } & MP1A & 624.3 & 6634.6 & 0.2 & Within Screen, port dry \\
\hline & & & & & & & & PP1 & 629.7 & 6629.2 & -5.2 & Below Screen \\
\hline & & & & & & & & MP1B & 635.3 & 6623.6 & -10.8 & Below Screen, port dry \\
\hline \multirow{3}{*}{2} & \multirow{3}{*}{800.8} & \multirow{3}{*}{807.8} & \multirow{3}{*}{6458.1} & \multirow{3}{*}{6451.1} & \multirow{3}{*}{7.0} & \multirow{3}{*}{$\mathrm{I}$} & \multirow{3}{*}{$\mathrm{Tp}$} & MP2A & 807.3 & 6451.6 & 0.5 & Within Screen, port dry \\
\hline & & & & & & & & PP2 & 812.6 & 6446.3 & -4.8 & Below Screen \\
\hline & & & & & & & & MP2B & 818.3 & 6440.6 & -10.5 & Below Screen \\
\hline \multirow{4}{*}{3} & \multirow{4}{*}{964.8} & \multirow{4}{*}{980.9} & \multirow{4}{*}{6294.1} & \multirow{4}{*}{6278.0} & \multirow{4}{*}{16.1} & \multirow{4}{*}{ I } & \multirow{4}{*}{$\mathrm{Tb} 4$} & MP3A & 969.0 & 6289.9 & 11.9 & Within Screen, port dry \\
\hline & & & & & & & & MP3B & 979.3 & 6279.6 & 1.6 & Within Screen, port dry \\
\hline & & & & & & & & PP3 & 984.7 & 6274.2 & -3.8 & Below Screen \\
\hline & & & & & & & & MP3C & 990.3 & 6268.6 & -9.4 & Below Screen, 6 ' water in sump \\
\hline \multirow{5}{*}{4} & \multirow{5}{*}{1235.1} & \multirow{5}{*}{1278.9} & \multirow{5}{*}{6023.8} & \multirow{5}{*}{5980.0} & \multirow{5}{*}{43.8} & & & MP4A & 1254.4 & 6004.5 & 24.5 & Within Screen, Regional Aquifer \\
\hline & & & & & & & & PP4A & 1259.6 & 5999.3 & 19.3 & Within Screen \\
\hline & & & & & & RT & $\mathrm{Tp}$ & MP4B & 1275.1 & 5983.8 & 3.8 & Within Screen \\
\hline & & & & & & & & PP4B & 1280.5 & 5978.4 & -1.6 & Below Screen \\
\hline & & & & & & & & MP4C & 1286.1 & 5972.8 & -7.2 & Below Screen \\
\hline & & & & & & & & MP5A & 1350.1 & 5908.8 & 5.2 & Within Screen \\
\hline 5 & 1348.4 & 1355.3 & 5910.5 & 5903.6 & 6.9 & $\mathrm{RD}$ & $\mathrm{Tp}$ & PP5 & 1355.4 & 5903.5 & -0.1 & Below Screen \\
\hline & & & & & & & & MP5B & 1361.1 & 5897.8 & -5.8 & Below Screen \\
\hline & & & & & & & & MP6A & 1640.1 & 5618.8 & 4.7 & Within Screen \\
\hline 6 & 1637.9 & 1644.8 & 5621.0 & 5614.1 & 6.9 & $\mathrm{RD}$ & $\mathrm{Tp}$ & PP6 & 1645.5 & 5613.4 & -0.7 & Below Screen \\
\hline & & & & & & & & MP6B & 1651.1 & 5607.8 & -6.3 & Below Screen, Port in \\
\hline
\end{tabular}

Note: CDV-R-15-3 Brass Cap Ground Elevation: $7258.9 \mathrm{ft}$; all measurements are from this elevation;

MP = Monitor Port; PP = Pump Port; Monitor Ports shown in bold are instrumented ports 

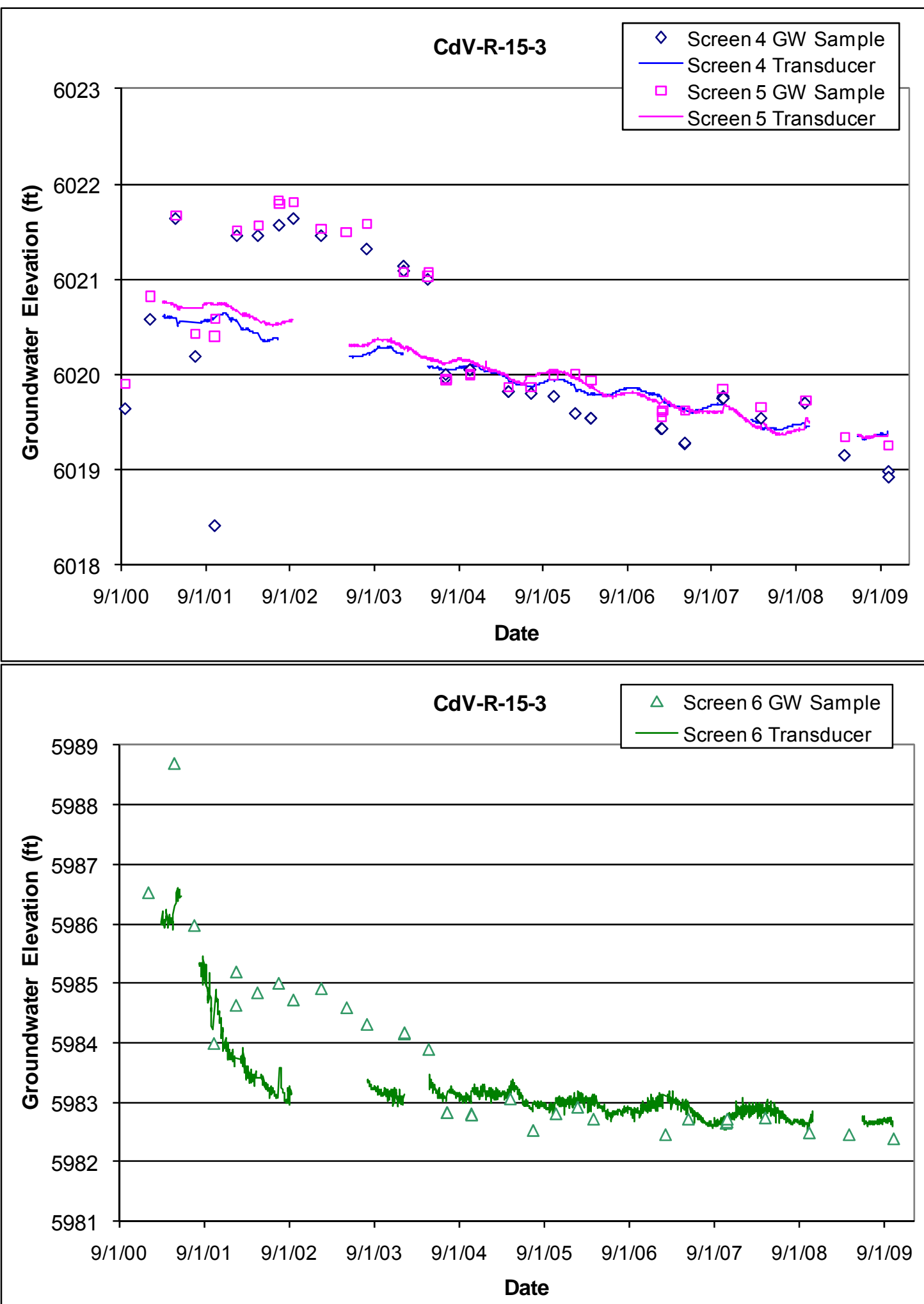


\subsection{CdV-R-37-2}

Location: CdV-R-37-2 is located on a mesa between Cañon de Valle and Water Canyon at Technical Area (TA) 37 in the Water Canyon watershed.

Completion Type: Multiple completion, one screen in an intermediate zone, three screens in regional zones.

Period of Record: Westbay ${ }^{\circledR}$ installed October 8, 2001; transducers installed August 8, 2003; data through 2009.

Remarks: The intermediate screen has been dry since well installation; the transducer at this screen was removed in January 2006. The three regional screens have similar heads that show downward gradient of about $1 \mathrm{ft}$ between each screen. The screens do not indicate a water level response to atmospheric pressure fluctuations.

\begin{tabular}{|c|c|c|c|c|c|c|c|c|c|c|c|c|}
\hline \multicolumn{13}{|c|}{ Measurement and Sampling Ports in CDV-R-37-2 } \\
\hline Screen & $\begin{array}{c}\text { Screen } \\
\text { Top } \\
\text { Depth (ft) }\end{array}$ & $\begin{array}{c}\text { Screen } \\
\text { Bottom } \\
\text { Depth } \\
\text { (ft) }\end{array}$ & $\begin{array}{l}\text { Screen } \\
\text { Top } \\
\text { Elev (ft) }\end{array}$ & $\begin{array}{l}\text { Screen } \\
\text { Bottom } \\
\text { Elev (ft) }\end{array}$ & $\begin{array}{c}\text { Screen } \\
\text { Length } \\
\text { (ft) }\end{array}$ & $\begin{array}{l}\text { Hydro } \\
\text { Zone } \\
\text { Code }\end{array}$ & $\begin{array}{c}\text { Geo } \\
\text { Unit } \\
\text { Code }\end{array}$ & Port & $\begin{array}{c}\text { Port } \\
\text { Depth (ft) }\end{array}$ & $\begin{array}{c}\text { Port } \\
\text { Elevation } \\
\text { (ft) }\end{array}$ & \begin{tabular}{|} 
Distance \\
from \\
Bottom of \\
Screen \\
(ft)
\end{tabular} & Comment \\
\hline \multirow{3}{*}{1} & \multirow{3}{*}{914.4} & \multirow{3}{*}{939.5} & \multirow{3}{*}{6416.2} & \multirow{3}{*}{6391.1} & \multirow{3}{*}{25.1} & \multirow{3}{*}{ I } & \multirow{3}{*}{ Tp } & $\overline{M P 1 A}$ & 934.9 & 6395.7 & 4.6 & Within Screen (Dry) \\
\hline & & & & & & & & PP1 & 940.2 & 6390.4 & -0.7 & Below Screen \\
\hline & & & & & & & & MP1B & 945.9 & 6384.7 & -6.4 & Below Screen \\
\hline \multirow{3}{*}{2} & \multirow{3}{*}{1188.7} & \multirow{3}{*}{1213.8} & \multirow{3}{*}{6141.9} & \multirow{3}{*}{6116.8} & \multirow{3}{*}{25.1} & \multirow{3}{*}{ RT } & \multirow{3}{*}{$\mathrm{Tt}$} & MP2A & 1200.3 & 6130.3 & 13.5 & Within Screen \\
\hline & & & & & & & & PP2 & 1205.7 & 6124.9 & 8.1 & Within Screen \\
\hline & & & & & & & & MP2B & 1216.2 & 6114.4 & -2.4 & Below Screen \\
\hline \multirow{3}{*}{3} & \multirow{3}{*}{1353.7} & \multirow{3}{*}{1377.1} & \multirow{3}{*}{5976.9} & \multirow{3}{*}{5953.5} & \multirow{3}{*}{23.4} & \multirow{3}{*}{$\mathrm{RD}$} & \multirow{3}{*}{$\mathrm{Tt}$} & $\overline{M P 3 A}$ & 1359.3 & $\overline{5971.3}$ & 17.8 & Within Screen \\
\hline & & & & & & & & PP3 & 1365.0 & 5965.6 & 12.1 & Within Screen \\
\hline & & & & & & & & MP3B & 1375.2 & 5955.4 & 1.9 & Within Screen \\
\hline \multirow{3}{*}{4} & \multirow{3}{*}{1549.3} & \multirow{3}{*}{1556.0} & \multirow{3}{*}{5781.3} & \multirow{3}{*}{5774.6} & \multirow{3}{*}{6.7} & \multirow{3}{*}{ RD } & \multirow{3}{*}{$\mathrm{Tt}$} & $\overline{\text { MP4A }}$ & 1550.6 & 5780.0 & 5.4 & Within Screen \\
\hline & & & & & & & & PP4 & 1556.0 & 5774.6 & 0 & Base of Screen \\
\hline & & & & & & & & MP4B & 1561.6 & 5769.0 & -5.6 & Below Screen \\
\hline
\end{tabular}

Note: CDV-R-37-2 Brass Cap Ground Elevation: $7330.6 \mathrm{ft}$; all measurements are from this elevation;

$\mathrm{MP}=$ Monitor Port; PP = Pump Port; Monitor Ports shown in bold are instrumented ports

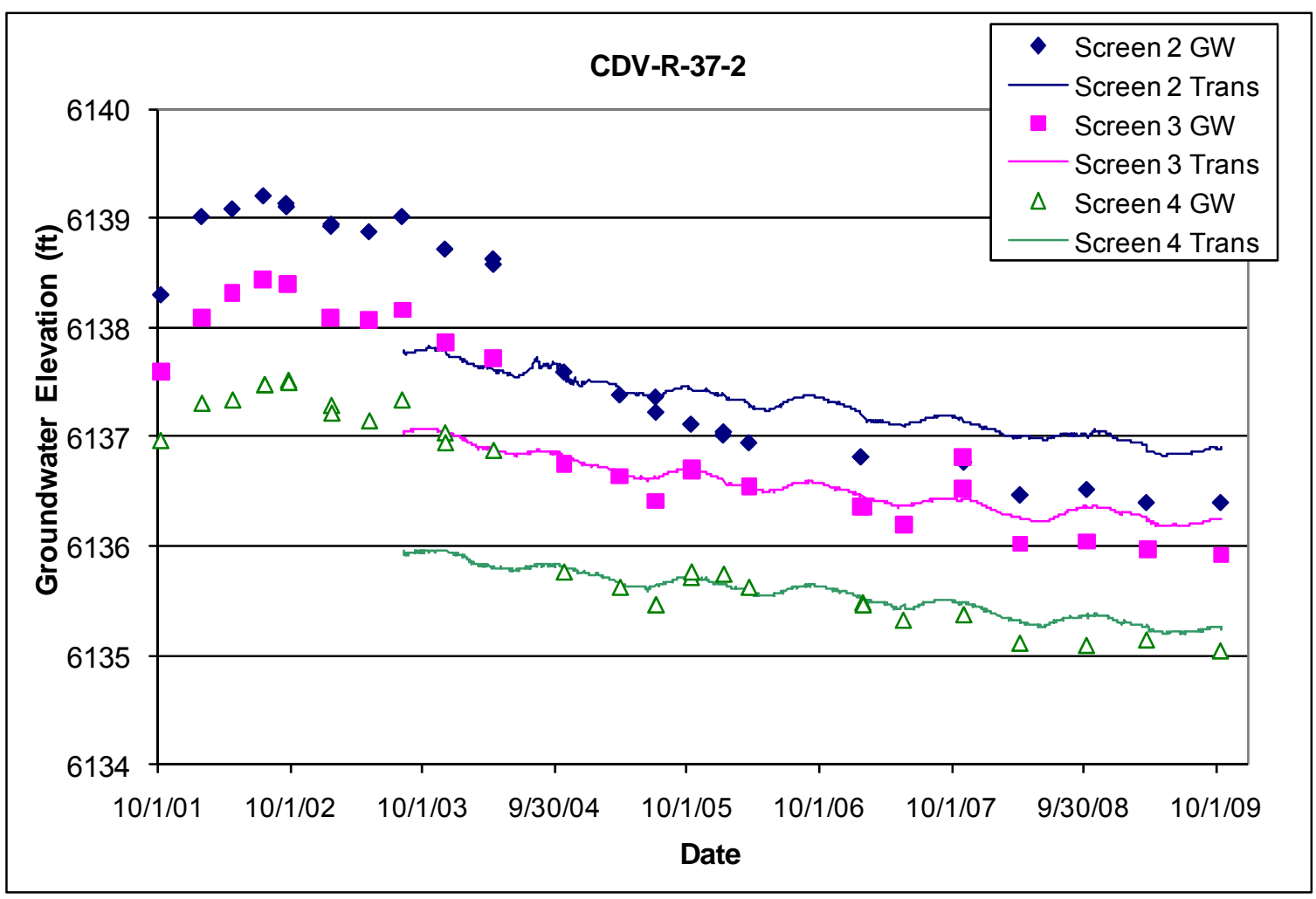




\subsection{R-1}

Location: R-1 is located in Mortandad Canyon about $220 \mathrm{ft}$ west of former monitoring well TW-8.

Completion Type: Single completion at the top of the regional aquifer. The top of the screen is about $29 \mathrm{ft}$ below the water table.

Period of Record: Well completed November 2003, transducer installed January 2005, transducer data through 2009.

Remarks: R-1 was completed to a depth of $1080.1 \mathrm{ft}$, about $80 \mathrm{ft}$ into the regional aquifer. The well is $100 \%$ barometrically efficient; the aquifer has no immediate response to atmospheric pressure fluctuations. The aquifer indicates a seasonal response to supply well pumping and primarily responds to pumping at PM-5 and possibly to PM-4.

\begin{tabular}{|c|c|c|c|c|c|c|c|c|c|c|c|c|c|c|}
\hline \multicolumn{15}{|c|}{ R-1 Construction Information } \\
\hline Screen & $\begin{array}{l}\text { Screen } \\
\text { Top } \\
\text { Depth (ft) }\end{array}$ & $\begin{array}{c}\text { Screen } \\
\text { Bottom } \\
\text { Depth } \\
\text { (ft) }\end{array}$ & $\begin{array}{c}\text { Screen } \\
\text { Top } \\
\text { Elev (ft) }\end{array}$ & $\begin{array}{l}\text { Screen } \\
\text { Bottom } \\
\text { Elev (ft) }\end{array}$ & $\begin{array}{c}\text { Screen } \\
\text { Length } \\
\text { (ft) }\end{array}$ & $\begin{array}{c}\text { Pump } \\
\text { Intake } \\
\text { Depth } \\
\text { (ft) }\end{array}$ & $\begin{array}{c}\text { Pump } \\
\text { Intake } \\
\text { Elevation } \\
\text { (ft) }\end{array}$ & $\begin{array}{l}\text { Depth to } \\
\text { Top of } \\
\text { Sump (ft) }\end{array}$ & $\begin{array}{c}\text { Top of } \\
\text { Sump } \\
\text { Elevation } \\
\text { (ft) }\end{array}$ & $\begin{array}{l}\text { Depth to } \\
\text { Sump } \\
\text { Bottom } \\
\text { (ft) }\end{array}$ & $\begin{array}{c}\text { Sump } \\
\text { Length } \\
\text { (ft) }\end{array}$ & $\begin{array}{c}\text { Sump } \\
\text { Volume } \\
\text { (L) }\end{array}$ & $\begin{array}{c}\text { Hydro } \\
\text { Zone } \\
\text { Code }\end{array}$ & $\begin{array}{c}\text { Geo } \\
\text { Unit } \\
\text { Code }\end{array}$ \\
\hline 1 & 1031.1 & 1057.4 & 5850.1 & 5823.8 & 26.3 & 1027.7 & 5853.5 & 1057.4 & 5823.8 & 1080.1 & 22.7 & 69.7 & RT & $\mathrm{Tp}$ \\
\hline
\end{tabular}

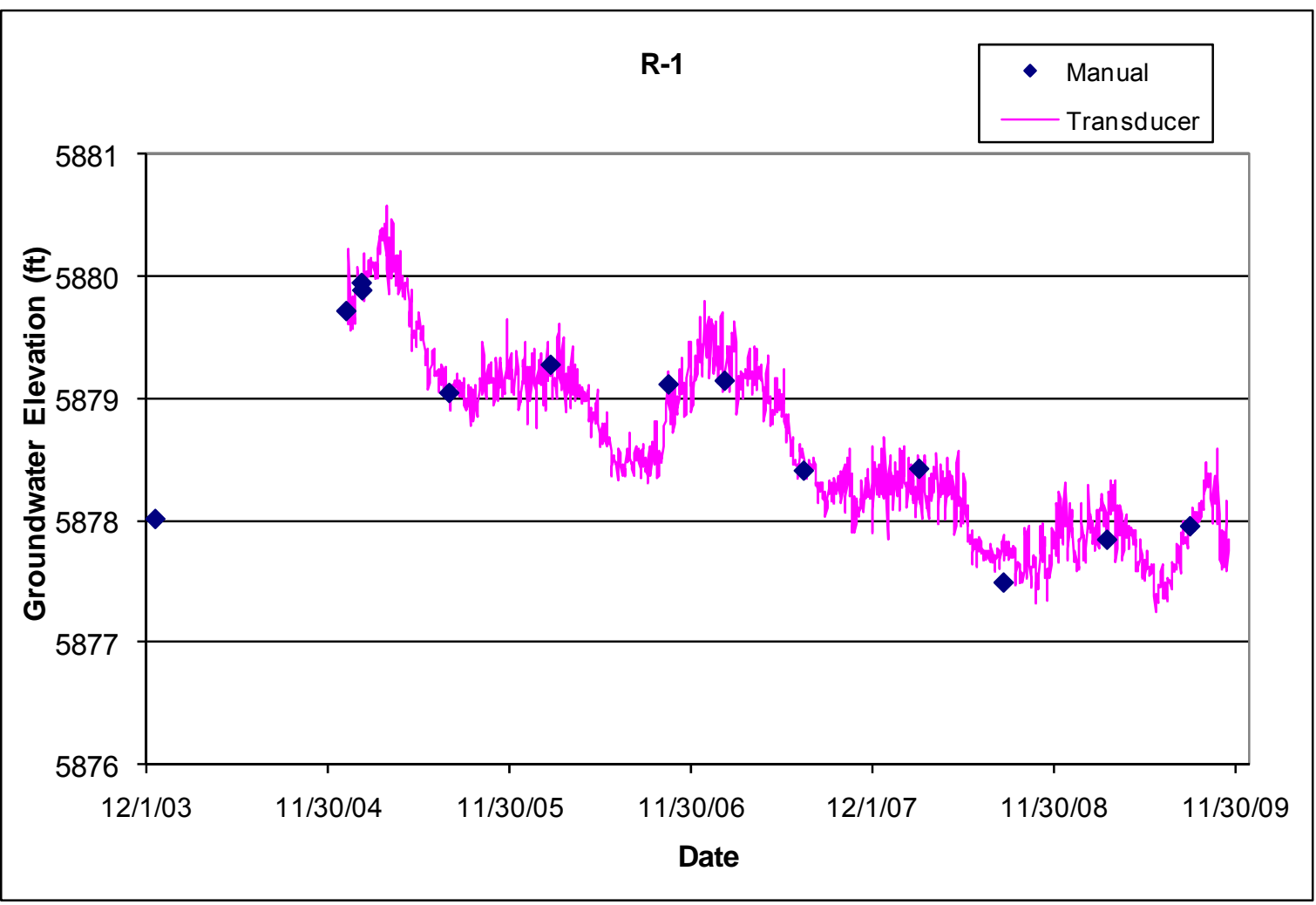




\section{$3.4 \quad \mathrm{R}-2$}

Location: R-2 is located in middle Pueblo Canyon between TW-4 and TW-2.

Completion Type: Single completion at the top of the regional aquifer. The top of the screen is about $8 \mathrm{ft}$ below the water table.

Period of Record: Well completed October 2003, transducer installed January 2005, transducer data through 2009.

Remarks: R-2 was completed to a depth of $943.3 \mathrm{ft}$, about $50 \mathrm{ft}$ into the regional aquifer. The well is $100 \%$ barometrically efficient; the aquifer has no immediate response to atmospheric pressure fluctuations. The well does not indicate a seasonal response to supply well pumping or an apparent response to pumping of any specific supply well.

\begin{tabular}{|c|c|c|c|c|c|c|c|c|c|c|c|c|c|c|}
\hline \multicolumn{15}{|c|}{ R-2 Construction Information } \\
\hline Screen & \begin{tabular}{|c|} 
Screen \\
Top \\
Depth (ft)
\end{tabular} & $\begin{array}{c}\text { Screen } \\
\text { Bottom } \\
\text { Depth } \\
\text { (ft) }\end{array}$ & $\begin{array}{l}\text { Screen } \\
\text { Top } \\
\text { Elev (ft) }\end{array}$ & $\begin{array}{l}\text { Screen } \\
\text { Bottom } \\
\text { Elev (ft) }\end{array}$ & $\begin{array}{c}\text { Screen } \\
\text { Length } \\
\text { (ft) }\end{array}$ & $\begin{array}{l}\text { Pump } \\
\text { Intake } \\
\text { Depth } \\
\text { (ft) }\end{array}$ & $\begin{array}{c}\text { Pump } \\
\text { Intake } \\
\text { Elevation } \\
\text { (ft) }\end{array}$ & $\begin{array}{l}\text { Depth to } \\
\text { Top of } \\
\text { Sump (ft) }\end{array}$ & $\begin{array}{c}\text { Top of } \\
\text { Sump } \\
\text { Elevation } \\
\text { (ft) }\end{array}$ & $\begin{array}{c}\text { Depth to } \\
\text { Sump } \\
\text { Bottom (ft) }\end{array}$ & $\begin{array}{c}\text { Sump } \\
\text { Length } \\
\text { (ft) }\end{array}$ & $\begin{array}{c}\text { Sump } \\
\text { Volume } \\
\text { (L) }\end{array}$ & $\begin{array}{l}\text { Hydro } \\
\text { Zone } \\
\text { Code }\end{array}$ & $\begin{array}{l}\text { Geo } \\
\text { Unit } \\
\text { Code }\end{array}$ \\
\hline 1 & 906.4 & 929.6 & 5864.0 & 5840.8 & 23.2 & 917.0 & 5853.4 & 929.6 & 5840.8 & 943.3 & 13.7 & 42.1 & RT & $T p$ \\
\hline
\end{tabular}

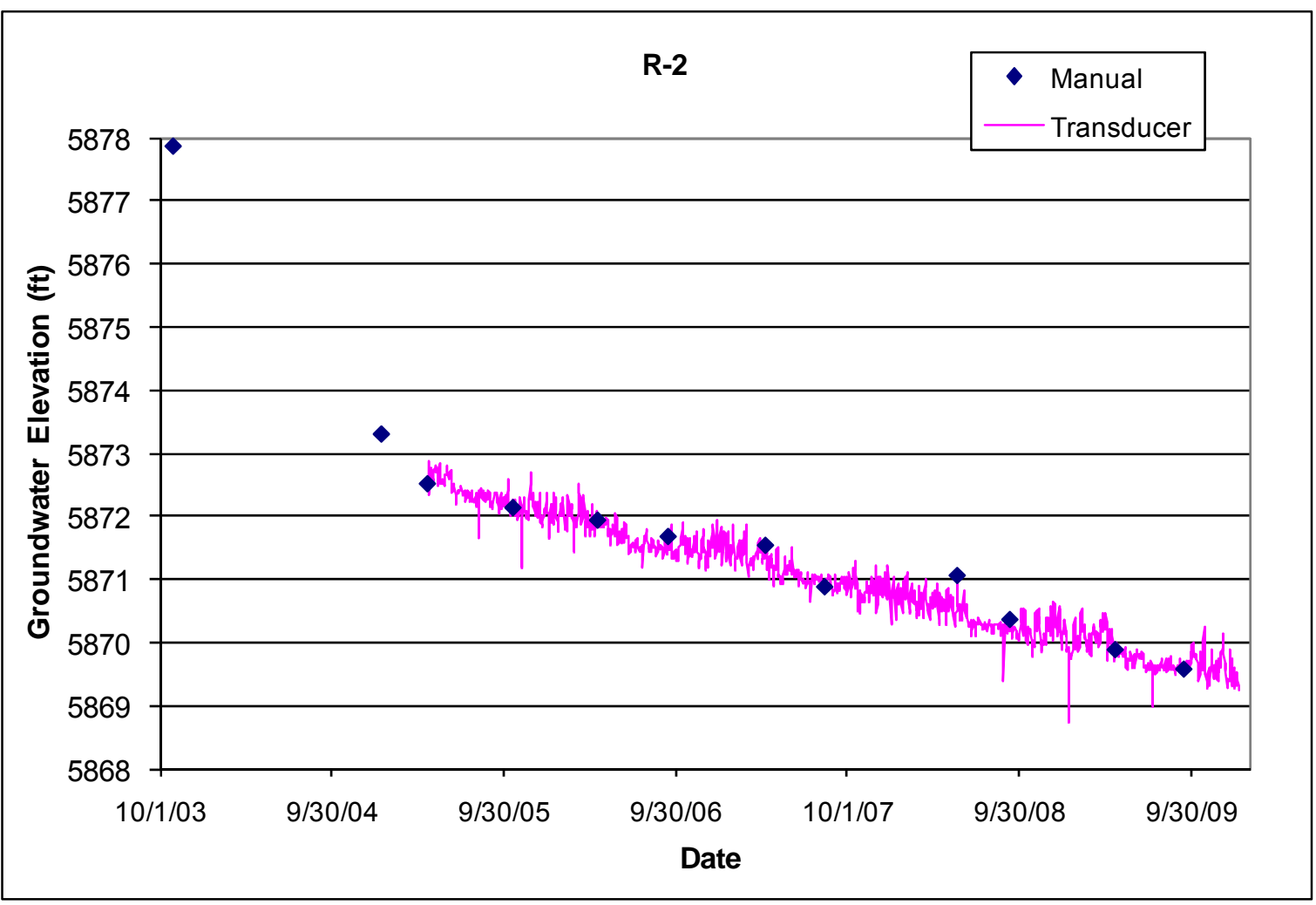




\section{$3.5 \quad \mathrm{R}-4$}

Location: R-4 is located in Pueblo Canyon near the new LAC Sewage Treatment Plant.

Completion Type: Single completion at the top of the regional aquifer. The top of the screen is about $49 \mathrm{ft}$ below the piezometric water table in a confined zone.

Period of Record: Well completed September 2003, transducer installed January 2005, data through 2009. The transducer failed in January 2008 and was replaced in March 2008.

Remarks: R-4 was completed to a depth of $840 \mathrm{ft}$, about $90 \mathrm{ft}$ into the regional aquifer. The well is $100 \%$ barometrically efficient; the aquifer has no immediate response to atmospheric pressure fluctuations. The aquifer indicates a seasonal response to supply well pumping and appears to respond primarily to pumping PM-3, and possibly to pumping at O-4 and the Guaje well field.

\begin{tabular}{|c|c|c|c|c|c|c|c|c|c|c|c|c|c|c|}
\hline \multicolumn{15}{|c|}{ R-4 Construction Information } \\
\hline Screen & $\begin{array}{c}\text { Screen } \\
\text { Top } \\
\text { Depth } \\
\text { (ft) }\end{array}$ & $\begin{array}{c}\text { Screen } \\
\text { Bottom } \\
\text { Depth } \\
\text { (ft) }\end{array}$ & $\begin{array}{l}\text { Screen } \\
\text { Top } \\
\text { Elev (ft) }\end{array}$ & $\begin{array}{l}\text { Screen } \\
\text { Bottom } \\
\text { Elev (ft) }\end{array}$ & $\begin{array}{c}\text { Screen } \\
\text { Length } \\
\text { (ft) }\end{array}$ & $\begin{array}{l}\text { Pump } \\
\text { Intake } \\
\text { Depth } \\
\text { (ft) }\end{array}$ & $\begin{array}{c}\text { Pump } \\
\text { Intake } \\
\text { Elev } \\
\text { (ft) }\end{array}$ & $\begin{array}{l}\text { Depth to } \\
\text { Top of } \\
\text { Sump } \\
\text { (ft) }\end{array}$ & $\begin{array}{c}\text { Top of } \\
\text { Sump } \\
\text { Elev } \\
\text { (ft) }\end{array}$ & $\begin{array}{l}\text { Depth to } \\
\text { Sump } \\
\text { Bottom } \\
\text { (ft) }\end{array}$ & $\begin{array}{c}\text { Sump } \\
\text { Length } \\
\text { (ft) }\end{array}$ & $\begin{array}{c}\text { Sump } \\
\text { Volume } \\
\text { (L) }\end{array}$ & $\begin{array}{l}\text { Hydro } \\
\text { Zone } \\
\text { Code }\end{array}$ & $\begin{array}{c}\text { Geo } \\
\text { Unit } \\
\text { Code }\end{array}$ \\
\hline 1 & 792.9 & 816 & 5784.6 & 5761.5 & 23.1 & 787.5 & 5790.0 & 816.0 & 5761.5 & 840.0 & 24.0 & 73.7 & RT & $\mathrm{Tp}$ \\
\hline
\end{tabular}

Note: R-4 Brass Cap Ground Elevation: $6577.49 \mathrm{ft}$; all measurements are from this elevation

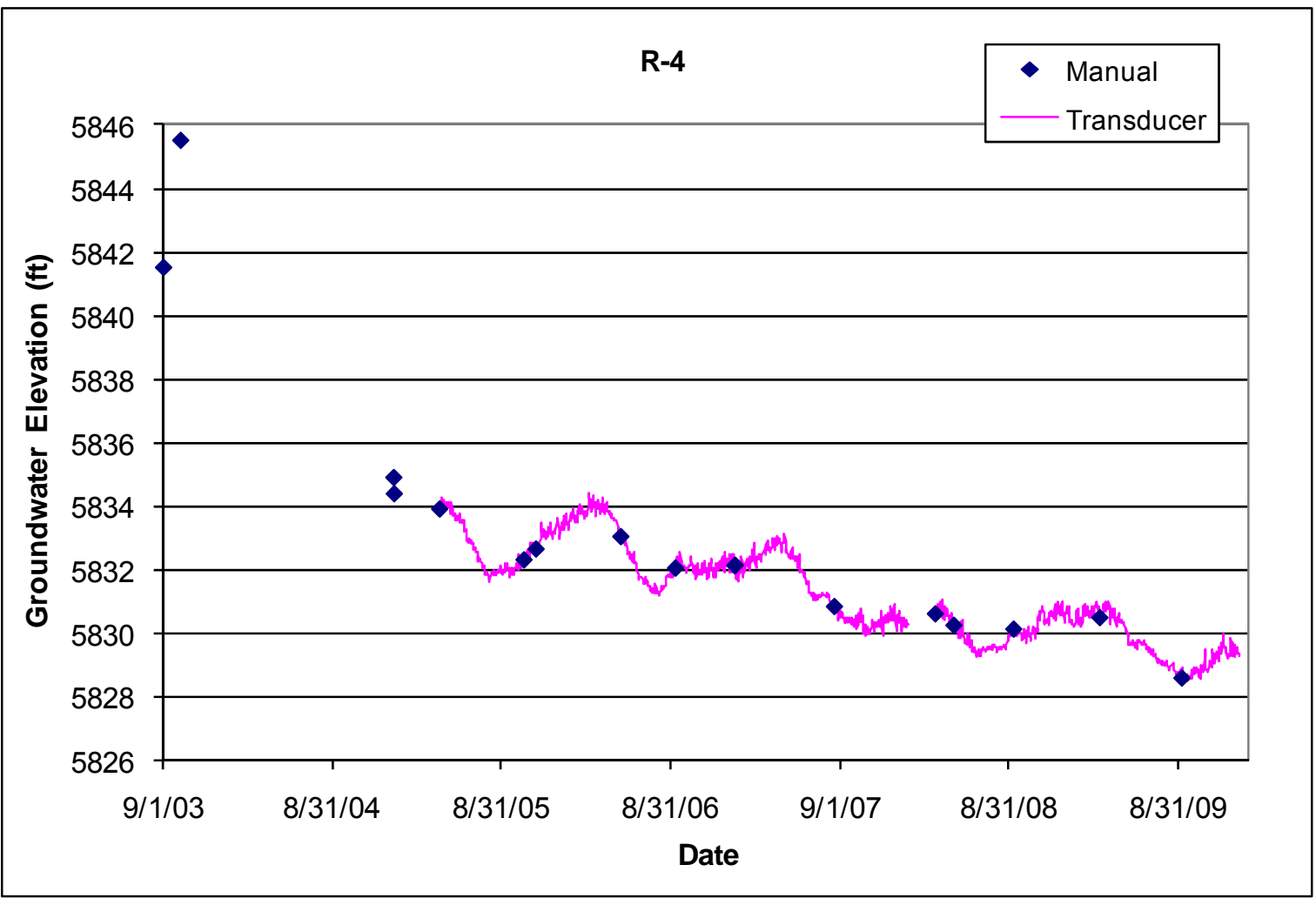




\section{$3.6 \quad \mathrm{R}-5$}

Location: R-5 is located in lower Pueblo Canyon upstream of supply well O-1.

Completion Type: Multiple completion, two screens in intermediate zones, two screens in regional zones.

Period of Record: Westbay ${ }^{\circledR}$ installed July 17, 2001, transducers installed December 17, 2001, and April 4, 2005, intermittent data through 2009.

Remarks: Screen 1 has been dry since well installation, although there is about $3 \mathrm{ft}$ of water above port MP1B in the sump below screen 1. The screen 2 intermediate groundwater level is about $6 \mathrm{ft}$ below the bottom of screen 1. The two regional screens have heads about 10 to $15 \mathrm{ft}$ apart. The water level at the top of the regional aquifer at screen 3 declined below port MP3A in 2001; samples are collected and groundwater level is monitored from port MP3B. The water level at screen 4 responds primarily to supply well pumping at PM-1, but screen 3 apparently shows little or no response. The R-5 regional aquifer screens do not indicate a response to atmospheric pressure fluctuations.

\begin{tabular}{|c|c|c|c|c|c|c|c|c|c|c|c|c|c|}
\hline \multicolumn{14}{|c|}{ R-5 Construction and Port Data } \\
\hline Screen & $\begin{array}{c}\text { Screen } \\
\text { Top } \\
\text { Depth } \\
\text { (ft) }\end{array}$ & $\begin{array}{c}\text { Screen } \\
\text { Bottom } \\
\text { Depth } \\
\text { (ft) }\end{array}$ & $\begin{array}{c}\text { Screen } \\
\text { Top } \\
\text { Elev } \\
\text { (ft) }\end{array}$ & $\begin{array}{l}\text { Screen } \\
\text { Bottom } \\
\text { Elev (ft) }\end{array}$ & $\begin{array}{c}\text { Screen } \\
\text { Length } \\
\text { (ft) }\end{array}$ & $\begin{array}{l}\text { Hydro } \\
\text { Zone } \\
\text { Code }\end{array}$ & $\begin{array}{l}\text { Geo } \\
\text { Unit } \\
\text { Code }\end{array}$ & Port & $\begin{array}{l}\text { Port } \\
\text { Depth } \\
\text { (ft) }\end{array}$ & $\begin{array}{c}\text { Port } \\
\text { Elevation } \\
\text { (ft) }\end{array}$ & $\begin{array}{l}\text { Distance } \\
\text { from } \\
\text { Bottom } \\
\text { of Screen } \\
\text { (ft) }\end{array}$ & $\begin{array}{l}\text { Sump } \\
\text { Volume } \\
\text { (L) }\end{array}$ & Comment \\
\hline \multirow{3}{*}{1} & \multirow{3}{*}{326.4} & \multirow{3}{*}{331.5} & \multirow{3}{*}{6146.2} & \multirow{3}{*}{6141.1} & \multirow{3}{*}{5.1} & \multirow{3}{*}{ I } & \multirow{3}{*}{ Tp } & MP1A & 329.5 & 6143.1 & 2.0 & & Within Screen, Screen Dry \\
\hline & & & & & & & & PP1 & 334.9 & 6137.7 & -3.4 & 9.8 & Below Screen \\
\hline & & & & & & & & MP1B & 350.4 & 6122.2 & -18.9 & 54.7 & Below Screen, $3 \mathrm{ft}$ of water \\
\hline \multirow{3}{*}{2} & \multirow{3}{*}{372.8} & \multirow{3}{*}{388.8} & \multirow{3}{*}{6099.8} & \multirow{3}{*}{6083.8} & \multirow{3}{*}{16.0} & \multirow{3}{*}{ I } & \multirow{3}{*}{ Tp } & MP2A & 383.9 & 6088.7 & 4.9 & & Within Screen \\
\hline & & & & & & & & PP2 & 388.8 & 6083.8 & 0.0 & 0.0 & At Bottom of Screen \\
\hline & & & & & & & & MP2B & 394.4 & 6078.2 & -5.6 & 16.2 & Below Screen \\
\hline \multirow{3}{*}{3} & \multirow{3}{*}{676.9} & \multirow{3}{*}{720.3} & \multirow{3}{*}{5795.7} & \multirow{3}{*}{5752.3} & \multirow{3}{*}{43.4} & \multirow{3}{*}{ RT } & \multirow{3}{*}{ Tsf } & MP3A & 695.1 & 5777.5 & 25.2 & & Within Screen, Port Dry \\
\hline & & & & & & & & MP3B & 718.6 & 5754.0 & 1.7 & & Within Screen, Port sampled \\
\hline & & & & & & & & PP3 & 724.0 & 5748.6 & -3.7 & 10.7 & Below Screen \\
\hline \multirow{3}{*}{4} & \multirow{3}{*}{858.7} & \multirow{3}{*}{863.7} & \multirow{3}{*}{5613.9} & \multirow{3}{*}{5608.9} & \multirow{3}{*}{5.0} & \multirow{3}{*}{ RD } & \multirow{3}{*}{ Tsfb } & MP4A & 860.9 & 5611.7 & 2.8 & & Within Screen \\
\hline & & & & & & & & PP4 & 866.3 & 5606.3 & -2.6 & 7.5 & Below Screen \\
\hline & & & & & & & & MP4B & 871.9 & 5600.7 & -8.2 & 23.7 & Below Screen \\
\hline
\end{tabular}

Note: R-5 Brass Cap Ground Elevation: $6472.6 \mathrm{ft}$; all measurements are from this elevation;

MP = Monitor Port; PP = Pump Port; Monitor Ports shown in bold are instrumented ports 

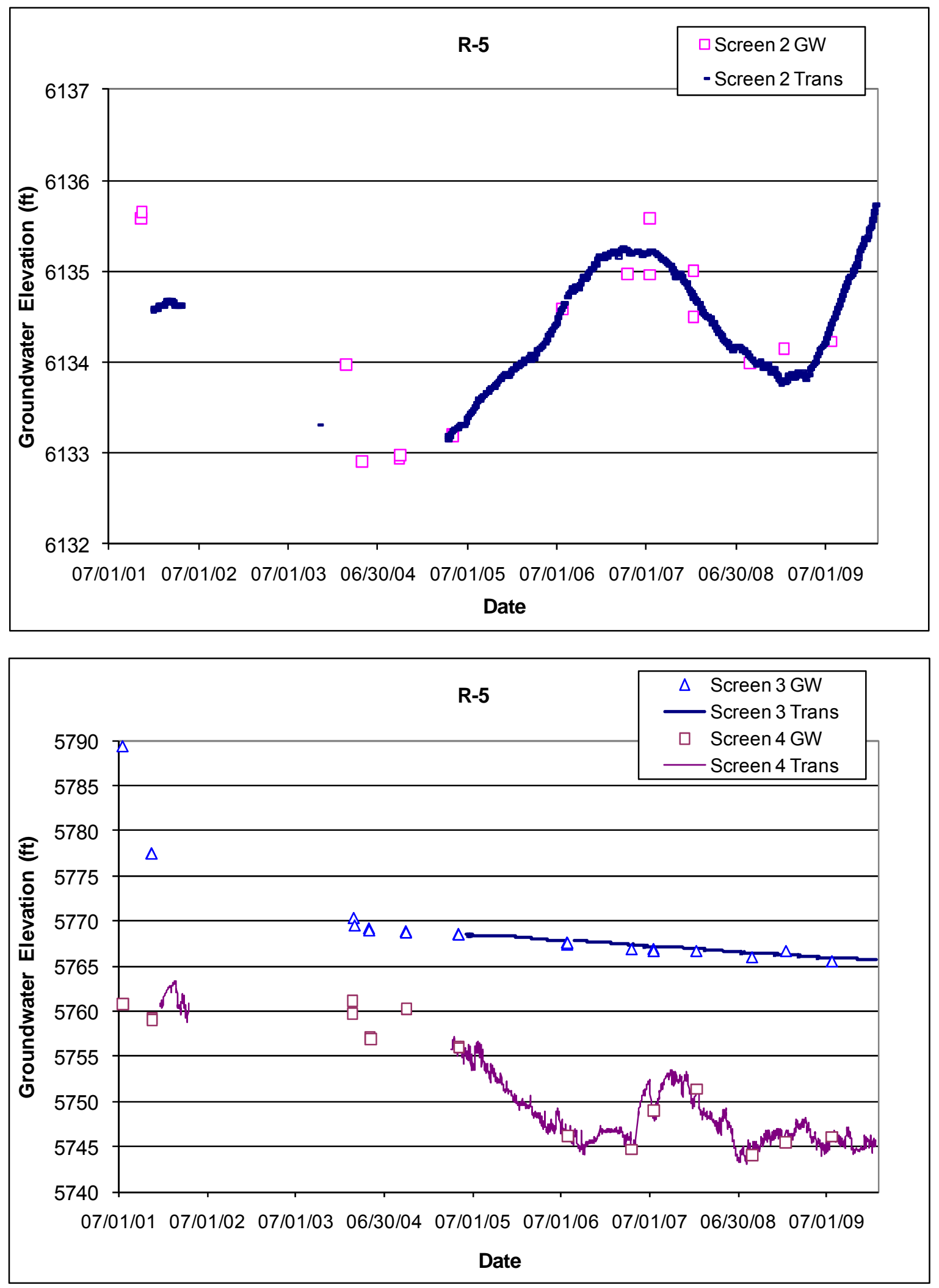


\section{$3.7 \quad \mathrm{R}-6$}

Location: R-6 is located at the east end of DP Mesa between DP Canyon and Los Alamos Canyon. Completion Type: Single completion at the top of the regional aquifer. The top of the screen is about $49 \mathrm{ft}$ below the water table.

Period of Record: Well completed November 2004, transducer installed December 2004, data through 2009.

Remarks: R-6 was completed to a depth of $1252 \mathrm{ft}$, about $100 \mathrm{ft}$ into the regional aquifer. The well is $100 \%$ barometrically efficient; the aquifer has no immediate response to atmospheric pressure fluctuations.

\begin{tabular}{|c|c|c|c|c|c|c|c|c|c|c|c|c|c|c|}
\hline \multicolumn{15}{|c|}{ R-6 Construction Information } \\
\hline Screen & $\begin{array}{l}\text { Screen } \\
\text { Top } \\
\text { Depth } \\
\text { (ft) }\end{array}$ & $\begin{array}{c}\text { Screen } \\
\text { Bottom } \\
\text { Depth } \\
\text { (ft) }\end{array}$ & $\begin{array}{l}\text { Screen } \\
\text { Top } \\
\text { Elev (ft) }\end{array}$ & $\begin{array}{l}\text { Screen } \\
\text { Bottom } \\
\text { Elev }(\mathrm{ft})\end{array}$ & $\begin{array}{c}\text { Screen } \\
\text { Length } \\
\text { (ft) }\end{array}$ & $\begin{array}{c}\text { Pump } \\
\text { Intake } \\
\text { Depth } \\
\text { (ft) }\end{array}$ & $\begin{array}{c}\text { Pump } \\
\text { Intake } \\
\text { Elev } \\
\text { (ft) }\end{array}$ & $\begin{array}{c}\text { Depth to } \\
\text { Top of } \\
\text { Sump } \\
\text { (ft) }\end{array}$ & $\begin{array}{c}\text { Top of } \\
\text { Sump } \\
\text { Elev } \\
\text { (ft) }\end{array}$ & $\begin{array}{l}\text { Depth to } \\
\text { Sump } \\
\text { Bottom } \\
\text { (ft) }\end{array}$ & $\begin{array}{c}\text { Sump } \\
\text { Length } \\
\text { (ft) }\end{array}$ & $\begin{array}{l}\text { Sump } \\
\text { Volume } \\
\text { (L) }\end{array}$ & $\begin{array}{l}\text { Hydro } \\
\text { Zone } \\
\text { Code }\end{array}$ & $\begin{array}{c}\text { Geo } \\
\text { Unit } \\
\text { Code }\end{array}$ \\
\hline 1 & 1205.0 & 1228.0 & 5790.8 & 5767.8 & 23.0 & & 6995.8 & 1228.0 & 5767.8 & 1252.0 & 24.0 & 73.7 & RT & $\overline{T f}$ \\
\hline
\end{tabular}

Note: Brass Cap Ground Elevation: $6995.8 \mathrm{ft}$; all measurements are from this elevation

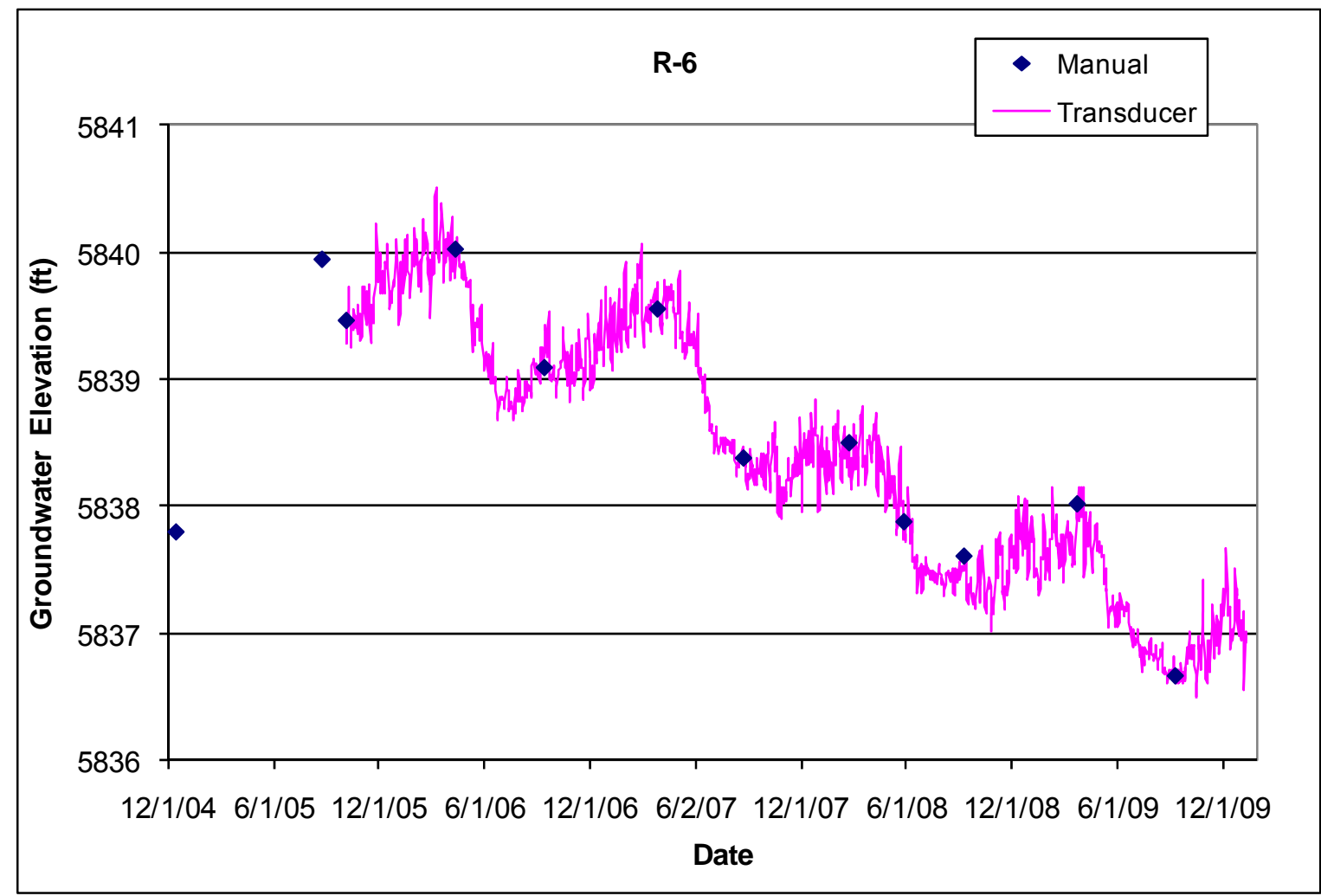




\section{$3.8 \quad \mathrm{R}-7$}

Location: R-7 is located in middle Los Alamos Canyon about 1 mile upstream of supply well O-4.

Completion Type: Multiple completion, two screens in intermediate zones, one screen at the top of the regional aquifer.

Period of Record: Westbay ${ }^{\circledR}$ installed February 25, 2001, transducers installed February 28, 2001, intermittent data to July 20, 2009. Equipment problems caused data loss from July 2009 to January 2010.

Remarks: Initial transducer data from MP1A are not valid because transducer apparently did not connect properly to port. Port MP1A at intermediate screen 1 went dry during sampling on December 18, 2003. Pressure data from port MP1B located in the sump have indicated 3 to 4 $\mathrm{ft}$ of water present above the port but below the screen since 2005. The screen 2 intermediate screen has been dry since well installation but port MP2B indicates about $1 \mathrm{ft}$ of water in the sump above the port since mid 2008. The regional aquifer at R-7 screen 3 does not indicate a response to atmospheric pressure fluctuations and does not show a seasonal water level response to supply well pumping or a response to pumping any of the water supply wells.

\begin{tabular}{|c|c|c|c|c|c|c|c|c|c|c|c|c|}
\hline \multicolumn{13}{|c|}{ R-7 Construction and Port Data } \\
\hline Screen & \begin{tabular}{|c|} 
Screen \\
Top \\
Depth (ft)
\end{tabular} & \begin{tabular}{|c|} 
Screen \\
Bottom \\
Depth \\
(ft)
\end{tabular} & $\begin{array}{c}\text { Screen } \\
\text { Top } \\
\text { Elev (ft) }\end{array}$ & $\begin{array}{l}\text { Screen } \\
\text { Bottom } \\
\text { Elev (ft) }\end{array}$ & $\begin{array}{c}\text { Screen } \\
\text { Length } \\
\text { (ft) }\end{array}$ & $\begin{array}{c}\text { Hydro } \\
\text { Zone } \\
\text { Code }\end{array}$ & $\begin{array}{l}\text { Geo } \\
\text { Unit } \\
\text { Code }\end{array}$ & Port & $\begin{array}{c}\text { Port } \\
\text { Depth (ft) }\end{array}$ & $\begin{array}{c}\text { Port } \\
\text { Elevation } \\
(\mathrm{ft})\end{array}$ & $\begin{array}{c}\begin{array}{c}\text { Distance } \\
\text { from } \\
\text { Bottom of } \\
\text { Screen (ft) }\end{array} \\
\end{array}$ & Comment \\
\hline \multirow{3}{*}{1} & \multirow{3}{*}{363.2} & \multirow{3}{*}{379.2} & \multirow{3}{*}{6416.0} & \multirow{3}{*}{6400.0} & \multirow{3}{*}{16.0} & \multirow{3}{*}{1} & \multirow{3}{*}{$\mathrm{Tp}$} & MP1A & 378.0 & 6401.2 & 1.2 & Within screen - Screen dry \\
\hline & & & & & & & & PP1 & 383.3 & 6395.9 & -4.1 & Below screen \\
\hline & & & & & & & & MP1B & 389.0 & 6390.2 & -9.8 & Below screen \\
\hline \multirow{3}{*}{2} & \multirow{3}{*}{730.4} & \multirow{3}{*}{746.4} & \multirow{3}{*}{6048.8} & \multirow{3}{*}{6032.8} & \multirow{3}{*}{16.0} & \multirow{3}{*}{1} & \multirow{3}{*}{$\mathrm{Tp}$} & MP2A & 744.8 & 6034.4 & 1.6 & Within screen - Screen dry \\
\hline & & & & & & & & PP2 & 750.1 & 6029.1 & -3.7 & Below screen \\
\hline & & & & & & & & MP2B & 755.8 & 6023.4 & -9.4 & Below screen \\
\hline \multirow{4}{*}{3} & \multirow{4}{*}{895.5} & \multirow{4}{*}{937.4} & \multirow{4}{*}{5883.7} & \multirow{4}{*}{5841.8} & \multirow{4}{*}{41.9} & \multirow{4}{*}{ RT } & \multirow{4}{*}{ Tp } & MP3A & 915.1 & 5864.1 & 22.3 & Within screen \\
\hline & & & & & & & & MP3B & 935.3 & 5843.9 & 2.1 & Within screen \\
\hline & & & & & & & & PP3 & 940.6 & 5838.6 & -3.2 & Below screen \\
\hline & & & & & & & & MP3C & 946.3 & 5832.9 & -8.9 & Below screen \\
\hline
\end{tabular}

Note: R-7 Brass Cap Ground Elevation: $6779.2 \mathrm{ft}$; all measurements are from this elevation

$\mathrm{MP}=$ Monitor Port; PP = Pump Port; Monitor Ports shown in bold are instrumented ports 

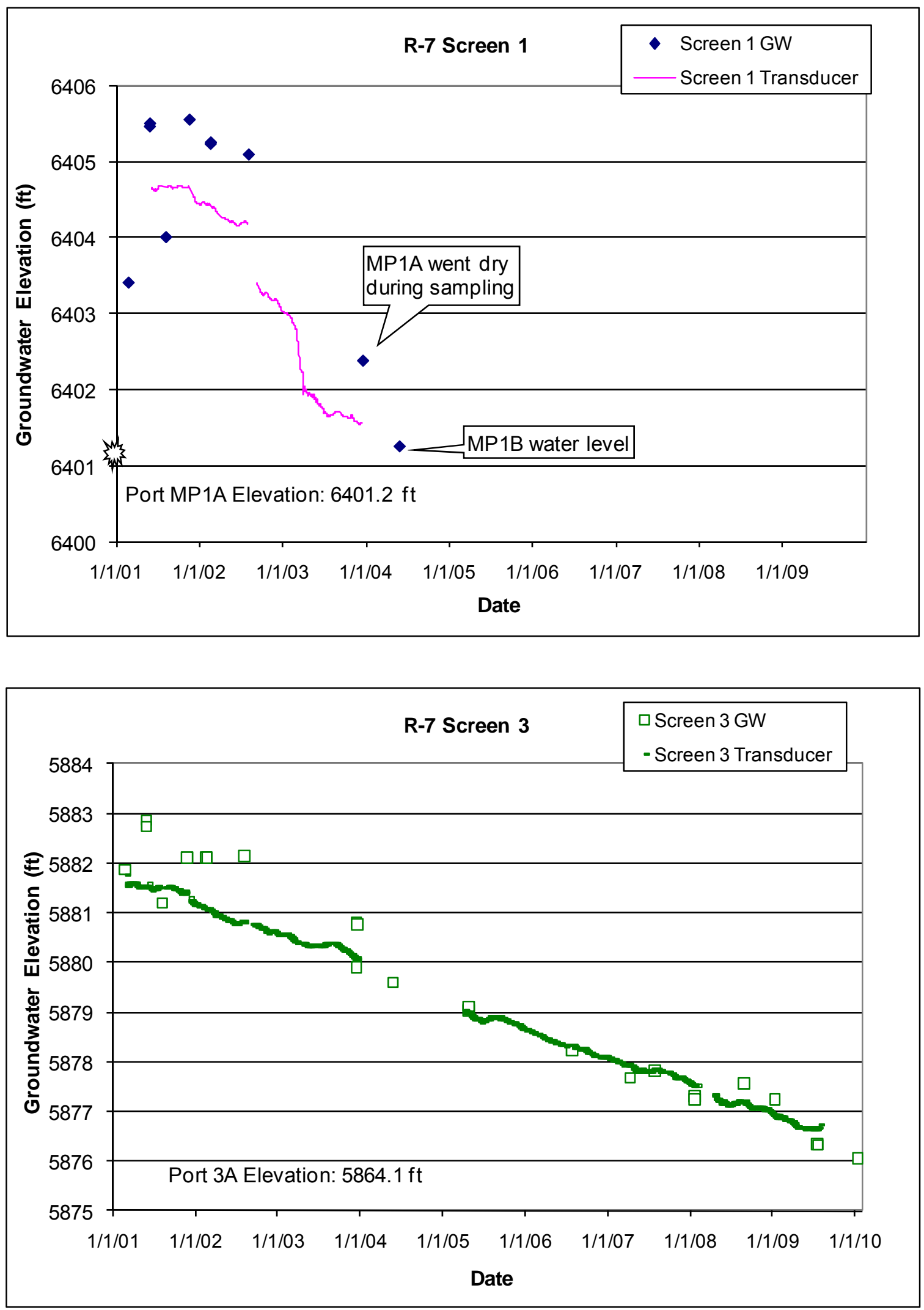


\section{$3.9 \quad$ R-8}

Location: R-8 is located in middle Los Alamos Canyon about 0.75 miles downstream of the confluence with DP Canyon and supply well O-4.

Completion Type: Multiple completion, two screens in the regional aquifer. The top of screen 1 is about $16 \mathrm{ft}$ below the water table.

Period of Record: Westbay ${ }^{\circledR}$ installed February 23, 2002, transducers installed April 7, 2005, data through 2009.

Remarks: Screens are $66 \mathrm{ft}$ apart, head in screen 2 about $20 \mathrm{ft}$ lower than screen 1 . The groundwater does not indicate a response to atmospheric pressure fluctuations, but the groundwater at both screens responds to pumping supply well PM-3.

\begin{tabular}{|c|c|c|c|c|c|c|c|c|c|c|c|c|}
\hline \multicolumn{13}{|c|}{ R-8 Construction and Port Data } \\
\hline Screen & $\begin{array}{c}\text { Screen } \\
\text { Top } \\
\text { Depth } \\
\text { (ft) }\end{array}$ & $\begin{array}{c}\text { Screen } \\
\text { Bottom } \\
\text { Depth } \\
\text { (ft) }\end{array}$ & $\begin{array}{l}\text { Screen } \\
\text { Top } \\
\text { Elev (ft) }\end{array}$ & $\begin{array}{l}\text { Screen } \\
\text { Bottom } \\
\text { Elev (ft) }\end{array}$ & $\begin{array}{l}\text { Screen } \\
\text { Length } \\
\text { (ft) }\end{array}$ & $\begin{array}{l}\text { Hydro } \\
\text { Zone } \\
\text { Code }\end{array}$ & \begin{tabular}{|l|} 
Geo \\
Unit \\
Code
\end{tabular} & Port & $\begin{array}{l}\text { Port } \\
\text { Depth } \\
\text { (ft) }\end{array}$ & $\begin{array}{c}\text { Port } \\
\text { Elevation } \\
\text { (ft) }\end{array}$ & $\begin{array}{l}\text { Distance } \\
\text { from } \\
\text { Bottom } \\
\text { of } \\
\text { Screen } \\
\text { (ft) }\end{array}$ & Comment \\
\hline \multirow{5}{*}{1} & \multirow{5}{*}{705.3} & \multirow{5}{*}{755.7} & \multirow{5}{*}{5839.4} & \multirow{5}{*}{5789.04} & \multirow{5}{*}{50.4} & \multirow{5}{*}{ RT } & \multirow{5}{*}{$\mathrm{Tp}$} & $\overline{M P 1 A}$ & 711.1 & 5833.64 & 44.6 & Within Screen \\
\hline & & & & & & & & MP1B & 721.4 & 5823.34 & 34.3 & Within Screen \\
\hline & & & & & & & & MP1C & 751.3 & 5793.44 & 4.4 & Within Screen \\
\hline & & & & & & & & PP1 & 756.7 & 5788.04 & -1.0 & Below Screen \\
\hline & & & & & & & & MP1D & 762.3 & 5782.44 & -6.6 & Below Screen \\
\hline \multirow{3}{*}{2} & \multirow{3}{*}{821.3} & \multirow{3}{*}{828.0} & \multirow{3}{*}{5723.4} & \multirow{3}{*}{5716.74} & \multirow{3}{*}{6.7} & \multirow{3}{*}{$\mathrm{RD}$} & \multirow{3}{*}{$\mathrm{Tp}$} & $\mathrm{MP} 2 \mathrm{~A}$ & 825.0 & 5719.74 & 3.0 & Within Screen \\
\hline & & & & & & & & PP2 & 830.4 & 5714.34 & $\overline{-2.4}$ & Below Screen \\
\hline & & & & & & & & MP2B & 836.0 & 5708.7 & -8.0 & Below Screen \\
\hline
\end{tabular}

Note: R-8 Brass Cap Ground Elevation: $6544.74 \mathrm{ft}$; all measurements are from this elevation;

MP = Monitor Port; PP = Pump Port; Monitor Ports shown in bold are instrumented ports

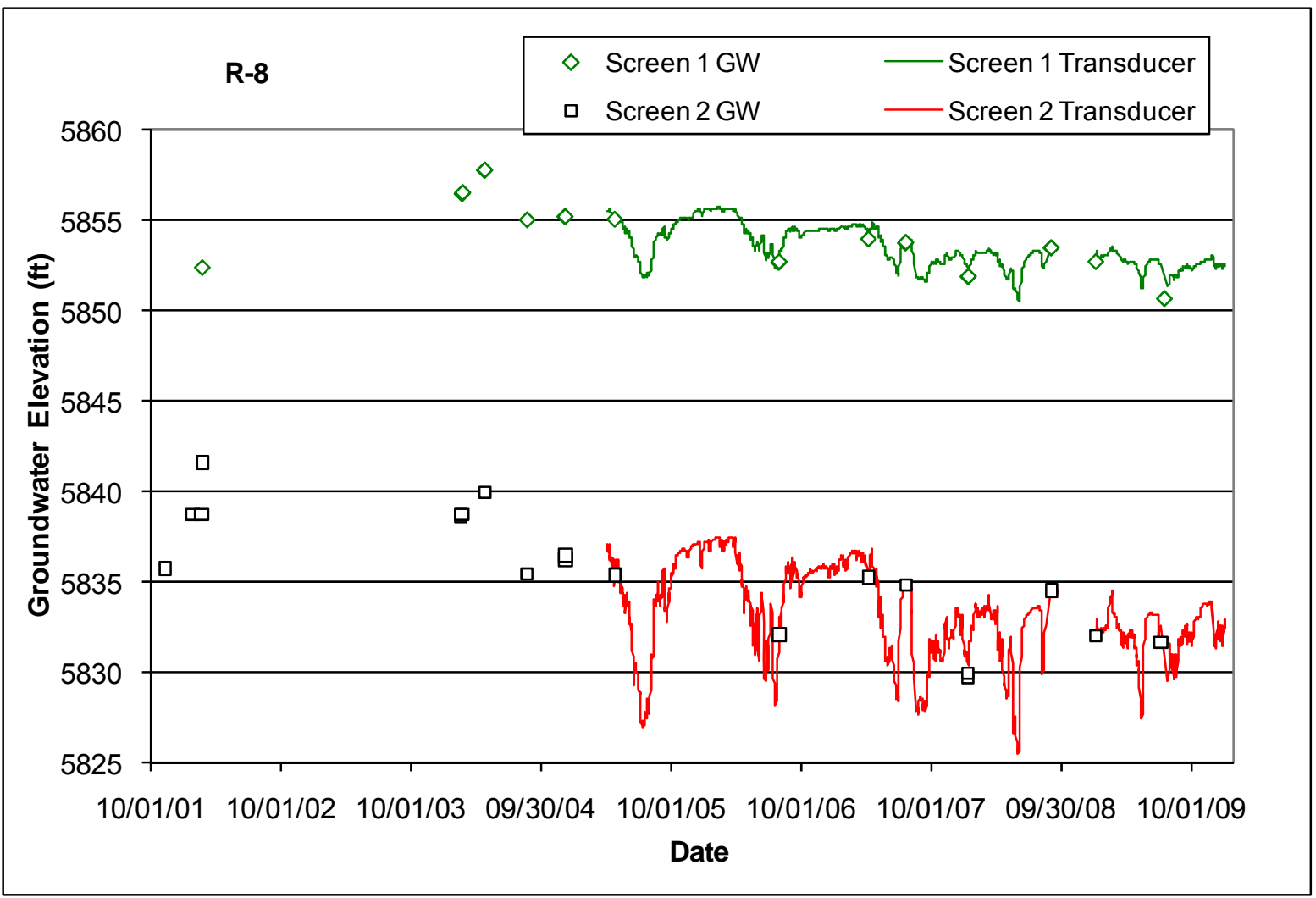




\subsection{R-9}

Location: R-9 is located in Los Alamos Canyon near the eastern LANL boundary.

Completion Type: Single completion at the top of the regional aquifer. The screen straddles the water table.

Period of Record: March 2, 1998, to August 12, 1998, in temporary well. Final well completed October 1999. Transducer installed April 5, 2005, data through 2009.

Remarks: R-9 was completed to a depth of $758 \mathrm{ft}$, about $70 \mathrm{ft}$ into the regional aquifer. The well is $100 \%$ barometrically efficient; the groundwater has no immediate response to atmospheric pressure fluctuations. However, the aquifer indicates a delayed $65 \%$ response to atmospheric pressure.

\begin{tabular}{|c|c|c|c|c|c|c|c|c|c|c|c|c|c|c|}
\hline \multicolumn{15}{|c|}{ R-9 Construction Information } \\
\hline Screen & $\begin{array}{c}\text { Screen } \\
\text { Top } \\
\text { Depth (ft) }\end{array}$ & $\begin{array}{c}\text { Screen } \\
\text { Bottom } \\
\text { Depth } \\
\text { (ft) }\end{array}$ & $\begin{array}{c}\text { Screen } \\
\text { Top } \\
\text { Elev (ft) }\end{array}$ & $\begin{array}{l}\text { Screen } \\
\text { Bottom } \\
\text { Elev (ft) }\end{array}$ & $\begin{array}{c}\text { Screen } \\
\text { Length } \\
\text { (ft) }\end{array}$ & $\begin{array}{l}\text { Pump } \\
\text { Intake } \\
\text { Depth } \\
\text { (ft) }\end{array}$ & $\begin{array}{c}\text { Pump } \\
\text { Intake } \\
\text { Elevation } \\
\text { (ft) }\end{array}$ & $\begin{array}{c}\text { Depth to } \\
\text { Top of } \\
\text { Sump (ft) }\end{array}$ & $\begin{array}{c}\text { Top of } \\
\text { Sump } \\
\text { Elevation } \\
\text { (ft) }\end{array}$ & $\begin{array}{l}\text { Depth } \\
\text { to } \\
\text { Sump } \\
\text { Bottom } \\
\text { (ft) }\end{array}$ & $\begin{array}{c}\text { Sump } \\
\text { Length } \\
\text { (ft) }\end{array}$ & $\begin{array}{c}\text { Sump } \\
\text { Volume } \\
\text { (L) }\end{array}$ & $\begin{array}{c}\text { Hydro } \\
\text { Zone } \\
\text { Code }\end{array}$ & $\begin{array}{c}\text { Geo } \\
\text { Unit } \\
\text { Code }\end{array}$ \\
\hline 1 & 683.0 & 748.5 & 5699.8 & 5634.3 & 65.5 & 741.4 & 5641.4 & 748.5 & 5634.3 & 758 & 9.5 & 29.7 & RT & $\overline{T s f b}$ \\
\hline
\end{tabular}

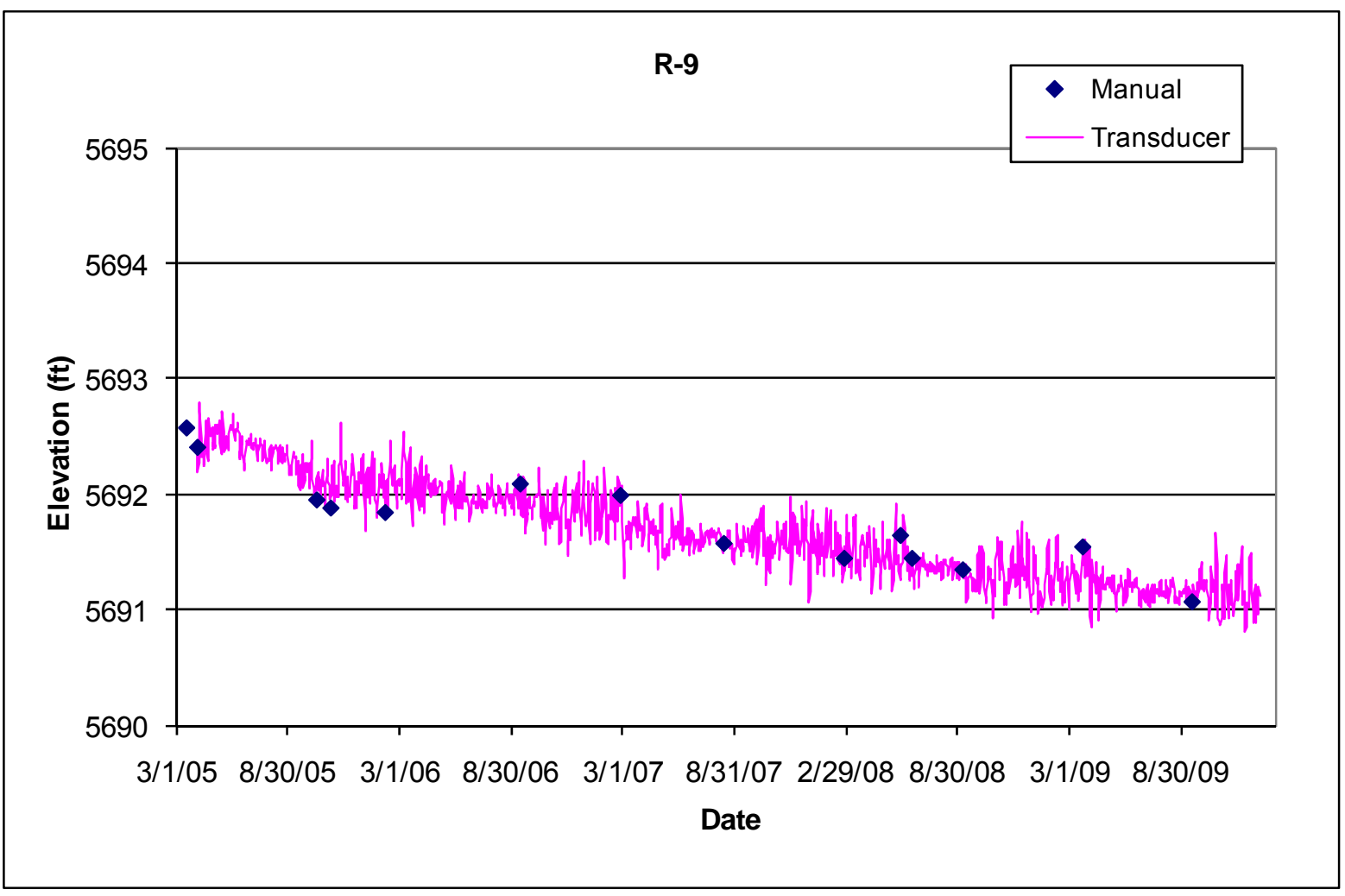




\subsection{R-10}

Location: R-10 is located in lower Sandia Canyon on San Ildefonso land east of the LANL boundary.

Completion Type: Dual completion in two deeper zones within the regional aquifer. Baski packer and dual valve sampling system with single submersible pump installed in May 2006.

Period of Record: Well completed October 2005, transducers installed July 26, 2006, data through 2009. The transducers were removed during repair of the Baski system in 2008 and 2009.

Remarks: R-10 screen 1 is $174 \mathrm{ft}$ deeper than the screen at R-10a; due to relatively low hydraulic conductivity of the formation between these screens, the head at R-10 screen 1 is $30 \mathrm{ft}$ lower than at R-10a. The screen 2 water level gage tube was inoperable until repaired in February 2008; water level data for R-10 screen 2 in 2006 and 2007 are not available. The groundwater at R-10 screens exhibit a barometric efficiency of about $45 \%$. The regional aquifer at both screens responds to pumping at supply well PM-1.

\begin{tabular}{|c|c|c|c|c|c|c|c|c|c|c|c|c|c|c|}
\hline \multicolumn{15}{|c|}{ R-10 Construction Information } \\
\hline Screen & $\begin{array}{c}\text { Screen } \\
\text { Top } \\
\text { Depth } \\
\text { (ft) }\end{array}$ & $\begin{array}{c}\text { Screen } \\
\text { Bottom } \\
\text { Depth } \\
\text { (ft) }\end{array}$ & $\begin{array}{c}\text { Screen } \\
\text { Top } \\
\text { Elev }(\mathrm{ft})\end{array}$ & $\begin{array}{l}\text { Screen } \\
\text { Bottom } \\
\text { Elev (ft) }\end{array}$ & $\begin{array}{c}\text { Screen } \\
\text { Length } \\
\text { (ft) }\end{array}$ & $\begin{array}{c}\text { Pump } \\
\text { Intake } \\
\text { Depth } \\
\text { (ft) }\end{array}$ & $\begin{array}{c}\text { Pump } \\
\text { Intake } \\
\text { Elev } \\
\text { (ft) }\end{array}$ & $\begin{array}{l}\text { Depth to } \\
\text { Top of } \\
\text { Packerl } \\
\text { Sump (ft) }\end{array}$ & $\begin{array}{c}\text { Top of } \\
\text { Packerl } \\
\text { Sump } \\
\text { Elev (ft) }\end{array}$ & \begin{tabular}{|} 
Depth to \\
Sump \\
Bottom \\
(ft)
\end{tabular} & $\begin{array}{c}\text { Sump } \\
\text { Length } \\
\text { (ft) }\end{array}$ & $\begin{array}{c}\text { Sump } \\
\text { Volume } \\
\text { (L) }\end{array}$ & $\begin{array}{c}\text { Hydro } \\
\text { Zone } \\
\text { Code }\end{array}$ & $\begin{array}{l}\text { Geo } \\
\text { Unit } \\
\text { Code }\end{array}$ \\
\hline 1 & 874.0 & 897.0 & 5488.3 & 5465.3 & 23.0 & 884.3 & 5478.0 & 905.2 & 5457.2 & 905.2 & 8.2 & 25.5 & $\mathrm{RD}$ & Tsf \\
\hline 2 & 1042.0 & 1065.0 & 5320.3 & 5297.3 & 23.0 & 1053.1 & 5309.2 & 1065.0 & 5297.3 & 1081.6 & 16.6 & 5.8 & RD & Tsf \\
\hline
\end{tabular}

Note: R-10 Brass Cap Ground Elevation: $6362.31 \mathrm{ft}$; all measurements are from this elevation

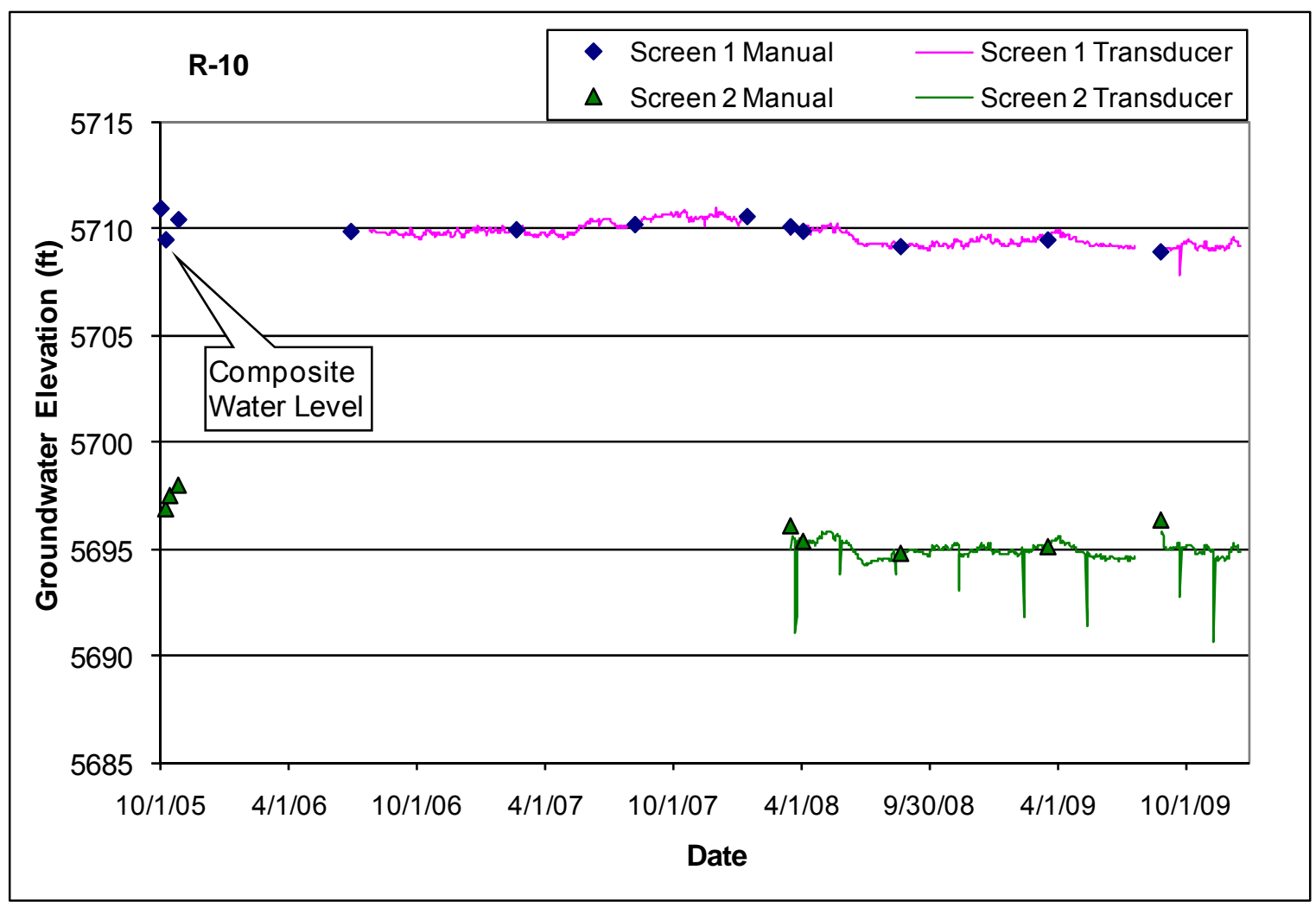




\subsection{R-10a}

Location: R-10a is located in lower Sandia Canyon on San Ildefonso land east of the LANL boundary adjacent to R-10.

Completion Type: Single completion at the top of the regional aquifer. The top of the screen is about $67 \mathrm{ft}$ below the water table.

Period of Record: Well completed August 2005, transducer installed April 3, 2006, data through 2009.

Remarks: The R-10a water level is about $30 \mathrm{ft}$ higher than at R-10 screen 1 . The groundwater at R10 a shows an immediate $58 \%$ response to atmospheric pressure fluctuations for a well barometric efficiency of $42 \%$. There is no apparent response to supply well pumping at R10a.

\begin{tabular}{|c|c|c|c|c|c|c|c|c|c|c|c|c|c|c|}
\hline \multicolumn{15}{|c|}{ R-10a Construction Information } \\
\hline Screen & $\begin{array}{c}\text { Screen } \\
\text { Top } \\
\text { Depth } \\
\text { (ft) }\end{array}$ & $\begin{array}{c}\text { Screen } \\
\text { Bottom } \\
\text { Depth } \\
\text { (ft) }\end{array}$ & $\begin{array}{l}\text { Screen } \\
\text { Top } \\
\text { Elev (ft) }\end{array}$ & $\begin{array}{l}\text { Screen } \\
\text { Bottom } \\
\text { Elev (ft) }\end{array}$ & $\begin{array}{c}\text { Screen } \\
\text { Length } \\
\text { (ft) }\end{array}$ & $\begin{array}{c}\text { Pump } \\
\text { Intake } \\
\text { Depth } \\
\text { (ft) }\end{array}$ & $\begin{array}{c}\text { Pump } \\
\text { Intake } \\
\text { Elev } \\
(\mathrm{ft})\end{array}$ & \begin{tabular}{|c} 
Depth to \\
Top of \\
Sump \\
(ft)
\end{tabular} & $\begin{array}{c}\text { Top of } \\
\text { Sump } \\
\text { Elev } \\
\text { (ft) }\end{array}$ & $\begin{array}{l}\text { Depth to } \\
\text { Sump } \\
\text { Bottom } \\
\text { (ft) }\end{array}$ & $\begin{array}{c}\text { Sump } \\
\text { Length } \\
\text { (ft) }\end{array}$ & $\begin{array}{c}\text { Sump } \\
\text { Volume } \\
\text { (L) }\end{array}$ & $\begin{array}{l}\text { Hydro } \\
\text { Zone } \\
\text { Code }\end{array}$ & $\begin{array}{l}\text { Geo } \\
\text { Unit } \\
\text { Code }\end{array}$ \\
\hline 1 & 690.0 & 700.0 & 5673.7 & 5663.7 & 10.0 & 685.6 & 5678.1 & 700.0 & 5663.7 & 709.1 & 9.1 & 27.9 & RT & Tsf \\
\hline
\end{tabular}

Note: Brass Cap Ground Elevation: $6363.74 \mathrm{ft}$; all measurements are from this elevation

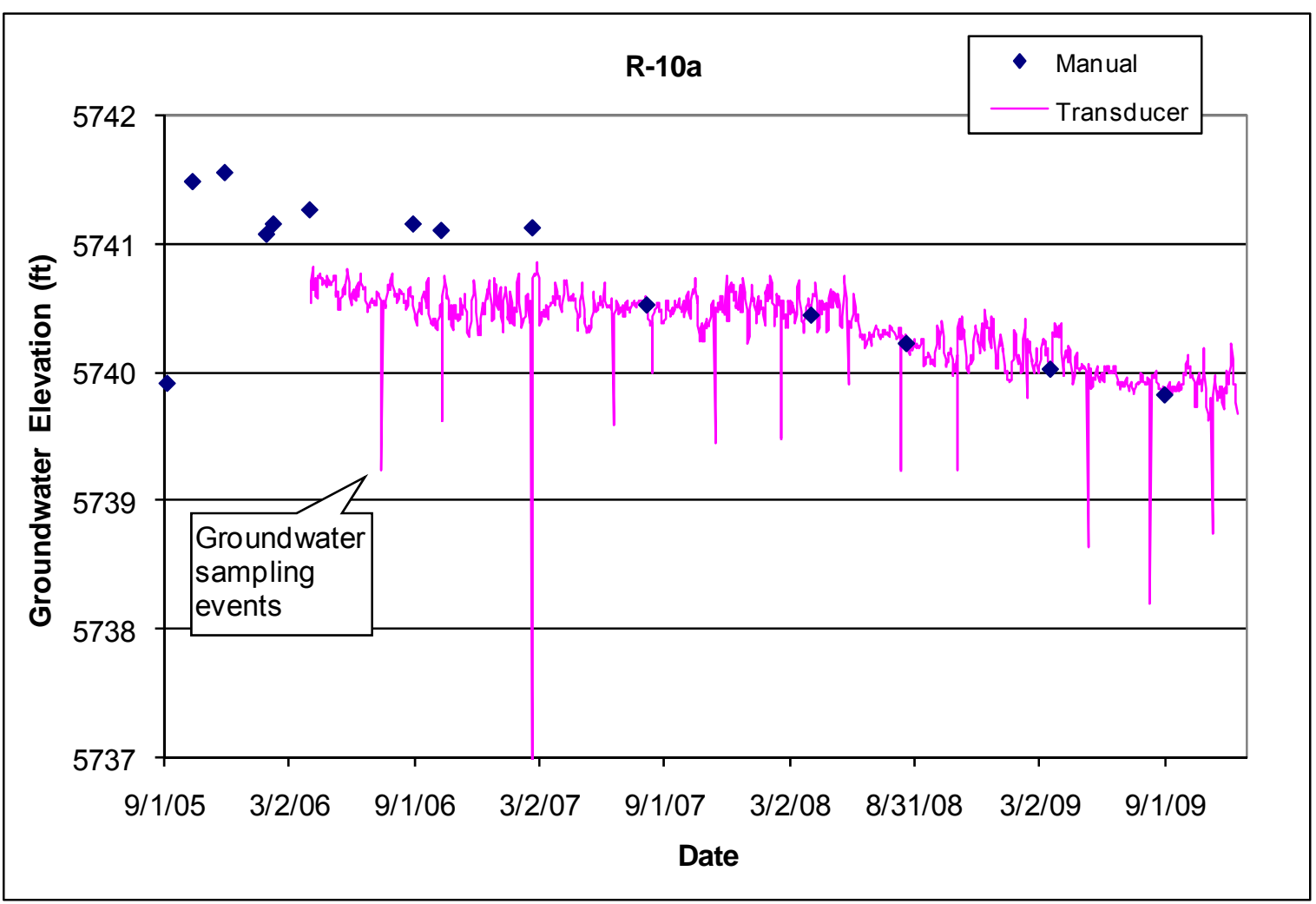




\subsection{R-11}

Location: R-11 is located in middle Sandia Canyon about 0.5 miles upstream of supply well PM-3.

Completion Type: Single completion at the top of the regional aquifer. The top of the screen is about $20 \mathrm{ft}$ below the water table.

Period of Record: Transducer installed May 4, 2005; data through 2009.

Remarks: R-11 was completed in 2004 to a depth of $901.7 \mathrm{ft}$, about $66 \mathrm{ft}$ into the regional aquifer. The well is $100 \%$ barometrically efficient; the groundwater has no immediate response to atmospheric pressure fluctuations. The aquifer at $\mathrm{R}-11$ exhibits a seasonal response to supply well pumping but does not indicate a direct response to any specific supply well.

\begin{tabular}{|c|c|c|c|c|c|c|c|c|c|c|c|c|c|c|}
\hline \multicolumn{15}{|c|}{ R-11 Construction Information } \\
\hline Screen & $\begin{array}{c}\text { Screen } \\
\text { Top } \\
\text { Depth } \\
\text { (ft) }\end{array}$ & \begin{tabular}{|c} 
Screen \\
Bottom \\
Depth \\
(ft)
\end{tabular} & $\begin{array}{c}\text { Screen } \\
\text { Top } \\
\text { Elev } \\
\text { (ft) }\end{array}$ & \begin{tabular}{|c} 
Screen \\
Bottom \\
Elev \\
(ft)
\end{tabular} & $\begin{array}{c}\text { Screen } \\
\text { Length } \\
\text { (ft) }\end{array}$ & $\begin{array}{l}\text { Pump } \\
\text { Intake } \\
\text { Depth } \\
\text { (ft) }\end{array}$ & $\begin{array}{c}\text { Pump } \\
\text { Intake } \\
\text { Elev } \\
\text { (ft) }\end{array}$ & \begin{tabular}{|c} 
Depth to \\
Top of \\
Sump \\
(ft)
\end{tabular} & $\begin{array}{c}\text { Top of } \\
\text { Sump } \\
\text { Elev } \\
\text { (ft) }\end{array}$ & \begin{tabular}{|} 
Depth to \\
Sump \\
Bottom \\
(ft)
\end{tabular} & $\begin{array}{c}\text { Sump } \\
\text { Length } \\
\text { (ft) }\end{array}$ & $\begin{array}{c}\text { Sump } \\
\text { Volume } \\
\text { (L) }\end{array}$ & \begin{tabular}{|l|} 
Hydro \\
Zone \\
Code \\
\end{tabular} & $\begin{array}{l}\text { Geo } \\
\text { Unit } \\
\text { Code }\end{array}$ \\
\hline 1 & 855.0 & 877.9 & 5818.7 & 5795.8 & 22.9 & 850 & 5823.7 & 877.9 & 5795.8 & 901.7 & 23.8 & 73.1 & RT & Tp \\
\hline
\end{tabular}

Note: R-11 Brass Cap Ground Elevation: $6673.72 \mathrm{ft}$; all measurements are from this elevation

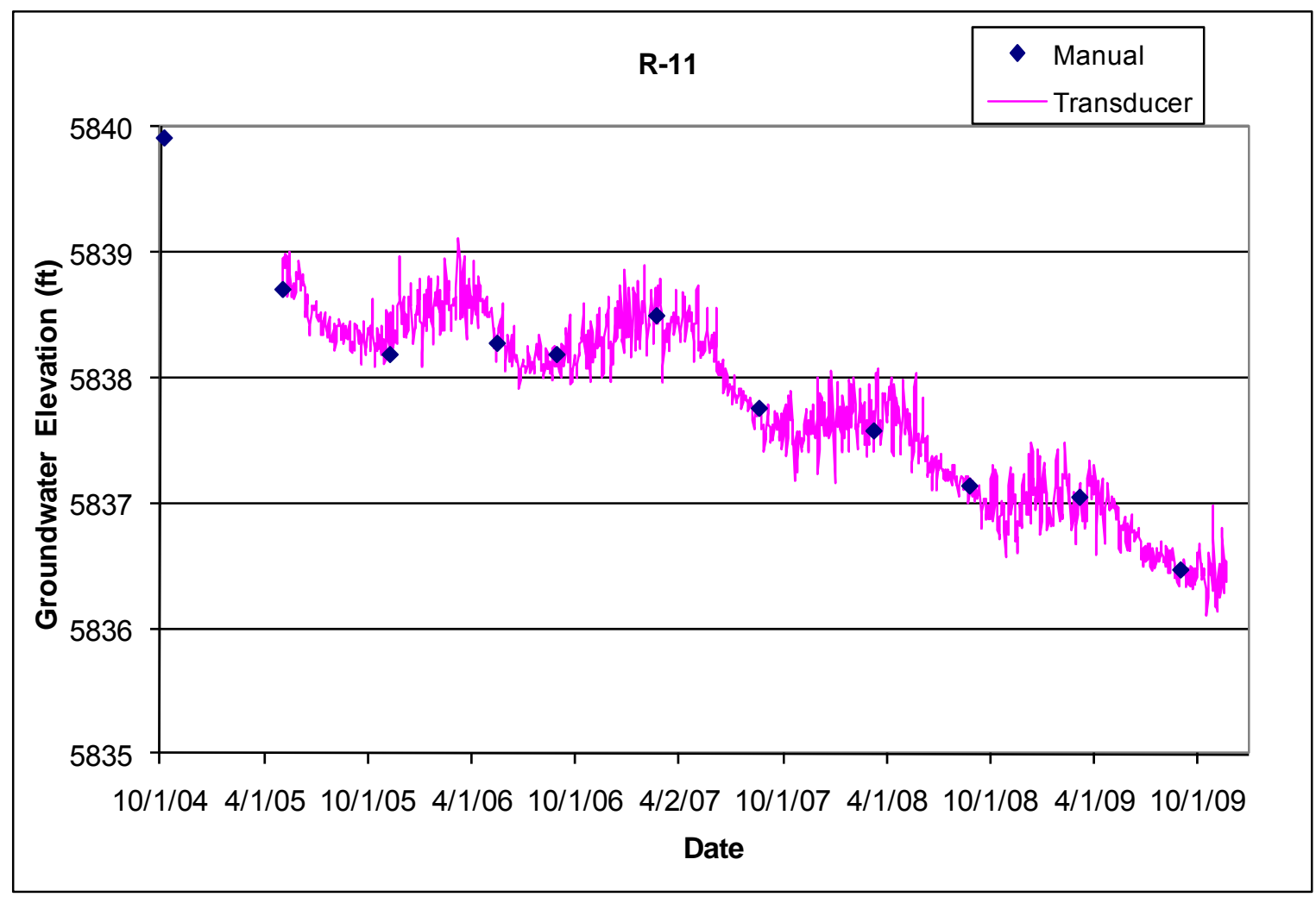




\subsection{R-12 (Regional)}

Monitoring well R-12 was recompleted as a dual screen intermediate monitoring well in December 2007. Refer to Section 4 for recent R-12 intermediate groundwater level status.

Location: R-12 is located in lower Sandia Canyon near State Route (SR) 4 and supply well PM-1. Completion Type: Multiple completion, two screens in intermediate zones, one screen at the top of the regional aquifer until September 2006. Well recompleted as two intermediate screens on December 13, 2007, when screen 3 was plugged and abandoned.

Period of Record: Westbay ${ }^{\circledR}$ installed March 21, 2000, transducers installed December 14, 2000 , intermittent data to September 21, 2006, when transducers were removed for removal of the Westbay ${ }^{\circledR}$ system for well rehabilitation. No regional aquifer water level data after 2006. Transducers were reinstalled at intermediate screens 1 and 2 on December 13, 2007; data through 2009.

Remarks: In December 2007, screen 3 was abandoned and a Baski packer with dual pump sampling system was installed at the two intermediate screens. The regional aquifer at screen 3 did not exhibit a seasonal response to supply well pumping, or a response to pumping of any specific supply well, including nearby supply well PM-1. There is no immediate response to atmospheric pressure fluctuations at any screen.

\begin{tabular}{|c|c|c|c|c|c|c|c|c|c|c|c|c|c|}
\hline \multicolumn{14}{|c|}{ R-12 Former Westbay Port Data } \\
\hline Screen & $\begin{array}{c}\text { Screen } \\
\text { Top } \\
\text { Depth } \\
\text { (ft) }\end{array}$ & $\begin{array}{c}\text { Screen } \\
\text { Bottom } \\
\text { Depth } \\
\text { (ft) }\end{array}$ & $\begin{array}{c}\text { Screen } \\
\text { Top } \\
\text { Elev } \\
\text { (ft) }\end{array}$ & \begin{tabular}{|c|} 
Screen \\
Bottom \\
Elev \\
(ft)
\end{tabular} & $\begin{array}{c}\text { Screen } \\
\text { Length } \\
\text { (ft) }\end{array}$ & $\begin{array}{l}\text { Hydro } \\
\text { Zone } \\
\text { Code }\end{array}$ & $\begin{array}{c}\text { Geo } \\
\text { Unit } \\
\text { Code }\end{array}$ & Port & $\begin{array}{l}\text { Port } \\
\text { Depth } \\
\text { (ft) }\end{array}$ & $\begin{array}{c}\text { Port } \\
\text { Elev (ft) }\end{array}$ & $\begin{array}{c}\text { Distance } \\
\text { from Bottom } \\
\text { of Screen } \\
\text { (ft) }\end{array}$ & $\begin{array}{c}\text { Sump } \\
\text { Volume } \\
\text { (L) }\end{array}$ & Comment \\
\hline \multirow{3}{*}{1} & \multirow{3}{*}{459.0} & \multirow{3}{*}{467.5} & \multirow{3}{*}{6040.6} & \multirow{3}{*}{6032.1} & \multirow{3}{*}{8.5} & \multirow{3}{*}{ I } & \multirow{3}{*}{ Tb4 } & MP1A & 468.1 & 6031.5 & -0.6 & 1.1 & Below screen \\
\hline & & & & & & & & PP1 & 473.5 & 6026.1 & -6.0 & 11.3 & Below screen \\
\hline & & & & & & & & MP1B & 479.1 & 6020.5 & -11.6 & 21.9 & Below screen \\
\hline \multirow{3}{*}{2} & \multirow{3}{*}{504.5} & \multirow{3}{*}{508.0} & \multirow{3}{*}{5995.1} & \multirow{3}{*}{5991.6} & \multirow{3}{*}{3.5} & \multirow{3}{*}{ I } & \multirow{3}{*}{ Tb4 } & MP2A & 507.0 & 5992.6 & 1.0 & & Within screen \\
\hline & & & & & & & & PP2 & 512.4 & 5987.2 & -4.4 & 8.3 & Below screen \\
\hline & & & & & & & & MP2B & 518.0 & 5981.6 & -10.0 & 18.9 & Below screen \\
\hline \multirow{5}{*}{3} & \multirow{5}{*}{801.0} & \multirow{5}{*}{839.0} & \multirow{5}{*}{5698.6} & \multirow{5}{*}{5660.6} & \multirow{5}{*}{38} & \multirow{5}{*}{ RT } & \multirow{5}{*}{ Tsfb } & MP3A & 810.8 & 5688.8 & 28.2 & & Within screen \\
\hline & & & & & & & & PP3A & 816.2 & 5683.4 & 22.8 & & Within screen \\
\hline & & & & & & & & MP3B & 821.8 & 5677.8 & 17.2 & & Within screen \\
\hline & & & & & & & & PP3B & 827.2 & 5672.4 & 11.8 & & Within screen \\
\hline & & & & & & & & MP3C & 832.9 & 5666.7 & 6.1 & & Within screen \\
\hline
\end{tabular}

Brass Cap Elevation: $6499.6 \mathrm{ft}$; all measurements are from this elevation; $\mathrm{MP}=$ measurement port; $\mathrm{PP}=$ pumping port

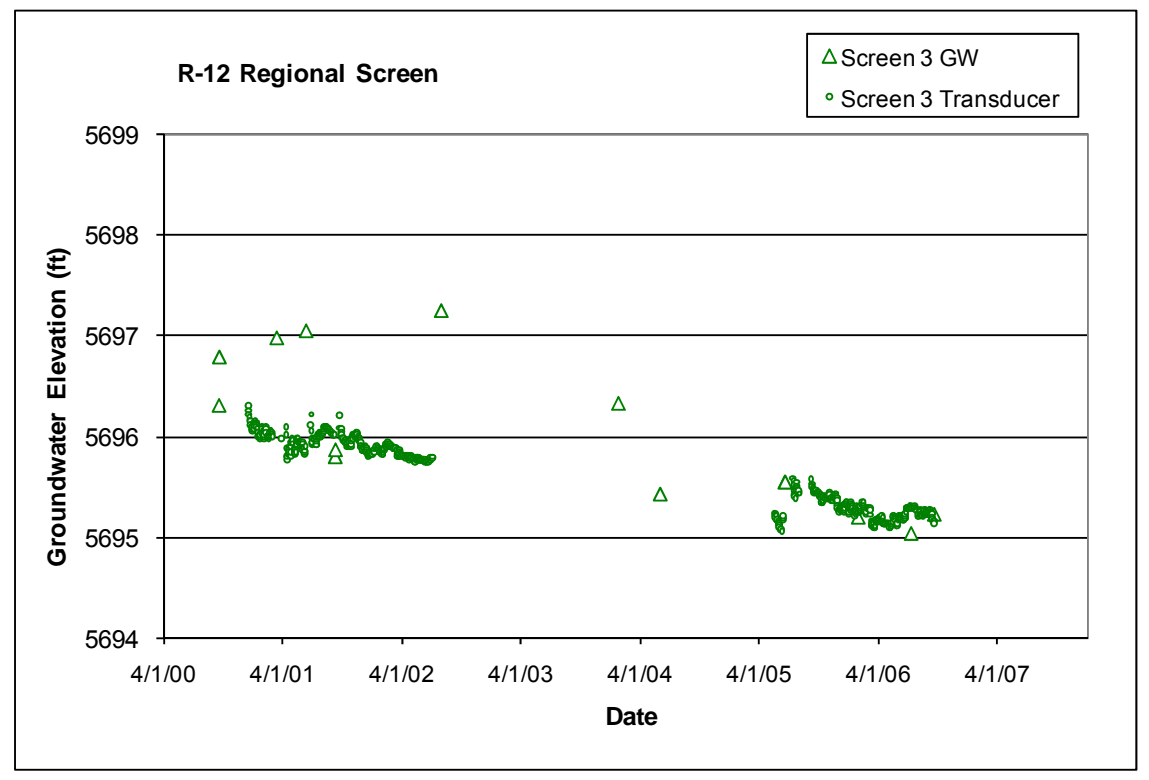




\subsection{R-13}

Location: R-13 is located in lower Mortandad Canyon near the LANL boundary.

Completion Type: Single completion at the top of the regional aquifer. The top of the screen is about $122 \mathrm{ft}$ below the water table.

Period of Record: Well completed October 2001, transducer installed January 3, 2005, data through 2009. The transducer failed and was replaced in June 2009.

Remarks: R-13 was completed to a depth of $1029.4 \mathrm{ft}$, about $200 \mathrm{ft}$ into the regional aquifer. The well is $100 \%$ barometrically efficient; the groundwater has no immediate response to atmospheric pressure fluctuations. However, the aquifer indicates a delayed $30 \%$ response to atmospheric pressure. R-13 exhibits a seasonal response to supply well pumping and responds primarily to pumping at PM-4 (McLin 2006) and possibly to PM-2 and PM-5, but apparently does not respond significantly to pumping at nearby supply well PM-3.

\begin{tabular}{|c|c|c|c|c|c|c|c|c|c|c|c|c|c|c|}
\hline \multicolumn{15}{|c|}{ R-13 Construction Information } \\
\hline Screen & \begin{tabular}{|c|} 
Screen \\
Top \\
Depth (ft)
\end{tabular} & $\begin{array}{c}\text { Screen } \\
\text { Bottom } \\
\text { Depth } \\
\text { (ft) }\end{array}$ & $\begin{array}{l}\text { Screen } \\
\text { Top } \\
\text { Elev (ft) }\end{array}$ & $\begin{array}{l}\text { Screen } \\
\text { Bottom } \\
\text { Elev (ft) }\end{array}$ & $\begin{array}{c}\text { Screen } \\
\text { Length } \\
(\mathrm{ft})\end{array}$ & $\begin{array}{l}\text { Pump } \\
\text { Intake } \\
\text { Depth } \\
\text { (ft) }\end{array}$ & $\begin{array}{c}\text { Pump } \\
\text { Intake } \\
\text { Elevation } \\
\text { (ft) }\end{array}$ & $\begin{array}{l}\text { Depth to } \\
\text { Top of } \\
\text { Sump (ft) }\end{array}$ & $\begin{array}{c}\text { Top of } \\
\text { Sump } \\
\text { Elevation } \\
\text { (ft) }\end{array}$ & $\begin{array}{c}\text { Depth to } \\
\text { Sump } \\
\text { Bottom (ft) }\end{array}$ & $\begin{array}{c}\text { Sump } \\
\text { Length } \\
\text { (ft) }\end{array}$ & $\begin{array}{c}\text { Sump } \\
\text { Volume } \\
\text { (L) }\end{array}$ & $\begin{array}{l}\text { Hydro } \\
\text { Zone } \\
\text { Code }\end{array}$ & $\begin{array}{l}\text { Geo } \\
\text { Unit } \\
\text { Code }\end{array}$ \\
\hline 1 & 958.3 & 1018.7 & 5714.8 & 5654.4 & 60.4 & 933.0 & 5740.1 & 1018.7 & 5654.4 & 1029.4 & 10.7 & 33.5 & RT & $\mathrm{Tp}$ \\
\hline
\end{tabular}

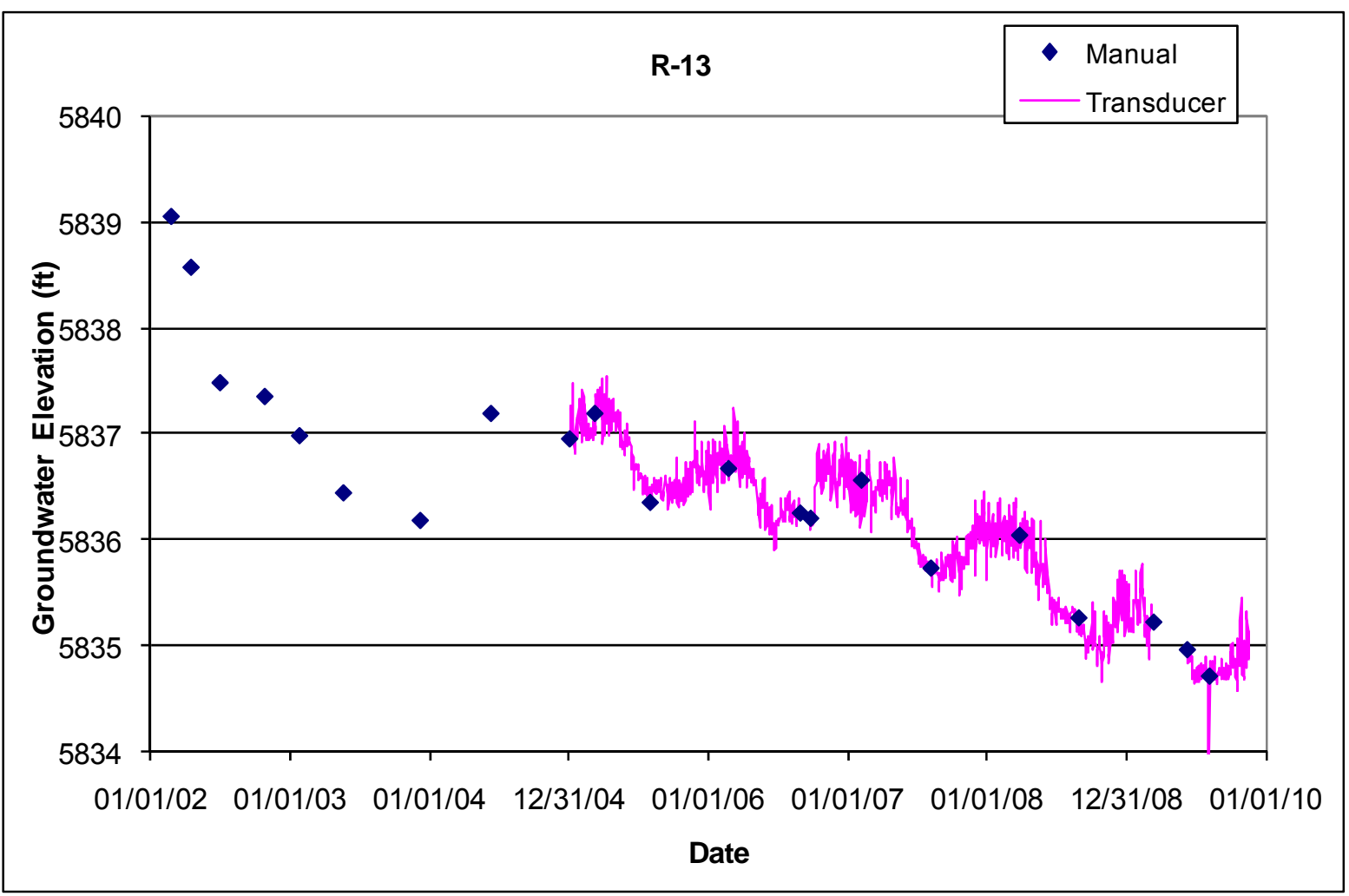




\subsection{R-14}

Location: R-14 is located in upper Ten Site Canyon about 0.5 miles upgradient of supply well PM-5.

Completion Type: Formerly multiple completion, two screens in the regional aquifer; recompleted in February 2008 to single screen at the top of the regional aquifer when screen 2 was plugged and abandoned. The top of screen 1 is about $20 \mathrm{ft}$ below the water table.

Period of Record: Westbay ${ }^{\circledR}$ system installed November 23, 2002, transducers installed December 14,2004 , water level data from Westbay ${ }^{\circledR}$ system to February 25,2008 . Transducer installed in recompleted single screen well June 10, 2008; data through 2009.

Remarks: Screens were formerly $53 \mathrm{ft}$ apart; heads between screens were within $0.5 \mathrm{ft}$ of each other. The aquifer shows no response to atmospheric pressure fluctuations. The aquifer at R-14 responds primarily to pumping supply well PM-5. After removal of the Westbay ${ }^{\circledR}$ system, an error in the Westbay ${ }^{\circledR}$ pipe tally resulted in correction of all Westbay ${ }^{\circledR}$ derived water level data downward by $3.3 \mathrm{ft}$.

\begin{tabular}{|c|c|c|c|c|c|c|c|c|c|c|c|c|}
\hline \multicolumn{13}{|c|}{ R-14 Construction Information } \\
\hline Screen & $\begin{array}{c}\text { Screen } \\
\text { Top } \\
\text { Depth } \\
\text { (ft) }\end{array}$ & $\begin{array}{c}\text { Screen } \\
\text { Bottom } \\
\text { Depth } \\
\text { (ft) }\end{array}$ & $\begin{array}{c}\text { Screen } \\
\text { Top Elev } \\
\text { (ft) }\end{array}$ & $\begin{array}{l}\text { Screen } \\
\text { Bottom } \\
\text { Elev (ft) }\end{array}$ & $\begin{array}{c}\text { Screen } \\
\text { Length } \\
\text { (ft) }\end{array}$ & $\begin{array}{c}\text { Pump } \\
\text { Depth } \\
\text { (ft) }\end{array}$ & $\begin{array}{c}\text { Pump } \\
\text { Elev (ft) }\end{array}$ & $\begin{array}{c}\text { Top of } \\
\text { Packerl } \\
\text { Plug (ft) }\end{array}$ & $\begin{array}{c}\text { Sump } \\
\text { Length } \\
\text { (ft) }\end{array}$ & $\begin{array}{c}\text { Sump } \\
\text { Volume } \\
\text { (L) }\end{array}$ & $\begin{array}{c}\text { Hydro } \\
\text { Zone } \\
\text { Code }\end{array}$ & $\begin{array}{c}\text { Geo } \\
\text { Unit } \\
\text { Code }\end{array}$ \\
\hline 1 & 1200.6 & 1233.2 & 5861.48 & 5828.88 & $\overline{32.6}$ & 1198.0 & 5864.1 & 1244.7 & 11.5 & 36.0 & $\overline{\mathrm{RT}}$ & $\mathrm{Tp}$ \\
\hline 2 & 1286.5 & 1293.1 & 5775.58 & 5768.98 & 6.6 & \multicolumn{5}{|c|}{ Screen 2 Plugged and Abandoned 2/08 } & $\mathrm{RD}$ & $T p$ \\
\hline
\end{tabular}

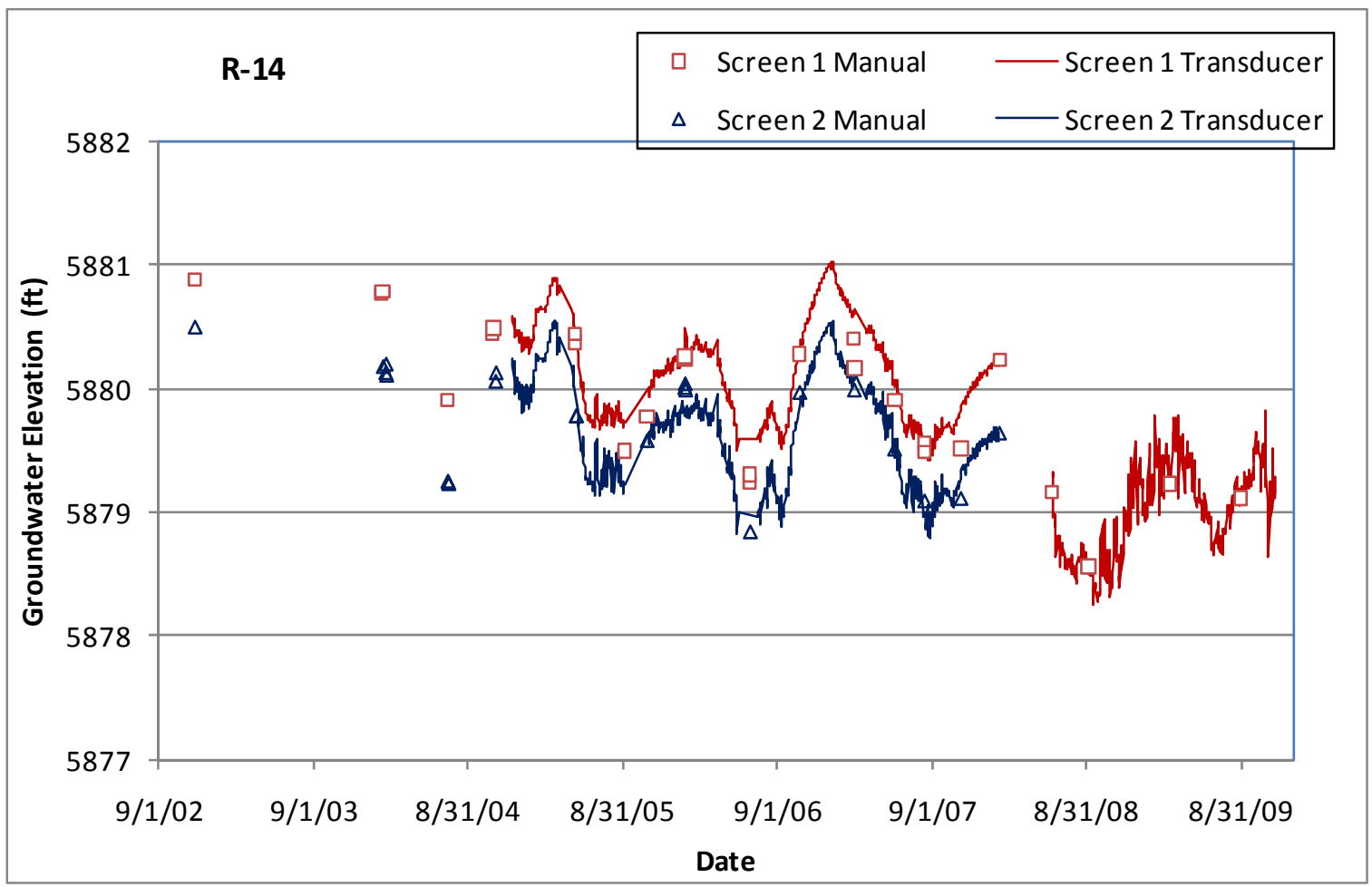




\subsection{R-15}

Location: R-15 is located in lower Mortandad Canyon downstream of the sediment traps.

Completion Type: Single completion at the top of the regional aquifer. The screen straddles the water table.

Period of Record: Well completed September 1999, transducer installed December 23, 2004, transducer data through 2009.

Remarks: R-15 was completed in 1999 to a depth of $1030.6 \mathrm{ft}$, about $140 \mathrm{ft}$ into the regional aquifer. The well is $100 \%$ barometrically efficient; the aquifer does not respond to atmospheric pressure fluctuations. The aquifer at R-15 responds to pumping supply wells PM-4 and PM-5.

\begin{tabular}{|c|c|c|c|c|c|c|c|c|c|c|c|c|c|c|}
\hline \multicolumn{15}{|c|}{ R-15 Construction Information } \\
\hline Screen & $\begin{array}{c}\text { Screen } \\
\text { Top } \\
\text { Depth } \\
\text { (ft) }\end{array}$ & $\begin{array}{c}\text { Screen } \\
\text { Bottom } \\
\text { Depth } \\
\text { (ft) }\end{array}$ & $\begin{array}{c}\text { Screen } \\
\text { Top } \\
\text { Elev } \\
\text { (ft) }\end{array}$ & $\begin{array}{c}\text { Screen } \\
\text { Bottom } \\
\text { Elev } \\
(\mathrm{ft})\end{array}$ & $\begin{array}{c}\text { Screen } \\
\text { Length } \\
\text { (ft) }\end{array}$ & $\begin{array}{l}\text { Pump } \\
\text { Intake } \\
\text { Depth } \\
\text { (ft) }\end{array}$ & $\begin{array}{c}\text { Pump } \\
\text { Intake } \\
\text { Elev } \\
\text { (ft) }\end{array}$ & $\begin{array}{l}\text { Depth to } \\
\text { Top of } \\
\text { Sump (ft) }\end{array}$ & $\begin{array}{c}\text { Top of } \\
\text { Sump } \\
\text { Elev } \\
\text { (ft) }\end{array}$ & $\begin{array}{c}\text { Depth to } \\
\text { Sump } \\
\text { Bottom } \\
\text { (ft) }\end{array}$ & $\begin{array}{c}\text { Sump } \\
\text { Length } \\
\text { (ft) }\end{array}$ & $\begin{array}{l}\text { Sump } \\
\text { Volume } \\
\text { (L) }\end{array}$ & $\begin{array}{l}\text { Hydro } \\
\text { Zone } \\
\text { Code }\end{array}$ & $\begin{array}{l}\text { Geo } \\
\text { Unit } \\
\text { Code }\end{array}$ \\
\hline 1 & 958.6 & 1020.3 & 5861.4 & 5799.7 & 61.7 & 1015.6 & 5804.4 & 1020.3 & 5799.7 & 1030.6 & 10.3 & 39.8 & RT & $\mathrm{Tp}$ \\
\hline
\end{tabular}

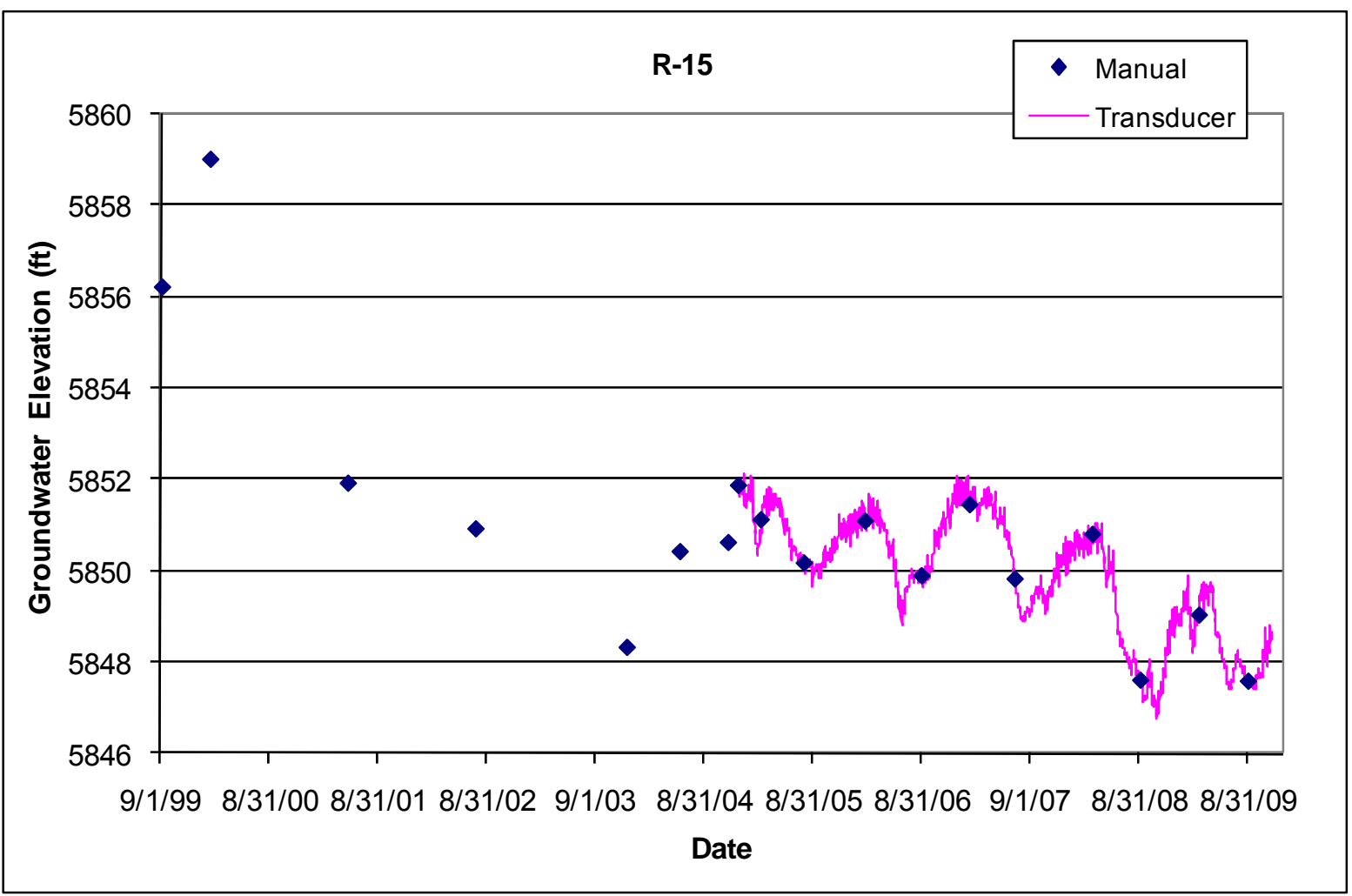




\subsection{R-16}

Location: R-16 is located northeast of White Rock in lower Cañada del Buey near the confluence with lower Mortandad Canyon.

Completion Type: Multiple completion, four screens in the regional aquifer, screen 1 is blocked by casing and is not useable.

Period of Record: Westbay ${ }^{\circledR}$ installed December 14, 2002, transducers installed June 16, 2005, transducer data to July 12,2006 , when the Westbay ${ }^{\circledR}$ system was removed for additional screen development. The Westbay ${ }^{\circledR}$ system was reinstalled and transducers were reinstalled October 18, 2006. Westbay ${ }^{\circledR}$ transducer data extend to April 15, 2009, when the Westbay ${ }^{\circledR}$ system was removed for well rehabilitation and conversion. A single submersible pump with dual valve Baski sampling system was installed on October 14, 2009, to monitor screens 2 and 4; screen 3 not monitored after April 15, 2009 (LANL 2009). Groundwater level data from the dual screen sampling system are available from October 14, 2009, through 2009.

Remarks: Screens 2 and 3 are about $144 \mathrm{ft}$ apart with a head difference of over $80 \mathrm{ft}$. Screens 3 and 4 show similar water level trends. The aquifer response to atmospheric pressure declines downward from screen 2 to screen 4 , from $68 \%$ at screen 2 to $57 \%$ at screen 4 .

\begin{tabular}{|c|c|c|c|c|c|c|c|c|c|c|c|c|c|c|c|c|}
\hline \multicolumn{17}{|c|}{ R-16 Construction Information } \\
\hline Screen & $\begin{array}{c}\text { Screen } \\
\text { Top } \\
\text { Depth } \\
\text { (ft) }\end{array}$ & \begin{tabular}{|c} 
Screen \\
Bottom \\
Depth \\
(ft)
\end{tabular} & $\begin{array}{c}\text { Screen } \\
\text { Top } \\
\text { Elev (ft) }\end{array}$ & $\begin{array}{c}\text { Screen } \\
\text { Bottom } \\
\text { Elev } \\
\text { (ft) }\end{array}$ & $\begin{array}{c}\text { Screen } \\
\text { Length } \\
\text { (ft) }\end{array}$ & $\begin{array}{c}\text { APV } \\
\text { Intake } \\
\text { Depth } \\
\text { (ft) }\end{array}$ & \begin{tabular}{|c|} 
APV \\
Intake \\
Elev \\
(ft) \\
\end{tabular} & $\begin{array}{c}\text { Depth } \\
\text { to Top } \\
\text { of } \\
\text { Sump } \\
\text { (ft) }\end{array}$ & \begin{tabular}{|c} 
Top of \\
Sump \\
Elev \\
(ft)
\end{tabular} & \begin{tabular}{|} 
Depth \\
to \\
Packerl \\
Sump \\
Bottom \\
(ft)
\end{tabular} & $\begin{array}{c}\text { Packer } \\
\text { Bottom } \\
\text { Depth } \\
\text { (ft) }\end{array}$ & $\begin{array}{c}\text { Bottom } \\
\text { of } \\
\text { Sump } \\
\text { Elev (ft) }\end{array}$ & $\begin{array}{c}\text { Sump } \\
\text { Length } \\
\text { (ft) }\end{array}$ & $\begin{array}{l}\text { Hydro } \\
\text { Zone } \\
\text { Code }\end{array}$ & $\begin{array}{c}\text { Geo } \\
\text { Unit } \\
\text { Code }\end{array}$ & Comment \\
\hline 1 & 641.0 & 648.6 & 5615.9 & 5608.3 & 7.6 & N/A & N/A & N/A & N/A & N/A & $\mathrm{N} / \mathrm{A}$ & N/A & $\mathrm{N} / \mathrm{A}$ & RT & $\mathrm{Tp}$ & Screen unusable \\
\hline 2 & 863.4 & 870.9 & 5393.5 & 5386.0 & 7.5 & 872.8 & 5384.1 & 870.9 & 5386.0 & 881.2 & 885.6 & 5375.6 & 10.3 & $\mathrm{RD}$ & Tsf & Upper zone \\
\hline 3 & 1014.8 & 1022.4 & 5242.1 & 5234.5 & 7.6 & $\mathrm{~N} / \mathrm{A}$ & N/A & $\mathrm{N} / \mathrm{A}$ & $\mathrm{N} / \mathrm{A}$ & $\mathrm{N} / \mathrm{A}$ & N/A & N/A & $\mathrm{N} / \mathrm{A}$ & $\mathrm{RD}$ & Tsf & Screen sealed off \\
\hline 4 & 1237.0 & 1244.6 & 5019.9 & 5012.3 & 7.6 & 1234.6 & 5022.3 & 1244.6 & 5012.3 & 1276.7 & 1223.0 & 4980.2 & 32.1 & $\mathrm{RD}$ & Tsf & Lower zone \\
\hline
\end{tabular}

Brass Cap Elevation: $6256.87 \mathrm{ft}$; all measurements are from this elevation

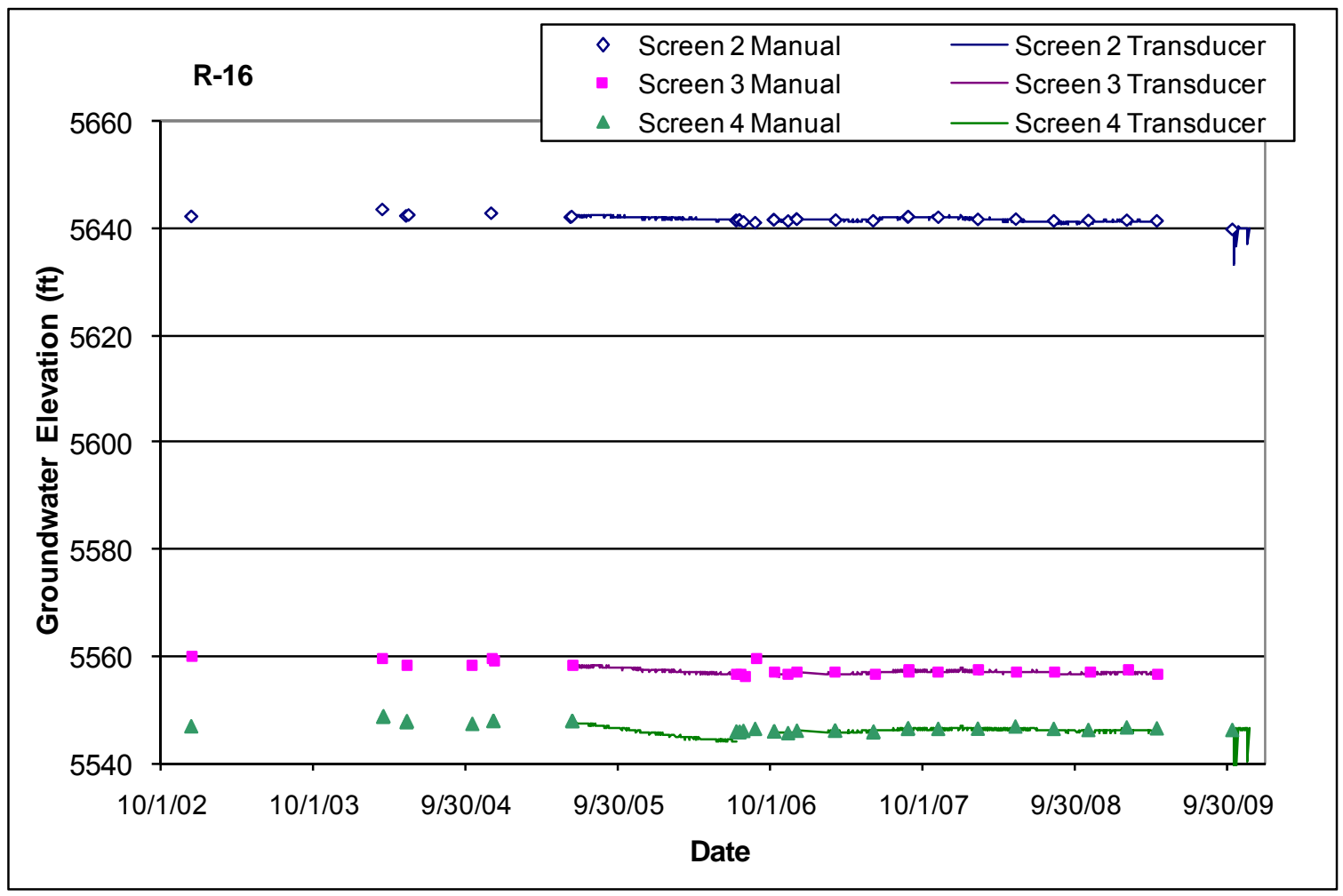



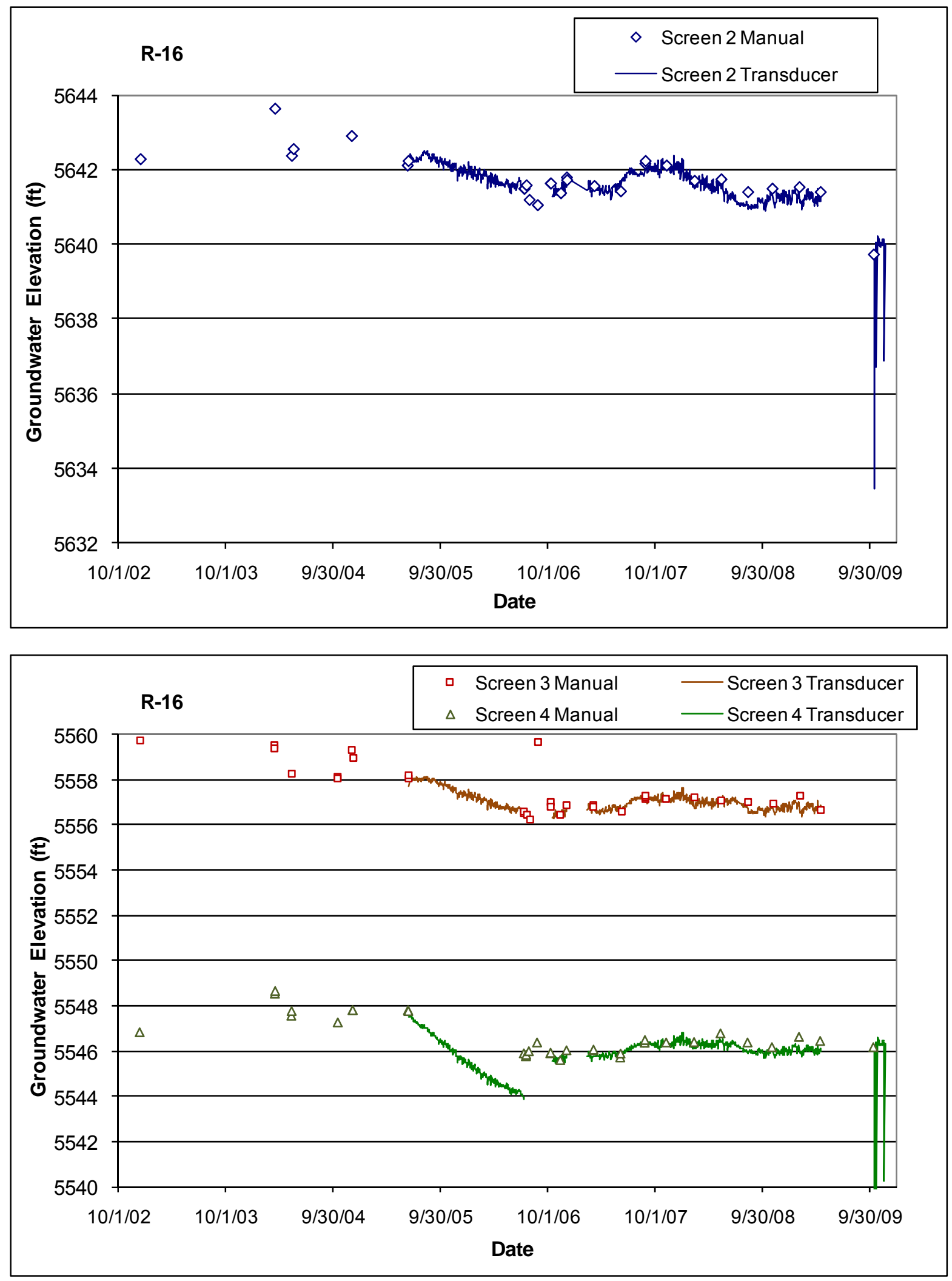


\subsection{R-16r}

Location: R-16r is located northeast of White Rock adjacent to R-16 in lower Cañada del Buey near the confluence with lower Mortandad Canyon.

Completion Type: Single completion at the top of the regional aquifer. R-16r provides data for the top of the regional aquifer in place of R-16 screen 1, which is blocked by casing and is not useable. The top of the screen is about $36 \mathrm{ft}$ below the water table.

Period of Record: Well completed October 11, 2005, transducers installed February 21, 2006, data through 2009.

Remarks: R-16r water level at the top of the regional aquifer about $50 \mathrm{ft}$ higher than the water level at R-16 screen 2, which is located about $250 \mathrm{ft}$ lower than the R-16r screen. The well is $90 \%$ barometrically efficient; the aquifer indicates a $10 \%$ response to atmospheric pressure; however, the aquifer shows a delayed response to atmospheric pressure fluctuations.

\begin{tabular}{|c|c|c|c|c|c|c|c|c|c|c|c|c|c|c|}
\hline \multicolumn{15}{|c|}{ R-16r Construction Information } \\
\hline Screen & $\begin{array}{l}\text { Screen } \\
\text { Top } \\
\text { Depth } \\
\text { (ft) }\end{array}$ & $\begin{array}{c}\text { Screen } \\
\text { Bottom } \\
\text { Depth } \\
\text { (ft) }\end{array}$ & $\begin{array}{c}\text { Screen } \\
\text { Top } \\
\text { Elev (ft) }\end{array}$ & $\begin{array}{l}\text { Screen } \\
\text { Bottom } \\
\text { Elev (ft) }\end{array}$ & $\begin{array}{c}\text { Screen } \\
\text { Length } \\
(\mathrm{ft})\end{array}$ & $\begin{array}{c}\text { Pump } \\
\text { Intake } \\
\text { Depth } \\
\text { (ft) }\end{array}$ & $\begin{array}{c}\text { Pump } \\
\text { Intake } \\
\text { Elevation } \\
\text { (ft) }\end{array}$ & $\begin{array}{c}\text { Depth to } \\
\text { Top of } \\
\text { Sump } \\
\text { (ft) }\end{array}$ & $\begin{array}{c}\text { Top of } \\
\text { Sump } \\
\text { Elevation } \\
\text { (ft) }\end{array}$ & $\begin{array}{c}\text { Depth to } \\
\text { Sump } \\
\text { Bottom (ft) }\end{array}$ & $\begin{array}{c}\text { Sump } \\
\text { Length } \\
\text { (ft) }\end{array}$ & $\begin{array}{l}\text { Sump } \\
\text { Volume } \\
\text { (L) }\end{array}$ & $\begin{array}{l}\text { Hydro } \\
\text { Zone } \\
\text { Code }\end{array}$ & $\begin{array}{c}\text { Geo } \\
\text { Unit } \\
\text { Code }\end{array}$ \\
\hline 1 & 600.0 & 617.6 & 5657.0 & 5639.4 & 17.6 & 596.6 & 5660.4 & 617.6 & 5639.4 & 631.4 & 13.8 & 42.4 & RT & Tpt \\
\hline
\end{tabular}

Note: Brass Cap Ground Elevation: $6256.97 \mathrm{ft}$; all measurements are from this elevation

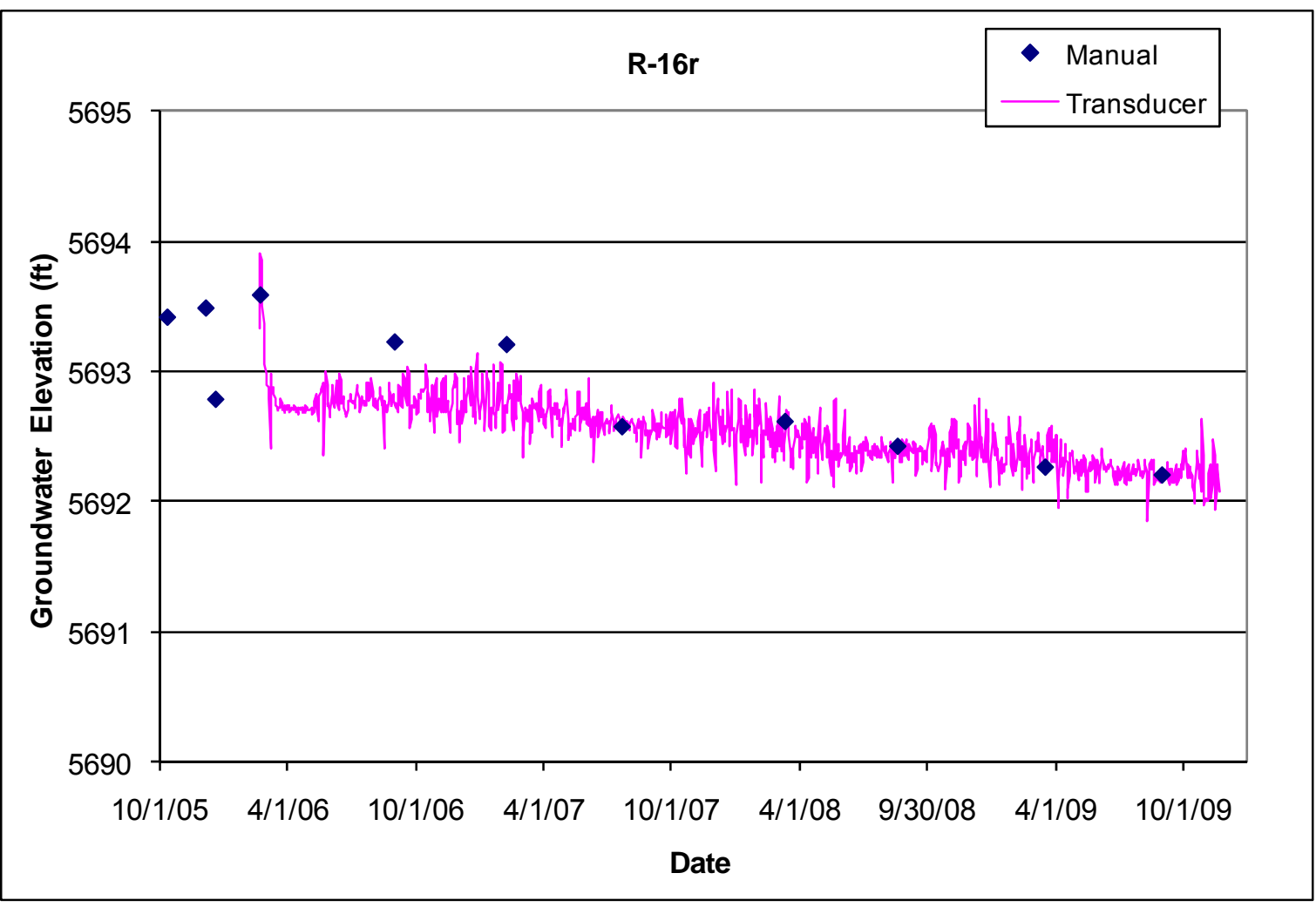




\section{$3.20 \quad$ R-17}

Location: R-17 is located in middle Pajarito Canyon below the confluence with Two-Mile Canyon and about 1 mile southwest of supply well PM-5.

Completion Type: Dual completion within the regional aquifer with a Baski packer and dual valve system and single submersible pump. The top of screen 1 is located about $20 \mathrm{ft}$ below the water table. The screens are $44 \mathrm{ft}$ apart.

Period of Record: Completed January 4, 2006, transducers installed December 12, 2006, transducer data through 2009.

Remarks: R-17 was completed to a depth of $1140.9 \mathrm{ft}$, about $100 \mathrm{ft}$ into the regional aquifer. Screen 1 is $100 \%$ barometrically efficient; the aquifer does not show a response to atmospheric pressure fluctuations. Screen 2 is $90 \%$ barometrically efficient. Both screens show a seasonal response to supply well pumping; screen 2 shows a response to pumping supply wells PM-2, PM-4, and PM-5.

\begin{tabular}{|c|c|c|c|c|c|c|c|c|c|c|c|c|c|c|}
\hline \multicolumn{15}{|c|}{ R-17 Construction Information } \\
\hline Screen & $\begin{array}{c}\text { Screen } \\
\text { Top } \\
\text { Depth } \\
\text { (ft) }\end{array}$ & $\begin{array}{c}\text { Screen } \\
\text { Bottom } \\
\text { Depth } \\
\text { (ft) } \\
\end{array}$ & $\begin{array}{c}\text { Screen } \\
\text { Top } \\
\text { Elev (ft) }\end{array}$ & $\begin{array}{l}\text { Screen } \\
\text { Bottom } \\
\text { Elev (ft) }\end{array}$ & $\begin{array}{c}\text { Screen } \\
\text { Length } \\
(\mathrm{ft}) \\
\end{array}$ & $\begin{array}{c}\text { Pump } \\
\text { Intake } \\
\text { Depth } \\
\text { (ft) }\end{array}$ & $\begin{array}{c}\text { Pump } \\
\text { Intake } \\
\text { Elev (ft) } \\
\end{array}$ & \begin{tabular}{|c|} 
Depth to \\
Top of \\
Packerl \\
Sump (ft)
\end{tabular} & $\begin{array}{c}\text { Top of } \\
\text { Packerl } \\
\text { Sump } \\
\text { Elevation } \\
\text { (ft) } \\
\end{array}$ & $\begin{array}{c}\text { Depth to } \\
\text { Sump } \\
\text { Bottom } \\
\text { (ft) }\end{array}$ & \begin{tabular}{|c|}
$\begin{array}{c}\text { Sump } \\
\text { Length } \\
(\mathrm{ft})\end{array}$ \\
\end{tabular} & \begin{tabular}{|c|} 
Sump \\
Volume \\
$(\mathrm{L})$
\end{tabular} & \begin{tabular}{|c|} 
Hydro \\
Zone \\
Code
\end{tabular} & $\begin{array}{c}\text { Geo } \\
\text { Unit } \\
\text { Code } \\
\end{array}$ \\
\hline 1 & 1057.0 & 1080.0 & 5864.5 & 5841.5 & 23.0 & 1089.6 & 5831.9 & 1101.2 & 5820.4 & 1101.2 & 21.1 & 66.1 & \begin{tabular}{l|l}
$\mathrm{RT}$ \\
\end{tabular} & Tpf \\
\hline 2 & 1124.0 & 1134.0 & 5797.5 & 5787.5 & 10.0 & 1128.6 & 5792.9 & 1134.0 & 5787.5 & 1140.9 & 6.9 & 21.6 & $\mathrm{RD}$ & Tpf \\
\hline
\end{tabular}

Note: Brass Cap Ground Elevation: $6921.51 \mathrm{ft}$; all measurements are from this elevation

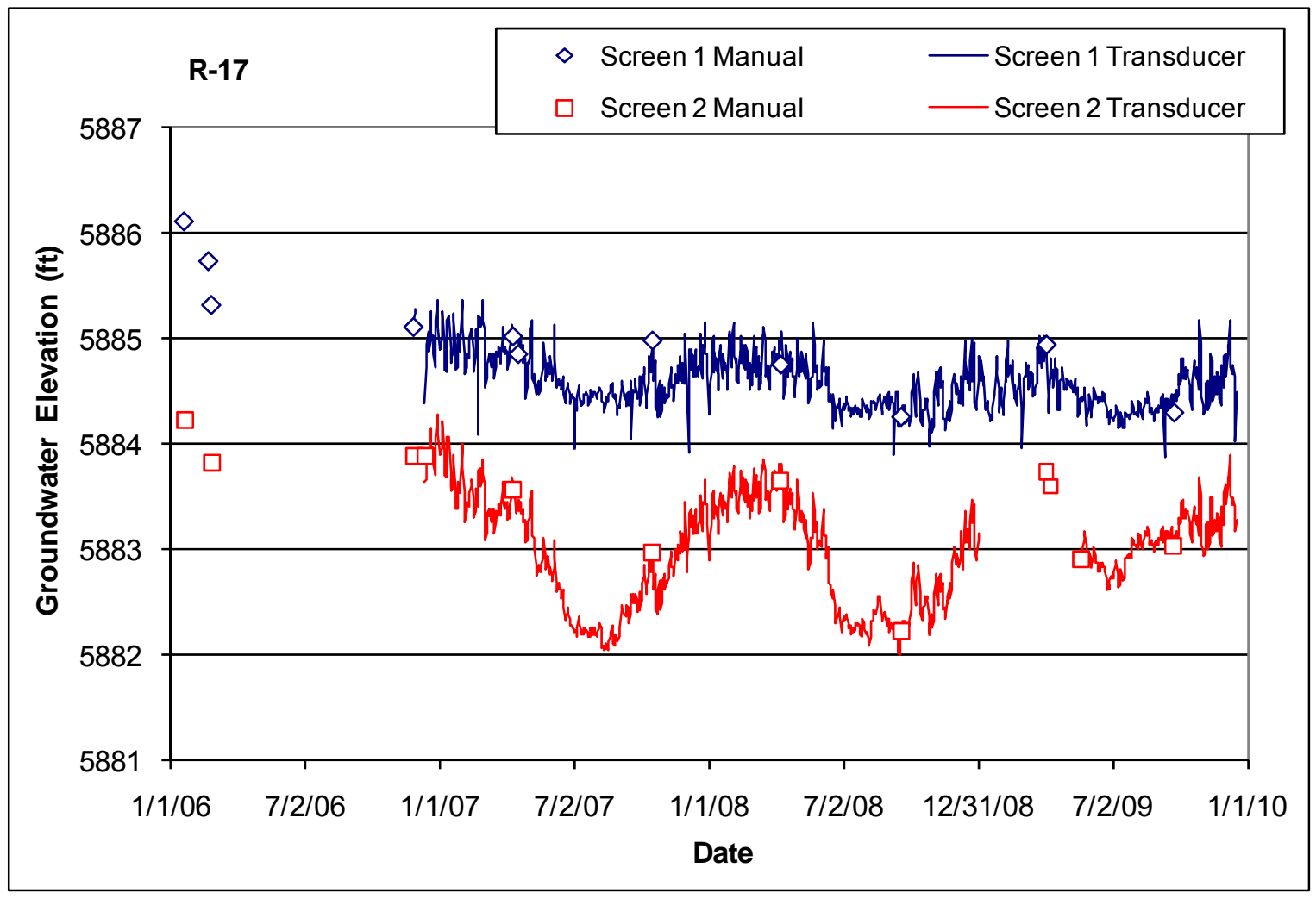




\subsection{R-18}

Location: R-18 is located on a mesa at TA-14 between Pajarito Canyon and Cañon de Valle, about $3000 \mathrm{ft}$ northeast of R-25.

Completion Type: Single completion at the top of the regional aquifer. The top of the screen is about $70 \mathrm{ft}$ bellow the water table.

Period of Record: Completed December 12, 2004, transducer installed October 11, 2005, transducer data through 2009.

Remarks: R-18 was completed to a depth of $1405 \mathrm{ft}$, about $118 \mathrm{ft}$ into the regional aquifer. The well is $100 \%$ barometrically efficient; the aquifer does not indicate a response to atmospheric pressure fluctuations. There is no apparent response to supply well pumping.

\begin{tabular}{|c|c|c|c|c|c|c|c|c|c|c|c|c|c|c|}
\hline \multicolumn{15}{|c|}{ R-18 Construction Information } \\
\hline Zone & $\begin{array}{l}\text { Screen } \\
\text { Top } \\
\text { Depth } \\
\text { (ft) }\end{array}$ & $\begin{array}{c}\text { Screen } \\
\text { Bottom } \\
\text { Depth } \\
\text { (ft) }\end{array}$ & $\begin{array}{c}\text { Screen } \\
\text { Top } \\
\text { Elev } \\
\text { (ft) }\end{array}$ & $\begin{array}{c}\text { Screen } \\
\text { Bottom } \\
\text { Elev } \\
\text { (ft) }\end{array}$ & $\begin{array}{l}\text { Screen } \\
\text { Length } \\
\text { (ft) }\end{array}$ & $\begin{array}{c}\text { Pump } \\
\text { Intake } \\
\text { Depth } \\
\text { (ft) }\end{array}$ & $\begin{array}{c}\text { Pump } \\
\text { Intake } \\
\text { Elev } \\
\text { (ft) }\end{array}$ & $\begin{array}{l}\text { Depth to } \\
\text { Top of } \\
\text { Sump } \\
\text { (ft) }\end{array}$ & $\begin{array}{c}\text { Top of } \\
\text { Sump } \\
\text { Elev } \\
\text { (ft) }\end{array}$ & $\begin{array}{l}\text { Depth to } \\
\text { Sump } \\
\text { Bottom } \\
\text { (ft) }\end{array}$ & $\begin{array}{l}\text { Sump } \\
\text { Length } \\
\text { (ft) }\end{array}$ & $\begin{array}{c}\text { Sump } \\
\text { Volume } \\
\text { (L) }\end{array}$ & $\begin{array}{c}\text { Hydro } \\
\text { Zone } \\
\text { Code }\end{array}$ & $\begin{array}{l}\text { Geo } \\
\text { Unit } \\
\text { Code }\end{array}$ \\
\hline$\overline{1}$ & 1358.0 & 1381 & 6046.8 & 6023.8 & 23.0 & 1353 & 6051.8 & 1381.0 & 6023.8 & 1405 & 24.0 & 75.1 & $\overline{\mathrm{RT}}$ & $\overline{T p f}$ \\
\hline
\end{tabular}

Note: Brass Cap Ground Elevation: $7404.83 \mathrm{ft}$; all measurements are from this elevation

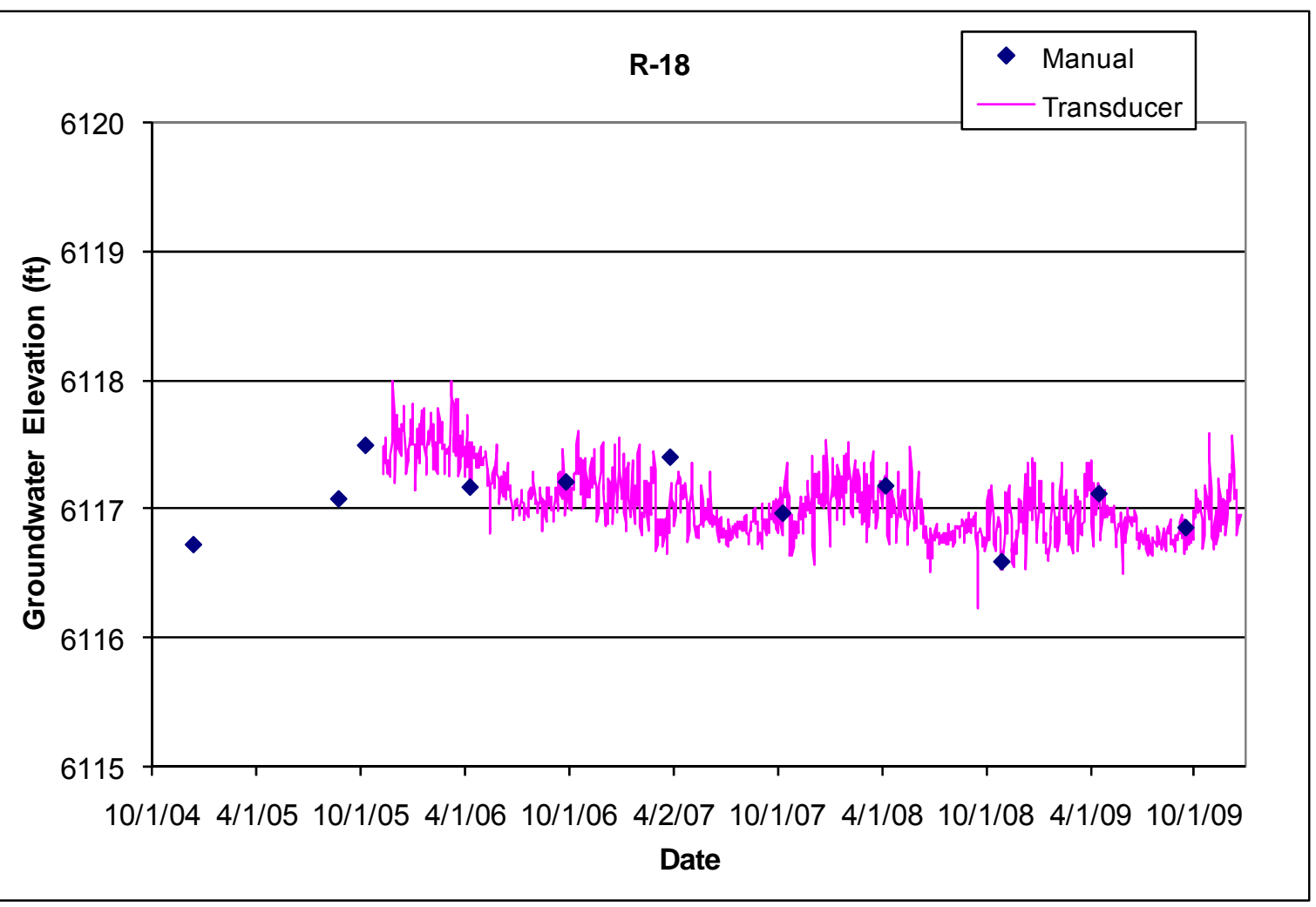




\subsection{R-19}

Location: R-19 is located on a mesa south of Three-Mile Canyon about 1.2 miles west of supply well PM-2.

Completion Type: Multiple completion, two screens in intermediate zones, and five screens in the regional aquifer. Screen 3 straddles the regional water table.

Period of Record: Westbay ${ }^{\circledR}$ installed September 11, 2000, transducers installed June 04, 2002, equipment problems occurred within two weeks. Transducers reinstalled December 10, 2004; transducer data to June 25, 2007, when the transducer string cable failed. Cable rebuilt and transducers reinstalled January 10, 2008; data are available intermittently through 2009.

Remarks: Screen 1 has been dry since Westbay ${ }^{\circledR}$ installation. Screen 3 at the top of the regional aquifer does not show a response to atmospheric pressure fluctuations, but the deeper screens 4 through 7 indicate $40 \%$ to $50 \%$ response. The deeper screens (4 through 7 ) in the regional aquifer respond to supply well pumping at PM-2 and PM-4, and possibly to PM-5.

\begin{tabular}{|c|c|c|c|c|c|c|c|c|c|c|c|c|c|}
\hline \multicolumn{14}{|c|}{ R-19 Construction Information and Port Data } \\
\hline Screen & $\begin{array}{l}\text { Screen } \\
\text { Top } \\
\text { Depth } \\
\text { (ft) }\end{array}$ & $\begin{array}{c}\text { Screen } \\
\text { Bottom } \\
\text { Depth } \\
\text { (ft) }\end{array}$ & $\begin{array}{c}\text { Screen } \\
\text { Top } \\
\text { Elev (ft) }\end{array}$ & $\begin{array}{l}\text { Screen } \\
\text { Bottom } \\
\text { Elev (ft) }\end{array}$ & $\begin{array}{c}\text { Screen } \\
\text { Length } \\
\text { (ft) }\end{array}$ & $\begin{array}{l}\text { Hydro } \\
\text { Zone } \\
\text { Code }\end{array}$ & $\begin{array}{c}\text { Geo } \\
\text { Unit } \\
\text { Code }\end{array}$ & Port & $\begin{array}{c}\text { Port } \\
\text { Depth } \\
\text { (ft) }\end{array}$ & $\begin{array}{c}\text { Port } \\
\text { Elevation } \\
\text { (ft) }\end{array}$ & \begin{tabular}{|} 
Distance \\
from \\
Bottom of \\
Screen \\
(ft)
\end{tabular} & $\begin{array}{c}\text { Sump } \\
\text { Volume } \\
\text { (L) }\end{array}$ & Comment \\
\hline \multirow{3}{*}{1} & \multirow{3}{*}{827.2} & \multirow{3}{*}{843.6} & \multirow{3}{*}{6239.1} & \multirow{3}{*}{6222.7} & \multirow{3}{*}{16.4} & \multirow{3}{*}{ I } & \multirow{3}{*}{ Qbog } & MP1A & 844.2 & 6222.1 & -0.6 & 1.3 & Below Screen \\
\hline & & & & & & & & PP1 & 849.6 & 6216.7 & -6 & 13.0 & Below Screen \\
\hline & & & & & & & & MP1B & 855.2 & 6211.1 & -11.6 & 25.1 & Below Screen \\
\hline \multirow{3}{*}{2} & \multirow{3}{*}{893.3} & \multirow{3}{*}{909.6} & \multirow{3}{*}{6173.0} & \multirow{3}{*}{6156.7} & \multirow{3}{*}{16.3} & \multirow{3}{*}{ I } & \multirow{3}{*}{$\mathrm{Tp}$} & MP2A & 909.3 & 6157.0 & 0.3 & & Within Screen \\
\hline & & & & & & & & PP2 & 914.7 & 6151.6 & -5.1 & 11.0 & Below Screen \\
\hline & & & & & & & & MP2B & 920.3 & 6146.0 & -10.7 & 23.1 & Below Screen \\
\hline \multirow{4}{*}{3} & \multirow{4}{*}{1171.4} & \multirow{4}{*}{1215.4} & \multirow{4}{*}{5894.9} & \multirow{4}{*}{5850.9} & \multirow{4}{*}{44.0} & \multirow{4}{*}{ RT } & \multirow{4}{*}{ Tpf } & MP3A & 1190.7 & 5875.6 & 24.7 & & Within Screen \\
\hline & & & & & & & & PP3 & 1196.1 & 5870.2 & 19.3 & & Within Screen \\
\hline & & & & & & & & MP3B & 1201.7 & 5864.6 & 13.7 & & Within Screen \\
\hline & & & & & & & & MP3C & 1212.8 & 5853.5 & 2.6 & & Within Screen \\
\hline \multirow{3}{*}{4} & \multirow{3}{*}{1410.2} & \multirow{3}{*}{1417.4} & \multirow{3}{*}{5656.1} & \multirow{3}{*}{5648.9} & & & & MP4A & 1412.9 & 5653.4 & 4.5 & & Within Screen \\
\hline & & & & & 7.2 & RD & Tpf & PP4 & 1418.3 & 5648.0 & -0.9 & 1.9 & Below Screen \\
\hline & & & & & & & & MP4B & 1423.9 & 5642.4 & -6.5 & 14.1 & Below Screen \\
\hline & & & & & & & & MP5A & 1586.1 & 5480.2 & 3.7 & & Within Screen \\
\hline 5 & 1582.6 & 1589.8 & 5483.7 & 5476.5 & 7.2 & $\mathrm{RD}$ & Tpf & PP5 & 1591.5 & 5474.8 & \begin{tabular}{|l|}
-1.7 \\
\end{tabular} & 3.7 & Below Screen \\
\hline & & & & & & & & MP5B & 1597.1 & 5469.2 & -7.3 & 15.8 & Below Screen \\
\hline & & & & & & & & MP6A & 1730.1 & 5336.2 & 3.8 & & Within Screen \\
\hline 6 & 1726.8 & 1733.9 & 5339.5 & 5332.4 & 7.1 & RD & Tpf & PP6 & 1735.4 & 5330.9 & -1.5 & 3.2 & Below Screen \\
\hline & & & & & & & & MP6B & 1741.1 & 5325.2 & -7.2 & 15.6 & Below Screen \\
\hline & & & & & & & & MP7A & 1834.7 & 5231.6 & 4.8 & & Within Screen \\
\hline 7 & 1832.4 & 1839.5 & 5233.9 & 5226.8 & 7.1 & RD & Tpf & PP7 & 1840.0 & 5226.3 & -0.5 & 1.1 & Below Screen \\
\hline & & & & & & & & MP7B & 1845.7 & 5220.6 & -6.2 & 13.4 & Below Screen \\
\hline
\end{tabular}

Note: R-19 Brass Cap Ground Elevation: $7066.3 \mathrm{ft}$; all measurements are from this elevation;

MP = Monitor Port; PP = Pump Port; Monitor Ports shown in bold are instrumented ports 

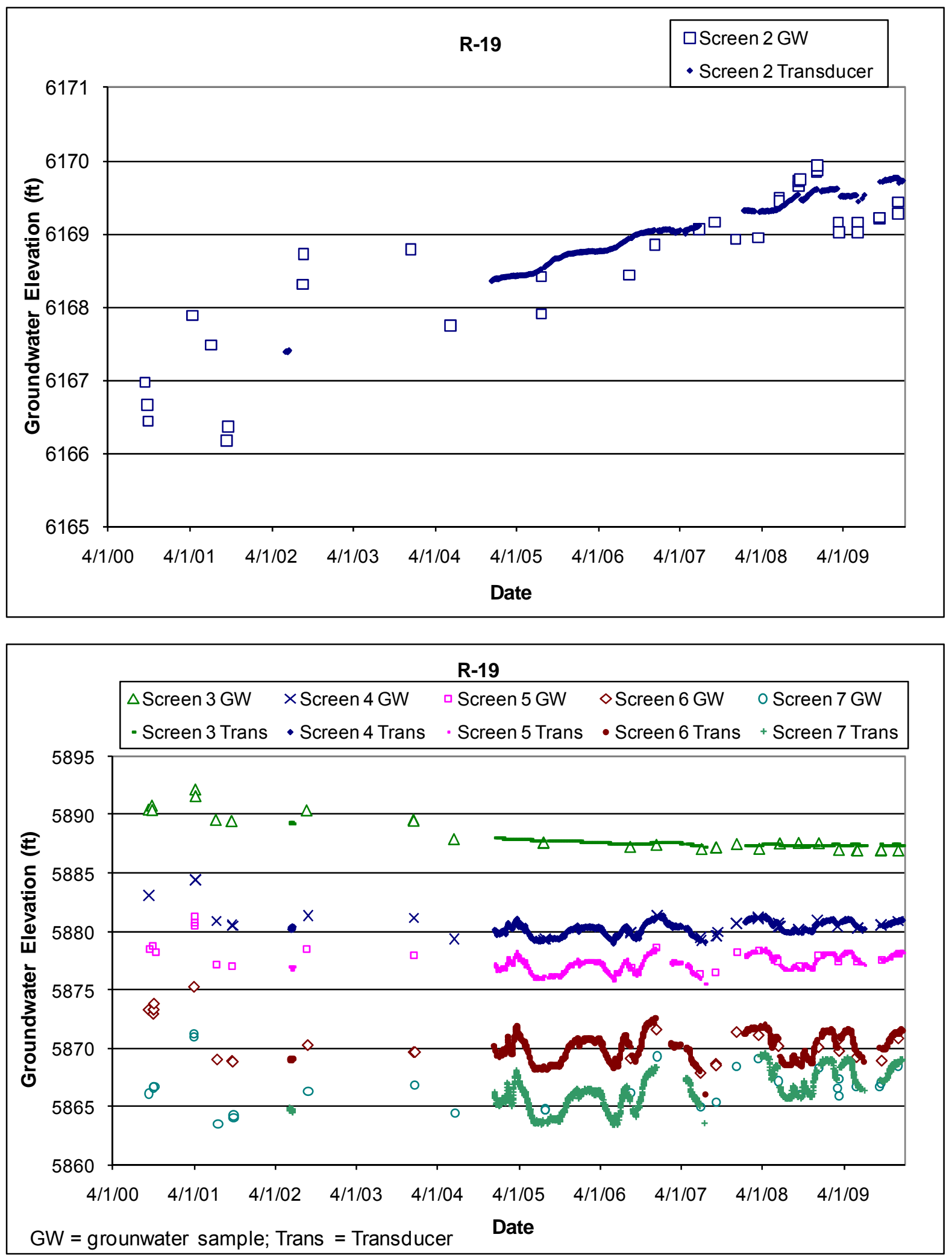


\subsection{R-20}

Location: R-20 is located in lower Pajarito Canyon about $1300 \mathrm{ft}$ east of supply well PM-2.

Completion Type: Multiple completion, originally three screens in the regional aquifer. Screen 3 was plugged and abandoned November 2007, leaving two screens in the regional aquifer. The top of screen 1 is about $76 \mathrm{ft}$ below the regional water table.

Period of Record: Westbay ${ }^{\circledR}$ installed January 18, 2003, transducers installed March 26, 2003, intermittent transducer data to June 1,2006 , when the Westbay ${ }^{\circledR}$ system was removed. No water level data in the last half of 2006 and in 2007 during well rehabilitation. Transducers installed at screens 1 and 2 in May 2008; data through 2009.

Remarks: Two packers installed between screens 1 and 2 and a dual pump Baski sampling system installed May 2008 (LANL January 2008). Screen 1 shows no response to atmospheric pressure fluctuations. Screen 3 responded to supply well pumping at PM-2 and PM-4. The shallower screens 1 and 2 show a muted response to supply well pumping.

\begin{tabular}{|c|c|c|c|c|c|c|c|c|c|c|c|c|c|c|c|}
\hline \multicolumn{16}{|c|}{ R-20 Construction Information } \\
\hline Screen & $\begin{array}{c}\text { Screen } \\
\text { Top } \\
\text { Depth } \\
\text { (ft) }\end{array}$ & $\begin{array}{c}\text { Screen } \\
\text { Bottom } \\
\text { Depth } \\
\text { (ft) }\end{array}$ & $\begin{array}{l}\text { Screen } \\
\text { Top } \\
\text { Elev (ft) }\end{array}$ & $\begin{array}{l}\text { Screen } \\
\text { Bottom } \\
\text { Elev (ft) }\end{array}$ & $\begin{array}{c}\text { Screen } \\
\text { Length } \\
\text { (ft) }\end{array}$ & $\begin{array}{c}\text { Pump } \\
\text { Intake } \\
\text { Depth } \\
\text { (ft) }\end{array}$ & $\begin{array}{c}\text { Pump } \\
\text { Intake } \\
\text { Elev } \\
\text { (ft) }\end{array}$ & $\begin{array}{c}\text { Second } \\
\text { Packer } \\
\text { Bottom } \\
\text { Depth } \\
\text { (ft) }\end{array}$ & $\begin{array}{l}\text { Depth } \\
\text { to Top } \\
\text { of } \\
\text { Sump } \\
\text { (ft) }\end{array}$ & $\begin{array}{c}\text { Top of } \\
\text { Sump } \\
\text { Elev } \\
\text { (ft) }\end{array}$ & \begin{tabular}{|c} 
Depth to \\
Packerl \\
Sump \\
Bottom \\
(ft)
\end{tabular} & $\begin{array}{c}\text { Sump } \\
\text { Length } \\
\text { (ft) }\end{array}$ & $\begin{array}{l}\text { Sump } \\
\text { Vol } \\
\text { (gal) }\end{array}$ & $\begin{array}{l}\text { Hydro } \\
\text { Zone } \\
\text { Code }\end{array}$ & $\begin{array}{l}\text { Geo } \\
\text { Unit } \\
\text { Code }\end{array}$ \\
\hline 1 & 904.6 & 912.2 & 5789.8 & 5782.2 & 7.6 & 908.43 & 5785.9 & & 912.2 & 5782.2 & 918.7 & $\begin{array}{l}6.5 \\
\end{array}$ & 5.3 & RT & Tb4 \\
\hline 2 & 1147.1 & 1154.7 & 5547.3 & 5539.7 & 7.6 & $\mid 1141.7$ & 5552.6 & 1133.8 & 1154.7 & \begin{tabular}{|l|}
5539.7 \\
\end{tabular} & 1183.5 & 28.8 & 23.8 & $\mathrm{RD}$ & Tpp \\
\hline 3 & 1328.8 & 1336.5 & 5365.6 & 5357.9 & 7.7 & \multicolumn{8}{|c|}{ Screen 3 plugged and abandoned November 2007} & RD & Tsf \\
\hline
\end{tabular}

Note: R-20 Brass Cap Ground Elevation: $6694.35 \mathrm{ft}$; all measurements are from this elevation 

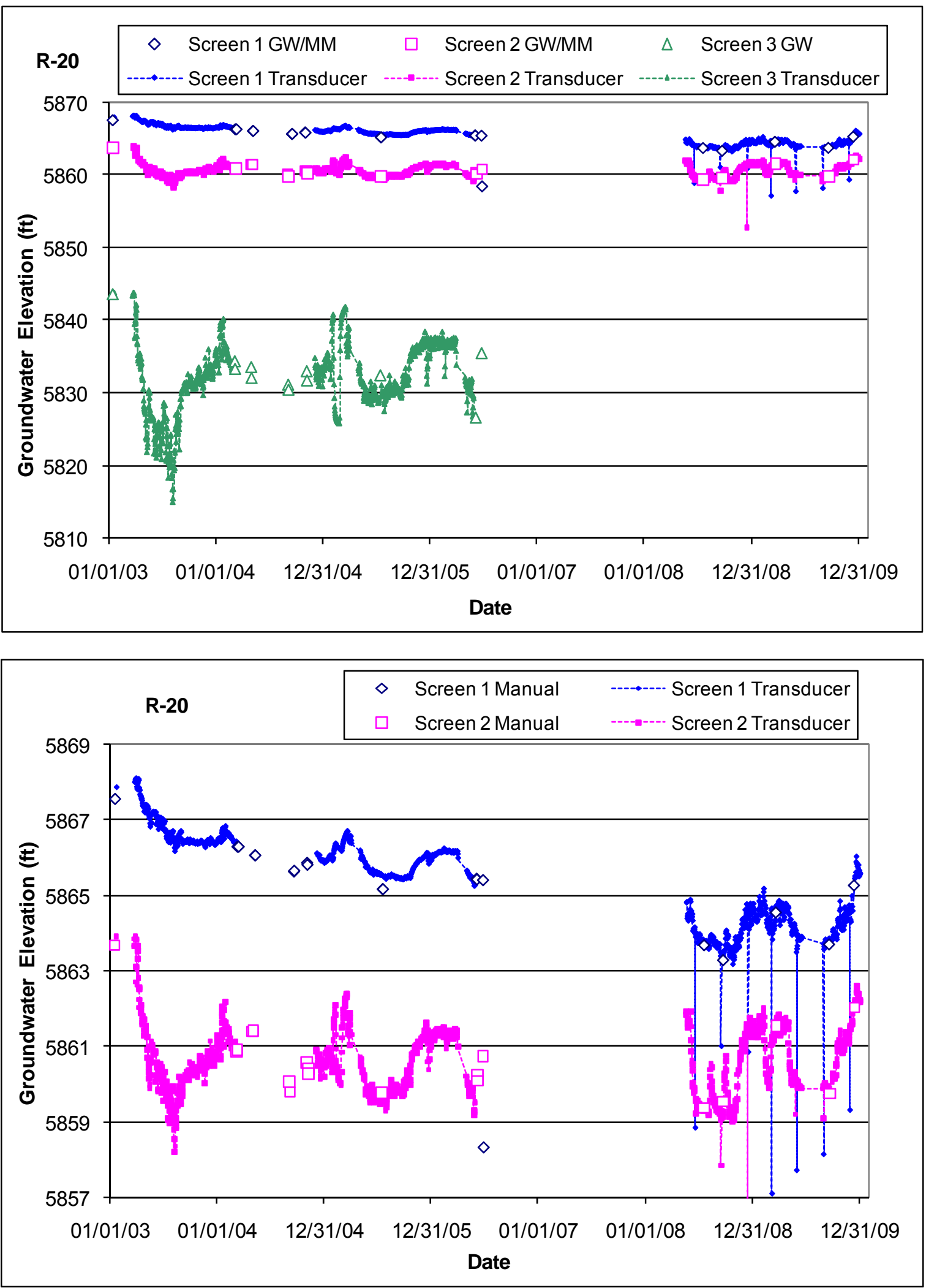


\subsection{R-21}

Location: R-21 is located in Cañada del Buey north of TA-54.

Completion Type: Single completion at the top of the regional aquifer. The top of the screen is about $87 \mathrm{ft}$ below the water table.

Period of Record: Well completed November 2002, transducer installed May 23, 2005, transducer data through 2009.

Remarks: R-21 installed to a depth of $941.4 \mathrm{ft}$, about $140 \mathrm{ft}$ into the regional aquifer. The well is $100 \%$ barometrically efficient; the aquifer does not respond to atmospheric pressure fluctuations. The well responds to pumping of PM-2, PM-4, and possibly another well or combination of wells.

\begin{tabular}{|c|c|c|c|c|c|c|c|c|c|c|c|c|c|c|}
\hline \multicolumn{15}{|c|}{ R-21 Construction Information } \\
\hline Screen & $\begin{array}{l}\text { Screen } \\
\text { Top } \\
\text { Depth } \\
\text { (ft) }\end{array}$ & \begin{tabular}{|c|} 
Screen \\
Bottom \\
Depth \\
(ft)
\end{tabular} & \begin{tabular}{|c} 
Screen \\
Top \\
Elev \\
(ft)
\end{tabular} & $\begin{array}{l}\text { Screen } \\
\text { Bottom } \\
\text { Elev (ft) }\end{array}$ & $\begin{array}{l}\text { Screen } \\
\text { Length } \\
\text { (ft) }\end{array}$ & $\begin{array}{l}\text { Pump } \\
\text { Intake } \\
\text { Depth } \\
\text { (ft) }\end{array}$ & $\begin{array}{c}\text { Pump } \\
\text { Intake } \\
\text { Elev } \\
\text { (ft) }\end{array}$ & \begin{tabular}{|} 
Depth to \\
Top of \\
Sump \\
(ft)
\end{tabular} & $\begin{array}{c}\text { Top of } \\
\text { Sump } \\
\text { Elev } \\
\text { (ft) }\end{array}$ & \begin{tabular}{|c} 
Depth to \\
Sump \\
Bottom \\
(ft)
\end{tabular} & $\begin{array}{c}\text { Sump } \\
\text { Length } \\
\text { (ft) }\end{array}$ & $\begin{array}{c}\text { Sump } \\
\text { Volume } \\
\text { (L) }\end{array}$ & $\begin{array}{l}\text { Hydro } \\
\text { Zone } \\
\text { Code }\end{array}$ & $\begin{array}{l}\text { Geo } \\
\text { Unit } \\
\text { Code }\end{array}$ \\
\hline 1 & 888.8 & 906.8 & 5767.4 & 5749.4 & 18.0 & 861 & 5795.2 & 906.8 & 5749.4 & 941.4 & 34.6 & 192.4 & RT & $\overline{T p f}$ \\
\hline
\end{tabular}

Note: R-21 Brass Cap Ground Elevation: $6656.24 \mathrm{ft}$; all measurements are from this elevation

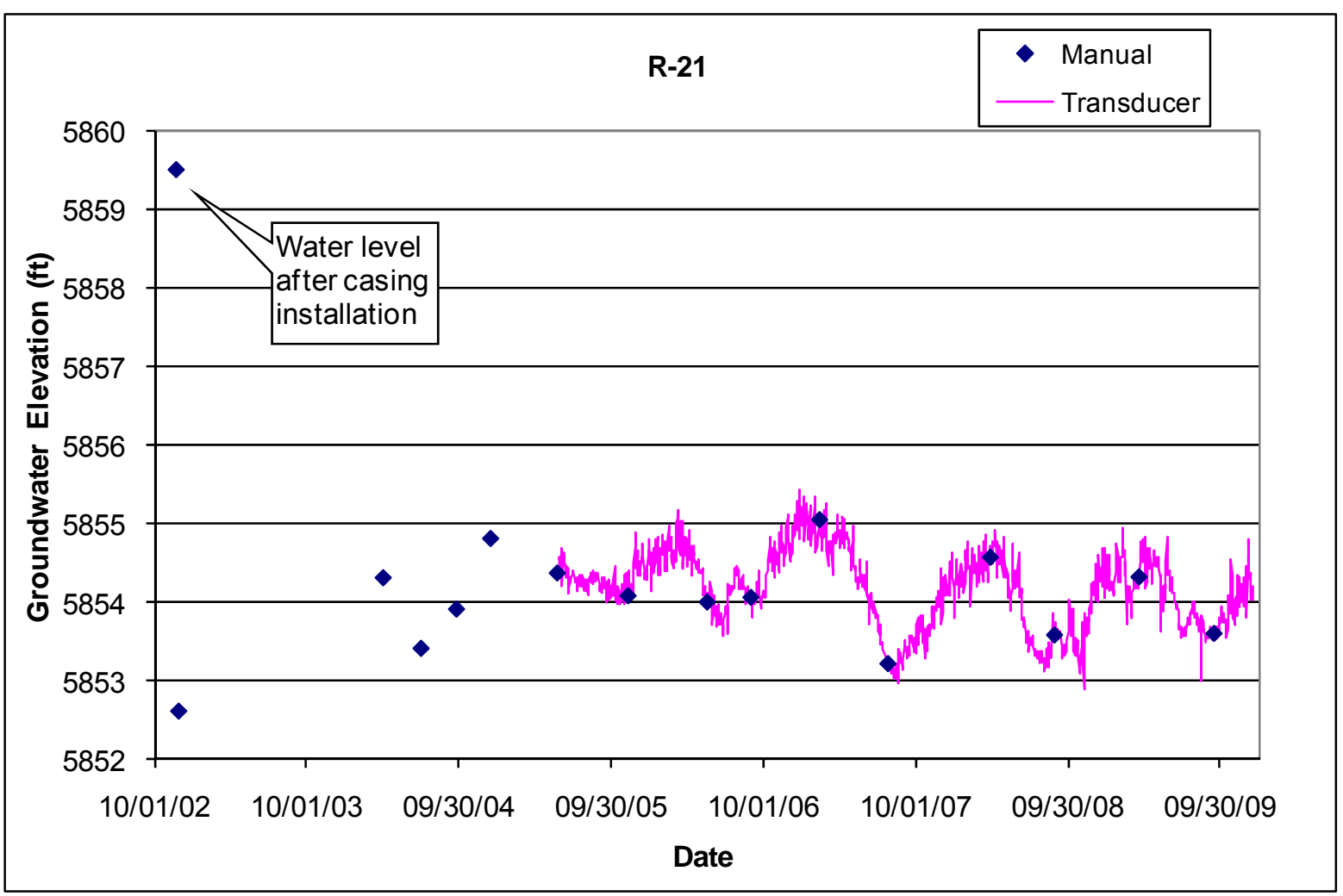




\subsection{R-22}

Location: R-22 is located at the east end of Mesita del Buey, east of TA-54.

Completion Type: Multiple completion, five screens in the regional aquifer. Screen 1 straddles the regional water table.

Period of Record: Westbay ${ }^{\circledR}$ installed December 11, 2000, transducers installed March 26, 2003, intermittent transducer data to April 13,2009, when the transducers were removed in preparation for removing the Westbay ${ }^{\circledR}$ system.

Remarks: Screens 1 and 2 have similar head values about $6 \mathrm{ft}$ apart. Screens 3, 4, and 5 have similar heads within $6 \mathrm{ft}$ of each other, but about $60 \mathrm{ft}$ lower than screens 1 and 2 . Screens 4 and 5 have nearly identical head values. The R-22 screens do not show an immediate response to atmospheric pressure fluctuations, but show a delayed response ranging from $20 \%$ to $95 \%$. The deeper aquifer at R-22 screens 3, 4, and 5 shows an apparent small seasonal response to supply well pumping. The Westbay ${ }^{\circledR}$ system was removed on May 3,2009 , for well rehabilitation (LANL 2009).

\begin{tabular}{|c|c|c|c|c|c|c|c|c|c|c|c|c|c|}
\hline \multicolumn{14}{|c|}{ R-22 Construction and Port Information } \\
\hline Screen & $\begin{array}{c}\text { Screen } \\
\text { Top } \\
\text { Depth (ft) }\end{array}$ & $\begin{array}{c}\text { Screen } \\
\text { Bottom } \\
\text { Depth } \\
\text { (ft) }\end{array}$ & $\begin{array}{l}\text { Screen } \\
\text { Top } \\
\text { Elev (ft) }\end{array}$ & $\begin{array}{l}\text { Screen } \\
\text { Bottom } \\
\text { Elev (ft) }\end{array}$ & $\begin{array}{c}\text { Screen } \\
\text { Length } \\
\text { (ft) }\end{array}$ & $\begin{array}{c}\text { Hydro } \\
\text { Zone } \\
\text { Code }\end{array}$ & $\begin{array}{l}\text { Geo } \\
\text { Unit } \\
\text { Code }\end{array}$ & Port & $\begin{array}{c}\text { Port } \\
\text { Depth (ft) }\end{array}$ & $\begin{array}{c}\text { Port } \\
\text { Elevation } \\
\text { (ft) }\end{array}$ & \begin{tabular}{|c}
$\begin{array}{c}\text { Distance } \\
\text { from } \\
\text { Bottom of } \\
\text { Screen (ft) }\end{array}$ \\
\end{tabular} & $\begin{array}{c}\text { Sump } \\
\text { Volume } \\
\text { (L) }\end{array}$ & Comment \\
\hline \multirow{3}{*}{1} & \multirow{3}{*}{872.3} & \multirow{3}{*}{914.2} & \multirow{3}{*}{5778.2} & \multirow{3}{*}{5736.3} & \multirow{3}{*}{41.9} & \multirow{3}{*}{ RT } & \multirow{3}{*}{ Tb4 } & MP1A & 907.1 & 5743.4 & 7.1 & & Within Screen \\
\hline & & & & & & & & PP1 & 912.4 & 5738.1 & 1.8 & & Within Screen \\
\hline & & & & & & & & MP1B & 918.1 & 5732.4 & -3.9 & 9.1 & Below Screen \\
\hline \multirow{3}{*}{2} & \multirow{3}{*}{947.0} & \multirow{3}{*}{988.9} & \multirow{3}{*}{5703.5} & \multirow{3}{*}{5661.6} & \multirow{3}{*}{41.9} & \multirow{3}{*}{ RD } & \multirow{3}{*}{ Tb4 } & MP2A & 962.8 & \begin{tabular}{|l|}
5687.7 \\
\end{tabular} & 26.1 & & Within Screen \\
\hline & & & & & & & & PP2 & 967.7 & 5682.8 & 21.2 & & Within Screen \\
\hline & & & & & & & & MP2B & 973.4 & 5677.1 & 15.5 & & Within Screen \\
\hline \multirow{3}{*}{3} & \multirow{3}{*}{1272.2} & \multirow{3}{*}{1278.9} & \multirow{3}{*}{5378.3} & \multirow{3}{*}{5371.6} & \multirow{3}{*}{6.7} & \multirow{3}{*}{ RD } & \multirow{3}{*}{ Tpf } & MP3A & 1273.5 & 5377.0 & 5.4 & & Within Screen \\
\hline & & & & & & & & PP3 & 1278.9 & 5371.6 & 0 & & Within Screen \\
\hline & & & & & & & & MP3B & 1284.5 & 5366.0 & -5.6 & 13.1 & Below Screen \\
\hline \multirow{3}{*}{4} & \multirow{3}{*}{1378.2} & \multirow{3}{*}{1384.9} & \multirow{3}{*}{5272.3} & \multirow{3}{*}{5265.6} & \multirow{3}{*}{6.7} & \multirow{3}{*}{$\mathrm{RD}$} & \multirow{3}{*}{$\mathrm{Tb}$} & MP4A & 1378.0 & 5272.5 & 6.9 & & Above Screen \\
\hline & & & & & & & & PP4 & 1383.4 & 5267.1 & 1.5 & & Within Screen \\
\hline & & & & & & & & MP4B & 1389.1 & 5261.4 & -4.2 & 9.9 & Below Screen \\
\hline \multirow{3}{*}{5} & & & & & & & & MP5A & 1448.2 & 5202.3 & 4.1 & & Within Screen \\
\hline & 1447.3 & 1452.3 & 5203.2 & 5198.2 & 5.0 & $\mathrm{RD}$ & Tpf & PP5 & 1453.6 & 5196.9 & -1.3 & 3.0 & Below Screen \\
\hline & & & & & & & & MP5B & 1459.2 & 5191.3 & -6.9 & 16.2 & Below Screen \\
\hline
\end{tabular}

Note: R-22 Brass Cap Ground Elevation: $6650.5 \mathrm{ft}$; all measurements are from this elevation; MP = Monitor Port; PP = Pump Port; Monitor Ports shown in bold are instrumented ports 

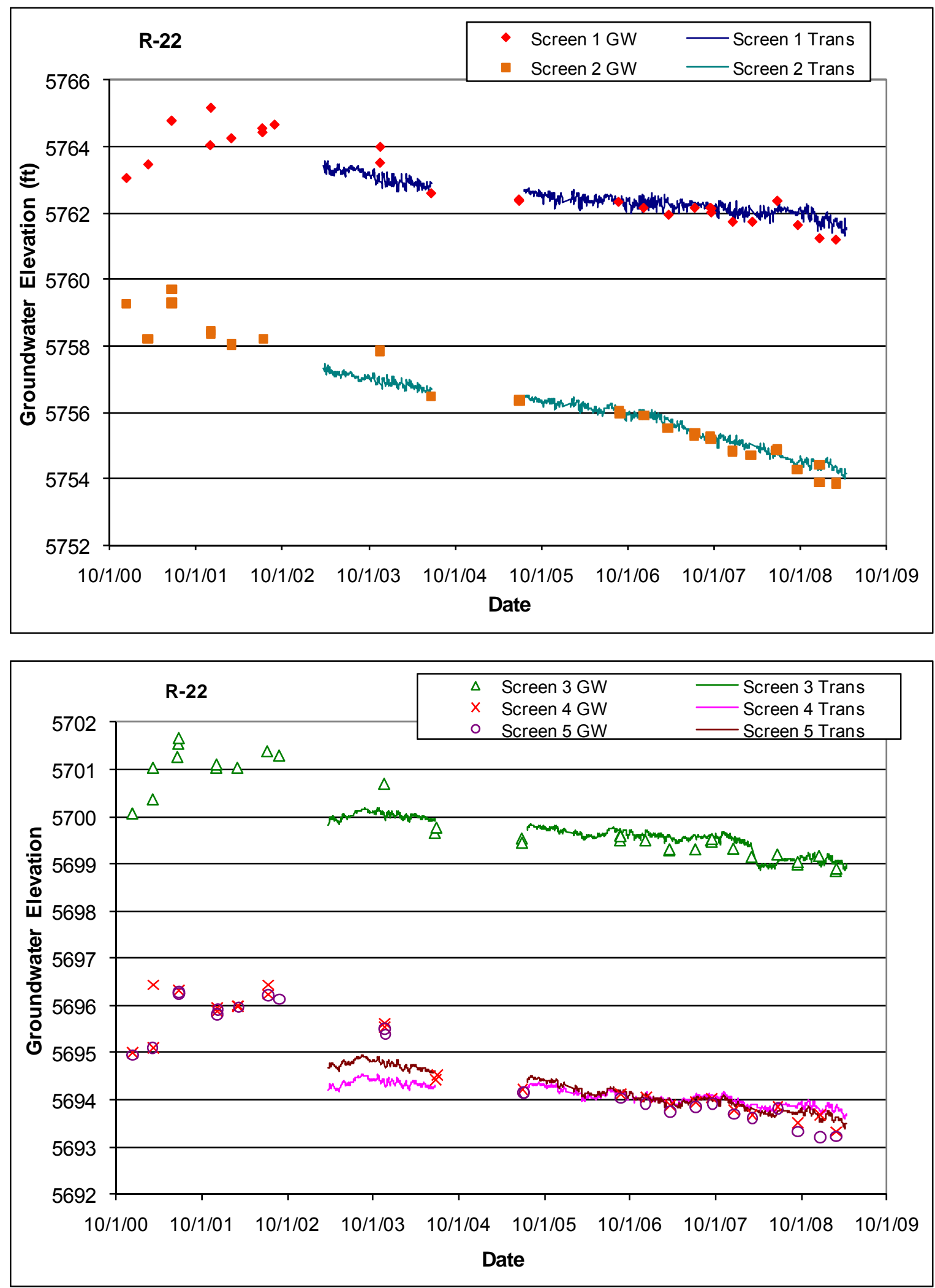


\subsection{R-23}

Location: R-23 is located in lower Pajarito Canyon near SR-4 and the eastern LANL boundary.

Completion Type: Single completion at the top of the regional aquifer. The screen straddles the water table.

Period of Record: Well completed October 2002, transducer installed June 20, 2005, transducer data through 2009.

Remarks: R-23 was installed to a depth of $886.3 \mathrm{ft}$, about $60 \mathrm{ft}$ into the regional aquifer. The well is $100 \%$ barometrically efficient; the aquifer has no immediate response to atmospheric pressure fluctuations, however, the aquifer has a delayed response to atmospheric pressure. The aquifer at R-23 shows no apparent response to pumping the PM well field or the Buckman well field.

\begin{tabular}{|c|c|c|c|c|c|c|c|c|c|c|c|c|c|c|}
\hline \multicolumn{15}{|c|}{ R-23 Construction Information } \\
\hline Screen & $\begin{array}{c}\text { Screen } \\
\text { Top } \\
\text { Depth (ft) }\end{array}$ & $\begin{array}{c}\text { Screen } \\
\text { Bottom } \\
\text { Depth } \\
\text { (ft) }\end{array}$ & $\begin{array}{l}\text { Screen } \\
\text { Top } \\
\text { Elev (ft) }\end{array}$ & $\begin{array}{l}\text { Screen } \\
\text { Bottom } \\
\text { Elev (ft) }\end{array}$ & $\begin{array}{c}\text { Screen } \\
\text { Length } \\
\text { (ft) }\end{array}$ & $\begin{array}{l}\text { Pump } \\
\text { Intake } \\
\text { Depth } \\
\text { (ft) }\end{array}$ & $\begin{array}{c}\text { Pump } \\
\text { Intake } \\
\text { Elevation } \\
\text { (ft) }\end{array}$ & $\begin{array}{l}\text { Depth } \\
\text { to Top } \\
\text { of } \\
\text { Sump } \\
\text { (ft) }\end{array}$ & $\begin{array}{c}\text { Top of } \\
\text { Sump } \\
\text { Elevation } \\
\text { (ft) }\end{array}$ & $\begin{array}{c}\text { Depth to } \\
\text { Sump } \\
\text { Bottom } \\
\text { (ft) }\end{array}$ & $\begin{array}{c}\text { Sump } \\
\text { Length } \\
\text { (ft) }\end{array}$ & $\begin{array}{c}\text { Sump } \\
\text { Volume } \\
\text { (L) }\end{array}$ & $\begin{array}{c}\text { Hydro } \\
\text { Zone } \\
\text { Code }\end{array}$ & $\begin{array}{l}\text { Geo } \\
\text { Unit } \\
\text { Code }\end{array}$ \\
\hline 1 & 816.0 & 873.2 & 5711.8 & 5654.6 & 57.2 & 870.7 & 5657.1 & 873.2 & 5654.6 & 886.3 & 13.1 & 41.0 & $\overline{\mathrm{RT}}$ & Tsf \\
\hline
\end{tabular}

Note: R-23 Brass Cap Ground Elevation: $6527.75 \mathrm{ft}$; all measurements are from this elevation

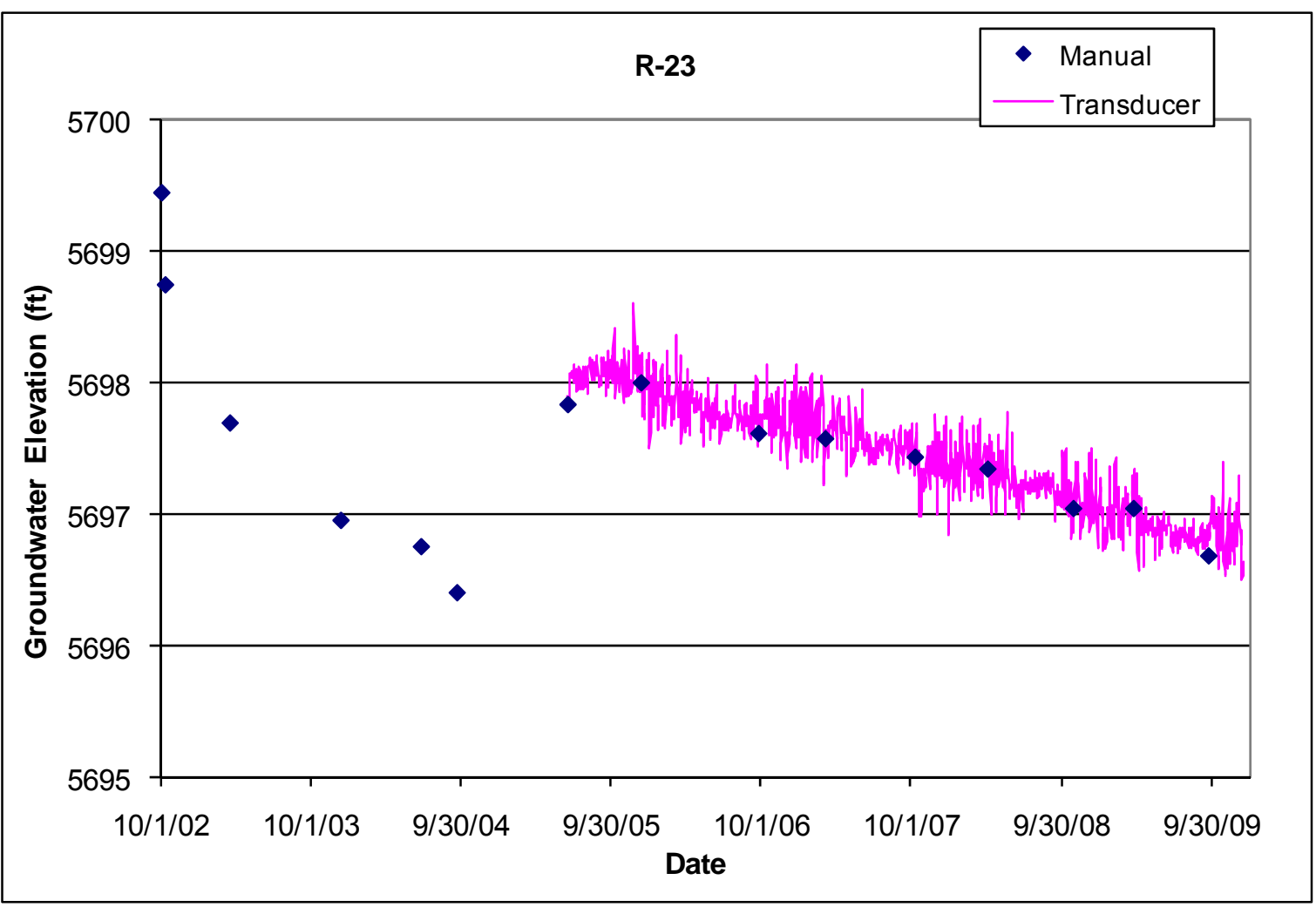




\section{$3.27 \quad$ R-24}

Location: R-24 is located in Bayo Canyon north of the former Bayo Sewage Treatment Plant.

Completion Type: Single completion at the top of the regional aquifer. The top of the screen is in a confined zone about $110 \mathrm{ft}$ below the water table.

Period of Record: Well completed September 2005, transducer installed March 1, 2006, data through 2009.

Remarks: R-24 installed to a depth of $861 \mathrm{ft}$, about $150 \mathrm{ft}$ into the regional aquifer. The well is $100 \%$ barometrically efficient; the aquifer does not respond to atmospheric pressure fluctuations. The aquifer at R-24 responds primarily to pumping at supply well PM-3 but may also respond to pumping the Guaje well field and supply well O-4.

\begin{tabular}{|c|c|c|c|c|c|c|c|c|c|c|c|c|c|c|}
\hline \multicolumn{15}{|c|}{ R-24 Construction Information } \\
\hline Screen & $\begin{array}{c}\text { Screen } \\
\text { Top } \\
\text { Depth } \\
\text { (ft) }\end{array}$ & $\begin{array}{c}\text { Screen } \\
\text { Bottom } \\
\text { Depth } \\
\text { (ft) }\end{array}$ & $\begin{array}{c}\text { Screen } \\
\text { Top } \\
\text { Elev (ft) }\end{array}$ & $\begin{array}{l}\text { Screen } \\
\text { Bottom } \\
\text { Elev (ft) }\end{array}$ & $\begin{array}{c}\text { Screen } \\
\text { Length } \\
\text { (ft) }\end{array}$ & $\begin{array}{c}\text { Pump } \\
\text { Intake } \\
\text { Depth } \\
\text { (ft) }\end{array}$ & $\begin{array}{c}\text { Pump } \\
\text { Intake } \\
\text { Elevation } \\
\text { (ft) }\end{array}$ & $\begin{array}{l}\text { Depth } \\
\text { to Top } \\
\text { of } \\
\text { Sump } \\
\text { (ft) }\end{array}$ & $\begin{array}{c}\text { Top of } \\
\text { Sump } \\
\text { Elevation } \\
\text { (ft) }\end{array}$ & $\begin{array}{l}\text { Depth to } \\
\text { Sump } \\
\text { Bottom } \\
\text { (ft) }\end{array}$ & \begin{tabular}{|c} 
Sump \\
Length \\
(ft)
\end{tabular} & $\begin{array}{c}\text { Sump } \\
\text { Volume } \\
\text { (L) }\end{array}$ & $\begin{array}{c}\text { Hydro } \\
\text { Zone } \\
\text { Code }\end{array}$ & $\begin{array}{l}\text { Geo } \\
\text { Unit } \\
\text { Code }\end{array}$ \\
\hline 1 & $\overline{825.0}$ & $\overline{848.0}$ & 5722.4 & 5699.4 & 23.0 & 818.7 & 5728.7 & 848.0 & $\overline{5699.4}$ & 861 & 13.0 & 40.7 & RT & $\overline{T s f}$ \\
\hline
\end{tabular}

Note: R-24 Brass Cap Ground Elevation: $6547.38 \mathrm{ft}$; all measurements are from this elevation

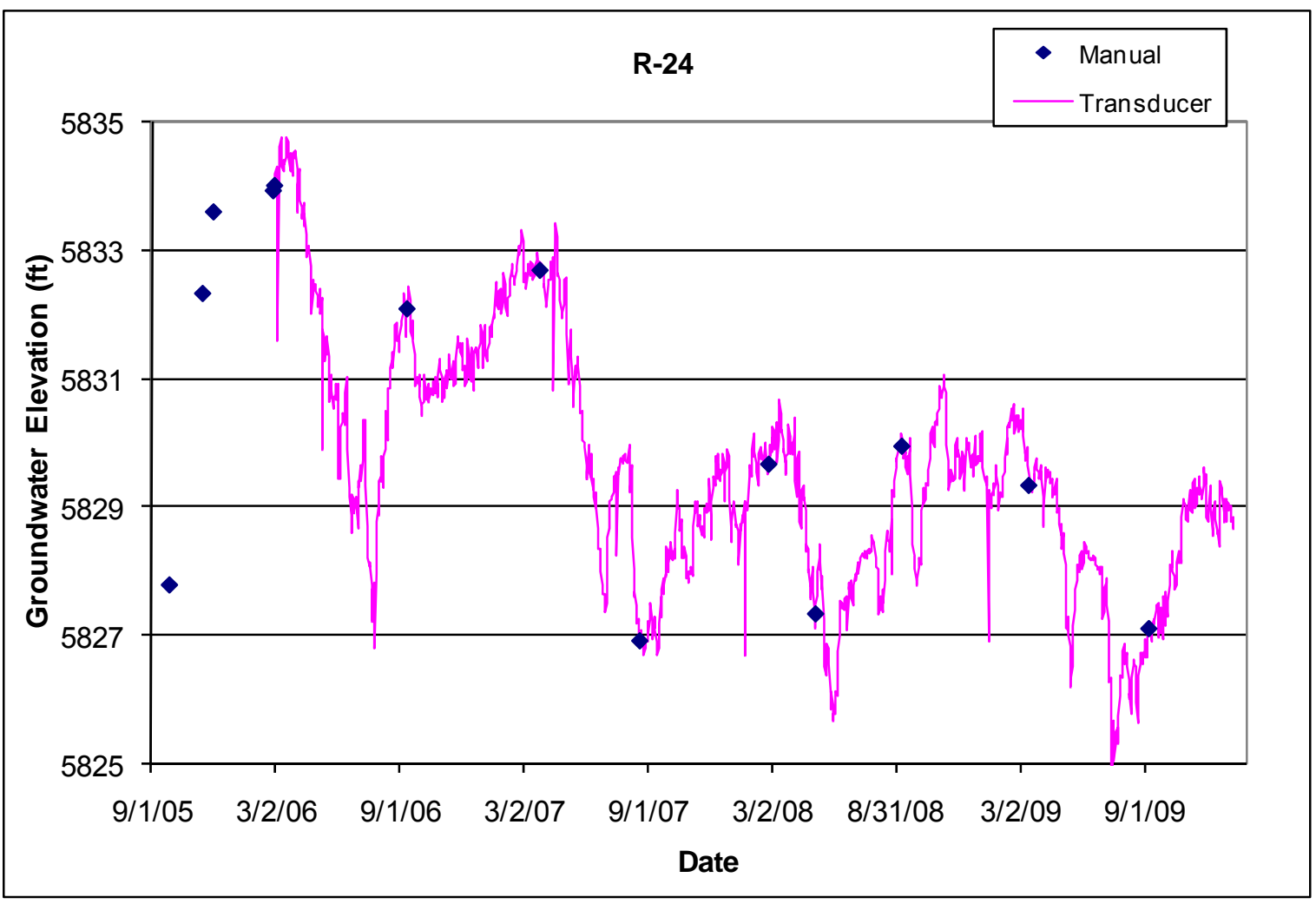




\subsection{R-25}

Location: R-25 is located at TA-16 within the Cañon de Valle watershed.

Completion Type: Multiple completion, four screens in intermediate zones, and five screens in the regional aquifer. Screens 3 and 9 were damaged during installation and are not reliable for water level monitoring. Screen 5 straddles the regional water table.

Period of Record: Westbay ${ }^{\circledR}$ installed October 3, 2000, transducers installed February 26, 2001, and between sampling events through 2002. Transducers installed again June 2, 2005; data through 2009.

Remarks: Recurring problems with the transducer cables from 2001 to 2005 caused loss of data. The transducer cables were rebuilt in 2005. Screens 1 and 2 appear to be in the same intermediate zone. Screen 4 appears to be in a separate intermediate zone. The water level at screen 5 , the top of the regional aquifer, declines significantly during low flow sampling and recovers slowly. There is no significant response to atmospheric pressure at any of the screens. Intermediate screens 1 , 2, and 4 responded to snowmelt runoff in 2005,2007 , and 2008. The regional aquifer screens do not indicate an apparent response to supply well pumping. The intermediate groundwater at screens 1,2 , and 4 and the sump water at screen 3 responded to drilling and installation of adjacent well R-25c (replacement for R-25 screen 3) in August 2008 (LANL September 2008).

\begin{tabular}{|c|c|c|c|c|c|c|c|c|c|c|c|c|c|c|}
\hline \multicolumn{15}{|c|}{ R-25 Construction and Port Information } \\
\hline Screen & \begin{tabular}{|c|} 
Screen \\
Top \\
Depth \\
(ft)
\end{tabular} & $\begin{array}{c}\text { Screen } \\
\text { Bottom } \\
\text { Depth } \\
\text { (ft) }\end{array}$ & $\begin{array}{c}\text { Screen } \\
\text { Top } \\
\text { Elev (ft) }\end{array}$ & $\begin{array}{l}\text { Screen } \\
\text { Bottom } \\
\text { Elev (ft) }\end{array}$ & $\begin{array}{c}\text { Screen } \\
\text { Length } \\
\text { (ft) }\end{array}$ & $\begin{array}{l}\text { Hydro } \\
\text { Zone } \\
\text { Code }\end{array}$ & $\begin{array}{c}\text { Geo } \\
\text { Unit } \\
\text { Code }\end{array}$ & Port & $\begin{array}{c}\text { Port } \\
\text { Depth } \\
\text { (ft) }\end{array}$ & $\begin{array}{c}\text { Port } \\
\text { Elev (ft) }\end{array}$ & \begin{tabular}{|c|} 
Distance \\
from \\
Bottom \\
of \\
Screen \\
(ft)
\end{tabular} & $\begin{array}{c}\text { Sump } \\
\text { Vol } \\
\text { above } \\
\text { Port } \\
\text { (L) }\end{array}$ & $\begin{array}{c}\text { Sump } \\
\text { Vol } \\
\text { Total } \\
\text { (L) }\end{array}$ & Comment \\
\hline \multirow{3}{*}{1} & \multirow{3}{*}{737.6} & \multirow{3}{*}{758.4} & \multirow{3}{*}{6778.5} & \multirow{3}{*}{6757.7} & \multirow{3}{*}{20.8} & \multirow{3}{*}{ I } & \multirow{3}{*}{ Qbo } & MP1A & 754.8 & 6761.3 & 3.6 & & & Within Screen \\
\hline & & & & & & & & PP1 & 760.1 & 6756.0 & -1.7 & 4.9 & & Below Screen \\
\hline & & & & & & & & MP1B & 765.8 & 6750.3 & -7.4 & 21.4 & 31.9 & Below Screen \\
\hline \multirow{3}{*}{2} & \multirow{3}{*}{882.6} & \multirow{3}{*}{893.4} & \multirow{3}{*}{6633.5} & \multirow{3}{*}{6622.7} & \multirow{3}{*}{10.8} & \multirow{3}{*}{ I } & \multirow{3}{*}{ Tpf } & MP2A & 891.8 & 6624.3 & 1.6 & & & Within Screen \\
\hline & & & & & & & & PP2 & 897.2 & 6618.9 & -3.8 & 11.0 & & Below Screen \\
\hline & & & & & & & & MP2B & 902.8 & 6613.3 & -9.4 & 27.2 & 37.9 & Below Screen \\
\hline \multirow{3}{*}{3} & \multirow{3}{*}{1054.6} & \multirow{3}{*}{1064.6} & \multirow{3}{*}{6461.5} & \multirow{3}{*}{6451.5} & \multirow{3}{*}{10.0} & \multirow{3}{*}{ I } & \multirow{3}{*}{ Tpf } & MP3A & 1063.4 & 6452.7 & 1.2 & & & Within Screen, screen damaged \\
\hline & & & & & & & & PP3 & 1068.8 & 6447.3 & -4.2 & 12.2 & & Below Screen \\
\hline & & & & & & & & MP3B & 1084.2 & 6431.9 & -19.6 & 56.8 & 72.4 & Below Screen, sump water \\
\hline \multirow{3}{*}{4} & \multirow{3}{*}{1184.6} & \multirow{3}{*}{1194.6} & & & & & & MP4A & 1192.4 & 6323.7 & 2.2 & & & Within Screen \\
\hline & & & 6331.5 & 6321.5 & 10.0 & I & Tpf & PP4 & 1197.8 & 6318.3 & -3.2 & 9.3 & & Below Screen \\
\hline & & & & & & & & MP4B & 1203.4 & 6312.7 & -8.8 & 25.5 & 36.5 & Below Screen \\
\hline & & & & & & & & MP5A & 1303.4 & 6212.7 & 1.3 & & & Within Screen \\
\hline 5 & 1294.7 & 1304.7 & 6221.4 & 6211.4 & 10.0 & RT & Tpf & PP5 & 1308.8 & 6207.3 & -4.1 & 11.9 & & Below Screen \\
\hline & & & & & & & & MP5B & 1314.4 & 6201.7 & -9.7 & 28.1 & 39.1 & Below Screen \\
\hline & & & & & & & & MP6A & 1406.3 & 6109.8 & 8.4 & & & Within Screen \\
\hline 6 & 1404.7 & 1414.7 & 6111.4 & 6101.4 & 10.0 & $\mathrm{RD}$ & Tpf & PP6 & 1411.7 & 6104.4 & 3 & & & Within Screen \\
\hline & & & & & & & & MP6B & 1417.3 & 6098.8 & -2.6 & 7.5 & 18.5 & Below Screen \\
\hline & & & & & & & & MP7A & 1606.0 & 5910.1 & 8.7 & & & Within Screen \\
\hline 7 & 1604.7 & 1614.7 & 5911.4 & 5901.4 & 10.0 & $\mathrm{RD}$ & Tpf & PP7 & 1611.4 & 5904.7 & 3.3 & & & Within Screen \\
\hline & & & & & & & & MP7B & 1617.1 & 5899.0 & -2.4 & 7.0 & 17.7 & Below Screen \\
\hline & & & & & & & & MP8A & 1796.0 & 5720.1 & 8.7 & & & Within Screen \\
\hline 8 & 1794.7 & 1804.7 & 5721.4 & 5711.4 & 10.0 & $\mathrm{RD}$ & Tpf & PP8 & 1801.4 & 5714.7 & 3.3 & & & Within Screen \\
\hline & & & & & & & & MP8B & 1807.0 & 5709.1 & -2.3 & 6.7 & 17.4 & Below Screen \\
\hline 9 & 1894.7 & 1904.7 & 5621.4 & 5611.4 & 10.0 & $\mathrm{RD}$ & Tpf & MP9 & 1825.1 & 5691.0 & 79.6 & & & Screen 9 blocked by sediment \\
\hline
\end{tabular}

Note: R-25 Brass Cap Ground Elevation: $7516.1 \mathrm{ft}$; all measurements are from this elevation

MP = Monitor Port; PP = Pump Port; Monitor Ports shown in bold are instrumented ports 

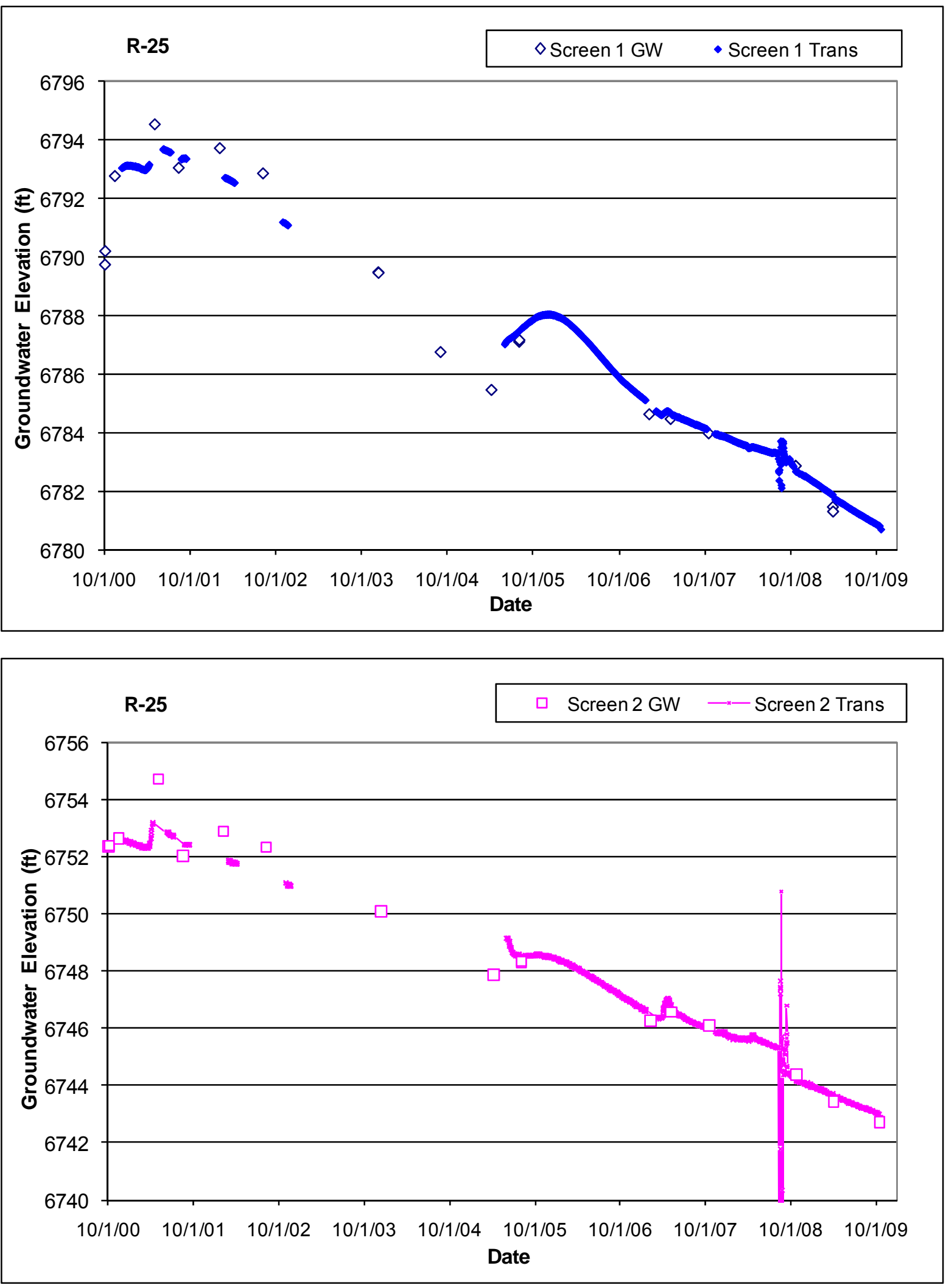

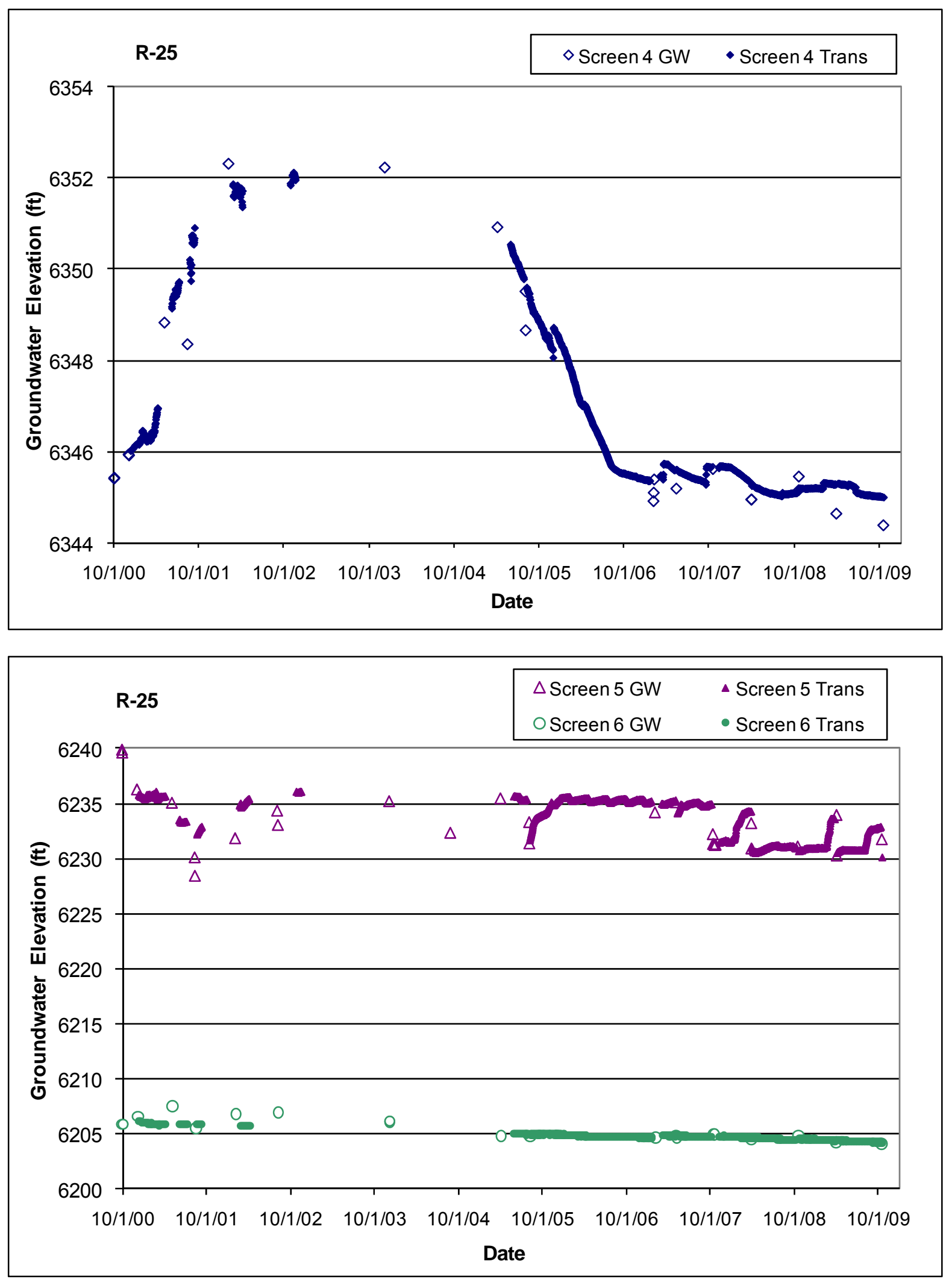


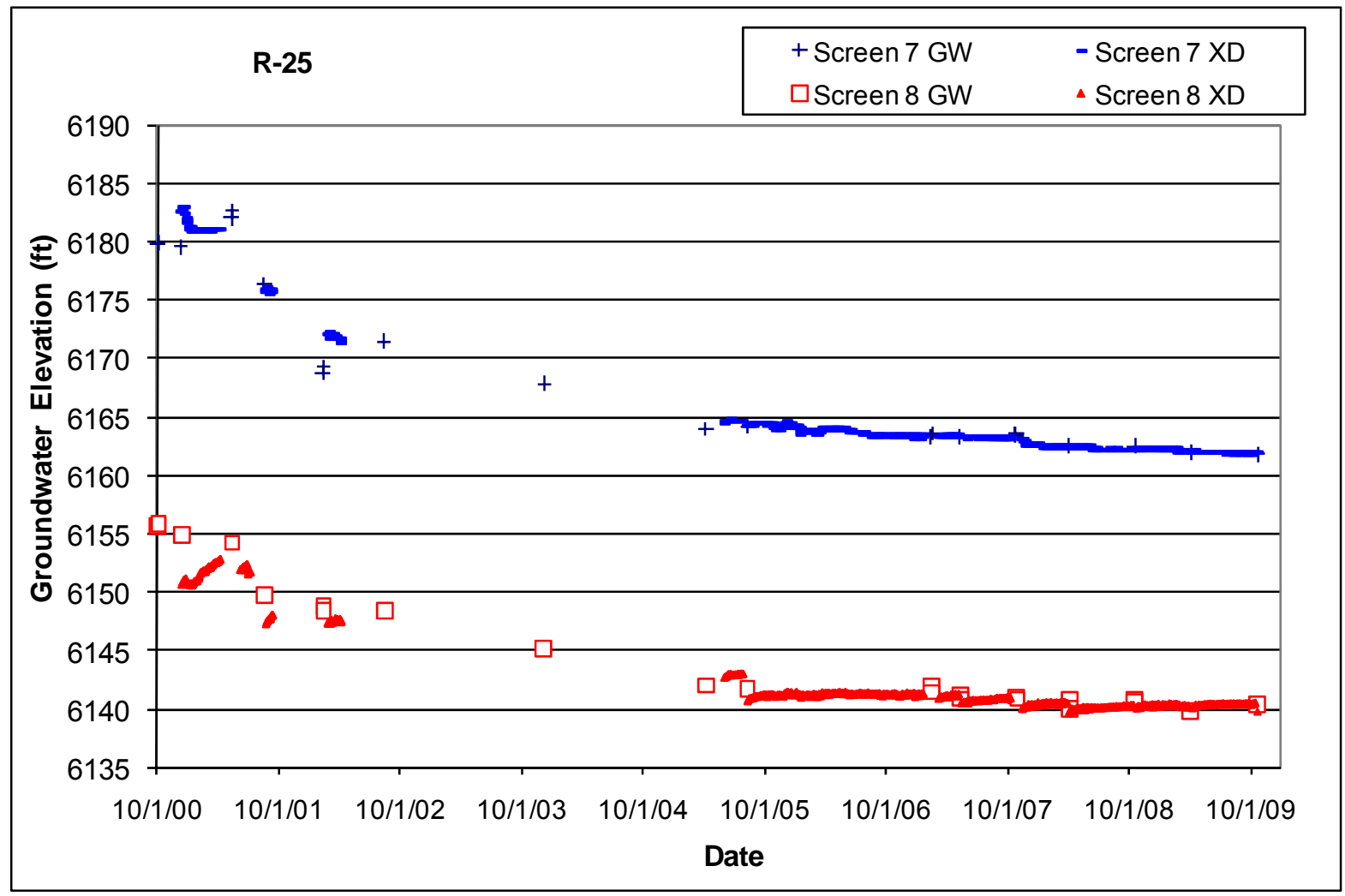




\subsection{R-26}

Location: R-26 is located at the western LANL boundary near Cañon de Valle.

Completion Type: Multiple completion, screen 1 is in an intermediate zone, and screen 2 is within the regional aquifer. The top of screen 2 is about $319 \mathrm{ft}$ below the regional water table.

Period of Record: Westbay ${ }^{\circledR}$ installed July 18, 2004, transducers installed July 29, 2005, transducer data through 2009.

Remarks: Screen 2 is in a tight zone and/or improperly completed zone. Sampling attempts at MP2A caused plugging of the port and sampler with bentonite; the transducers were installed in the B ports on November 3, 2005; water level data from screen 2 at port MP2B appear valid with some questions as to validity pending additional data and review. There is no apparent response to supply well pumping at R-26.

\begin{tabular}{|c|c|c|c|c|c|c|c|c|c|c|c|c|c|}
\hline \multicolumn{14}{|c|}{ R-26 Construction and Port Information } \\
\hline Screen & $\begin{array}{c}\text { Screen } \\
\text { Top } \\
\text { Depth } \\
\text { (ft) }\end{array}$ & $\begin{array}{c}\text { Screen } \\
\text { Bottom } \\
\text { Depth } \\
\text { (ft) }\end{array}$ & $\begin{array}{c}\text { Screen } \\
\text { Top } \\
\text { Elev (ft) }\end{array}$ & $\begin{array}{l}\text { Screen } \\
\text { Bottom } \\
\text { Elev (ft) }\end{array}$ & $\begin{array}{c}\text { Screen } \\
\text { Length } \\
(\mathrm{ft})\end{array}$ & $\begin{array}{l}\text { Hydro } \\
\text { Zone } \\
\text { Code }\end{array}$ & $\begin{array}{l}\text { Geo } \\
\text { Unit } \\
\text { Code }\end{array}$ & Port & $\begin{array}{l}\text { Port } \\
\text { Depth } \\
\text { (ft) }\end{array}$ & $\begin{array}{c}\text { Port } \\
\text { Elevation } \\
\text { (ft) }\end{array}$ & $\begin{array}{c}\text { Distance } \\
\text { from } \\
\text { Bottom } \\
\text { of Screen } \\
\text { (ft) }\end{array}$ & $\begin{array}{c}\text { Sump } \\
\text { Volume } \\
\text { (L) }\end{array}$ & Comment \\
\hline \multirow{3}{*}{1} & \multirow{3}{*}{651.8} & \multirow{3}{*}{669.9} & \multirow{3}{*}{6989.9} & \multirow{3}{*}{6971.8} & \multirow{3}{*}{18.1} & \multirow{3}{*}{$\mathrm{I}$} & \multirow{3}{*}{ Qct } & $\overline{M P 1 A}$ & 659.3 & 6982.4 & 10.6 & & Within Screen \\
\hline & & & & & & & & PP1 & 664.7 & 6977.0 & 5.2 & & Within Screen \\
\hline & & & & & & & & MP1B & 670.3 & 6971.4 & -0.4 & 0.8 & Below Screen \\
\hline \multirow{3}{*}{2} & \multirow{3}{*}{1421.8} & \multirow{3}{*}{1445.0} & \multirow{3}{*}{6219.9} & \multirow{3}{*}{6196.7} & \multirow{3}{*}{23.2} & \multirow{3}{*}{ RT } & \multirow{3}{*}{ Tp } & $\overline{\text { MP2A }}$ & 1427.0 & 6214.7 & 18.0 & & Within Screen \\
\hline & & & & & & & & PP2 & 1432.4 & 6209.3 & 12.6 & & Within Screen \\
\hline & & & & & & & & MP2B & 1438 & 6203.7 & 7.0 & & Within Screen \\
\hline
\end{tabular}

Note: R-26 Brass Cap Ground Elevation: $7641.69 \mathrm{ft}$; all measurements are from this elevation;

MP = Monitor Port; PP = Pump Port; Monitor Ports shown in bold are instrumented ports 


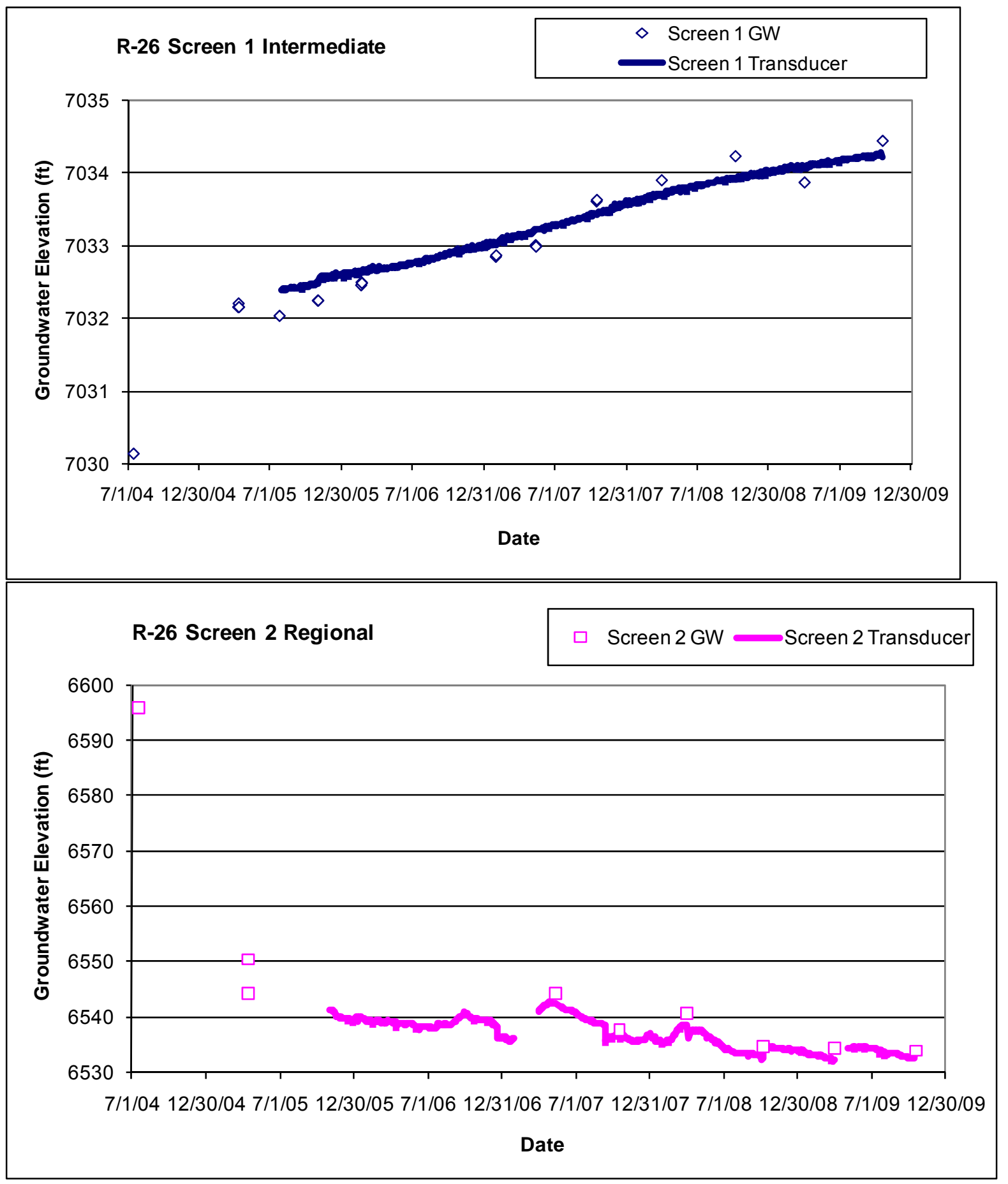




\section{$3.30 \quad$ R-27}

Location: R-27 is located in middle Water Canyon about 0.35 miles north of DT-10.

Completion Type: Single completion at the top of the regional aquifer in Puye fanglomerates. The top of the screen is about $38 \mathrm{ft}$ below the water table.

Period of Record: Well completed November 2005, transducer installed September 29, 2006, transducer data through 2009.

Remarks: R-27 is installed to a depth of $878.7 \mathrm{ft}$, about $60 \mathrm{ft}$ into the regional aquifer. The well is $100 \%$ barometrically efficient; the aquifer does not show a response to atmospheric pressure fluctuations. The aquifer at R-27 may show a small seasonal response to supply well pumping at PM-2.

\begin{tabular}{|c|c|c|c|c|c|c|c|c|c|c|c|c|c|c|}
\hline \multicolumn{15}{|c|}{ R-27 Construction Information } \\
\hline Screen & $\begin{array}{c}\text { Screen } \\
\text { Top } \\
\text { Depth } \\
\text { (ft) }\end{array}$ & $\begin{array}{c}\text { Screen } \\
\text { Bottom } \\
\text { Depth } \\
\text { (ft) }\end{array}$ & $\begin{array}{c}\text { Screen } \\
\text { Top } \\
\text { Elev } \\
\text { (ft) }\end{array}$ & $\begin{array}{l}\text { Screen } \\
\text { Bottom } \\
\text { Elev (ft) }\end{array}$ & \begin{tabular}{|} 
Screen \\
Length \\
$(\mathrm{ft})$
\end{tabular} & $\begin{array}{c}\text { Pump } \\
\text { Intake } \\
\text { Depth } \\
\text { (ft) }\end{array}$ & $\begin{array}{c}\text { Pump } \\
\text { Intake } \\
\text { Elevation } \\
\text { (ft) }\end{array}$ & $\begin{array}{c}\text { Depth to } \\
\text { Top of } \\
\text { Sump } \\
\text { (ft) }\end{array}$ & \begin{tabular}{|c} 
Top of \\
Sump \\
Elevation \\
(ft)
\end{tabular} & $\begin{array}{c}\text { Depth to } \\
\text { Sump } \\
\text { Bottom } \\
\text { (ft) }\end{array}$ & $\begin{array}{c}\text { Sump } \\
\text { Length } \\
\text { (ft) }\end{array}$ & $\begin{array}{c}\text { Sump } \\
\text { Volume } \\
\text { (L) }\end{array}$ & \begin{tabular}{|c|} 
Hydro \\
Zone \\
Code
\end{tabular} & $\begin{array}{c}\text { Geo } \\
\text { Unit } \\
\text { Code }\end{array}$ \\
\hline 1 & 852.0 & 875.0 & 5861.7 & 5838.7 & 23.0 & 847 & 5866.7 & 875.0 & 5838.7 & 878.7 & 3.7 & 11.6 & RT & Tpf \\
\hline
\end{tabular}

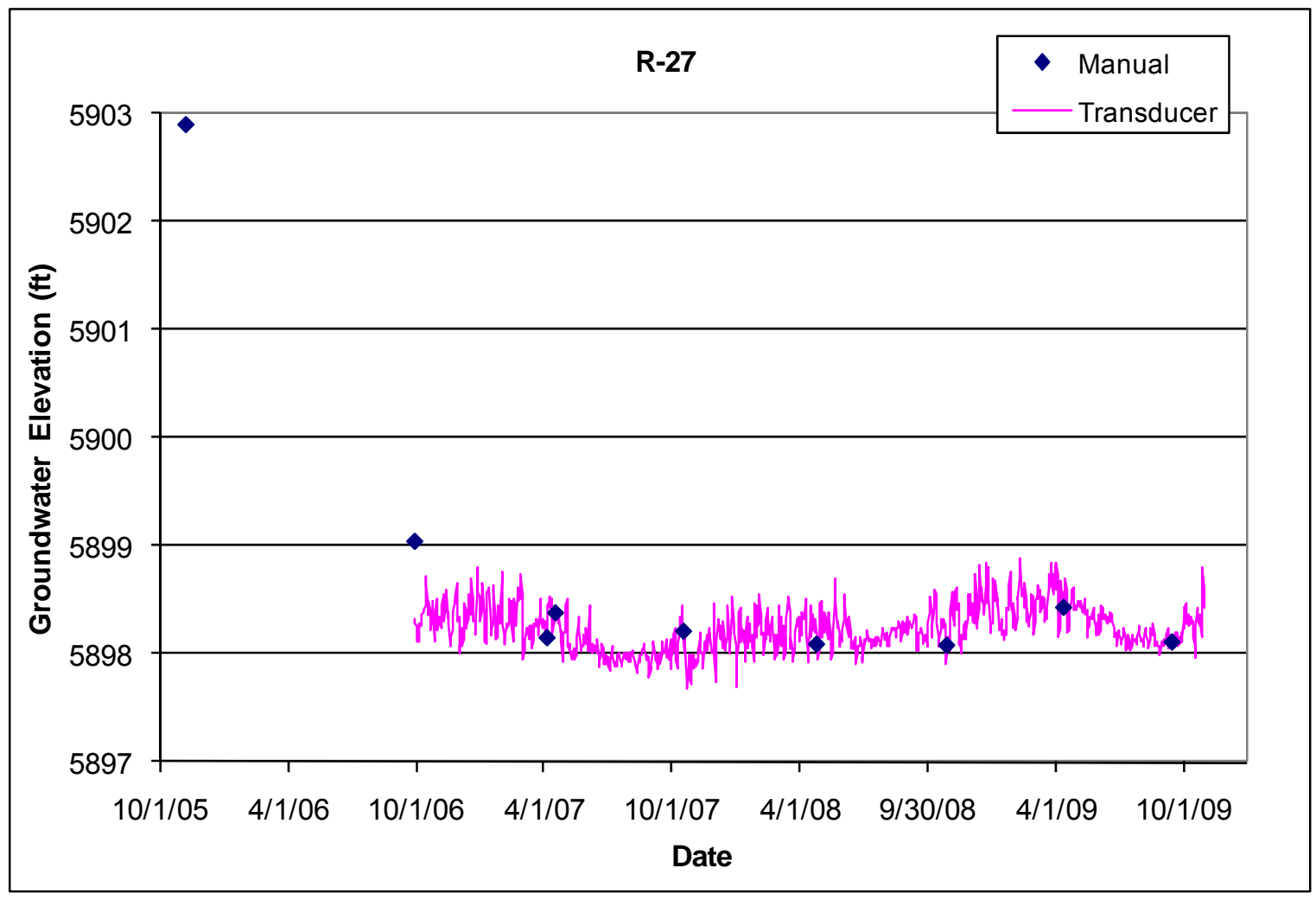




\subsection{R-28}

Location: R-28 is located in middle/lower Mortandad Canyon between and about $1300 \mathrm{ft}$ from both R42 and $\mathrm{R}-45$.

Completion Type: Single completion at the top of the regional aquifer. The top of the screen is about $45 \mathrm{ft}$ below the water table.

Period of Record: Well completed December 2003, transducer installed January 7, 2005, data through 2009.

Remarks: R-28 installed to a depth of $980.3 \mathrm{ft}$, about $100 \mathrm{ft}$ into the regional aquifer. The well is $100 \%$ barometrically efficient; the aquifer does not respond to atmospheric pressure fluctuations. R28 exhibits a seasonal response to supply well pumping and responds primarily to pumping at PM-4 and PM-2 and possibly to PM-5, but apparently does not respond significantly to pumping at nearby supply well PM-3.

\begin{tabular}{|c|c|c|c|c|c|c|c|c|c|c|c|c|c|c|}
\hline \multicolumn{15}{|c|}{ R-28 Construction Information } \\
\hline Screen & $\begin{array}{c}\text { Screen } \\
\text { Top } \\
\text { Depth } \\
\text { (ft) }\end{array}$ & \begin{tabular}{|c|} 
Screen \\
Bottom \\
Depth \\
(ft)
\end{tabular} & $\begin{array}{l}\text { Screen } \\
\text { Top } \\
\text { Elev (ft) }\end{array}$ & $\begin{array}{l}\text { Screen } \\
\text { Bottom } \\
\text { Elev (ft) }\end{array}$ & $\begin{array}{c}\text { Screen } \\
\text { Length } \\
\text { (ft) }\end{array}$ & $\begin{array}{l}\text { Pump } \\
\text { Intake } \\
\text { Depth } \\
\text { (ft) }\end{array}$ & $\begin{array}{c}\text { Pump } \\
\text { Intake } \\
\text { Elevation } \\
\text { (ft) }\end{array}$ & \begin{tabular}{|} 
Depth to \\
Top of \\
Sump \\
(ft)
\end{tabular} & $\begin{array}{c}\text { Top of } \\
\text { Sump } \\
\text { Elevation } \\
\text { (ft) }\end{array}$ & $\begin{array}{l}\text { Depth to } \\
\text { Sump } \\
\text { Bottom } \\
\text { (ft) }\end{array}$ & $\begin{array}{c}\text { Sump } \\
\text { Length } \\
\text { (ft) }\end{array}$ & $\begin{array}{c}\text { Sump } \\
\text { Volume } \\
\text { (L) }\end{array}$ & $\begin{array}{c}\text { Hydro } \\
\text { Zone } \\
\text { Code }\end{array}$ & $\begin{array}{c}\text { Geo } \\
\text { Unit } \\
\text { Code }\end{array}$ \\
\hline 1 & 934.3 & 958.1 & 5794.3 & 5770.5 & 23.8 & 929.6 & 5799.0 & 958.1 & 5770.5 & 980.3 & 22.2 & 68.2 & RT & Tpf \\
\hline
\end{tabular}

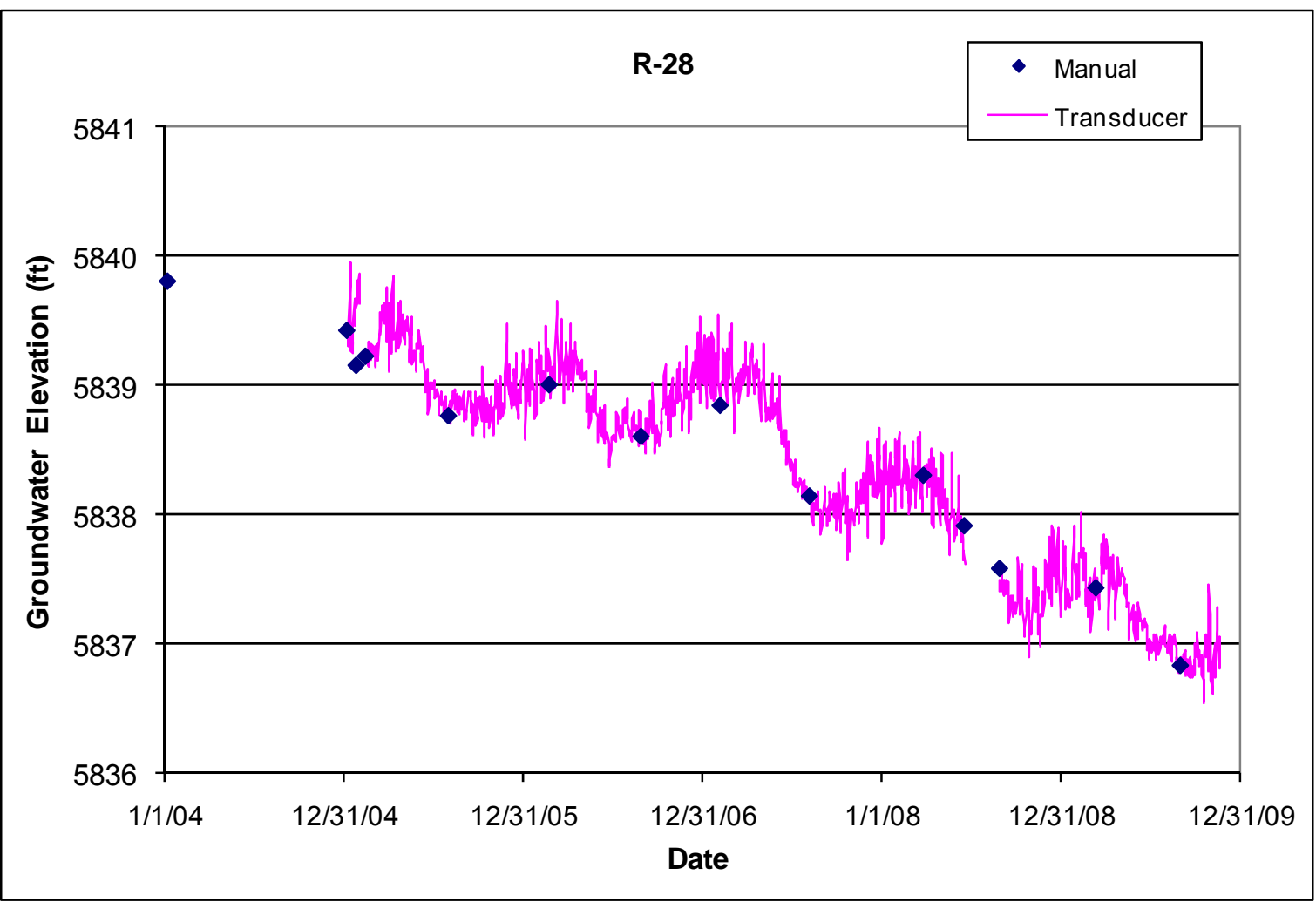




\subsection{R-31}

Location: R-31 is located in the southern part of LANL in the north Ancho Canyon tributary.

Completion Type: Multiple completion, one screen in an intermediate zone, and four screens in the regional aquifer. The intermediate screen 1 has been dry since Westbay ${ }^{\circledR}$ installation.

Period of Record: Westbay ${ }^{\circledR}$ installed April 7, 2000, transducers installed May 4, 2000, transducer data through 2009.

Remarks: Screen 5 has the highest head values, followed by screen 4 and screen 2; screen 3 has the lowest head values. Port MP2A was dry after Westbay installation so port MP2B is used to collect samples and groundwater level data. Screens 2 and 3 have $80 \%$ and $100 \%$ response to atmospheric pressure fluctuations, respectively, while screens 3 and 4 have about $45 \%$ response. Screens 4 and 5 show seasonal responses to supply well pumping that coincide with the non-pumping water levels at PM-2.

\begin{tabular}{|c|c|c|c|c|c|c|c|c|c|c|c|c|c|}
\hline \multicolumn{14}{|c|}{ R-31 Construction and Port Information } \\
\hline Screen & $\begin{array}{c}\text { Screen } \\
\text { Top } \\
\text { Depth } \\
\text { (ft) }\end{array}$ & $\begin{array}{c}\text { Screen } \\
\text { Bottom } \\
\text { Depth } \\
\text { (ft) }\end{array}$ & \begin{tabular}{|c} 
Screen \\
Top \\
Elev \\
(ft)
\end{tabular} & $\begin{array}{l}\text { Screen } \\
\text { Bottom } \\
\text { Elev (ft) }\end{array}$ & $\begin{array}{c}\text { Screen } \\
\text { Length } \\
\text { (ft) }\end{array}$ & $\begin{array}{l}\text { Hydro } \\
\text { Zone } \\
\text { Code }\end{array}$ & $\begin{array}{l}\text { Geo } \\
\text { Unit } \\
\text { Code }\end{array}$ & Port & $\begin{array}{c}\text { Port } \\
\text { Depth } \\
\text { (ft) }\end{array}$ & $\begin{array}{c}\text { Port } \\
\text { Elev (ft) }\end{array}$ & \begin{tabular}{|c|} 
Distance \\
from \\
Bottom of \\
Screen \\
(ft)
\end{tabular} & $\begin{array}{l}\text { Sump } \\
\text { Volume } \\
\text { (L) }\end{array}$ & Comment \\
\hline \multirow{3}{*}{1} & \multirow{3}{*}{439.1} & \multirow{3}{*}{454.4} & \multirow{3}{*}{5923.4} & \multirow{3}{*}{5908.1} & \multirow{3}{*}{15.3} & \multirow{3}{*}{ I } & \multirow{3}{*}{$\mathrm{Tb} 4$} & MP1A & 453.8 & 5908.7 & 0.6 & & Screen dry \\
\hline & & & & & & & & $\overline{P P 1}$ & 459.2 & 5903.3 & -4.8 & 13.9 & Below screen \\
\hline & & & & & & & & MP1B & 464.8 & 5897.7 & -10.4 & 30.1 & Below screen \\
\hline \multirow{4}{*}{2} & \multirow{4}{*}{515.0} & \multirow{4}{*}{545.7} & \multirow{4}{*}{5847.5} & \multirow{4}{*}{5816.8} & \multirow{4}{*}{30.7} & \multirow{4}{*}{ RT } & \multirow{4}{*}{ Tb4 } & MP2A & 532.2 & 5830.3 & 13.5 & & Within screen, port dry \\
\hline & & & & & & & & MP2B & 542.5 & 5820.0 & 3.2 & & Within screen \\
\hline & & & & & & & & PP2 & 547.9 & 5814.6 & -2.2 & 6.4 & Below screen \\
\hline & & & & & & & & MP2C & 553.5 & 5809.0 & -7.8 & 22.6 & Below screen \\
\hline \multirow{3}{*}{3} & \multirow{3}{*}{666.3} & \multirow{3}{*}{676.3} & \multirow{3}{*}{5696.2} & \multirow{3}{*}{5686.2} & \multirow{3}{*}{10.0} & \multirow{3}{*}{$\mathrm{RD}$} & \multirow{3}{*}{$\mathrm{Tb} 4$} & MP3A & 670.3 & 5692.2 & 6.0 & & Within screen \\
\hline & & & & & & & & PP3 & 675.6 & 5686.9 & 0.7 & & Within screen \\
\hline & & & & & & & & $\overline{M P 3 B}$ & 681.3 & 5681.2 & -5.0 & 14.5 & Below screen \\
\hline \multirow{3}{*}{4} & \multirow{3}{*}{826.6} & \multirow{3}{*}{836.6} & \multirow{3}{*}{5535.9} & \multirow{3}{*}{5525.9} & \multirow{3}{*}{10.0} & \multirow{3}{*}{$\mathrm{RD}$} & \multirow{3}{*}{ Tpt } & MP4A & 830.9 & 5531.6 & 5.7 & & Within screen \\
\hline & & & & & & & & PP4 & 836.3 & 5526.2 & 0.3 & & Within screen \\
\hline & & & & & & & & MP4B & 841.9 & 5520.6 & -5.3 & 15.3 & Below screen \\
\hline & & & & & & & & MP5A & 1011.3 & 5351.2 & 5.8 & & Within screen \\
\hline 5 & 1007.1 & 1017.1 & 5355.4 & 5345.4 & 10.0 & $\mathrm{RD}$ & Tpt & PP5 & 1016.7 & 5345.8 & 0.4 & & Within screen \\
\hline & & & & & & & & MP5B & 1022.3 & 5340.2 & -5.2 & 15.1 & Below screen \\
\hline
\end{tabular}

Brass Cap Elevation: $6362.5 \mathrm{ft}$; all measurements are from this elevation; $\mathrm{MP}=$ measurement port; $\mathrm{PP}=$ pumping port

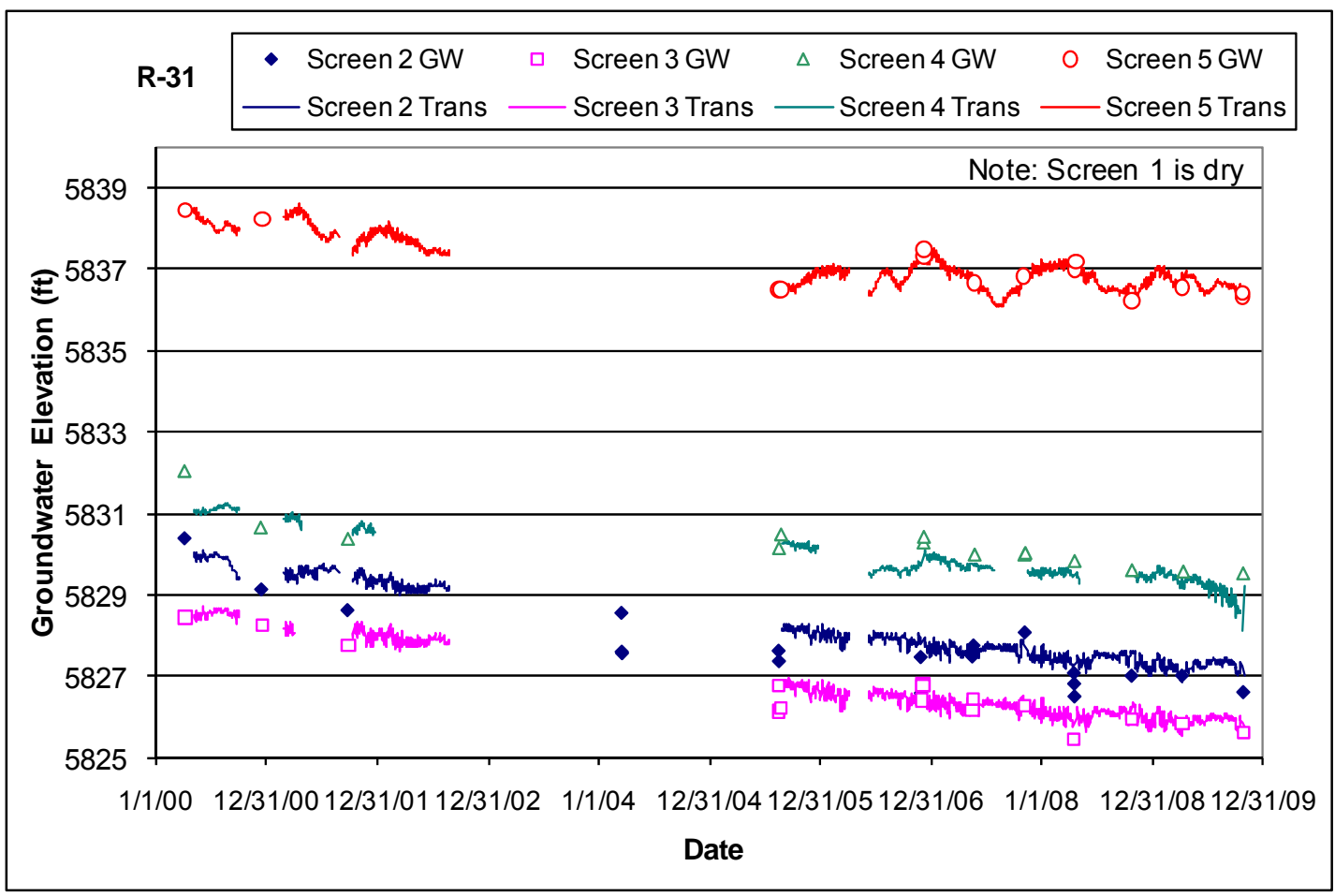




\subsection{R-32}

Location: R-32 is located in lower Pajarito Canyon about 1 mile east of supply well PM-2 and downgradient of Material Disposal Area (MDA) L at TA-54.

Completion Type: Multiple completion, three screens in the regional aquifer until September 2007 when screens 2 and 3 were plugged and abandoned. Screen 1 is about $90 \mathrm{ft}$ below the water table.

Period of Record: Westbay ${ }^{\circledR}$ installed December 14, 2002, transducers installed January 21, 2003 , transducer data through August 2007. The Westbay ${ }^{\circledR}$ system was removed on September 18 , 2007, and the well was rehabilitated to a single completion well at screen 1 in September 2007. A submersible pump was installed in November 2007 and a transducer was installed at screen 1 in February 2008; transducer data through 2009.

Remarks: Screens 2 and 3 had nearly identical head values and responded to pumping supply wells PM-2 and PM-4. Screen 1 apparently responded to long-term pumping of PM-4 in 2003, but vaguely to aquifer test pumping at PM-2 in 2004 and PM-4 in 2005. Screens 2 and 3 responded to the PM-2 aquifer test in January 2003 (McLin 2005), to the PM-4 aquifer test in January 2005 (McLin 2006), and to PM-4 pumping in June 2006 and July 2007.

\begin{tabular}{|c|c|c|c|c|c|c|c|c|c|c|c|c|c|c|}
\hline \multicolumn{15}{|c|}{ R-32 Construction Information } \\
\hline Screen & $\begin{array}{c}\text { Screen } \\
\text { Top } \\
\text { Depth } \\
\text { (ft) }\end{array}$ & \begin{tabular}{|c|} 
Screen \\
Bottom \\
Depth \\
(ft)
\end{tabular} & $\begin{array}{c}\text { Screen } \\
\text { Top } \\
\text { Elev } \\
\text { (ft) }\end{array}$ & $\begin{array}{l}\text { Screen } \\
\text { Bottom } \\
\text { Elev (ft) }\end{array}$ & $\begin{array}{l}\text { Screen } \\
\text { Length } \\
\text { (ft) }\end{array}$ & $\begin{array}{c}\text { Pump } \\
\text { Intake } \\
\text { Depth } \\
\text { (ft) }\end{array}$ & $\begin{array}{l}\text { Pump } \\
\text { Intake } \\
\text { Elev (ft) }\end{array}$ & $\begin{array}{l}\text { Depth to } \\
\text { Top of } \\
\text { Sump } \\
\text { (ft) }\end{array}$ & $\begin{array}{c}\text { Top of } \\
\text { Sump } \\
\text { Elevation } \\
\text { (ft) }\end{array}$ & $\begin{array}{l}\text { Depth to } \\
\text { Sump } \\
\text { Bottom } \\
\text { (ft) }\end{array}$ & $\begin{array}{c}\text { Sump } \\
\text { Length } \\
\text { (ft) }\end{array}$ & $\begin{array}{c}\text { Sump } \\
\text { Volume } \\
\text { (L) }\end{array}$ & $\begin{array}{c}\text { Hydro } \\
\text { Zone } \\
\text { Code }\end{array}$ & $\begin{array}{l}\text { Geo } \\
\text { Unit } \\
\text { Code }\end{array}$ \\
\hline 1 & 867.5 & 875.2 & 5770.1 & 5762.4 & 7.7 & 858.6 & 5779.0 & 875.2 & 5762.4 & 893.6 & 18.4 & 57.5 & RT & Tb4 \\
\hline 2 & 931.8 & 934.9 & 5705.8 & 5702.7 & 3.1 & & \multicolumn{6}{|c|}{ Sceen plugged and abandoned Sept 2007} & $\mathrm{RD}$ & Tpf \\
\hline 3 & 972.9 & 980.6 & 5657.0 & 5657.0 & 7.7 & & \multicolumn{6}{|c|}{ Sceen plugged and abandoned Sept 2007} & $\mathrm{RD}$ & Tpf \\
\hline
\end{tabular}

Note: R-32 Brass Cap Ground Elevation: $6637.63 \mathrm{ft}$; all measurements are from this elevation 

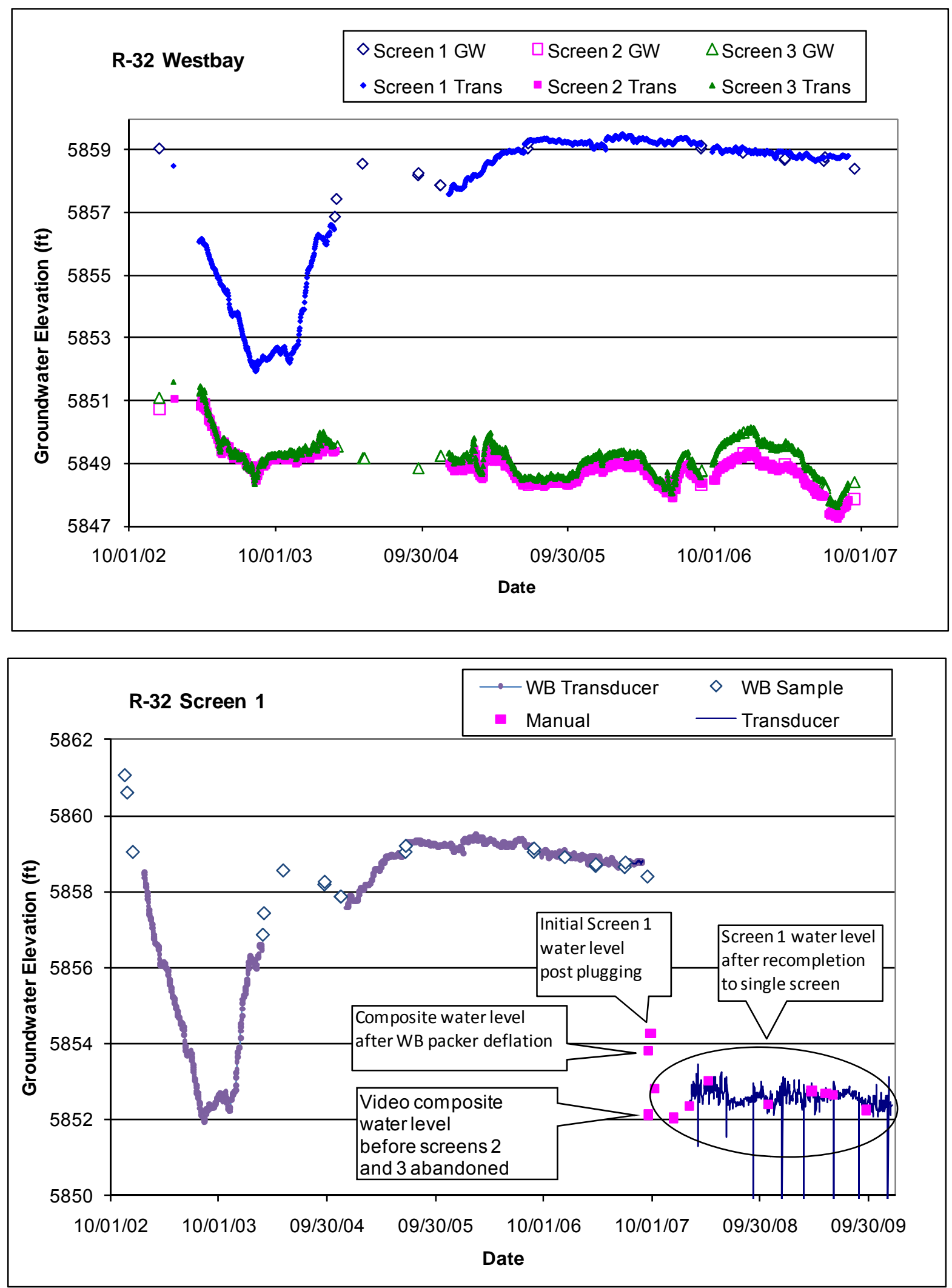


\section{$3.34 \quad \mathrm{R}-33$}

Location: R-33 is located in lower Ten Site Canyon about $1500 \mathrm{ft}$ northeast of supply well PM-5. Completion Type: Dual screen completion in the regional aquifer.

Period of Record: Well completed October 2004, transducers installed February 2005 but equipment problems hindered data collection. Transducers calibrated and the packer inflated in August 2006 and again in October 2006 with nitrogen bottle to maintain packer pressure. Water level data for screen 2 from October 24, 2006, to November 8, 2007; data for screen 1 ended December 5, 2006. New transducers installed July 2008; water level data through 2009.

Remarks: R-33 screen 1 installed about $10 \mathrm{ft}$ below the regional water table at a depth of about 1020 $\mathrm{ft}$, and screen 2 within the regional aquifer to a depth of $1126 \mathrm{ft}$, about $140 \mathrm{ft}$ into the regional aquifer. Transducer equipment problems occurred from February 2005 until October 2006 when transducers and packer equipment became operational. The original transducer equipment was removed from the well on November 8,2007 , in preparation for removing the Barcad sampling system from the well. A dual valve Baski sampling system was installed July 2008 (LANL August 2008). The water level at screen 2 responds primarily to pumping of supply well PM-5 but also to pumping at PM-4.

\begin{tabular}{|c|c|c|c|c|c|c|c|c|c|c|c|c|c|c|}
\hline \multicolumn{15}{|c|}{ R-33 Construction Information } \\
\hline Screen & $\begin{array}{c}\text { Screen } \\
\text { Top } \\
\text { Depth } \\
\text { (ft) }\end{array}$ & $\begin{array}{c}\text { Screen } \\
\text { Bottom } \\
\text { Depth } \\
\text { (ft) }\end{array}$ & $\begin{array}{l}\text { Screen } \\
\text { Top } \\
\text { Elev (ft) }\end{array}$ & $\begin{array}{l}\text { Screen } \\
\text { Bottom } \\
\text { Elev (ft) }\end{array}$ & $\begin{array}{l}\text { Screen } \\
\text { Length } \\
\text { (ft) }\end{array}$ & $\begin{array}{c}\text { APV } \\
\text { Intake } \\
\text { Depth } \\
\text { (ft) }\end{array}$ & $\begin{array}{c}\text { APV } \\
\text { Intake } \\
\text { Elev (ft) }\end{array}$ & $\begin{array}{c}\text { Depth to } \\
\text { Top of } \\
\text { Packerl } \\
\text { Sump } \\
\text { (ft) }\end{array}$ & $\begin{array}{c}\text { Top of } \\
\text { Packerl } \\
\text { Sump } \\
\text { Elevation } \\
\text { (ft) }\end{array}$ & $\begin{array}{c}\text { Depth } \\
\text { to } \\
\text { Sump } \\
\text { Bottom } \\
\text { (ft) }\end{array}$ & $\begin{array}{c}\text { Sump } \\
\text { Length } \\
\text { (ft) }\end{array}$ & $\begin{array}{c}\text { Sump } \\
\text { Volume } \\
\text { (L) }\end{array}$ & $\begin{array}{l}\text { Hydro } \\
\text { Zone } \\
\text { Code }\end{array}$ & $\begin{array}{l}\text { Geo } \\
\text { Unit } \\
\text { Code }\end{array}$ \\
\hline 1 & 995.5 & 1018.5 & 5857.8 & 5834.8 & 23.0 & 1067.0 & 5786.3 & 1074.6 & 5778.8 & 1074.6 & 56.1 & 175.3 & RT & Tpp \\
\hline 2 & $\overline{1112.4}$ & 1122.3 & 5740.9 & 5731.0 & 9.9 & 1110.8 & 5742.6 & 1122.3 & 5731.0 & 1126.0 & 3.7 & 11.6 & $\mathrm{RD}$ & Tpp \\
\hline
\end{tabular}

Note: R-33 Brass Cap Ground Elevation: $6853.33 \mathrm{ft}$; all measurements are from this elevation; APV = access port valve

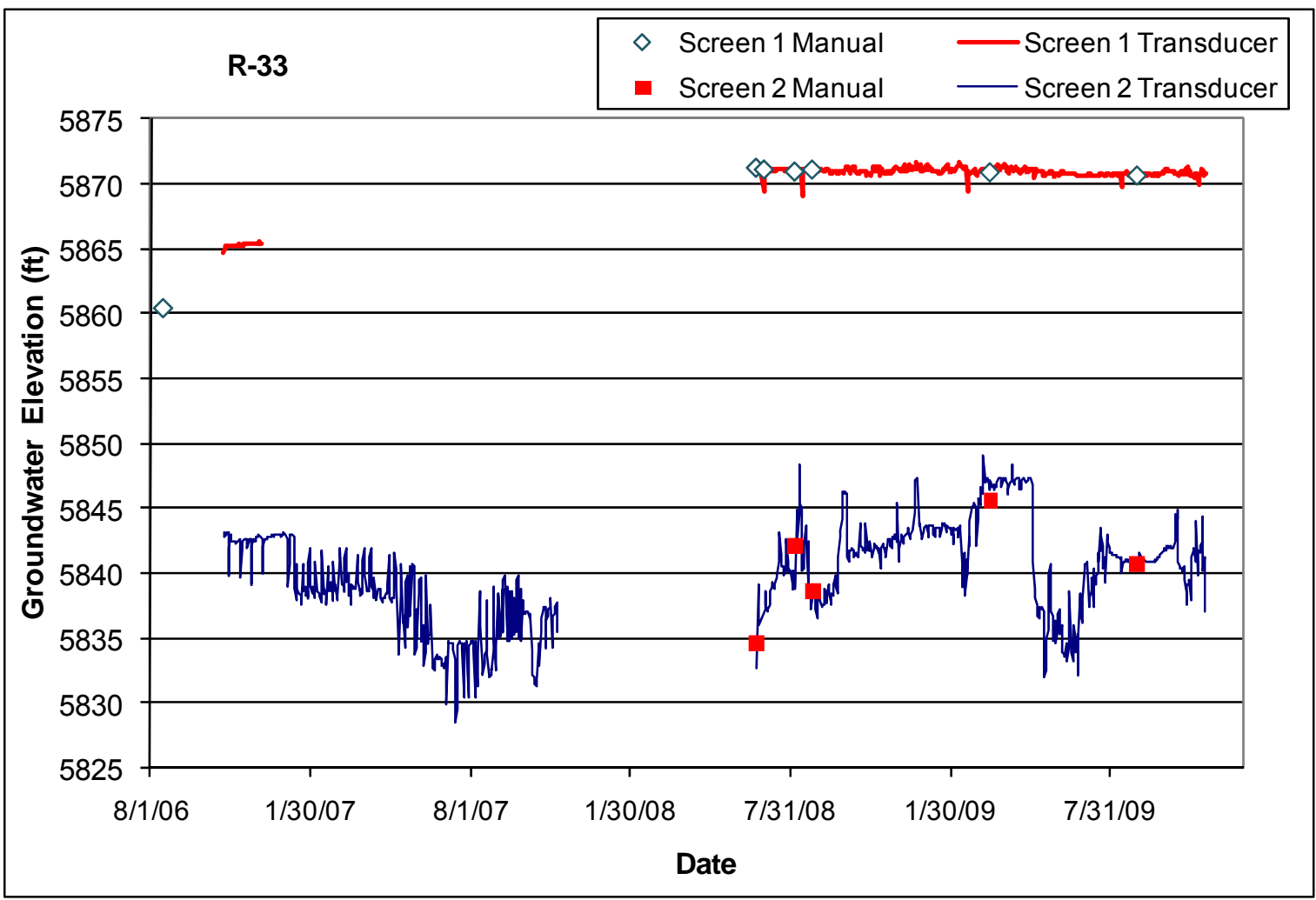




\subsection{R-34}

Location: R-34 is located in Cedro Canyon on San Ildefonso land east of LANL.

Completion Type: Single completion in the regional aquifer. The top of the screen is about $90 \mathrm{ft}$ below the water table.

Period of Record: Well completed August 2004, transducer installed January 2005, water level data through 2009.

Remarks: R-34 installed at the top of the regional aquifer at a depth of $920.7 \mathrm{ft}$, about $110 \mathrm{ft}$ into the regional aquifer. The well is $100 \%$ barometrically efficient; the aquifer does not respond to atmospheric pressure fluctuations. R-34 exhibits a seasonal response to supply well pumping but does not indicate a response to any specific supply well.

\begin{tabular}{|c|c|c|c|c|c|c|c|c|c|c|c|c|c|c|}
\hline \multicolumn{15}{|c|}{ R-34 Construction Information } \\
\hline Screen & $\begin{array}{l}\text { Screen } \\
\text { Top } \\
\text { Depth } \\
\text { (ft) }\end{array}$ & $\begin{array}{c}\text { Screen } \\
\text { Bottom } \\
\text { Depth } \\
\text { (ft) }\end{array}$ & $\begin{array}{c}\text { Screen } \\
\text { Top } \\
\text { Elev } \\
\text { (ft) }\end{array}$ & \begin{tabular}{|c} 
Screen \\
Bottom \\
Elev \\
(ft)
\end{tabular} & $\begin{array}{l}\text { Screen } \\
\text { Length } \\
\text { (ft) }\end{array}$ & $\begin{array}{c}\text { Pump } \\
\text { Intake } \\
\text { Depth } \\
\text { (ft) }\end{array}$ & $\begin{array}{c}\text { Pump } \\
\text { Intake } \\
\text { Elev } \\
\text { (ft) }\end{array}$ & $\begin{array}{l}\text { Depth } \\
\text { to Top } \\
\text { of } \\
\text { Sump } \\
\text { (ft) }\end{array}$ & $\begin{array}{c}\text { Top of } \\
\text { Sump } \\
\text { Elev } \\
\text { (ft) }\end{array}$ & $\begin{array}{c}\text { Depth to } \\
\text { Sump } \\
\text { Bottom } \\
\text { (ft) }\end{array}$ & $\begin{array}{c}\text { Sump } \\
\text { Length } \\
\text { (ft) }\end{array}$ & $\begin{array}{c}\text { Sump } \\
\text { Volume } \\
\text { (L) }\end{array}$ & $\begin{array}{c}\text { Hydro } \\
\text { Zone } \\
\text { Code }\end{array}$ & $\begin{array}{l}\text { Geo } \\
\text { Unit } \\
\text { Code }\end{array}$ \\
\hline 1 & 883.7 & 906.6 & 5746.3 & 5723.4 & 22.9 & 881.6 & 5748.4 & 906.6 & 5723.4 & 920.7 & 14.1 & 44.1 & $\overline{\mathrm{RT}}$ & $\overline{T p p}$ \\
\hline
\end{tabular}

Note: R-34 Brass Cap Ground Elevation: $6629.99 \mathrm{ft}$; all measurements are from this elevation

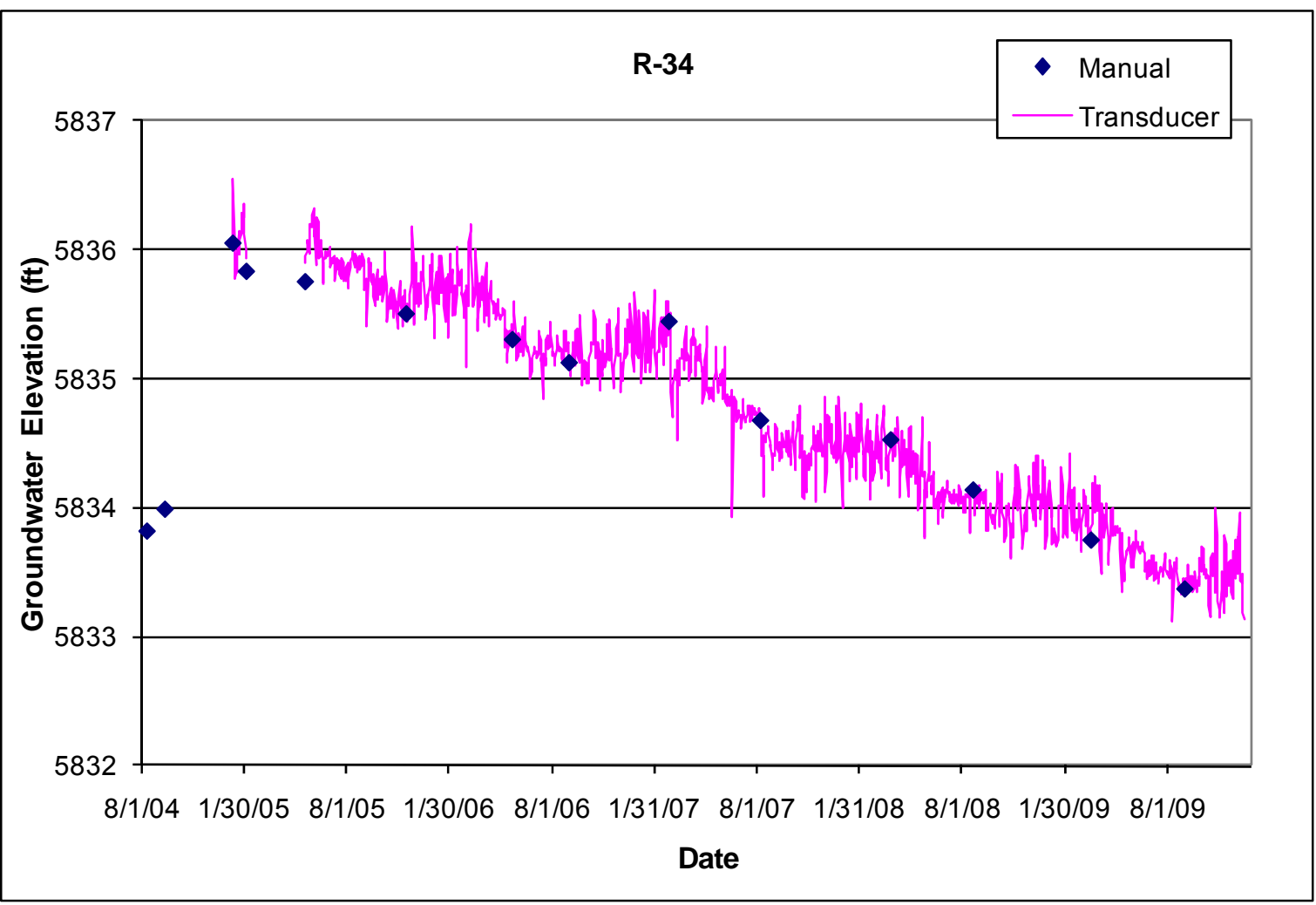




\subsection{R-35a}

Location: R-35a is located in Sandia Canyon about $340 \mathrm{ft}$ southwest of supply well PM-3.

Completion Type: Single completion in the regional aquifer. The top of the screen is about $220 \mathrm{ft}$ below the water table at the same elevation as the top of the PM-3 screen.

Period of Record: Well completed June 2007, transducer installed August 3, 2007; water level data through 2009.

Remarks: R-35a installed at a depth of $1082.2 \mathrm{ft}$, about $290 \mathrm{ft}$ into the regional aquifer. R-35a responds primarily to pumping supply well PM-3, about 3 to $4 \mathrm{ft}$ daily, but also shows a response to pumping supply well $\mathrm{O}-4$. When the well was completed, the static water level at $\mathrm{R}-35 \mathrm{a}$ was about $7 \mathrm{ft}$ lower than nearby monitoring well R-35b, which is screened at the top of the aquifer.

\begin{tabular}{|c|c|c|c|c|c|c|c|c|c|c|c|c|c|c|}
\hline \multicolumn{15}{|c|}{ R-35a Construction Information } \\
\hline Screen & $\begin{array}{c}\text { Screen } \\
\text { Top } \\
\text { Depth } \\
\text { (ft) }\end{array}$ & $\begin{array}{c}\text { Screen } \\
\text { Bottom } \\
\text { Depth } \\
\text { (ft) }\end{array}$ & $\begin{array}{l}\text { Screen } \\
\text { Top } \\
\text { Elev (ft) }\end{array}$ & $\begin{array}{l}\text { Screen } \\
\text { Bottom } \\
\text { Elev (ft) }\end{array}$ & $\begin{array}{c}\text { Screen } \\
\text { Length } \\
\text { (ft) }\end{array}$ & $\begin{array}{c}\text { Pump } \\
\text { Intake } \\
\text { Depth } \\
\text { (ft) }\end{array}$ & $\begin{array}{c}\text { Pump } \\
\text { Intake } \\
\text { Elev } \\
\text { (ft) }\end{array}$ & $\begin{array}{l}\text { Depth to } \\
\text { Top of } \\
\text { Sump } \\
\text { (ft) }\end{array}$ & $\begin{array}{c}\text { Top of } \\
\text { Sump } \\
\text { Elev } \\
\text { (ft) }\end{array}$ & $\begin{array}{l}\text { Depth to } \\
\text { Sump } \\
\text { Bottom } \\
\text { (ft) }\end{array}$ & $\begin{array}{l}\text { Sump } \\
\text { Length } \\
\text { (ft) }\end{array}$ & $\begin{array}{c}\text { Sump } \\
\text { Volume } \\
\text { (L) }\end{array}$ & $\begin{array}{c}\text { Hydro } \\
\text { Zone } \\
\text { Code }\end{array}$ & $\begin{array}{c}\text { Geo } \\
\text { Unit } \\
\text { Code }\end{array}$ \\
\hline 1 & 1013.1 & 1062.2 & 5610.0 & 5560.9 & 49.1 & 998.3 & 5624.8 & 1062.2 & 5560.9 & 1086.2 & 24.0 & 75.1 & $\overline{R D}$ & Tsfu \\
\hline
\end{tabular}

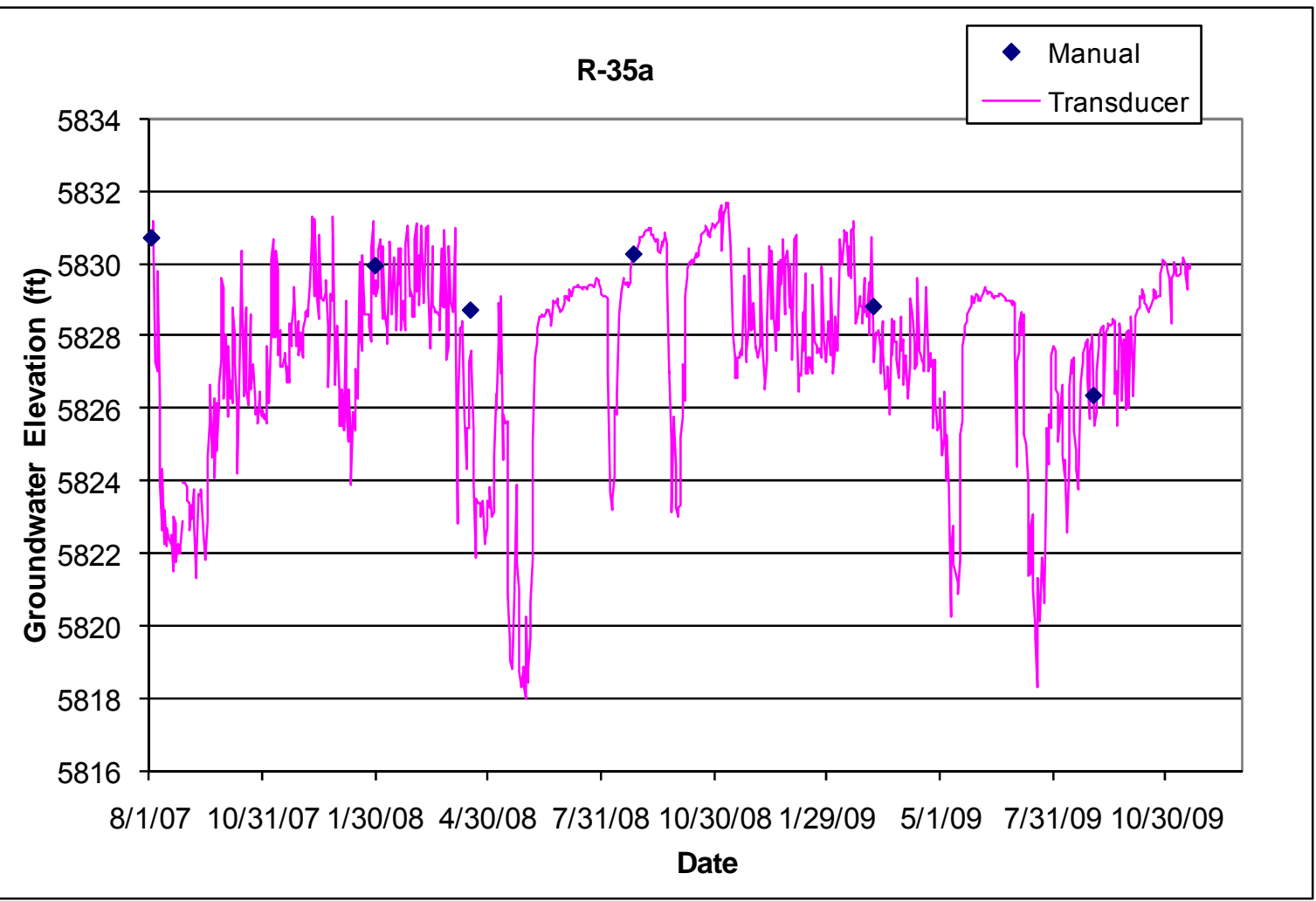

Note: Hydrograph shows mean daily values 


\subsection{R-35b}

Location: R-35b is located in Sandia Canyon about $90 \mathrm{ft}$ west of R-35a and about $400 \mathrm{ft}$ southwest of supply well PM-3.

Completion Type: Single completion at the top of the regional aquifer. The top of the screen was about $37 \mathrm{ft}$ below the water table when the well was installed.

Period of Record: Well completed July 2007, transducer installed August 3, 2007; water level data through 2009.

Remarks: R-35b installed near the top of the regional aquifer at a depth of $872.2 \mathrm{ft}$, about $80 \mathrm{ft}$ into the regional aquifer. The well is $100 \%$ barometrically efficient; the aquifer does not respond to atmospheric pressure fluctuations. R-35b does not indicate a response to pumping of nearby well PM-3.

\begin{tabular}{|c|c|c|c|c|c|c|c|c|c|c|c|c|c|c|}
\hline \multicolumn{15}{|c|}{ R-35b Construction Information } \\
\hline Screen & \begin{tabular}{|} 
Screen \\
Top \\
Depth \\
(ft)
\end{tabular} & $\begin{array}{c}\text { Screen } \\
\text { Bottom } \\
\text { Depth } \\
\text { (ft) }\end{array}$ & $\begin{array}{l}\text { Screen } \\
\text { Top } \\
\text { Elev (ft) }\end{array}$ & $\begin{array}{l}\text { Screen } \\
\text { Bottom } \\
\text { Elev (ft) }\end{array}$ & $\begin{array}{c}\text { Screen } \\
\text { Length } \\
\text { (ft) }\end{array}$ & $\begin{array}{c}\text { Pump } \\
\text { Intake } \\
\text { Depth } \\
\text { (ft) }\end{array}$ & $\begin{array}{c}\text { Pump } \\
\text { Intake } \\
\text { Elev } \\
\text { (ft) }\end{array}$ & $\begin{array}{c}\text { Depth to } \\
\text { Top of } \\
\text { Sump } \\
\text { (ft) }\end{array}$ & $\begin{array}{c}\text { Top of } \\
\text { Sump } \\
\text { Elev } \\
\text { (ft) }\end{array}$ & $\begin{array}{l}\text { Depth to } \\
\text { Sump } \\
\text { Bottom } \\
\text { (ft) }\end{array}$ & $\begin{array}{c}\text { Sump } \\
\text { Length } \\
\text { (ft) }\end{array}$ & $\begin{array}{c}\text { Sump } \\
\text { Volume } \\
\text { (L) }\end{array}$ & $\begin{array}{c}\text { Hydro } \\
\text { Zone } \\
\text { Code }\end{array}$ & $\begin{array}{l}\text { Geo } \\
\text { Unit } \\
\text { Code }\end{array}$ \\
\hline 1 & 825.4 & 848.5 & 5799.8 & 5776.7 & 23.1 & 832.7 & 5792.5 & 848.5 & 5776.7 & 872.2 & 23.7 & 74.1 & $\overline{\mathrm{RT}}$ & Tpf \\
\hline
\end{tabular}

Note: Brass Cap Ground Elevation: $6625.21 \mathrm{ft}$; all measurements are from this elevation

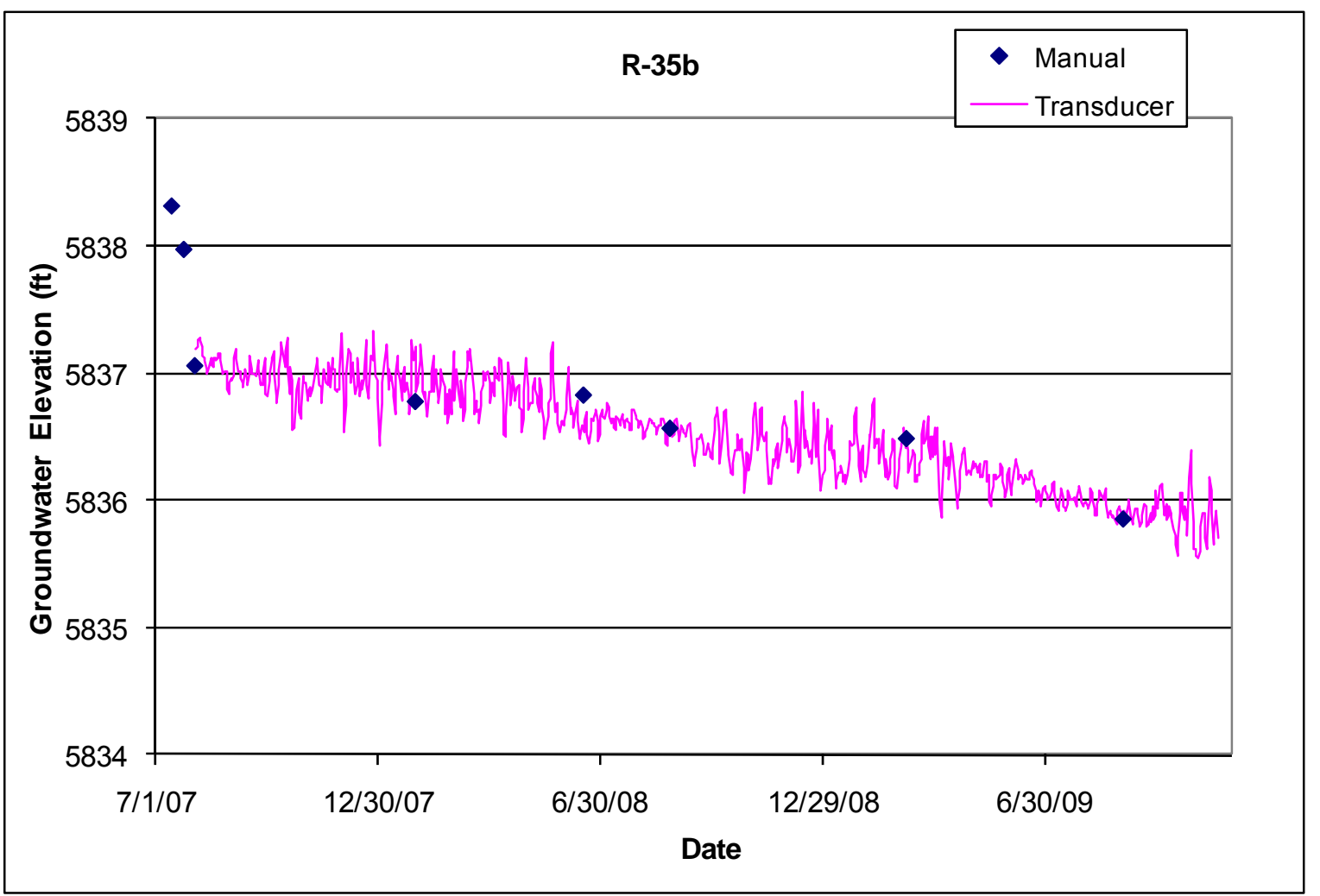




\subsection{R-36}

Location: R-36 is located in lower Sandia Canyon about $2200 \mathrm{ft}$ southeast of supply well PM-3.

Completion Type: Single completion at the top of the regional aquifer.

Period of Record: Well completed February 2008, transducer installed March 31, 2008; water level data through 2009.

Remarks: R-36 installed near the top of the regional aquifer to a depth of $803.7 \mathrm{ft}$; top of screen is about $17 \mathrm{ft}$ below the regional water table. The well is $100 \%$ barometrically efficient; the aquifer does not respond to atmospheric pressure fluctuations. Available water level data indicate that R-36 does not appear to respond to supply well pumping at nearby wells PM-1 and PM-3.

\begin{tabular}{|c|c|c|c|c|c|c|c|c|c|c|c|c|c|c|}
\hline \multicolumn{15}{|c|}{ R-36 Construction Information } \\
\hline Screen & $\begin{array}{c}\text { Screen } \\
\text { Top } \\
\text { Depth } \\
\text { (ft) }\end{array}$ & $\begin{array}{c}\text { Screen } \\
\text { Bottom } \\
\text { Depth } \\
\text { (ft) }\end{array}$ & \begin{tabular}{|c} 
Screen \\
Top \\
Elev \\
(ft)
\end{tabular} & \begin{tabular}{|c} 
Screen \\
Bottom \\
Elev \\
(ft)
\end{tabular} & $\begin{array}{c}\text { Screen } \\
\text { Length } \\
\text { (ft) }\end{array}$ & $\begin{array}{l}\text { Pump } \\
\text { Intake } \\
\text { Depth } \\
\text { (ft) }\end{array}$ & $\begin{array}{c}\text { Pump } \\
\text { Intake } \\
\text { Elev } \\
\text { (ft) }\end{array}$ & $\begin{array}{c}\text { Depth to } \\
\text { Top of } \\
\text { Sump } \\
\text { (ft) }\end{array}$ & $\begin{array}{c}\text { Top of } \\
\text { Sump } \\
\text { Elev } \\
\text { (ft) }\end{array}$ & $\begin{array}{l}\text { Depth to } \\
\text { Sump } \\
\text { Bottom } \\
\text { (ft) }\end{array}$ & $\begin{array}{c}\text { Sump } \\
\text { Length } \\
\text { (ft) }\end{array}$ & $\begin{array}{c}\text { Sump } \\
\text { Volume } \\
\text { (L) }\end{array}$ & $\begin{array}{l}\text { Hydro } \\
\text { Zone } \\
\text { Code }\end{array}$ & $\begin{array}{c}\text { Geo } \\
\text { Unit } \\
\text { Code }\end{array}$ \\
\hline 1 & 766.9 & 789.9 & 5824.5 & 5801.5 & 23.0 & 764.5 & 5826.9 & 789.9 & 5801.5 & 803.7 & 13.8 & 43.2 & RT & Tsfu \\
\hline
\end{tabular}

Note: Brass Cap Ground Elevation: $6591.37 \mathrm{ft}$; all measurements are from this elevation

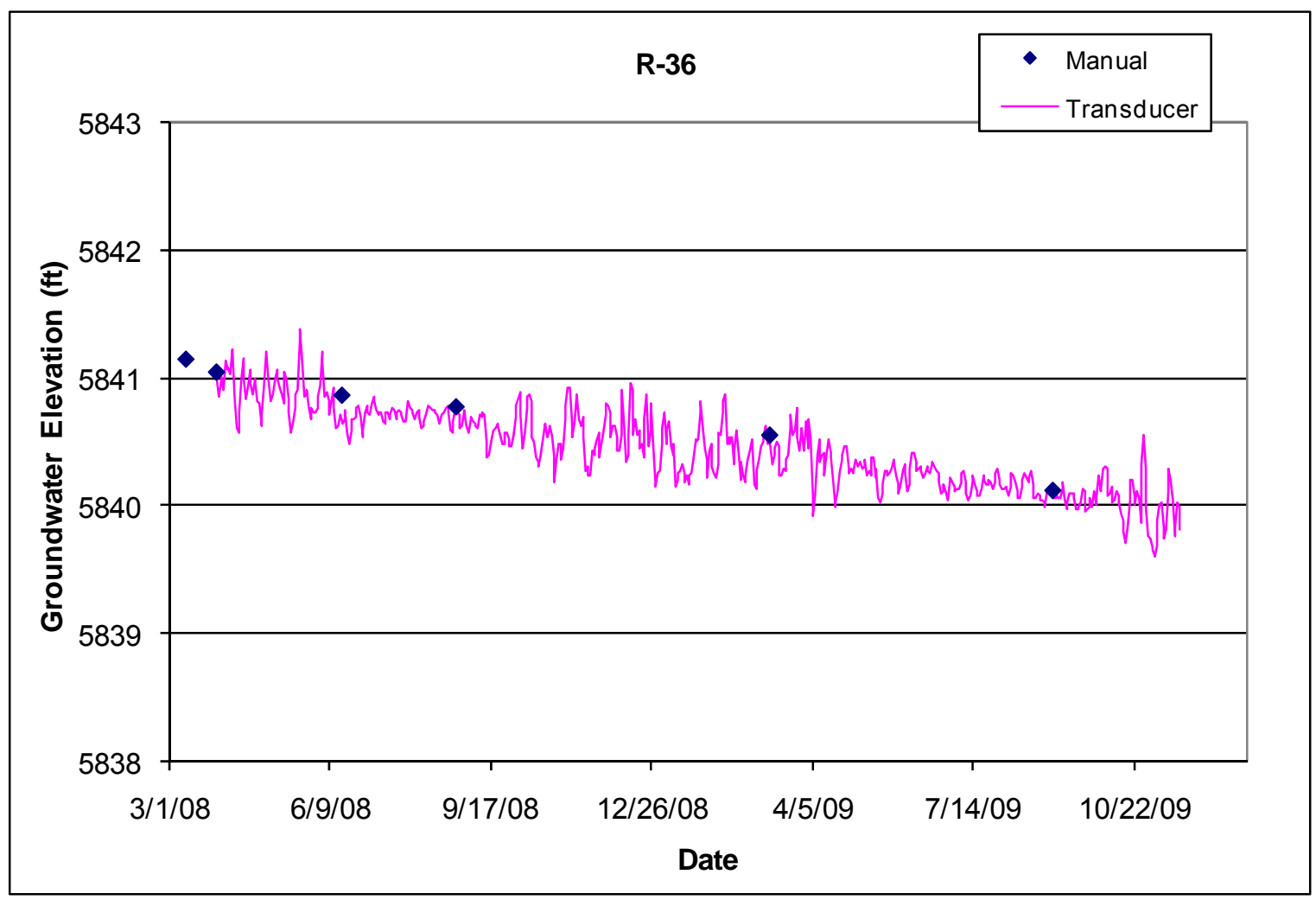




\subsection{R-37}

Location: R-37 is located on an unnamed mesa at TA-54 between Cañada del Buey and the south fork of Cañada del Buey. R-37 is about $3000 \mathrm{ft}$ southeast of supply well PM-4 and $2500 \mathrm{ft}$ northeast of supply well PM-2.

Completion Type: Dual completion in a perched intermediate zone and in the top of the regional aquifer. A Baski dual pump sampling system was installed on November 11, 2009, but due to a problem with the Bennett pump, the system was removed on December 14, 2009, and reinstalled on December 16, 2009.

Period of Record: Well completed June 2009, transducers installed November 12, 2009, and again on December 17, 2009; water level data through 2009.

Remarks: The top of screen 2 is about $12 \mathrm{ft}$ below the regional water table. The well is $100 \%$ barometrically efficient; the aquifer does not respond to atmospheric pressure fluctuations. Available water level data indicate that R-37 responds to supply well pumping at nearby well PM-4.

\begin{tabular}{|c|c|c|c|c|c|c|c|c|c|c|c|c|c|}
\hline \multicolumn{14}{|c|}{ R-37 Construction Information } \\
\hline Screen & $\begin{array}{c}\text { Screen } \\
\text { Top } \\
\text { Depth } \\
\text { (ft) } \\
\end{array}$ & $\begin{array}{c}\text { Screen } \\
\text { Bottom } \\
\text { Depth } \\
\text { (ft) } \\
\end{array}$ & $\begin{array}{c}\text { Screen } \\
\text { Top } \\
\text { Elev } \\
\text { (ft) } \\
\end{array}$ & $\begin{array}{c}\text { Screen } \\
\text { Bottom } \\
\text { Elev } \\
\text { (ft) } \\
\end{array}$ & $\begin{array}{c}\text { Screen } \\
\text { Length } \\
(\mathrm{ft})\end{array}$ & $\begin{array}{c}\text { Pump } \\
\text { Intake } \\
\text { Depth } \\
\text { (ft) }\end{array}$ & $\begin{array}{c}\text { Pump } \\
\text { Intake } \\
\text { Elev } \\
\text { (ft) } \\
\end{array}$ & $\begin{array}{l}\text { Depth to } \\
\text { Packerl } \\
\text { Sump } \\
\text { Bottom } \\
\text { (ft) }\end{array}$ & $\begin{array}{c}\text { Depth } \\
\text { to } \\
\text { bottom } \\
\text { of } \\
\text { Packer }\end{array}$ & $\begin{array}{c}\text { Sump } \\
\text { Length } \\
\text { (ft) }\end{array}$ & $\begin{array}{c}\text { Bottom } \\
\text { of Well } \\
\text { Elev } \\
\text { (ft) }\end{array}$ & $\begin{array}{l}\text { Hydro } \\
\text { Zone } \\
\text { Code } \\
\end{array}$ & $\begin{array}{l}\text { Geo } \\
\text { Unit } \\
\text { Code } \\
\end{array}$ \\
\hline 1 & 929.3 & 950.0 & 5941.3 & 5920.6 & 20.7 & 948.9 & 5921.7 & 959.3 & NA & 9.3 & 5911.3 & $\mathrm{I}$ & Tpf \\
\hline 2 & 1026.0 & 1046.6 & 5844.6 & 5824.0 & 20.6 & 1055.9 & 5814.7 & 1068.8 & 964.1 & 22.2 & 5801.8 & RT & Tpf \\
\hline
\end{tabular}

Note: Brass Cap Elevation: $6870.59 \mathrm{ft}$; all measurements are from this elevation

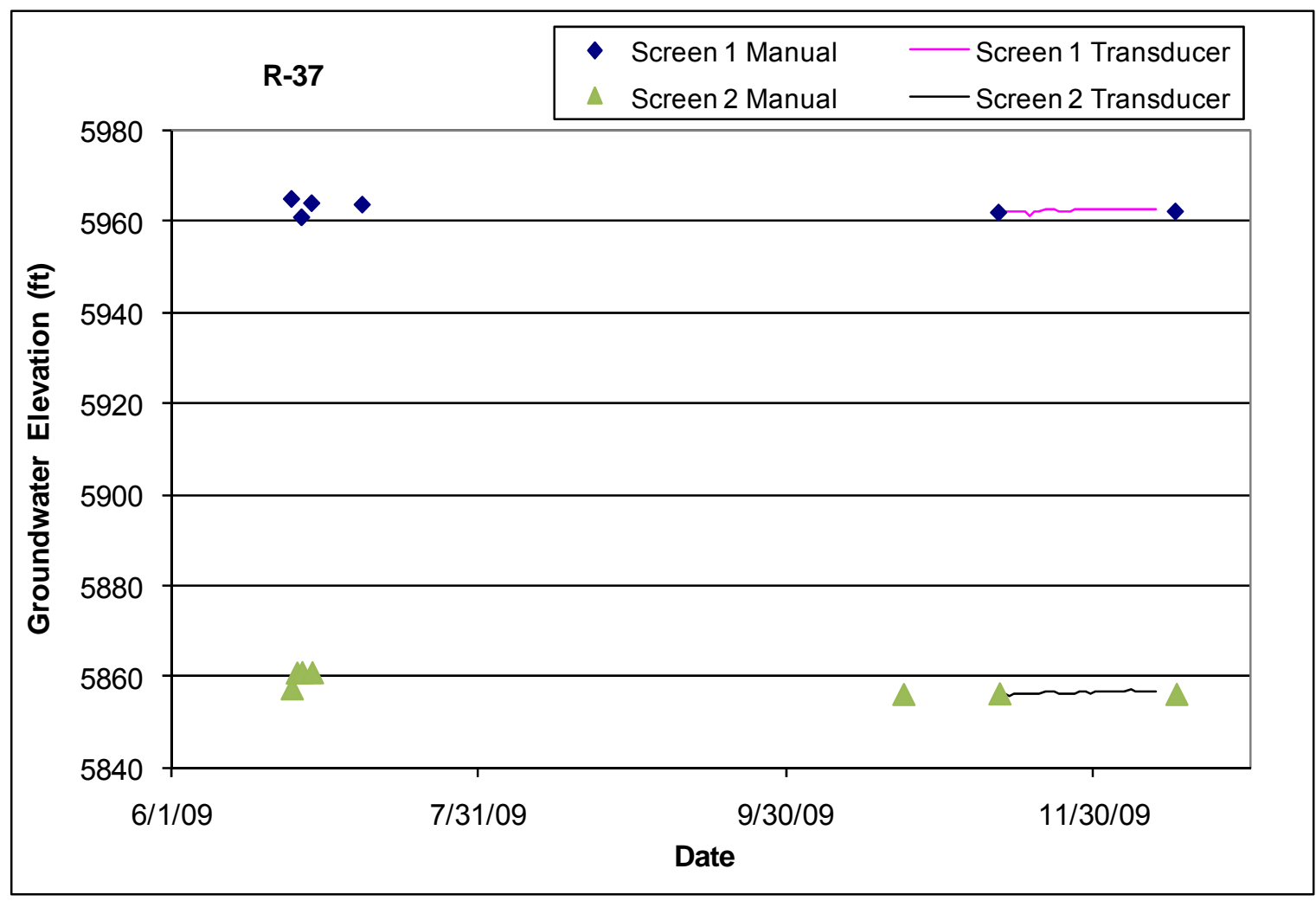



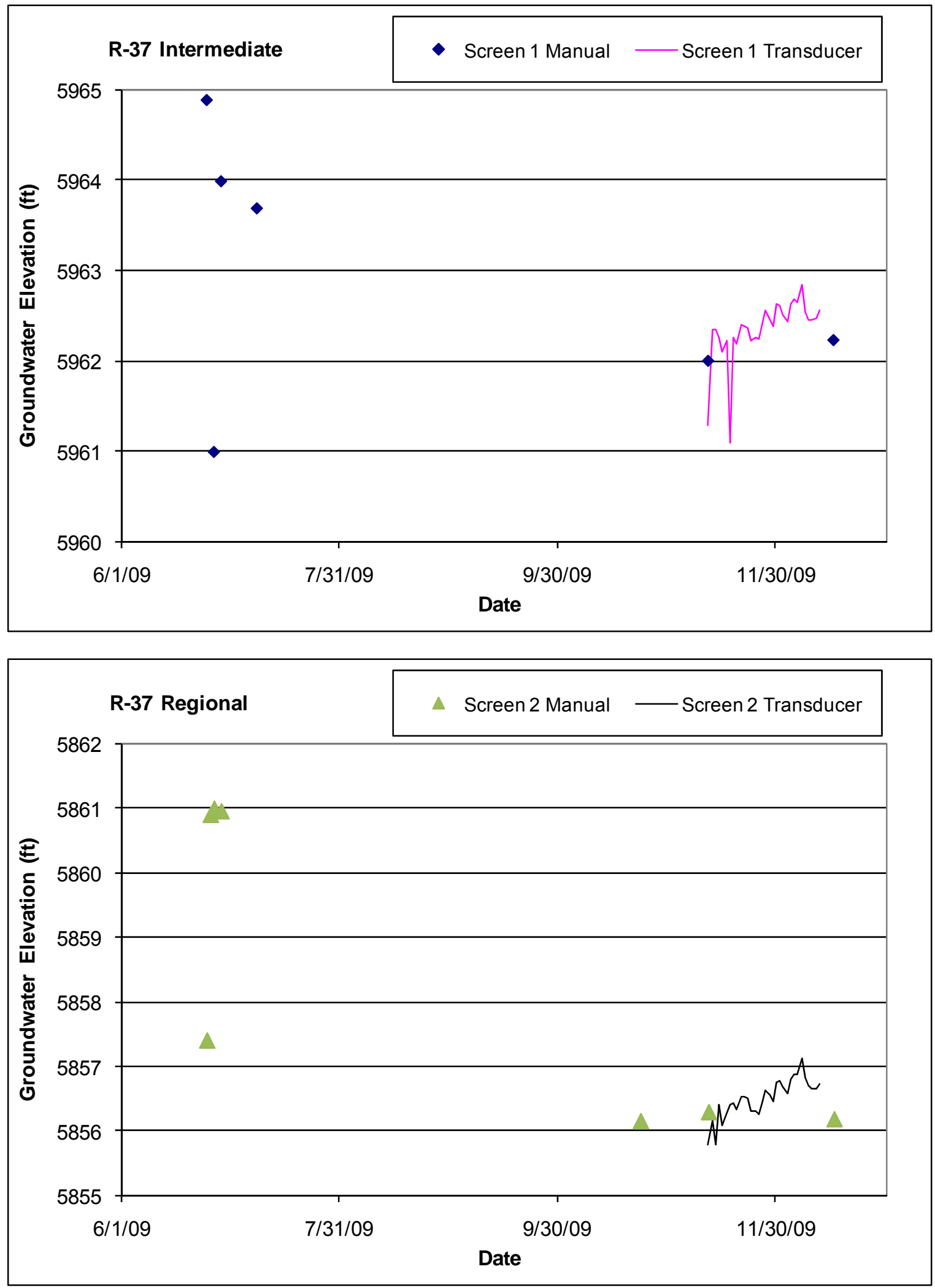


\section{$3.40 \quad$ R-38}

Location: R-38 is located in middle Cañada del Buey northeast of MDA L.

Completion Type: Single completion at the top of the regional aquifer in Cerros del Rio basalt.

Period of Record: Well completed December 2008, transducer installed March 25, 2009; data through 2009.

Remarks: R-38 installed near the top of the regional aquifer to a depth of $853 \mathrm{ft}$; top of screen is about $10 \mathrm{ft}$ below the regional water table. The well is $100 \%$ barometrically efficient; however, the aquifer has a delayed response to atmospheric pressure fluctuations.

\begin{tabular}{|c|c|c|c|c|c|c|c|c|c|c|c|c|c|c|}
\hline \multicolumn{15}{|c|}{ R-38 Construction Information } \\
\hline Screen & $\begin{array}{c}\text { Screen } \\
\text { Top } \\
\text { Depth } \\
\text { (ft) }\end{array}$ & $\begin{array}{c}\text { Screen } \\
\text { Bottom } \\
\text { Depth } \\
\text { (ft) }\end{array}$ & $\begin{array}{c}\text { Screen } \\
\text { Top } \\
\text { Elev } \\
\text { (ft) }\end{array}$ & $\begin{array}{c}\text { Screen } \\
\text { Bottom } \\
\text { Elev } \\
\text { (ft) }\end{array}$ & $\begin{array}{l}\text { Screen } \\
\text { Length } \\
\text { (ft) }\end{array}$ & $\begin{array}{c}\text { Pump } \\
\text { Intake } \\
\text { Depth } \\
\text { (ft) }\end{array}$ & $\begin{array}{c}\text { Pump } \\
\text { Intake } \\
\text { Elev } \\
\text { (ft) }\end{array}$ & $\begin{array}{l}\text { Depth to } \\
\text { Top of } \\
\text { Sump } \\
\text { (ft) }\end{array}$ & $\begin{array}{c}\text { Top of } \\
\text { Sump } \\
\text { Elev } \\
\text { (ft) }\end{array}$ & $\begin{array}{c}\text { Depth } \\
\text { to } \\
\text { Sump } \\
\text { Bottom } \\
\text { (ft) }\end{array}$ & $\begin{array}{c}\text { Sump } \\
\text { Length } \\
\text { (ft) }\end{array}$ & $\begin{array}{c}\text { Sump } \\
\text { Volume } \\
\text { (L) }\end{array}$ & $\begin{array}{c}\text { Hydro } \\
\text { Zone } \\
\text { Code }\end{array}$ & $\begin{array}{l}\text { Geo } \\
\text { Unit } \\
\text { Code }\end{array}$ \\
\hline 1 & 821.2 & 831.2 & 5847.4 & 5837.4 & 10.0 & & & 831.2 & 5837.4 & 853.0 & 21.8 & 84.2 & $\overline{R T}$ & Tb4 \\
\hline
\end{tabular}

Note: Brass Cap Ground Elevation: $6668.58 \mathrm{ft}$; all measurements are from this elevation

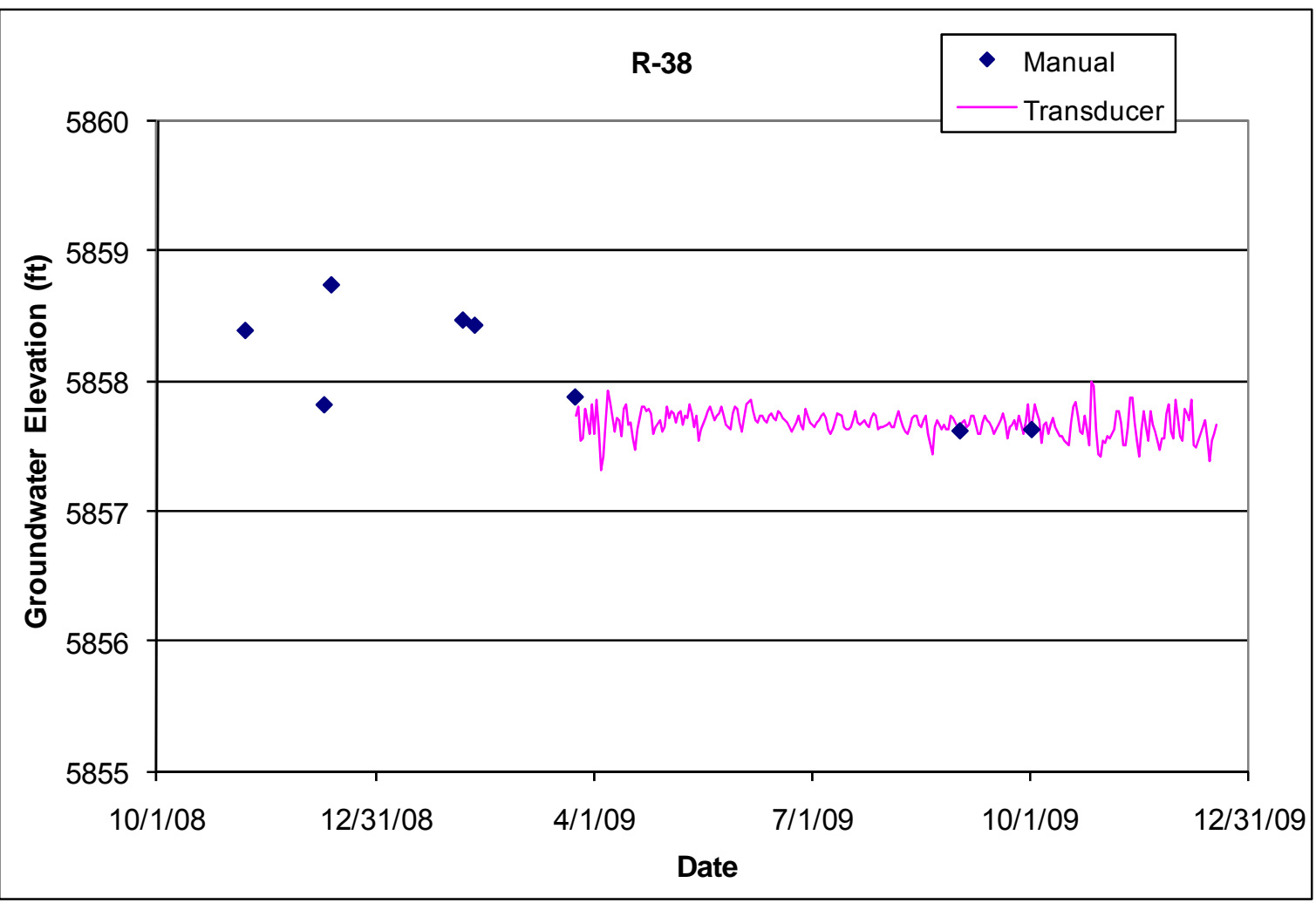




\subsection{R-39}

Location: R-39 is located in lower Pajarito Canyon southeast and downgradient of TA-54 and MDA G and about $700 \mathrm{ft}$ southwest of monitoring well R-22.

Completion Type: Single completion at the top of the regional aquifer in Cerros del Rio basalt.

Period of Record: Well completed December 2008. Transducer installed May 15, 2009; data through 2009.

Remarks: R-39 installed near the top of the regional aquifer to a depth of $875.6 \mathrm{ft}$; top of the screen is about $30 \mathrm{ft}$ below the regional water table. The well is $80 \%$ barometrically efficient; the aquifer indicates a partial response to atmospheric pressure fluctuations.

\begin{tabular}{|c|c|c|c|c|c|c|c|c|c|c|c|c|c|c|}
\hline \multicolumn{15}{|c|}{ R-39 Construction Information } \\
\hline Screen & $\begin{array}{l}\text { Screen } \\
\text { Top } \\
\text { Depth } \\
\text { (ft) }\end{array}$ & $\begin{array}{c}\text { Screen } \\
\text { Bottom } \\
\text { Depth } \\
\text { (ft) }\end{array}$ & $\begin{array}{c}\text { Screen } \\
\text { Top } \\
\text { Elev } \\
\text { (ft) }\end{array}$ & $\begin{array}{c}\text { Screen } \\
\text { Bottom } \\
\text { Elev } \\
\text { (ft) }\end{array}$ & $\begin{array}{c}\text { Screen } \\
\text { Length } \\
\text { (ft) }\end{array}$ & $\begin{array}{c}\text { Pump } \\
\text { Intake } \\
\text { Depth } \\
\text { (ft) }\end{array}$ & $\begin{array}{c}\text { Pump } \\
\text { Intake } \\
\text { Elev } \\
\text { (ft) }\end{array}$ & $\begin{array}{l}\text { Depth } \\
\text { to Top } \\
\text { of } \\
\text { Sump } \\
\text { (ft) }\end{array}$ & $\begin{array}{c}\text { Top of } \\
\text { Sump } \\
\text { Elev } \\
\text { (ft) }\end{array}$ & $\begin{array}{l}\text { Depth to } \\
\text { Sump } \\
\text { Bottom } \\
\text { (ft) }\end{array}$ & $\begin{array}{c}\text { Sump } \\
\text { Length } \\
\text { (ft) }\end{array}$ & $\begin{array}{c}\text { Sump } \\
\text { Volume } \\
\text { (L) }\end{array}$ & $\begin{array}{l}\text { Hydro } \\
\text { Zone } \\
\text { Code }\end{array}$ & $\begin{array}{l}\text { Geo } \\
\text { Unit } \\
\text { Code }\end{array}$ \\
\hline 1 & 859.0 & 869.0 & 5721.8 & 5711.8 & 10.0 & 858.8 & 5722.1 & 869.0 & 5711.8 & 875.6 & 6.5 & 25.3 & $\overline{R T}$ & $\overline{T b 4}$ \\
\hline
\end{tabular}

Note: Brass Cap Ground Elevation: $6580.86 \mathrm{ft}$; all measurements are from this elevation

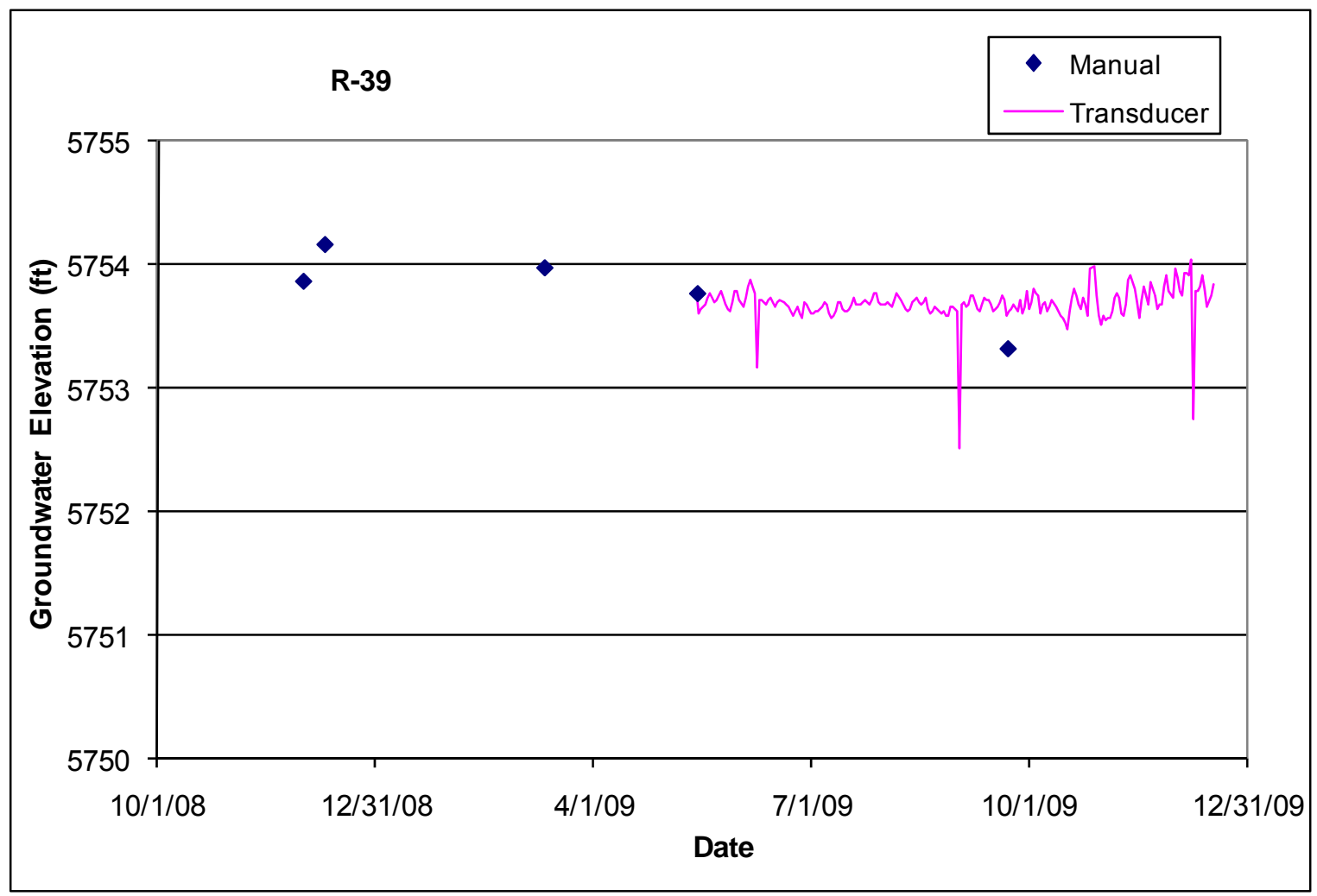




\subsection{R-40}

Location: R-40 is located in lower Pajarito Canyon east of TA-18 and $400 \mathrm{ft}$ north of supply well PM-2.

Completion Type: Three screens in two piezometers; one intermediate 3-in.-ID PVC piezometer screen (R-40i) and two 5-in. ID stainless steel screens (R-40) with the upper screen in an intermediate zone and the lower screen at the top of the regional aquifer.

Period of Record: Well completed January 2009. Transducers installed at all three screens August 27, 2009; data through 2009. A temporary transducer was installed at the R-40 upper screen from February 11 to March 3, 2009, to monitor the slow recovery of the lower intermediate zone after attempting an aquifer test.

Remarks: Screen R-40i and the upper R-40 screen are completed in intermediate perched zones within the Cerros del Rio basalt. The lower R-40 screen is installed in Puye fanglomerates near the top of the regional aquifer to a depth of $895 \mathrm{ft}$; the lower R-40 screen straddles the regional water table. The regional aquifer indicates a response to pumping supply well PM-4; no data available as of January 2010 for possible response to nearby well PM-2.

\begin{tabular}{|c|c|c|c|c|c|c|c|c|c|c|c|c|c|c|c|}
\hline \multicolumn{16}{|c|}{ R-40 and R-40i Construction Information } \\
\hline Screen & $\begin{array}{c}\text { Screen } \\
\text { Top } \\
\text { Depth } \\
\text { (ft) }\end{array}$ & $\begin{array}{c}\text { Screen } \\
\text { Bottom } \\
\text { Depth } \\
\text { (ft) }\end{array}$ & $\begin{array}{c}\text { Screen } \\
\text { Top } \\
\text { Elev } \\
\text { (ft) }\end{array}$ & $\begin{array}{c}\text { Screen } \\
\text { Bottom } \\
\text { Elev } \\
\text { (ft) }\end{array}$ & $\begin{array}{c}\text { Screen } \\
\text { Length } \\
\text { (ft) }\end{array}$ & $\begin{array}{c}\text { Pump } \\
\text { Intake } \\
\text { Depth } \\
\text { (ft) }\end{array}$ & $\begin{array}{c}\text { Pump } \\
\text { Intake } \\
\text { Elev } \\
\text { (ft) }\end{array}$ & $\begin{array}{l}\text { Depth } \\
\text { to Top } \\
\text { of } \\
\text { Sump } \\
\text { (ft) }\end{array}$ & $\begin{array}{c}\text { Top of } \\
\text { Sump } \\
\text { Elev } \\
\text { (ft) }\end{array}$ & 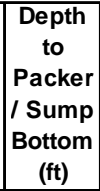 & $\begin{array}{c}\text { Sump } \\
\text { Length } \\
\text { (ft) }\end{array}$ & $\begin{array}{c}\text { Sump } \\
\text { Vol } \\
\text { (L) }\end{array}$ & \begin{tabular}{|c|} 
Hydro \\
Zone \\
Code
\end{tabular} & $\begin{array}{c}\text { Geo } \\
\text { Unit } \\
\text { Code }\end{array}$ & Comment \\
\hline R-40i & 649.7 & 669.0 & 6069.5 & 6050.2 & 19.3 & 669.0 & 6050.2 & 669.0 & 6050.2 & 674.6 & 5.6 & 7.8 & $\mathrm{~T}$ & $\mathrm{~Tb} 4$ & 3" ID PVC Casing \\
\hline 1 & 751.6 & 785.1 & 5967.6 & 5934.1 & 33.5 & 778.0 & 5941.2 & 785.1 & 5934.1 & 794.1 & 9.0 & 34.8 & $\mathrm{I}$ & $\mathrm{Tb} 4$ & 5" ID SS Casing \\
\hline 2 & 849.3 & 870.0 & 5869.9 & 5849.2 & 20.7 & 871.0 & 5848.2 & 870.0 & 5849.2 & 895.0 & 25.0 & 96.5 & RT & Tpf & 5" ID SS Casing \\
\hline
\end{tabular}

Note: Brass Cap Ground Elevation: $6719.24 \mathrm{ft}$; all measurements are from this elevation

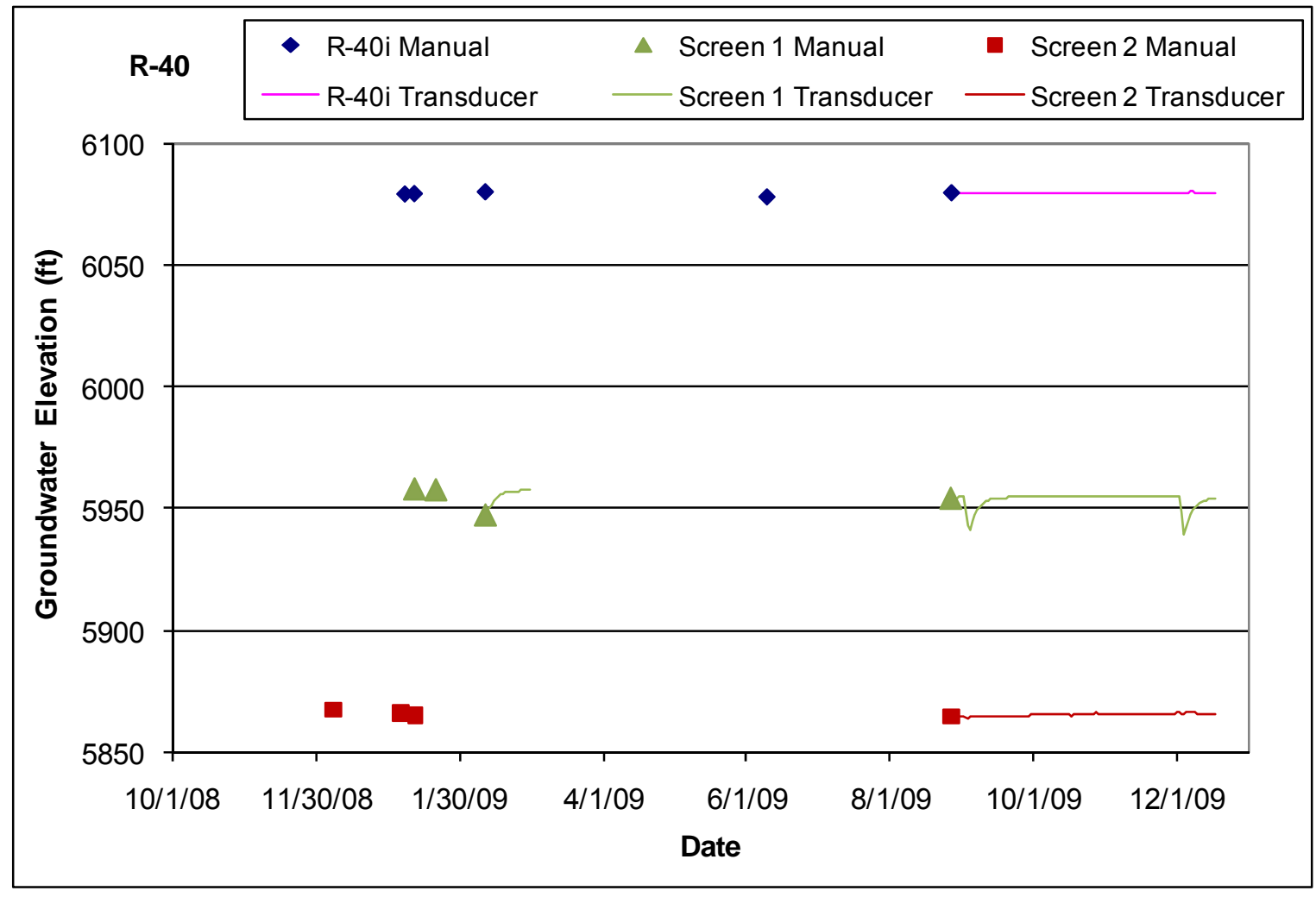



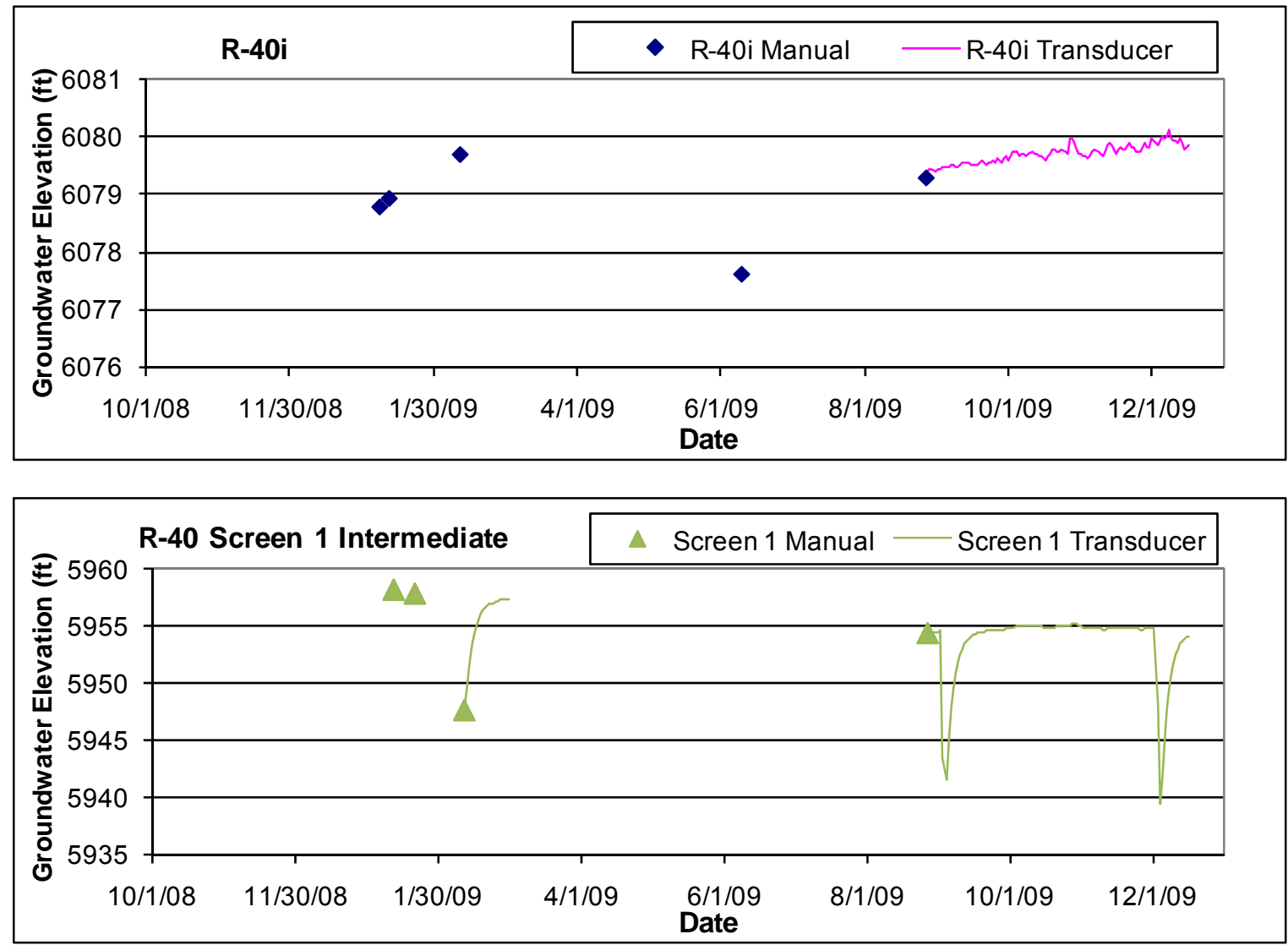

Note scale change for R-40 Screen 1 hydrograph

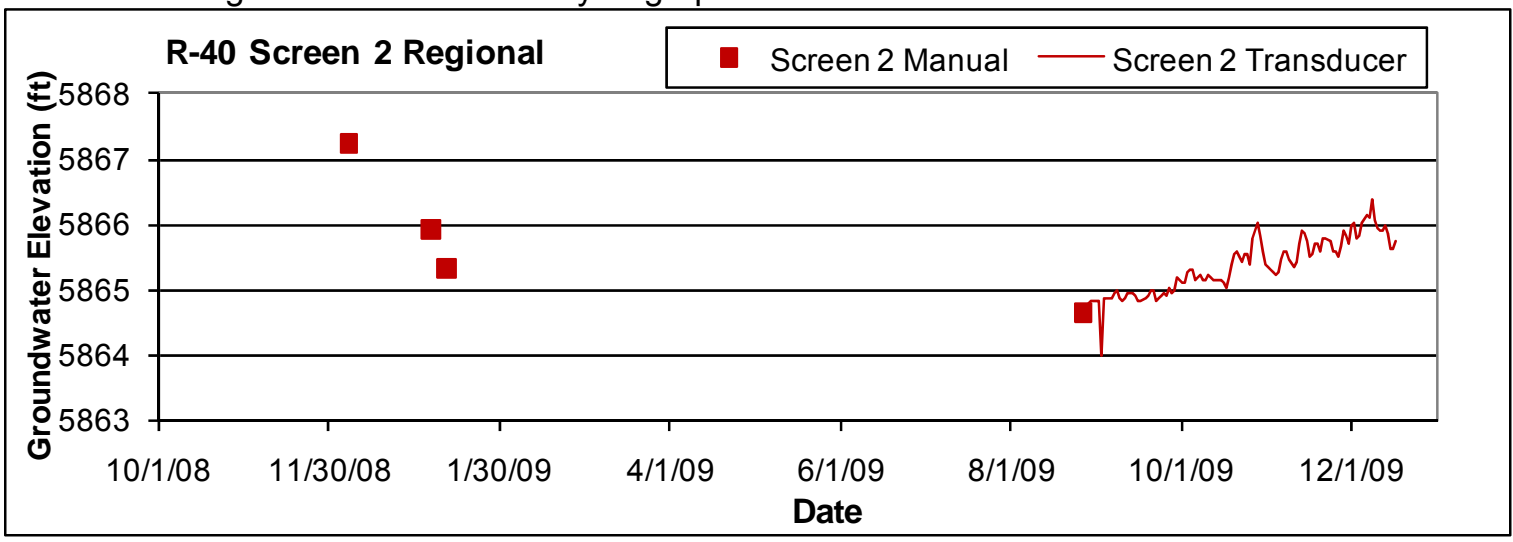




\subsection{R-41}

Location: R-41 is located about $100 \mathrm{ft}$ east of MDA G at TA-54 and about $650 \mathrm{ft}$ north of monitoring well R-22.

Completion Type: Dual completion in a dry intermediate zone and at the top of the regional aquifer in Santa Fe Group sediments.

Period of Record: Well completed March 2009. Temporary transducer installed from May 15 to June 8, 2009. Dedicated transducer installed July 27, 2009; data through 2009.

Remarks: Screen 1 has been dry since installation. Screen 2 is installed near the top of the regional aquifer to a depth of $997.1 \mathrm{ft}$; the top of the screen is about $4 \mathrm{ft}$ below the regional water table.

\begin{tabular}{|c|c|c|c|c|c|c|c|c|c|c|c|c|c|c|}
\hline \multicolumn{15}{|c|}{ R-41 Construction Information } \\
\hline Screen & $\begin{array}{l}\text { Screen } \\
\text { Top } \\
\text { Depth } \\
\text { (ft) }\end{array}$ & $\begin{array}{c}\text { Screen } \\
\text { Bottom } \\
\text { Depth } \\
\text { (ft) }\end{array}$ & $\begin{array}{l}\text { Screen } \\
\text { Top } \\
\text { Elev (ft) }\end{array}$ & $\begin{array}{l}\text { Screen } \\
\text { Bottom } \\
\text { Elev (ft) }\end{array}$ & $\begin{array}{c}\text { Screen } \\
\text { Length } \\
\text { (ft) }\end{array}$ & $\begin{array}{c}\text { Pump } \\
\text { Intake } \\
\text { Depth } \\
\text { (ft) }\end{array}$ & $\begin{array}{c}\text { Pump } \\
\text { Intake } \\
\text { Elev } \\
\text { (ft) }\end{array}$ & $\begin{array}{l}\text { Depth } \\
\text { to Top } \\
\text { of } \\
\text { Packerl } \\
\text { Sump } \\
\text { (ft) }\end{array}$ & $\begin{array}{c}\text { Top of } \\
\text { Packerl } \\
\text { Sump } \\
\text { Elev (ft) }\end{array}$ & \begin{tabular}{|c|} 
Depth \\
to \\
Sump \\
Bottom \\
(ft) \\
\end{tabular} & \begin{tabular}{|c|} 
Sump \\
Length \\
(ft)
\end{tabular} & $\begin{array}{c}\text { Sump } \\
\text { Vol } \\
\text { (gal.) }\end{array}$ & $\begin{array}{l}\text { Hydro } \\
\text { Zone } \\
\text { Code }\end{array}$ & $\begin{array}{l}\text { Geo } \\
\text { Unit } \\
\text { Code }\end{array}$ \\
\hline 1 & 928.0 & 937.7 & 5732.5 & 5722.8 & 9.7 & NA & $\overline{\mathrm{NA}}$ & 944.8 & 5715.7 & 944.8 & 7.1 & 7.2 & $\mathrm{~T}$ & Tsf \\
\hline 2 & 965.3 & 975.0 & 5695.2 & 5685.5 & 9.7 & 978.5 & 5682.0 & 975.0 & 5685.5 & 997.1 & 22.1 & 22.5 & RT & Tsf \\
\hline
\end{tabular}

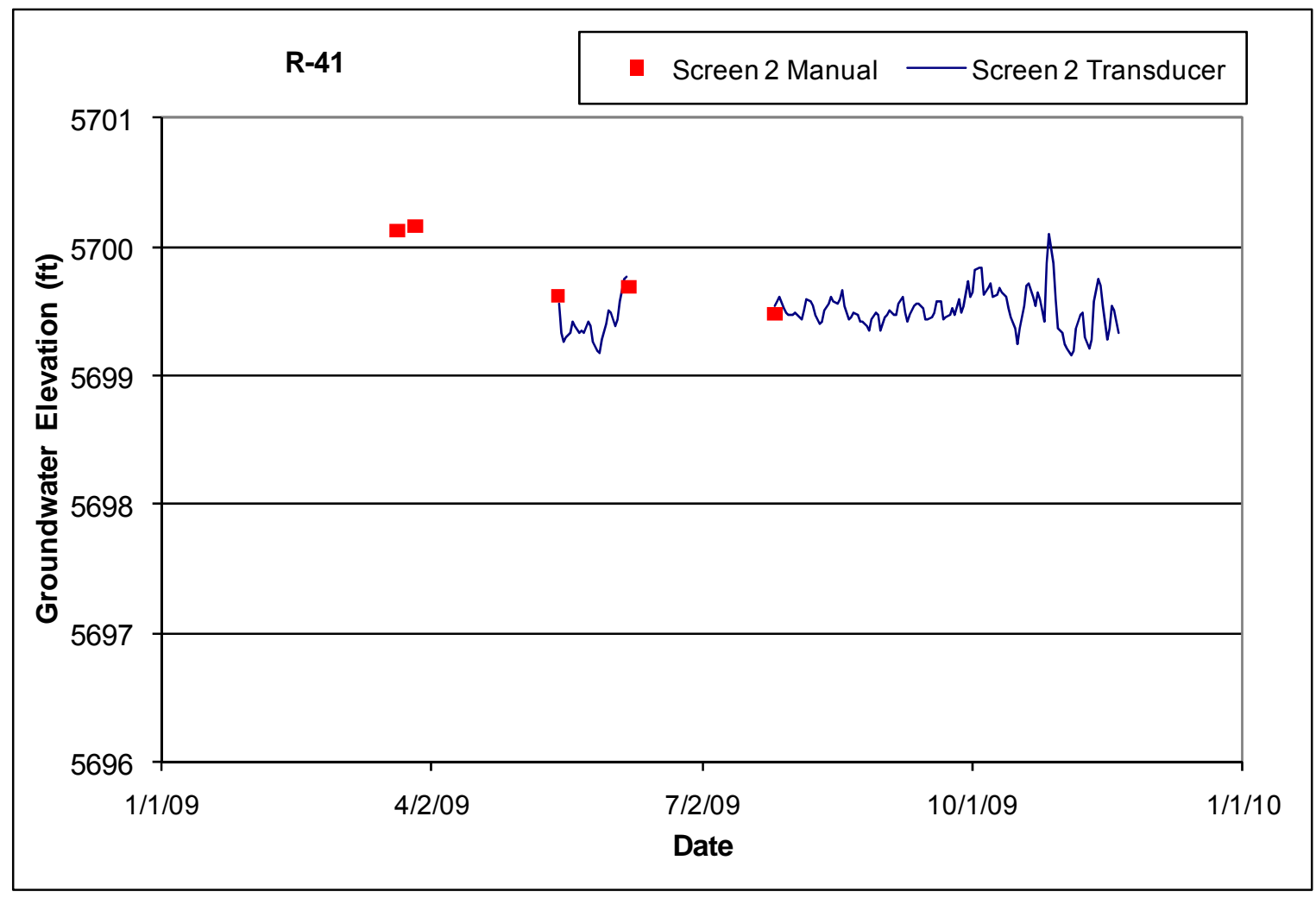




\subsection{R-42}

Location: R-42 is located in lower Mortandad Canyon between R-15 and R-28.

Completion Type: Single completion within the regional aquifer in Santa Fe Group sediments.

Period of Record: Well completed August 2008. Transducer installed January 26, 2009; data through 2009.

Remarks: R-42 installed in the regional aquifer to a depth of $973.5 \mathrm{ft}$. The top of the screen is about $12 \mathrm{ft}$ below the water table. The well is $100 \%$ barometrically efficient; the aquifer does not respond to atmospheric pressure fluctuations. The aquifer responds to supply well pumping but available data do not indicate a specific response to any individual pumping well.

\begin{tabular}{|c|c|c|c|c|c|c|c|c|c|c|c|c|c|c|}
\hline \multicolumn{15}{|c|}{ R-42 Construction Information } \\
\hline Screen & $\begin{array}{c}\text { Screen } \\
\text { Top } \\
\text { Depth } \\
\text { (ft) }\end{array}$ & $\begin{array}{c}\text { Screen } \\
\text { Bottom } \\
\text { Depth } \\
\text { (ft) }\end{array}$ & $\begin{array}{l}\text { Screen } \\
\text { Top } \\
\text { Elev (ft) }\end{array}$ & $\begin{array}{l}\text { Screen } \\
\text { Bottom } \\
\text { Elev (ft) }\end{array}$ & $\begin{array}{c}\text { Screen } \\
\text { Length } \\
\text { (ft) }\end{array}$ & $\begin{array}{c}\text { Pump } \\
\text { Intake } \\
\text { Depth } \\
\text { (ft) }\end{array}$ & $\begin{array}{c}\text { Pump } \\
\text { Intake } \\
\text { Elev } \\
\text { (ft) }\end{array}$ & $\begin{array}{l}\text { Depth } \\
\text { to Top } \\
\text { of } \\
\text { Sump } \\
\text { (ft) }\end{array}$ & $\begin{array}{c}\text { Top of } \\
\text { Sump } \\
\text { Elev } \\
\text { (ft) }\end{array}$ & \begin{tabular}{|c} 
Depth \\
to \\
Sump \\
Bottom \\
(ft)
\end{tabular} & $\begin{array}{c}\text { Sump } \\
\text { Length } \\
\text { (ft) }\end{array}$ & $\begin{array}{c}\text { Sump } \\
\text { Vol } \\
\text { (L) }\end{array}$ & $\begin{array}{l}\text { Hydro } \\
\text { Zone } \\
\text { Code }\end{array}$ & $\begin{array}{c}\text { Geo } \\
\text { Unit } \\
\text { Code }\end{array}$ \\
\hline 1 & 931.8 & 952.9 & 5827.2 & 5806.1 & 21.1 & 930.9 & 5828.2 & 952.9 & 5806.1 & 973.5 & 20.6 & 79.5 & RT & Tsfu \\
\hline
\end{tabular}

Note: Brass Cap Ground Elevation: $6759.02 \mathrm{ft}$; all measurements are from this elevation

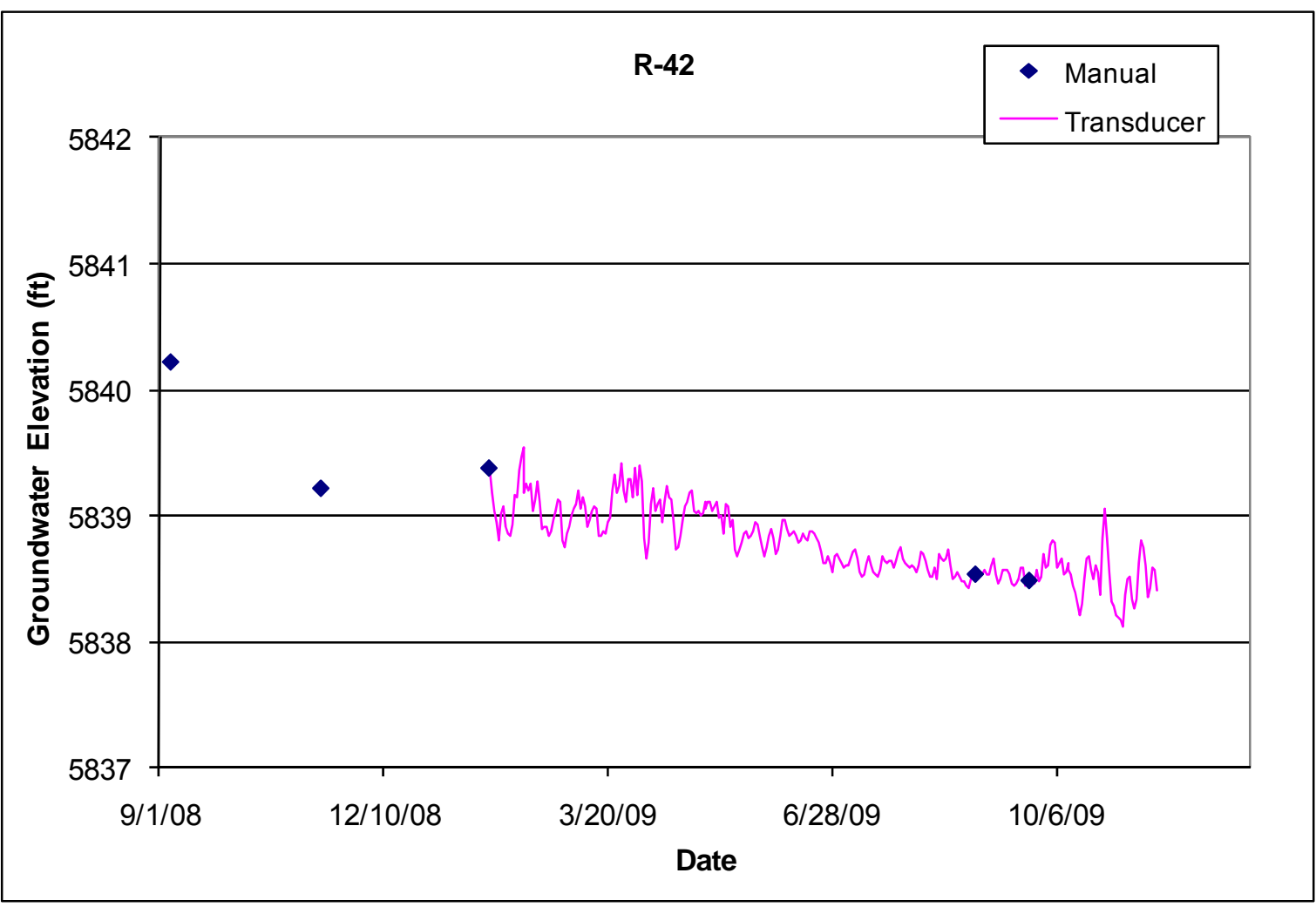




\subsection{R-43}

Location: R-43 is located in middle Sandia Canyon.

Completion Type: Dual completion within the regional aquifer. The top of screen 1 is about $10 \mathrm{ft}$ below the water table.

Period of Record: Well completed October 2008. Transducers installed June 25, 2009; data through 2009.

Remarks: R-43 installed in the regional aquifer to a depth of $990 \mathrm{ft}$, about $95 \mathrm{ft}$ into the aquifer. A Baski packer with dual valve, single submersible pump sampling system was installed June 8,2009 . The screens are $44.5 \mathrm{ft}$ apart with a head difference of about $1 \mathrm{ft}$. The well is $100 \%$ barometrically efficient; the aquifer does not respond to atmospheric pressure fluctuations.

\begin{tabular}{|c|c|c|c|c|c|c|c|c|c|c|c|c|c|c|}
\hline \multicolumn{15}{|c|}{ R-43 Construction Information } \\
\hline Screen & $\begin{array}{l}\text { Screen } \\
\text { Top } \\
\text { Depth } \\
\text { (ft) }\end{array}$ & $\begin{array}{c}\text { Screen } \\
\text { Bottom } \\
\text { Depth } \\
\text { (ft) }\end{array}$ & $\begin{array}{l}\text { Screen } \\
\text { Top } \\
\text { Elev (ft) }\end{array}$ & $\begin{array}{l}\text { Screen } \\
\text { Bottom } \\
\text { Elev (ft) }\end{array}$ & $\begin{array}{c}\text { Screen } \\
\text { Length } \\
\text { (ft) }\end{array}$ & \begin{tabular}{|c|} 
APV \\
Intake \\
Depth \\
(ft) \\
\end{tabular} & $\begin{array}{c}\text { APV } \\
\text { Intake } \\
\text { Elev } \\
\text { (ft) }\end{array}$ & $\begin{array}{l}\text { Depth to } \\
\text { Top of } \\
\text { Packerl } \\
\text { Sump } \\
\text { (ft) }\end{array}$ & $\begin{array}{c}\text { Top of } \\
\text { Packerl } \\
\text { Sump } \\
\text { Elev (ft) }\end{array}$ & $\begin{array}{c}\text { Bottom } \\
\text { of } \\
\text { Packer } \\
\text { (ft) }\end{array}$ & $\begin{array}{c}\text { Sump } \\
\text { Length } \\
\text { (ft) }\end{array}$ & $\begin{array}{c}\text { Bottom } \\
\text { of } \\
\text { Sumpl } \\
\text { Well } \\
\text { Elev (ft) }\end{array}$ & $\begin{array}{l}\text { Hydro } \\
\text { Zone } \\
\text { Code }\end{array}$ & $\begin{array}{l}\text { Geo } \\
\text { Unit } \\
\text { Code }\end{array}$ \\
\hline 1 & 903.9 & 924.6 & 5828.8 & 5808.1 & 20.7 & 948.4 & 5784.3 & 960.7 & 5772.0 & NA & 36.1 & 5772.0 & RT & Tsfu \\
\hline 2 & 969.1 & 979.1 & 5763.6 & 5753.6 & 10.0 & 967.5 & 5765.2 & 990.4 & 5742.3 & 965.4 & 11.3 & 5742.3 & RD & Tsfu \\
\hline
\end{tabular}

Note: Brass Cap Ground Elevation: $6732.65 \mathrm{ft}$; all measurements are from this elevation

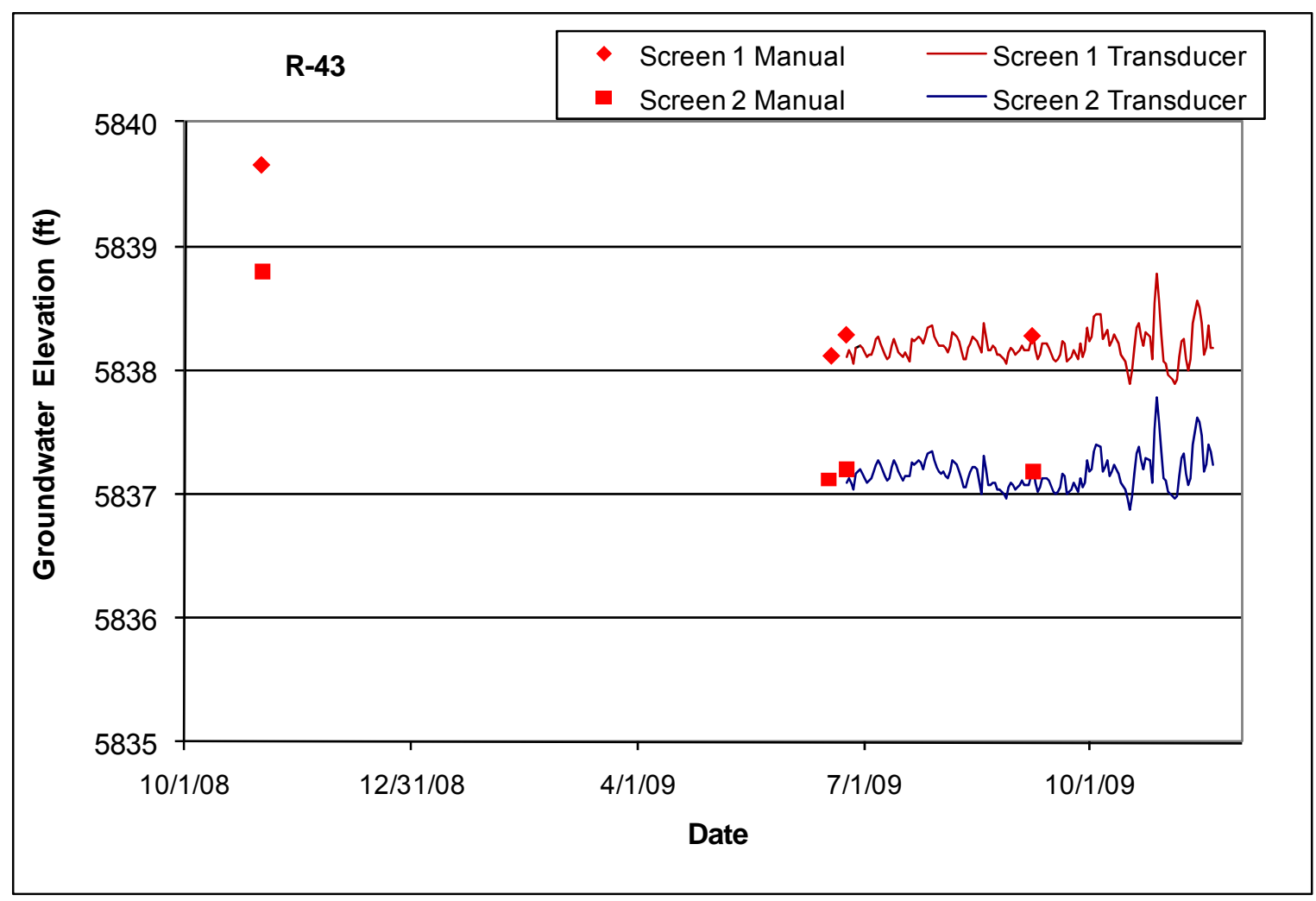




\subsection{R-44}

Location: R-44 is located in lower Mortandad Canyon about $925 \mathrm{ft}$ west of R-13.

Completion Type: Dual screen completion within the regional aquifer.

Period of Record: Well completed January 2009; transducers installed July 8, 2009; data through 2009.

Remarks: R-44 installed in the regional aquifer to a depth of $1016 \mathrm{ft}$, about $110 \mathrm{ft}$ into the aquifer. The screens are $80 \mathrm{ft}$ apart. Both screens exhibit a response to pumping supply well PM-4; however, screen 2 shows more response than screen 1. During pumping PM-4, the head difference between screens was about $0.25 \mathrm{ft}$; however, after PM- 4 was shut down for the season in 2009 , the head difference declined. The well is $100 \%$ barometrically efficient; however, the aquifer shows a delayed response to atmospheric pressure fluctuations.

\begin{tabular}{|c|c|c|c|c|c|c|c|c|c|c|c|c|c|c|c|}
\hline \multicolumn{16}{|c|}{ R-44 Construction Information } \\
\hline Screen & \begin{tabular}{|c|} 
Screen \\
Top \\
Depth \\
(ft)
\end{tabular} & $\begin{array}{c}\text { Screen } \\
\text { Bottom } \\
\text { Depth } \\
\text { (ft) }\end{array}$ & \begin{tabular}{|c|} 
Screen \\
Top \\
Elev \\
(ft)
\end{tabular} & $\begin{array}{c}\text { Screen } \\
\text { Bottom } \\
\text { Elev } \\
\text { (ft) }\end{array}$ & $\begin{array}{c}\text { Screen } \\
\text { Length } \\
\text { (ft) }\end{array}$ & $\begin{array}{c}\text { APV } \\
\text { Intake } \\
\text { Depth } \\
\text { (ft) }\end{array}$ & $\begin{array}{c}\text { APV } \\
\text { Intake } \\
\text { Elev } \\
\text { (ft) }\end{array}$ & $\begin{array}{c}\text { Depth to } \\
\text { Top of } \\
\text { Sump } \\
\text { (ft) }\end{array}$ & $\begin{array}{c}\text { Top of } \\
\text { Sump } \\
\text { Elev } \\
\text { (ft) }\end{array}$ & $\begin{array}{c}\text { Top/Bot } \\
\text { tom of } \\
\text { Packer } \\
\text { (ft) }\end{array}$ & \begin{tabular}{|} 
Depth to \\
Sump \\
Bottom \\
(ft)
\end{tabular} & $\begin{array}{c}\text { Sump } \\
\text { Length } \\
\text { (ft) }\end{array}$ & $\begin{array}{c}\text { Sump } \\
\text { Volume } \\
\text { (L) }\end{array}$ & $\begin{array}{l}\text { Hydro } \\
\text { Zone } \\
\text { Code }\end{array}$ & \begin{tabular}{|c|} 
Geo \\
Unit \\
Code
\end{tabular} \\
\hline 1 & 895.0 & 905.0 & 5819.9 & 5809.9 & 10.0 & 921.9 & 5793.0 & 905.0 & 5809.9 & 936.3 & 936.3 & 31.3 & 120.9 & RT & Tpf \\
\hline 2 & 985.3 & 995.2 & 5729.6 & 5719.7 & 9.9 & 983.2 & 5731.7 & 995.2 & 5719.7 & \begin{tabular}{|c|c|}
941.1 \\
\end{tabular} & 1016.0 & 20.8 & 80.3 & $\mathrm{RD}$ & Tpf \\
\hline
\end{tabular}

Note: Brass Cap Ground Elevation: $6714.91 \mathrm{ft}$; all measurements are from this elevation

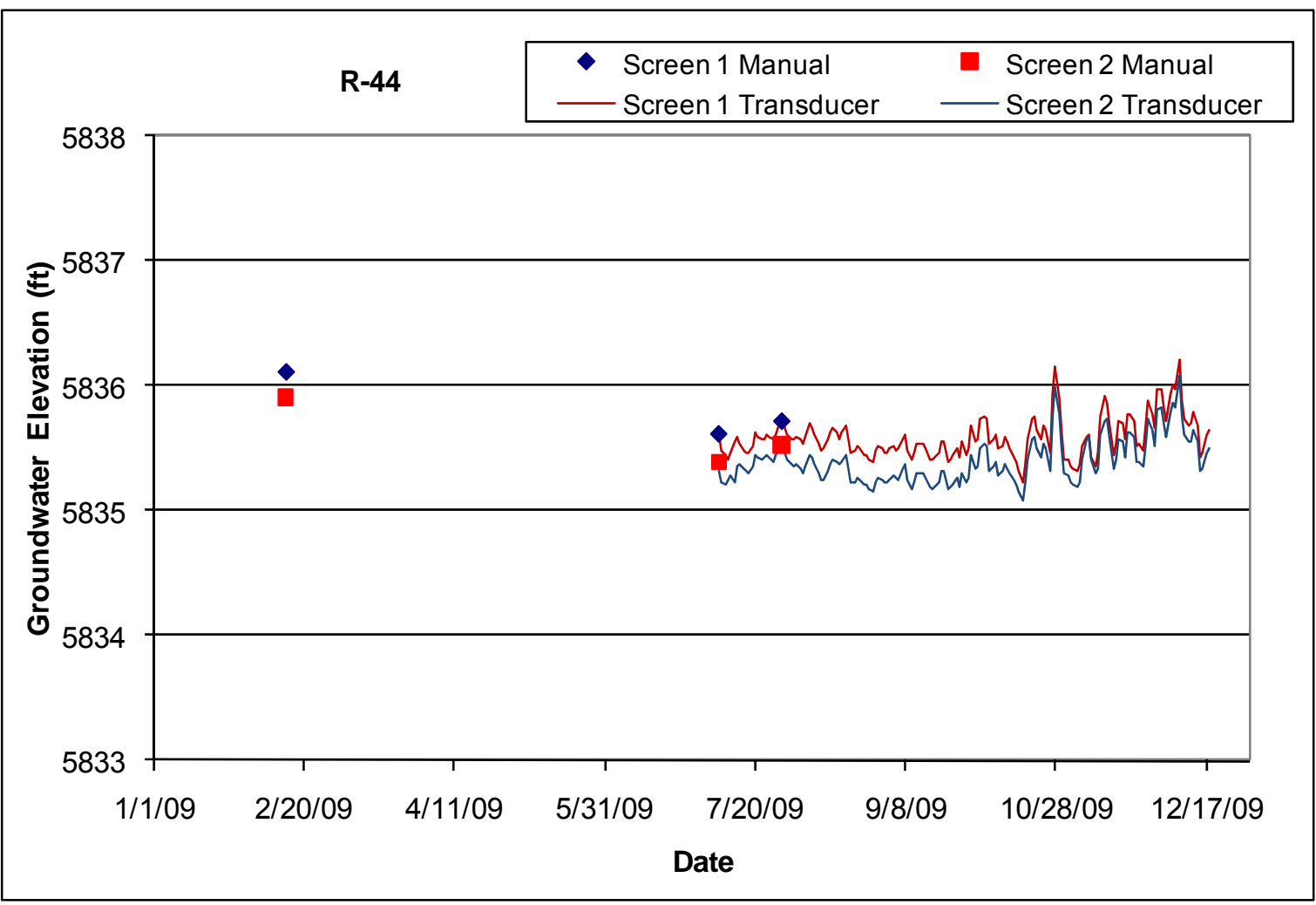




\subsection{R-45}

Location: R-45 is located in lower Mortandad Canyon about $925 \mathrm{ft}$ north of R-44 and $1285 \mathrm{ft}$ east of R-28.

Completion Type: Dual screen completion within the regional aquifer.

Period of Record: Well completed January 2009. Temporary transducers installed from June 30 to July 7, 2009. Dedicated transducers installed July 28, 2009; data through 2009.

Remarks: R-45 installed in the regional aquifer to a depth of $1016 \mathrm{ft}$, about $147 \mathrm{ft}$ into the aquifer. The screens are $85 \mathrm{ft}$ apart. Both screens exhibit a response to pumping supply well PM-4; however, screen 2 shows more response than screen 1. During pumping PM-4, the head difference between screens was about $0.108 \mathrm{ft}$; however after PM-4 was shut down for the season in 2009 , the head difference declined. The well is $100 \%$ barometrically efficient; however, the aquifer shows a delayed response to atmospheric pressure fluctuations.

\begin{tabular}{|c|c|c|c|c|c|c|c|c|c|c|c|c|c|c|c|}
\hline \multicolumn{16}{|c|}{ R-45 Construction Information } \\
\hline Screen & $\begin{array}{c}\text { Screen } \\
\text { Top } \\
\text { Depth } \\
\text { (ft) }\end{array}$ & \begin{tabular}{|c|} 
Screen \\
Bottom \\
Depth \\
(ft)
\end{tabular} & \begin{tabular}{|c|} 
Screen \\
Top \\
Elev \\
(ft)
\end{tabular} & $\begin{array}{c}\text { Screen } \\
\text { Bottom } \\
\text { Elev } \\
\text { (ft) }\end{array}$ & $\begin{array}{c}\text { Screen } \\
\text { Length } \\
\text { (ft) }\end{array}$ & \begin{tabular}{|c|} 
APV \\
Intake \\
Depth \\
(ft)
\end{tabular} & \begin{tabular}{|c|} 
APV \\
Intake \\
Elev \\
(ft)
\end{tabular} & $\begin{array}{l}\text { Top of } \\
\text { Sump } \\
\text { Depth } \\
\text { (ft) }\end{array}$ & $\begin{array}{c}\text { Top of } \\
\text { Sump } \\
\text { Elev } \\
\text { (ft) }\end{array}$ & $\begin{array}{c}\text { Topl } \\
\text { Bottom } \\
\text { of } \\
\text { Packer } \\
\text { (ft) }\end{array}$ & $\mid \begin{array}{c}\text { Depth to } \\
\text { Sump } \\
\text { Bottom } \\
\text { (ft) }\end{array}$ & $\begin{array}{c}\text { Sump } \\
\text { Length } \\
\text { (ft) }\end{array}$ & $\begin{array}{c}\text { Sump } \\
\text { Volume } \\
\text { (L) }\end{array}$ & $\begin{array}{l}\text { Hydro } \\
\text { Zone } \\
\text { Code }\end{array}$ & $\begin{array}{l}\text { Geo } \\
\text { Unit } \\
\text { Code }\end{array}$ \\
\hline 1 & 880.0 & 890.0 & 5824.0 & $\overline{5814.0}$ & 10.0 & 905.5 & 5798.5 & 890.0 & 5814.0 & 921.3 & 921.26 & 31.26 & 120.7 & $\overline{\mathrm{RT}}$ & Tpf \\
\hline 2 & 974.9 & 994.9 & 5729.1 & 5709.1 & 20.0 & 973.2 & 5730.8 & 994.9 & 5709.1 & 926.0 & 1016.0 & 21.1 & 81.5 & $\mathrm{RD}$ & Tsfu \\
\hline
\end{tabular}

Note: Brass Cap Ground Elevation: $6704.02 \mathrm{ft}$; all measurements are from this elevation

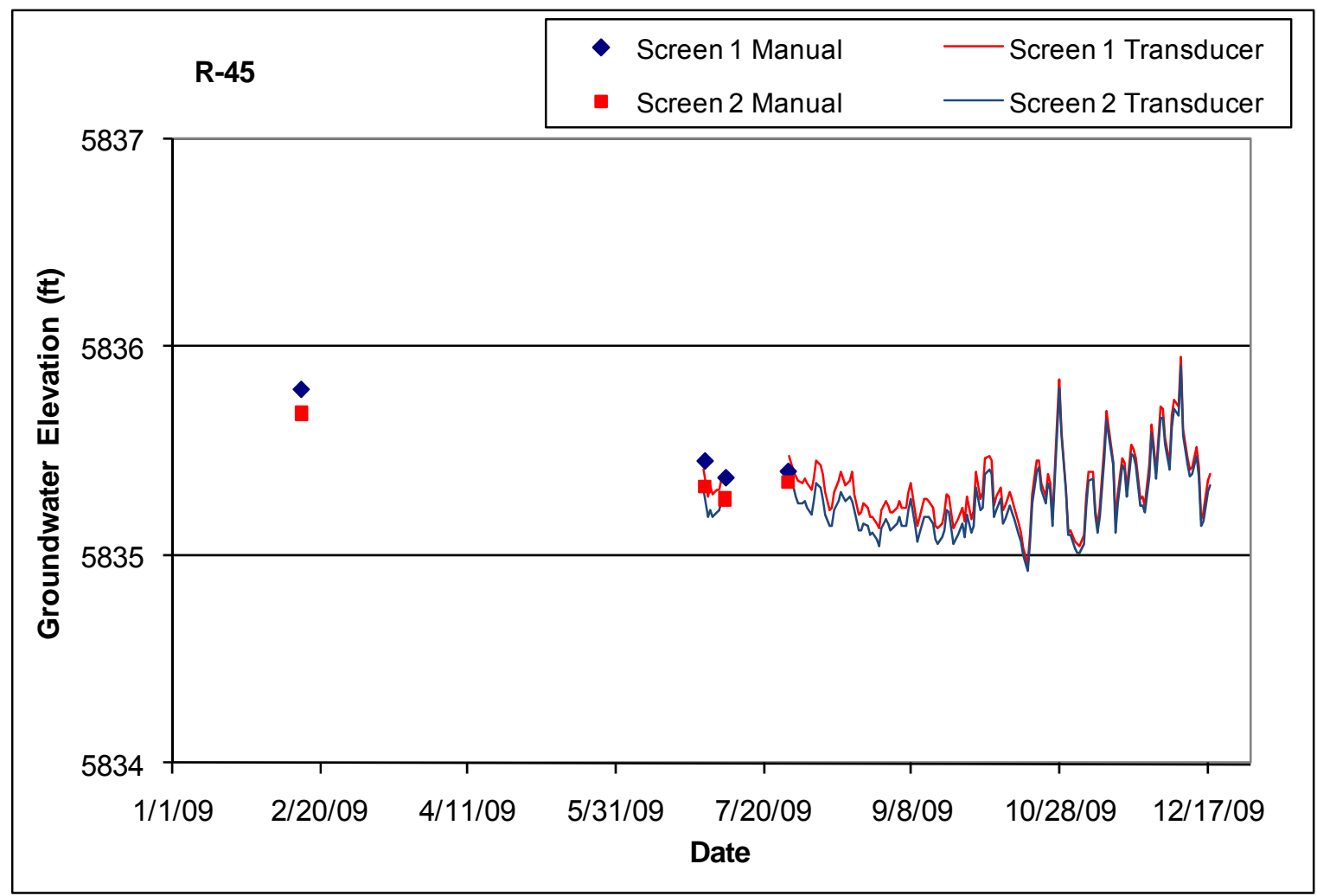




\subsection{R-46}

Location: R-46 is located on a mesa between Mortandad Canyon and Pajarito Canyon about $800 \mathrm{ft}$ east (downgradient) of MDA C and $4700 \mathrm{ft}$ west (upgradient) of supply well PM-5.

Completion Type: Single completion at the top of the regional aquifer. The screen is located about 12 $\mathrm{ft}$ below the water table.

Period of Record: Well completed February 2009, transducer installed June 6, 2009, groundwater level data through 2009.

Remarks: R-46 installed in the regional aquifer to a depth of $1382.2 \mathrm{ft}$. The well has a $90 \%$ barometric efficiency, indicating that the aquifer may have a small response to atmospheric pressure fluctuations.

\begin{tabular}{|c|c|c|c|c|c|c|c|c|c|c|c|c|c|c|}
\hline \multicolumn{15}{|c|}{ R-46 Construction Information } \\
\hline Screen & $\begin{array}{c}\text { Screen } \\
\text { Top } \\
\text { Depth } \\
\text { (ft) }\end{array}$ & $\begin{array}{c}\text { Screen } \\
\text { Bottom } \\
\text { Depth } \\
\text { (ft) }\end{array}$ & $\begin{array}{c}\text { Screen } \\
\text { Top } \\
\text { Elev (ft) }\end{array}$ & $\begin{array}{l}\text { Screen } \\
\text { Bottom } \\
\text { Elev (ft) }\end{array}$ & $\begin{array}{c}\text { Screen } \\
\text { Length } \\
\text { (ft) }\end{array}$ & $\begin{array}{c}\text { Pump } \\
\text { Intake } \\
\text { Depth } \\
\text { (ft) }\end{array}$ & $\begin{array}{c}\text { Pump } \\
\text { Intake } \\
\text { Elev } \\
\text { (ft) }\end{array}$ & $\begin{array}{c}\text { Depth to } \\
\text { Top of } \\
\text { Sump } \\
\text { (ft) }\end{array}$ & \begin{tabular}{|c|} 
Top of \\
Sump \\
Elev \\
(ft)
\end{tabular} & \begin{tabular}{|} 
Depth to \\
Sump \\
Bottom \\
(ft)
\end{tabular} & $\begin{array}{c}\text { Sump } \\
\text { Length } \\
\text { (ft) }\end{array}$ & $\begin{array}{c}\text { Sump } \\
\text { Volume } \\
\text { (L) }\end{array}$ & $\begin{array}{c}\text { Hydro } \\
\text { Zone } \\
\text { Code }\end{array}$ & $\begin{array}{l}\text { Geo } \\
\text { Unit } \\
\text { Code }\end{array}$ \\
\hline 1 & 1340.0 & $\overline{1360.7}$ & 5873.3 & 5852.6 & 20.7 & & & 1360.7 & 5852.6 & 1382.2 & 21.5 & 83.0 & $\overline{\mathrm{RT}}$ & Tpf \\
\hline
\end{tabular}

Note: Brass Cap Ground Elevation: $7213.33 \mathrm{ft}$; all measurements are from this elevation

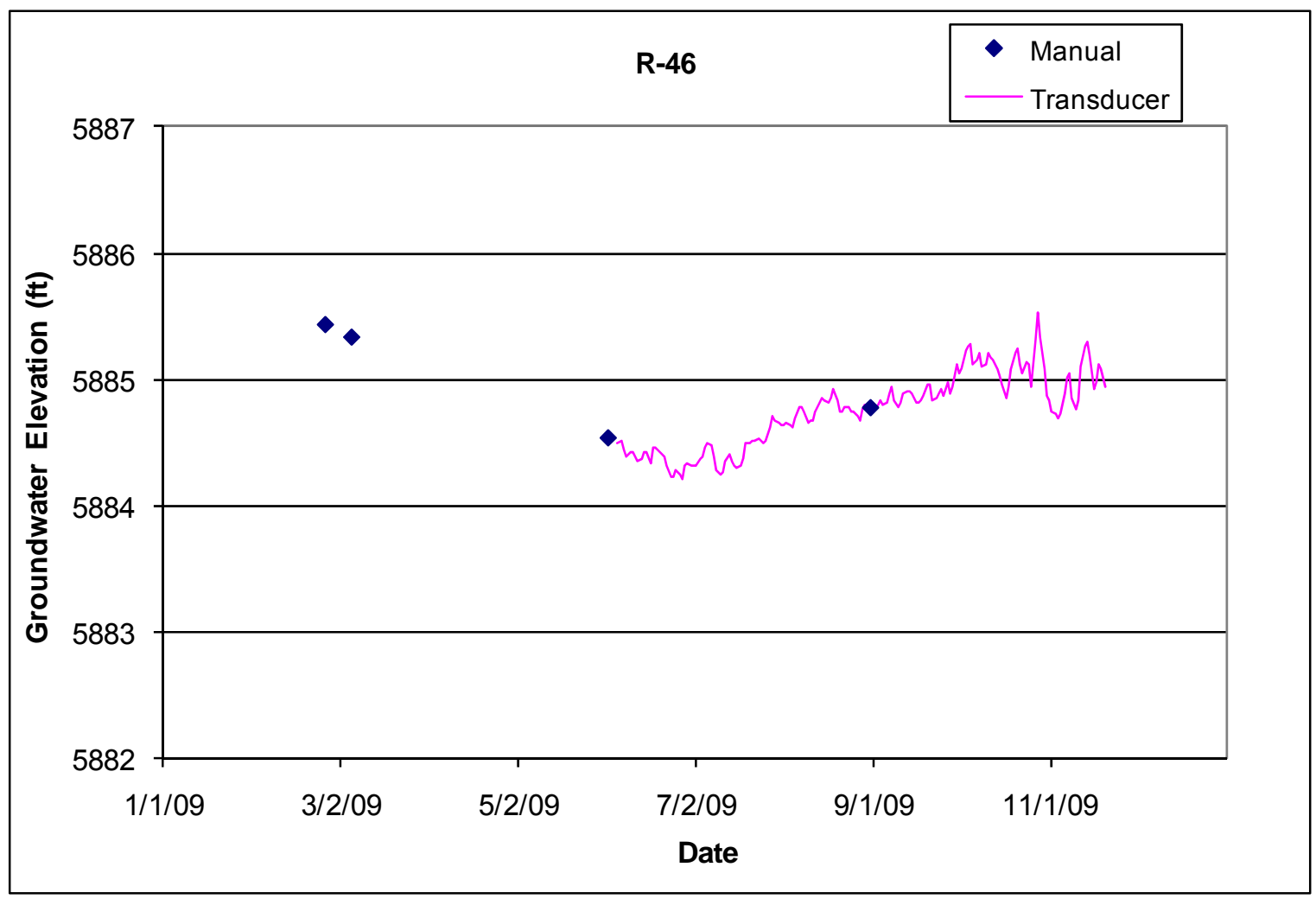




\subsection{R-48}

Location: R-48 is located at the east side of TA-16 about $1800 \mathrm{ft}$ south of R-25. R-48 was formerly borehole CdV-16-3i, which was deepened and completed in the regional aquifer.

Completion Type: Single completion at the top of the regional aquifer. The screen is located about $147 \mathrm{ft}$ below the water table in Tschicoma dacite.

Period of Record: Well completed September 2009, aquifer test conducted October 2009, transducer installed November 23, 2009, groundwater level data through 2009.

Remarks: R-48 installed in the regional aquifer to a depth of $1540 \mathrm{ft}$. The well is $100 \%$ barometrically efficient; the aquifer does not respond to atmospheric pressure fluctuations.

\begin{tabular}{|c|c|c|c|c|c|c|c|c|c|c|c|c|c|}
\hline \multicolumn{14}{|c|}{ R-48 Construction Information } \\
\hline Screen & $\begin{array}{c}\text { Screen } \\
\text { Top } \\
\text { Depth } \\
\text { (ft) }\end{array}$ & $\begin{array}{c}\text { Screen } \\
\text { Bottom } \\
\text { Depth } \\
\text { (ft) }\end{array}$ & $\begin{array}{c}\text { Screen } \\
\text { Top } \\
\text { Elev (ft) }\end{array}$ & $\begin{array}{l}\text { Screen } \\
\text { Bottom } \\
\text { Elev (ft) }\end{array}$ & $\begin{array}{c}\text { Screen } \\
\text { Length } \\
\text { (ft) }\end{array}$ & $\begin{array}{c}\text { Pump } \\
\text { Intake } \\
\text { Depth } \\
\text { (ft) }\end{array}$ & $\begin{array}{c}\text { Pump } \\
\text { Intake } \\
\text { Elev } \\
\text { (ft) }\end{array}$ & $\begin{array}{c}\text { Depth to } \\
\text { Top of } \\
\text { Sump } \\
\text { (ft) }\end{array}$ & $\begin{array}{c}\text { Top of } \\
\text { Sump } \\
\text { Elev } \\
\text { (ft) }\end{array}$ & \begin{tabular}{|} 
Depth to \\
Sump \\
Bottom \\
(ft)
\end{tabular} & $\begin{array}{c}\text { Sump } \\
\text { Length } \\
\text { (ft) }\end{array}$ & $\begin{array}{l}\text { Hydro } \\
\text { Zone } \\
\text { Code }\end{array}$ & $\begin{array}{c}\text { Geo } \\
\text { Unit } \\
\text { Code }\end{array}$ \\
\hline 1 & 1500.0 & 1520.6 & 5986.8 & 5966.2 & 20.6 & & & 1520.6 & 5966.2 & 1540 & 19.4 & RT & $\mathrm{Tt}$ \\
\hline
\end{tabular}

Note: Brass Cap Ground Elevation: $7486.78 \mathrm{ft}$; all measurements are from this elevation

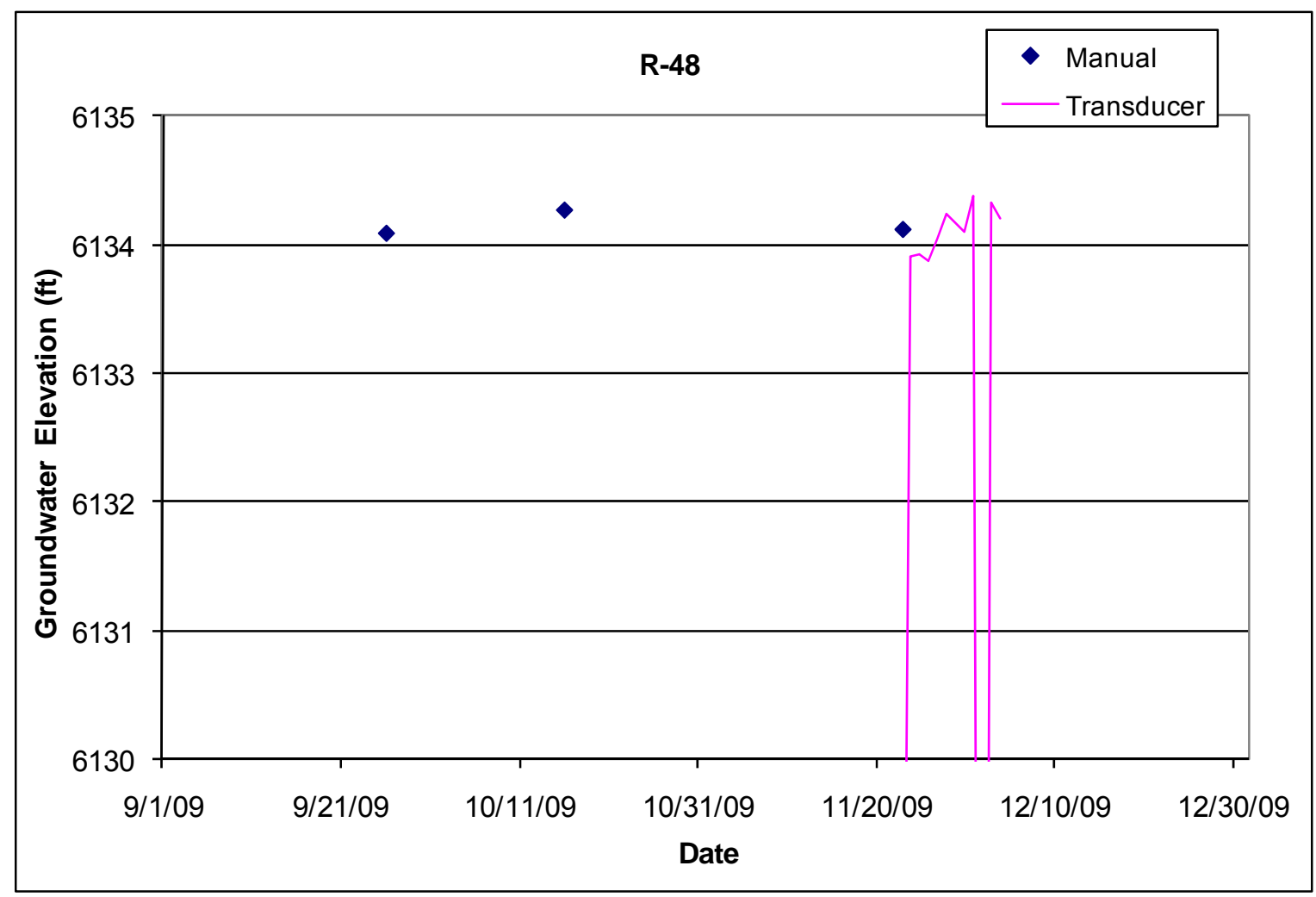




\subsection{R-49}

Location: R-49 is located in lower Pajarito Canyon south of TA-54 and MDA G and about $1100 \mathrm{ft}$ west of R-39.

Completion Type: Dual completion, two screens in the regional aquifer. The screens are $50 \mathrm{ft}$ apart. The upper screen is located in basalt about $35 \mathrm{ft}$ below the water table.

Period of Record: Well completed June 2009, transducers installed August 20, 2009, groundwater level data through 2009.

Remarks: R-49 installed in the regional aquifer to a depth of $949.3 \mathrm{ft}$. The well is $100 \%$ barometrically efficient; the aquifer does not respond to atmospheric pressure fluctuations; however, the groundwater shows a delayed response to atmospheric pressure fluctuations.

\begin{tabular}{|c|c|c|c|c|c|c|c|c|c|c|c|c|c|c|c|}
\hline \multicolumn{16}{|c|}{ R-49 Construction Information } \\
\hline Screen & $\begin{array}{c}\text { Screen } \\
\text { Top } \\
\text { Depth } \\
\text { (ft) }\end{array}$ & $\begin{array}{c}\text { Screen } \\
\text { Bottom } \\
\text { Depth } \\
\text { (ft) }\end{array}$ & $\begin{array}{c}\text { Screen } \\
\text { Top } \\
\text { Elev (ft) }\end{array}$ & $\begin{array}{l}\text { Screen } \\
\text { Bottom } \\
\text { Elev (ft) }\end{array}$ & $\begin{array}{c}\text { Screen } \\
\text { Length } \\
\text { (ft) }\end{array}$ & $\begin{array}{c}\text { APV } \\
\text { Intake } \\
\text { Depth } \\
\text { (ft) }\end{array}$ & $\begin{array}{c}\text { Pump } \\
\text { Intake } \\
\text { Elev } \\
\text { (ft) }\end{array}$ & \begin{tabular}{|c|} 
Depth \\
to Top \\
of \\
Packerl \\
Sump \\
(ft)
\end{tabular} & $\mid \begin{array}{c}\text { Top of } \\
\text { Packerl } \\
\text { Sump } \\
\text { Elev (ft) }\end{array}$ & \begin{tabular}{|} 
Bottom \\
of \\
Packer \\
(ft)
\end{tabular} & $\begin{array}{c}\text { Depth } \\
\text { to } \\
\text { Sump } \\
\text { Bottom } \\
\text { (ft) }\end{array}$ & $\begin{array}{c}\text { Sump } \\
\text { Length } \\
\text { (ft) }\end{array}$ & $\begin{array}{c}\text { Sump } \\
\text { Volume } \\
\text { (L) }\end{array}$ & \begin{tabular}{|c|} 
Hydro \\
Zone \\
Code
\end{tabular} & $\begin{array}{c}\text { Geo } \\
\text { Unit } \\
\text { Code }\end{array}$ \\
\hline 1 & 845.0 & 855.0 & 5739.5 & 5729.5 & 10.0 & 874.3 & 5710.3 & 887.6 & 5697.0 & N/A & 887.6 & 32.6 & 125.8 & RT & $\mathrm{Tb} 4$ \\
\hline 2 & 905.6 & 926.4 & 5678.9 & 5658.1 & 20.8 & 904.4 & 5680.1 & 926.4 & 5658.1 & 892.3 & 949.3 & 22.9 & 88.4 & RD & Tpt \\
\hline
\end{tabular}

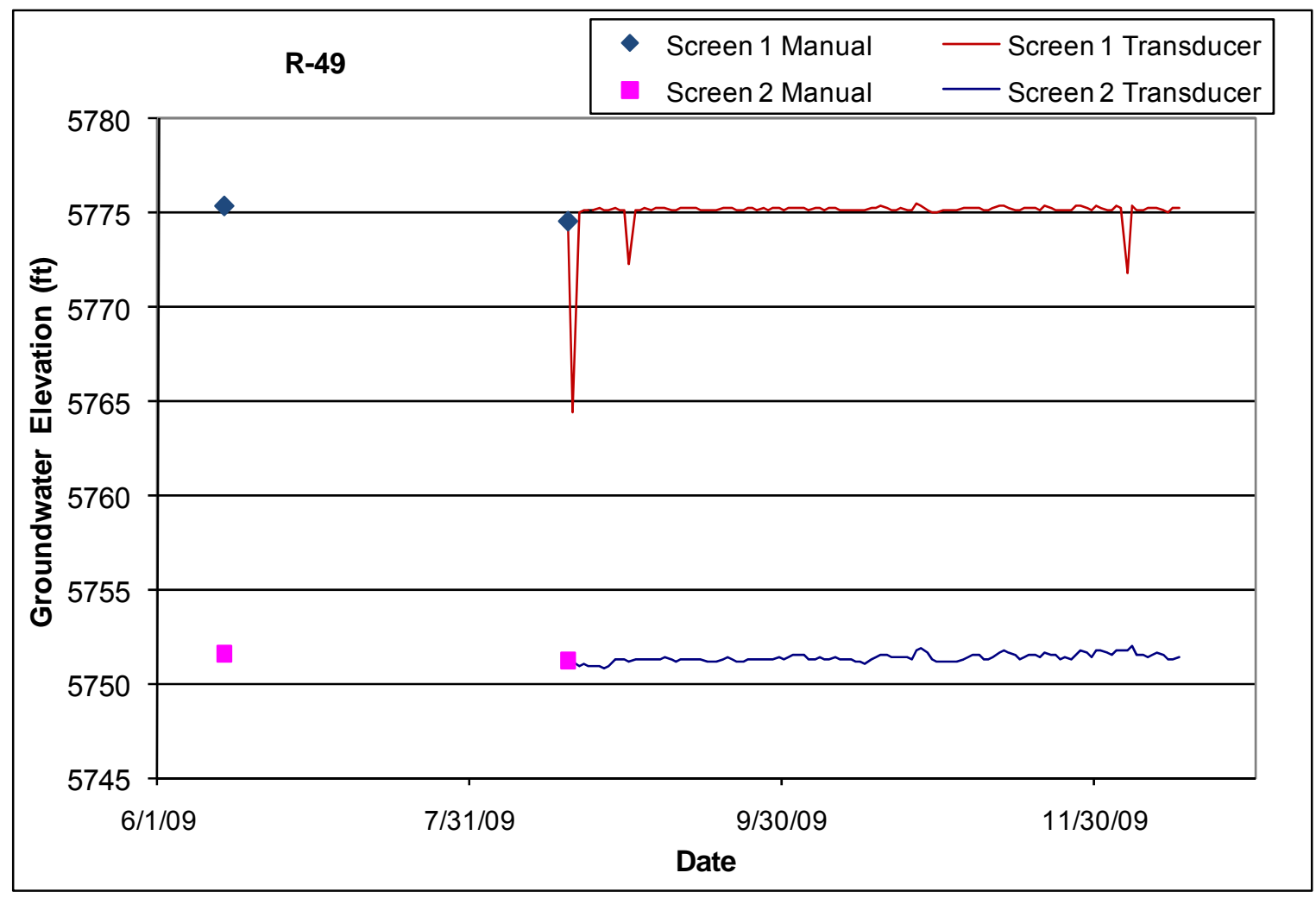




\subsection{Test Well 1}

Location: TW-1 is located in lower Pueblo Canyon downstream of supply well O-1.

Completion Type: Single completion within the regional aquifer. The top of the screen was about 120 $\mathrm{ft}$ below the water table in 2006.

Period of Record: Well completed January 1950, transducer installed January 23, 1992, intermittent water level data to February 6, 2006, when the transducer was removed for well plugging and abandonment.

Remarks: TW-1 installed in the regional aquifer at a depth of $642 \mathrm{ft}$, about $100 \mathrm{ft}$ into the regional aquifer. Water level in TW-1 is recharged locally by surface water from Pueblo Canyon (Koch and Rogers 2003) and does not correlate with the water level of surrounding regional aquifer wells.

\begin{tabular}{|c|c|c|c|c|c|c|c|c|c|c|c|c|c|c|}
\hline \multicolumn{15}{|c|}{ TW-1 Construction Information } \\
\hline Screen & $\begin{array}{l}\text { Screen } \\
\text { Top } \\
\text { Depth } \\
\text { (ft) }\end{array}$ & \begin{tabular}{|c|} 
Screen \\
Bottom \\
Depth \\
(ft)
\end{tabular} & $\begin{array}{c}\text { Screen } \\
\text { Top } \\
\text { Elev (ft) }\end{array}$ & $\begin{array}{l}\text { Screen } \\
\text { Bottom } \\
\text { Elev (ft) }\end{array}$ & $\begin{array}{c}\text { Screen } \\
\text { Length } \\
\text { (ft) }\end{array}$ & $\begin{array}{l}\text { Pump } \\
\text { Intake } \\
\text { Depth } \\
\text { (ft) }\end{array}$ & $\begin{array}{c}\text { Pump } \\
\text { Intake } \\
\text { Elev } \\
\text { (ft) }\end{array}$ & $\begin{array}{l}\text { Depth to } \\
\text { Top of } \\
\text { Sump } \\
\text { (ft) }\end{array}$ & $\begin{array}{c}\text { Top of } \\
\text { Sump } \\
\text { Elev } \\
\text { (ft) }\end{array}$ & $\begin{array}{l}\text { Depth to } \\
\text { Sump } \\
\text { Bottom } \\
\text { (ft) }\end{array}$ & $\begin{array}{c}\text { Sump } \\
\text { Length } \\
\text { (ft) }\end{array}$ & $\begin{array}{l}\text { Sump } \\
\text { Volume } \\
\text { (L) }\end{array}$ & $\begin{array}{l}\text { Hydro } \\
\text { Zone } \\
\text { Code }\end{array}$ & $\begin{array}{l}\text { Geo } \\
\text { Unit } \\
\text { Code }\end{array}$ \\
\hline 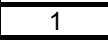 & 632.0 & 642 & 5737.2 & 5727.2 & 10.0 & & & 642.0 & 5727.2 & 642 & 0.0 & $\overline{0.0}$ & RT & Tpt \\
\hline
\end{tabular}

Note: TW-1 Ground Elevation: $6369.19 \mathrm{ft}$; all measurements are from this elevation

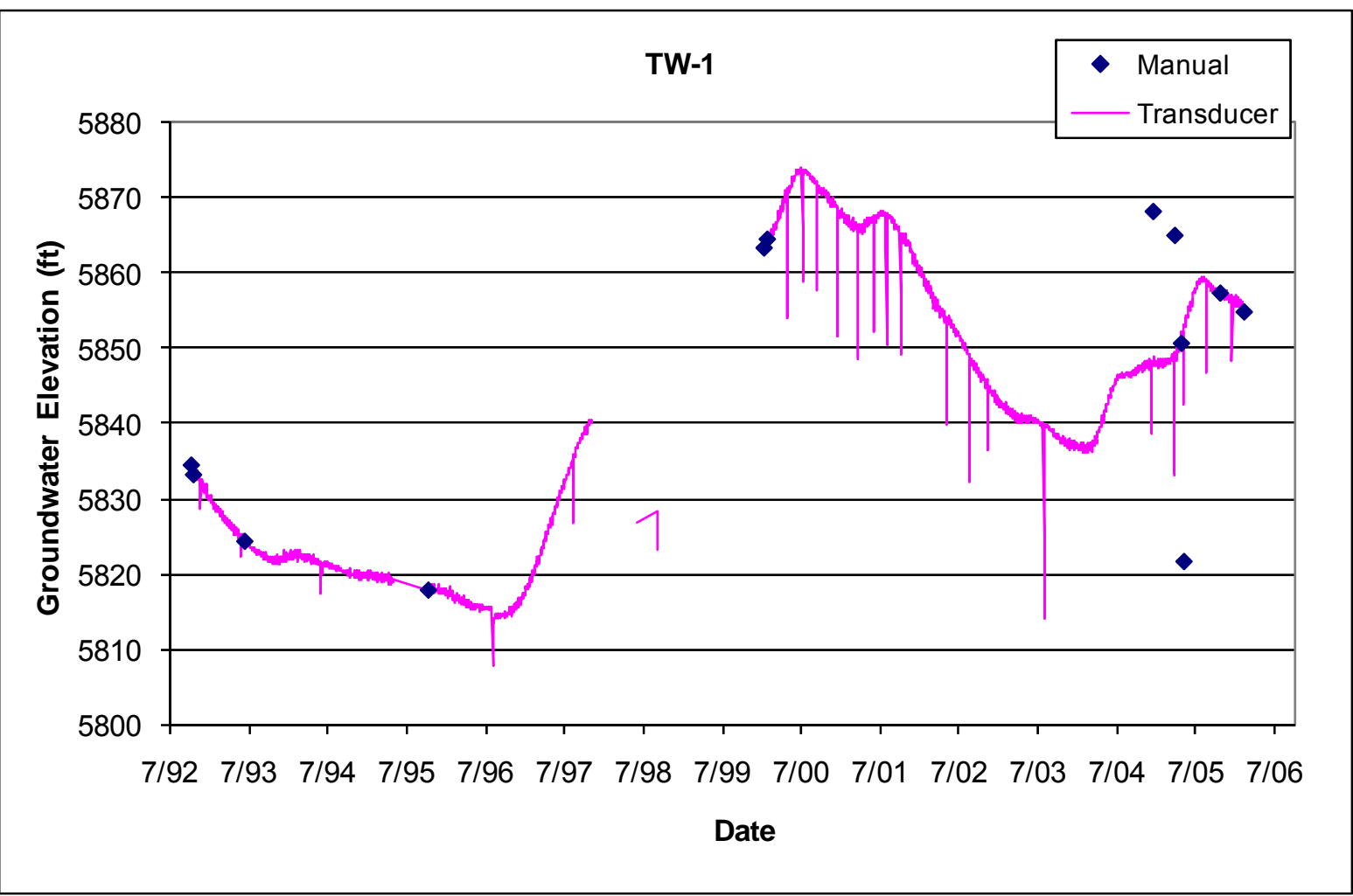




\subsection{Test Well 2}

Location: TW-2 is located in middle Pueblo Canyon.

Completion Type: Single completion at the top of the regional aquifer.

Period of Record: Well originally drilled in 1949, recompleted in 1990. Transducer installed June 1993; data to January 1996. Transducer reinstalled January 2000; transducer data to March 2005.

Remarks: TW-2 is completed at the top of the regional aquifer at a depth of $834 \mathrm{ft}$, about $35 \mathrm{ft}$ into the regional aquifer. The transducer failed in November 2000, transducer data since then are questionable. A manual measurement attempt in March 2005 resulted in the measurement tape stuck in the well. Thus, transducer water level data since November 2000 are not valid with respect to elevation, but are shown for reference and character information only. TW- 2 is scheduled to be plugged and abandoned in 2010.

\begin{tabular}{|c|c|c|c|c|c|c|c|c|c|c|c|c|c|c|}
\hline \multicolumn{15}{|c|}{ TW-2 Construction Information } \\
\hline Screen & $\begin{array}{c}\text { Screen } \\
\text { Top } \\
\text { Depth } \\
\text { (ft) }\end{array}$ & $\begin{array}{c}\text { Screen } \\
\text { Bottom } \\
\text { Depth } \\
\text { (ft) }\end{array}$ & $\begin{array}{l}\text { Screen } \\
\text { Top } \\
\text { Elev (ft) }\end{array}$ & $\begin{array}{l}\text { Screen } \\
\text { Bottom } \\
\text { Elev (ft) }\end{array}$ & $\begin{array}{c}\text { Screen } \\
\text { Length } \\
\text { (ft) }\end{array}$ & $\begin{array}{c}\text { Pump } \\
\text { Intake } \\
\text { Depth } \\
\text { (ft) }\end{array}$ & $\begin{array}{c}\text { Pump } \\
\text { Intake } \\
\text { Elev } \\
\text { (ft) }\end{array}$ & \begin{tabular}{|} 
Depth to \\
Top of \\
Sump \\
(ft)
\end{tabular} & $\begin{array}{c}\text { Top of } \\
\text { Sump } \\
\text { Elev } \\
\text { (ft) }\end{array}$ & \begin{tabular}{|} 
Depth to \\
Sump \\
Bottom \\
(ft)
\end{tabular} & $\begin{array}{c}\text { Sump } \\
\text { Length } \\
\text { (ft) }\end{array}$ & $\begin{array}{l}\text { Sump } \\
\text { Volume } \\
\text { (L) }\end{array}$ & $\begin{array}{c}\text { Hydro } \\
\text { Zone } \\
\text { Code }\end{array}$ & $\begin{array}{l}\text { Geo } \\
\text { Unit } \\
\text { Code }\end{array}$ \\
\hline 1 & 768.0 & 824 & 5880.1 & 5824.1 & 56.0 & & & 824.0 & $\overline{5824.1}$ & 834 & 10.0 & 55.6 & RT & Tpt \\
\hline
\end{tabular}

Note: Test Well 2 Ground Elevation: $6648.06 \mathrm{ft}$; all measurements are from this elevation

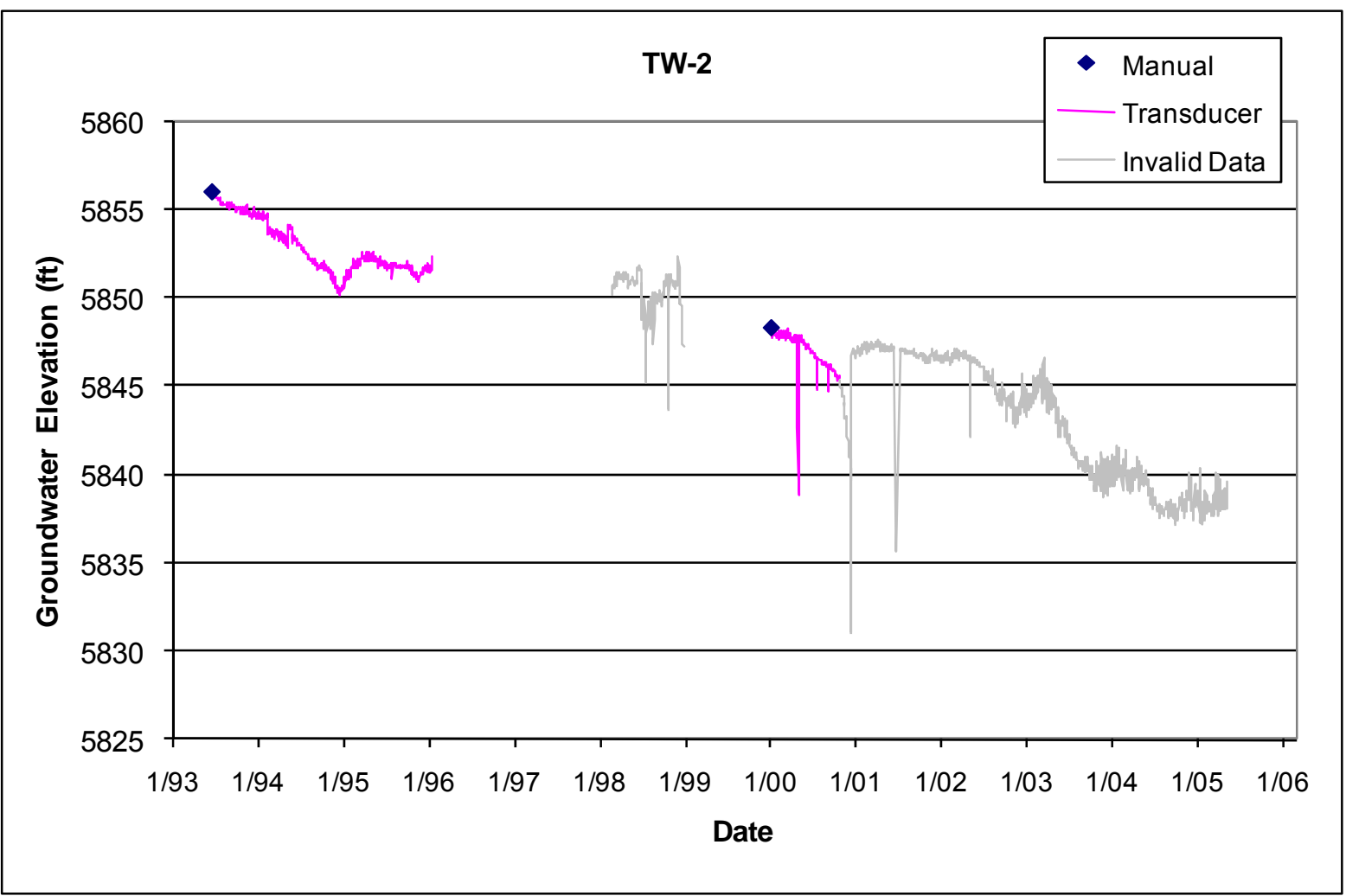




\subsection{Test Well 3}

Location: TW-3 is located in middle Los Alamos Canyon at the confluence with DP Canyon.

Completion Type: Single completion at the top of the regional aquifer.

Period of Record: Well drilled in 1949, transducer installed November 1992, intermittent data to February 2006.

Remarks: TW-3 completed at the top of the regional aquifer at a depth of $815 \mathrm{ft}$, about $30 \mathrm{ft}$ into the regional aquifer. Transducer removed February 9, 2006, in preparation for well plugging and abandonment. The well was re-opened and sampled in July 2009 and January 2010.

\begin{tabular}{|c|c|c|c|c|c|c|c|c|c|c|c|c|c|c|}
\hline \multicolumn{15}{|c|}{ TW-3 Construction Information } \\
\hline Screen & $\begin{array}{l}\text { Screen } \\
\text { Top } \\
\text { Depth } \\
\text { (ft) }\end{array}$ & \begin{tabular}{|c|} 
Screen \\
Bottom \\
Depth \\
(ft)
\end{tabular} & $\begin{array}{l}\text { Screen } \\
\text { Top } \\
\text { Elev (ft) }\end{array}$ & $\begin{array}{l}\text { Screen } \\
\text { Bottom } \\
\text { Elev (ft) }\end{array}$ & $\begin{array}{c}\text { Screen } \\
\text { Length } \\
\text { (ft) }\end{array}$ & $\begin{array}{l}\text { Pump } \\
\text { Intake } \\
\text { Depth } \\
\text { (ft) }\end{array}$ & $\begin{array}{c}\text { Pump } \\
\text { Intake } \\
\text { Elev } \\
\text { (ft) }\end{array}$ & $\begin{array}{l}\text { Depth to } \\
\text { Top of } \\
\text { Sump } \\
\text { (ft) }\end{array}$ & $\begin{array}{c}\text { Top of } \\
\text { Sump } \\
\text { Elev } \\
\text { (ft) }\end{array}$ & $\begin{array}{l}\text { Depth to } \\
\text { Sump } \\
\text { Bottom } \\
\text { (ft) }\end{array}$ & $\begin{array}{c}\text { Sump } \\
\text { Length } \\
\text { (ft) }\end{array}$ & $\begin{array}{c}\text { Sump } \\
\text { Volume } \\
\text { (L) }\end{array}$ & $\begin{array}{c}\text { Hydro } \\
\text { Zone } \\
\text { Code }\end{array}$ & $\begin{array}{l}\text { Geo } \\
\text { Unit } \\
\text { Code }\end{array}$ \\
\hline 1 & 805.0 & 815.0 & $\overline{5821.9}$ & 5811.9 & 10.0 & & & 815.0 & 5811.9 & 815.0 & 0.0 & 0.0 & RT & Tpt \\
\hline
\end{tabular}

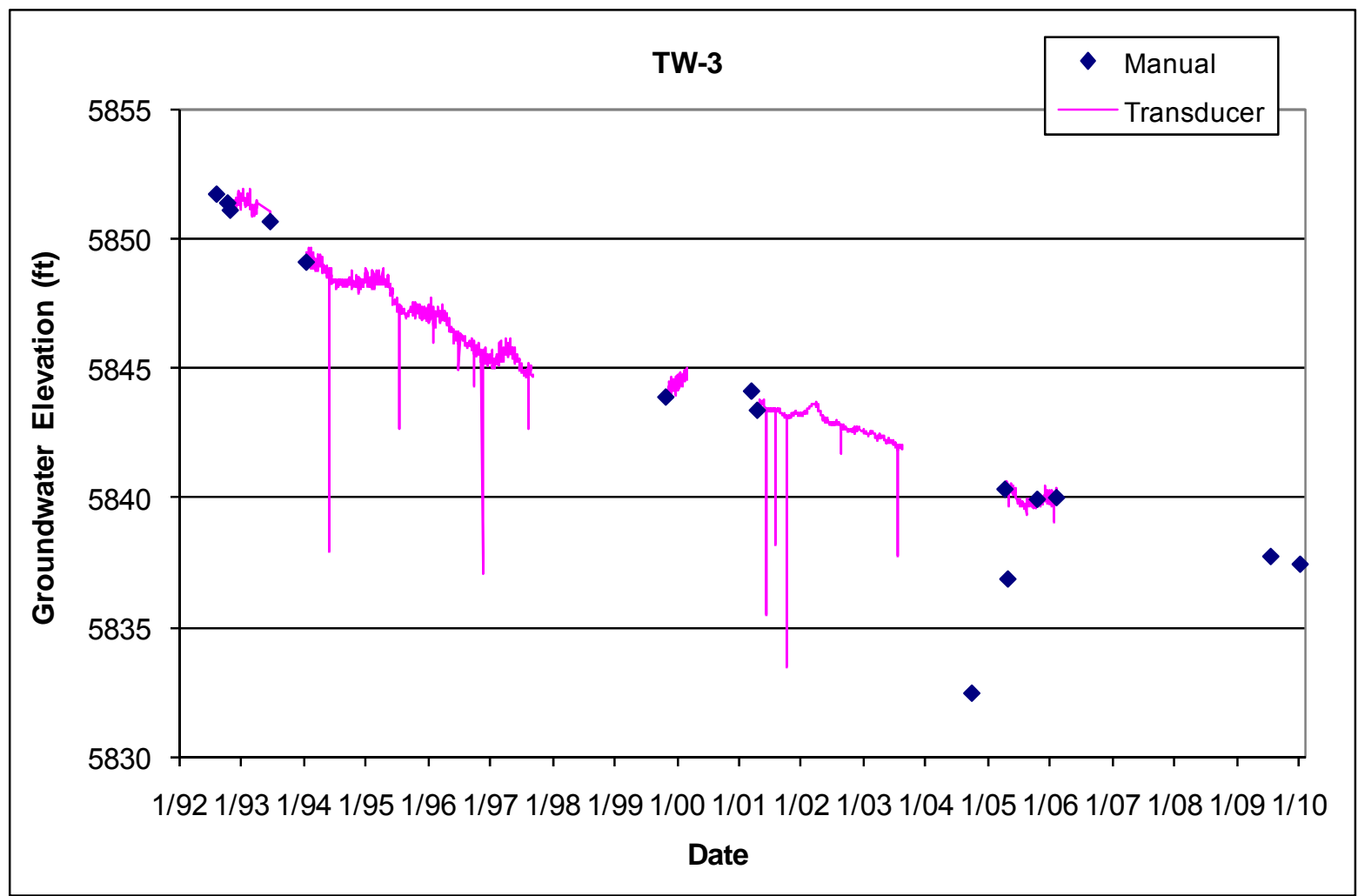




\subsection{Test Well 4}

Location: TW-4 is located in upper Pueblo Canyon east of Acid Canyon.

Completion Type: Single completion at the top of the regional aquifer.

Period of Record: Well drilled in 1950, transducer installed June 1993 but problems occurred with the transducer. Transducer reinstalled July 1997, intermittent data to February 8, 2006.

Remarks: Completed at the top of the regional aquifer to a depth of $1205 \mathrm{ft}$, about $30 \mathrm{ft}$ into the regional aquifer. Transducer removed February 8, 2006, in preparation for well plugging and abandonment.

\begin{tabular}{|c|c|c|c|c|c|c|c|c|c|c|c|c|c|c|}
\hline \multicolumn{15}{|c|}{ TW-4 Construction Information } \\
\hline Screen & $\begin{array}{c}\text { Screen } \\
\text { Top } \\
\text { Depth } \\
\text { (ft) }\end{array}$ & \begin{tabular}{|c|} 
Screen \\
Bottom \\
Depth \\
(ft)
\end{tabular} & \begin{tabular}{|c|} 
Screen \\
Top \\
Elev \\
(ft)
\end{tabular} & $\begin{array}{l}\text { Screen } \\
\text { Bottom } \\
\text { Elev (ft) }\end{array}$ & $\begin{array}{c}\text { Screen } \\
\text { Length } \\
\text { (ft) }\end{array}$ & $\begin{array}{l}\text { Pump } \\
\text { Intake } \\
\text { Depth } \\
\text { (ft) }\end{array}$ & $\begin{array}{l}\text { Pump } \\
\text { Intake } \\
\text { Elev (ft) }\end{array}$ & $\begin{array}{l}\text { Depth to } \\
\text { Top of } \\
\text { Sump } \\
\text { (ft) }\end{array}$ & \begin{tabular}{|c|} 
Top of \\
Sump \\
Elev \\
(ft)
\end{tabular} & $\begin{array}{l}\text { Depth to } \\
\text { Sump } \\
\text { Bottom } \\
\text { (ft) }\end{array}$ & $\begin{array}{c}\text { Sump } \\
\text { Length } \\
\text { (ft) }\end{array}$ & $\begin{array}{c}\text { Sump } \\
\text { Volume } \\
\text { (L) }\end{array}$ & $\begin{array}{c}\text { Hydro } \\
\text { Zone } \\
\text { Code }\end{array}$ & $\begin{array}{l}\text { Geo } \\
\text { Unit } \\
\text { Code }\end{array}$ \\
\hline 1 & 1195.0 & 1205 & 6049.6 & 6039.6 & 10.0 & & & 1205.0 & 6039.6 & 1205.0 & 0.0 & 0.0 & RT & $\overline{\mathrm{Tt}}$ \\
\hline
\end{tabular}

Note: TW-4 Ground Elevation: $7244.56 \mathrm{ft}$; all measurements are from this elevation

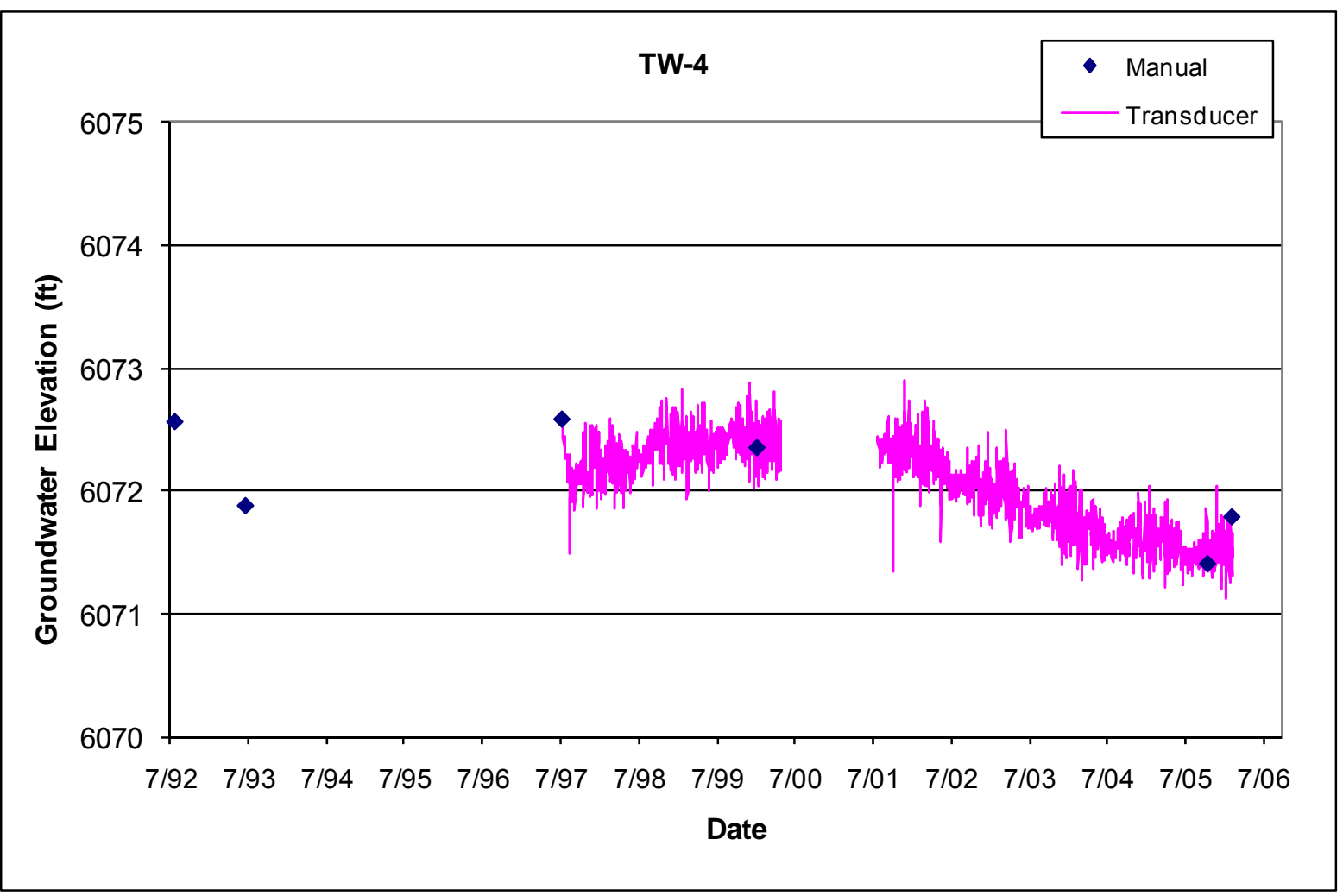




\subsection{Test Well 8}

Location: TW-8 was located in middle Mortandad Canyon about $220 \mathrm{ft}$ east of R-1, which was drilled to replace TW-8.

Completion Type: Single completion at the top of the regional aquifer. The screen straddled the water table.

Period of Record: Well drilled in 1960, transducer installed June 1993, transducer data to March 1997. Transducer reinstalled January 2000; intermittent data to June 19, 2008, when the transducer was removed. Several manual measurements were obtained in June and July 2009 during preparations for plugging and abandonment.

Remarks: TW-8 was completed at the top of the regional aquifer at a depth of $1065 \mathrm{ft}$, about $70 \mathrm{ft}$ into the regional aquifer. The well was nearly $100 \%$ barometrically efficient; the aquifer had no response to atmospheric pressure fluctuations. The aquifer indicated a seasonal response to supply well pumping and primarily responded to pumping PM-5 and possibly to pumping PM4. The well was plugged and abandoned on August 13, 2009.

\begin{tabular}{|c|c|c|c|c|c|c|c|c|c|c|c|c|c|c|}
\hline \multicolumn{15}{|c|}{ TW-8 Construction Information } \\
\hline Screen & $\begin{array}{l}\text { Screen } \\
\text { Top } \\
\text { Depth } \\
\text { (ft) }\end{array}$ & $\begin{array}{c}\text { Screen } \\
\text { Bottom } \\
\text { Depth } \\
\text { (ft) }\end{array}$ & $\begin{array}{l}\text { Screen } \\
\text { Top } \\
\text { Elev (ft) }\end{array}$ & $\begin{array}{l}\text { Screen } \\
\text { Bottom } \\
\text { Elev (ft) }\end{array}$ & $\begin{array}{c}\text { Screen } \\
\text { Length } \\
\text { (ft) }\end{array}$ & $\begin{array}{c}\text { Pump } \\
\text { Intake } \\
\text { Depth } \\
\text { (ft) }\end{array}$ & $\begin{array}{c}\text { Pump } \\
\text { Intake } \\
\text { Elev } \\
\text { (ft) }\end{array}$ & $\begin{array}{c}\text { Depth to } \\
\text { Top of } \\
\text { Sump (ft) }\end{array}$ & $\begin{array}{c}\text { Top of } \\
\text { Sump } \\
\text { Elev } \\
\text { (ft) }\end{array}$ & $\begin{array}{l}\text { Depth to } \\
\text { Sump } \\
\text { Bottom } \\
\text { (ft) }\end{array}$ & $\begin{array}{c}\text { Sump } \\
\text { Length } \\
\text { (ft) }\end{array}$ & $\begin{array}{c}\text { Sump } \\
\text { Volume } \\
\text { (L) }\end{array}$ & $\begin{array}{l}\text { Hydro } \\
\text { Zone } \\
\text { Code }\end{array}$ & \begin{tabular}{|c|} 
Geo \\
Unit \\
Code
\end{tabular} \\
\hline 1 & 953.0 & 1065 & 5920.5 & 5808.5 & 112.0 & & & 1065.0 & 5808.5 & 1065.0 & 0.0 & 0.0 & RT & Tpf \\
\hline
\end{tabular}

Note: Ground Elevation $6873.5 \mathrm{ft}$; all measurements are from this elevation

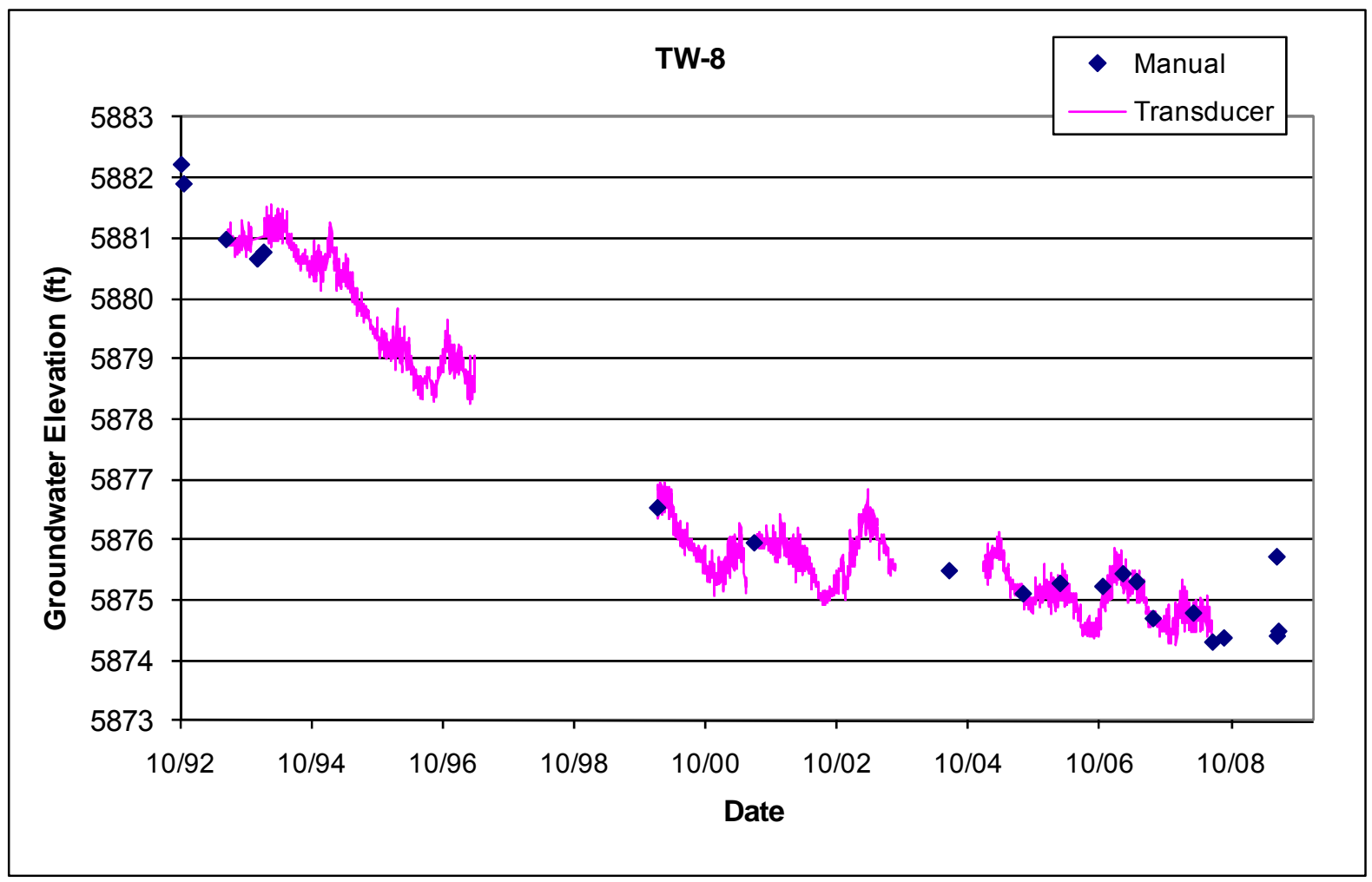




\subsection{Test Well DT-5A}

Location: DT-5A is located at TA-49 near the southern boundary of LANL.

Completion Type: Single completion at the top of the regional aquifer. The screen straddles the water table.

Period of Record: Well drilled in 1960, transducer installed June 1993, data to September 1996.

Transducer reinstalled January 2000 but equipment problems occurred. Transducer reinstalled April 2001; data through 2009.

Remarks: DT-5A completed at the top of the regional aquifer at a depth of $1819.5 \mathrm{ft}$, about $650 \mathrm{ft}$ into the regional aquifer. The long screen encompasses Tb4 basalt and Tp fanglomerates. The well is $100 \%$ barometrically efficient; the aquifer does not respond immediately to atmospheric pressure fluctuations but shows a delayed response. The long-term water level shows a decline of about $0.2 \mathrm{ft} / \mathrm{yr}$, likely in response to supply well pumping.

\begin{tabular}{|c|c|c|c|c|c|c|c|c|c|c|c|c|c|c|}
\hline \multicolumn{15}{|c|}{ Test Well DT-5A Construction Information } \\
\hline Screen & $\begin{array}{c}\text { Screen } \\
\text { Top } \\
\text { Depth } \\
\text { (ft) }\end{array}$ & $\begin{array}{c}\text { Screen } \\
\text { Bottom } \\
\text { Depth } \\
\text { (ft) }\end{array}$ & $\begin{array}{c}\text { Screen } \\
\text { Top } \\
\text { Elev (ft) }\end{array}$ & $\begin{array}{l}\text { Screen } \\
\text { Bottom } \\
\text { Elev (ft) }\end{array}$ & \begin{tabular}{|c} 
Screen \\
Length \\
(ft)
\end{tabular} & $\begin{array}{l}\text { Pump } \\
\text { Intake } \\
\text { Depth } \\
\text { (ft) }\end{array}$ & $\begin{array}{c}\text { Pump } \\
\text { Intake } \\
\text { Elev } \\
\text { (ft) }\end{array}$ & $\begin{array}{c}\text { Depth to } \\
\text { Top of } \\
\text { Sump } \\
\text { (ft) }\end{array}$ & \begin{tabular}{|c|} 
Top of \\
Sump \\
Elev \\
(ft)
\end{tabular} & $\begin{array}{c}\text { Depth to } \\
\text { Sump } \\
\text { Bottom } \\
\text { (ft) }\end{array}$ & $\begin{array}{c}\text { Sump } \\
\text { Length } \\
\text { (ft) }\end{array}$ & $\begin{array}{c}\text { Sump } \\
\text { Volume } \\
\text { (L) }\end{array}$ & $\begin{array}{c}\text { Hydro } \\
\text { Zone } \\
\text { Code }\end{array}$ & $\begin{array}{l}\text { Geo } \\
\text { Unit } \\
\text { Code }\end{array}$ \\
\hline 1 & 1171.5 & 1788.5 & 5972.4 & 5355.4 & 617.0 & & & 1788.5 & 5355.4 & 1819.5 & 31.0 & 306.4 & $\overline{\mathrm{RT}}$ & $\mathrm{Tb} 4$ \\
\hline
\end{tabular}

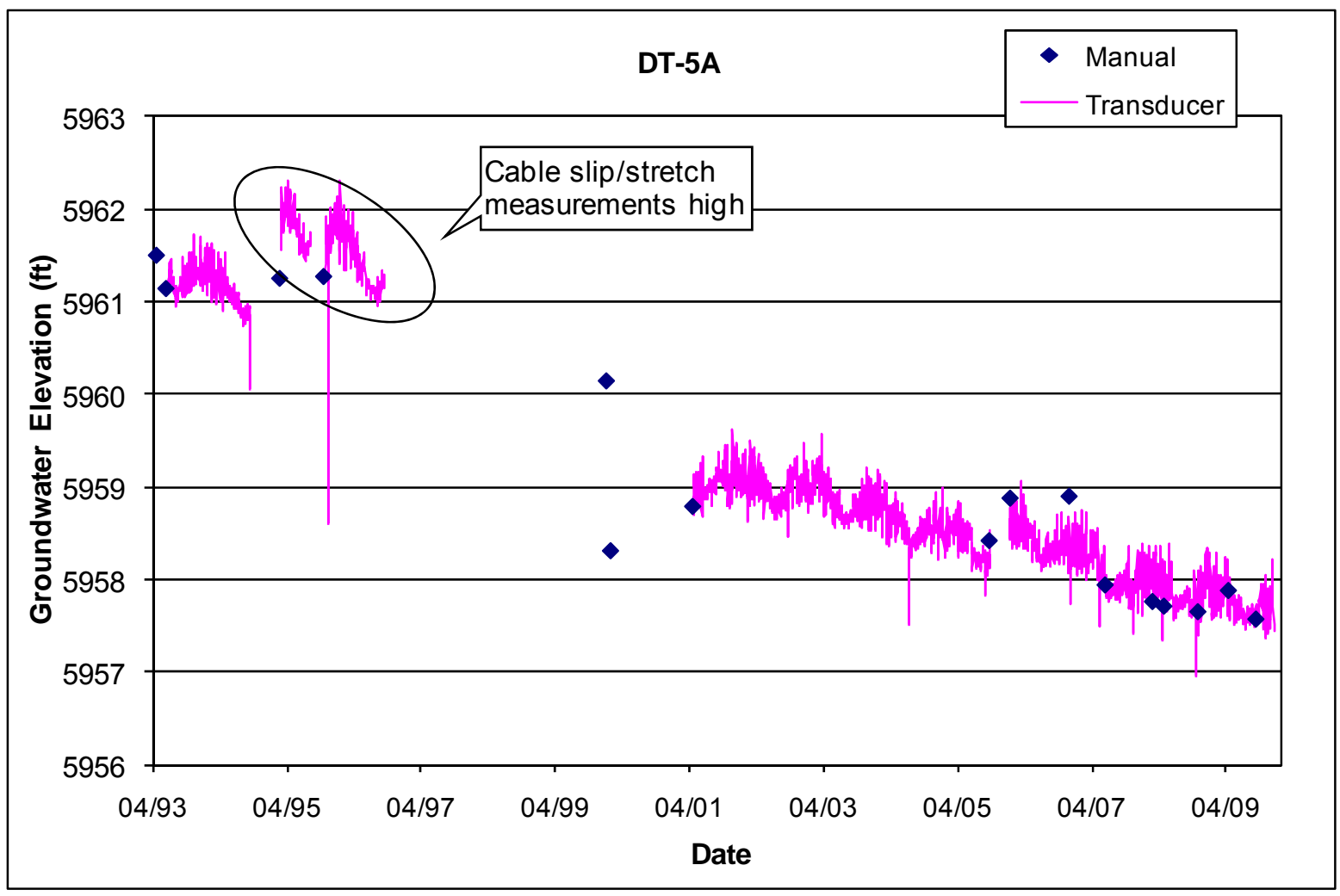




\subsection{Test Well DT-9}

Location: DT-9 is located at TA-49 near the southern LANL boundary.

Completion Type: Single completion at the top of the regional aquifer. The screen straddles the water table.

Period of Record: Well drilled in 1960, transducer installed November 1992, intermittent data to July 2002. Transducer reinstalled June 2005, data through 2009.

Remarks: DT-9 completed at the top of the regional aquifer at a depth of $1501 \mathrm{ft}$, about $500 \mathrm{ft}$ into the regional aquifer. The long screen encompasses Tb4 basalt and Tp fanglomerates. The well is $100 \%$ barometrically efficient; the aquifer does not respond immediately to atmospheric pressure fluctuations but shows a delayed response. The aquifer shows a long-term decline of about $0.35 \mathrm{ft} / \mathrm{yr}$, likely associated with supply well pumping.

\begin{tabular}{|c|c|c|c|c|c|c|c|c|c|c|c|c|c|c|}
\hline \multicolumn{15}{|c|}{ Test Well DT-9 Construction Information } \\
\hline Screen & $\begin{array}{c}\text { Screen } \\
\text { Top } \\
\text { Depth } \\
\text { (ft) }\end{array}$ & $\begin{array}{c}\text { Screen } \\
\text { Bottom } \\
\text { Depth } \\
\text { (ft) }\end{array}$ & $\begin{array}{c}\text { Screen } \\
\text { Top } \\
\text { Elev (ft) }\end{array}$ & $\begin{array}{l}\text { Screen } \\
\text { Bottom } \\
\text { Elev (ft) }\end{array}$ & $\begin{array}{c}\text { Screen } \\
\text { Length } \\
\text { (ft) }\end{array}$ & $\begin{array}{l}\text { Pump } \\
\text { Intake } \\
\text { Depth } \\
\text { (ft) }\end{array}$ & $\begin{array}{c}\text { Pump } \\
\text { Intake } \\
\text { Elev } \\
\text { (ft) }\end{array}$ & $\begin{array}{l}\text { Depth to } \\
\text { Top of } \\
\text { Sump } \\
\text { (ft) }\end{array}$ & $\begin{array}{c}\text { Top of } \\
\text { Sump } \\
\text { Elev } \\
\text { (ft) }\end{array}$ & \begin{tabular}{|} 
Depth to \\
Sump \\
Bottom \\
(ft)
\end{tabular} & $\begin{array}{c}\text { Sump } \\
\text { Length } \\
\text { (ft) }\end{array}$ & $\begin{array}{c}\text { Sump } \\
\text { Volume } \\
\text { (L) }\end{array}$ & $\begin{array}{l}\text { Hydro } \\
\text { Zone } \\
\text { Code }\end{array}$ & $\begin{array}{l}\text { Geo } \\
\text { Unit } \\
\text { Code }\end{array}$ \\
\hline 1 & 819.0 & 1500.0 & 6116.0 & 5435.0 & 681.0 & & & 1500.0 & 5435.0 & 1500.0 & 0.0 & 0.0 & RT & $\mathrm{Tb} 4$ \\
\hline
\end{tabular}

Note: Brass Cap Elevation $6935.0 \mathrm{ft}$; all measurements are from this elevation

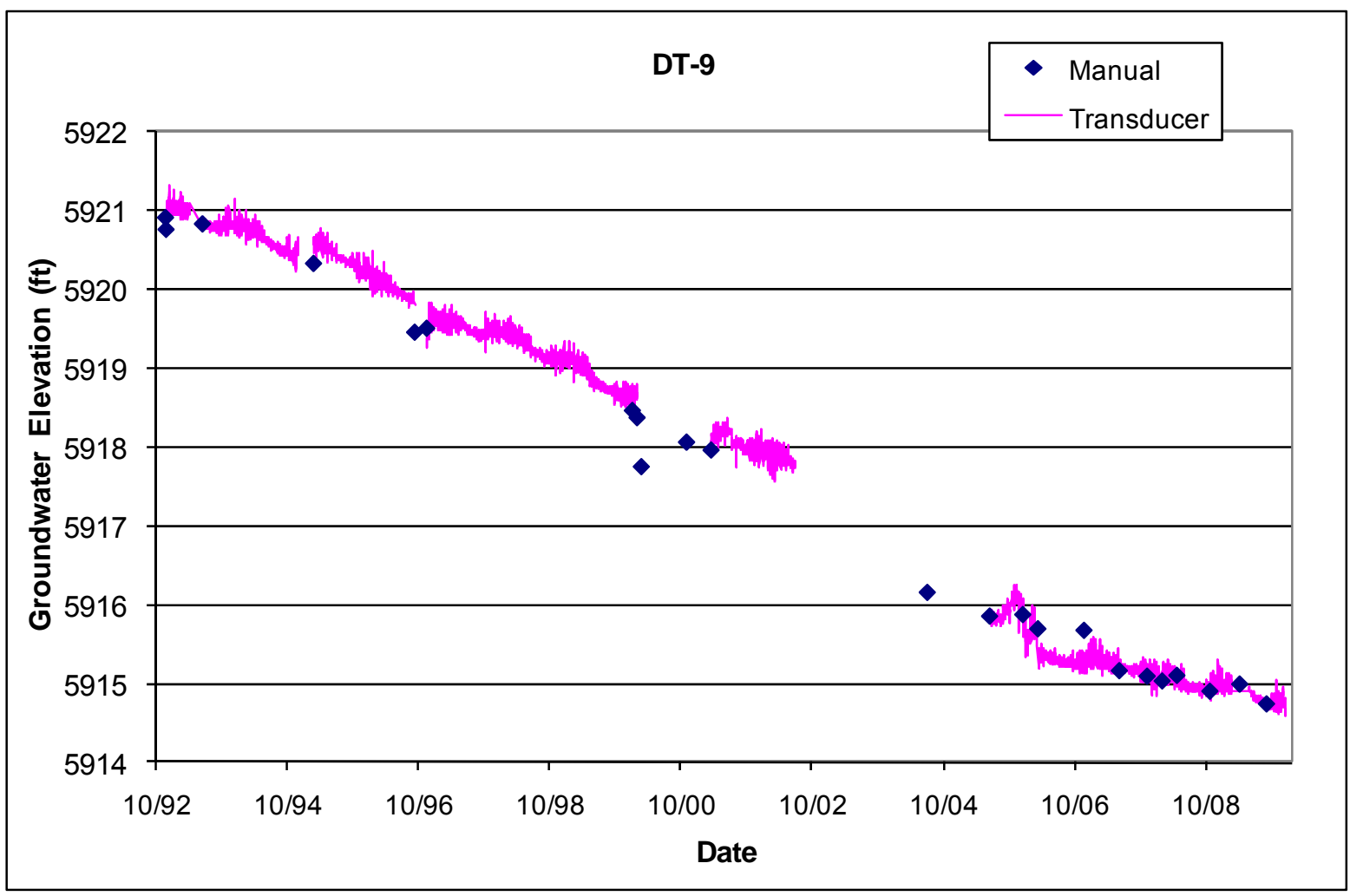




\subsection{Test Well DT-10}

Location: DT-10 is located at TA-49 near the southern LANL boundary.

Completion Type: Single completion at the top of the regional aquifer. The screen straddles the water table.

Period of Record: Well drilled in 1960, transducer installed June 1993 and again in November 1996 and June 2005. Transducer equipment failed June 2006, new transducer installed January 2007; data through 2009.

Remarks: DT-10 completed at the top of the regional aquifer at a depth of $1408 \mathrm{ft}$, about $300 \mathrm{ft}$ into the regional aquifer. The long screen encompasses Tb4 basalt and Tp fanglomerates. The well is about $70 \%$ barometrically efficient; the aquifer shows a $30 \%$ response to atmospheric pressure fluctuations. The aquifer exhibits a long-term water level decline of about $0.32 \mathrm{ft} / \mathrm{yr}$, likely associated with supply well pumping.

\begin{tabular}{|c|c|c|c|c|c|c|c|c|c|c|c|c|c|c|}
\hline \multicolumn{15}{|c|}{ Test Well DT-10 Construction Information } \\
\hline Screen & $\begin{array}{c}\text { Screen } \\
\text { Top } \\
\text { Depth } \\
\text { (ft) } \\
\end{array}$ & $\begin{array}{c}\text { Screen } \\
\text { Bottom } \\
\text { Depth } \\
\text { (ft) } \\
\end{array}$ & $\begin{array}{c}\text { Screen } \\
\text { Top } \\
\text { Elev }(\mathrm{ft})\end{array}$ & $\begin{array}{l}\text { Screen } \\
\text { Bottom } \\
\text { Elev (ft) }\end{array}$ & \begin{tabular}{|c|} 
Screen \\
Length \\
(ft)
\end{tabular} & $\begin{array}{l}\text { Pump } \\
\text { Intake } \\
\text { Depth } \\
\text { (ft) }\end{array}$ & $\begin{array}{c}\text { Pump } \\
\text { Intake } \\
\text { Elev } \\
\text { (ft) } \\
\end{array}$ & $\begin{array}{c}\text { Depth to } \\
\text { Top of } \\
\text { Sump } \\
\text { (ft) }\end{array}$ & $\begin{array}{c}\text { Top of } \\
\text { Sump } \\
\text { Elev (ft) }\end{array}$ & $\begin{array}{c}\text { Depth to } \\
\text { Sump } \\
\text { Bottom } \\
\text { (ft) }\end{array}$ & $\begin{array}{c}\text { Sump } \\
\text { Length } \\
\text { (ft) }\end{array}$ & $\begin{array}{c}\text { Sump } \\
\text { Volume } \\
\text { (L) }\end{array}$ & $\begin{array}{l}\text { Hydro } \\
\text { Zone } \\
\text { Code } \\
\end{array}$ & $\begin{array}{l}\text { Geo } \\
\text { Unit } \\
\text { Code } \\
\end{array}$ \\
\hline 1 & 1078.4 & 1408.0 & 5941.5 & 5611.9 & 329.6 & & & 1408.0 & 5611.9 & 1408.0 & 0.0 & 0.0 & RT & $\mathrm{Tb} 4$ \\
\hline
\end{tabular}

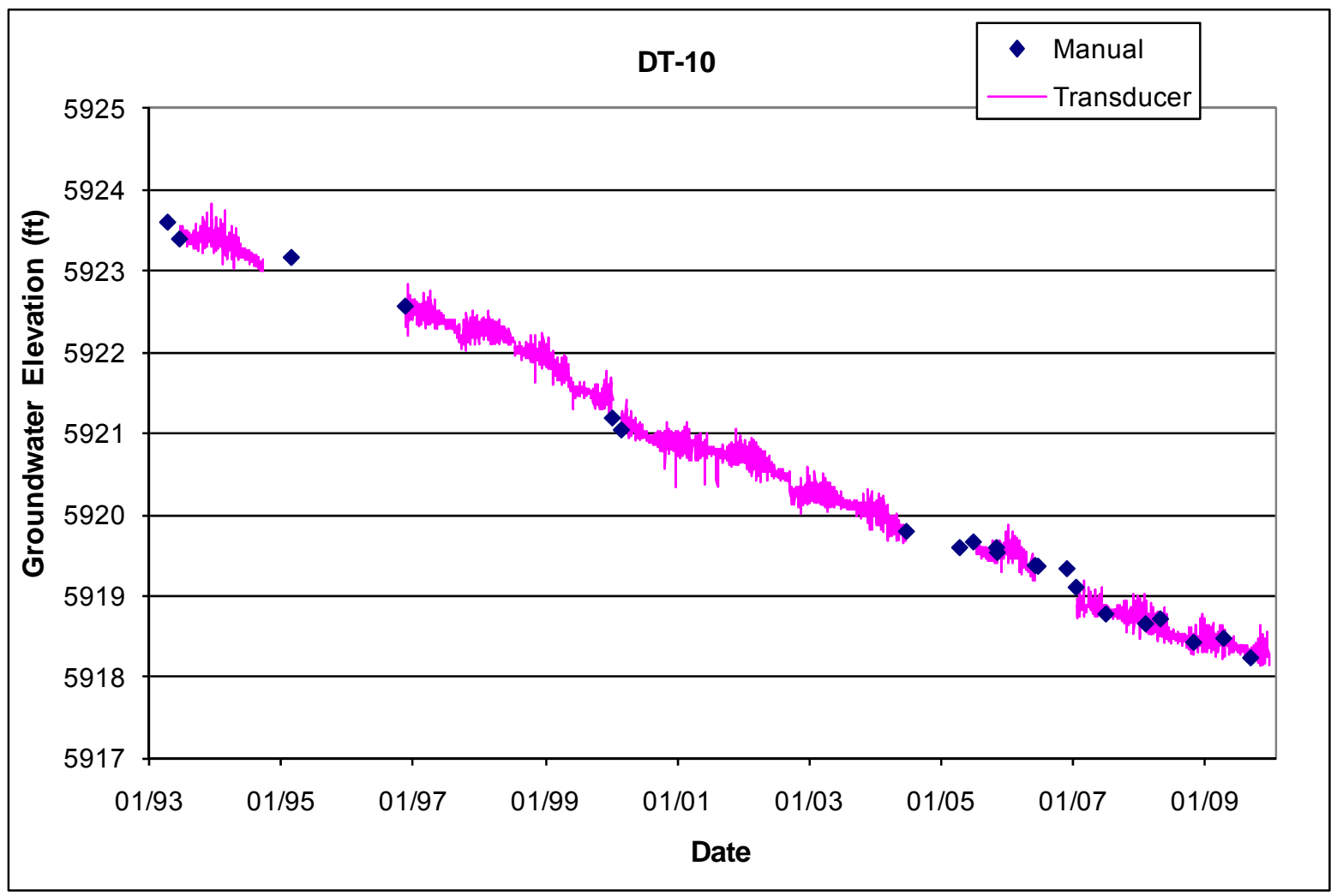




\subsection{Groundwater Level Data from Intermediate Wells}

Table 4-1 lists the monitoring wells that specifically monitor intermediate groundwater at LANL; the table includes the well name, completed depth, surveyed location coordinates, and the date of completion. Note that R-12 was converted from a three-screen regional/intermediate to a two-screen intermediate monitoring well in December 2007. Table 4-2 lists the well construction information for the intermediate wells and for regional aquifer wells that have intermediate screens. The table includes information for the depth to the top and bottom of screens, screen casing size, geologic formation where the screen is completed, and whether the well/screen contains intermediate groundwater. The hydrographs for intermediate zones in the multiple completion regional aquifer wells are shown in the previous section.

Figure 4-1 shows the locations of the intermediate wells and regional wells that monitor intermediate groundwater. (Note that multiple completion regional wells that do not contain intermediate groundwater, such as CdV-R-15-3, CdV-R-37-2, and R-31, are not shown in Figure 4-1 because the intermediate screens in these wells are dry.) Appendix Table B-2 lists the average annual water levels for each intermediate screen. 
Table 4-1. General Information for Intermediate Wells at LANL

\begin{tabular}{|c|c|c|c|c|c|}
\hline Well Name & $\begin{array}{c}\text { Date } \\
\text { Completed }\end{array}$ & $\begin{array}{c}\text { Completed } \\
\text { Depth (ft) }\end{array}$ & Easting (ft) & Northing (ft) & $\begin{array}{c}\text { Surface } \\
\text { Elevation (ft) }\end{array}$ \\
\hline 03-B-9 & $6 / 3 / 2005$ & 31.8 & 1616671.90 & 1773331.38 & 7457.98 \\
\hline 03-B-10 & $6 / 10 / 2005$ & 31.1 & 1616682.08 & 1773307.21 & 7458.28 \\
\hline 03-B-13 & $6 / 4 / 2005$ & 32.0 & 1616691.69 & 1773317.07 & 7458.26 \\
\hline 16-26644 & $8 / 17 / 2007$ & 150.0 & 1612087.16 & 1763729.94 & 7591.43 \\
\hline 90LP-SE-16-02669 & $6 / 10 / 2005$ & 163.4 & 1612152.57 & 1763749.00 & 7583.26 \\
\hline $\mathrm{BCO}-1$ & $11 / 23 / 1994$ & 68.0 & 1640648.74 & 1778914.70 & 6641.97 \\
\hline CdV-16-1(i) & $11 / 9 / 2003$ & 657.8 & 1615078.20 & 1764415.20 & 7382.17 \\
\hline CdV-16-2(i) & $12 / 8 / 2003$ & 1037.1 & 1616741.20 & 1764237.20 & 7457.11 \\
\hline CdV-16-2(i)r & $7 / 30 / 2005$ & 863.2 & 1616673.24 & 1764219.40 & 7456.67 \\
\hline CDV-37-1(i) & $12 / 2 / 2009$ & 657.8 & & & \\
\hline LADP-3 & $12 / 17 / 1993$ & 326.0 & 1632989.00 & 1773469.10 & 6756.70 \\
\hline LAOI(a)-1.1 & 10/28/1994 & 309.8 & 1629427.38 & 1773924.51 & 6835.20 \\
\hline LAOI-3.2 & $5 / 1 / 2005$ & 165.0 & 1637642.10 & 1773066.93 & 6622.60 \\
\hline LAOI-3.2a & $1 / 20 / 2006$ & 194.1 & 1637619.97 & 1773100.91 & 6624.43 \\
\hline LAOI-7 & 9/21/2005 & 264.9 & 1644788.53 & 1771584.11 & 6458.35 \\
\hline MCOBT-4.4 & $6 / 30 / 2001$ & 545.0 & 1634196.30 & 1768513.00 & 6836.18 \\
\hline MCOI-1 & $1 / 9 / 2005$ & 825.6 & 1628044.51 & 1769957.39 & 7106.20 \\
\hline MCOI-4 & $11 / 6 / 2004$ & 525.7 & 1634128.53 & 1768542.01 & 6837.20 \\
\hline MCOI-5 & 10/25/2004 & 699.0 & 1635247.94 & 1768300.46 & 6819.70 \\
\hline MCOI-6 & $1 / 13 / 2005$ & 713.2 & 1635345.65 & 1768428.06 & 6811.10 \\
\hline MCOI-8 & $1 / 7 / 2005$ & 675.0 & 1633329.74 & 1769214.40 & 6859.20 \\
\hline MSC-16-02665 & 10/23/1997 & 124.0 & 1614427.59 & 1762530.55 & 7516.92 \\
\hline $\mathrm{PCl}-2$ & $4 / 10 / 2009$ & 533.3 & 1627648.27 & 1765872.63 & 6920.95 \\
\hline POI-4 & $5 / 1 / 1996$ & 176.5 & 1649432.46 & 1772587.08 & 6372.29 \\
\hline R-3i & $8 / 16 / 2005$ & 220.3 & 1649196.5 & 1772599.2 & 6390.15 \\
\hline R-6i & $12 / 20 / 2004$ & 615.0 & 1635992.34 & 1773889.89 & 6996.90 \\
\hline R-9i & $3 / 10 / 2000$ & 309.9 & 1648202.70 & 1770837.80 & 6383.20 \\
\hline $\mathrm{R}-12$ & $01 / 11 / 00$ & 886.0 & 1647424.20 & 1767913.40 & 6499.60 \\
\hline$R-23 i$ & $11 / 10 / 2005$ & 550.7 & 1647898.02 & 1755148.04 & 6527.88 \\
\hline$R-25 b$ & 10/13/2008 & 782.3 & 1615125.60 & 1764074.70 & 7517.00 \\
\hline R-25c & 9/17/2008 & 1080.6 & 1615073.72 & 1764083.07 & 7517.59 \\
\hline R-27i & $10 / 17 / 2009$ & 630.2 & & & \\
\hline R-47i & 11/15/2009 & 865.5 & & & \\
\hline SCl-1 & 10/7/2006 & 377.9 & 1636822.9 & 1770298.2 & 6738.27 \\
\hline SCl-2 & $8 / 31 / 2008$ & 570.0 & 1637155.34 & 1769651.16 & 6735.70 \\
\hline TA-53i & $3 / 10 / 2009$ & 620.8 & 1635850.97 & 1771320.08 & 6987.17 \\
\hline TW-1A & $1 / 11 / 1950$ & 225.0 & 1650056.87 & 1772065.87 & 6369.28 \\
\hline TW-2A & $2 / 7 / 1950$ & 133.0 & 1634184.87 & 1777288.12 & 6650.40 \\
\hline
\end{tabular}




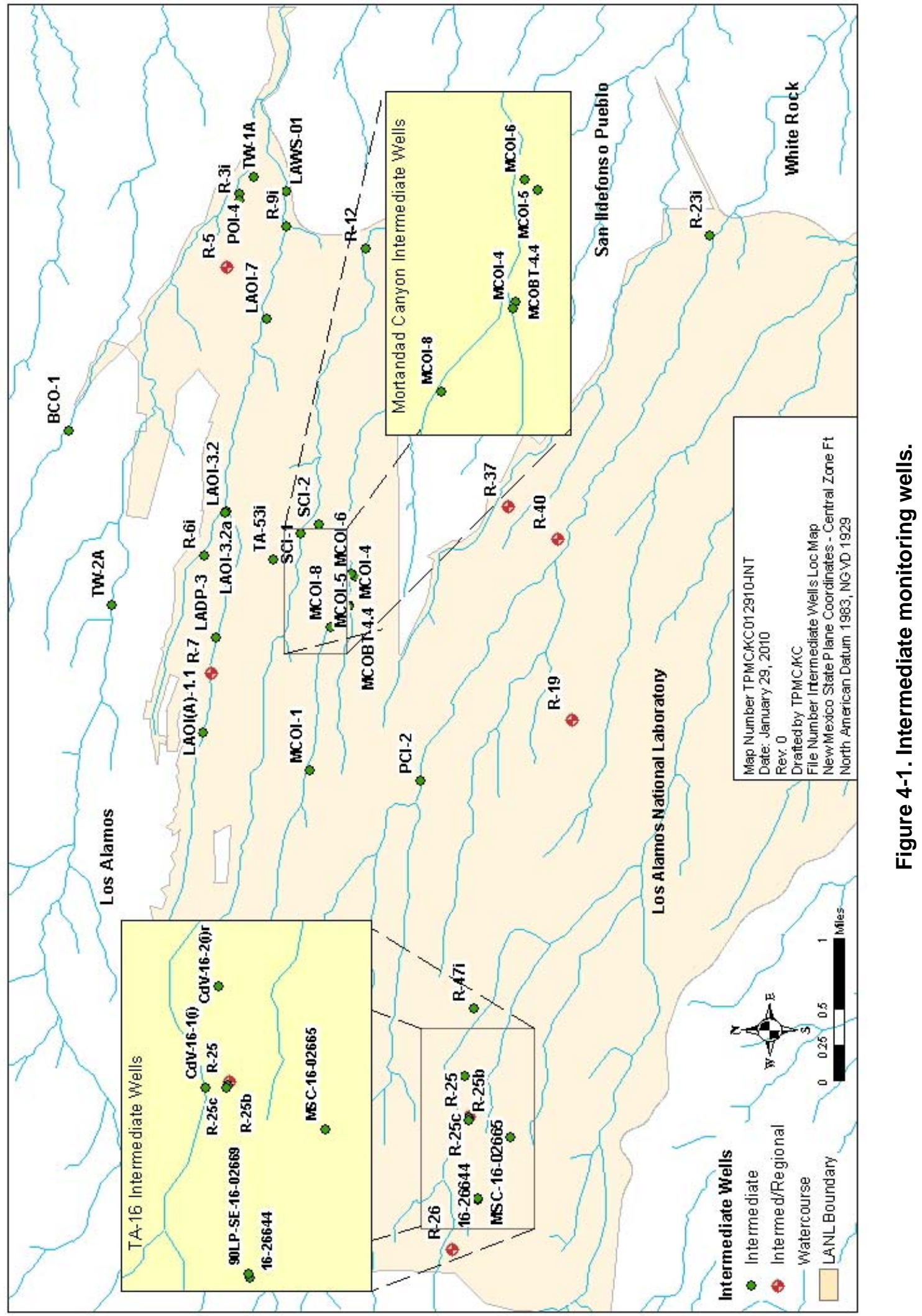


Table 4-2. Well Completion Information for Intermediate Wells and Screens

\begin{tabular}{|c|c|c|c|c|c|c|c|}
\hline Well Name & Screen Common Name & $\begin{array}{l}\text { Screen } \\
\text { Material }\end{array}$ & $\begin{array}{c}\text { Top of } \\
\text { Screen } \\
\text { (ft) }\end{array}$ & $\begin{array}{c}\text { Bottom } \\
\text { of } \\
\text { Screen } \\
\text { (ft) }\end{array}$ & $\begin{array}{c}\text { Screen } \\
\text { Inside } \\
\text { Diameter } \\
\text { (in.) }\end{array}$ & $\begin{array}{c}\text { Geologic } \\
\text { Unit }\end{array}$ & Comment \\
\hline 03-B-9 & 03-B-9 Screen \#1 & PVC & 21.3 & 31.3 & 2.00 & Qbt3 & \\
\hline 03-B-10 & 03-B-10 Screen \#1 & PVC & 20.6 & 30.6 & 2.00 & Qbt3 & \\
\hline $03-B-13$ & 03-B-13 Screen \#1 & PVC & 21.5 & 31.5 & 2.00 & Qbt3 & \\
\hline $16-26644$ & 16-26644 Screen \#1 & PVC & 130.0 & 145.0 & 2.00 & Qbt3 & \\
\hline 90LP-SE-16-02669 & 16-02669 Screen \#1 & PVC & 131.5 & 162.5 & 2.00 & Qbt3 & Dry \\
\hline CdV-16-1(i) & CdV-16-1(i) Screen \#1 & SS304 & 624.0 & 634.0 & 4.50 & Qbo & \\
\hline CdV-16-1(i) $\mathrm{CH}$ & CdV-16-1(i) PZ\#1 & PVC & 50.0 & 80.0 & 1.50 & Qbt3 & Dry \\
\hline CdV-16-2(i) & CdV-16-2(i) Screen \#1 & SS304 & 850.2 & 867.8 & 4.46 & $\mathrm{Tp}$ & Dry \\
\hline CdV-16-2(i) & CdV-16-2(i) Screen \#2 & SS304 & 992.0 & 1015.2 & 4.46 & $T p$ & P\&A 2009 \\
\hline CdV-16-2(i)r & CdV-16-2(i)r Screen \#1 & SS304 & 850.0 & 859.7 & 4.46 & Tpf & \\
\hline CdV-16-3(i) & Open Borehole & NA & NA & NA & NA & $\mathrm{Tt}$ & Completed as R-48 \\
\hline CDV-37-1(i) & CDV-37-1(i) Screen \#1 & SS304 & 632.0 & 652.5 & 5.00 & Tpf & \\
\hline CdV-R-15-3 & CdV-R-15-3 Screen 1 & SS312 & 617.7 & 624.5 & 4.50 & Qbo & Dry \\
\hline CdV-R-15-3 & CdV-R-15-3 Screen 2 & SS312 & 800.8 & 807.8 & 4.50 & $T p$ & Dry \\
\hline CdV-R-15-3 & CdV-R-15-3 Screen 3 & SS312 & 964.8 & 980.9 & 4.50 & $\mathrm{~Tb}$ & Dry \\
\hline CdV-R-37-2 & CdV-R37-2 Screen \#1 & SS304 & 914.4 & 939.5 & 4.50 & $T p$ & Dry \\
\hline BCO-1 & BCO-1 Screen \#1 & $\overline{P V C}$ & 57.0 & 67.0 & 4.00 & Tpf & Dry \\
\hline LADP-3 & LADP-3 Screen \#1 & PVC & 316.0 & 325.0 & 3.00 & Qbog & \\
\hline LAOI(A)-1.1 & LAOI(A)-1.1 Screen \#1 & PVC & 295.2 & 305.0 & 3.00 & Qbog & \\
\hline LAOI-3.2 & LAOI-3 Screen \#1 & PVC & 153.3 & 162.8 & 4.46 & $\mathrm{~Tb}$ & \\
\hline LAOI-3.2a & LAOI-3a Screen \#1 & SS304 & 181.4 & 191.0 & 3.10 & Tpf & \\
\hline LAOI-7 & LAOI-7 Screen \#1 & SS304 & 240.0 & 259.6 & 3.00 & Tb4 & \\
\hline MCOBT-4.4 & MCOBT4.4 Screen \#1 & SS304 & 485.4 & 524.0 & 4.50 & Tpf & \\
\hline MCOI-1 & MCOI-1 Screen \#1 & SS & 815.0 & 825.5 & 1.10 & Tpf & \\
\hline MCOI-4 & MCOI-4 Screen \#1 & PVC & 498.9 & 522.0 & 4.50 & Tpf & \\
\hline MCOI-5 & MCOI-5 Screen \#1 & PVC & 689.0 & \begin{tabular}{l|l|}
699.0 \\
\end{tabular} & 4.50 & $\mathrm{~Tb}$ & \\
\hline MCOI-6 & MCOI-6 Screen \#1 & PVC & 686.0 & 708.3 & 4.50 & $\mathrm{~Tb}$ & \\
\hline MCOI-8 & MCOI-6 Screen \#1 & PVC & 665.0 & 675.0 & 4.46 & $\mathrm{~Tb}$ & \\
\hline MSC-16-02665 & 16-02665 Screen \#1 & PVC & 93.5 & 123.5 & 2.00 & Qbt3 & Usually dry \\
\hline $\mathrm{PCl}-2$ & PCl-2 Screen \#1 & SS304 & 512.0 & 522.0 & 5.00 & Tpf & \\
\hline POI-4 & POI-4 Screen \#1 & PVC & 159.0 & 174.0 & 4.00 & Tb4 & \\
\hline$R-3 i$ & R-3i Screen \#1 & PVC & 215.2 & 220.0 & 2.00 & $\mathrm{~Tb} 4$ & \\
\hline $\mathrm{R}-12$ & R-12 Screen \#1 & SS304 & 459.0 & 467.5 & 4.50 & $\mathrm{~Tb}$ & \\
\hline $\mathrm{R}-12$ & R-12 Screen \#2 & SS304 & 504.5 & 508.0 & 4.50 & $T p$ & \\
\hline R-19 & R-19 Screen \#1 & SS304 & 827.2 & 843.6 & 4.50 & Qbog & Dry \\
\hline R-19 & R-19 Screen \#2 & SS304 & 893.3 & 909.6 & 4.50 & $\mathrm{Tp}$ & \\
\hline R-23i & R-23i Screen \#1 & SS304 & 400.3 & 420.0 & 2.10 & Tb4 & \\
\hline R-23i & R-23i Screen \#2 & SS304 & 470.2 & 480.1 & 4.50 & Tb4 & \\
\hline R-23i & R-23i Screen \#3 & SS304 & 524.0 & 547.0 & 4.50 & Tb4 & \\
\hline R-25 & R-25 Screen \#1 & SS304 & 737.6 & 758.4 & 5.17 & Qbo & \\
\hline R-25 & R-25 Screen \#2 & SS304 & 882.6 & 893.4 & 5.17 & $\mathrm{Tp}$ & \\
\hline $\mathrm{R}-25$ & R-25 Screen \#3 damaged & SS304 & 1054.6 & 1064.6 & 5.17 & $\mathrm{Tp}$ & Dry, sump water \\
\hline R-25 & R-25 Screen \#4 & SS304 & 1184.6 & 1194.6 & 5.17 & $T p$ & \\
\hline R-25b & R-25b Screen \#1 & SS304 & 750.0 & 770.8 & 5.00 & Qbo & \\
\hline R-25c & R-25c Screen \#1 & SS304 & 1039.6 & 1060.0 & 5.00 & Tpf & Dry \\
\hline R-26 & R-26 Screen \#1 (Upper) & SS304 & 643.0 & 662.0 & 4.50 & Qct & \\
\hline R-26 PZ-1 & R-26 Piezometer Screen \#1 & $\overline{P V C}$ & 230.0 & 250.0 & 1.00 & Qbt3 & Dry \\
\hline R-26 PZ-2 & R-26 Piezometer Screen \#2 & PVC & 150.0 & 180.0 & 1.00 & Qbt3 & Dry \\
\hline
\end{tabular}

Note: SS = stainless steel, PVC = polyvinyl chloride, Qbo = Otowi Member of the Bandelier Tuff, Tp = Puye Formation, $\mathrm{Qbog}=$ Guaje Pumice member of the Bandelier Tuff, Tpf = fluvial facies of the Puye Formation, Tb $=$ undifferentiated basalt, Tb4 = Cerros del Rio Basaltic Rocks; Qbt3 = Unit 3 of the Tshirege Member of the Bandelier Tuff, $\mathrm{Tt}=$ Tschicoma Formation (dacite). 
Table 4-2. Well Completion Information for Intermediate Wells and Screens (Continued)

\begin{tabular}{|c|c|c|c|c|c|c|c|}
\hline Well Name & Screen Common Name & $\begin{array}{l}\text { Screen } \\
\text { Material }\end{array}$ & $\begin{array}{c}\text { Top of } \\
\text { Screen } \\
\text { (ft) }\end{array}$ & $\begin{array}{c}\text { Bottom } \\
\text { of } \\
\text { Screen } \\
\text { (ft) }\end{array}$ & $\begin{array}{l}\text { Screen } \\
\text { Inside } \\
\text { Diameter } \\
\text { (in.) }\end{array}$ & $\begin{array}{c}\text { Geologic } \\
\text { Unit }\end{array}$ & Comment \\
\hline R-27i & R-27i Screen \#1 & SS304 & 619.0 & 629.0 & 5.00 & Qbt3 & \\
\hline R-31 & R-31 Screen \#1 & SS304 & 439.1 & 454.4 & 4.50 & $\mathrm{~Tb}$ & Dry \\
\hline R-37 & R-37 Screen \#1 & SS304 & 929.3 & 950.0 & 5.00 & $\mathrm{~Tb} 4$ & \\
\hline R-40 & R-40i & PVC & 649.67 & 669.02 & 3.00 & $\mathrm{~Tb} 4$ & \\
\hline $\mathrm{R}-40$ & R-40 Screen \#1 & SS304 & 751.59 & 785.06 & 5.00 & $\mathrm{~Tb} 4$ & \\
\hline R-41 & R-41 Screen \#1 & SS304 & 928 & 937.7 & 5.00 & Tsf & Dry \\
\hline R-47i & R-47i Screen \#1 & SS304 & 840 & 860.6 & 5.00 & Tpf & \\
\hline R-5 & R-5 Screen \#1 & SS304 & 326.4 & 331.5 & 4.50 & $\mathrm{Tp}$ & Dry \\
\hline R-5 & R-5 Screen \#2 & SS304 & 372.8 & 388.8 & 4.50 & $\mathrm{Tp}$ & \\
\hline R-6i & R-6i Screen \#1 & SS304 & 602.0 & 612.0 & 4.46 & Tpf & \\
\hline $\mathrm{R}-7$ & R-7 Screen \#1 & SS304 & 363.2 & 379.2 & 4.50 & $\mathrm{Tp}$ & Dry since 2005 \\
\hline R-7 & R-7 Screen \#2 & SS304 & 730.4 & 746.4 & 4.50 & $\mathrm{Tp}$ & Dry \\
\hline R-9i & R-9i Screen \#1 & SS304 & 189.1 & 199.5 & 5.00 & $\mathrm{~Tb}$ & \\
\hline R-9i & R-9i Screen \#2 & SS304 & 269.6 & 280.3 & 5.00 & $\mathrm{~Tb}$ & \\
\hline $\mathrm{SCl}-1$ & SCl-1 Screen \#1 & PVC & 358.4 & 377.9 & 3.80 & Tpf & \\
\hline $\mathrm{SCl}-2$ & SCl-2 Screen \#1 & PVC & 548 & 568 & 2.00 & $\mathrm{~Tb} 4$ & near R-43 \\
\hline TA-53i & TA-53i Screen \#1 & SS304 & 600 & 610 & 5.00 & Tpf & \\
\hline \begin{tabular}{|l} 
Test Well 1A \\
\end{tabular} & TW-1A Screen \#1 & CS & 215.0 & 225.0 & 6.00 & $\mathrm{~Tb}$ & \\
\hline Test Well 2A & TW-2A Screen \#1a & CS & 123.0 & 133.0 & 6.00 & $\mathrm{Tp}$ & \\
\hline
\end{tabular}

Note: SS = stainless steel, PVC = polyvinyl chloride, Qbo = Otowi Member of the Bandelier Tuff, Tp = Puye Formation, $\mathrm{Qbog}=$ Guaje Pumice member of the Bandelier Tuff, Tpf $=$ fluvial facies of the Puye Formation, $\mathrm{Tb}=$ undifferentiated basalt, Tb4 = Cerros del Rio Basaltic Rocks; Qbt3 = Unit 3 of the Tshirege Member of the Bandelier Tuff, $\mathrm{Tt}=$ Tschicoma Formation (dacite).

The following sections include additional port and construction information for single and multiple completion intermediate wells at LANL. Time-series groundwater level data are shown for each well. 


\section{$4.1 \quad 03-B-9$}

Location: 03-B-9 was located at TA-3 behind building SM-30.

Completion Type: Single completion in an intermediate perched zone in Unit 3 of the Bandelier Tuff. The wellhead was completed below ground surface with a well cap flush with an asphalt roadway.

Period of Record: Well completed June 2006, transducer installed June 2006, periodic measurements to September 25, 2009.

Remarks: The surface completion was reworked in 2007 but snowmelt and storm runoff would pond on the well cover; surface water penetrated the well cover and entered the well. The well was plugged and abandoned September 25, 2009 (LANL October 2009).

\begin{tabular}{|c|c|c|c|c|c|c|c|c|c|c|c|c|c|c|}
\hline \multicolumn{15}{|c|}{ 03-B-9 Construction Information } \\
\hline Screen & $\begin{array}{l}\text { Screen } \\
\text { Top } \\
\text { Depth } \\
\text { (ft) } \\
\end{array}$ & $\begin{array}{c}\text { Screen } \\
\text { Bottom } \\
\text { Depth } \\
\text { (ft) } \\
\end{array}$ & $\begin{array}{l}\text { Screen } \\
\text { Top } \\
\text { Elev (ft) }\end{array}$ & $\begin{array}{l}\text { Screen } \\
\text { Bottom } \\
\text { Elev (ft) }\end{array}$ & $\begin{array}{c}\text { Screen } \\
\text { Length } \\
\text { (ft) }\end{array}$ & \begin{tabular}{|c|} 
Pump \\
Intake \\
Depth \\
(ft) \\
\end{tabular} & $\begin{array}{c}\text { Pump } \\
\text { Intake } \\
\text { Elev } \\
\text { (ft) } \\
\end{array}$ & $\begin{array}{c}\text { Depth to } \\
\text { Top of } \\
\text { Sump } \\
\text { (ft) }\end{array}$ & $\begin{array}{c}\text { Top of } \\
\text { Sump } \\
\text { Elev } \\
\text { (ft) }\end{array}$ & \begin{tabular}{|c|} 
Depth to \\
Sump \\
Bottom (ft)
\end{tabular} & $\begin{array}{c}\text { Sump } \\
\text { Length } \\
\text { (ft) }\end{array}$ & $\begin{array}{c}\text { Sump } \\
\text { Volume } \\
(L)\end{array}$ & \begin{tabular}{|c|} 
Hydro \\
Zone \\
Code \\
\end{tabular} & $\begin{array}{l}\text { Geo } \\
\text { Unit } \\
\text { Code }\end{array}$ \\
\hline 1 & 21.30 & 31.3 & 7436.7 & 7426.7 & 10.0 & None & \begin{tabular}{|l|} 
None \\
\end{tabular} & 31.3 & 7426.7 & 31.8 & 0.5 & 0.3 & $T$ & Qbt3 \\
\hline
\end{tabular}

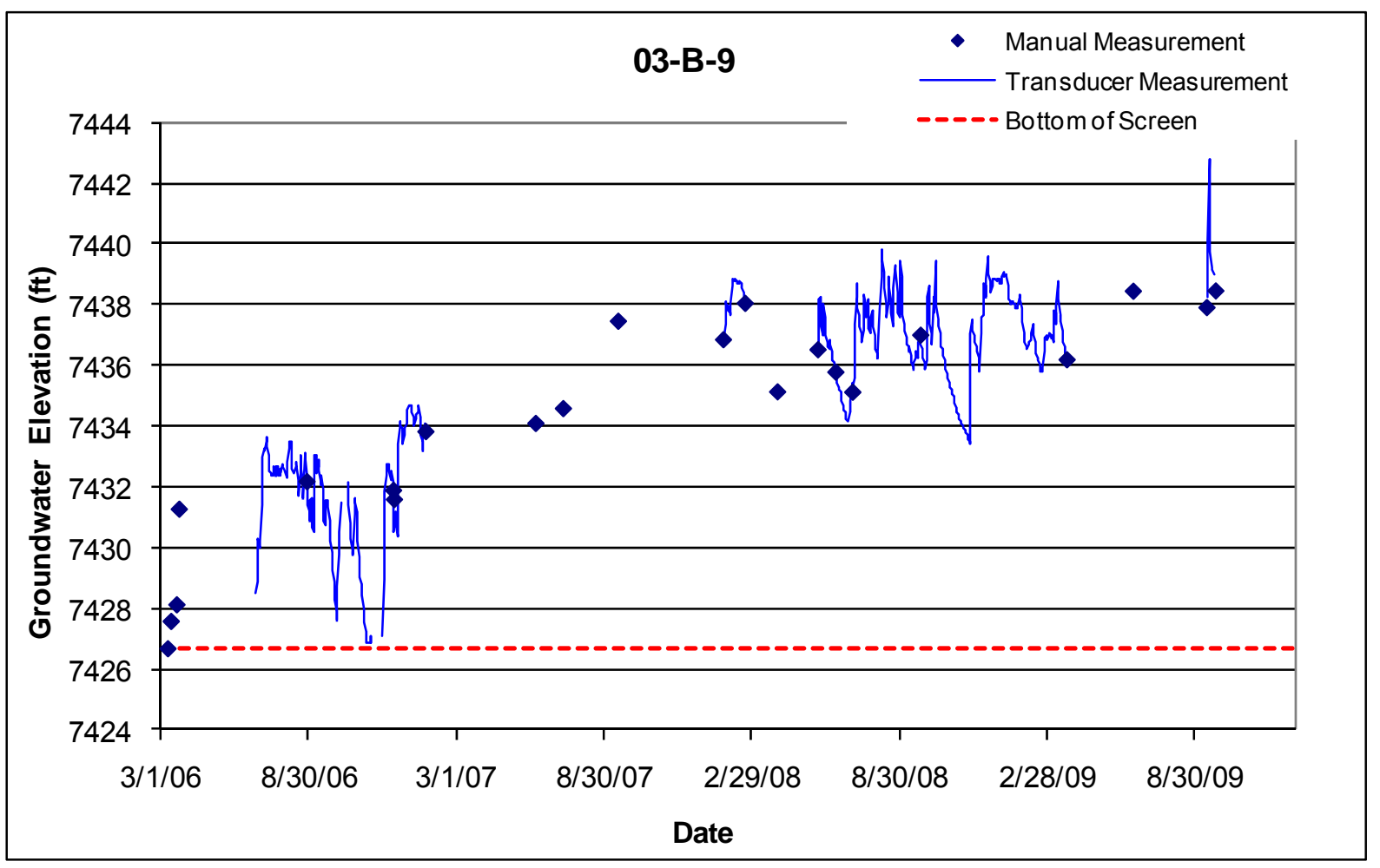




\section{$4.2 \quad 03-B-10$}

Location: 03-B-10 was located at TA-3 behind building SM-30.

Completion Type: Single completion in an intermediate perched zone in Unit 3 of the Bandelier Tuff. The wellhead was completed below ground surface with a waterproof well cap flush with an asphalt roadway.

Period of Record: Well completed June 2006, transducer installed June 2006, periodic measurements until September 25, 2009. Transducer equipment problems occurred in 2008.

Remarks: The surface completion was reworked in 2007. Surface water entered the well protective cover at times and may have entered the well. The well was plugged and abandoned September 25, 2009 (LANL October 2009).

\begin{tabular}{|c|c|c|c|c|c|c|c|c|c|c|c|c|c|c|}
\hline \multicolumn{15}{|c|}{ 03-B-10 Construction Information } \\
\hline Screen & $\begin{array}{c}\text { Screen } \\
\text { Top } \\
\text { Depth } \\
\text { (ft) }\end{array}$ & $\begin{array}{c}\text { Screen } \\
\text { Bottom } \\
\text { Depth } \\
(\mathrm{ft})\end{array}$ & $\begin{array}{l}\text { Screen } \\
\text { Top } \\
\text { Elev (ft) }\end{array}$ & $\begin{array}{l}\text { Screen } \\
\text { Bottom } \\
\text { Elev (ft) }\end{array}$ & $\begin{array}{c}\text { Screen } \\
\text { Length } \\
\text { (ft) }\end{array}$ & $\begin{array}{c}\text { Pump } \\
\text { Intake } \\
\text { Depth } \\
\text { (ft) }\end{array}$ & $\begin{array}{c}\text { Pump } \\
\text { Intake } \\
\text { Elev } \\
\text { (ft) }\end{array}$ & $\begin{array}{c}\text { Depth to } \\
\text { Top of } \\
\text { Sump } \\
\text { (ft) }\end{array}$ & $\begin{array}{c}\text { Top of } \\
\text { Sump } \\
\text { Elev } \\
\text { (ft) }\end{array}$ & $\begin{array}{l}\text { Depth to } \\
\text { Sump } \\
\text { Bottom } \\
\text { (ft) }\end{array}$ & $\begin{array}{c}\text { Sump } \\
\text { Length } \\
\text { (ft) }\end{array}$ & $\begin{array}{c}\text { Sump } \\
\text { Volume } \\
\text { (L) }\end{array}$ & $\begin{array}{l}\text { Hydro } \\
\text { Zone } \\
\text { Code }\end{array}$ & $\begin{array}{l}\text { Geo } \\
\text { Unit } \\
\text { Code }\end{array}$ \\
\hline & 20.60 & 30.6 & 7437.7 & 7427.7 & 10.0 & None & None & 30.6 & 7427.7 & 31.1 & & 0.3 & 1 & Qbt3 \\
\hline
\end{tabular}

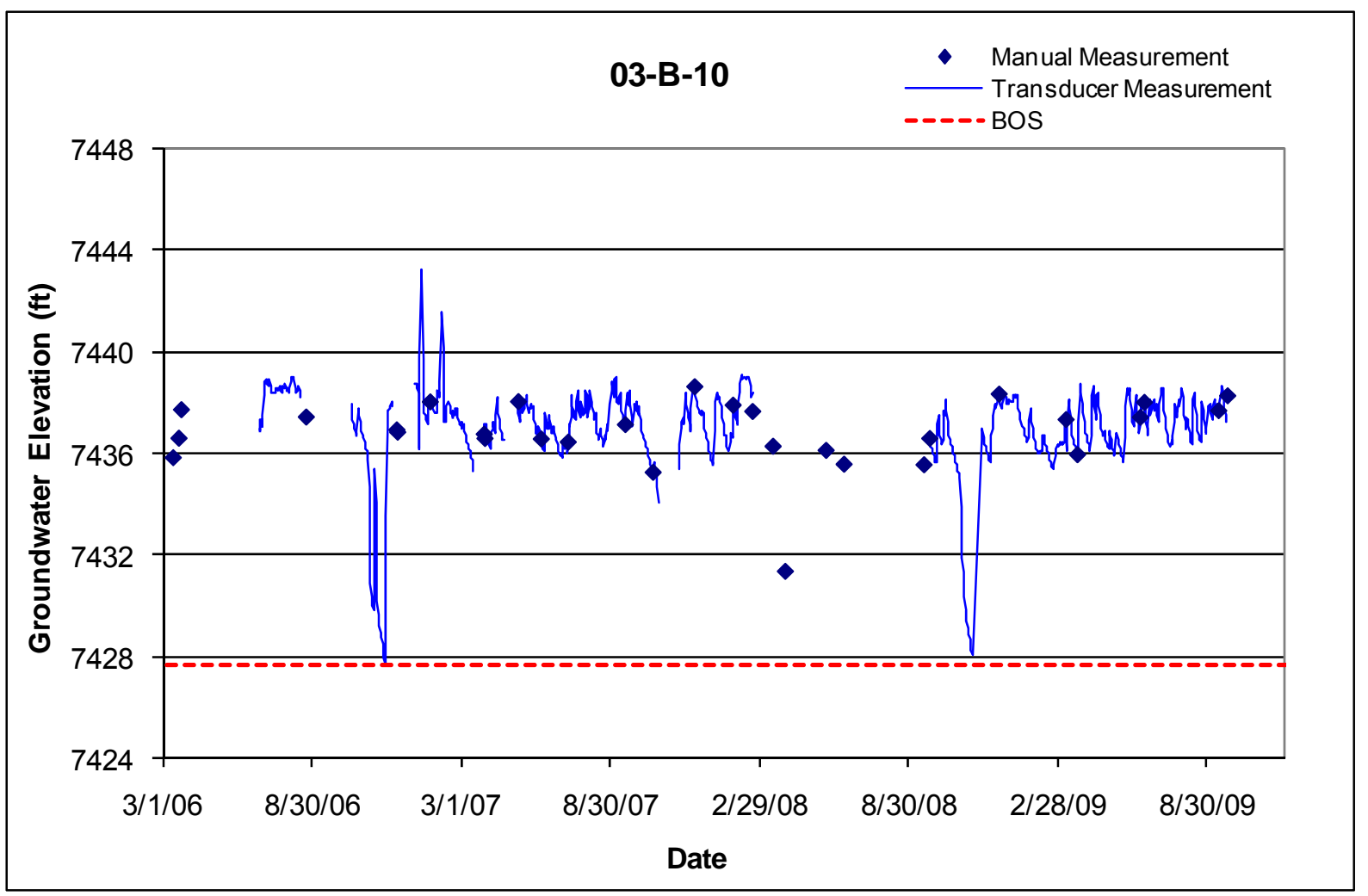




\section{$4.3 \quad 03-B-13$}

Location: $03-\mathrm{B}-13$ is located at TA-3 behind building SM-30.

Completion Type: Single completion in an intermediate perched zone in Unit 3 of the Bandelier Tuff. The wellhead is completed below ground surface with a waterproof well cap flush with an asphalt roadway.

Period of Record: Well completed June 2006, transducer installed June 2006, periodic measurements through 2009. Transducer equipment problems occurred in 2008.

Remarks: The surface completion was reworked in 2007. Surface water enters the well protective cover at times and may enter the well.

\begin{tabular}{|c|c|c|c|c|c|c|c|c|c|c|c|c|c|c|}
\hline \multicolumn{15}{|c|}{ 03-B-13 Construction Information } \\
\hline Screen & $\begin{array}{l}\text { Screen } \\
\text { Top } \\
\text { Depth } \\
\text { (ft) }\end{array}$ & $\begin{array}{c}\text { Screen } \\
\text { Bottom } \\
\text { Depth } \\
\text { (ft) }\end{array}$ & $\begin{array}{c}\text { Screen } \\
\text { Top } \\
\text { Elev (ft) }\end{array}$ & $\begin{array}{l}\text { Screen } \\
\text { Bottom } \\
\text { Elev (ft) }\end{array}$ & $\begin{array}{l}\text { Screen } \\
\text { Length } \\
\text { (ft) }\end{array}$ & $\begin{array}{c}\text { Pump } \\
\text { Intake } \\
\text { Depth } \\
\text { (ft) }\end{array}$ & $\begin{array}{c}\text { Pump } \\
\text { Intake } \\
\text { Elev } \\
\text { (ft) }\end{array}$ & $\begin{array}{l}\text { Depth } \\
\text { to Top } \\
\text { of } \\
\text { Sump } \\
\text { (ft) }\end{array}$ & $\begin{array}{c}\text { Top of } \\
\text { Sump } \\
\text { Elev } \\
\text { (ft) }\end{array}$ & \begin{tabular}{|c} 
Depth to \\
Sump \\
Bottom \\
(ft)
\end{tabular} & $\begin{array}{l}\text { Sump } \\
\text { Length } \\
\text { (ft) }\end{array}$ & $\begin{array}{c}\text { Sump } \\
\text { Volume } \\
\text { (L) }\end{array}$ & $\begin{array}{c}\text { Hydro } \\
\text { Zone } \\
\text { Code }\end{array}$ & $\begin{array}{c}\text { Geo } \\
\text { Unit } \\
\text { Code }\end{array}$ \\
\hline 1 & 21.50 & 31.5 & 7436.8 & 7426.8 & 10.0 & None & None & 31.5 & 7426.8 & 32.0 & 0.5 & 0.3 & $\mathrm{~T}$ & Qbt3 \\
\hline
\end{tabular}

Note: Ground elevation is $7458.26 \mathrm{ft}$; all depths from this elevation

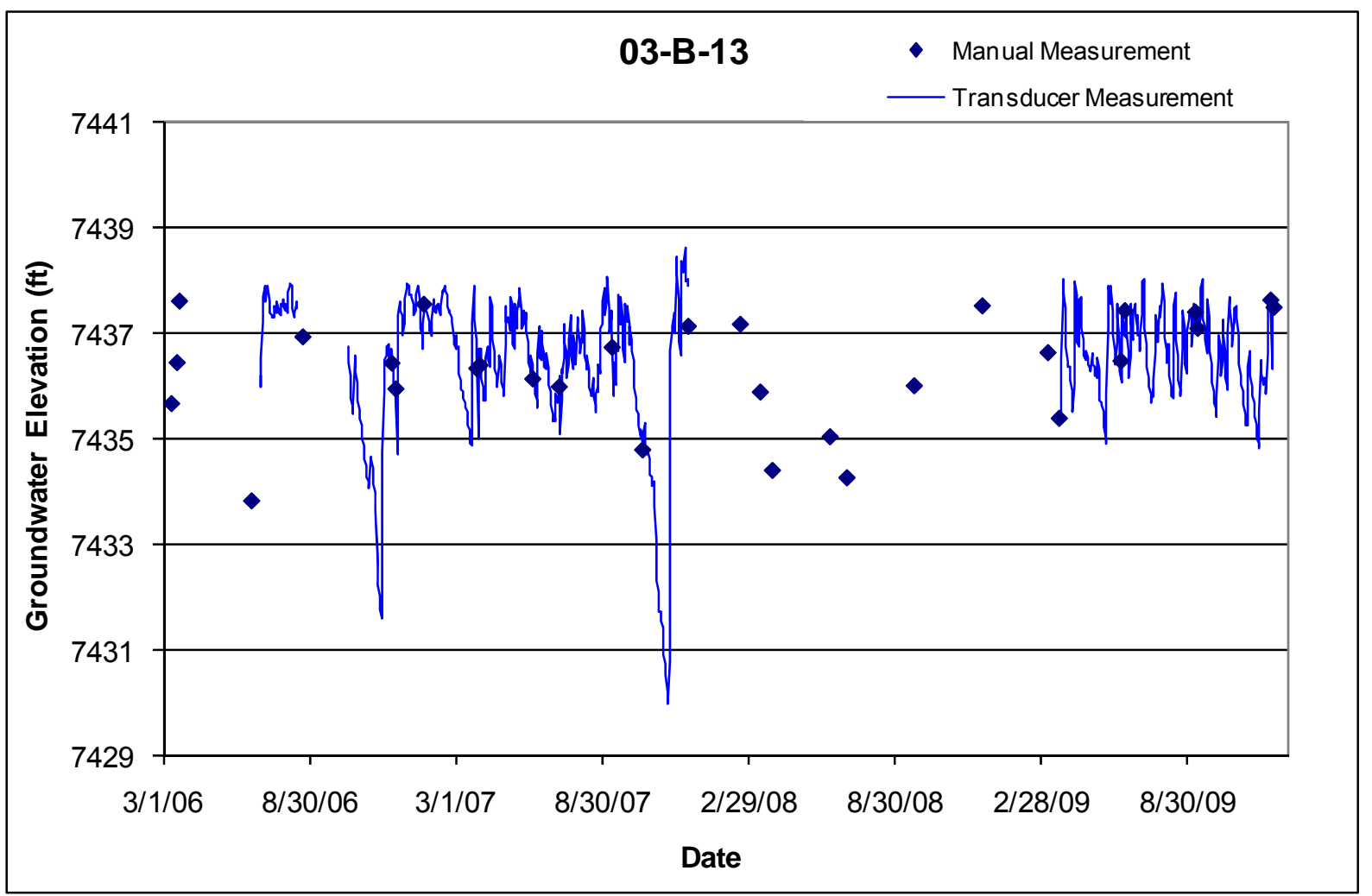




\section{$4.4 \quad 16-26644$}

Location: $16-26644$ is located at TA-16 southeast and downgradient of the $90 \mathrm{LP}$ Pond and about $70 \mathrm{ft}$ west of well 90LP-SE-16-02669.

Completion Type: Single completion in an intermediate zone in Unit 3 of the Bandelier Tuff.

Period of Record: Well drilled in August 2007, periodic manual measurements through 2009. A dedicated Bennett pump and transducer were installed in January 2010; data pending.

Remarks: The well has contained water when checked since completion of drilling, but several nearby boreholes and wells to a similar depth are dry.

\begin{tabular}{|c|c|c|c|c|c|c|c|c|c|c|c|c|c|c|}
\hline \multicolumn{15}{|c|}{ 16-26644 Construction Information } \\
\hline Screen & $\begin{array}{c}\text { Screen } \\
\text { Top } \\
\text { Depth } \\
\text { (ft) }\end{array}$ & \begin{tabular}{|c} 
Screen \\
Bottom \\
Depth \\
(ft)
\end{tabular} & $\begin{array}{c}\text { Screen } \\
\text { Top } \\
\text { Elev } \\
\text { (ft) }\end{array}$ & $\begin{array}{l}\text { Screen } \\
\text { Bottom } \\
\text { Elev (ft) }\end{array}$ & $\begin{array}{c}\text { Screen } \\
\text { Length } \\
\text { (ft) }\end{array}$ & $\begin{array}{c}\text { Pump } \\
\text { Intake } \\
\text { Depth } \\
\text { (ft) }\end{array}$ & $\begin{array}{c}\text { Pump } \\
\text { Intake } \\
\text { Elev } \\
\text { (ft) }\end{array}$ & $\begin{array}{c}\text { Depth to } \\
\text { Top of } \\
\text { Sump } \\
\text { (ft) }\end{array}$ & $\begin{array}{c}\text { Top of } \\
\text { Sump } \\
\text { Elev } \\
\text { (ft) }\end{array}$ & $\begin{array}{l}\text { Depth to } \\
\text { Sump } \\
\text { Bottom } \\
\text { (ft) }\end{array}$ & $\begin{array}{c}\text { Sump } \\
\text { Length } \\
\text { (ft) }\end{array}$ & $\begin{array}{c}\text { Sump } \\
\text { Volume } \\
\text { (L) }\end{array}$ & $\begin{array}{l}\text { Hydro } \\
\text { Zone } \\
\text { Code }\end{array}$ & $\begin{array}{l}\text { Geo } \\
\text { Unit } \\
\text { Code }\end{array}$ \\
\hline 1 & 130.0 & 145.0 & 7461.4 & 7446.4 & 15.0 & None & None & 145.0 & 7446.4 & 150.0 & 5.0 & 3.1 & $\mathrm{I}$ & Qbt3 \\
\hline
\end{tabular}

Note: Ground Elevation: $7591.43 \mathrm{ft}$; all measurements are from this elevation

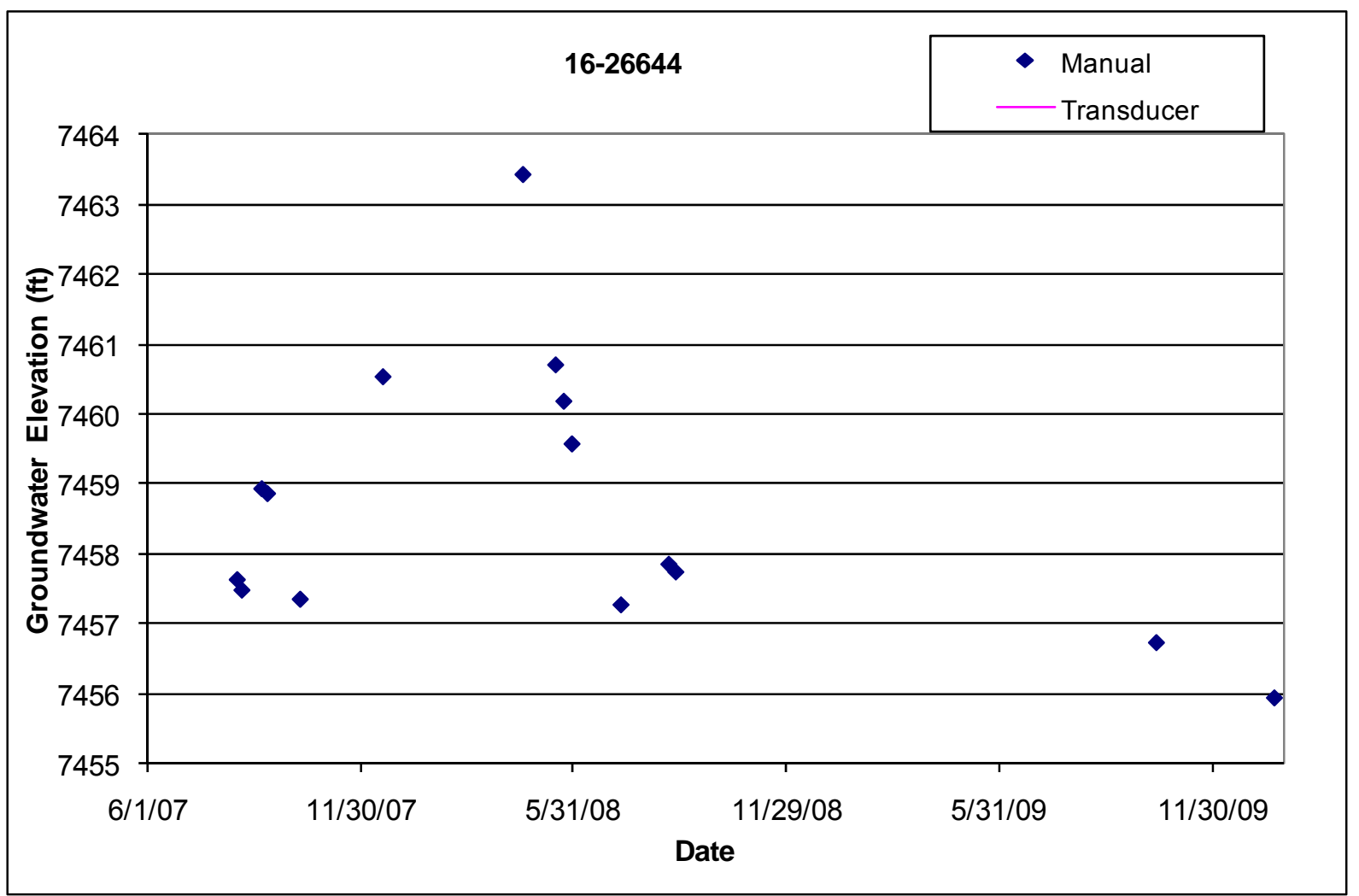




\subsection{LP-SE-16-02669}

Location: 90LP-SE-16-02669 is located at TA-16 downgradient of the 90LP Pond.

Completion Type: Single completion in an intermediate zone in Unit 3 of the Bandelier Tuff.

Period of Record: Well drilled in March 1998, periodic measurements through 2009.

Remarks: The borehole contained water at the completion of drilling, but since completion of the well, water has not been present in the well; the well was last checked March 23, 2009.

\begin{tabular}{|c|c|c|c|c|c|c|c|c|c|c|c|c|c|c|}
\hline \multicolumn{15}{|c|}{ 90LP-SE-16-02669 Construction Information } \\
\hline Screen & $\begin{array}{l}\text { Screen } \\
\text { Top } \\
\text { Depth } \\
\text { (ft) }\end{array}$ & $\begin{array}{c}\text { Screen } \\
\text { Bottom } \\
\text { Depth } \\
\text { (ft) }\end{array}$ & \begin{tabular}{|c|} 
Screen \\
Top \\
Elev \\
(ft)
\end{tabular} & $\begin{array}{l}\text { Screen } \\
\text { Bottom } \\
\text { Elev (ft) }\end{array}$ & $\begin{array}{l}\text { Screen } \\
\text { Length } \\
\text { (ft) }\end{array}$ & $\begin{array}{c}\text { Pump } \\
\text { Intake } \\
\text { Depth } \\
\text { (ft) }\end{array}$ & $\begin{array}{c}\text { Pump } \\
\text { Intake } \\
\text { Elev } \\
\text { (ft) }\end{array}$ & $\begin{array}{l}\text { Depth to } \\
\text { Top of } \\
\text { Sump } \\
\text { (ft) }\end{array}$ & $\begin{array}{c}\text { Top of } \\
\text { Sump } \\
\text { Elev } \\
\text { (ft) }\end{array}$ & $\begin{array}{l}\text { Depth to } \\
\text { Sump } \\
\text { Bottom } \\
\text { (ft) }\end{array}$ & $\begin{array}{c}\text { Sump } \\
\text { Length } \\
\text { (ft) }\end{array}$ & $\begin{array}{c}\text { Sump } \\
\text { Volume } \\
\text { (L) }\end{array}$ & $\begin{array}{c}\text { Hydro } \\
\text { Zone } \\
\text { Code }\end{array}$ & $\begin{array}{c}\text { Geo } \\
\text { Unit } \\
\text { Code }\end{array}$ \\
\hline 1 & 131.5 & 163.0 & 7451.8 & 7420.3 & 31.5 & None & None & 163.0 & 7420.3 & 163.4 & 0.4 & 0.2 & 1 & Qbt3 \\
\hline
\end{tabular}

Note: Ground Elevation: $7583.26 \mathrm{ft}$; all measurements are from this elevation 


\subsection{CdV-16-1(i)}

Location: CdV-16-1(i) is located at TA-16 downgradient of the TA-6-260 outfall and about $360 \mathrm{ft}$ north or intermediate well R-25b.

Completion Type: Single completion in an intermediate zone. The screen is located at similar depth as R-25 screen 1 and R-25b.

Period of Record: Well drilled in November 2003. Transducer installed September 2005; data through 2009.

Remarks: Well completed in an intermediate zone in the Otowi Member of the Tshirege Formation; the water level is about $50 \mathrm{ft}$ above the top of the screen. The well is $100 \%$ barometrically efficient; the groundwater does not respond to atmospheric pressure fluctuations. The intermediate groundwater rose in response to snowmelt runoff in the spring of 2007 and 2008 and responded to drilling activities at R-25b and R-35c in 2008.

\begin{tabular}{|c|c|c|c|c|c|c|c|c|c|c|c|c|c|c|}
\hline \multicolumn{15}{|c|}{ CDV-16-1(i) Construction Information } \\
\hline Screen & $\begin{array}{c}\text { Screen } \\
\text { Top } \\
\text { Depth } \\
\text { (ft) }\end{array}$ & $\begin{array}{c}\text { Screen } \\
\text { Bottom } \\
\text { Depth } \\
\text { (ft) }\end{array}$ & $\begin{array}{l}\text { Screen } \\
\text { Top } \\
\text { Elev (ft) }\end{array}$ & $\begin{array}{c}\text { Screen } \\
\text { Bottom } \\
\text { Elev } \\
\text { (ft) }\end{array}$ & $\begin{array}{c}\text { Screen } \\
\text { Length } \\
\text { (ft) }\end{array}$ & $\begin{array}{l}\text { Pump } \\
\text { Intake } \\
\text { Depth } \\
\text { (ft) }\end{array}$ & $\begin{array}{c}\text { Pump } \\
\text { Intake } \\
\text { Elev } \\
\text { (ft) }\end{array}$ & $\begin{array}{c}\text { Depth to } \\
\text { Top of } \\
\text { Sump } \\
\text { (ft) }\end{array}$ & \begin{tabular}{|c} 
Top of \\
Sump \\
Elev \\
(ft)
\end{tabular} & $\begin{array}{l}\text { Depth to } \\
\text { Sump } \\
\text { Bottom } \\
\text { (ft) }\end{array}$ & $\begin{array}{c}\text { Sump } \\
\text { Length } \\
\text { (ft) }\end{array}$ & $\begin{array}{c}\text { Sump } \\
\text { Volume } \\
\text { (L) }\end{array}$ & $\begin{array}{l}\text { Hydro } \\
\text { Zone } \\
\text { Code }\end{array}$ & $\begin{array}{c}\text { Geo } \\
\text { Unit } \\
\text { Code }\end{array}$ \\
\hline$\overline{1}$ & 624.0 & 634 & 6758.2 & 6748.2 & 10.0 & 618.8 & 6763.4 & 634.0 & \begin{tabular}{|c|}
6748.2 \\
\end{tabular} & 657.8 & 23.8 & 73.1 & $T$ & Qbo \\
\hline
\end{tabular}

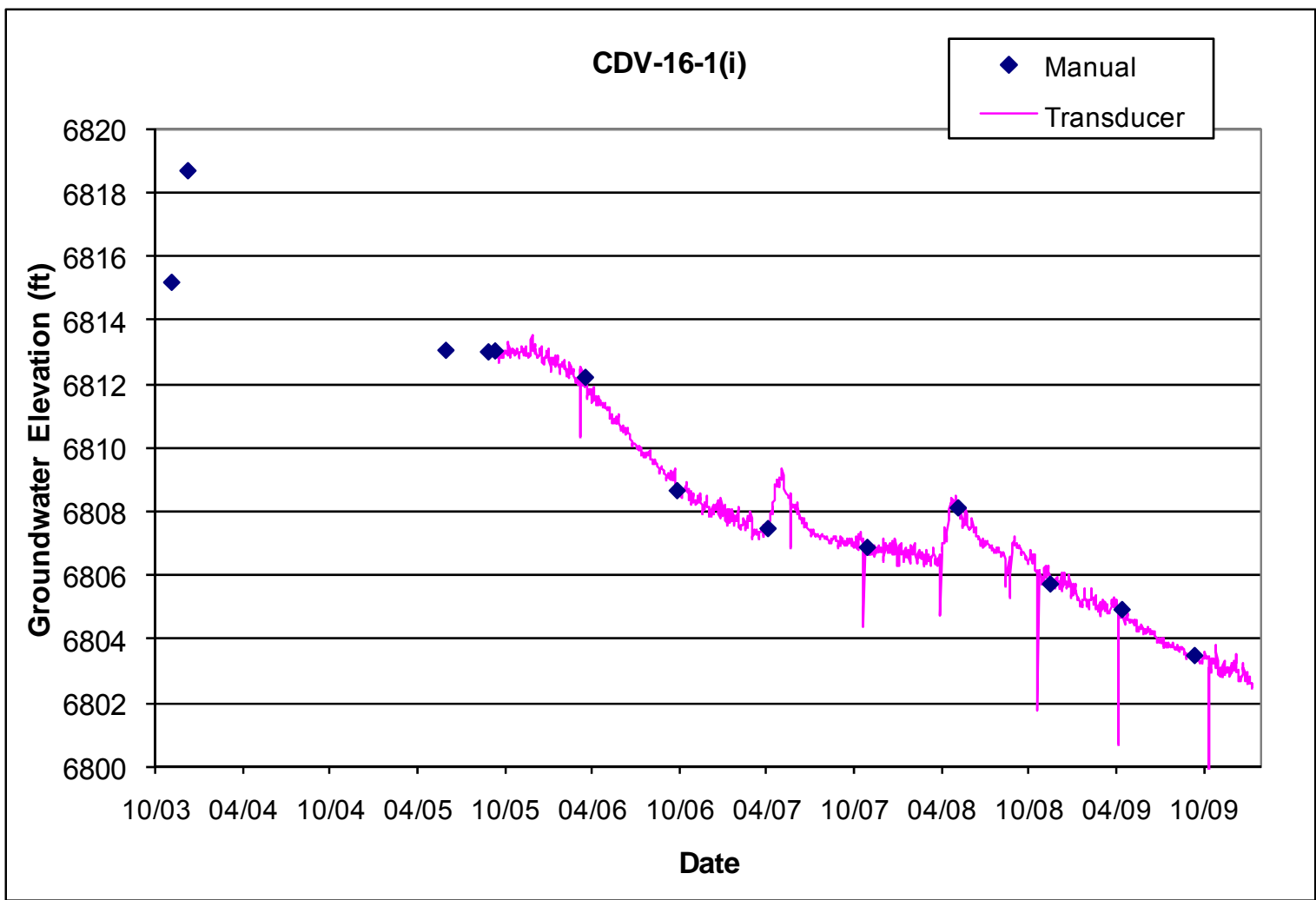




\subsection{CdV-16-2(i)r}

Location: CdV-16-2(i)r is located at TA-16 downgradient of the TA-6-260 outfall and about $1450 \mathrm{ft}$ east of R-25.

Completion Type: Single completion in intermediate zone in the Puye Formation.

Period of Record: Well completed July 2005, periodic manual measurements in 2005. A transducer was installed February 16, 2006; data through 2009.

Remarks: Well replaces CdV-16-2(i). The water level is about $20 \mathrm{ft}$ above bottom of screen. The well is about $90 \%$ barometrically efficient. The groundwater did not indicate a response to snowmelt runoff in 2007 but showed a small response to snowmelt runoff in the spring of 2008. Nearby dry well CdV-16-2(i) was plugged and abandoned in July 2009 (LANL August 2009b). The groundwater level at CdV-16-2(i)r began to recover on July 9, 2009, when pressure grouting activities commenced during plugging of the nearby well.

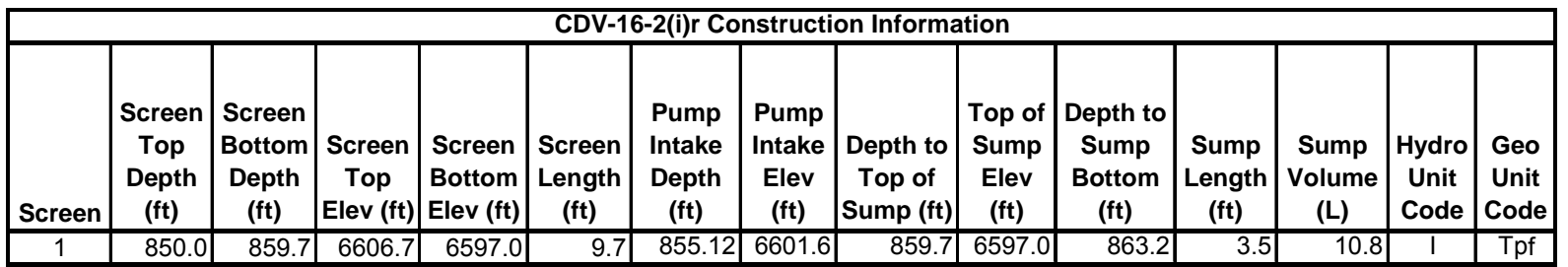

Note: Ground Elevation: $7456.67 \mathrm{ft}$; all measurements are from this elevation

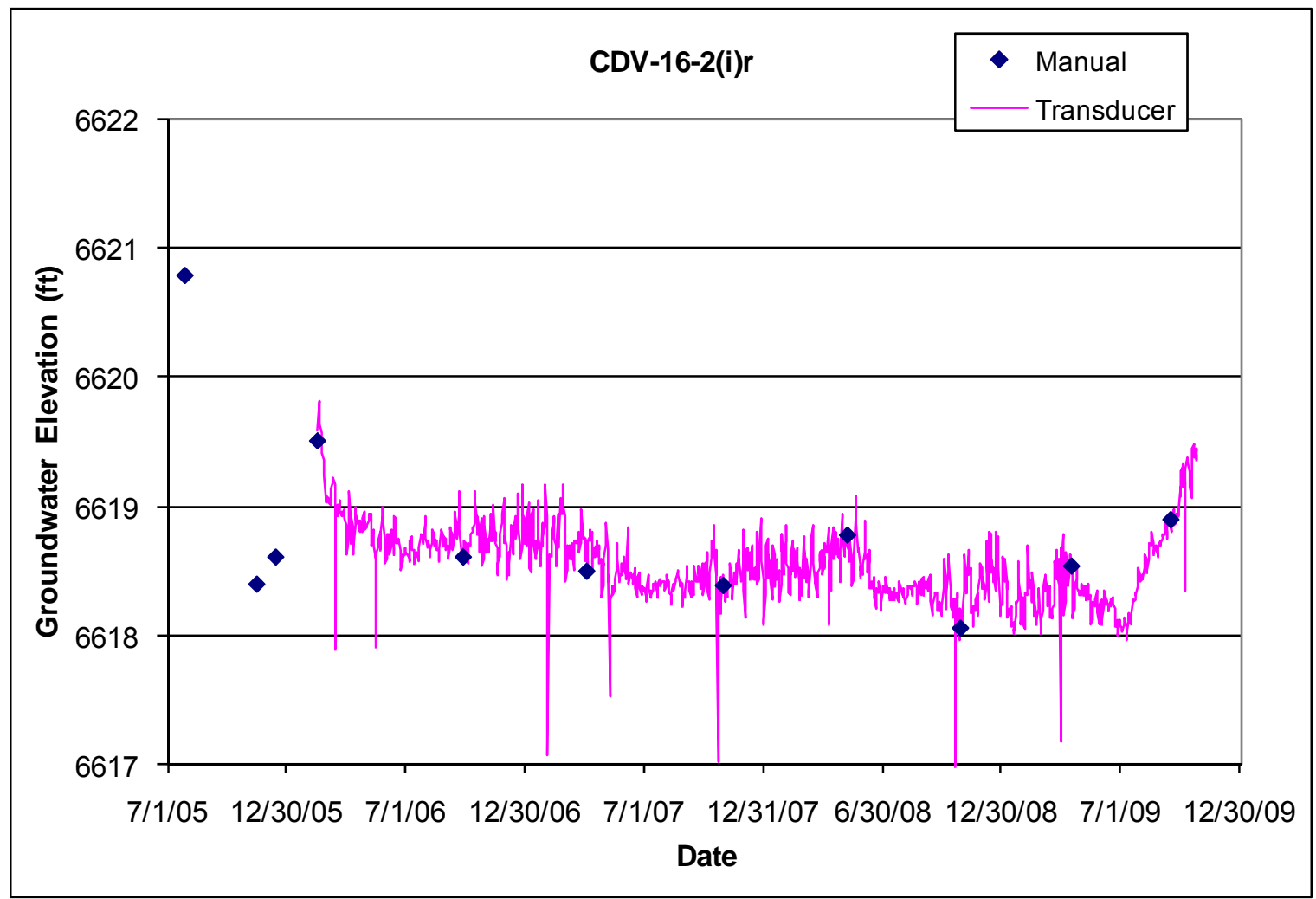




\subsection{CdV-16-3(i)}

Location: CdV-16-3(i) is located at TA-16 downgradient of the TA-6-260 outfall.

Completion Type: Open borehole, well not installed.

Period of Record: Well drilled in 2004, periodic manual measurements through 2005. Well monitoring ceased in 2005.

Remarks: Water not present in borehole when drilling was completed. Since January 2004, the borehole has contained about $40 \mathrm{ft}$ of water. Note that the water level is similar to the top of the regional aquifer at CdV-R-37-2. CdV-16-3(i) was deepened and completed as regional aquifer well R-48 September 2009.

\begin{tabular}{|c|c|c|c|c|c|c|c|c|c|c|c|c|c|c|}
\hline \multicolumn{15}{|c|}{ CDV-16-3(i) Construction Information } \\
\hline Screen & $\begin{array}{c}\text { Screen } \\
\text { Top } \\
\text { Depth } \\
\text { (ft) }\end{array}$ & $\begin{array}{c}\text { Screen } \\
\text { Bottom } \\
\text { Depth } \\
\text { (ft) }\end{array}$ & \begin{tabular}{|c} 
Screen \\
Top \\
Elev \\
(ft)
\end{tabular} & $\begin{array}{c}\text { Screen } \\
\text { Bottom } \\
\text { Elev } \\
\text { (ft) }\end{array}$ & $\begin{array}{c}\text { Screen } \\
\text { Length } \\
\text { (ft) }\end{array}$ & $\begin{array}{c}\text { Pump } \\
\text { Intake } \\
\text { Depth } \\
\text { (ft) }\end{array}$ & $\begin{array}{c}\text { Pump } \\
\text { Intake } \\
\text { Elev } \\
\text { (ft) }\end{array}$ & $\begin{array}{l}\text { Depth } \\
\text { to Top } \\
\text { of } \\
\text { Sump } \\
\text { (ft) }\end{array}$ & $\begin{array}{c}\text { Top of } \\
\text { Sump } \\
\text { Elev } \\
\text { (ft) }\end{array}$ & $\begin{array}{c}\text { Depth to } \\
\text { Borehole } \\
\text { Bottom } \\
\text { (ft) }\end{array}$ & $\begin{array}{c}\text { Sump } \\
\text { Length } \\
\text { (ft) }\end{array}$ & $\begin{array}{c}\text { Sump } \\
\text { Volume } \\
\text { (L) }\end{array}$ & $\begin{array}{l}\text { Hydro } \\
\text { Zone } \\
\text { Code }\end{array}$ & $\begin{array}{l}\text { Geo } \\
\text { Unit } \\
\text { Code }\end{array}$ \\
\hline None & & & & & 0.0 & None & None & & & 1390 & & 0.0 & RT & $\overline{T t}$ \\
\hline
\end{tabular}

Note: Mag NailGround Elevation: $7486.4 \mathrm{ft}$; all measurements are from this elevation;

Well not completed, open borehole with surface pad and protective casing

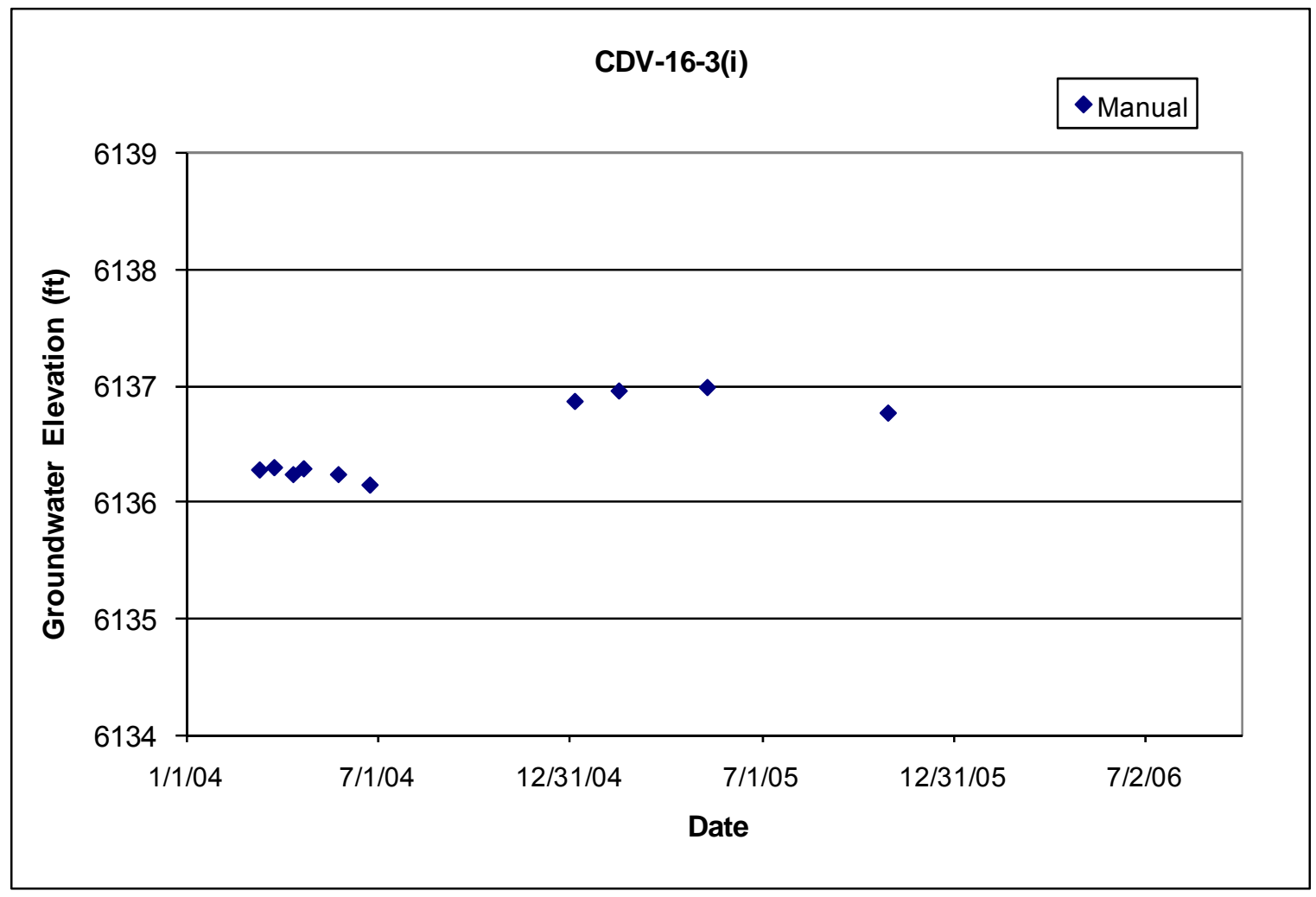




\subsection{CDV-37-1(i)}

Location: CDV-37-1(i) is located in Water Canyon near the confluence with Cañon de Valle. Completion Type: Single completion in an intermediate zone in the Puye Formation fanglomerates. Period of Record: Well completed December 2009. Transducer installation pending as of January 2010.

Remarks: A dedicated submersible pump was installed in January 2010. The screen is located about 5 $\mathrm{ft}$ below the level of the perched intermediate groundwater. After well completion the groundwater level was $627.9 \mathrm{ft}$ below ground surface.

\begin{tabular}{|c|c|c|c|c|c|c|c|c|c|c|c|c|c|c|}
\hline \multicolumn{15}{|c|}{ CDV-37-1(i) Construction Information } \\
\hline Screen & $\begin{array}{l}\text { Screen } \\
\text { Top } \\
\text { Depth } \\
\text { (ft) }\end{array}$ & $\begin{array}{c}\text { Screen } \\
\text { Bottom } \\
\text { Depth } \\
\text { (ft) }\end{array}$ & $\begin{array}{c}\text { Screen } \\
\text { Top } \\
\text { Elev } \\
\text { (ft) }\end{array}$ & $\begin{array}{c}\text { Screen } \\
\text { Bottom } \\
\text { Elev } \\
\text { (ft) }\end{array}$ & $\begin{array}{c}\text { Screen } \\
\text { Length } \\
\text { (ft) }\end{array}$ & $\begin{array}{c}\text { Pump } \\
\text { Intake } \\
\text { Depth } \\
\text { (ft) }\end{array}$ & $\begin{array}{c}\text { Pump } \\
\text { Intake } \\
\text { Elev } \\
\text { (ft) }\end{array}$ & $\begin{array}{c}\text { Depth to } \\
\text { Top of } \\
\text { Sump } \\
\text { (ft) }\end{array}$ & $\begin{array}{c}\text { Top of } \\
\text { Sump } \\
\text { Elev } \\
\text { (ft) }\end{array}$ & \begin{tabular}{|} 
Depth to \\
Sump \\
Bottom \\
(ft)
\end{tabular} & $\begin{array}{l}\text { Sump } \\
\text { Length } \\
\text { (ft) }\end{array}$ & $\begin{array}{l}\text { Bottom } \\
\text { of Well } \\
\text { Elev (ft) }\end{array}$ & $\begin{array}{c}\text { Hydro } \\
\text { Zone } \\
\text { Code }\end{array}$ & $\begin{array}{c}\text { Geo } \\
\text { Unit } \\
\text { Code }\end{array}$ \\
\hline 1 & 632.0 & 652.5 & -632.0 & -652.5 & 20.5 & & 0.0 & 652.5 & -652.5 & 657.8 & 5.3 & -657.8 & $T$ & Tpf \\
\hline
\end{tabular}

Note: Brass Cap Ground Elevation: $X X X X \mathrm{ft}$; all measurements are from this elevation 


\subsection{LADP-3}

Location: LADP-3 is located in middle Los Alamos Canyon downgradient of TA-21 and about 0.9 miles upstream of the confluence with DP Canyon.

Completion Type: Single completion in an intermediate zone in the Guaje Pumice bed.

Period of Record: Well drilled in 1993. Transducer first installed May 1994, reinstalled in May 2005, intermittent transducer data through 2009.

Remarks: No manual measurement available for April 2002 transducer installation, data from April 2002 to November 2003 questionable. The water level declined below the transducer from April 2006 to November 2006 and again from March 2009 to June 2009. The well is $100 \%$ barometrically efficient; the groundwater does not respond to atmospheric pressure fluctuations. The groundwater did not indicate a response to snowmelt runoff in 2007 and 2008. A dedicated Bennett pump was installed in July 2008.

\begin{tabular}{|c|c|c|c|c|c|c|c|c|c|c|c|c|c|c|}
\hline \multicolumn{15}{|c|}{ LADP-3 Construction Information } \\
\hline Screen & $\begin{array}{l}\text { Screen } \\
\text { Top } \\
\text { Depth } \\
\text { (ft) }\end{array}$ & $\begin{array}{c}\text { Screen } \\
\text { Bottom } \\
\text { Depth } \\
\text { (ft) }\end{array}$ & $\begin{array}{c}\text { Screen } \\
\text { Top } \\
\text { Elev } \\
\text { (ft) }\end{array}$ & $\begin{array}{c}\text { Screen } \\
\text { Bottom } \\
\text { Elev } \\
\text { (ft) }\end{array}$ & $\begin{array}{l}\text { Screen } \\
\text { Length } \\
\text { (ft) }\end{array}$ & $\begin{array}{c}\text { Pump } \\
\text { Intake } \\
\text { Depth } \\
\text { (ft) }\end{array}$ & $\begin{array}{c}\text { Pump } \\
\text { Intake } \\
\text { Elev } \\
\text { (ft) }\end{array}$ & \begin{tabular}{|} 
Depth to \\
Top of \\
Sump \\
(ft)
\end{tabular} & $\begin{array}{c}\text { Top of } \\
\text { Sump } \\
\text { Elev } \\
\text { (ft) }\end{array}$ & \begin{tabular}{|c|} 
Depth to \\
Sump \\
Bottom \\
(ft)
\end{tabular} & $\begin{array}{l}\text { Sump } \\
\text { Length } \\
\text { (ft) }\end{array}$ & $\begin{array}{c}\text { Sump } \\
\text { Volume } \\
\text { (L) }\end{array}$ & $\begin{array}{c}\text { Hydro } \\
\text { Zone } \\
\text { Code }\end{array}$ & $\begin{array}{l}\text { Geo } \\
\text { Unit } \\
\text { Code }\end{array}$ \\
\hline 1 & 316.0 & 326 & 6440.7 & 6430.7 & 10.0 & 325.0 & 6431.7 & 326.0 & 6430.7 & 326 & $\overline{0.0}$ & 0.0 & $\mathrm{~T}$ & Qbog \\
\hline
\end{tabular}

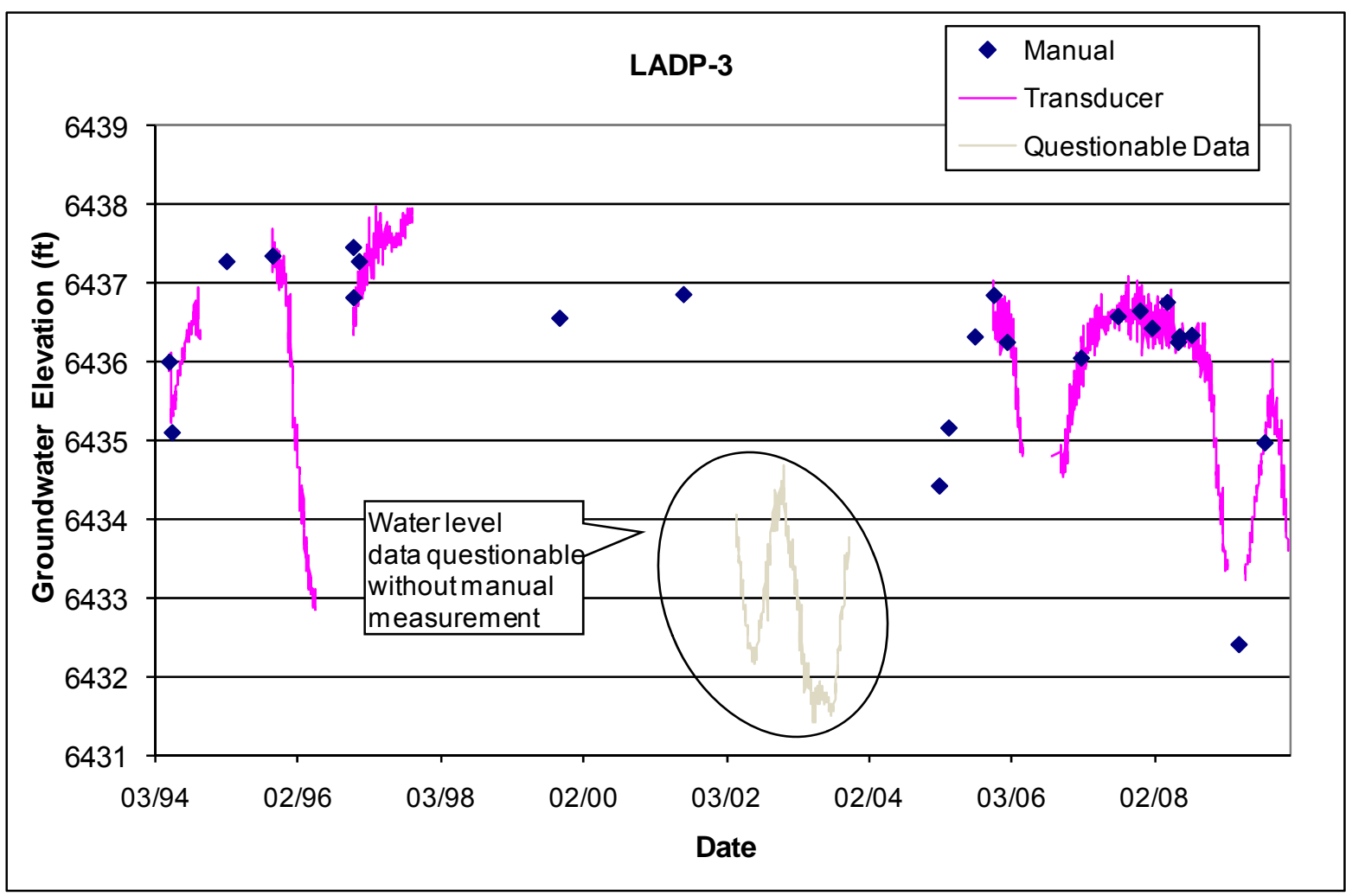




\subsection{LAOI(a)-1.1}

Location: LAOI(a)-1.1 is located in middle Los Alamos Canyon downstream of TA-2 and TA-41. Completion Type: Single completion in an intermediate zone in the Guaje Pumice bed.

Period of Record: Well drilled in 1994. Transducer initially installed June 1997, reinstalled in April 2005; transducer data through 2009.

Remarks: The well is $100 \%$ barometrically efficient; the groundwater does not respond to atmospheric pressure fluctuations. The groundwater did not indicate a response to snowmelt runoff in 2007 and 2008. A dedicated Bennett pump was installed July 2008.

\begin{tabular}{|c|c|c|c|c|c|c|c|c|c|c|c|c|c|c|}
\hline \multicolumn{15}{|c|}{ LAOI(A)-1.1 Construction Information } \\
\hline Screen & $\begin{array}{c}\text { Screen } \\
\text { Top } \\
\text { Depth } \\
\text { (ft) }\end{array}$ & $\begin{array}{c}\text { Screen } \\
\text { Bottom } \\
\text { Depth } \\
\text { (ft) }\end{array}$ & \begin{tabular}{|c} 
Screen \\
Top \\
Elev \\
(ft)
\end{tabular} & $\begin{array}{l}\text { Screen } \\
\text { Bottom } \\
\text { Elev (ft) }\end{array}$ & $\begin{array}{c}\text { Screen } \\
\text { Length } \\
\text { (ft) }\end{array}$ & $\begin{array}{c}\text { Pump } \\
\text { Intake } \\
\text { Depth } \\
\text { (ft) }\end{array}$ & $\begin{array}{c}\text { Pump } \\
\text { Intake } \\
\text { Elev } \\
\text { (ft) }\end{array}$ & \begin{tabular}{|} 
Depth to \\
Top of \\
Sump \\
(ft)
\end{tabular} & \begin{tabular}{|c|} 
Top of \\
Sump \\
Elev \\
(ft)
\end{tabular} & \begin{tabular}{|} 
Depth to \\
Sump \\
Bottom \\
(ft)
\end{tabular} & $\begin{array}{c}\text { Sump } \\
\text { Length } \\
\text { (ft) }\end{array}$ & $\begin{array}{c}\text { Sump } \\
\text { Volume } \\
\text { (L) }\end{array}$ & $\begin{array}{l}\text { Hydro } \\
\text { Zone } \\
\text { Code }\end{array}$ & \begin{tabular}{|c|} 
Geo \\
Unit \\
Code
\end{tabular} \\
\hline 1 & 295.2 & 305 & 6540.0 & 6530.2 & 9.8 & 308.0 & 6527.2 & 305.0 & 6530.2 & 309.8 & 4.8 & 6.7 & $\mathrm{~T}$ & Qbog \\
\hline
\end{tabular}

Note: $\mathrm{LAOI}(\mathrm{A})-1.1$ Ground Elevation: $6835.2 \mathrm{ft}$; all measurements are from this elevation

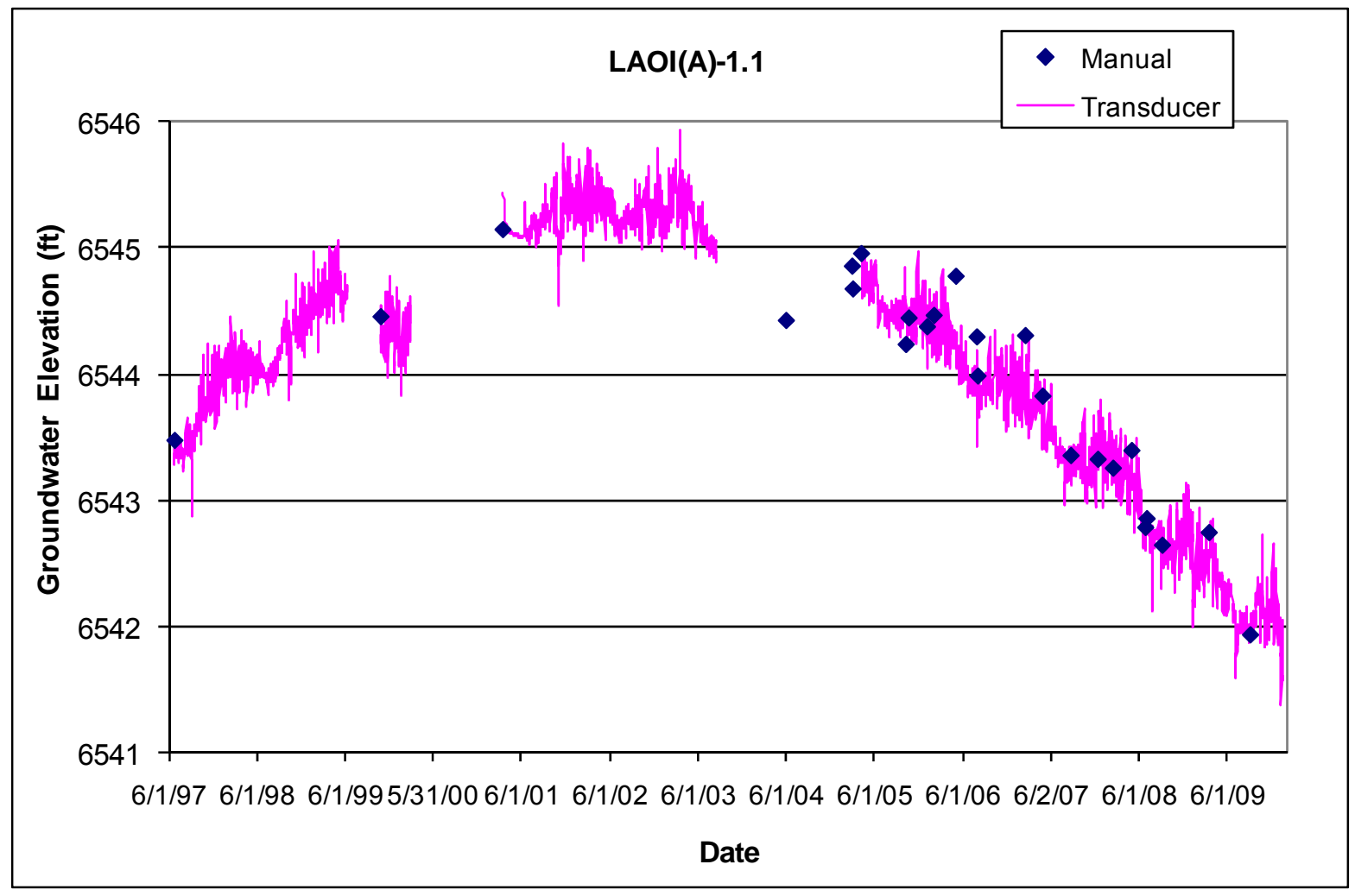




\subsection{LAOI-3.2}

Location: LAOI-3.2 is located in middle Los Alamos Canyon at the confluence with DP Canyon. Completion Type: Single completion in an intermediate zone in the Guaje Pumice bed.

Period of Record: Well completed in March 2005. Transducer installed September 2005; transducer data through 2009.

Remarks: The transducer was removed in October 2005 for pump installation. The transducer was reinstalled in November 2005. The water level declined below the level of the transducer for a time during pumping of the well in December 2005. The well is $100 \%$ barometrically efficient; the groundwater does not respond to atmospheric pressure fluctuations. The groundwater did not indicate a response to snowmelt runoff in 2007 and 2008.

\begin{tabular}{|c|c|c|c|c|c|c|c|c|c|c|c|c|c|c|}
\hline \multicolumn{15}{|c|}{ LAOI-3.2 Construction Information } \\
\hline Screen & $\begin{array}{c}\text { Screen } \\
\text { Top } \\
\text { Depth } \\
\text { (ft) }\end{array}$ & $\begin{array}{c}\text { Screen } \\
\text { Bottom } \\
\text { Depth } \\
\text { (ft) }\end{array}$ & $\begin{array}{c}\text { Screen } \\
\text { Top } \\
\text { Elev (ft) }\end{array}$ & $\begin{array}{l}\text { Screen } \\
\text { Bottom } \\
\text { Elev (ft) }\end{array}$ & $\begin{array}{l}\text { Screen } \\
\text { Length } \\
\text { (ft) }\end{array}$ & $\begin{array}{c}\text { Pump } \\
\text { Intake } \\
\text { Depth } \\
\text { (ft) }\end{array}$ & $\begin{array}{l}\text { Pump } \\
\text { Intake } \\
\text { Elev } \\
\text { (ft) }\end{array}$ & $\begin{array}{l}\text { Depth to } \\
\text { Top of } \\
\text { Sump } \\
\text { (ft) }\end{array}$ & $\begin{array}{c}\text { Top of } \\
\text { Sump } \\
\text { Elev } \\
\text { (ft) }\end{array}$ & $\begin{array}{l}\text { Depth to } \\
\text { Sump } \\
\text { Bottom } \\
\text { (ft) }\end{array}$ & $\begin{array}{c}\text { Sump } \\
\text { Length } \\
\text { (ft) }\end{array}$ & $\begin{array}{c}\text { Sump } \\
\text { Volume } \\
\text { (L) }\end{array}$ & $\begin{array}{l}\text { Hydro } \\
\text { Zone } \\
\text { Code }\end{array}$ & $\begin{array}{l}\text { Geo } \\
\text { Unit } \\
\text { Code }\end{array}$ \\
\hline 1 & 153.3 & 162.8 & 6469.3 & 6459.8 & 9.5 & 159.3 & 6463.3 & 162.8 & 6459.8 & 165 & 2.2 & 1.5 & $\mathrm{~T}$ & Qbog \\
\hline
\end{tabular}

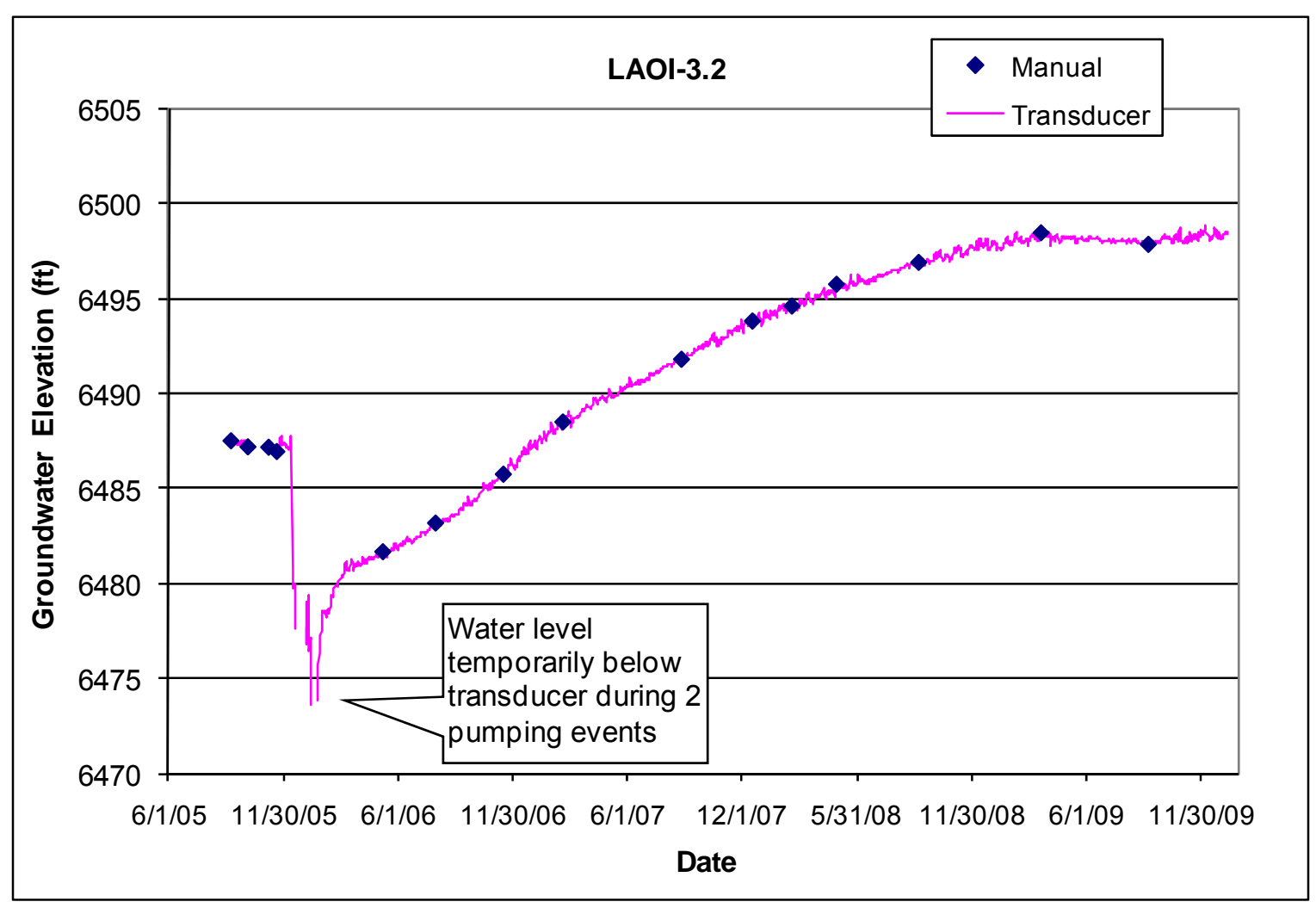




\subsection{LAOI-3.2a}

Location: LAOI-3.2a is located in middle Los Alamos Canyon near the confluence with DP Canyon and about $50 \mathrm{ft}$ northwest of LAOI-3.2.

Completion Type: Single completion in an intermediate zone in Puye fanglomerate.

Period of Record: Well completed in January 2006. Transducer installed August 2006; transducer data through 2009.

Remarks: The water level is about $6 \mathrm{ft}$ above the bottom of the screen. The well is $100 \%$ barometrically efficient, the groundwater does not respond to atmospheric pressure fluctuations. The groundwater did not indicate a response to snowmelt runoff in 2007 and 2008.

\begin{tabular}{|c|c|c|c|c|c|c|c|c|c|c|c|c|c|c|}
\hline \multicolumn{15}{|c|}{ LAOI-3.2a Construction Information } \\
\hline Screen & $\begin{array}{l}\text { Screen } \\
\text { Top } \\
\text { Depth } \\
\text { (ft) }\end{array}$ & \begin{tabular}{|c|} 
Screen \\
Bottom \\
Depth \\
(ft)
\end{tabular} & $\begin{array}{c}\text { Screen } \\
\text { Top } \\
\text { Elev } \\
\text { (ft) }\end{array}$ & $\begin{array}{c}\text { Screen } \\
\text { Bottom } \\
\text { Elev } \\
\text { (ft) }\end{array}$ & $\begin{array}{c}\text { Screen } \\
\text { Length } \\
\text { (ft) }\end{array}$ & $\begin{array}{l}\text { Pump } \\
\text { Intake } \\
\text { Depth } \\
\text { (ft) }\end{array}$ & $\begin{array}{c}\text { Pump } \\
\text { Intake } \\
\text { Elev } \\
\text { (ft) }\end{array}$ & \begin{tabular}{|c} 
Depth to \\
Top of \\
Sump \\
(ft)
\end{tabular} & $\begin{array}{c}\text { Top of } \\
\text { Sump } \\
\text { Elev } \\
\text { (ft) }\end{array}$ & \begin{tabular}{|c} 
Depth to \\
Sump \\
Bottom \\
(ft)
\end{tabular} & $\begin{array}{c}\text { Sump } \\
\text { Length } \\
\text { (ft) }\end{array}$ & $\begin{array}{c}\text { Sump } \\
\text { Volume } \\
\text { (L) }\end{array}$ & $\begin{array}{l}\text { Hydro } \\
\text { Zone } \\
\text { Code }\end{array}$ & $\begin{array}{l}\text { Geo } \\
\text { Unit } \\
\text { Code }\end{array}$ \\
\hline 1 & $\overline{181.4}$ & 191 & 6443.0 & 6433.4 & $\overline{9.6}$ & 189 & 6435.4 & 191.0 & 6433.4 & 191.4 & $\overline{0.4}$ & $\overline{0.6}$ & $\mathrm{~T}$ & Tpf \\
\hline
\end{tabular}

Note: Ground Elevation: $6624.43 \mathrm{ft}$; all measurements are from this elevation

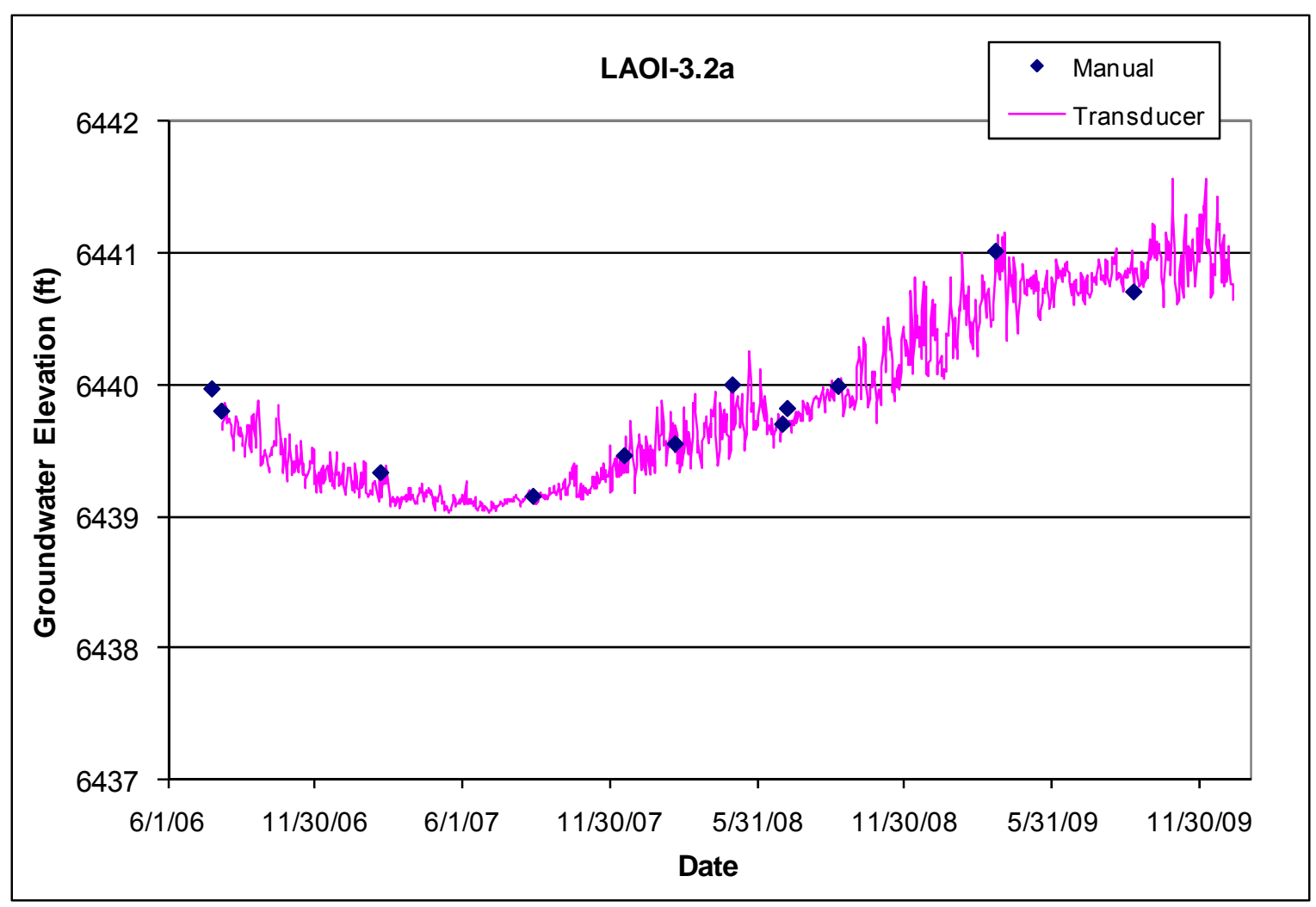




\subsection{LAOI-7}

Location: LAOI-7 is located in middle Los Alamos Canyon about 0.75 miles upstream of R-9i.

Completion Type: Single completion in an intermediate zone in Cerros del Rio basalt.

Period of Record: Well completed in September 2005, transducer installed May 2006, data through 2009.

Remarks: The well has an estimated 18\% barometric efficiency (Kleinfelder 2006a); the groundwater shows a delayed, partial response to atmospheric pressure fluctuations. The groundwater rose about $11 \mathrm{ft}$ in response to snowmelt runoff in 2007 and $5 \mathrm{ft}$ in 2008.

\begin{tabular}{|c|c|c|c|c|c|c|c|c|c|c|c|c|c|c|}
\hline \multicolumn{15}{|c|}{ LAOI-7 Construction Information } \\
\hline Screen & $\begin{array}{l}\text { Screen } \\
\text { Top } \\
\text { Depth } \\
\text { (ft) }\end{array}$ & $\begin{array}{c}\text { Screen } \\
\text { Bottom } \\
\text { Depth } \\
\text { (ft) }\end{array}$ & $\begin{array}{c}\text { Screen } \\
\text { Top } \\
\text { Elev } \\
\text { (ft) }\end{array}$ & \begin{tabular}{|c} 
Screen \\
Bottom \\
Elev \\
(ft)
\end{tabular} & $\begin{array}{c}\text { Screen } \\
\text { Length } \\
\text { (ft) }\end{array}$ & $\begin{array}{c}\text { Pump } \\
\text { Intake } \\
\text { Depth } \\
\text { (ft) }\end{array}$ & $\begin{array}{c}\text { Pump } \\
\text { Intake } \\
\text { Elev } \\
\text { (ft) }\end{array}$ & \begin{tabular}{|} 
Depth to \\
Top of \\
Sump \\
(ft)
\end{tabular} & $\begin{array}{c}\text { Top of } \\
\text { Sump } \\
\text { Elev } \\
\text { (ft) }\end{array}$ & $\begin{array}{l}\text { Depth to } \\
\text { Sump } \\
\text { Bottom } \\
\text { (ft) }\end{array}$ & $\begin{array}{c}\text { Sump } \\
\text { Length } \\
\text { (ft) }\end{array}$ & $\begin{array}{c}\text { Sump } \\
\text { Volume } \\
\text { (L) }\end{array}$ & $\begin{array}{l}\text { Hydro } \\
\text { Zone } \\
\text { Code }\end{array}$ & $\begin{array}{c}\text { Geo } \\
\text { Unit } \\
\text { Code }\end{array}$ \\
\hline 1 & 240.0 & 259.6 & 6218.4 & 6198.8 & 19.6 & 240.0 & 6218.4 & 259.6 & 6198.8 & 264.9 & 5.3 & 7.4 & 1 & Tb4 \\
\hline
\end{tabular}

Note: Brass Cap Elevation: $6458.35 \mathrm{ft}$; all measurements are from this elevation

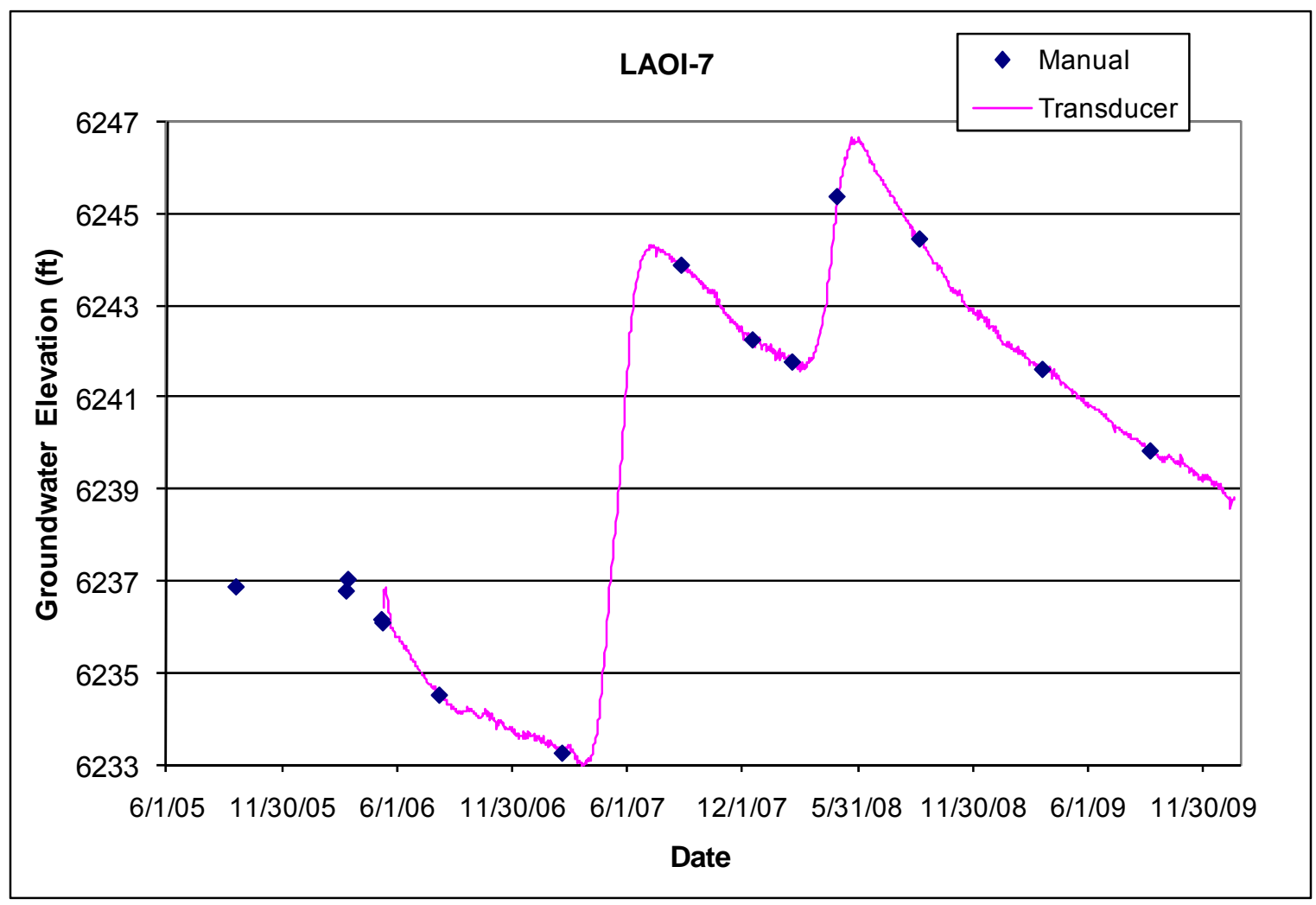




\subsection{MCOBT-4.4}

Location: MCOBT-4.4 was located in lower Mortandad Canyon near the confluence with Ten Site Canyon.

Completion Type: Single completion at the base of the Puye Formation fanglomerate member and the top of Cerros del Rio basalt.

Period of Record: Well completed in June 2001, transducer installed July 2002, data to June 19, 2008, when the transducer was removed and monitoring ceased due to lack of measureable water.

Remarks: MCOI-4 is located about $70 \mathrm{ft}$ west of MCOBT-4.4; the water level at MCOBT-4.4 declined after the installation of MCOI-4. The bottom of the transducer gage tube is located above the pump and about $1.2 \mathrm{ft}$ above the bottom of the screen. The water level declined below the gage tube for portions of 2006 and most of 2007 and 2008. The water level remained near the bottom of the screen after 2006. MCOBT-4.4 was plugged and abandoned in July 2009 (LANL September 2009b).

\begin{tabular}{|c|c|c|c|c|c|c|c|c|c|c|c|c|c|c|}
\hline \multicolumn{15}{|c|}{ MCOBT-4.4 Construction Information } \\
\hline Screen & $\begin{array}{l}\text { Screen } \\
\text { Top } \\
\text { Depth } \\
\text { (ft) }\end{array}$ & $\begin{array}{c}\text { Screen } \\
\text { Bottom } \\
\text { Depth } \\
\text { (ft) }\end{array}$ & $\begin{array}{c}\text { Screen } \\
\text { Top } \\
\text { Elev } \\
\text { (ft) }\end{array}$ & $\begin{array}{l}\text { Screen } \\
\text { Bottom } \\
\text { Elev (ft) }\end{array}$ & $\begin{array}{l}\text { Screen } \\
\text { Length } \\
\text { (ft) }\end{array}$ & $\begin{array}{l}\text { Pump } \\
\text { Intake } \\
\text { Depth } \\
\text { (ft) }\end{array}$ & $\begin{array}{c}\text { Pump } \\
\text { Intake } \\
\text { Elev } \\
\text { (ft) }\end{array}$ & $\begin{array}{l}\text { Depth to } \\
\text { Top of } \\
\text { Sump } \\
\text { (ft) }\end{array}$ & $\begin{array}{c}\text { Top of } \\
\text { Sump } \\
\text { Elev } \\
\text { (ft) }\end{array}$ & $\begin{array}{l}\text { Depth to } \\
\text { Sump } \\
\text { Bottom } \\
\text { (ft) }\end{array}$ & $\begin{array}{c}\text { Sump } \\
\text { Length } \\
\text { (ft) }\end{array}$ & $\begin{array}{c}\text { Sump } \\
\text { Volume } \\
\text { (L) }\end{array}$ & $\begin{array}{c}\text { Hydro } \\
\text { Zone } \\
\text { Code }\end{array}$ & $\begin{array}{l}\text { Geo } \\
\text { Unit } \\
\text { Code }\end{array}$ \\
\hline 1 & 485.4 & 524.0 & 6350.8 & 6312.2 & 38.6 & 524 & 6312.2 & 524.0 & 6312.2 & 545.0 & 21.0 & 64.5 & $\mathrm{I}$ & Tpf \\
\hline
\end{tabular}

Note: Brass Cap Elevation: $6836.18 \mathrm{ft}$; all measurements are from this elevation

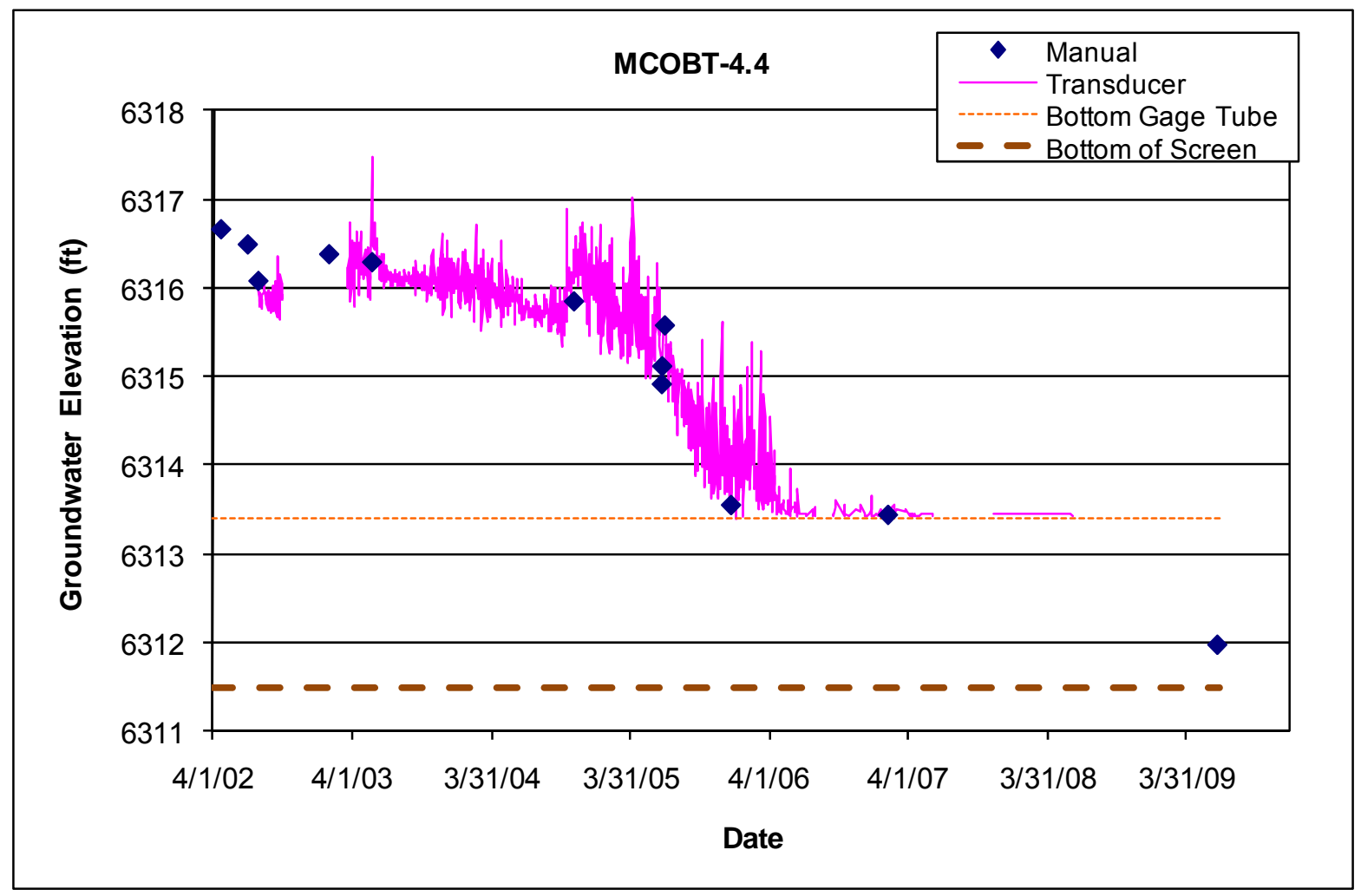




\subsection{MCOI-1}

Location: MCOI-1 is located adjacent to upper Mortandad Canyon below the confluence with Effluent Canyon.

Completion Type: Single completion in the Puye Formation.

Period of Record: Well completed in January 2005. Periodic manual checks for water through 2007. Monitoring of well ceased in 2007.

Remarks: MCOI-1 was dry when completed and has not contained water during periodic checks. Soundings for water throughout 2006 and 2007 have been dry with a total depth of about 814 $\mathrm{ft}$ below ground surface, encountering sand at total depth. This total depth is above the screen; thus it appears that the well screen in the 1-in.-diameter PVC may have parted from the tubing or has been somehow damaged, potentially rendering the well inoperative.

\begin{tabular}{|c|c|c|c|c|c|c|c|c|c|c|c|c|c|c|}
\hline \multicolumn{15}{|c|}{ MCOI-1 Construction Information } \\
\hline Screen & $\begin{array}{l}\text { Screen } \\
\text { Top } \\
\text { Depth } \\
\text { (ft) }\end{array}$ & $\begin{array}{c}\text { Screen } \\
\text { Bottom } \\
\text { Depth } \\
(\mathrm{ft})\end{array}$ & \begin{tabular}{|c} 
Screen \\
Top \\
Elev \\
(ft)
\end{tabular} & $\begin{array}{c}\text { Screen } \\
\text { Bottom } \\
\text { Elev } \\
\text { (ft) }\end{array}$ & $\begin{array}{c}\text { Screen } \\
\text { Length } \\
\text { (ft) }\end{array}$ & $\begin{array}{c}\text { Pump } \\
\text { Intake } \\
\text { Depth } \\
\text { (ft) }\end{array}$ & $\begin{array}{c}\text { Pump } \\
\text { Intake } \\
\text { Elev } \\
\text { (ft) }\end{array}$ & $\begin{array}{c}\text { Depth to } \\
\text { Top of } \\
\text { Sump } \\
\text { (ft) }\end{array}$ & $\begin{array}{c}\text { Top of } \\
\text { Sump } \\
\text { Elev } \\
\text { (ft) }\end{array}$ & \begin{tabular}{|} 
Depth to \\
Sump \\
Bottom \\
(ft)
\end{tabular} & $\begin{array}{c}\text { Sump } \\
\text { Length } \\
\text { (ft) }\end{array}$ & $\begin{array}{c}\text { Sump } \\
\text { Volume } \\
\text { (L) }\end{array}$ & $\begin{array}{l}\text { Hydro } \\
\text { Zone } \\
\text { Code }\end{array}$ & $\begin{array}{l}\text { Geo } \\
\text { Unit } \\
\text { Code }\end{array}$ \\
\hline 1 & 815.0 & 825.5 & 6291.2 & 6280.8 & 10.5 & None & None & 825.5 & 6280.8 & 825.58 & 0.1 & 0.0 & $\mathrm{~T}$ & $\mathrm{Tp}$ \\
\hline
\end{tabular}




\subsection{MCOI-4}

Location: MCOI-4 is located in lower Mortandad Canyon near the confluence with Ten Site Canyon and about $70 \mathrm{ft}$ upstream of MCOBT-4.4.

Completion Type: Single completion at the base of the Puye Formation fanglomerate member and the top of Cerros del Rio basalt.

Period of Record: Well completed in November 2004, transducer installed October 2005, data through 2009.

Remarks: Since 2006, the water level in MCOI-4 has been 2 to $3 \mathrm{ft}$ higher than in adjacent well MCOBT-4.4 and relatively constant about $1 \mathrm{ft}$ above the bottom of the screen. During plugging operations at MCO-BT-4.4 from July 15 to 17,2009 , the water level at MCOI-4 rose about $1 \mathrm{ft}$ and then declined over the next two weeks.

\begin{tabular}{|c|c|c|c|c|c|c|c|c|c|c|c|c|c|c|}
\hline \multicolumn{15}{|c|}{ MCOI-4 Construction Information } \\
\hline Screen & $\begin{array}{l}\text { Screen } \\
\text { Top } \\
\text { Depth } \\
\text { (ft) }\end{array}$ & \begin{tabular}{|c|} 
Screen \\
Bottom \\
Depth \\
(ft)
\end{tabular} & $\begin{array}{c}\text { Screen } \\
\text { Top } \\
\text { Elev } \\
\text { (ft) }\end{array}$ & $\begin{array}{c}\text { Screen } \\
\text { Bottom } \\
\text { Elev } \\
\text { (ft) }\end{array}$ & $\begin{array}{c}\text { Screen } \\
\text { Length } \\
\text { (ft) }\end{array}$ & $\begin{array}{c}\text { Pump } \\
\text { Intake } \\
\text { Depth } \\
\text { (ft) }\end{array}$ & $\begin{array}{c}\text { Pump } \\
\text { Intake } \\
\text { Elev } \\
\text { (ft) }\end{array}$ & \begin{tabular}{|} 
Depth to \\
Top of \\
Sump \\
(ft)
\end{tabular} & $\begin{array}{c}\text { Top of } \\
\text { Sump } \\
\text { Elev } \\
\text { (ft) }\end{array}$ & $\begin{array}{l}\text { Depth to } \\
\text { Sump } \\
\text { Bottom } \\
\text { (ft) }\end{array}$ & $\begin{array}{c}\text { Sump } \\
\text { Length } \\
\text { (ft) }\end{array}$ & $\begin{array}{c}\text { Sump } \\
\text { Volume } \\
\text { (L) }\end{array}$ & $\begin{array}{c}\text { Hydro } \\
\text { Zone } \\
\text { Code }\end{array}$ & $\begin{array}{l}\text { Geo } \\
\text { Unit } \\
\text { Code }\end{array}$ \\
\hline 1 & 499.0 & 522.0 & 6338.2 & 6315.2 & 23.0 & 524.0 & 6313.2 & 522.0 & 6315.2 & 525.7 & \begin{tabular}{|c|}
3.7 \\
\end{tabular} & 11.6 & $T$ & Tpf \\
\hline
\end{tabular}

Note: Ground Elevation: $6837.20 \mathrm{ft}$; all measurements are from this elevation

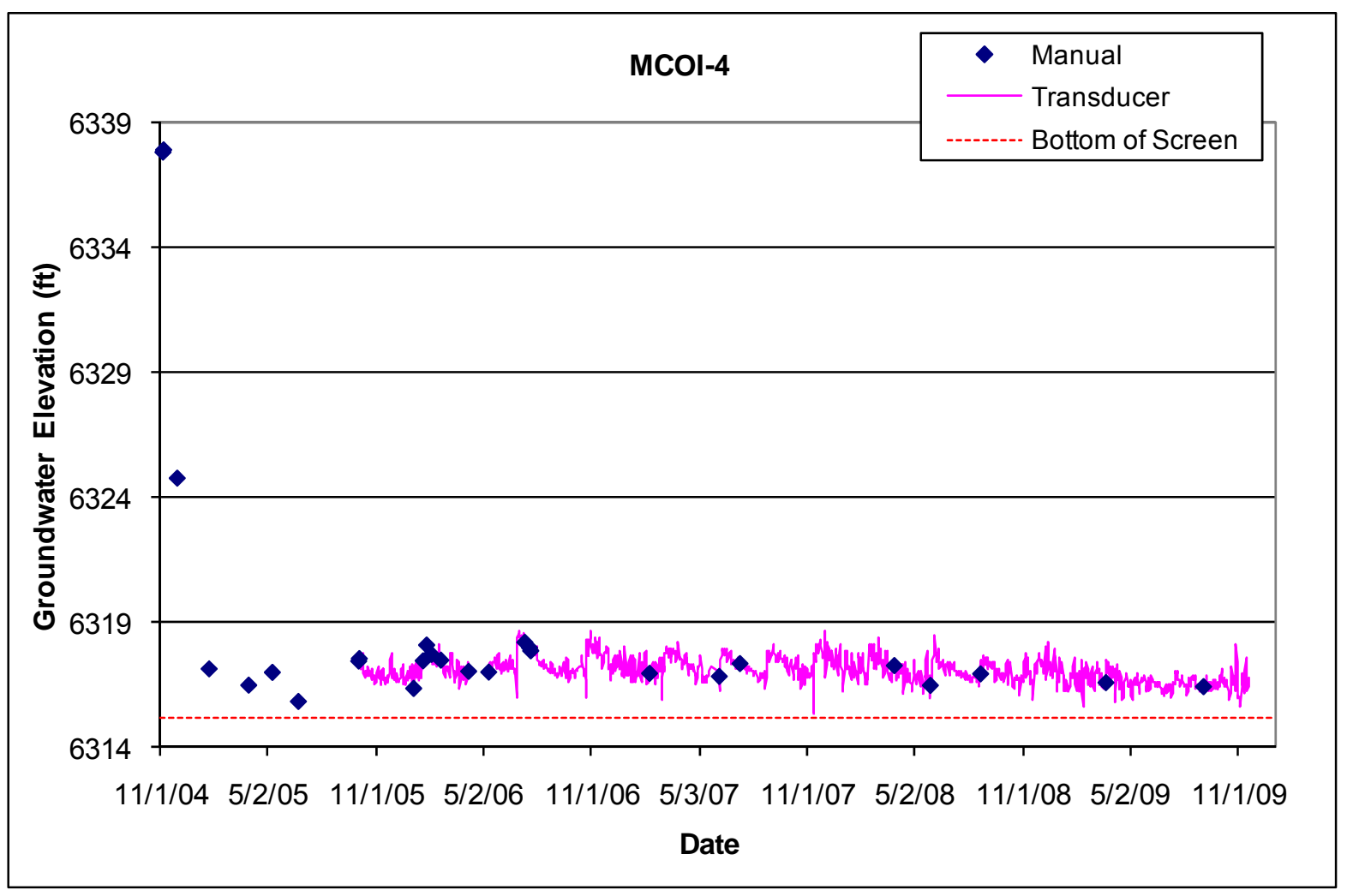




\subsection{MCOI-5}

Location: MCOI-5 is located in lower Mortandad Canyon near regional aquifer well R-15.

Completion Type: Single completion in Cerros del Rio basalt.

Period of Record: Well completed in October 2004, transducer installed August 2005, data through 2009.

Remarks: The transducer was removed for bailing sampling in 2005. A dedicated submersible pump was installed March 2006. The intermediate groundwater has a delayed response to atmospheric pressure fluctuations.

\begin{tabular}{|c|c|c|c|c|c|c|c|c|c|c|c|c|c|c|}
\hline \multicolumn{15}{|c|}{ MCOI-5 Construction Information } \\
\hline Screen & \begin{tabular}{|c} 
Screen \\
Top \\
Depth \\
(ft)
\end{tabular} & $\begin{array}{c}\text { Screen } \\
\text { Bottom } \\
\text { Depth } \\
\text { (ft) }\end{array}$ & $\begin{array}{c}\text { Screen } \\
\text { Top } \\
\text { Elev } \\
\text { (ft) }\end{array}$ & $\begin{array}{c}\text { Screen } \\
\text { Bottom } \\
\text { Elev } \\
\text { (ft) }\end{array}$ & $\begin{array}{c}\text { Screen } \\
\text { Length } \\
\text { (ft) }\end{array}$ & \begin{tabular}{|c|} 
Pump \\
Intake \\
Depth \\
(ft)
\end{tabular} & $\begin{array}{c}\text { Pump } \\
\text { Intake } \\
\text { Elev } \\
\text { (ft) }\end{array}$ & $\begin{array}{l}\text { Depth to } \\
\text { Top of } \\
\text { Sump } \\
\text { (ft) }\end{array}$ & $\begin{array}{c}\text { Top of } \\
\text { Sump } \\
\text { Elev } \\
\text { (ft) }\end{array}$ & \begin{tabular}{|c} 
Depth to \\
Sump \\
Bottom \\
(ft)
\end{tabular} & $\begin{array}{c}\text { Sump } \\
\text { Length } \\
\text { (ft) }\end{array}$ & $\begin{array}{c}\text { Sump } \\
\text { Volume } \\
\text { (L) }\end{array}$ & $\begin{array}{l}\text { Hydro } \\
\text { Zone } \\
\text { Code }\end{array}$ & $\begin{array}{c}\text { Geo } \\
\text { Unit } \\
\text { Code }\end{array}$ \\
\hline 1 & 689.0 & 699.0 & 6130.7 & 6120.7 & 10.0 & 696.0 & 6123.7 & 699.0 & 6120.7 & 702.7 & 3.7 & 11.6 & 1 & $\mathrm{~Tb} 4$ \\
\hline
\end{tabular}

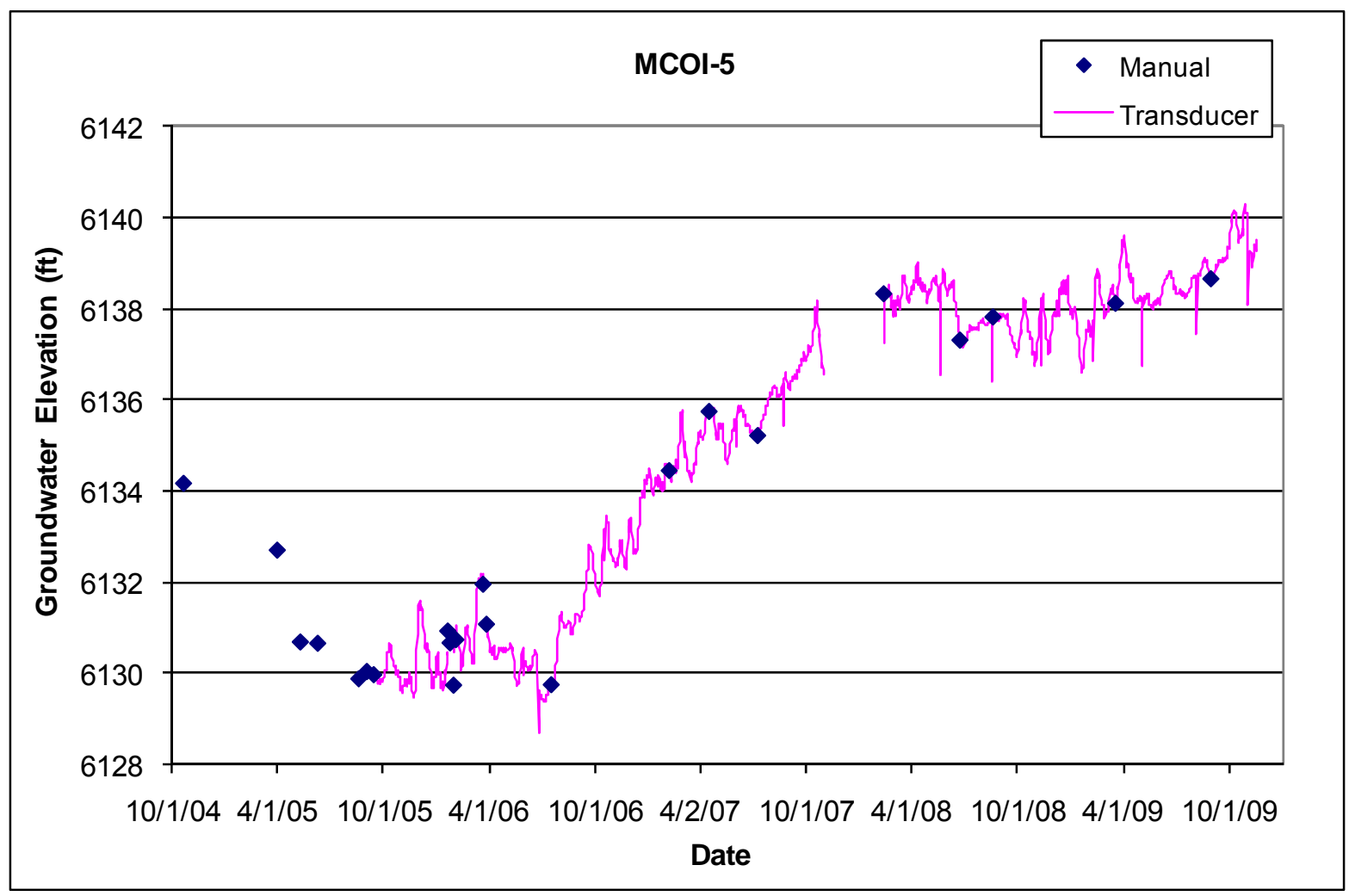




\subsection{MCOI-6}

Location: MCOI-6 is located in lower Mortandad Canyon about $160 \mathrm{ft}$ northeast of MCOI-5.

Completion Type: Single completion in Cerros del Rio basalt.

Period of Record: Well completed in January 2005, transducer installed August 2005, data through 2009.

Remarks: The groundwater level is about $20 \mathrm{ft}$ above the top of the screen and 17 to $18 \mathrm{ft}$ higher than at MCOI-5. The intermediate groundwater has a delayed response to atmospheric pressure fluctuations.

\begin{tabular}{|c|c|c|c|c|c|c|c|c|c|c|c|c|c|c|}
\hline \multicolumn{15}{|c|}{ MCOI-6 Construction Information } \\
\hline Screen & $\begin{array}{l}\text { Screen } \\
\text { Top } \\
\text { Depth } \\
\text { (ft) }\end{array}$ & $\begin{array}{c}\text { Screen } \\
\text { Bottom } \\
\text { Depth } \\
\text { (ft) }\end{array}$ & $\begin{array}{c}\text { Screen } \\
\text { Top } \\
\text { Elev } \\
\text { (ft) }\end{array}$ & $\begin{array}{c}\text { Screen } \\
\text { Bottom } \\
\text { Elev } \\
\text { (ft) }\end{array}$ & $\begin{array}{c}\text { Screen } \\
\text { Length } \\
\text { (ft) }\end{array}$ & $\begin{array}{l}\text { Pump } \\
\text { Intake } \\
\text { Depth } \\
\text { (ft) }\end{array}$ & $\begin{array}{c}\text { Pump } \\
\text { Intake } \\
\text { Elev } \\
\text { (ft) }\end{array}$ & $\begin{array}{c}\text { Depth to } \\
\text { Top of } \\
\text { Sump } \\
\text { (ft) }\end{array}$ & $\begin{array}{c}\text { Top of } \\
\text { Sump } \\
\text { Elev } \\
\text { (ft) }\end{array}$ & $\begin{array}{c}\text { Depth to } \\
\text { Sump } \\
\text { Bottom } \\
\text { (ft) }\end{array}$ & $\begin{array}{l}\text { Sump } \\
\text { Length } \\
\text { (ft) }\end{array}$ & $\begin{array}{c}\text { Sump } \\
\text { Volume } \\
\text { (L) }\end{array}$ & $\begin{array}{c}\text { Hydro } \\
\text { Zone } \\
\text { Code }\end{array}$ & $\begin{array}{l}\text { Geo } \\
\text { Unit } \\
\text { Code }\end{array}$ \\
\hline 1 & 686.0 & 708.3 & 6125.1 & 6102.8 & 22.3 & 689.0 & 6122.1 & 708.3 & 6102.8 & 713.2 & 4.9 & 15.3 & $\mathrm{~T}$ & $\overline{T b 4}$ \\
\hline
\end{tabular}

Note: Brass cap elevation: $6811.10 \mathrm{ft}$; all measurements are from this elevation

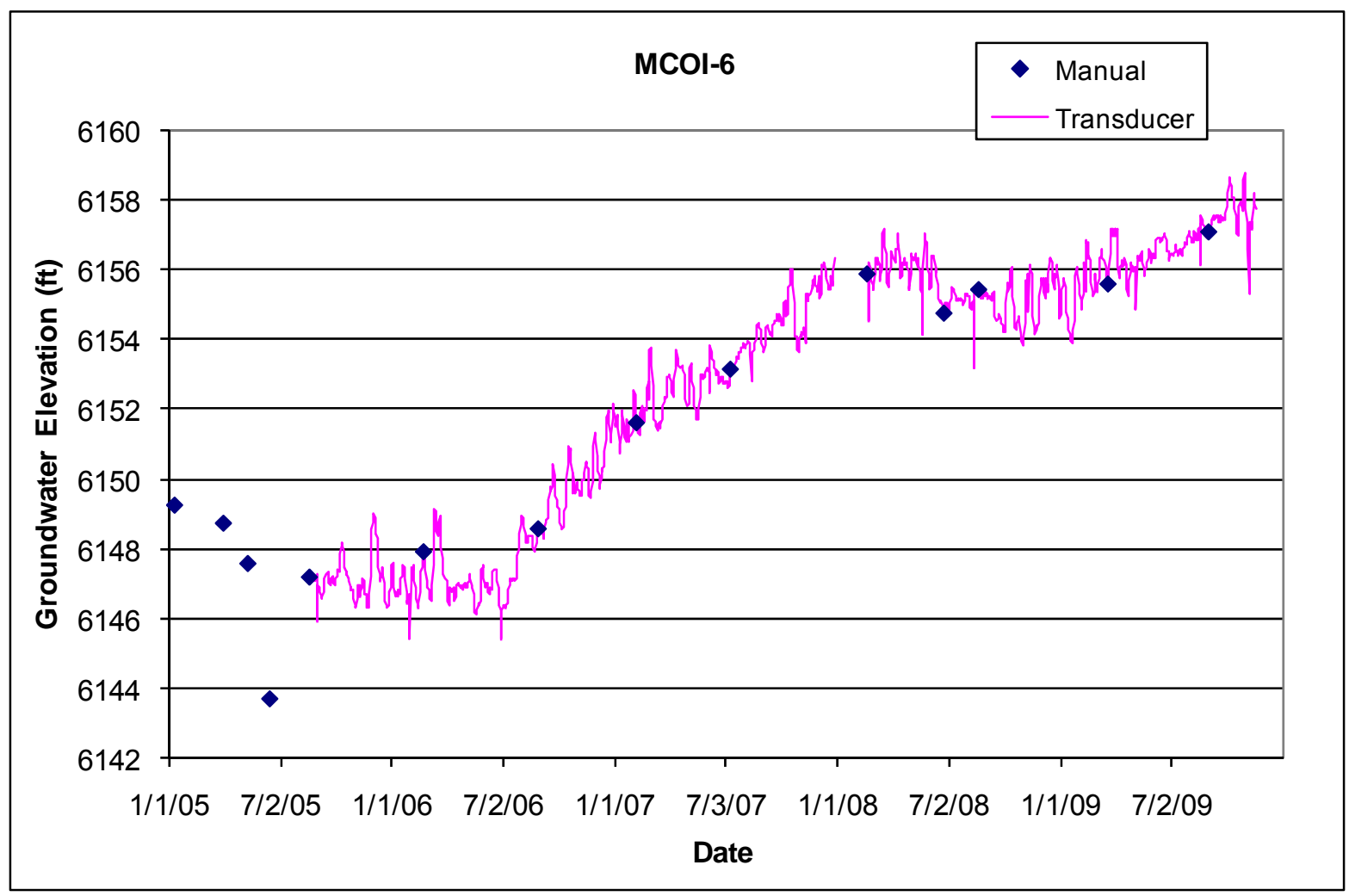




\subsection{MCOI-8}

Location: MCOI-8 is located in lower Mortandad Canyon above the confluence with Ten Site Canyon. Completion Type: Single completion in Cerros del Rio basalt.

Period of Record: Well completed in January 2005, transducer installed August 2005, data through 2009.

Remarks: Since well completion, water has been measured in the sump of the well; thus data are not valid groundwater level data.

\begin{tabular}{|c|c|c|c|c|c|c|c|c|c|c|c|c|c|c|}
\hline \multicolumn{15}{|c|}{ MCOI-8 Construction Information } \\
\hline Screen & $\begin{array}{l}\text { Screen } \\
\text { Top } \\
\text { Depth } \\
\text { (ft) }\end{array}$ & $\begin{array}{c}\text { Screen } \\
\text { Bottom } \\
\text { Depth } \\
\text { (ft) }\end{array}$ & $\begin{array}{c}\text { Screen } \\
\text { Top } \\
\text { Elev } \\
\text { (ft) }\end{array}$ & $\begin{array}{c}\text { Screen } \\
\text { Bottom } \\
\text { Elev } \\
\text { (ft) }\end{array}$ & $\begin{array}{c}\text { Screen } \\
\text { Length } \\
\text { (ft) }\end{array}$ & $\begin{array}{l}\text { Pump } \\
\text { Intake } \\
\text { Depth } \\
\text { (ft) }\end{array}$ & $\begin{array}{c}\text { Pump } \\
\text { Intake } \\
\text { Elev } \\
\text { (ft) }\end{array}$ & $\begin{array}{c}\text { Depth to } \\
\text { Top of } \\
\text { Sump (ft) }\end{array}$ & $\begin{array}{c}\text { Top of } \\
\text { Sump } \\
\text { Elev } \\
\text { (ft) }\end{array}$ & $\begin{array}{c}\text { Depth to } \\
\text { Sump } \\
\text { Bottom } \\
\text { (ft) }\end{array}$ & $\begin{array}{c}\text { Sump } \\
\text { Length } \\
\text { (ft) }\end{array}$ & $\begin{array}{c}\text { Sump } \\
\text { Volume } \\
\text { (L) }\end{array}$ & $\begin{array}{l}\text { Hydro } \\
\text { Zone } \\
\text { Code }\end{array}$ & $\begin{array}{l}\text { Geo } \\
\text { Unit } \\
\text { Code }\end{array}$ \\
\hline 1 & 665.0 & 675.0 & $\overline{6194.2}$ & 6184.2 & 10.0 & None & None & 675.0 & 6184.2 & 678.6 & 3.6 & 11.4 & $\mathrm{~T}$ & Tb4 \\
\hline
\end{tabular}

Note: Ground Elevation: $6859.20 \mathrm{ft}$; all measurements are from this elevation

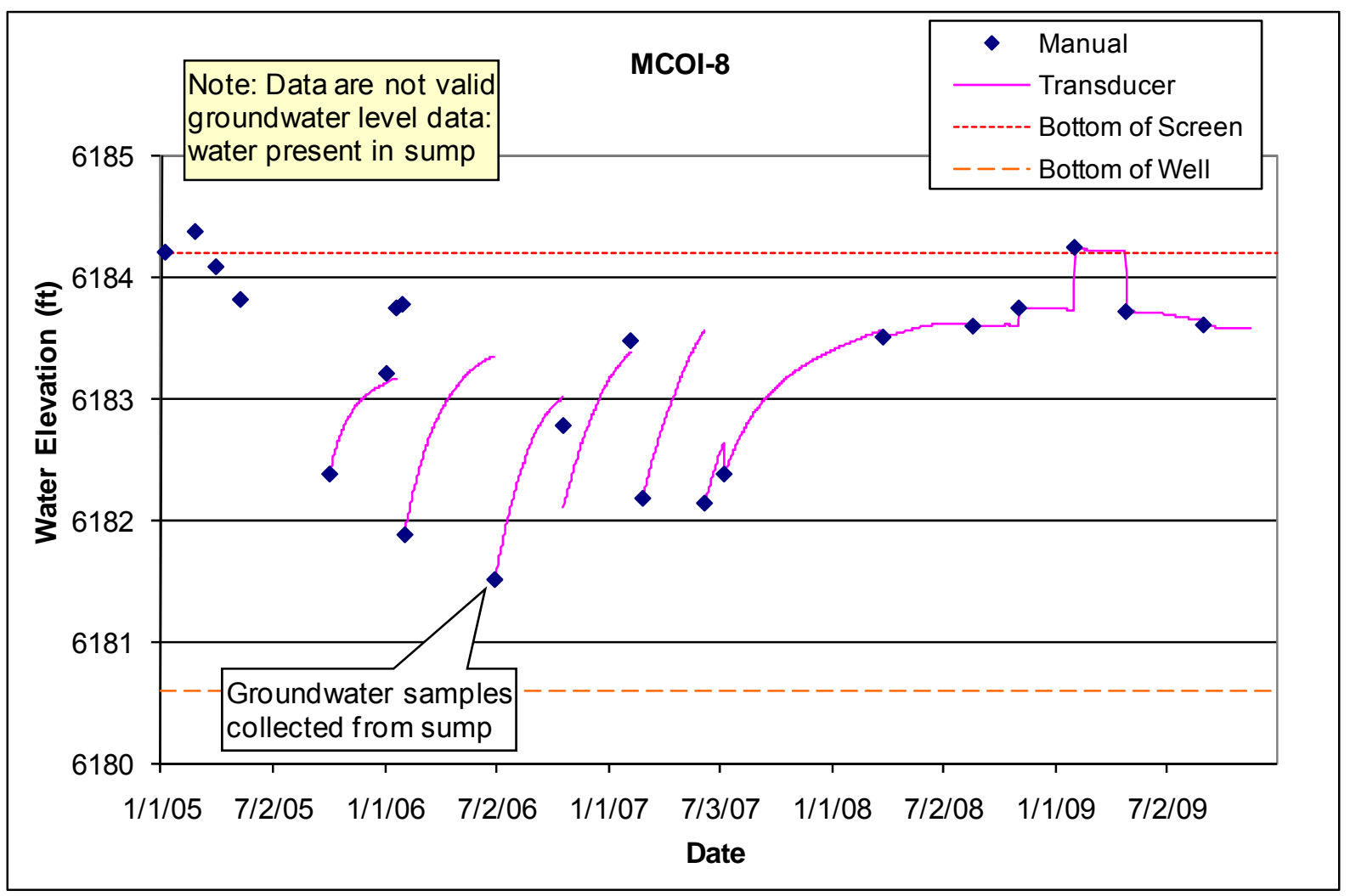




\subsection{MSC-16-02665}

Location: MSC-16-02665 is located at TA-16 at the head of Martin Spring Canyon (S-Site Canyon) about $1500 \mathrm{ft}$ west of R-48 and about $700 \mathrm{ft}$ northwest of Martin Spring.

Completion Type: Single completion in Unit 3 of the Bandelier tuff.

Period of Record: Well completed October 1997, no transducer has been installed, periodic manual measurements through March 2009.

Remarks: MSC-16-02665 has usually been dry; water has been observed in the well after heavy precipitation periods and snowmelt runoff (LANL 2003, p. 4-58). The well was dry when checked in the spring of 2005, 2006, 2007, 2008, and 2009.

\begin{tabular}{|c|c|c|c|c|c|c|c|c|c|c|c|c|c|c|}
\hline \multicolumn{15}{|c|}{ MSC-16-02665 Construction Information } \\
\hline Screen & $\begin{array}{c}\text { Screen } \\
\text { Top } \\
\text { Depth } \\
\text { (ft) }\end{array}$ & $\begin{array}{c}\text { Screen } \\
\text { Bottom } \\
\text { Depth } \\
\text { (ft) }\end{array}$ & $\begin{array}{c}\text { Screen } \\
\text { Top } \\
\text { Elev } \\
\text { (ft) }\end{array}$ & $\begin{array}{c}\text { Screen } \\
\text { Bottom } \\
\text { Elev } \\
\text { (ft) }\end{array}$ & $\begin{array}{c}\text { Screen } \\
\text { Length } \\
\text { (ft) }\end{array}$ & $\begin{array}{c}\text { Pump } \\
\text { Intake } \\
\text { Depth } \\
\text { (ft) }\end{array}$ & $\begin{array}{c}\text { Pump } \\
\text { Intake } \\
\text { Elev } \\
\text { (ft) }\end{array}$ & $\begin{array}{c}\text { Depth to } \\
\text { Top of } \\
\text { Sump } \\
\text { (ft) }\end{array}$ & \begin{tabular}{|c} 
Top of \\
Sump \\
Elev \\
(ft)
\end{tabular} & \begin{tabular}{|} 
Depth to \\
Sump \\
Bottom \\
(ft)
\end{tabular} & $\begin{array}{c}\text { Sump } \\
\text { Length } \\
\text { (ft) }\end{array}$ & $\begin{array}{c}\text { Sump } \\
\text { Volume } \\
\text { (L) }\end{array}$ & $\begin{array}{l}\text { Hydro } \\
\text { Zone } \\
\text { Code }\end{array}$ & $\begin{array}{l}\text { Geo } \\
\text { Unit } \\
\text { Code }\end{array}$ \\
\hline 1 & 93.5 & 123.5 & 7423.4 & 7393.4 & 30.0 & None & None & 123.5 & 7393.4 & 124.0 & 0.5 & 0.3 & $\mathrm{~T}$ & Qbt3 \\
\hline
\end{tabular}

Note: Ground Elevation: $7516.92 \mathrm{ft}$; all measurements are from this elevation

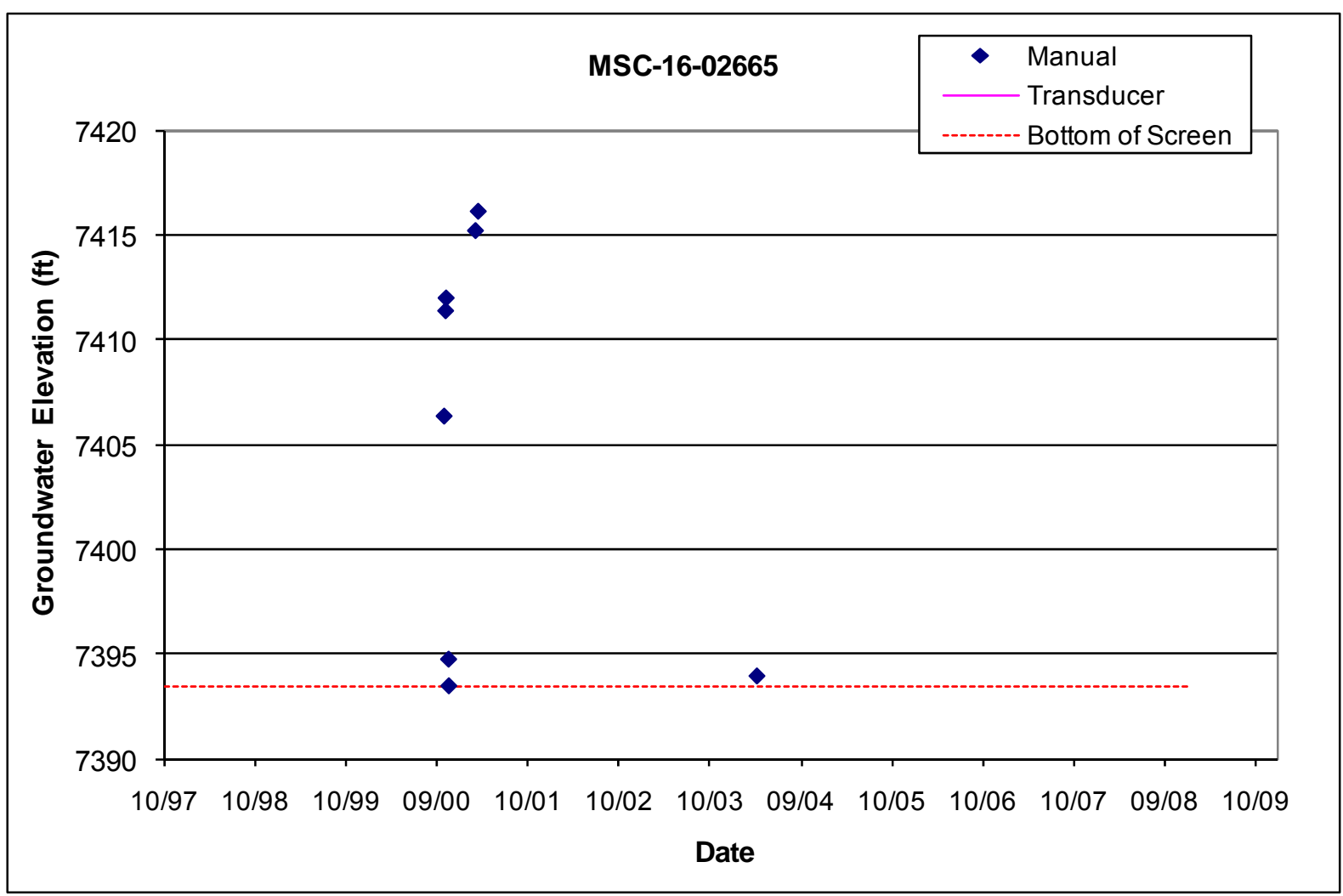




\subsection{2 $\mathrm{PCl}-2$}

Location: PCl-2 is located in middle Pajarito Canyon about $150 \mathrm{ft}$ west and upstream of R-17.

Completion Type: Single completion in the Puye fanglomerates and about $35 \mathrm{ft}$ above Tschicoma dacite (LANL September 2009).

Period of Record: Well completed April 2009, transducer installed June 25, 2009; data through 2009.

Remarks: The well is $100 \%$ barometrically efficient; however, the aquifer exhibits a delayed response to atmospheric pressure fluctuations.

\begin{tabular}{|c|c|c|c|c|c|c|c|c|c|c|c|c|c|c|}
\hline \multicolumn{15}{|c|}{ PCl-2 Construction Information } \\
\hline Screen & \begin{tabular}{|c} 
Screen \\
Top \\
Depth \\
(ft)
\end{tabular} & $\begin{array}{c}\text { Screen } \\
\text { Bottom } \\
\text { Depth } \\
\text { (ft) }\end{array}$ & $\begin{array}{c}\text { Screen } \\
\text { Top } \\
\text { Elev } \\
\text { (ft) }\end{array}$ & $\begin{array}{c}\text { Screen } \\
\text { Bottom } \\
\text { Elev } \\
\text { (ft) }\end{array}$ & $\begin{array}{c}\text { Screen } \\
\text { Length } \\
\text { (ft) }\end{array}$ & $\begin{array}{c}\text { Pump } \\
\text { Intake } \\
\text { Depth } \\
\text { (ft) }\end{array}$ & $\begin{array}{c}\text { Pump } \\
\text { Intake } \\
\text { Elev } \\
\text { (ft) }\end{array}$ & $\begin{array}{l}\text { Depth } \\
\text { to Top } \\
\text { of } \\
\text { Sump } \\
\text { (ft) }\end{array}$ & $\left|\begin{array}{c}\text { Top of } \\
\text { Sump } \\
\text { Elev } \\
\text { (ft) }\end{array}\right|$ & $\begin{array}{c}\text { Depth } \\
\text { to } \\
\text { Sump } \\
\text { Bottom } \\
\text { (ft) }\end{array}$ & $\begin{array}{c}\text { Sump } \\
\text { Length } \\
\text { (ft) }\end{array}$ & $\begin{array}{c}\text { Sump } \\
\text { Vol } \\
\text { (Gal.) }\end{array}$ & $\begin{array}{l}\text { Hydro } \\
\text { Zone } \\
\text { Code }\end{array}$ & $\begin{array}{c}\text { Geo } \\
\text { Unit } \\
\text { Code }\end{array}$ \\
\hline 1 & 512.0 & 522.0 & 6409.0 & 6399.0 & 10.0 & 529.3 & 6391.7 & 522.0 & 6399.0 & 533.3 & 11.3 & 2.9 & $\mathrm{~T}$ & $\overline{T p f}$ \\
\hline
\end{tabular}

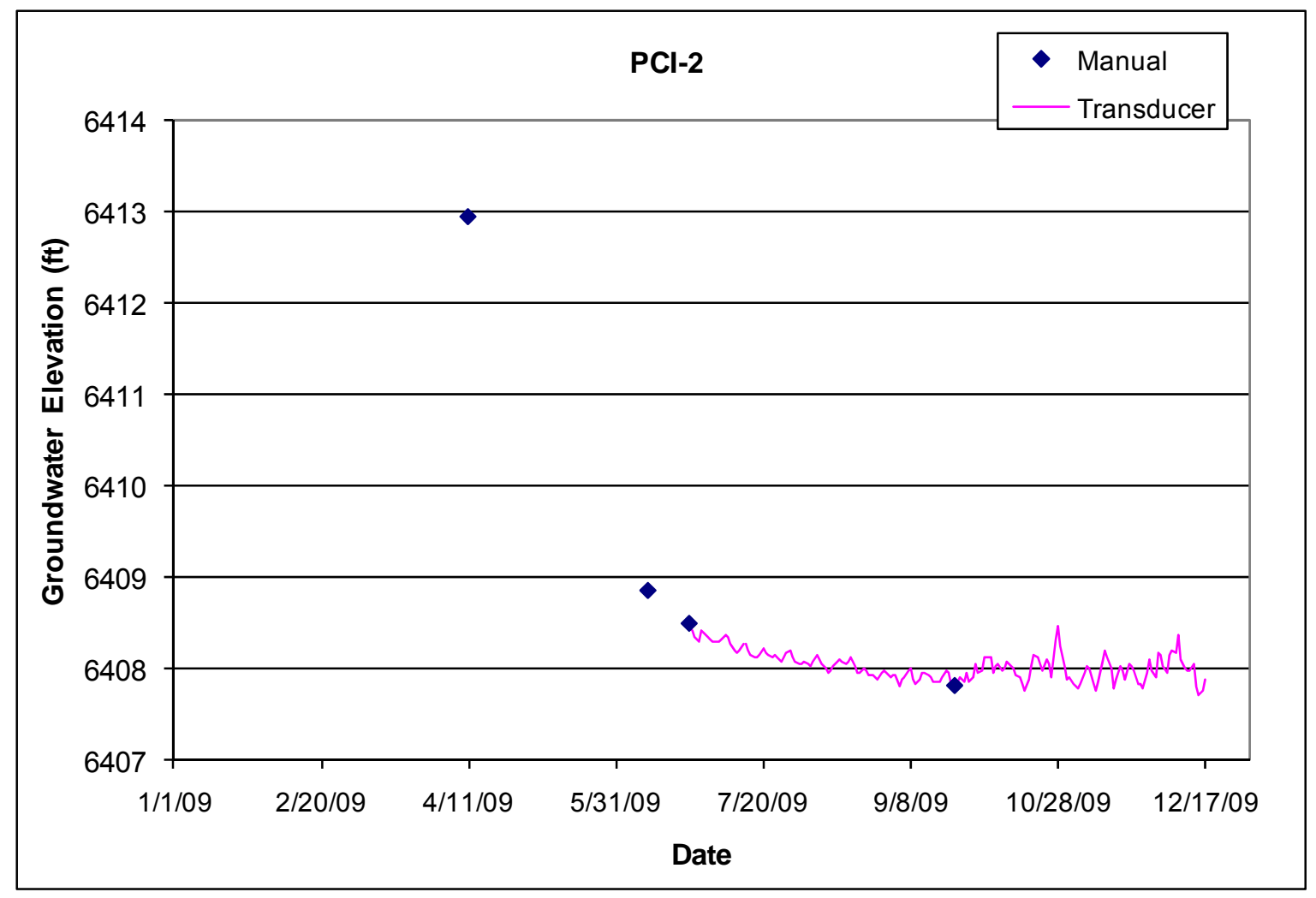




\subsection{POI-4}

Location: POI-4 is located in lower Pueblo Canyon about $800 \mathrm{ft}$ upstream of TW-1 and about $370 \mathrm{ft}$ north of supply well O-1.

Completion Type: Single completion in Cerros del Rio basalt.

Period of Record: Well completed in 1996, transducer installed April 2001 and again in April 2005; data through 2009.

Remarks: The well is $100 \%$ barometrically efficient; the groundwater displays a delayed response to atmospheric pressure fluctuations. The intermediate groundwater shows a seasonal water level fluctuation, generally lower in the summer and higher in the winter.

\begin{tabular}{|c|c|c|c|c|c|c|c|c|c|c|c|c|c|c|}
\hline \multicolumn{15}{|c|}{ POI-4 Construction Information } \\
\hline Screen & $\begin{array}{c}\text { Screen } \\
\text { Top } \\
\text { Depth } \\
\text { (ft) }\end{array}$ & $\begin{array}{c}\text { Screen } \\
\text { Bottom } \\
\text { Depth } \\
\text { (ft) }\end{array}$ & $\begin{array}{c}\text { Screen } \\
\text { Top } \\
\text { Elev } \\
\text { (ft) }\end{array}$ & $\begin{array}{c}\text { Screen } \\
\text { Bottom } \\
\text { Elev } \\
(\mathrm{ft})\end{array}$ & $\begin{array}{c}\text { Screen } \\
\text { Length } \\
\text { (ft) }\end{array}$ & $\begin{array}{c}\text { Pump } \\
\text { Intake } \\
\text { Depth } \\
\text { (ft) }\end{array}$ & $\begin{array}{c}\text { Pump } \\
\text { Intake } \\
\text { Elev } \\
\text { (ft) }\end{array}$ & $\begin{array}{l}\text { Depth to } \\
\text { Top of } \\
\text { Sump } \\
\text { (ft) }\end{array}$ & $\begin{array}{c}\text { Top of } \\
\text { Sump } \\
\text { Elev } \\
\text { (ft) }\end{array}$ & \begin{tabular}{|c} 
Depth to \\
Sump \\
Bottom \\
(ft)
\end{tabular} & $\begin{array}{c}\text { Sump } \\
\text { Length } \\
\text { (ft) }\end{array}$ & $\begin{array}{c}\text { Sump } \\
\text { Volume } \\
\text { (L) }\end{array}$ & $\begin{array}{l}\text { Hydro } \\
\text { Zone } \\
\text { Code }\end{array}$ & $\begin{array}{l}\text { Geo } \\
\text { Unit } \\
\text { Code }\end{array}$ \\
\hline 1 & 159.0 & 174.0 & 6213.3 & 6198.3 & 15.0 & 173.0 & 6199.3 & 174.0 & 6198.3 & 176.5 & 2.5 & 6.2 & $T$ & $\overline{\mathrm{Tb} 4}$ \\
\hline
\end{tabular}

Note: Ground Elevation: $6372.29 \mathrm{ft}$; all measurements are from this elevation

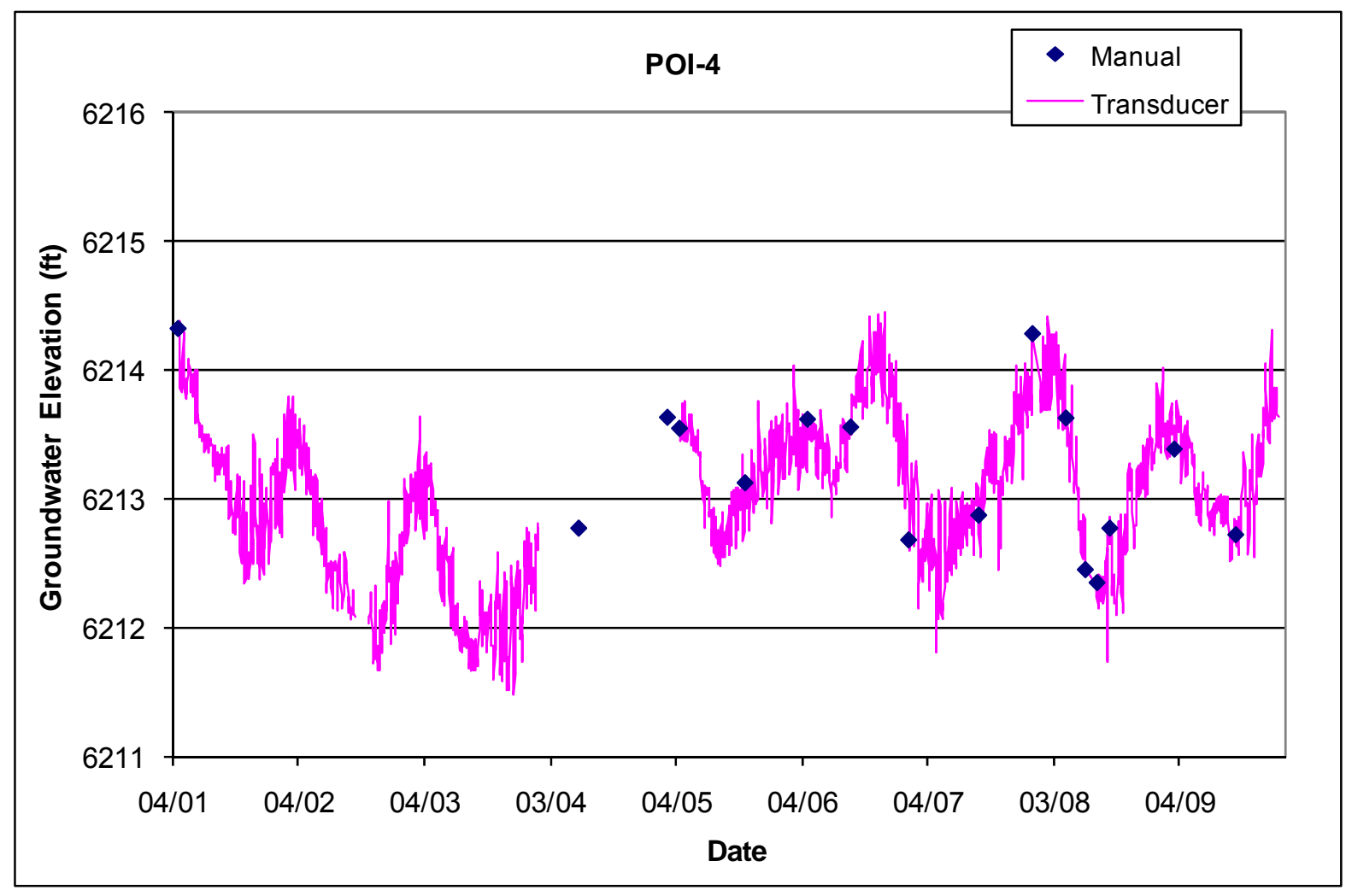




\subsection{R-3i}

Location: R-3i is located in lower Pueblo Canyon about $240 \mathrm{ft}$ west of intermediate well POI-4 and about $425 \mathrm{ft} \mathrm{northwest} \mathrm{of} \mathrm{supply} \mathrm{well} \mathrm{O-1.}$

Completion Type: Single completion in the Cerros del Rio basalt.

Period of Record: Well completed August 2005, transducer installed April 2007, data through 2009.

Remarks: The well is $100 \%$ barometrically efficient; the groundwater does not respond to atmospheric pressure fluctuations. The groundwater level rises during winter and falls during summer, but did not show a significant response to snowmelt runoff in 2007 or 2008 . The intermediate groundwater appears to show a seasonal water level fluctuation similar to POI-4, but the water level at R-3i is 10 to $15 \mathrm{ft}$ lower than at POI-4.

\begin{tabular}{|c|c|c|c|c|c|c|c|c|c|c|c|c|c|c|}
\hline \multicolumn{15}{|c|}{ R-3i Construction Information } \\
\hline Screen & $\begin{array}{c}\text { Screen } \\
\text { Top } \\
\text { Depth } \\
\text { (ft) }\end{array}$ & $\begin{array}{c}\text { Screen } \\
\text { Bottom } \\
\text { Depth } \\
\text { (ft) }\end{array}$ & $\begin{array}{c}\text { Screen } \\
\text { Top } \\
\text { Elev } \\
\text { (ft) }\end{array}$ & \begin{tabular}{|c|} 
Screen \\
Bottom \\
Elev \\
(ft)
\end{tabular} & $\begin{array}{c}\text { Screen } \\
\text { Length } \\
\text { (ft) }\end{array}$ & $\begin{array}{c}\text { Pump } \\
\text { Intake } \\
\text { Depth } \\
\text { (ft) }\end{array}$ & $\begin{array}{c}\text { Pump } \\
\text { Intake } \\
\text { Elev } \\
\text { (ft) }\end{array}$ & \begin{tabular}{|} 
Depth to \\
Top of \\
Sump \\
(ft)
\end{tabular} & $\begin{array}{c}\text { Top of } \\
\text { Sump } \\
\text { Elev } \\
\text { (ft) }\end{array}$ & $\begin{array}{l}\text { Depth to } \\
\text { Sump } \\
\text { Bottom } \\
\text { (ft) }\end{array}$ & $\begin{array}{c}\text { Sump } \\
\text { Length } \\
\text { (ft) }\end{array}$ & $\begin{array}{c}\text { Sump } \\
\text { Volume } \\
\text { (L) }\end{array}$ & $\begin{array}{c}\text { Hydro } \\
\text { Zone } \\
\text { Code }\end{array}$ & $\begin{array}{l}\text { Geo } \\
\text { Unit } \\
\text { Code }\end{array}$ \\
\hline 1 & 215.2 & 220 & 6175.0 & 6170.2 & 4.8 & 217.0 & 6173.2 & 220.0 & 6170.2 & 220.34 & 0.3 & 0.2 & $T$ & Tb4 \\
\hline
\end{tabular}

Note: Ground Elevation: $6390.15 \mathrm{ft}$; all measurements are from this elevation

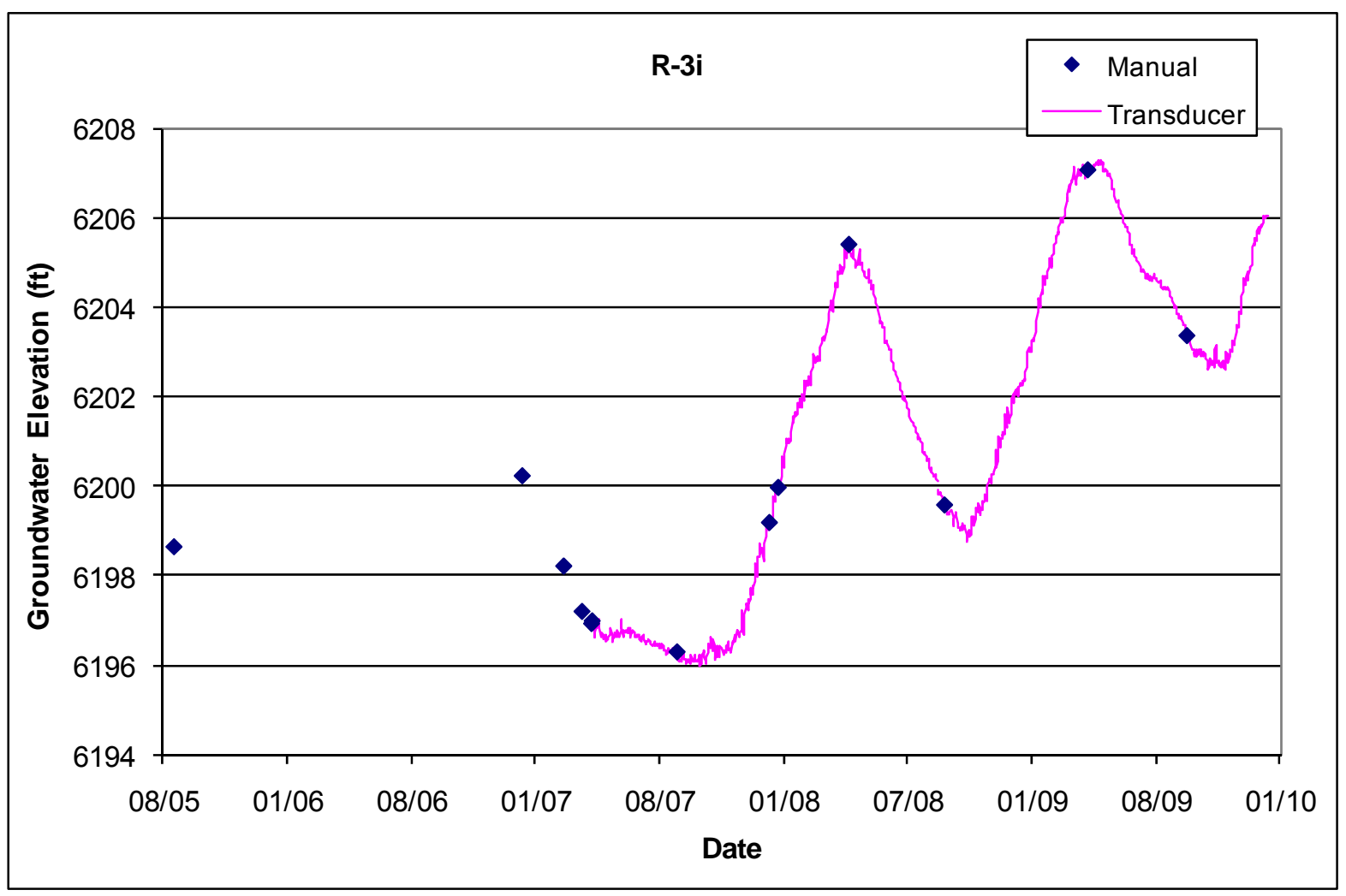




\subsection{R-6i}

Location: R-6i is located at the eastern extent of DP Mesa near the confluence of DP Canyon and Los Alamos Canyon and adjacent to regional aquifer monitoring well R-6.

Completion Type: Single completion in the Puye Formation fanglomerate member.

Period of Record: Well completed December 2004, transducer installed October 2005, data through 2009.

Remarks: The well is $100 \%$ barometrically efficient; the groundwater does not respond to atmospheric pressure fluctuations. The perched intermediate groundwater did not respond to snowmelt runoff in 2007 or 2008.

\begin{tabular}{|c|c|c|c|c|c|c|c|c|c|c|c|c|c|c|}
\hline \multicolumn{15}{|c|}{ R-6i Construction Information } \\
\hline Screen & $\begin{array}{c}\text { Screen } \\
\text { Top } \\
\text { Depth } \\
\text { (ft) }\end{array}$ & $\begin{array}{c}\text { Screen } \\
\text { Bottom } \\
\text { Depth } \\
\text { (ft) }\end{array}$ & $\begin{array}{c}\text { Screen } \\
\text { Top } \\
\text { Elev } \\
\text { (ft) }\end{array}$ & $\begin{array}{c}\text { Screen } \\
\text { Bottom } \\
\text { Elev } \\
\text { (ft) }\end{array}$ & $\begin{array}{c}\text { Screen } \\
\text { Length } \\
\text { (ft) }\end{array}$ & $\begin{array}{c}\text { Pump } \\
\text { Intake } \\
\text { Depth } \\
\text { (ft) }\end{array}$ & $\begin{array}{c}\text { Pump } \\
\text { Intake } \\
\text { Elev } \\
\text { (ft) }\end{array}$ & \begin{tabular}{|} 
Depth to \\
Top of \\
Sump \\
(ft)
\end{tabular} & $\begin{array}{c}\text { Top of } \\
\text { Sump } \\
\text { Elev } \\
\text { (ft) }\end{array}$ & \begin{tabular}{|} 
Depth to \\
Sump \\
Bottom \\
(ft)
\end{tabular} & $\begin{array}{c}\text { Sump } \\
\text { Length } \\
\text { (ft) }\end{array}$ & $\begin{array}{c}\text { Sump } \\
\text { Volume } \\
\text { (L) }\end{array}$ & $\begin{array}{l}\text { Hydro } \\
\text { Zone } \\
\text { Code }\end{array}$ & $\begin{array}{c}\text { Geo } \\
\text { Unit } \\
\text { Code }\end{array}$ \\
\hline 1 & 602.0 & 612 & 6394.9 & 6384.9 & 10.0 & 609.0 & 6387.9 & 612.0 & 6384.9 & 615 & 3.0 & 9.2 & $\mathrm{~T}$ & Tpf \\
\hline
\end{tabular}

Note: Brass Cap Ground Elevation: $6996.9 \mathrm{ft}$; all depths are from this elevation

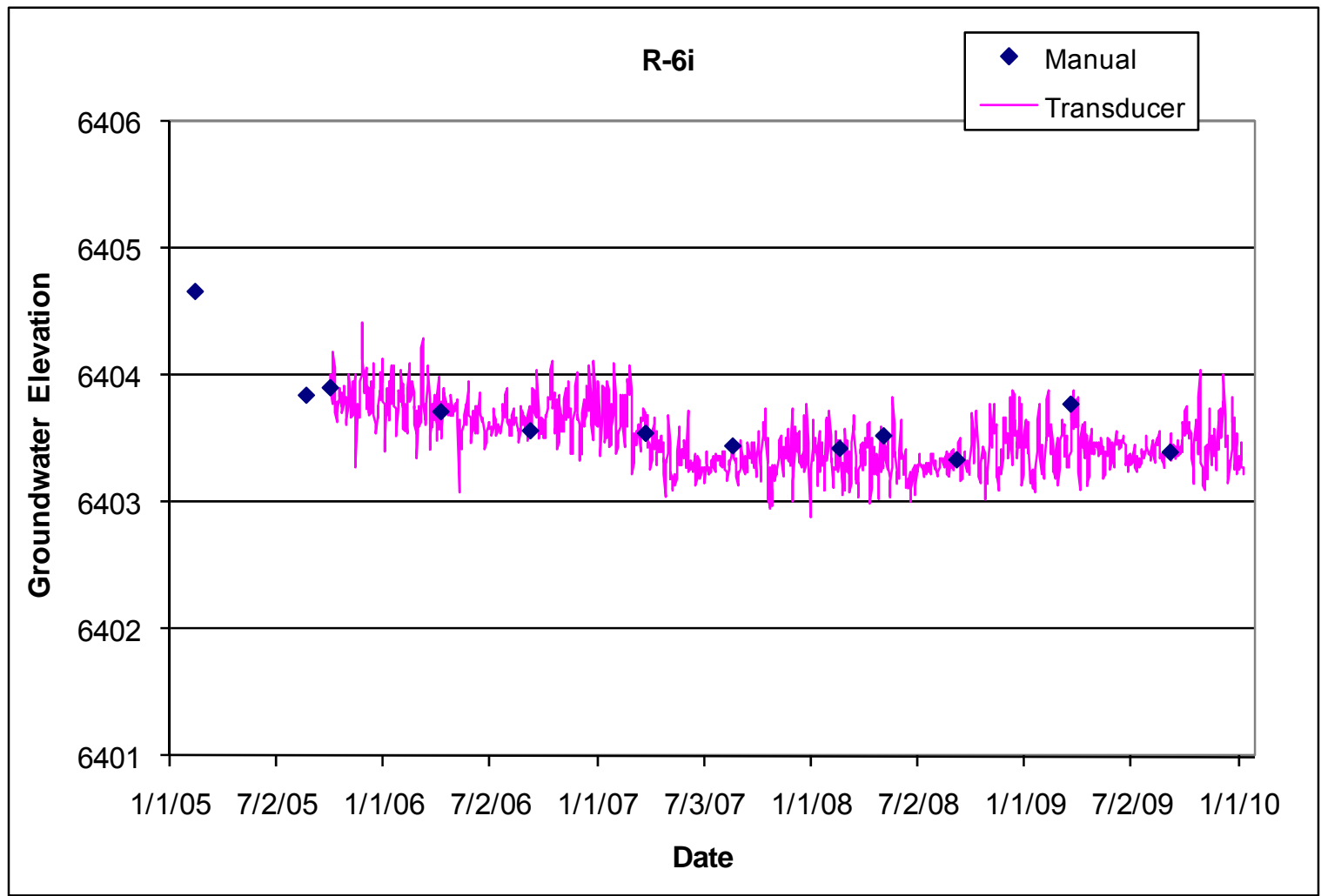




\subsection{R-9i}

Location: R-9i is located in Los Alamos Canyon near the eastern LANL boundary and adjacent to R-9. Completion Type: Dual Westbay ${ }^{\circledR}$ completion; both screens in Cerros del Rio basalt.

Period of Record: Well completed March 2000, transducers installed March 2001, intermittent data through 2009.

Remarks: The screens are about $70 \mathrm{ft}$ apart and the heads in the two intermediate zones are about $110 \mathrm{ft}$ apart. The water level at screen 1 is about $40 \mathrm{ft}$ above the top of the screen; the water level at screen 2 is about $15 \mathrm{ft}$ above the top of the screen. Groundwater at screen 1 appears to be recharged from large runoff events in lower Los Alamos Canyon; the water level responded to snowmelt runoff in 2001, 2005, 2007, and 2008, and to large storm runoff events in the summer of 2006, while the water level at screen 2 shows a reduced response.

\begin{tabular}{|c|c|c|c|c|c|c|c|c|c|c|c|c|c|}
\hline \multicolumn{14}{|c|}{ R-9i Construction and Port Information } \\
\hline Screen & $\begin{array}{c}\text { Screen } \\
\text { Top } \\
\text { Depth } \\
\text { (ft) }\end{array}$ & $\begin{array}{c}\text { Screen } \\
\text { Bottom } \\
\text { Depth } \\
\text { (ft) }\end{array}$ & $\begin{array}{c}\text { Screen } \\
\text { Top } \\
\text { Elev } \\
\text { (ft) }\end{array}$ & $\begin{array}{c}\text { Screen } \\
\text { Bottom } \\
\text { Elev } \\
\text { (ft) }\end{array}$ & $\begin{array}{l}\text { Screen } \\
\text { Length } \\
\text { (ft) }\end{array}$ & $\begin{array}{l}\text { Hydro } \\
\text { Zone } \\
\text { Code }\end{array}$ & $\begin{array}{c}\text { Geo } \\
\text { Unit } \\
\text { Code }\end{array}$ & Port & $\begin{array}{c}\text { Port } \\
\text { Depth } \\
\text { (ft) }\end{array}$ & $\begin{array}{l}\text { Port } \\
\text { Elev }(\mathrm{ft})\end{array}$ & $\begin{array}{l}\text { Distance } \\
\text { from } \\
\text { Bottom } \\
\text { of Screen } \\
\text { (ft) }\end{array}$ & $\begin{array}{l}\text { Sump } \\
\text { Volume } \\
\text { (L) }\end{array}$ & Comment \\
\hline \multirow{3}{*}{1} & \multirow{3}{*}{189.1} & \multirow{3}{*}{199.5} & \multirow{3}{*}{6194.1} & \multirow{3}{*}{6183.7} & \multirow{3}{*}{10.4} & \multirow{3}{*}{1} & \multirow{3}{*}{$\mathrm{Tb} 4$} & MP1A & 198.8 & $\overline{6184.4}$ & 0.7 & & Within screen \\
\hline & & & & & & & & PP1 & 204.1 & 6179.1 & -4.6 & 13.3 & Below screen \\
\hline & & & & & & & & MP1B & 209.8 & 6173.4 & -10.3 & 29.8 & Below screen \\
\hline \multirow{3}{*}{2} & \multirow{3}{*}{269.6} & \multirow{3}{*}{280.3} & \multirow{3}{*}{6113.6} & \multirow{3}{*}{6102.9} & \multirow{3}{*}{10.7} & \multirow{3}{*}{ I } & \multirow{3}{*}{ Tb4 } & $\overline{M P 2 A}$ & 278.8 & 6104.4 & 1.5 & & Within screen \\
\hline & & & & & & & & PP2 & 284.1 & 6099.1 & -3.8 & 11.0 & Below screen \\
\hline & & & & & & & & MP2B & 289.8 & 6093.4 & -9.5 & 27.5 & Below screen \\
\hline
\end{tabular}

Note: Brass Cap Elevation is $6383.2 \mathrm{ft}$; all measurements are from this elevation;

$\mathrm{MP}=$ Monitoring Port, $\mathrm{PP}=$ Pumping Port; Ports shown in Bold are instrumented with transducers

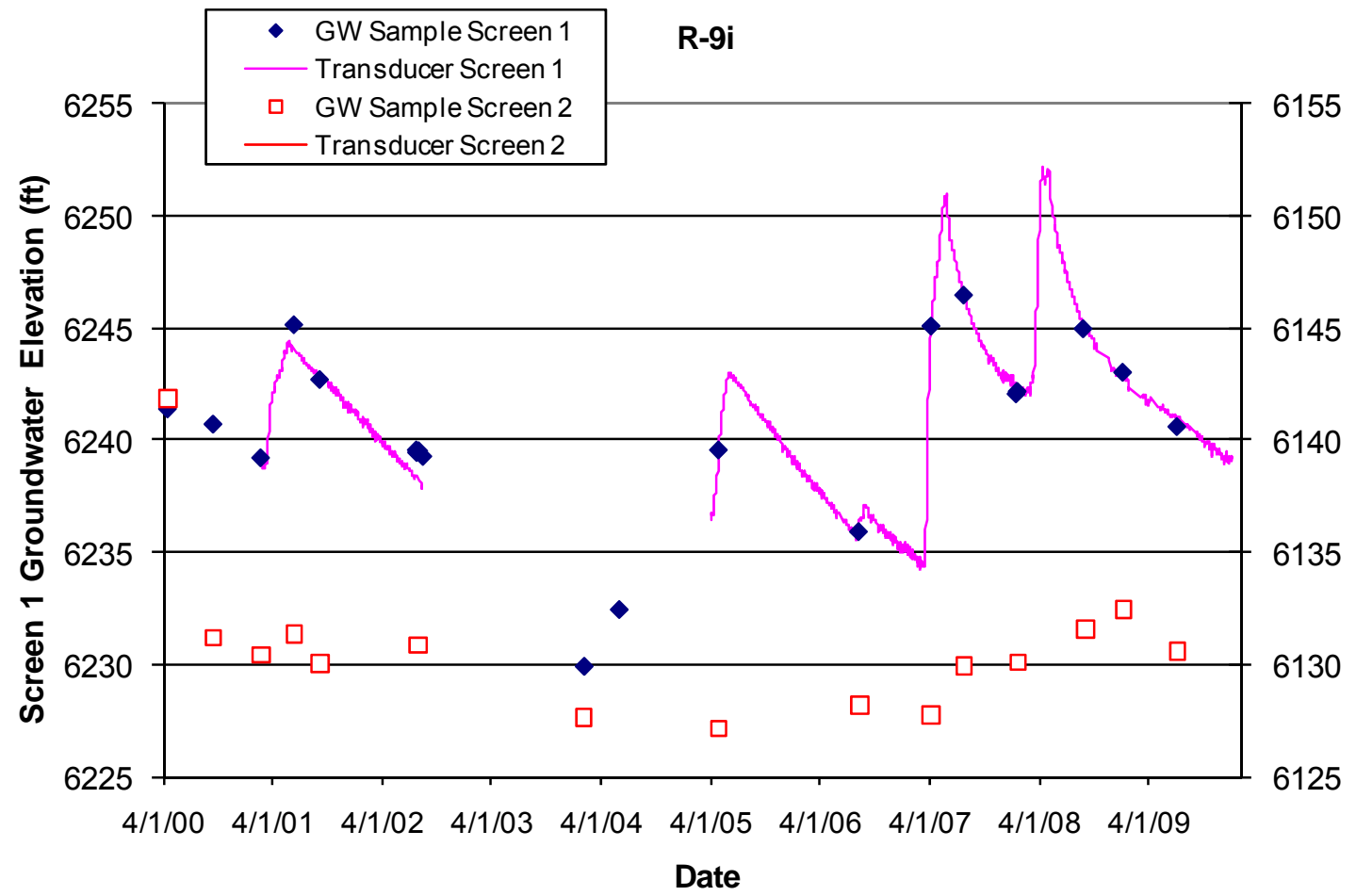




\subsection{R-12 (Intermediate)}

Location: R-12 is located in lower Sandia Canyon near SR-4 and supply well PM-1.

Completion Type: Multiple completion, originally two screens in intermediate zones, one screen at the top of the regional aquifer-until September 2006 when the well was recompleted as two intermediate screens; screen 3 was plugged and abandoned on December 13, 2007.

Period of Record: Westbay ${ }^{\circledR}$ system installed March 21, 2000, transducers installed December 14, 2000 , intermittent data to September 21, 2006, when transducers were removed for removal of the Westbay ${ }^{\circledR}$ system for well rehabilitation and conversion. No water level data for most of 2007. Transducers were reinstalled at screens 1 and 2 on December 13, 2007; data through 2009.

Remarks: In December 2007, screen 3 was abandoned and a Baski packer with dual pump sampling system was installed at the two intermediate screens. Intermediate screens 1 and 2 have similar head values about $380 \mathrm{ft}$ above the regional aquifer; intermediate screen 2 has a slightly higher head than screen 1 . The intermediate screens responded to snowmelt runoff events in Los Alamos Canyon in 2001, 2005, and 2008; no data available during 2007 and no snowmelt runoff in 2009. The groundwater at screens 1 and 2 show a delayed response to atmospheric pressure fluctuations with a barometric efficiency of about $70 \%$.

\begin{tabular}{|c|c|c|c|c|c|c|c|c|c|c|c|c|c|c|}
\hline \multicolumn{15}{|c|}{ R-12 Screen Data } \\
\hline Screen & $\begin{array}{l}\text { Screen } \\
\text { Top } \\
\text { Depth } \\
\text { (ft) }\end{array}$ & $\begin{array}{c}\text { Screen } \\
\text { Bottom } \\
\text { Depth } \\
\text { (ft) }\end{array}$ & $\begin{array}{c}\text { Screen } \\
\text { Top } \\
\text { Elev (ft) }\end{array}$ & $\begin{array}{l}\text { Screen } \\
\text { Bottom } \\
\text { Elev (ft) }\end{array}$ & $\begin{array}{c}\text { Screen } \\
\text { Length } \\
\text { (ft) }\end{array}$ & $\begin{array}{c}\text { Pump } \\
\text { Intake } \\
\text { Depth } \\
\text { (ft) }\end{array}$ & $\begin{array}{c}\text { Pump } \\
\text { Intake } \\
\text { Elevation } \\
\text { (ft) }\end{array}$ & $\begin{array}{c}\text { Depth to } \\
\text { Top of } \\
\text { Packerl } \\
\text { Sump (ft) }\end{array}$ & $\begin{array}{c}\text { Top of } \\
\text { Packerl } \\
\text { Sump } \\
\text { Elevation } \\
\text { (ft) }\end{array}$ & \begin{tabular}{|c|} 
Depth \\
to \\
Sump \\
Bottom \\
(ft)
\end{tabular} & $\begin{array}{c}\text { Sump } \\
\text { Length } \\
(\mathrm{ft})\end{array}$ & $\begin{array}{c}\text { Sump } \\
\text { Volume } \\
\text { (L) }\end{array}$ & $\begin{array}{c}\text { Hydro } \\
\text { Zone } \\
\text { Code }\end{array}$ & $\begin{array}{c}\text { Geo } \\
\text { Unit } \\
\text { Code }\end{array}$ \\
\hline 1 & 459.0 & 467.5 & 6040.6 & 6032.1 & 8.5 & 465.0 & 6034.6 & 470.7 & 6028.9 & 470.7 & 3.2 & 9.1 & $\mathrm{~T}$ & Tb4 \\
\hline 2 & 504.5 & 508.0 & 5995.1 & 5991.6 & 3.5 & 501.0 & 5998.6 & 508.0 & 5991.6 & 540.8 & 32.8 & 93.7 & $\mathrm{I}$ & $\mathrm{Tp}$ \\
\hline 3 & 801.0 & 839.0 & 5698.6 & 5660.6 & 38 & \multicolumn{7}{|c|}{ Screen 3 Plugged and Abandoned December 2007} & RT & Tsfb \\
\hline
\end{tabular}

Brass Cap Elevation: $6499.6 \mathrm{ft}$; all measurements are from this elevation

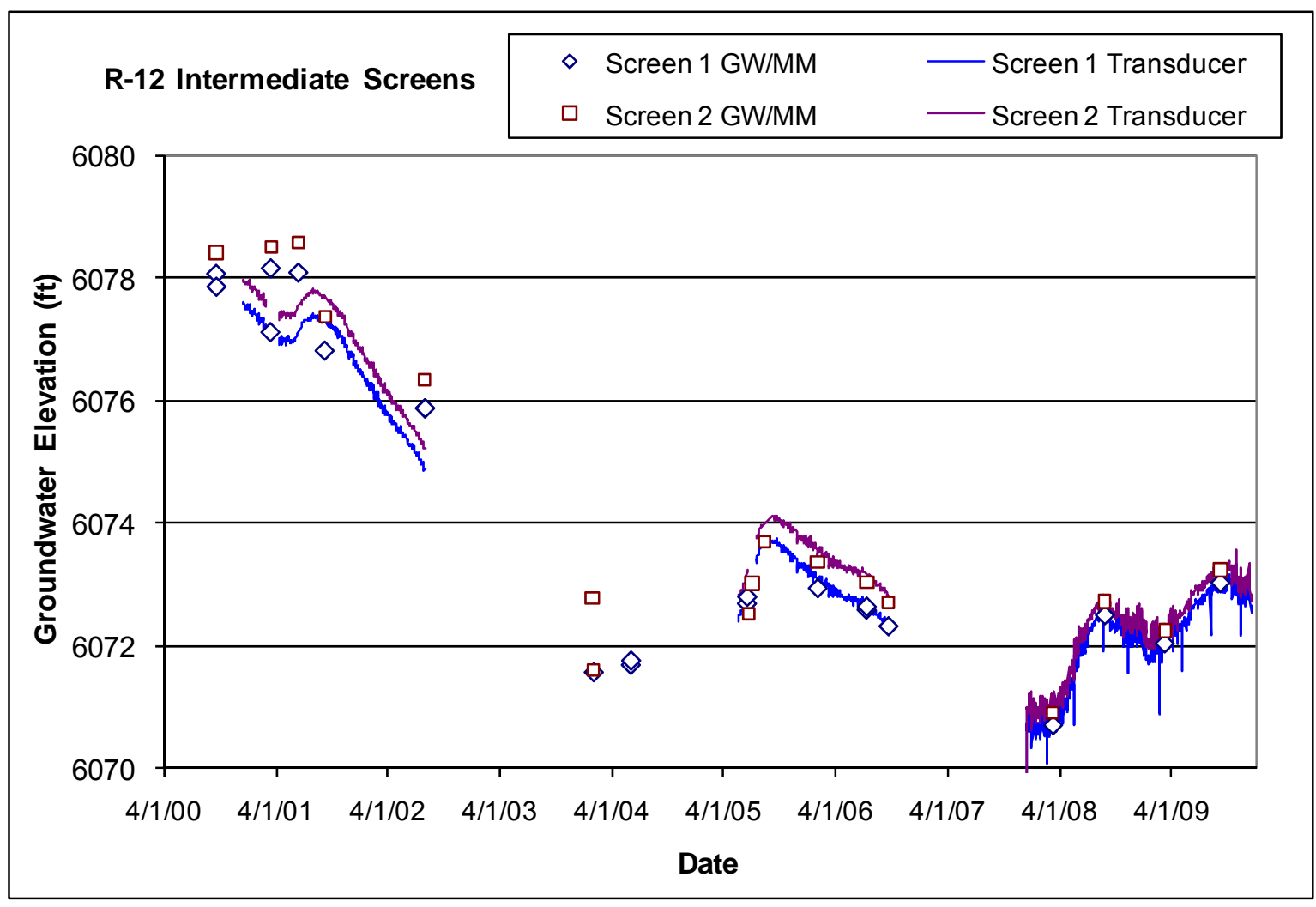




\subsection{R-23i}

Location: R-23i is located in lower Pajarito Canyon near SR-4 and adjacent to regional well R-23.

Completion Type: Multiple completion, three screens, screen 1 is in a 2.1-in.-diameter piezometer and screens 2 and 3 are in a 4 -in.-diameter well. A Baski packer and dual pump sampling system was installed at screens 2 and 3 in December 2006. All screens are in Cerros del Rio basalt.

Period of Record: Well completed November 2005; transducers installed at screens 2 and 3 in December 2006, transducer installed at screen 1 March 2009; data through 2009.

Remarks: The water levels at screens 2 and 3 are about $9 \mathrm{ft}$ apart; the water level at screen 1 is about $44 \mathrm{ft}$ higher than screen 2 . The screen 3 gage tubing through the packer has shown occasional partial plugging, but water levels in the tubing appear to be representative of screen 2. Possible response to snowmelt runoff at screens 2 and 3 in the spring of 2008. Packer inflation problems in 2009 caused loss of screens 2 and 3 groundwater level data. The Baski system was removed from the well in December 2009 to repair the packer.

\begin{tabular}{|c|c|c|c|c|c|c|c|c|c|c|c|c|c|c|c|}
\hline \multicolumn{16}{|c|}{ R-23i Construction Information } \\
\hline Screen & $\begin{array}{l}\text { Screen } \\
\text { Top } \\
\text { Depth } \\
\text { (ft) } \\
\end{array}$ & \begin{tabular}{|c|} 
Screen \\
Bottom \\
Depth \\
(ft)
\end{tabular} & $\begin{array}{c}\text { Screen } \\
\text { Top } \\
\text { Elev } \\
\text { (ft) } \\
\end{array}$ & \begin{tabular}{|c|} 
Screen \\
Bottom \\
Elev \\
(ft)
\end{tabular} & $\begin{array}{c}\text { Screen } \\
\text { Length } \\
\text { (ft) }\end{array}$ & $\begin{array}{l}\text { Pump } \\
\text { Intake } \\
\text { Depth } \\
\text { (ft) } \\
\end{array}$ & $\begin{array}{c}\text { Pump } \\
\text { Intake } \\
\text { Elev } \\
\text { (ft) } \\
\end{array}$ & $\begin{array}{c}\text { Depth to } \\
\text { Top of } \\
\text { Packerl } \\
\text { Sump (ft) }\end{array}$ & $\begin{array}{c}\text { Top of } \\
\text { Sump } \\
\text { Elev } \\
\text { (ft) } \\
\end{array}$ & $\begin{array}{c}\text { Depth to } \\
\text { Sump } \\
\text { Bottom } \\
\text { (ft) }\end{array}$ & $\begin{array}{c}\text { Sump } \\
\text { Length } \\
\text { (ft) } \\
\end{array}$ & \begin{tabular}{|c} 
Sump \\
Volume \\
(Gal.) \\
\end{tabular} & $\begin{array}{l}\text { Hydro } \\
\text { Zone } \\
\text { Code } \\
\end{array}$ & $\begin{array}{c}\text { Geo } \\
\text { Unit } \\
\text { Code } \\
\end{array}$ & Comment \\
\hline 1 & 400.3 & 420.0 & 6127.6 & 6107.9 & 19.7 & & & 420.0 & 6107.9 & 425.3 & 5.3 & 4.4 & $\mathrm{~T}$ & Tb4 & 2.1 in. Piez \\
\hline 2 & 470.2 & 480.1 & 6057.7 & 6047.8 & 9.9 & 477.1 & 6050.8 & 495.3 & 6032.5 & 495.3 & 15.2 & 12.6 & $\mathrm{I}$ & Tb4 & 4.5 in. well \\
\hline 3 & 524.0 & 547.0 & 6003.9 & 5980.9 & 23.0 & 516.7 & 6011.2 & 547.0 & 5980.9 & 550.7 & 3.7 & 3.1 & $T$ & Tb4 & 4.5 in. well \\
\hline
\end{tabular}

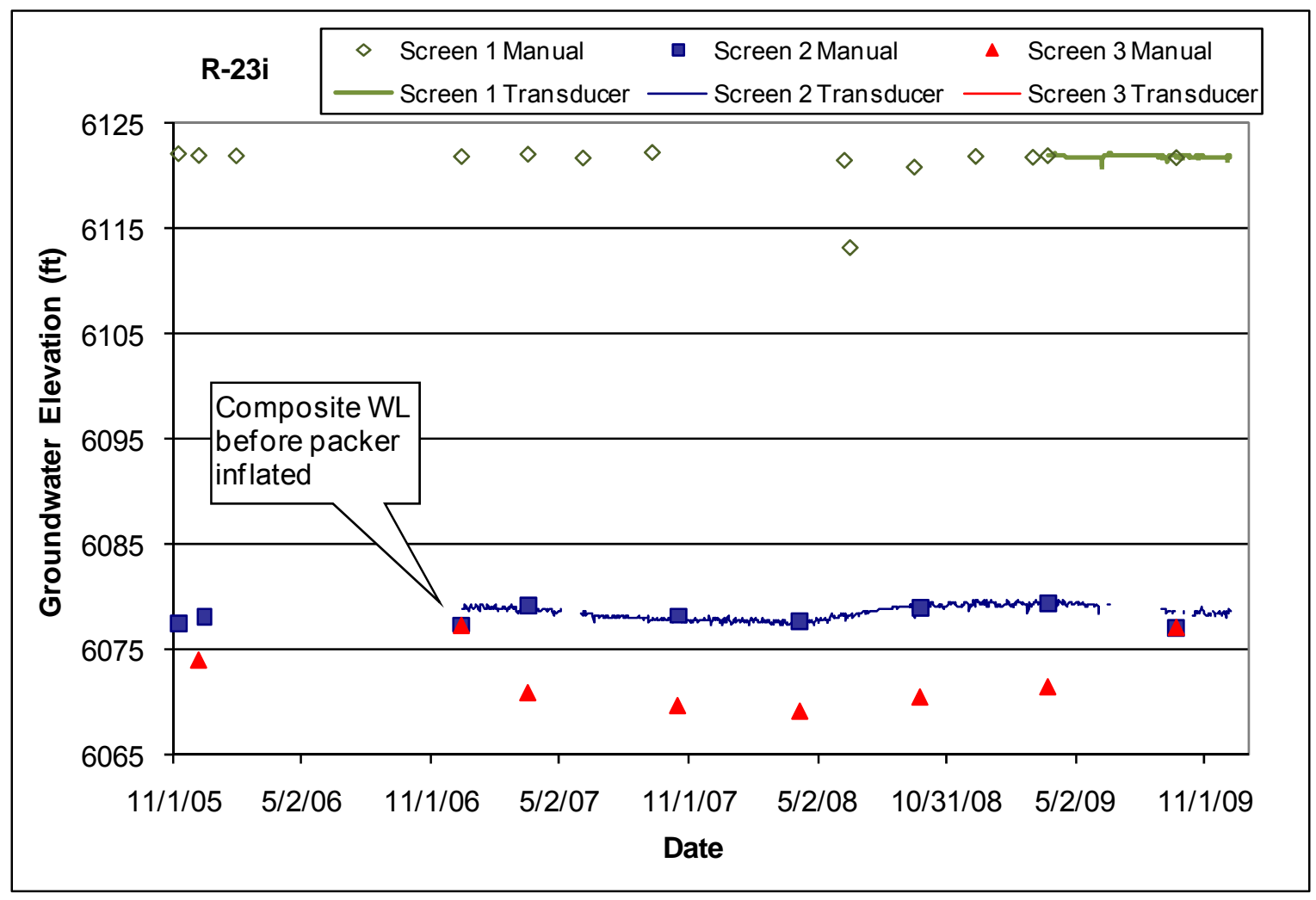



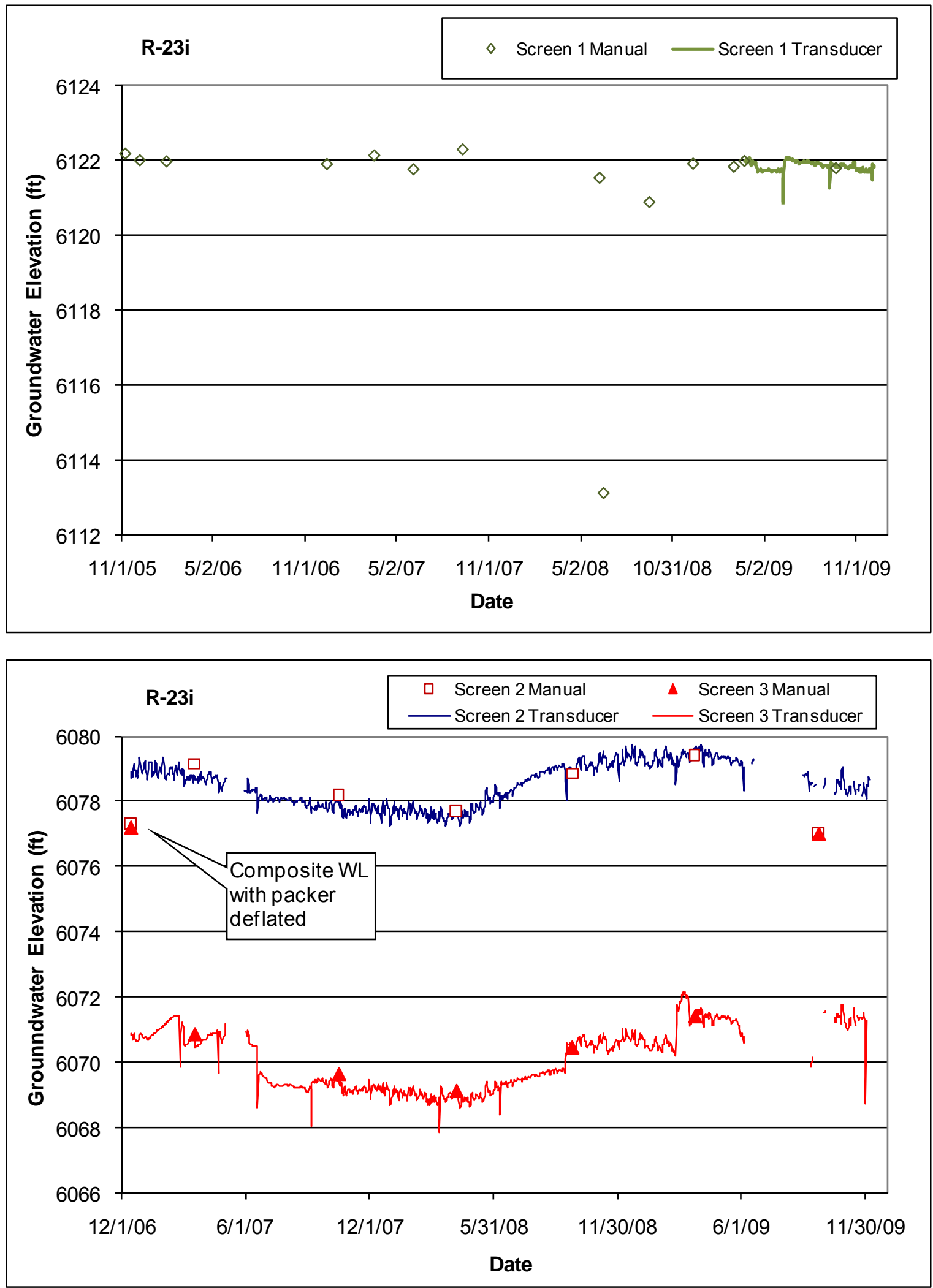


\subsection{R-25b}

Location: R-25b is located at TA-16 about $25 \mathrm{ft}$ west of monitoring well R-25.

Completion Type: Single completion, one screen in the Otowi Member of the Bandelier Tuff at a similar location as R-25 screen 1.

Period of Record: Well completed October 2008; periodic manual measurement through 2009.

Transducer installed January 13, 2010; transducer data pending.

Remarks: R-25b is screened adjacent to R-25 screen 1.

\begin{tabular}{|c|c|c|c|c|c|c|c|c|c|c|c|c|c|c|}
\hline \multicolumn{15}{|c|}{ R-25b Construction Information } \\
\hline Screen & $\begin{array}{c}\text { Screen } \\
\text { Top } \\
\text { Depth } \\
\text { (ft) }\end{array}$ & $\begin{array}{c}\text { Screen } \\
\text { Bottom } \\
\text { Depth } \\
\text { (ft) }\end{array}$ & $\begin{array}{c}\text { Screen } \\
\text { Top } \\
\text { Elev } \\
\text { (ft) }\end{array}$ & \begin{tabular}{|c|} 
Screen \\
Bottom \\
Elev \\
(ft)
\end{tabular} & $\begin{array}{l}\text { Screen } \\
\text { Length } \\
\text { (ft) }\end{array}$ & $\begin{array}{c}\text { Pump } \\
\text { Intake } \\
\text { Depth } \\
\text { (ft) }\end{array}$ & $\begin{array}{c}\text { Pump } \\
\text { Intake } \\
\text { Elev } \\
\text { (ft) }\end{array}$ & $\begin{array}{l}\text { Depth to } \\
\text { Top of } \\
\text { Sump } \\
\text { (ft) }\end{array}$ & $\begin{array}{c}\text { Top of } \\
\text { Sump } \\
\text { Elev } \\
\text { (ft) }\end{array}$ & $\begin{array}{l}\text { Depth to } \\
\text { Sump } \\
\text { Bottom } \\
\text { (ft) }\end{array}$ & $\begin{array}{c}\text { Sump } \\
\text { Length } \\
\text { (ft) }\end{array}$ & $\begin{array}{c}\text { Sump } \\
\text { Volume } \\
\text { (L) }\end{array}$ & $\begin{array}{l}\text { Hydro } \\
\text { Zone } \\
\text { Code }\end{array}$ & $\begin{array}{l}\text { Geo } \\
\text { Unit } \\
\text { Code }\end{array}$ \\
\hline 1 & 750.0 & 770.8 & 6767.0 & 6746.2 & 20.8 & 770.0 & 6747.0 & 770.8 & 6746.2 & 782.3 & 11.5 & $\overline{7.6}$ & $T$ & $\overline{\text { Qbo }}$ \\
\hline
\end{tabular}

Note: Brass Cap Ground Elevation: $7517.00 \mathrm{ft}$; all measurements are from this elevation

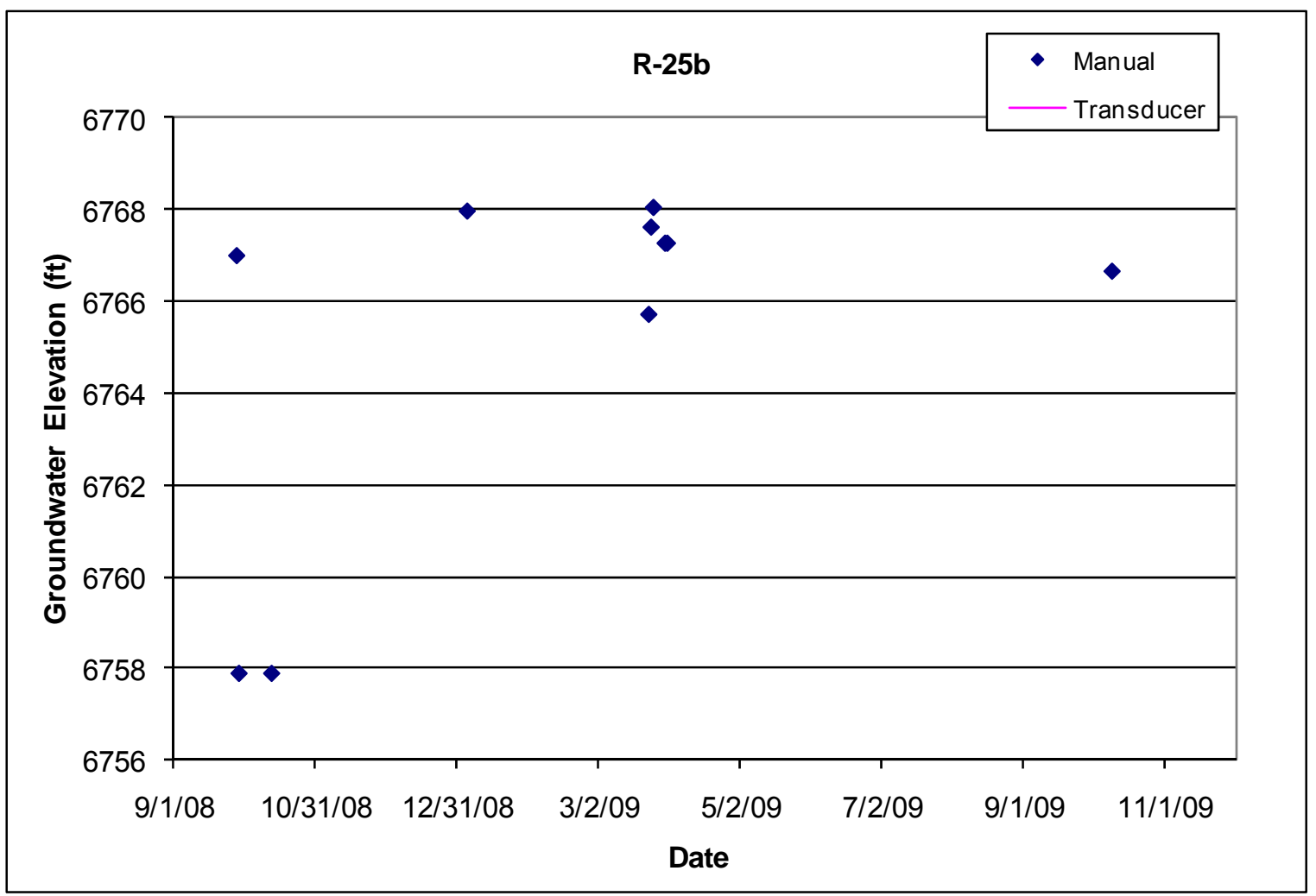




\subsection{R-25C}

Location: R-25c is located at TA-16 about $25 \mathrm{ft}$ west of monitoring well R-25b and about $50 \mathrm{ft}$ west of monitoring well R-25.

Completion Type: Single completion, one screen in the Puye fanglomerates at a similar location as R25 screen 3.

Period of Record: Well completed September 2008, transducer installed December 16, 2009. Data through 2009.

Remarks: R-25c is a replacement for R-25 screen 3 . The borehole contained water during drilling, but the well was dry (some water in sump) at completion and did not retain water during attempted slug testing (LANL December 2008).

\begin{tabular}{|c|c|c|c|c|c|c|c|c|c|c|c|c|c|c|}
\hline \multicolumn{15}{|c|}{ R-25c Construction Information } \\
\hline Screen & $\begin{array}{c}\text { Screen } \\
\text { Top } \\
\text { Depth } \\
\text { (ft) }\end{array}$ & $\begin{array}{c}\text { Screen } \\
\text { Bottom } \\
\text { Depth } \\
\text { (ft) }\end{array}$ & \begin{tabular}{|c} 
Screen \\
Top \\
Elev \\
(ft)
\end{tabular} & $\begin{array}{c}\text { Screen } \\
\text { Bottom } \\
\text { Elev } \\
\text { (ft) }\end{array}$ & $\begin{array}{c}\text { Screen } \\
\text { Length } \\
\text { (ft) }\end{array}$ & $\begin{array}{l}\text { Pump } \\
\text { Intake } \\
\text { Depth } \\
\text { (ft) }\end{array}$ & $\begin{array}{c}\text { Pump } \\
\text { Intake } \\
\text { Elevation } \\
\text { (ft) }\end{array}$ & $\begin{array}{c}\text { Depth to } \\
\text { Top of } \\
\text { Sump } \\
\text { (ft) }\end{array}$ & $\begin{array}{c}\text { Top of } \\
\text { Sump } \\
\text { Elev } \\
\text { (ft) }\end{array}$ & \begin{tabular}{|} 
Depth to \\
Sump \\
Bottom \\
(ft)
\end{tabular} & $\begin{array}{c}\text { Sump } \\
\text { Length } \\
\text { (ft) }\end{array}$ & $\begin{array}{c}\text { Sump } \\
\text { Volume } \\
\text { (L) }\end{array}$ & $\mid \begin{array}{c}\text { Hydro } \\
\text { Zone } \\
\text { Code }\end{array}$ & $\begin{array}{l}\text { Geo } \\
\text { Unit } \\
\text { Code }\end{array}$ \\
\hline 1 & $\overline{1039.6}$ & 1060.0 & 6478.0 & 6457.6 & 20.4 & None & None & 1060.0 & 6457.6 & 1080.6 & 20.6 & 79.5 & $\mathrm{~T}$ & Tpf \\
\hline
\end{tabular}




\subsection{R-26 PZ-2}

Location: R-26 PZ-2 is located at TA-16 about $90 \mathrm{ft}$ southwest of monitoring well R-26.

Completion Type: Dual completion, R-26 PZ-1 is the deeper piezometer while R-26 PZ-2 is the shallower piezometer.

Period of Record: Piezometer completed October 2003, manual measurements began in April 2009, and transducer installed December 16, 2009.

Remarks: R-26 PZ-1 has always been dry when checked.

\begin{tabular}{|c|c|c|c|c|c|c|c|c|c|c|c|c|}
\hline \multicolumn{13}{|c|}{ R-26 Piezometer Construction Information } \\
\hline Screen & $\begin{array}{l}\text { Screen } \\
\text { Top } \\
\text { Depth } \\
\text { (ft) }\end{array}$ & $\begin{array}{l}\text { Screen } \\
\text { Bottom } \\
\text { Depth } \\
\text { (ft) }\end{array}$ & $\begin{array}{c}\text { Screen } \\
\text { Top } \\
\text { Elev (ft) }\end{array}$ & $\begin{array}{l}\text { Screen } \\
\text { Bottom } \\
\text { Elev (ft) }\end{array}$ & $\begin{array}{c}\text { Screen } \\
\text { Length } \\
\text { (ft) }\end{array}$ & $\begin{array}{l}\text { Depth } \\
\text { to } \\
\text { Bottom } \\
\text { of } \\
\text { Sump } \\
\text { (ft) }\end{array}$ & $\begin{array}{c}\text { Bottom } \\
\text { of } \\
\text { Sump } \\
\text { Elev (ft) }\end{array}$ & $\begin{array}{c}\text { Sump } \\
\text { Length } \\
\text { (ft) }\end{array}$ & $\begin{array}{c}\text { Sump } \\
\text { Vol } \\
\text { (gal.) }\end{array}$ & $\begin{array}{c}1 \mathrm{CV} \\
\text { Purge } \\
\text { Vol } \\
\text { (gal.) }\end{array}$ & $\begin{array}{l}\text { Hydro } \\
\text { Zone } \\
\text { Code }\end{array}$ & $\begin{array}{c}\text { Geo } \\
\text { Unit } \\
\text { Code }\end{array}$ \\
\hline $\mathrm{PZ}-1$ & 230.0 & 250.0 & 7409.6 & 7389.6 & 20.0 & 250.0 & 7389.6 & 0.0 & 0.0 & 0.0 & $\mathrm{I}$ & Qbt3t \\
\hline $\mathrm{PZ}-2$ & 150.0 & 180.0 & 7489.6 & 7459.6 & 30.0 & 185.0 & 7454.6 & 5.0 & 0.8 & 1.5 & 1 & Qbt3t \\
\hline
\end{tabular}

Note: R-26 Ground Elevation: $7639.56 \mathrm{ft}$; all measurements are from this elevation; Top of Casing Elevation: $7641.95 \mathrm{ft}$.

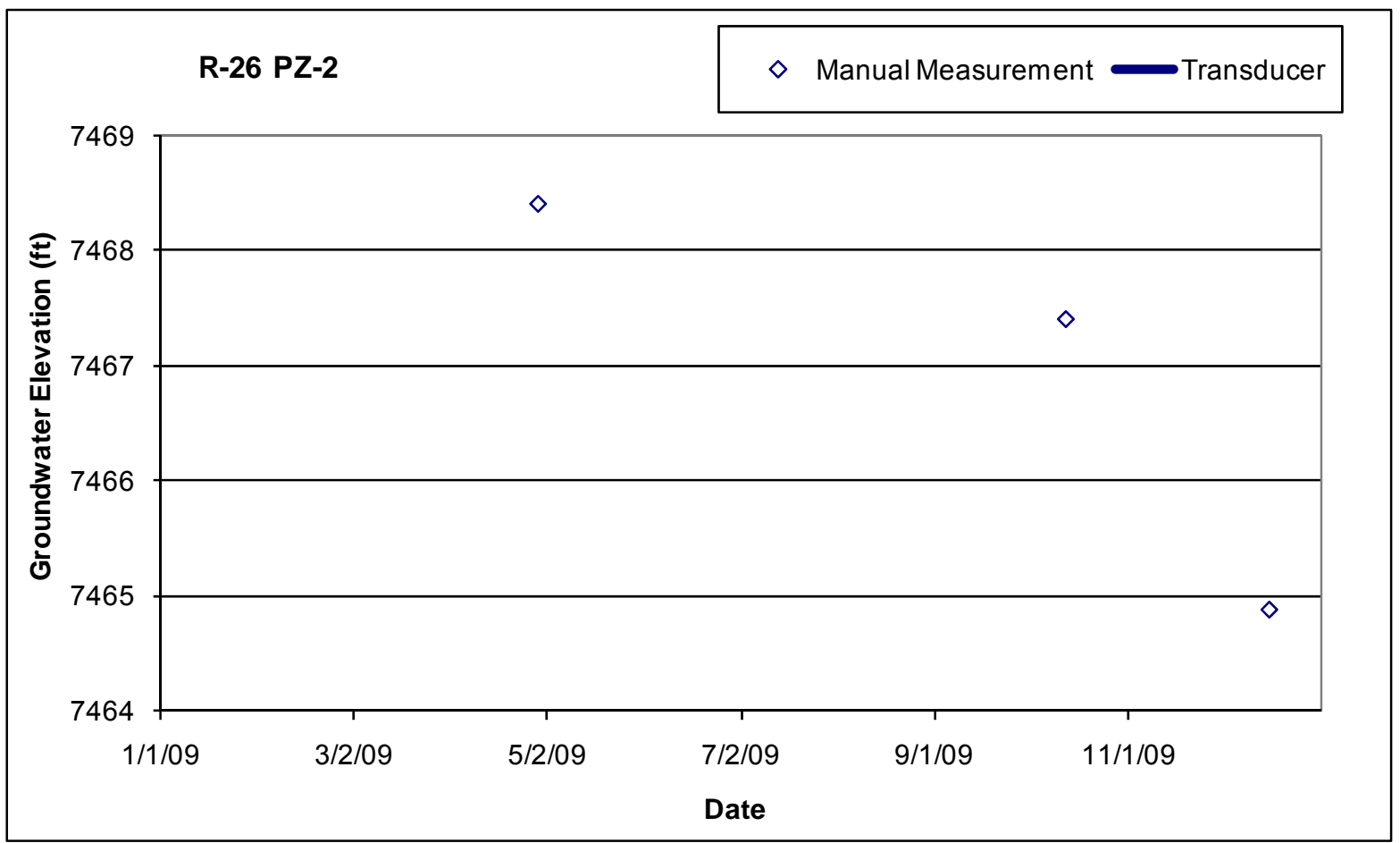




\subsection{R-27i}

Location: R-27i is located in Water Canyon near monitoring well R-27.

Completion Type: Single completion, one screen in the Puye fanglomerates.

Period of Record: Well completed October 2009, dedicated Bennett pump and transducer installation pending as of January 2010.

Remarks: Preliminary groundwater level measurements indicate the groundwater is 616 to $621 \mathrm{ft}$ below ground surface.

\begin{tabular}{|c|c|c|c|c|c|c|c|c|c|c|c|c|c|}
\hline \multicolumn{14}{|c|}{ R-27i Construction Information } \\
\hline Screen & $\begin{array}{c}\text { Screen } \\
\text { Top } \\
\text { Depth } \\
\text { (ft) }\end{array}$ & $\begin{array}{c}\text { Screen } \\
\text { Bottom } \\
\text { Depth } \\
\text { (ft) }\end{array}$ & $\begin{array}{c}\text { Screen } \\
\text { Top } \\
\text { Elev (ft) }\end{array}$ & $\begin{array}{l}\text { Screen } \\
\text { Bottom } \\
\text { Elev (ft) }\end{array}$ & $\begin{array}{c}\text { Screen } \\
\text { Length } \\
(\mathrm{ft})\end{array}$ & $\begin{array}{c}\text { Pump } \\
\text { Intake } \\
\text { Depth } \\
\text { (ft) }\end{array}$ & $\begin{array}{c}\text { Pump } \\
\text { Intake } \\
\text { Elev } \\
\text { (ft) }\end{array}$ & $\begin{array}{l}\text { Depth } \\
\text { to } \\
\text { Sump } \\
\text { Bottom } \\
\text { (ft) }\end{array}$ & $\begin{array}{l}\text { Bottom } \\
\text { of Well } \\
\text { Elev (ft) }\end{array}$ & $\begin{array}{l}\text { Sump } \\
\text { Length } \\
\text { (ft) }\end{array}$ & $\begin{array}{c}\text { Sump } \\
\text { Vol } \\
\text { (gal) }\end{array}$ & $\begin{array}{l}\text { Hydro } \\
\text { Zone } \\
\text { Code }\end{array}$ & $\begin{array}{l}\text { Geo } \\
\text { Unit } \\
\text { Code }\end{array}$ \\
\hline 1 & 619.0 & 629.0 & & & 10.0 & & & 630.2 & & 1.2 & 1.2 & 1 & Tpf \\
\hline
\end{tabular}




\section{$4.33 \mathrm{SCl}-1$}

Location: SCl-1 is located in Sandia Canyon between intermediate wells LAOI-3.2 in Los Alamos Canyon to the north and MCOI-6 in Mortandad Canyon to the southwest.

Completion Type: Single completion in the Puye Formation fanglomerate member; the screen is located above the Cerros del Rio basalt.

Period of Record: Well completed October 2006, transducer installed in February 2007, data through 2009.

Remarks: Originally drilled as core hole SCC-1, completed as intermediate well and named SCl-1. The well is immediately $100 \%$ barometrically efficient; additionally the groundwater shows a delayed response to atmospheric pressure fluctuations.

\begin{tabular}{|c|c|c|c|c|c|c|c|c|c|c|c|c|c|c|}
\hline \multicolumn{15}{|c|}{ SCl-1 Construction Information } \\
\hline Screen & $\begin{array}{l}\text { Screen } \\
\text { Top } \\
\text { Depth } \\
\text { (ft) }\end{array}$ & $\begin{array}{c}\text { Screen } \\
\text { Bottom } \\
\text { Depth } \\
\text { (ft) }\end{array}$ & $\begin{array}{c}\text { Screen } \\
\text { Top } \\
\text { Elev } \\
\text { (ft) }\end{array}$ & $\begin{array}{c}\text { Screen } \\
\text { Bottom } \\
\text { Elev } \\
\text { (ft) }\end{array}$ & $\begin{array}{c}\text { Screen } \\
\text { Length } \\
\text { (ft) }\end{array}$ & $\begin{array}{l}\text { Pump } \\
\text { Intake } \\
\text { Depth } \\
\text { (ft) }\end{array}$ & $\begin{array}{c}\text { Pump } \\
\text { Intake } \\
\text { Elev } \\
\text { (ft) }\end{array}$ & $\begin{array}{c}\text { Depth to } \\
\text { Top of } \\
\text { Sump (ft) }\end{array}$ & $\begin{array}{c}\text { Top of } \\
\text { Sump } \\
\text { Elev } \\
\text { (ft) }\end{array}$ & $\begin{array}{l}\text { Depth to } \\
\text { Sump } \\
\text { Bottom } \\
\text { (ft) }\end{array}$ & $\begin{array}{c}\text { Sump } \\
\text { Length } \\
\text { (ft) }\end{array}$ & $\begin{array}{c}\text { Sump } \\
\text { Volume } \\
\text { (L) }\end{array}$ & $\begin{array}{l}\text { Hydro } \\
\text { Zone } \\
\text { Code }\end{array}$ & $\begin{array}{l}\text { Geo } \\
\text { Unit } \\
\text { Code }\end{array}$ \\
\hline$\overline{1}$ & 358.4 & 377.9 & 6379.9 & $\overline{6360.4}$ & 19.5 & 376.0 & 6362.3 & 377.9 & 6360.4 & 377.9 & 0.0 & 0.0 & $T$ & Tpf \\
\hline
\end{tabular}

Note: Brass Cap Elevation: $6738.27 \mathrm{ft}$; all measurements are from this elevation

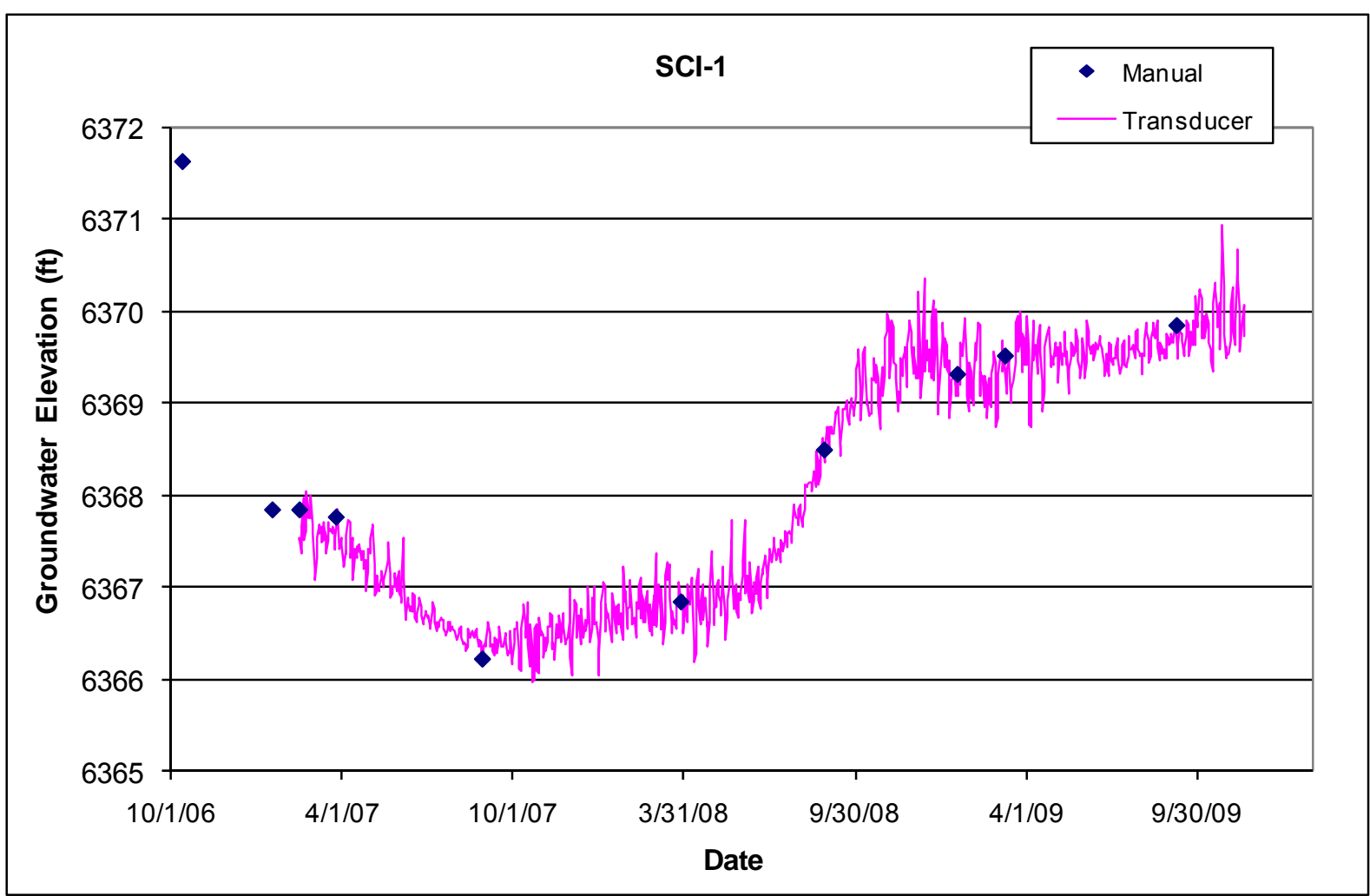




\section{$4.34 \mathrm{SCl}-2$}

Location: SCl-2 is located in middle Sandia Canyon adjacent to regional monitoring well R-43.

Completion Type: Single completion in Cerros del Rio basalt.

Period of Record: Well completed August 2008, temporary transducer installed November 2008 for R42 and R-43 aquifer testing; dedicated transducer installed February 10, 2009; data through 2009.

Remarks: The initial groundwater elevation at completion of the well was $6221.4 \mathrm{ft}$; subsequent measurements have been about $15 \mathrm{ft}$ lower. The well is $100 \%$ barometrically efficient, the groundwater does not respond to atmospheric pressure fluctuations; however, the groundwater shows a delayed response to atmospheric pressure fluctuations.

\begin{tabular}{|c|c|c|c|c|c|c|c|c|c|c|c|c|c|c|}
\hline \multicolumn{15}{|c|}{ SCl-2 Construction Information } \\
\hline Screen & $\begin{array}{c}\text { Screen } \\
\text { Top } \\
\text { Depth } \\
\text { (ft) } \\
\end{array}$ & $\begin{array}{c}\text { Screen } \\
\text { Bottom } \\
\text { Depth } \\
\text { (ft) }\end{array}$ & \begin{tabular}{|c|} 
Screen \\
Top \\
Elev \\
(ft) \\
\end{tabular} & $\begin{array}{c}\text { Screen } \\
\text { Bottom } \\
\text { Elev } \\
\text { (ft) }\end{array}$ & \begin{tabular}{|c}
$\begin{array}{c}\text { Screen } \\
\text { Length } \\
\text { (ft) }\end{array}$ \\
\end{tabular} & $\begin{array}{c}\text { Pump } \\
\text { Intake } \\
\text { Depth } \\
\text { (ft) } \\
\end{array}$ & $\begin{array}{c}\text { Pump } \\
\text { Intake } \\
\text { Elev } \\
\text { (ft) } \\
\end{array}$ & $\begin{array}{c}\text { Depth to } \\
\text { Top of } \\
\text { Sump (ft) }\end{array}$ & $\begin{array}{c}\text { Top of } \\
\text { Sump } \\
\text { Elev } \\
\text { (ft) }\end{array}$ & $\begin{array}{c}\text { Depth to } \\
\text { Sump } \\
\text { Bottom } \\
\text { (ft) }\end{array}$ & $\begin{array}{c}\text { Sump } \\
\text { Length } \\
\text { (ft) }\end{array}$ & $\begin{array}{c}\text { Sump } \\
\text { Volume } \\
\text { (L) }\end{array}$ & $\begin{array}{l}\text { Hydro } \\
\text { Zone } \\
\text { Code } \\
\end{array}$ & $\begin{array}{c}\text { Geo } \\
\text { Unit } \\
\text { Code } \\
\end{array}$ \\
\hline 1 & 548.0 & 568.0 & 6187.7 & 6167.7 & 20.0 & & & 568.0 & 6167.7 & 570 & 2.0 & 0.2 & $T$ & Tb4 \\
\hline
\end{tabular}

Note: Brass Cap Elevation: $6735.70 \mathrm{ft}$; all measurements are from this elevation

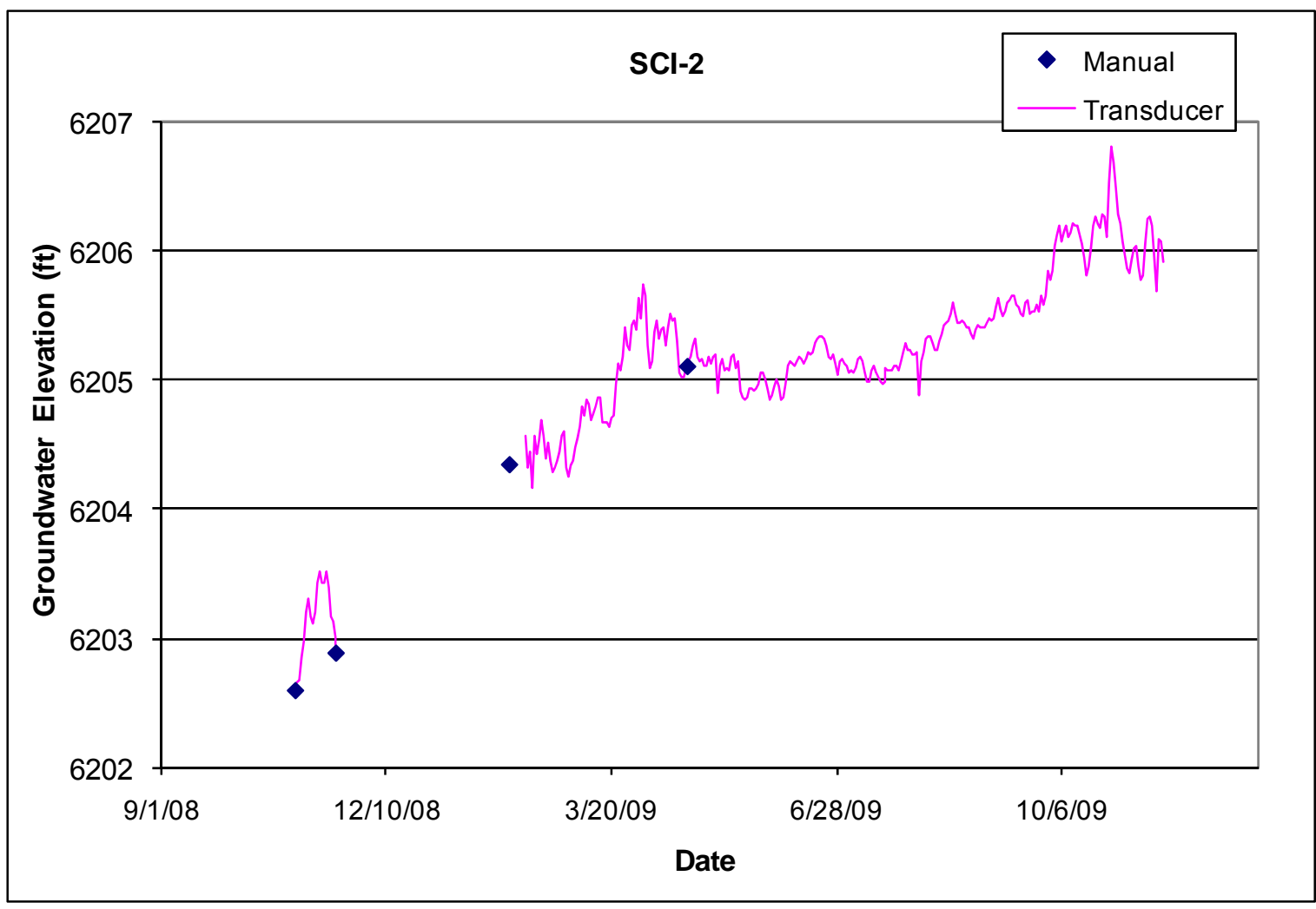




\subsection{TA-53i}

Location: TA-53i is located on Mesita de Los Alamos at TA-53 about $1400 \mathrm{ft}$ northwest of SCl-1. Completion Type: Single completion in Puye fanglomerates just above the Cerros del Rio basalt. Period of Record: Well completed March 2009, transducer installed June 2009; data through 2009. Remarks: The well is $100 \%$ barometrically efficient, the groundwater has no immediate response to atmospheric pressure fluctuations; however, the aquifer shows a delayed response to atmospheric pressure fluctuations.

\begin{tabular}{|c|c|c|c|c|c|c|c|c|c|c|c|c|c|c|}
\hline \multicolumn{15}{|c|}{ TA-53i Construction Information } \\
\hline Screen & $\begin{array}{c}\text { Screen } \\
\text { Top } \\
\text { Depth } \\
\text { (ft) }\end{array}$ & $\begin{array}{c}\text { Screen } \\
\text { Bottom } \\
\text { Depth } \\
\text { (ft) }\end{array}$ & $\begin{array}{c}\text { Screen } \\
\text { Top } \\
\text { Elev } \\
\text { (ft) }\end{array}$ & $\begin{array}{c}\text { Screen } \\
\text { Bottom } \\
\text { Elev } \\
\text { (ft) }\end{array}$ & $\begin{array}{c}\text { Screen } \\
\text { Length } \\
\text { (ft) }\end{array}$ & $\begin{array}{c}\text { Pump } \\
\text { Intake } \\
\text { Depth } \\
\text { (ft) }\end{array}$ & $\begin{array}{c}\text { Pump } \\
\text { Intake } \\
\text { Elev } \\
\text { (ft) }\end{array}$ & $\begin{array}{c}\text { Depth to } \\
\text { Top of } \\
\text { Sump } \\
\text { (ft) }\end{array}$ & $\begin{array}{c}\text { Top of } \\
\text { Sump } \\
\text { Elev } \\
\text { (ft) }\end{array}$ & $\begin{array}{l}\text { Depth to } \\
\text { Sump } \\
\text { Bottom } \\
\text { (ft) }\end{array}$ & $\begin{array}{c}\text { Sump } \\
\text { Length } \\
\text { (ft) }\end{array}$ & $\begin{array}{c}\text { Sump } \\
\text { Volume } \\
\text { (L) }\end{array}$ & $\begin{array}{l}\text { Hydro } \\
\text { Zone } \\
\text { Code }\end{array}$ & $\begin{array}{l}\text { Geo } \\
\text { Unit } \\
\text { Code }\end{array}$ \\
\hline 1 & 600.0 & 610 & 6387.2 & 6377.2 & 10.0 & & & 610.0 & 6377.2 & 620.8 & 10.8 & 41.7 & $\mathrm{I}$ & Tpf \\
\hline
\end{tabular}

Note: Brass Cap Elevation: $6987.17 \mathrm{ft}$; all measurements are from this elevation

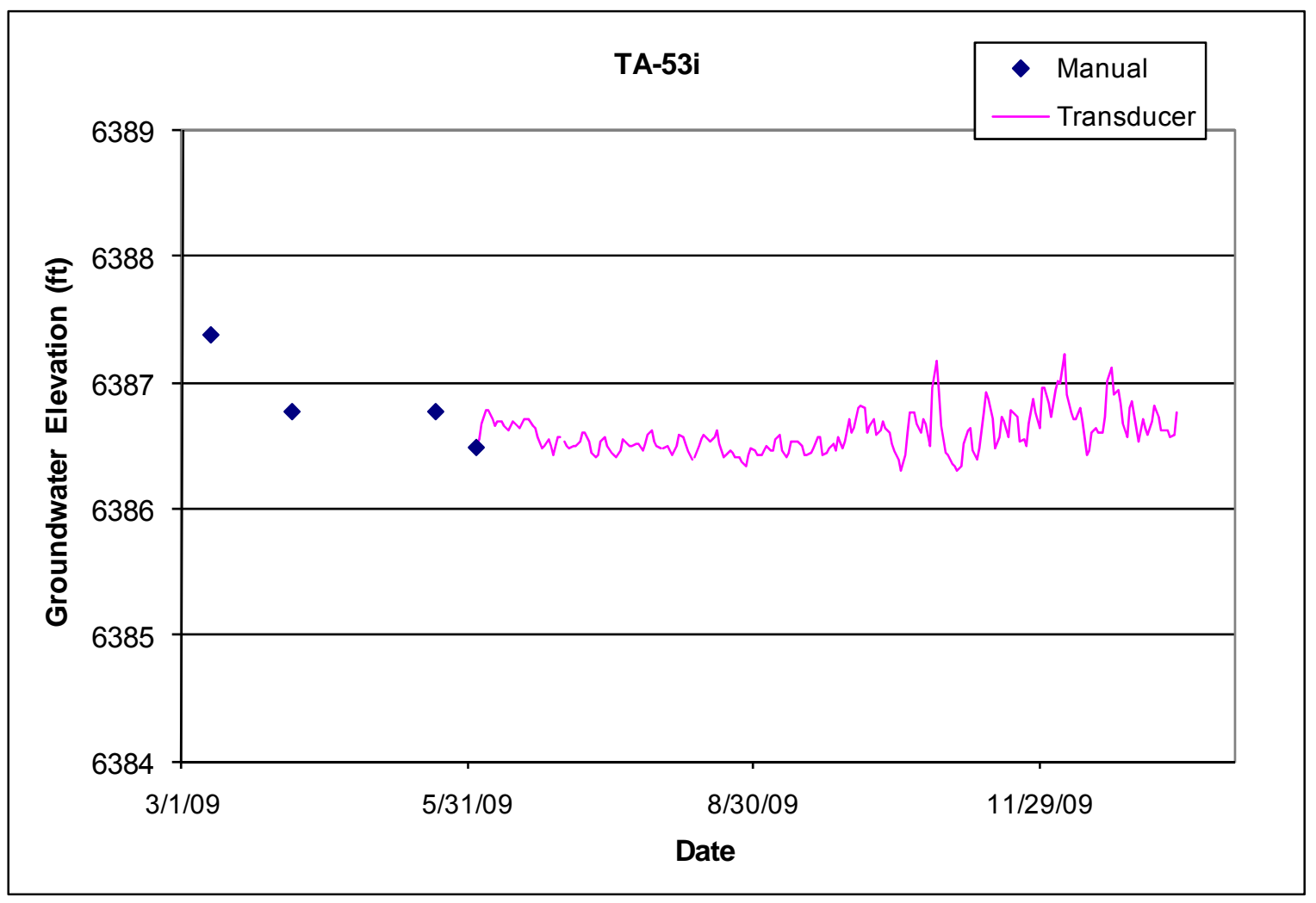




\subsection{Test Well 1A}

Location: TW-1A is located in lower Pueblo Canyon adjacent to TW-1.

Completion Type: Single completion in Cerros del Rio basalt.

Period of Record: Well completed in 1950, transducer installed June 1993, intermittent data to April 2005 when problems were encountered with equipment and the transducer was removed from the well.

Remarks: The wellhead equipment was removed from the well in February 2006 in preparation for plugging and abandonment of the well. The well is not planned for further monitoring.

\begin{tabular}{|c|c|c|c|c|c|c|c|c|c|c|c|c|c|c|}
\hline \multicolumn{15}{|c|}{ TW-1A Construction Information } \\
\hline Screen & $\begin{array}{l}\text { Screen } \\
\text { Top } \\
\text { Depth } \\
\text { (ft) }\end{array}$ & $\begin{array}{c}\text { Screen } \\
\text { Bottom } \\
\text { Depth } \\
\text { (ft) }\end{array}$ & $\begin{array}{c}\text { Screen } \\
\text { Top } \\
\text { Elev } \\
\text { (ft) }\end{array}$ & $\begin{array}{c}\text { Screen } \\
\text { Bottom } \\
\text { Elev } \\
\text { (ft) }\end{array}$ & $\begin{array}{l}\text { Screen } \\
\text { Length } \\
\text { (ft) }\end{array}$ & $\begin{array}{l}\text { Pump } \\
\text { Intake } \\
\text { Depth } \\
\text { (ft) }\end{array}$ & $\begin{array}{c}\text { Pump } \\
\text { Intake } \\
\text { Elev } \\
\text { (ft) }\end{array}$ & $\begin{array}{l}\text { Depth to } \\
\text { Top of } \\
\text { Sump } \\
\text { (ft) }\end{array}$ & $\begin{array}{c}\text { Top of } \\
\text { Sump } \\
\text { Elev } \\
\text { (ft) }\end{array}$ & $\begin{array}{l}\text { Depth to } \\
\text { Sump } \\
\text { Bottom } \\
\text { (ft) }\end{array}$ & $\begin{array}{c}\text { Sump } \\
\text { Length } \\
\text { (ft) }\end{array}$ & $\begin{array}{c}\text { Sump } \\
\text { Volume } \\
\text { (L) }\end{array}$ & $\begin{array}{c}\text { Hydro } \\
\text { Zone } \\
\text { Code }\end{array}$ & $\begin{array}{l}\text { Geo } \\
\text { Unit } \\
\text { Code }\end{array}$ \\
\hline 1 & 215.0 & 225 & 6154.3 & $\overline{6144.3}$ & 10.0 & None & None & 225.0 & 6144.3 & 225 & 0.0 & 0.0 & $\mathrm{~T}$ & Tb4 \\
\hline
\end{tabular}

Note: TW-1A Ground Elevation: $6369.28 \mathrm{ft}$; all measurements are from this elevation

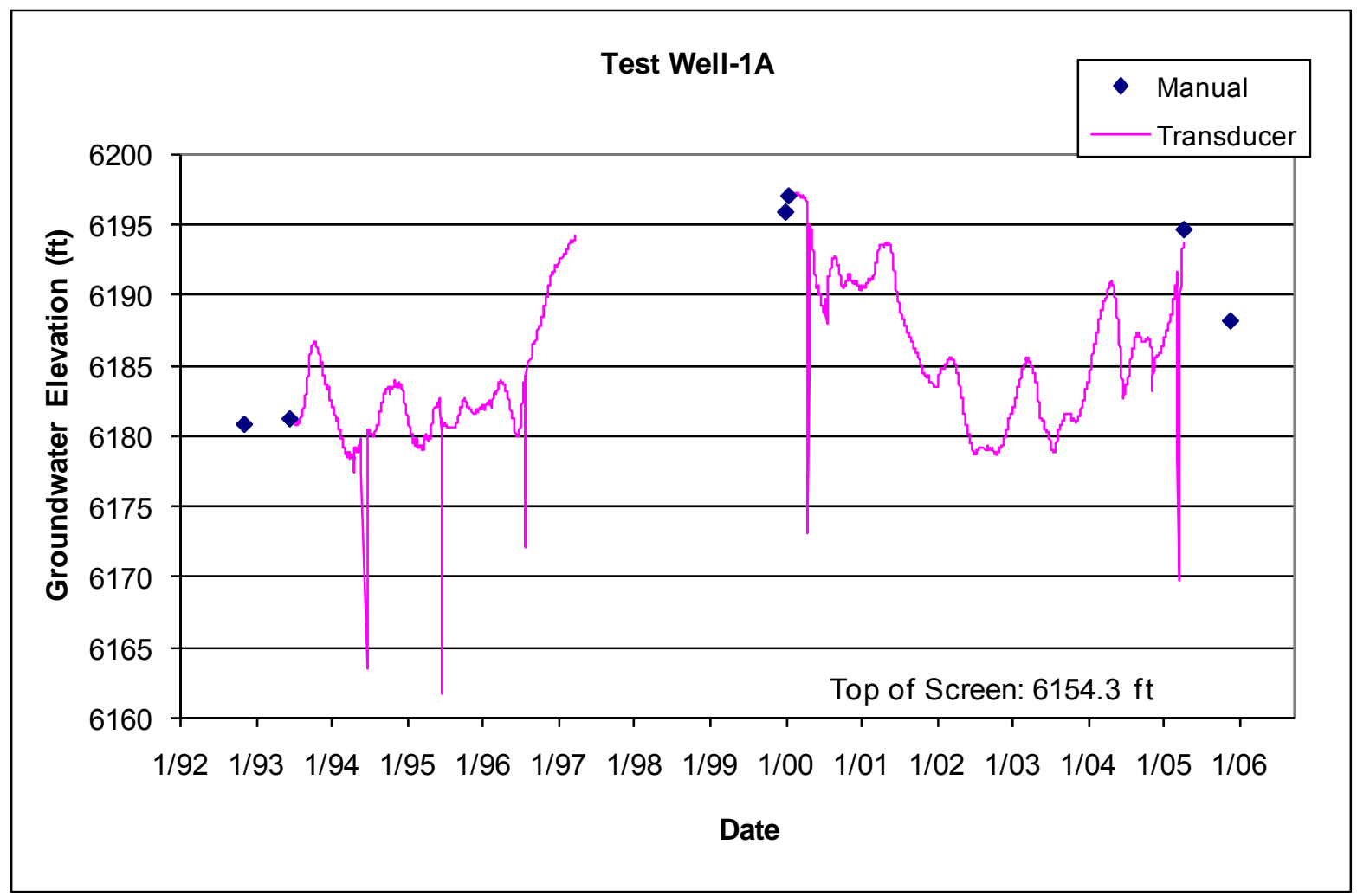




\subsection{Test Well 2A}

Location: TW-2A is located in middle Pueblo Canyon adjacent to TW-2.

Completion Type: Single completion in the Puye Formation.

Period of Record: Well completed in 1950, transducer installed January 1994 but equipment problems preclude data until 1995; intermittent data through 2009.

Remarks: Recent pumping of TW-2A when the water level is below $6535 \mathrm{ft}$ has shown slow recovery of the intermediate groundwater.

\begin{tabular}{|c|c|c|c|c|c|c|c|c|c|c|c|c|c|c|}
\hline \multicolumn{15}{|c|}{ TW-2A Construction Information } \\
\hline Screen & $\begin{array}{c}\text { Screen } \\
\text { Top } \\
\text { Depth } \\
\text { (ft) }\end{array}$ & $\begin{array}{c}\text { Screen } \\
\text { Bottom } \\
\text { Depth } \\
\text { (ft) }\end{array}$ & $\begin{array}{c}\text { Screen } \\
\text { Top } \\
\text { Elev } \\
\text { (ft) }\end{array}$ & $\begin{array}{c}\text { Screen } \\
\text { Bottom } \\
\text { Elev } \\
\text { (ft) }\end{array}$ & $\begin{array}{l}\text { Screen } \\
\text { Length } \\
\text { (ft) }\end{array}$ & $\begin{array}{c}\text { Pump } \\
\text { Intake } \\
\text { Depth } \\
\text { (ft) }\end{array}$ & $\begin{array}{c}\text { Pump } \\
\text { Intake } \\
\text { Elev } \\
\text { (ft) }\end{array}$ & $\begin{array}{c}\text { Depth to } \\
\text { Top of } \\
\text { Sump (ft) }\end{array}$ & $\begin{array}{c}\text { Top of } \\
\text { Sump } \\
\text { Elev } \\
\text { (ft) }\end{array}$ & $\begin{array}{l}\text { Depth to } \\
\text { Sump } \\
\text { Bottom } \\
\text { (ft) }\end{array}$ & $\begin{array}{c}\text { Sump } \\
\text { Length } \\
\text { (ft) }\end{array}$ & $\begin{array}{c}\text { Sump } \\
\text { Volume } \\
\text { (L) }\end{array}$ & $\begin{array}{c}\text { Hydro } \\
\text { Zone } \\
\text { Code }\end{array}$ & $\begin{array}{l}\text { Geo } \\
\text { Unit } \\
\text { Code }\end{array}$ \\
\hline 4 & $\overline{123.0}$ & 13 & 652 & 6517.4 & 10.0 & 130.0 & 6520.4 & 133.0 & 6517.4 & 133.0 & 0.0 & 0.0 & $\mathrm{~T}$ & $T p$ \\
\hline
\end{tabular}

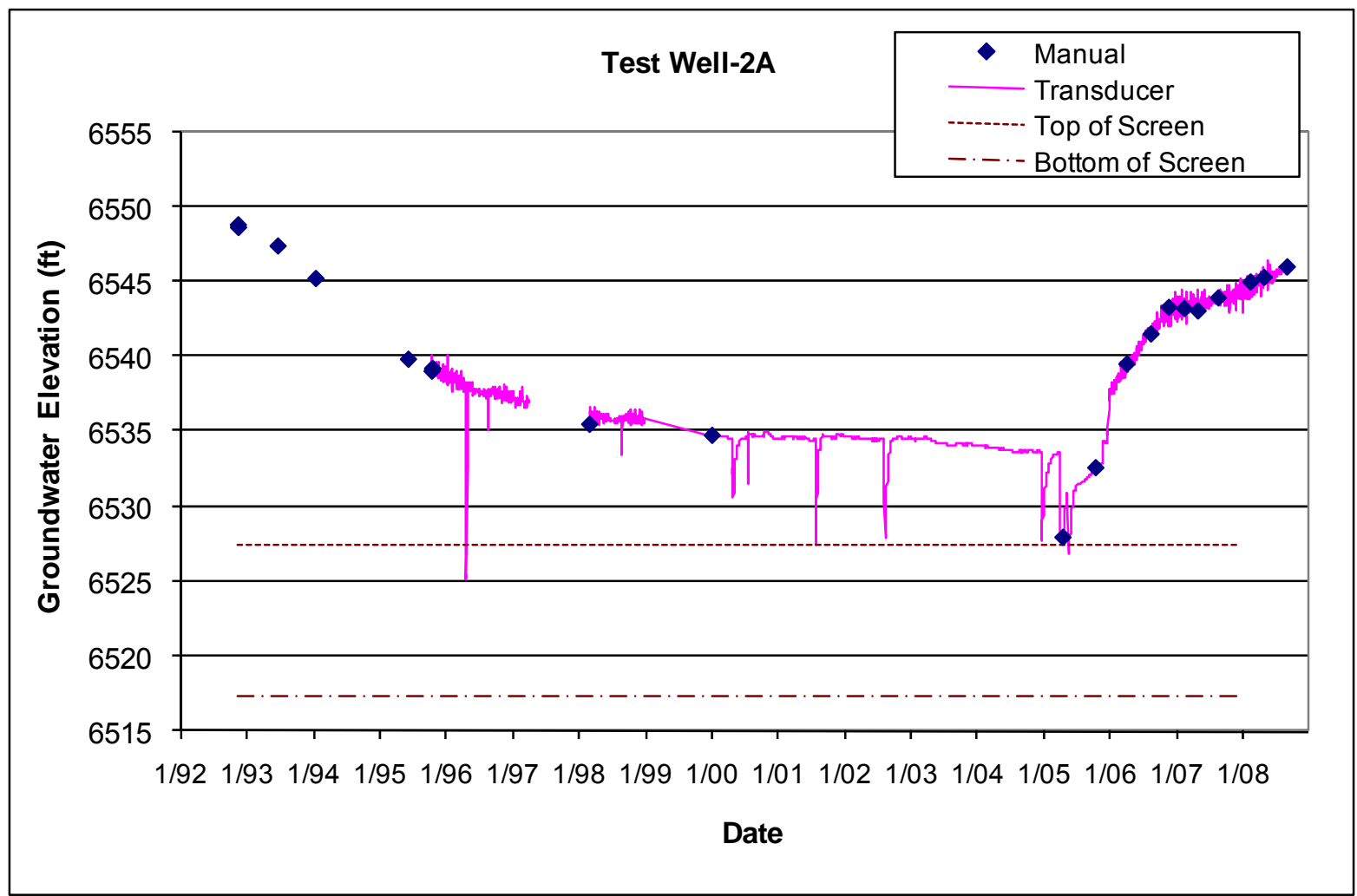




\subsection{Groundwater Level Data from Alluvial Wells}

Table 5-1 lists the alluvial wells that were monitored for groundwater levels in 2009. The table provides the well name, date of completion, well depth, surveyed location coordinates, ground surface elevation, and the screen top and bottom depths for each well. Figure 5-1 shows the locations of the wells. In the following alluvial groundwater sections, the first graph for each well represents the entire period of record, while the second graph represents groundwater level data for recent years. Alluvial groundwater levels respond to snowmelt runoff, storm runoff, and, in some canyons, effluent discharges. Some alluvial wells have been historically dry and do not show a seasonal response to precipitation and runoff.

Table 5-1. Information and Location Data for Alluvial Aquifer Wells at LANL

\begin{tabular}{|c|c|c|c|c|c|c|c|}
\hline Well Name & $\begin{array}{c}\text { Date } \\
\text { Completed }\end{array}$ & $\begin{array}{c}\text { Completed } \\
\text { Depth (ft) }\end{array}$ & Easting (ft) & Northing (ft) & $\begin{array}{c}\text { Surface } \\
\text { Elevation } \\
\text { (ft) }\end{array}$ & $\begin{array}{c}\text { Screen } \\
\text { Top } \\
\text { Depth } \\
\text { (ft) }\end{array}$ & $\begin{array}{c}\text { Screen } \\
\text { Bottom } \\
\text { Depth } \\
\text { (ft) }\end{array}$ \\
\hline 18-BG-1 & $8 / 1 / 1994$ & 35.0 & 1634152.90 & 1762575.36 & 6776.45 & 10.0 & 35.0 \\
\hline 18-BG-4 & 2/18/1998 & 6.5 & 1633510.00 & 1760760.00 & 6768.00 & 2.5 & 6.5 \\
\hline 18-MW-7 & $7 / 6 / 1994$ & 30.0 & 1634846.28 & 1761791.52 & 6755.50 & 10.0 & 30.0 \\
\hline 18-MW-8 & $8 / 4 / 1994$ & 37.9 & 1634714.26 & 1760658.14 & 6747.79 & 8.0 & 38.0 \\
\hline 18-MW-9 & $7 / 21 / 1994$ & 21.0 & 1635949.81 & 1760893.56 & 6732.91 & 6.0 & 31.0 \\
\hline 18-MW-17 & $8 / 1 / 1995$ & 22.0 & 1637778.20 & 1759717.10 & 6695.20 & 12.0 & 22.0 \\
\hline 18-MW-18 & 7/31/1995 & 23.0 & 1639925.00 & 1758247.20 & 6654.70 & 12.5 & 23.0 \\
\hline 39-UM-3 & $8 / 15 / 1994$ & 54.0 & 1637032.00 & 1747663.00 & 6394.20 & 44.0 & 54.0 \\
\hline 39-DM-6 & $8 / 15 / 1994$ & 60.0 & 1637094.00 & 1747228.00 & 6384.57 & 50.0 & 60.0 \\
\hline APCO-1 & $8 / 15 / 1990$ & 19.7 & 1649209.62 & 1773020.12 & 6367.53 & 4.7 & 14.7 \\
\hline CDBO-1 & 4/17/1985 & 13.0 & 1637968.59 & 1760943.96 & 6757.60 & 5.1 & 13.1 \\
\hline CDBO-2 & 4/18/1985 & 18.0 & 1638119.02 & 1761103.11 & 6758.20 & 5.9 & 17.9 \\
\hline CDBO-3 & 4/18/1985 & 12.0 & 1640677.11 & 1759611.02 & 6670.20 & 4.4 & 12.4 \\
\hline CDBO-4 & $4 / 18 / 1985$ & 12.0 & 1645474.90 & 1758546.90 & 6564.50 & 4.1 & 12.1 \\
\hline CDBO-5 & 6/1/1992 & 17.0 & 1633583.37 & 1765818.37 & 6879.01 & 7.0 & 17.0 \\
\hline CDBO-6 & $6 / 1 / 1992$ & 49.0 & 1636209.25 & 1764759.75 & 6817.20 & 34.0 & 44.0 \\
\hline CDBO-7 & $6 / 1 / 1992$ & 44.0 & 1637400.00 & 1763301.00 & 6771.81 & 29.0 & 39.0 \\
\hline CDBO-8 & $6 / 1 / 1992$ & 23.0 & 1639294.00 & 1762366.00 & 6722.47 & 3.0 & 13.0 \\
\hline CDBO-9 & $6 / 1 / 1992$ & 34.0 & 1642119.12 & 1759702.87 & 6633.00 & 19.0 & 29.0 \\
\hline CDV-16-02655 & 9/27/1997 & 7.6 & 1611299.09 & 1764153.13 & 7583.70 & 2.3 & 7.3 \\
\hline CDV-16-02656 & $11 / 5 / 1997$ & 8.2 & 1613634.46 & 1764932.79 & 7443.18 & 3.0 & 8.0 \\
\hline CDV-16-02657 & 10/10/1997 & 5.7 & 1613813.19 & 1764850.10 & 7433.25 & 0.4 & 5.4 \\
\hline CDV-16-02658 & 9/16/1997 & 7.2 & 1615071.38 & 1764469.56 & 7375.60 & 1.9 & 6.9 \\
\hline CDV-16-02659 & 9/8/1997 & 7.0 & 1616712.08 & 1765035.06 & 7300.50 & 1.7 & 6.7 \\
\hline FCO-1 & $8 / 22 / 1989$ & 12.4 & 1642409.00 & 1751177.00 & 6509.24 & 2.4 & 12.4 \\
\hline FLC-16-25278 & $10 / 10 / 2005$ & 3.2 & 1618820.88 & 1762605.72 & 7272.20 & 1.6 & 3.2 \\
\hline FLC-16-25279 & $10 / 10 / 2005$ & 4.3 & 1617679.48 & 1762856.43 & 7309.30 & 2.7 & 4.3 \\
\hline FLC-16-25280 & $10 / 10 / 2005$ & 4.2 & 1616646.29 & 1763365.10 & 7352.90 & 2.6 & 4.2 \\
\hline LAO-B & $4 / 28 / 1994$ & 27.2 & 1615148.80 & 1775170.40 & 7323.59 & 11.8 & 26.8 \\
\hline LAO-0.3 & $5 / 17 / 1994$ & 11.3 & 1624799.00 & 1774511.60 & 6968.13 & 5.9 & 10.9 \\
\hline LAO-0.6 & $5 / 6 / 1994$ & 13.4 & 1626748.10 & 1774332.90 & 6910.74 & 8.0 & 13.0 \\
\hline LAO-0.91 & $5 / 12 / 1994$ & 14.9 & 1628654.30 & 1774207.00 & 6861.74 & 9.5 & 14.5 \\
\hline LAO-1 & 2/1/1996 & 28.0 & 1629395.00 & 1773956.37 & 6836.24 & 8.0 & 28.0 \\
\hline
\end{tabular}




\begin{tabular}{|c|c|c|c|c|c|c|c|}
\hline Well Name & $\begin{array}{c}\text { Date } \\
\text { Completed }\end{array}$ & $\begin{array}{l}\text { Completed } \\
\text { Depth (ft) }\end{array}$ & Easting (ft) & Northing (ft) & $\begin{array}{c}\text { Surface } \\
\text { Elevation } \\
\text { (ft) }\end{array}$ & $\begin{array}{c}\text { Screen } \\
\text { Top } \\
\text { Depth } \\
\text { (ft) }\end{array}$ & $\begin{array}{c}\text { Screen } \\
\text { Bottom } \\
\text { Depth } \\
\text { (ft) }\end{array}$ \\
\hline LAO-1.2 & $8 / 15 / 1969$ & 18.0 & 1632646.25 & 1773361.37 & 6720.00 & 8.0 & 18.0 \\
\hline LAO-1.6g & $3 / 20 / 1996$ & 30.8 & 1636083.42 & 1772557.63 & 6658.01 & 10.5 & 25.5 \\
\hline LAO-1.8 & 4/15/1969 & 18.0 & 1635446.25 & 1772661.37 & 6680.00 & 8.0 & 18.0 \\
\hline LAO-2 & 2/1/1996 & 32.0 & 1637607.75 & 1773095.87 & 6592.97 & 7.0 & 32.0 \\
\hline LAO-3a & $9 / 14 / 1989$ & 14.7 & 1637980.87 & 1773099.75 & 6579.40 & 4.7 & 14.7 \\
\hline LAO- $4.5 \mathrm{c}$ & $11 / 1 / 1989$ & 23.3 & 1643547.37 & 1772076.50 & 6457.63 & 13.3 & 23.3 \\
\hline LAO-5 & $2 / 15 / 1966$ & 25.0 & 1646202.25 & 1771424.12 & 6398.30 & 5.0 & 25.0 \\
\hline LAO-6 & $2 / 1 / 1966$ & 16.0 & 1646222.12 & 1771329.50 & 6395.30 & 6.0 & 16.0 \\
\hline LAO-6a & $8 / 1 / 1989$ & 14.2 & 1646221.62 & 1771344.00 & 6395.88 & 4.2 & 14.2 \\
\hline LAUZ-1 & & 10.6 & 1633435.13 & 1774809.81 & 7032.42 & 5.4 & 10.4 \\
\hline LLAO-1b & $7 / 16 / 1997$ & 24.2 & 1659738.70 & 1772381.65 & 5850.34 & 11.3 & 21.3 \\
\hline LLAO-3 & $7 / 22 / 1997$ & 21.5 & 1665475.00 & 1775952.59 & 5692.62 & 8.7 & 18.7 \\
\hline LLAO-4 & 9/30/1996 & 18.1 & 1671820.23 & 1774468.01 & 5515.46 & 5.2 & 15.2 \\
\hline LLAO-5 & $6 / 27 / 1996$ & 24.2 & 1672275.40 & 1774271.60 & 5508.21 & 11.4 & 21.4 \\
\hline MCA-1 & $1 / 24 / 2005$ & 5.9 & 1626586.50 & 1770410.77 & 7070.60 & 2.4 & 5.4 \\
\hline MCA-2 & $10 / 24 / 2004$ & 65.0 & 1634097.23 & 1768585.88 & 6837.20 & 45.0 & 60.0 \\
\hline MCA-3a & $11 / 29 / 2004$ & 43.4 & 1633586.89 & 1769068.28 & 6853.00 & 42.9 & 43.4 \\
\hline MCA-3c & $11 / 30 / 2004$ & 43.4 & 1633586.89 & 1769068.28 & 6853.00 & 38.4 & 38.9 \\
\hline MCA-3b & $11 / 22 / 2004$ & 42.1 & 1633589.40 & 1769069.84 & 6852.90 & 40.9 & 41.4 \\
\hline MCA-3d & $12 / 2 / 2004$ & 55.8 & 1634886.02 & 1768523.27 & 6819.80 & 54.6 & 55.1 \\
\hline MCA-3e & $12 / 2 / 2004$ & 55.8 & 1634886.02 & 1768523.27 & 6819.80 & 51.0 & 51.5 \\
\hline MCA-3f & $12 / 2 / 2004$ & 55.8 & 1634886.02 & 1768523.27 & 6819.80 & 47.5 & 48.0 \\
\hline MCA-4 & $2 / 1 / 2005$ & 6.0 & 1625945.50 & 1770129.55 & 7135.10 & 3.3 & 5.3 \\
\hline MCA-5 & $2 / 1 / 2005$ & 5.4 & 1627354.17 & 1770233.59 & 7053.80 & 1.8 & 5.8 \\
\hline MCA-8 & $9 / 29 / 2004$ & 86.3 & 1641325.48 & 1767372.92 & 6668.80 & 66.0 & 81.0 \\
\hline MCA-9 & $12 / 4 / 2004$ & 113.0 & 1641470.29 & 1767393.22 & 6671.70 & 92.8 & 107.8 \\
\hline MCO-0.6 & 2/25/1999 & 3.1 & 1623987.80 & 1771179.50 & 7188.28 & 1.1 & 3.1 \\
\hline MCO-2 & $11 / 1 / 1960$ & 9.0 & 1625919.25 & 1770135.12 & 7136.60 & 2.0 & 9.0 \\
\hline MCO-3 & 3/1/1967 & 12.0 & 1627362.50 & 1770236.75 & 7052.60 & 2.0 & 12.0 \\
\hline MCO-4B & $8 / 1 / 1990$ & 33.9 & 1632036.37 & 1769697.00 & 6886.75 & 8.9 & 28.9 \\
\hline MCO-5 & $10 / 1 / 1960$ & 46.0 & 1632466.12 & 1769538.00 & 6875.66 & 21.0 & 46.0 \\
\hline MCO-6 & $3 / 1 / 1974$ & 47.0 & 1633635.37 & 1769012.75 & 6849.48 & 27.0 & 47.0 \\
\hline MCO-7 & $10 / 1 / 1960$ & 69.0 & 1634517.87 & 1768509.87 & 6827.31 & 39.0 & 69.0 \\
\hline MCO-7.5 & 4/1/1974 & 60.0 & 1635454.87 & 1768440.50 & 6808.88 & 35.0 & 60.0 \\
\hline MCWB-5 & $12 / 6 / 1994$ & 33.0 & 1632578.31 & 1769484.60 & 6876.22 & 17.0 & 27.0 \\
\hline MCWB-5.5B & $12 / 22 / 1994$ & 37.5 & 1633420.54 & 1769125.78 & 6856.89 & 22.5 & 32.5 \\
\hline MCWB-6.2A & 12/7/1994 & 45.5 & 1633754.49 & 1768968.15 & 6848.29 & 30.5 & 40.5 \\
\hline MCWB-6.5E & $12 / 21 / 1994$ & 50.0 & 1633833.36 & 1768583.81 & 6843.80 & 35.0 & 45.0 \\
\hline MCWB-7A & $12 / 9 / 1994$ & 52.0 & 1634356.62 & 1768551.02 & 6831.17 & 37.0 & 47.0 \\
\hline MCWB-7.4B & $12 / 13 / 1994$ & 70.0 & 1635287.73 & 1768407.84 & 6813.07 & 45.0 & 65.0 \\
\hline MCWB-7.7B & $12 / 20 / 1994$ & 70.0 & 1635921.84 & 1768517.26 & 6798.97 & 55.0 & 65.0 \\
\hline $\begin{array}{l}\text { MSC-16- } \\
06293\end{array}$ & $1 / 27 / 2000$ & 7.3 & 1615809.67 & 1761331.78 & 7370.79 & 2.0 & 7.0 \\
\hline $\begin{array}{l}\text { MSC-16- } \\
06294\end{array}$ & $1 / 26 / 2000$ & 7.6 & 1617848.17 & 1761298.78 & 7288.44 & 2.5 & 7.3 \\
\hline
\end{tabular}




\begin{tabular}{|c|c|c|c|c|c|c|c|}
\hline Well Name & $\begin{array}{c}\text { Date } \\
\text { Completed }\end{array}$ & $\begin{array}{l}\text { Completed } \\
\text { Depth (ft) }\end{array}$ & Easting (ft) & Northing (ft) & $\begin{array}{l}\text { Surface } \\
\text { Elevation } \\
\text { (ft) }\end{array}$ & $\begin{array}{l}\text { Screen } \\
\text { Top } \\
\text { Depth } \\
\text { (ft) }\end{array}$ & $\begin{array}{c}\text { Screen } \\
\text { Bottom } \\
\text { Depth } \\
\text { (ft) }\end{array}$ \\
\hline $\begin{array}{l}\text { MSC-16- } \\
06295\end{array}$ & $1 / 31 / 2000$ & 6.9 & 1618630.67 & 1761004.78 & 7257.03 & 1.5 & 6.5 \\
\hline MT-1 & $11 / 1 / 1988$ & 69.0 & 1635262.86 & 1768493.96 & 6811.63 & 39.0 & 59.0 \\
\hline MT-2 & $11 / 1 / 1988$ & 64.0 & 1636019.79 & 1768544.59 & 6796.20 & 44.0 & 64.0 \\
\hline MT-3 & $11 / 1 / 1988$ & 74.0 & 1635980.95 & 1768657.83 & 6796.65 & 44.0 & 64.0 \\
\hline MT-4 & $11 / 1 / 1988$ & 74.0 & 1636558.75 & 1768634.37 & 6783.59 & 54.0 & 64.0 \\
\hline PAO-1 & 10/30/1998 & 13.7 & 1624165.85 & 1778988.72 & 6954.97 & 5.9 & 10.9 \\
\hline PAO-2 & $11 / 2 / 1998$ & 13.9 & 1625040.90 & 1778710.00 & 6930.98 & 6.1 & 11.1 \\
\hline PAO-2.5 & $8 / 31 / 1998$ & 10.3 & 1630646.12 & 1777700.31 & 6722.39 & 2.4 & 7.4 \\
\hline PAO-3 & $8 / 27 / 1998$ & 13.5 & 1637747.70 & 1776856.31 & 6578.58 & 5.6 & 10.6 \\
\hline PAO-4 & $7 / 24 / 1997$ & 9.8 & 1646090.28 & 1775098.35 & 6437.37 & 2.0 & 7.0 \\
\hline PAO-5N & $3 / 24 / 1998$ & 15.3 & 1649271.93 & 1773133.50 & 6369.79 & 7.4 & 12.4 \\
\hline PAO-5S & $3 / 23 / 1998$ & 20.9 & 1649180.35 & 1772991.48 & 6368.30 & 8.1 & 18.1 \\
\hline PCO-1 & $6 / 30 / 1985$ & 12.0 & 1637919.25 & 1759990.62 & 6687.00 & 4.0 & 12.0 \\
\hline PCO-2 & 6/30/1985 & 9.5 & 1641700.37 & 1757442.75 & 6618.30 & 1.5 & 9.5 \\
\hline PCO-3 & $6 / 30 / 1985$ & 17.7 & 1646088.62 & 1755489.37 & 6546.30 & 5.7 & 17.7 \\
\hline SCA-1 & $8 / 25 / 2006$ & 2.1 & 1622482.45 & 1773264.59 & 7211.22 & 1.3 & 1.9 \\
\hline SCA-2 & $8 / 24 / 2006$ & 15.6 & 1636115.02 & 1770282.78 & 6749.08 & 10.3 & 15.0 \\
\hline SCA-3 & 9/9/2006 & 32.6 & 1637200.75 & 1769917.84 & 6723.22 & 27.6 & 32.0 \\
\hline SCA-4 & $9 / 10 / 2006$ & 42.0 & 1638261.23 & 1769566.62 & 6703.58 & 37.0 & 41.5 \\
\hline SCA-5 & $9 / 11 / 2006$ & 64.9 & 1639878.28 & 1769725.47 & 6669.02 & 55.0 & 64.4 \\
\hline SCO-1 & $8 / 15 / 1989$ & 19.3 & 1642297.62 & 1769502.25 & 6618.67 & 9.3 & 19.3 \\
\hline SCO-2 & 8/16/1989 & 19.4 & 1647259.00 & 1767864.00 & 6500.67 & 9.4 & 19.4 \\
\hline SCP-1abc & $9 / 12 / 2006$ & 41.8 & 1638254.68 & 1769567.80 & 6703.65 & 41.2 & 41.7 \\
\hline SCP-1abc & $9 / 12 / 2006$ & 41.8 & 1638254.68 & 1769567.80 & 6703.65 & 39.4 & 39.9 \\
\hline SCP-1abc & $9 / 12 / 2006$ & 41.8 & 1638254.68 & 1769567.80 & 6703.65 & 37.8 & 38.3 \\
\hline SCP-2a & $9 / 13 / 2006$ & 45.1 & 1637209.65 & 1769911.26 & 6722.95 & 44.5 & 45.0 \\
\hline SCP-2b & $9 / 12 / 2006$ & 50.1 & 1637205.05 & 1769914.53 & 6723.11 & 49.5 & 50.0 \\
\hline TSCA-6 & $11 / 9 / 2004$ & 21.3 & 1632954.60 & 1768471.44 & 6863.20 & 16.2 & 20.9 \\
\hline TSWB-6 & $12 / 21 / 1994$ & 40.0 & 1633383.09 & 1768490.75 & 6853.21 & 25.0 & 35.0 \\
\hline WCO-1 & 10/31/1989 & 34.4 & 1632758.75 & 1755069.12 & 6616.41 & 24.4 & 34.4 \\
\hline WCO-2 & 10/26/1989 & 23.5 & 1636870.37 & 1753228.37 & 6524.57 & 13.5 & 23.5 \\
\hline WCO-3 & $10 / 25 / 1989$ & 12.4 & 1640212.50 & 1750620.25 & 6436.43 & 7.4 & 12.4 \\
\hline
\end{tabular}




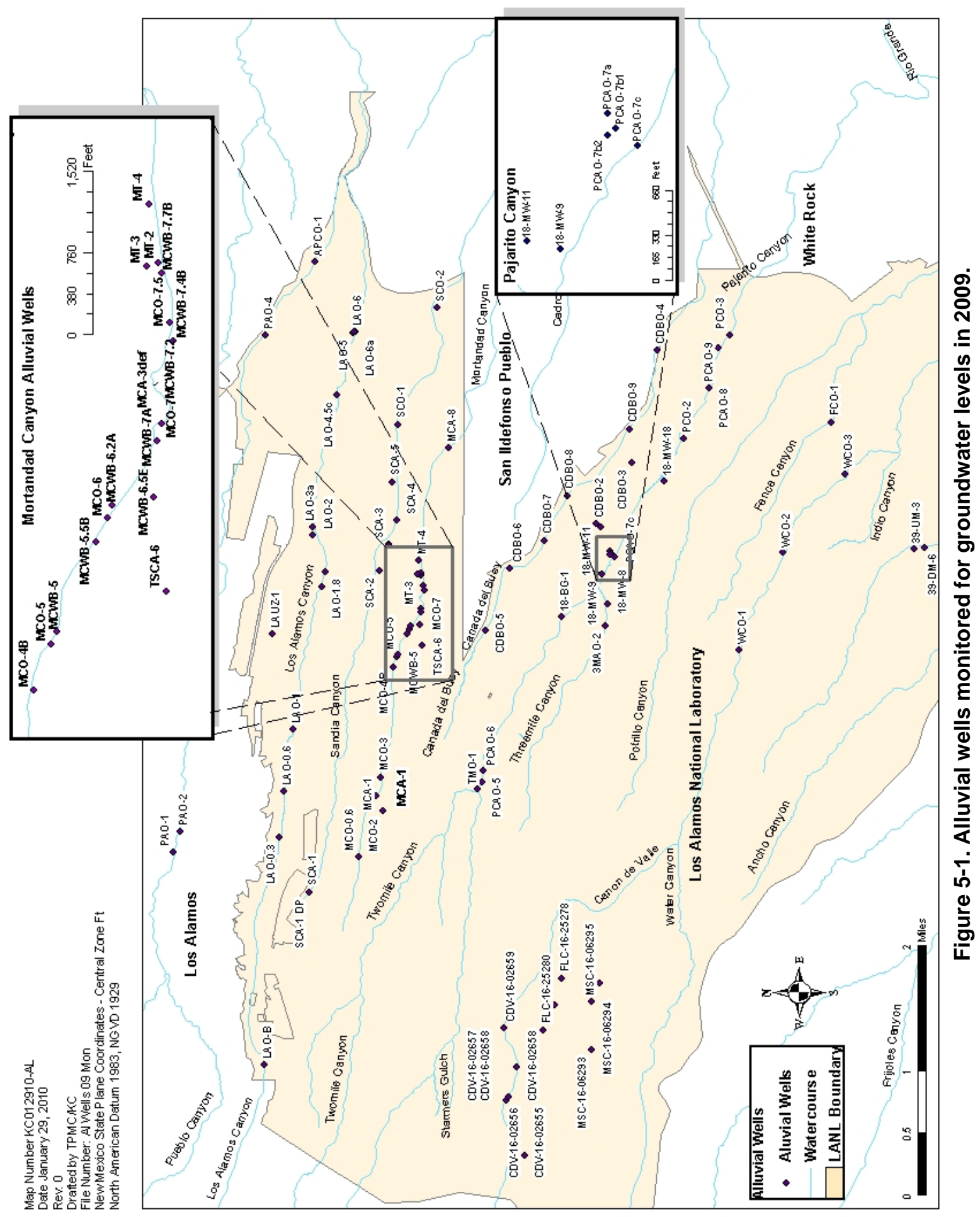




\subsection{8-BG-1}

Location: Lower Pajarito Canyon, about 0.4 miles west of the TA-18 facilities.

Period of Record: August 1, 1994, through December 17, 2009.

Remarks: None.

\begin{tabular}{|c|c|c|c|c|c|c|c|c|c|c|c|c|c|}
\hline \multicolumn{14}{|c|}{ 18-BG-1 Construction Information } \\
\hline Zone & $\begin{array}{c}\text { Screen } \\
\text { Top } \\
\text { Depth (ft) }\end{array}$ & $\begin{array}{c}\text { Screen } \\
\text { Bottom } \\
\text { Depth } \\
\text { (ft) }\end{array}$ & $\begin{array}{c}\text { Screen } \\
\text { Top } \\
\text { Elev (ft) }\end{array}$ & $\begin{array}{l}\text { Screen } \\
\text { Bottom } \\
\text { Elev (ft) }\end{array}$ & $\begin{array}{c}\text { Screen } \\
\text { Length } \\
\text { (ft) }\end{array}$ & $\begin{array}{c}\text { Pump } \\
\text { Intake } \\
\text { Depth } \\
\text { (ft) }\end{array}$ & $\begin{array}{c}\text { Pump } \\
\text { Intake } \\
\text { Elevation } \\
\text { (ft) }\end{array}$ & $\begin{array}{c}\text { Depth to } \\
\text { Top of } \\
\text { Sump (ft) }\end{array}$ & $\begin{array}{c}\text { Top of } \\
\text { Sump } \\
\text { Elevation } \\
\text { (ft) }\end{array}$ & \begin{tabular}{|c|} 
Depth to \\
Sump \\
Bottom (ft)
\end{tabular} & $\begin{array}{c}\text { Sump } \\
\text { Length } \\
\text { (ft) }\end{array}$ & $\begin{array}{c}\text { Sump } \\
\text { Volume } \\
\text { (L) }\end{array}$ & Comment \\
\hline 1 & 10.0 & 35.0 & 6766.5 & 6741.5 & 25.0 & & & 35.0 & 6741.5 & 35 & 0.0 & 0.0 & Alluvial groundwater \\
\hline
\end{tabular}

Note: Ground Elevation: $6776.45 \mathrm{ft}$; all depths are from this elevation
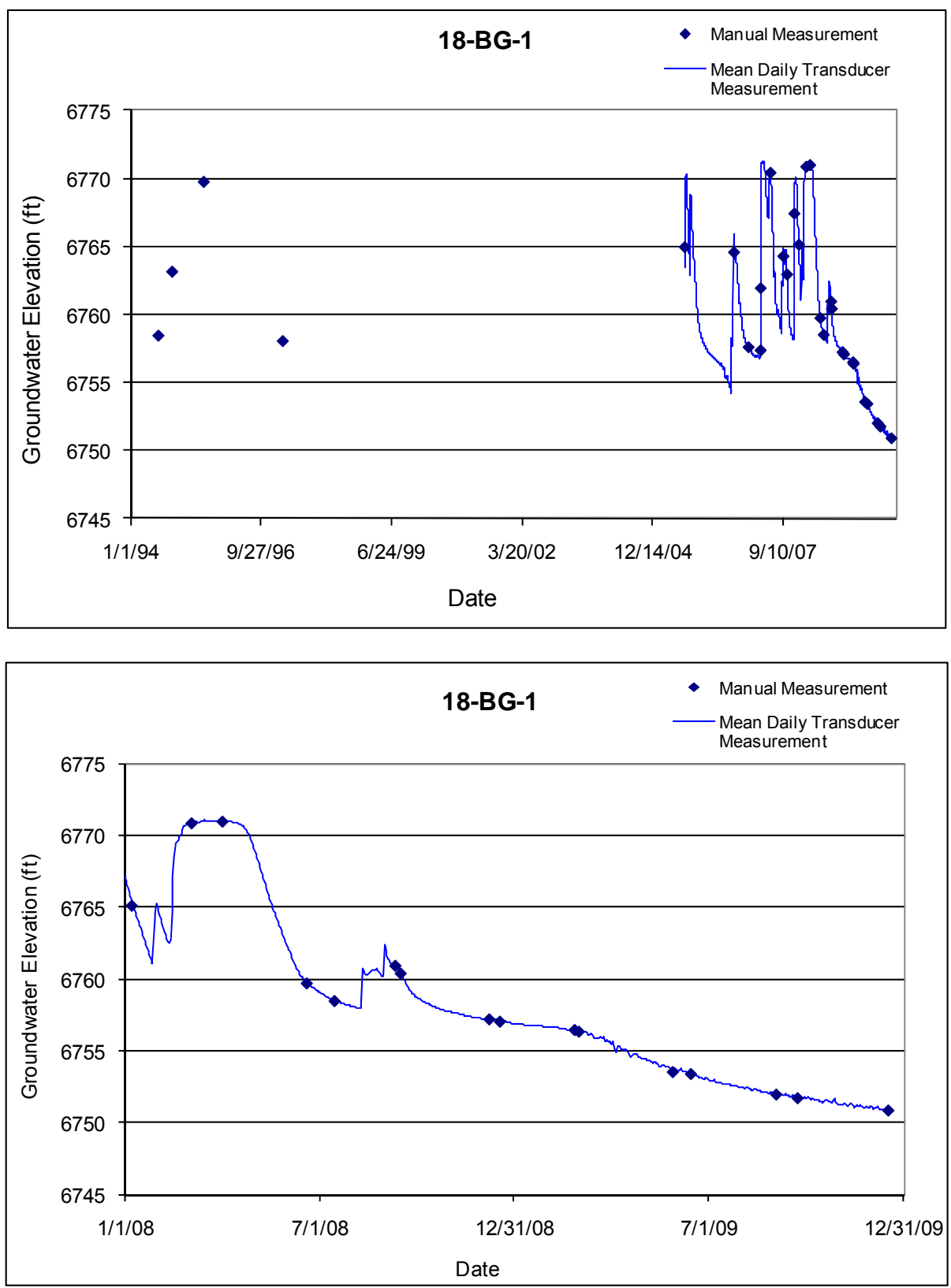


\subsection{8-BG-4}

Location: Three-Mile Canyon above the confluence with Pajarito Canyon, about 0.3 miles west of the TA-18 facilities.

Period of Record: February 18, 1998, through December 1, 2008.

Remarks: Monitoring of 18-BG-4 was discontinued on December 1, 2008, having been replaced with new monitoring well 3MAO-2 in 2008.

\begin{tabular}{|c|c|c|c|c|c|c|c|c|c|c|c|c|c|}
\hline \multicolumn{14}{|c|}{ 18-BG-4 Construction Information } \\
\hline Zone & $\begin{array}{l}\text { Screen } \\
\text { Top } \\
\text { Depth (ft) }\end{array}$ & $\begin{array}{c}\text { Screen } \\
\text { Bottom } \\
\text { Depth } \\
\text { (ft) }\end{array}$ & $\begin{array}{c}\text { Screen } \\
\text { Top } \\
\text { Elev (ft) }\end{array}$ & $\begin{array}{l}\text { Screen } \\
\text { Bottom } \\
\text { Elev (ft) }\end{array}$ & $\begin{array}{c}\text { Screen } \\
\text { Length } \\
\text { (ft) }\end{array}$ & $\begin{array}{c}\text { Pump } \\
\text { Intake } \\
\text { Depth } \\
\text { (ft) }\end{array}$ & $\begin{array}{c}\text { Pump } \\
\text { Intake } \\
\text { Elevation } \\
\text { (ft) }\end{array}$ & $\begin{array}{l}\text { Depth to } \\
\text { Top of } \\
\text { Sump (ft) }\end{array}$ & $\begin{array}{c}\text { Top of } \\
\text { Sump } \\
\text { Elevation } \\
\text { (ft) }\end{array}$ & $\begin{array}{l}\text { Depth to } \\
\text { Sump } \\
\text { Bottom (ft) }\end{array}$ & $\begin{array}{c}\text { Sump } \\
\text { Length } \\
\text { (ft) }\end{array}$ & $\begin{array}{c}\text { Sump } \\
\text { Volume } \\
\text { (L) }\end{array}$ & Comment \\
\hline 1 & 2.5 & 6.5 & 6765.5 & 6761.5 & 4.0 & & & 6.5 & 6761.5 & 6.5 & 0.0 & 0.0 & Alluvial groundwater \\
\hline
\end{tabular}
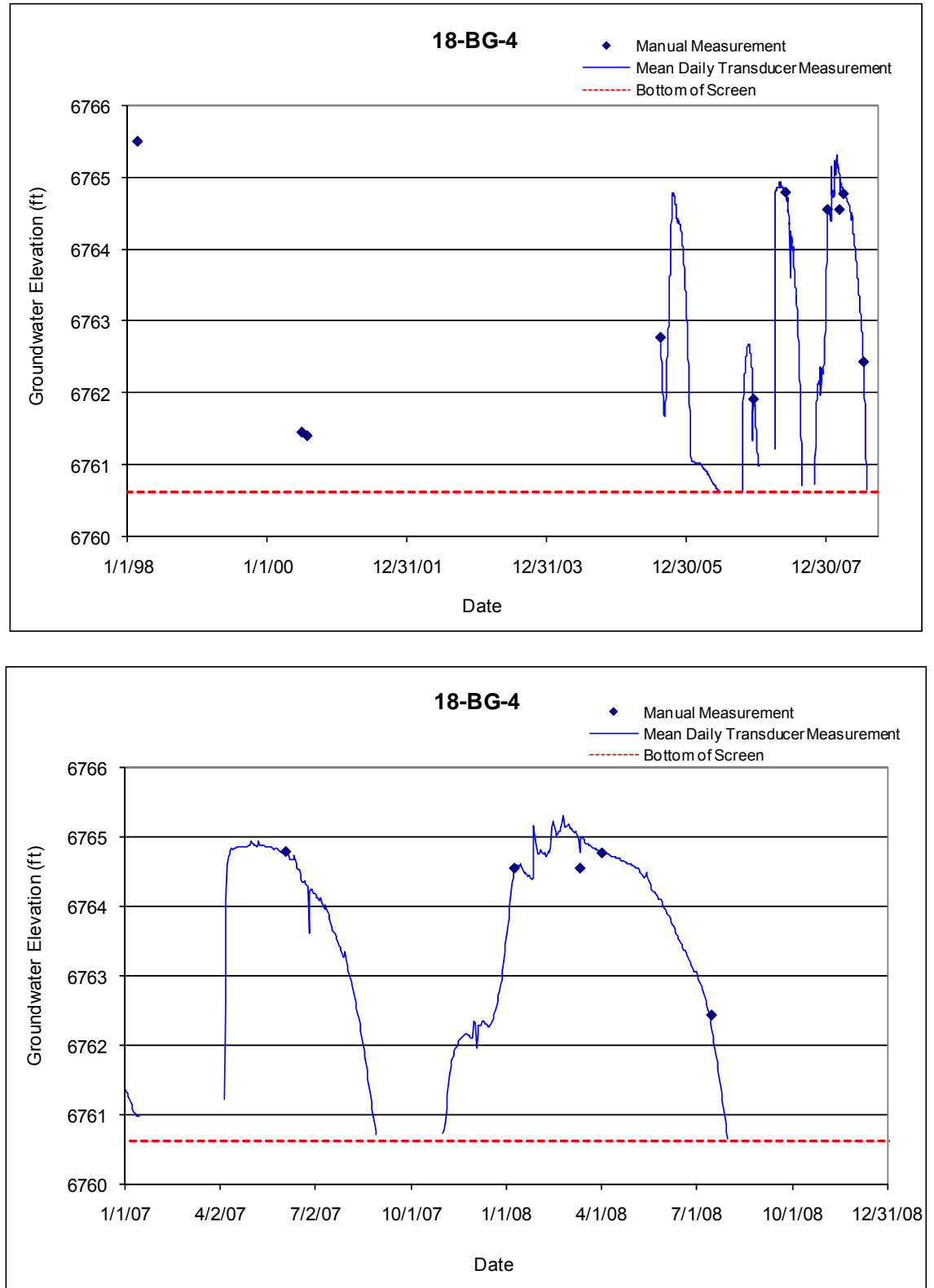


\section{$5.3 \quad 18-M W-7$}

Location: Pajarito Canyon, about 0.2 miles west of the TA-18 facilities.

Period of Record: July 6, 1994, through December 18, 2006.

Remarks: The transducer was removed on December 18, 2006; monitoring of this location was transferred to $18-\mathrm{MW}-11$.

\begin{tabular}{|c|c|c|c|c|c|c|c|c|c|c|c|c|c|}
\hline \multicolumn{14}{|c|}{ 18-MW-7 Construction Information } \\
\hline Zone & $\begin{array}{c}\text { Screen } \\
\text { Top } \\
\text { Depth (ft) }\end{array}$ & $\begin{array}{c}\text { Screen } \\
\text { Bottom } \\
\text { Depth } \\
\text { (ft) }\end{array}$ & $\begin{array}{c}\text { Screen } \\
\text { Top } \\
\text { Elev (ft) }\end{array}$ & $\begin{array}{l}\text { Screen } \\
\text { Bottom } \\
\text { Elev (ft) }\end{array}$ & $\begin{array}{c}\text { Screen } \\
\text { Length } \\
\text { (ft) }\end{array}$ & $\begin{array}{c}\text { Pump } \\
\text { Intake } \\
\text { Depth } \\
\text { (ft) }\end{array}$ & $\begin{array}{c}\text { Pump } \\
\text { Intake } \\
\text { Elevation } \\
\text { (ft) }\end{array}$ & $\begin{array}{c}\text { Depth to } \\
\text { Top of } \\
\text { Sump (ft) }\end{array}$ & $\begin{array}{c}\text { Top of } \\
\text { Sump } \\
\text { Elevation } \\
\text { (ft) }\end{array}$ & $\begin{array}{l}\text { Depth to } \\
\text { Sump } \\
\text { Bottom (ft) }\end{array}$ & $\begin{array}{c}\text { Sump } \\
\text { Length } \\
\text { (ft) }\end{array}$ & $\begin{array}{c}\text { Sump } \\
\text { Volume } \\
\text { (L) }\end{array}$ & Comment \\
\hline 1 & 10.0 & 30 & 6745.5 & 6725.5 & 20.0 & & & 30.0 & 6725.5 & 30 & 0.0 & 0.0 & Alluvial groundwater \\
\hline
\end{tabular}

Note: Ground Elevation: $6755.5 \mathrm{ft}$; all depths are from this elevation
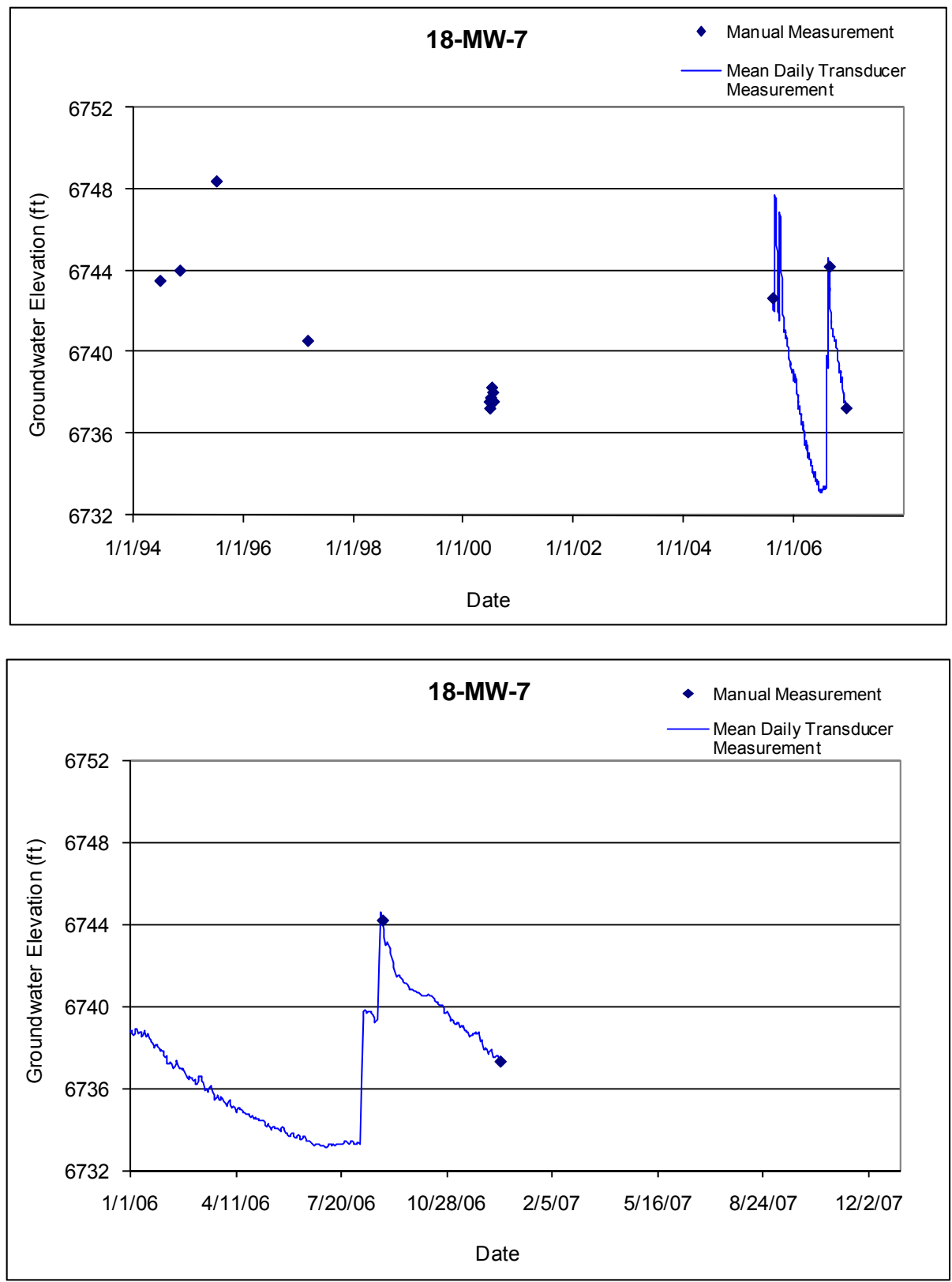


\section{$5.4 \quad 18-M W-8$}

Location: In Three-Mile Canyon above the confluence with Pajarito Canyon, about 0.1 miles west of the TA-18 facilities.

Period of Record: September 15, 1994, through December 18, 2009.

Remarks: None.

\begin{tabular}{|c|c|c|c|c|c|c|c|c|c|c|c|c|c|}
\hline \multicolumn{14}{|c|}{ 18-MW-8 Construction Information } \\
\hline Zone & $\begin{array}{c}\text { Screen } \\
\text { Top } \\
\text { Depth }(\mathrm{ft})\end{array}$ & $\begin{array}{c}\text { Screen } \\
\text { Bottom } \\
\text { Depth } \\
\text { (ft) }\end{array}$ & $\begin{array}{c}\text { Screen } \\
\text { Top } \\
\text { Elev (ft) }\end{array}$ & $\begin{array}{l}\text { Screen } \\
\text { Bottom } \\
\text { Elev (ft) }\end{array}$ & $\begin{array}{c}\text { Screen } \\
\text { Length } \\
\text { (ft) }\end{array}$ & $\begin{array}{c}\text { Pump } \\
\text { Intake } \\
\text { Depth } \\
\text { (ft) }\end{array}$ & $\begin{array}{c}\text { Pump } \\
\text { Intake } \\
\text { Elevation } \\
\text { (ft) }\end{array}$ & $\begin{array}{l}\text { Depth to } \\
\text { Top of } \\
\text { Sump (ft) }\end{array}$ & $\begin{array}{c}\text { Top of } \\
\text { Sump } \\
\text { Elevation } \\
\text { (ft) }\end{array}$ & \begin{tabular}{|} 
Depth to \\
Sump \\
Bottom (ft)
\end{tabular} & $\begin{array}{c}\text { Sump } \\
\text { Length } \\
\text { (ft) }\end{array}$ & $\begin{array}{c}\text { Sump } \\
\text { Volume } \\
\text { (L) }\end{array}$ & Comment \\
\hline 1 & 8.0 & 38.0 & 6739.8 & 6709.8 & 30.0 & & & 38.0 & 6709.8 & 38.0 & 0.0 & 0.0 & Alluvial groundwater \\
\hline
\end{tabular}

Note: Ground Elevation: $6747.79 \mathrm{ft}$; all depths are from this elevation
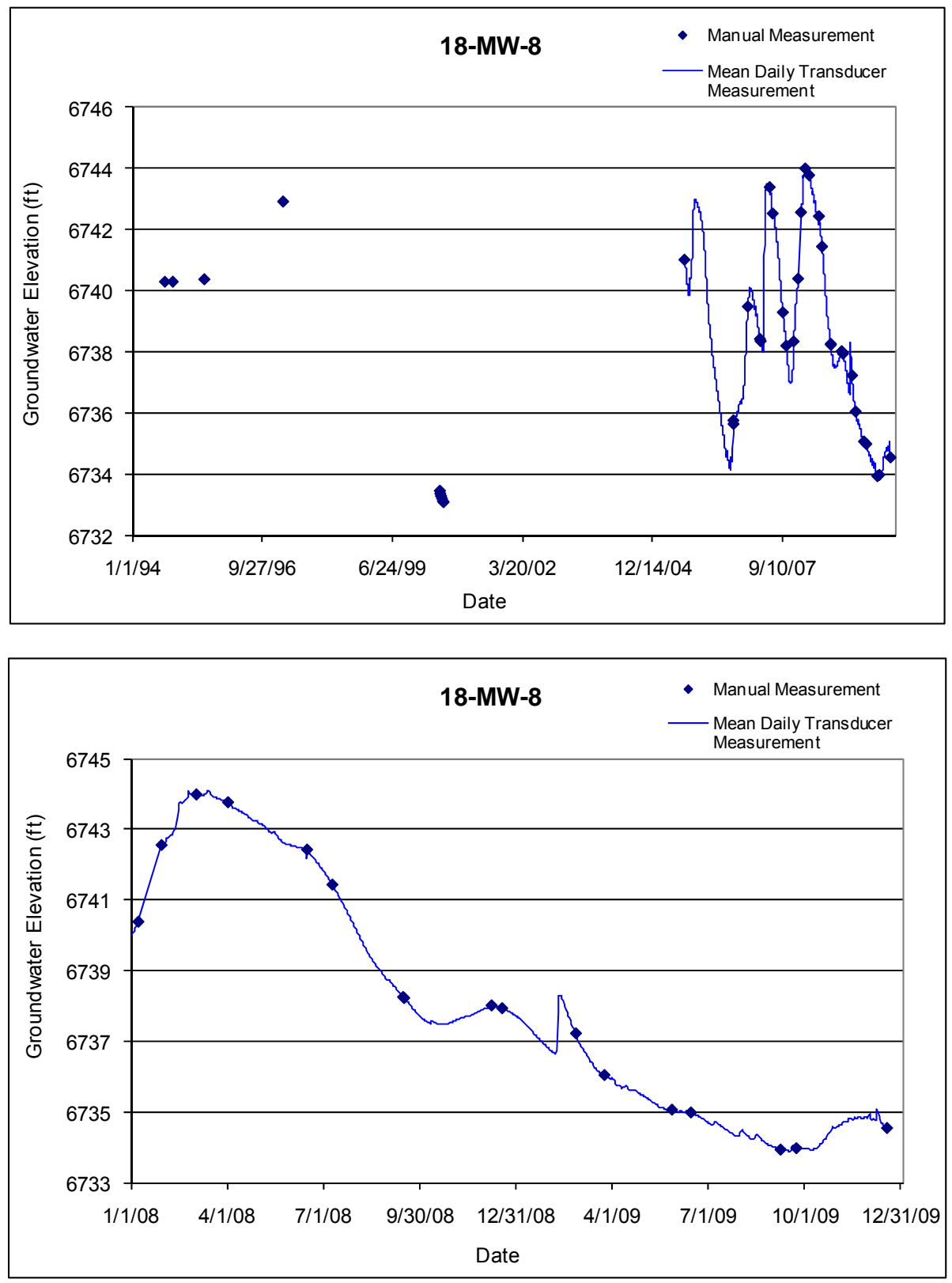


\section{$5.5 \quad 18-M W-9$}

Location: Pajarito Canyon, directly south of the main guard gate to TA-18.

Period of Record: July 21, 1994, through December 18, 2009.

Remarks: Data gap from December 2008 through April 2009 resulted from a succession of malfunctioning transducers.

\begin{tabular}{|c|c|c|c|c|c|c|c|c|c|c|c|c|c|}
\hline \multicolumn{14}{|c|}{ 18-MW-9 Construction Information } \\
\hline Zone & $\begin{array}{l}\text { Screen } \\
\text { Top } \\
\text { Depth (ft) }\end{array}$ & $\begin{array}{c}\text { Screen } \\
\text { Bottom } \\
\text { Depth } \\
\text { (ft) }\end{array}$ & $\begin{array}{c}\text { Screen } \\
\text { Top } \\
\text { Elev (ft) }\end{array}$ & $\begin{array}{l}\text { Screen } \\
\text { Bottom } \\
\text { Elev (ft) }\end{array}$ & $\begin{array}{c}\text { Screen } \\
\text { Length } \\
\text { (ft) }\end{array}$ & $\begin{array}{c}\text { Pump } \\
\text { Intake } \\
\text { Depth } \\
\text { (ft) }\end{array}$ & $\begin{array}{c}\text { Pump } \\
\text { Intake } \\
\text { Elevation } \\
\text { (ft) }\end{array}$ & $\begin{array}{c}\text { Depth to } \\
\text { Top of } \\
\text { Sump (ft) }\end{array}$ & $\begin{array}{c}\text { Top of } \\
\text { Sump } \\
\text { Elevation } \\
\text { (ft) }\end{array}$ & $\begin{array}{l}\text { Depth to } \\
\text { Sump } \\
\text { Bottom (ft) }\end{array}$ & $\begin{array}{c}\text { Sump } \\
\text { Length } \\
\text { (ft) }\end{array}$ & $\begin{array}{c}\text { Sump } \\
\text { Volume } \\
\text { (L) }\end{array}$ & Comment \\
\hline 1 & 6.0 & 21.0 & 6726.9 & 6711.9 & 15.0 & & & 21.0 & 6711.9 & 21 & 0.0 & 0.0 & Alluvial groundwater \\
\hline
\end{tabular}

Note: Ground Elevation: $6732.91 \mathrm{ft}$; all depths are from this elevation
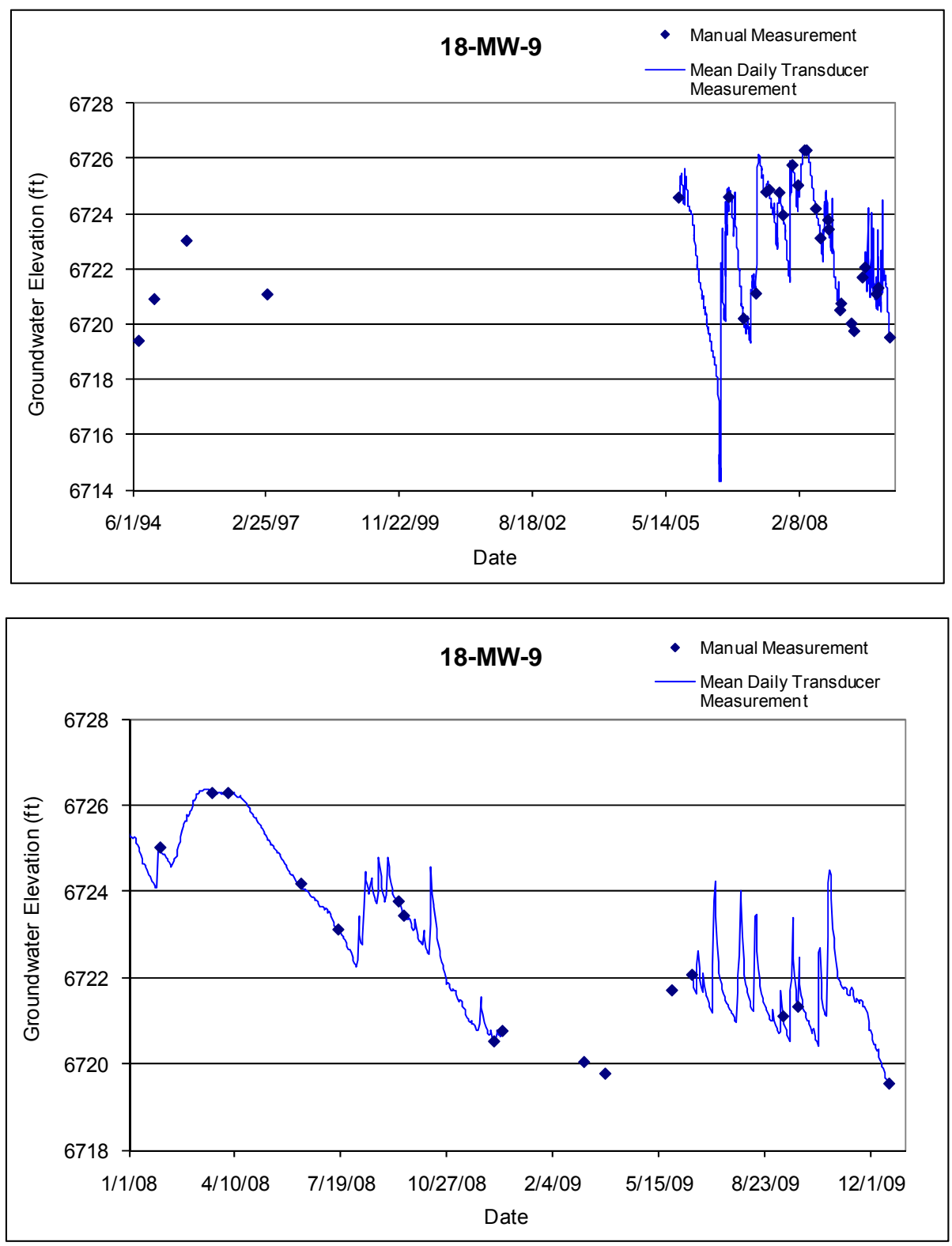


\section{$5.6 \quad 18-\mathrm{MW}-11$}

Location: Pajarito Canyon, approximately $200 \mathrm{ft}$ north of $18-\mathrm{MW}-9$ in the TA-18 parking lot. Period of Record: August 29, 2006, through December 18, 2009.

Remarks: None.

\begin{tabular}{|c|c|c|c|c|c|c|c|c|c|c|c|c|c|}
\hline \multicolumn{14}{|c|}{ 18-MW-11 Construction Information } \\
\hline Zone & \begin{tabular}{|c} 
Screen \\
Top \\
Depth (ft)
\end{tabular} & $\begin{array}{c}\text { Screen } \\
\text { Bottom } \\
\text { Depth } \\
\text { (ft) }\end{array}$ & $\begin{array}{c}\text { Screen } \\
\text { Top } \\
\text { Elev (ft) }\end{array}$ & $\begin{array}{l}\text { Screen } \\
\text { Bottom } \\
\text { Elev (ft) }\end{array}$ & $\begin{array}{c}\text { Screen } \\
\text { Length } \\
\text { (ft) }\end{array}$ & $\begin{array}{c}\text { Pump } \\
\text { Intake } \\
\text { Depth } \\
\text { (ft) }\end{array}$ & $\begin{array}{c}\text { Pump } \\
\text { Intake } \\
\text { Elevation } \\
\text { (ft) }\end{array}$ & $\begin{array}{c}\text { Depth to } \\
\text { Top of } \\
\text { Sump (ft) }\end{array}$ & $\begin{array}{c}\text { Top of } \\
\text { Sump } \\
\text { Elevation } \\
\text { (ft) }\end{array}$ & \begin{tabular}{|} 
Depth to \\
Sump \\
Bottom (ft)
\end{tabular} & $\begin{array}{c}\text { Sump } \\
\text { Length } \\
\text { (ft) }\end{array}$ & $\begin{array}{c}\text { Sump } \\
\text { Volume } \\
\text { (L) }\end{array}$ & Comment \\
\hline 1 & 27.0 & 47.0 & 6713.1 & 6693.1 & 20.0 & & & 47.0 & 6693.1 & $\overline{0}$ & 0.0 & 0.0 & Alluvial Groundwater \\
\hline
\end{tabular}

Note: Ground Elevation: $6740.13 \mathrm{ft}$; all measurements are from this elevation
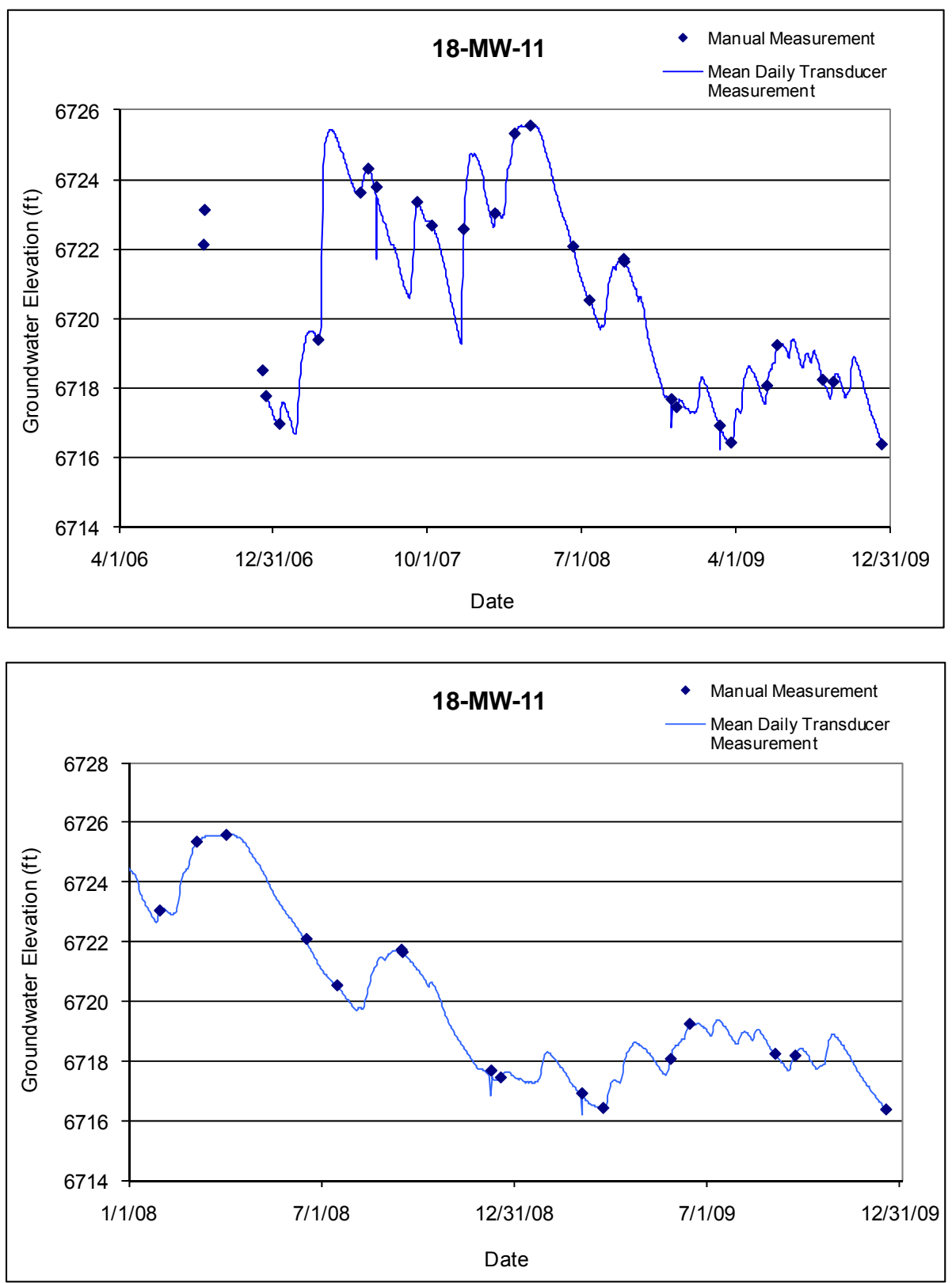


\subsection{8-MW-17}

Location: Pajarito Canyon, east of TA-18, approximately $50 \mathrm{ft}$ west of R-20.

Period of Record: August 1, 1995, through September 30, 2007.

Remarks: The pressure transducer in this well was removed September 30, 2007. Due to the 2-in.diameter inner casing, the transducer did not fit below the bladder pump, and was therefore installed immediately above the pump. The water was below the transducer sensor when water levels fell below $6678.4 \mathrm{ft}$.

\begin{tabular}{|c|c|c|c|c|c|c|c|c|c|c|c|c|c|}
\hline \multicolumn{14}{|c|}{ 18-MW-17 Construction Information } \\
\hline Zone & $\begin{array}{c}\text { Screen } \\
\text { Top } \\
\text { Depth (ft) }\end{array}$ & $\begin{array}{c}\text { Screen } \\
\text { Bottom } \\
\text { Depth } \\
\text { (ft) }\end{array}$ & $\begin{array}{c}\text { Screen } \\
\text { Top } \\
\text { Elev }(\mathrm{ft})\end{array}$ & $\begin{array}{l}\text { Screen } \\
\text { Bottom } \\
\text { Elev (ft) }\end{array}$ & $\begin{array}{c}\text { Screen } \\
\text { Length } \\
\text { (ft) }\end{array}$ & $\begin{array}{c}\text { Pump } \\
\text { Intake } \\
\text { Depth } \\
\text { (ft) }\end{array}$ & $\begin{array}{c}\text { Pump } \\
\text { Intake } \\
\text { Elevation } \\
\text { (ft) }\end{array}$ & $\begin{array}{l}\text { Depth to } \\
\text { Top of } \\
\text { Sump (ft) }\end{array}$ & $\begin{array}{c}\text { Top of } \\
\text { Sump } \\
\text { Elevation } \\
\text { (ft) }\end{array}$ & \begin{tabular}{|c|} 
Depth to \\
Sump \\
Bottom (ft)
\end{tabular} & $\begin{array}{c}\text { Sump } \\
\text { Length } \\
\text { (ft) }\end{array}$ & $\begin{array}{c}\text { Sump } \\
\text { Volume } \\
\text { (L) }\end{array}$ & Comment \\
\hline 1 & 12.0 & 22.0 & 6683.2 & 6673.2 & 10.0 & & & 22.0 & 6673.2 & 22.0 & 0.0 & 0.0 & Alluvial groundwater \\
\hline
\end{tabular}
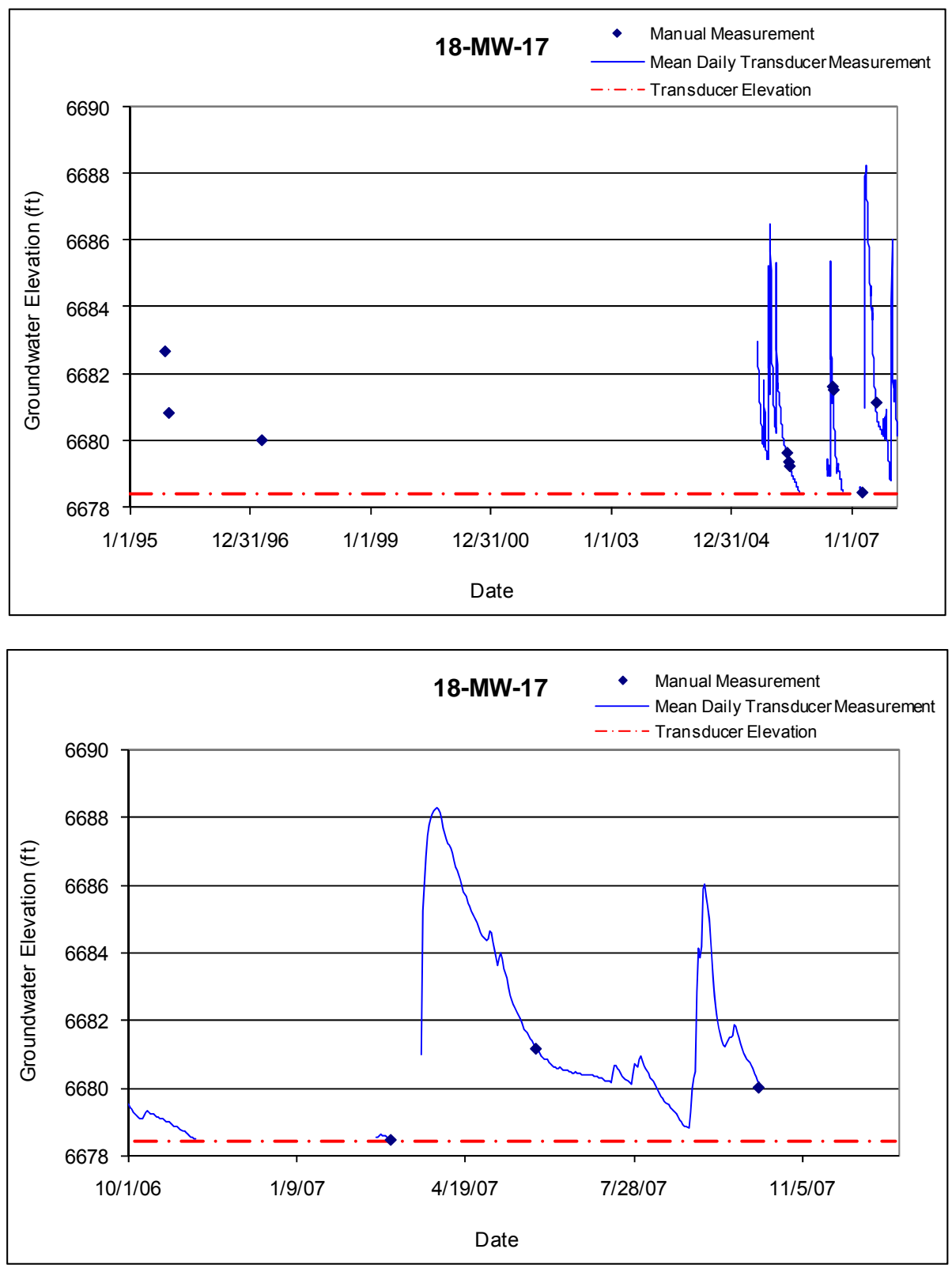


\section{$5.8 \quad 18-\mathrm{MW}-18$}

Location: Alluvial well 18-MW-18 is located in Pajarito Canyon, $1000 \mathrm{ft}$ east of 18-MW-17. Period of Record: July 31, 1995, through December 18, 2009.

Remarks: None.

\begin{tabular}{|c|c|c|c|c|c|c|c|c|c|c|c|c|c|}
\hline \multicolumn{14}{|c|}{ 18-MW-18 Construction Information } \\
\hline Zone & $\begin{array}{c}\text { Screen } \\
\text { Top } \\
\text { Depth (ft) }\end{array}$ & $\begin{array}{c}\text { Screen } \\
\text { Bottom } \\
\text { Depth } \\
\text { (ft) }\end{array}$ & $\begin{array}{c}\text { Screen } \\
\text { Top } \\
\text { Elev (ft) }\end{array}$ & $\begin{array}{l}\text { Screen } \\
\text { Bottom } \\
\text { Elev (ft) }\end{array}$ & $\begin{array}{c}\text { Screen } \\
\text { Length } \\
\text { (ft) }\end{array}$ & $\begin{array}{c}\text { Pump } \\
\text { Intake } \\
\text { Depth } \\
\text { (ft) }\end{array}$ & $\begin{array}{c}\text { Pump } \\
\text { Intake } \\
\text { Elevation } \\
\text { (ft) }\end{array}$ & \begin{tabular}{|} 
Depth to \\
Top of \\
Sump (ft)
\end{tabular} & $\begin{array}{c}\text { Top of } \\
\text { Sump } \\
\text { Elevation } \\
\text { (ft) }\end{array}$ & \begin{tabular}{|c|} 
Depth to \\
Sump \\
Bottom (ft)
\end{tabular} & $\begin{array}{c}\text { Sump } \\
\text { Length } \\
\text { (ft) }\end{array}$ & $\begin{array}{c}\text { Sump } \\
\text { Volume } \\
\text { (L) }\end{array}$ & Comment \\
\hline 1 & 12.5 & 23 & 6642.2 & 6631.7 & 10.5 & & & 23 & 6631.7 & 23 & 0 & 0 & Alluvial groundwater \\
\hline
\end{tabular}

Note: Ground Elevation: $6654.7 \mathrm{ft}$; all depths are from this elevation
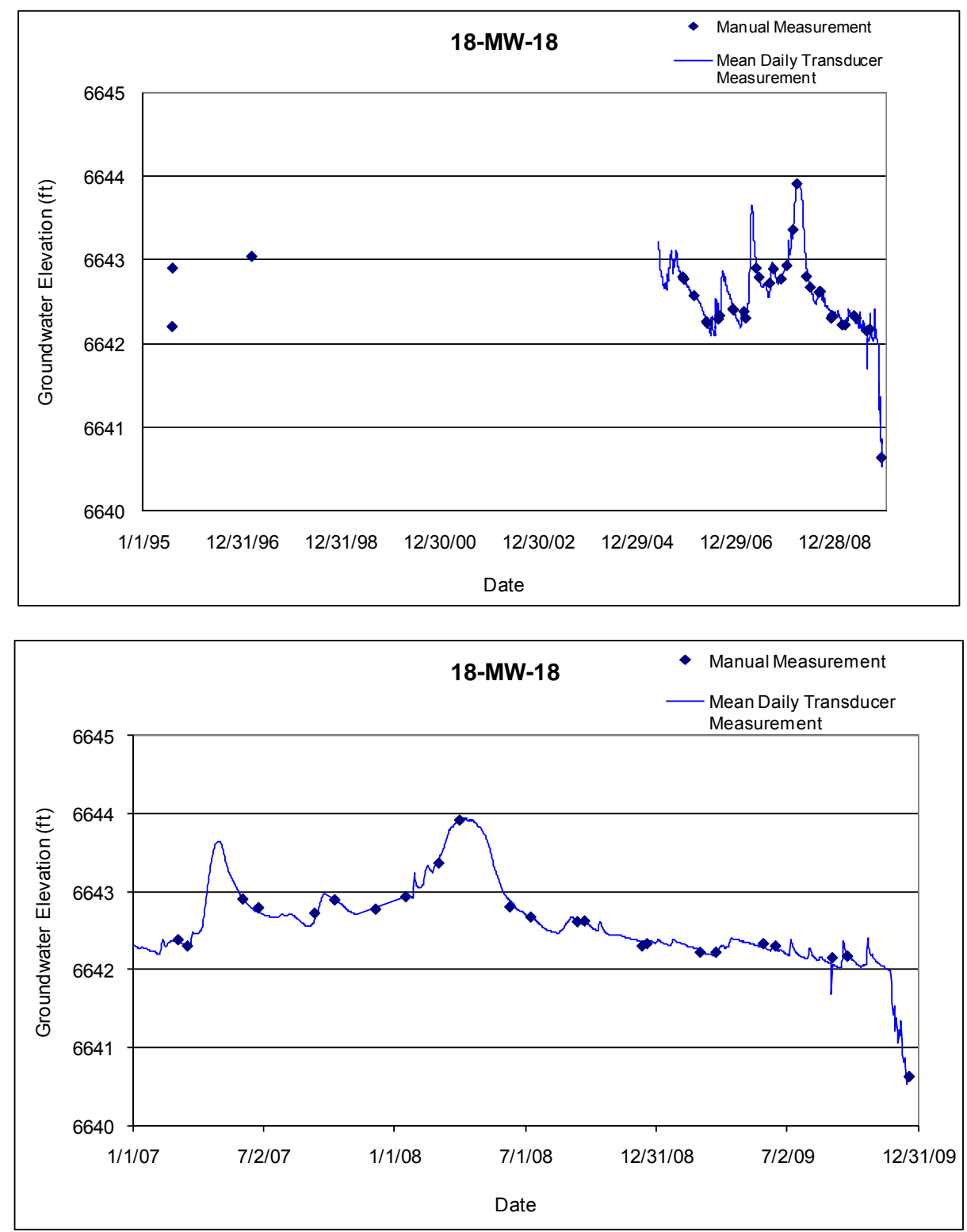


\subsection{MAO-2}

Location: In lower Three-Mile Canyon in TA-18, just above the confluence with Pajarito Canyon, on the south bank of the stream; located roughly half way between 18-BG-4 and 18-MW-18.

Period of Record: June 4, 2008, through December 17, 2009.

Remarks: None.

\begin{tabular}{|c|c|c|c|c|c|c|c|c|c|c|c|c|c|}
\hline \multicolumn{14}{|c|}{ 3MAO-2 Construction Information } \\
\hline Zone & $\begin{array}{c}\text { Screen } \\
\text { Top } \\
\text { Depth (ft) }\end{array}$ & $\begin{array}{c}\text { Screen } \\
\text { Bottom } \\
\text { Depth (ft) }\end{array}$ & \begin{tabular}{|} 
Screen \\
Top \\
Elevation \\
(ft)
\end{tabular} & $\begin{array}{c}\text { Screen } \\
\text { Bottom } \\
\text { Elevation } \\
\text { (ft) }\end{array}$ & $\begin{array}{c}\text { Screen } \\
\text { Length } \\
\text { (ft) }\end{array}$ & $\begin{array}{c}\text { Pump } \\
\text { Intake } \\
\text { Depth } \\
\text { (ft) }\end{array}$ & $\begin{array}{c}\text { Pump } \\
\text { Intake } \\
\text { Elevation } \\
\text { (ft) }\end{array}$ & $\begin{array}{l}\text { Depth to } \\
\text { Top of } \\
\text { Sump } \\
\text { (ft) }\end{array}$ & $\begin{array}{c}\text { Top of } \\
\text { Sump } \\
\text { Elevation } \\
\text { (ft) }\end{array}$ & \begin{tabular}{|} 
Depth to \\
Sump \\
Bottom \\
(ft)
\end{tabular} & $\begin{array}{c}\text { Sump } \\
\text { Length } \\
\text { (ft) }\end{array}$ & $\begin{array}{c}\text { Sump } \\
\text { Volume } \\
\text { (L) }\end{array}$ & Comment \\
\hline 1 & 14.7 & 24.7 & 6744.7 & 6734.7 & 10.0 & & & 24.7 & 6734.7 & 30.0 & 5.3 & 13.1 & Alluvial groundwater \\
\hline
\end{tabular}

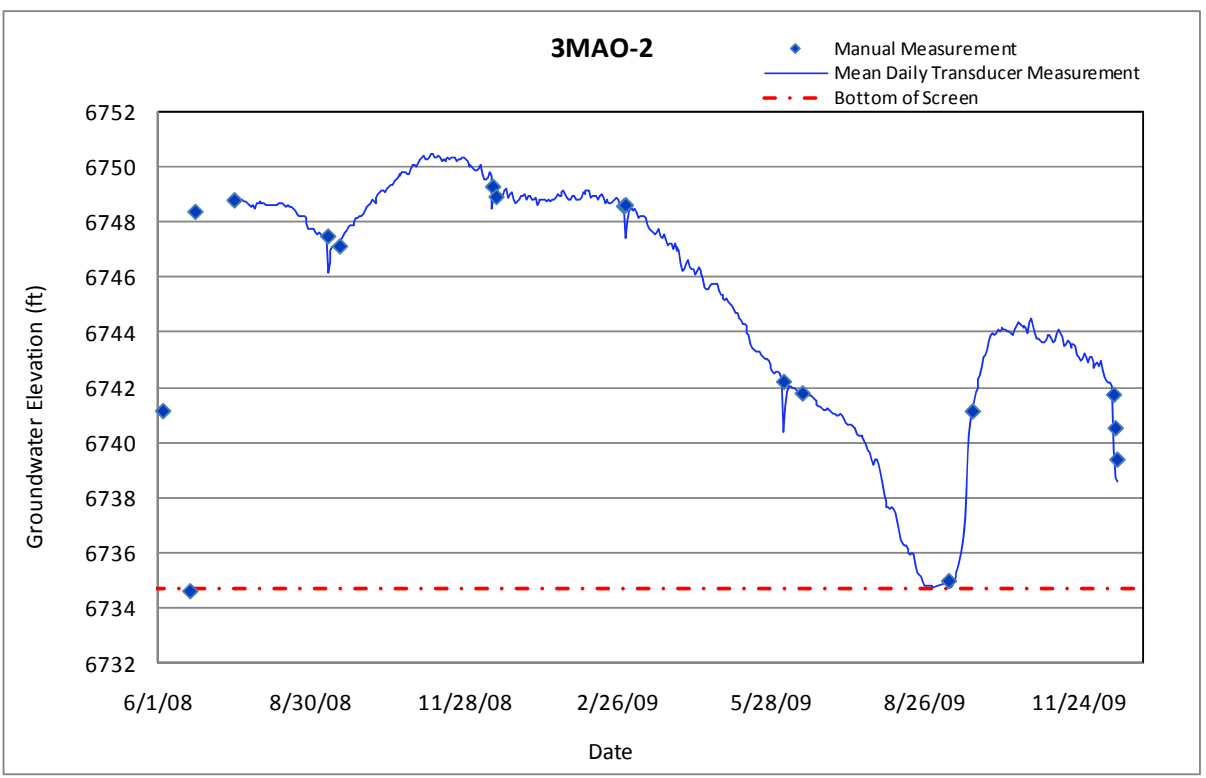




\subsection{9-UM-3}

Location: Ancho Canyon, TA-39, approximately $2100 \mathrm{ft}$ north of regional well R-31.

Period of Record: March 9, 2006, through July 2, 2009.

Remarks: Well has historically been dry during quarterly manual measurements. There is no transducer installed in this well. Monitoring was discontinued in August 2009.

\begin{tabular}{|c|c|c|c|c|c|c|c|c|c|c|c|c|c|}
\hline \multicolumn{14}{|c|}{ 39-UM-3 Construction Information } \\
\hline Zone & \begin{tabular}{|c} 
Screen \\
Top \\
Depth (ft)
\end{tabular} & $\begin{array}{c}\text { Screen } \\
\text { Bottom } \\
\text { Depth (ft) }\end{array}$ & $\begin{array}{c}\text { Screen } \\
\text { Top Elev } \\
\text { (ft) }\end{array}$ & $\begin{array}{l}\text { Screen } \\
\text { Bottom } \\
\text { Elev (ft) }\end{array}$ & $\begin{array}{l}\text { Screen } \\
\text { Length } \\
\text { (ft) }\end{array}$ & $\begin{array}{c}\text { Pump } \\
\text { Intake } \\
\text { Depth (ft) }\end{array}$ & $\begin{array}{c}\text { Pump } \\
\text { Intake } \\
\text { Elevation } \\
\text { (ft) }\end{array}$ & $\mid \begin{array}{c}\text { Depth to } \\
\text { Top of } \\
\text { Sump (ft) }\end{array}$ & $\begin{array}{c}\text { Top of } \\
\text { Sump } \\
\text { Elevation } \\
\text { (ft) }\end{array}$ & $\begin{array}{l}\text { Depth to } \\
\text { Sump } \\
\text { Bottom } \\
\text { (ft) }\end{array}$ & $\begin{array}{l}\text { Sump } \\
\text { Length } \\
\text { (ft) }\end{array}$ & $\begin{array}{c}\text { Sump } \\
\text { Volume } \\
\text { (L) }\end{array}$ & Comment \\
\hline 1 & 44.0 & 54.0 & 6350.2 & 6340.2 & 10.0 & & & 54.0 & 6340.2 & 54.0 & 0.0 & 0.0 & Alluvial groundwater \\
\hline
\end{tabular}

Note: Ground elevation is $6394.20 \mathrm{ft}$; all depths are from this elevation

\begin{tabular}{|c|c|}
\hline \multicolumn{2}{|c|}{ 39-UM-3 Manual Water Levels } \\
\hline Date & Comments \\
\hline $3 / 9 / 2006$ & Dry \\
\hline $6 / 13 / 2006$ & Dry \\
\hline $9 / 7 / 2006$ & Dry \\
\hline $11 / 30 / 2006$ & Dry \\
\hline $12 / 12 / 2006$ & Dry \\
\hline $3 / 15 / 2007$ & Dry \\
\hline $5 / 10 / 2007$ & Dry \\
\hline $6 / 6 / 2007$ & Dry \\
\hline $9 / 5 / 2007$ & Dry \\
\hline $11 / 1 / 2007$ & Dry \\
\hline $1 / 16 / 2008$ & Dry \\
\hline $4 / 7 / 2008$ & Dry \\
\hline $7 / 26 / 2008$ & Dry \\
\hline $10 / 15 / 2008$ & Dry \\
\hline $3 / 31 / 2009$ & Dry \\
\hline $7 / 2 / 2009$ & Dry \\
\hline
\end{tabular}




\section{$5.1139-D M-6$}

Location: Ancho Canyon, TA-39, approximately $1600 \mathrm{ft}$ north of regional well R-31.

Period of Record: March 9, 2006, through July 2, 2009.

Remarks: Well has historically been dry during quarterly manual measurements. There is no transducer installed in this well. Monitoring was discontinued In August 2009.

\begin{tabular}{|c|c|c|c|c|c|c|c|c|c|c|c|c|c|}
\hline \multicolumn{14}{|c|}{ 39-DM-6 Construction Information } \\
\hline Zone & $\begin{array}{c}\text { Screen } \\
\text { Top } \\
\text { Depth }(\mathrm{ft})\end{array}$ & $\begin{array}{c}\text { Screen } \\
\text { Bottom } \\
\text { Depth (ft) }\end{array}$ & $\begin{array}{c}\text { Screen } \\
\text { Top Elev } \\
\text { (ft) }\end{array}$ & $\begin{array}{l}\text { Screen } \\
\text { Bottom } \\
\text { Elev (ft) }\end{array}$ & $\begin{array}{l}\text { Screen } \\
\text { Length } \\
\text { (ft) }\end{array}$ & $\begin{array}{l}\text { Pump } \\
\text { Intake } \\
\text { Depth } \\
\text { (ft) }\end{array}$ & \begin{tabular}{|c} 
Pump \\
Intake \\
Elevation \\
(ft)
\end{tabular} & $\begin{array}{c}\text { Depth to } \\
\text { Top of } \\
\text { Sump (ft) }\end{array}$ & \begin{tabular}{|c|} 
Top of \\
Sump \\
Elevation \\
(ft)
\end{tabular} & $\begin{array}{l}\text { Depth to } \\
\text { Sump } \\
\text { Bottom } \\
\text { (ft) }\end{array}$ & $\begin{array}{l}\text { Sump } \\
\text { Length } \\
\text { (ft) }\end{array}$ & $\begin{array}{c}\text { Sump } \\
\text { Volume } \\
\text { (L) }\end{array}$ & Comment \\
\hline 1 & 50.0 & 60.0 & 6334.6 & 6324.6 & 10.0 & & & 60.0 & 6324.6 & 60.0 & 0.0 & 0.0 & Alluvial groundwater \\
\hline
\end{tabular}

\begin{tabular}{|c|c|}
\hline \multicolumn{2}{|c|}{ 39-DM-6 Manual Water Levels } \\
\hline Date & Comment \\
\hline $3 / 9 / 2006$ & Dry \\
\hline $6 / 13 / 2006$ & Dry \\
\hline $9 / 7 / 2006$ & Dry \\
\hline $11 / 30 / 2006$ & Dry \\
\hline $12 / 12 / 2006$ & Dry \\
\hline $3 / 15 / 2007$ & Dry \\
\hline $5 / 10 / 2007$ & Dry \\
\hline $6 / 6 / 2007$ & Dry \\
\hline $9 / 5 / 2007$ & Dry \\
\hline $11 / 1 / 2007$ & Dry \\
\hline $1 / 16 / 2008$ & Dry \\
\hline $4 / 7 / 2008$ & Dry \\
\hline $7 / 26 / 2008$ & Dry \\
\hline $10 / 15 / 2008$ & Dry \\
\hline $3 / 31 / 2009$ & Dry \\
\hline $7 / 2 / 2009$ & Dry \\
\hline
\end{tabular}




\subsection{APCO-1}

Location: In lower Pueblo Canyon, approximately 0.1 miles north of POI-4 and R-3i.

Period of Record: August 17, 1990, through January 12, 2010.

Remarks: A pressure transducer was installed in APCO-1 from February 17, 1993, through June 17, 1993; from January 11, 1994, through November 9, 1994; and from May 9, 2005, through present.

\begin{tabular}{|c|c|c|c|c|c|c|c|c|c|c|c|c|c|}
\hline \multicolumn{14}{|c|}{ APCO-1 Construction Information } \\
\hline Zone & $\begin{array}{c}\text { Screen } \\
\text { Top } \\
\text { Depth (ft) }\end{array}$ & $\begin{array}{c}\text { Screen } \\
\text { Bottom } \\
\text { Depth } \\
\text { (ft) }\end{array}$ & $\begin{array}{c}\text { Screen } \\
\text { Top } \\
\text { Elev (ft) }\end{array}$ & $\begin{array}{l}\text { Screen } \\
\text { Bottom } \\
\text { Elev (ft) }\end{array}$ & $\begin{array}{c}\text { Screen } \\
\text { Length } \\
\text { (ft) }\end{array}$ & $\begin{array}{c}\text { Pump } \\
\text { Intake } \\
\text { Depth } \\
\text { (ft) }\end{array}$ & $\begin{array}{c}\text { Pump } \\
\text { Intake } \\
\text { Elevation } \\
\text { (ft) }\end{array}$ & $\begin{array}{l}\text { Depth to } \\
\text { Top of } \\
\text { Sump (ft) }\end{array}$ & $\begin{array}{c}\text { Top of } \\
\text { Sump } \\
\text { Elevation } \\
\text { (ft) }\end{array}$ & \begin{tabular}{|l} 
Depth to \\
Sump \\
Bottom (ft)
\end{tabular} & $\begin{array}{c}\text { Sump } \\
\text { Length } \\
\text { (ft) }\end{array}$ & $\begin{array}{c}\text { Sump } \\
\text { Volume } \\
\text { (L) }\end{array}$ & Comment \\
\hline 1 & 4.7 & 14.7 & 6362.83 & 6352.83 & 10.0 & & & 14.7 & 6352.83 & 19.7 & 5.0 & 3.1 & Alluvial groundwater \\
\hline
\end{tabular}

Note: Ground Elevation: $6367.53 \mathrm{ft}$; all depths are from this elevation
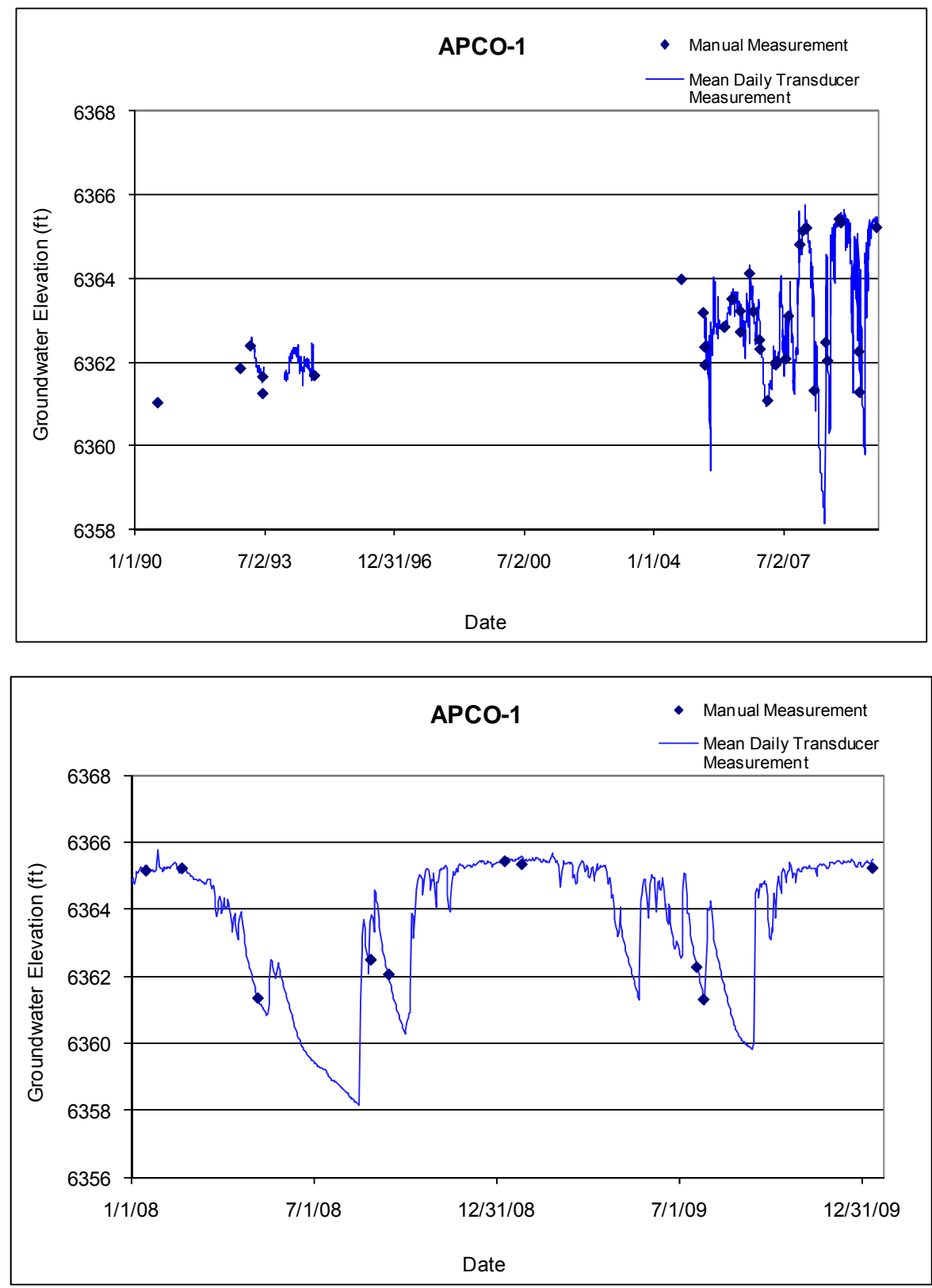


\subsection{CDBO-1}

Location: Alluvial well CDBO-1 is located in Cañada del Buey, approximately $1320 \mathrm{ft}$ north of regional well R-20.

Period of Record: March 8, 2006, through August 25, 2009.

Remarks: Well has historically been dry during quarterly measurements. There is no transducer installed in this well.

\begin{tabular}{|c|c|c|c|c|c|c|c|c|c|c|c|c|c|}
\hline \multicolumn{14}{|c|}{ CDBO-1 Construction Information } \\
\hline Zone & \begin{tabular}{|c|} 
Screen \\
Top \\
Depth (ft)
\end{tabular} & $\begin{array}{c}\text { Screen } \\
\text { Bottom } \\
\text { Depth (ft) }\end{array}$ & $\begin{array}{c}\text { Screen } \\
\text { Top Elev } \\
\text { (ft) }\end{array}$ & $\begin{array}{l}\text { Screen } \\
\text { Bottom } \\
\text { Elev (ft) }\end{array}$ & $\begin{array}{l}\text { Screen } \\
\text { Length } \\
\text { (ft) }\end{array}$ & $\begin{array}{c}\text { Pump } \\
\text { Intake } \\
\text { Depth (ft) }\end{array}$ & \begin{tabular}{|c|} 
Pump \\
Intake \\
Elevation \\
(ft)
\end{tabular} & $\begin{array}{c}\text { Depth to } \\
\text { Top of } \\
\text { Sump (ft) }\end{array}$ & \begin{tabular}{|c|} 
Top of \\
Sump \\
Elevation \\
(ft)
\end{tabular} & $\begin{array}{l}\text { Depth to } \\
\text { Sump } \\
\text { Bottom } \\
\text { (ft) }\end{array}$ & $\begin{array}{l}\text { Sump } \\
\text { Length } \\
\text { (ft) }\end{array}$ & $\begin{array}{l}\text { Sump } \\
\text { Volume } \\
\text { (L) }\end{array}$ & Comment \\
\hline 1 & 5.1 & 13.1 & 6752.5 & 6744.5 & 8.0 & & & 13.1 & 6744.5 & 13.0 & 0.1 & 0.2 & Alluvial groundwater \\
\hline
\end{tabular}

\begin{tabular}{|c|c|}
\hline \multicolumn{2}{|c|}{ CDBO-1 Manual Water Levels } \\
\hline Date & Comments \\
\hline $3 / 8 / 2006$ & Dry \\
\hline $6 / 26 / 2006$ & Dry \\
\hline $9 / 6 / 2006$ & Dry \\
\hline $9 / 27 / 2006$ & Dry \\
\hline $12 / 8 / 2006$ & Dry \\
\hline $2 / 22 / 2007$ & Dry \\
\hline $3 / 19 / 2007$ & Dry \\
\hline $6 / 5 / 2007$ & Dry \\
\hline $6 / 11 / 2007$ & Dry \\
\hline $9 / 10 / 2007$ & Dry \\
\hline $1 / 24 / 2008$ & Dry \\
\hline $2 / 11 / 2008$ & Dry \\
\hline $4 / 1 / 2008$ & Dry \\
\hline $5 / 22 / 2008$ & Dry \\
\hline $7 / 24 / 2008$ & Dry \\
\hline $8 / 11 / 2008$ & Dry \\
\hline $11 / 3 / 2008$ & Dry \\
\hline $2 / 3 / 2009$ & Dry \\
\hline $4 / 27 / 2009$ & Dry \\
\hline $8 / 25 / 2009$ & Dry \\
\hline
\end{tabular}




\subsection{CDBO-2}

Location: Alluvial well CDBO-2 is located in Cañada del Buey, approximately $260 \mathrm{ft}$ northeast of CDBO-1.

Period of Record: March 8, 2006, through August 25, 2009.

Remarks: Well has historically been dry during quarterly measurements. There is no transducer installed in this well.

\begin{tabular}{|c|c|c|c|c|c|c|c|c|c|c|c|c|c|}
\hline \multicolumn{14}{|c|}{ CDBO-2 Construction Information } \\
\hline Zone & \begin{tabular}{|c|} 
Screen \\
Top \\
Depth (ft)
\end{tabular} & $\begin{array}{c}\text { Screen } \\
\text { Bottom } \\
\text { Depth (ft) }\end{array}$ & $\begin{array}{c}\text { Screen } \\
\text { Top Elev } \\
\text { (ft) }\end{array}$ & $\begin{array}{l}\text { Screen } \\
\text { Bottom } \\
\text { Elev (ft) }\end{array}$ & $\begin{array}{c}\text { Screen } \\
\text { Length } \\
\text { (ft) }\end{array}$ & $\begin{array}{c}\text { Pump } \\
\text { Intake } \\
\text { Depth (ft) }\end{array}$ & $\begin{array}{c}\text { Pump } \\
\text { Intake } \\
\text { Elevation } \\
\text { (ft) }\end{array}$ & $\begin{array}{l}\text { Depth to } \\
\text { Top of } \\
\text { Sump (ft) }\end{array}$ & \begin{tabular}{|c} 
Top of \\
Sump \\
Elevation \\
(ft)
\end{tabular} & $\begin{array}{l}\text { Depth to } \\
\text { Sump } \\
\text { Bottom } \\
\text { (ft) }\end{array}$ & $\begin{array}{l}\text { Sump } \\
\text { Length } \\
\text { (ft) }\end{array}$ & $\begin{array}{c}\text { Sump } \\
\text { Volume } \\
\text { (L) }\end{array}$ & Comment \\
\hline 1 & 5.9 & 17.9 & 6742.3 & 6730.3 & 12.0 & & & 17.9 & 6730.3 & 18.0 & 0.1 & 0.2 & Alluvial groundwater \\
\hline
\end{tabular}

\begin{tabular}{|c|c|}
\hline \multicolumn{2}{|c|}{ CDBO-2 Manual Water Levels } \\
\hline Date Time & Comments \\
\hline $3 / 8 / 2006$ & Dry \\
\hline $6 / 26 / 2006$ & Dry \\
\hline $9 / 6 / 2006$ & Dry \\
\hline $9 / 27 / 2006$ & Dry \\
\hline $12 / 8 / 2006$ & Dry \\
\hline $2 / 22 / 2007$ & Dry \\
\hline $3 / 19 / 2007$ & Dry \\
\hline $6 / 5 / 2007$ & Dry \\
\hline $6 / 11 / 2007$ & Dry \\
\hline $9 / 10 / 2007$ & Dry \\
\hline $1 / 24 / 2008$ & Dry \\
\hline $2 / 11 / 2008$ & Dry \\
\hline $4 / 1 / 2008$ & Dry \\
\hline $5 / 22 / 2008$ & Dry \\
\hline $7 / 24 / 2008$ & Dry \\
\hline $8 / 11 / 2008$ & Dry \\
\hline $11 / 3 / 2008$ & Dry \\
\hline $2 / 3 / 2009$ & Dry \\
\hline $4 / 27 / 2009$ & Dry \\
\hline $8 / 25 / 2009$ & Dry \\
\hline
\end{tabular}




\subsection{CDBO-3}

Location: Alluvial well CDBO-3 is located in Cañada del Buey, approximately $630 \mathrm{ft}$ northwest of regional well R-21.

Period of Record: December 6, 2005, through August 25, 2009.

Remarks: Well has historically been dry during quarterly measurements. There is no transducer installed in this well.

\begin{tabular}{|c|c|c|c|c|c|c|c|c|c|c|c|c|c|}
\hline \multicolumn{14}{|c|}{ CDBO-3 Construction Information } \\
\hline Zone & $\begin{array}{c}\text { Screen } \\
\text { Top } \\
\text { Depth (ft) }\end{array}$ & $\begin{array}{c}\text { Screen } \\
\text { Bottom } \\
\text { Depth (ft) }\end{array}$ & $\begin{array}{c}\text { Screen } \\
\text { Top Elev } \\
\text { (ft) }\end{array}$ & $\begin{array}{l}\text { Screen } \\
\text { Bottom } \\
\text { Elev (ft) }\end{array}$ & $\begin{array}{c}\text { Screen } \\
\text { Length } \\
\text { (ft) }\end{array}$ & $\begin{array}{c}\text { Pump } \\
\text { Intake } \\
\text { Depth (ft) }\end{array}$ & $\begin{array}{c}\text { Pump } \\
\text { Intake } \\
\text { Elevation } \\
\text { (ft) }\end{array}$ & $\begin{array}{c}\text { Depth to } \\
\text { Top of } \\
\text { Sump (ft) }\end{array}$ & $\begin{array}{c}\text { Top of } \\
\text { Sump } \\
\text { Elevation } \\
\text { (ft) }\end{array}$ & $\begin{array}{c}\text { Depth to } \\
\text { Sump } \\
\text { Bottom } \\
\text { (ft) }\end{array}$ & $\begin{array}{c}\text { Sump } \\
\text { Length } \\
\text { (ft) }\end{array}$ & $\begin{array}{c}\text { Sump } \\
\text { Volume } \\
\text { (L) }\end{array}$ & Comment \\
\hline 1 & 4.4 & 12.4 & 6665.8 & 6657.8 & 8.0 & & & 12.4 & 6657.8 & 12.0 & 0.0 & 0.0 & Alluvial groundwater \\
\hline
\end{tabular}

\begin{tabular}{|c|c|}
\hline \multicolumn{2}{|c|}{ CDBO-3 Manual Water Levels } \\
\hline Date & Comments \\
\hline $12 / 6 / 2005$ & Dry \\
\hline $3 / 8 / 2006$ & Dry \\
\hline $6 / 26 / 2006$ & Dry \\
\hline $9 / 6 / 2006$ & Dry \\
\hline $9 / 27 / 2006$ & Dry \\
\hline $12 / 8 / 2006$ & Dry \\
\hline $2 / 22 / 2007$ & Dry \\
\hline $3 / 19 / 2007$ & Dry \\
\hline $6 / 5 / 2007$ & Dry \\
\hline $6 / 11 / 2007$ & Dry \\
\hline $9 / 10 / 2007$ & Dry \\
\hline $1 / 24 / 2008$ & Dry \\
\hline $2 / 11 / 2008$ & Dry \\
\hline $4 / 1 / 2008$ & Dry \\
\hline $5 / 22 / 2008$ & Dry \\
\hline $7 / 24 / 2008$ & Dry \\
\hline $8 / 11 / 2008$ & Dry \\
\hline $11 / 3 / 2008$ & Dry \\
\hline $2 / 3 / 2009$ & Dry \\
\hline $4 / 27 / 2009$ & Dry \\
\hline $8 / 25 / 2009$ & Dry \\
\hline
\end{tabular}




\subsection{CDBO-4}

Location: Alluvial well CDBO-4 is located in Cañada del Buey, approximately $1600 \mathrm{ft}$ north of regional well R-22.

Period of Record: December 7, 2005, through December 14, 2009.

Remarks: Well has historically been dry during quarterly measurements. A transducer was installed in this well January 9, 2009, and has not yet recorded any water in the well.

\begin{tabular}{|c|c|c|c|c|c|c|c|c|c|c|c|c|c|}
\hline \multicolumn{14}{|c|}{ CDBO-4 Construction Information } \\
\hline Zone & $\begin{array}{c}\text { Screen } \\
\text { Top } \\
\text { Depth (ft) }\end{array}$ & $\begin{array}{c}\text { Screen } \\
\text { Bottom } \\
\text { Depth (ft) }\end{array}$ & $\begin{array}{c}\text { Screen } \\
\text { Top Elev } \\
\text { (ft) }\end{array}$ & $\begin{array}{l}\text { Screen } \\
\text { Bottom } \\
\text { Elev (ft) }\end{array}$ & $\begin{array}{l}\text { Screen } \\
\text { Length } \\
\text { (ft) }\end{array}$ & $\begin{array}{c}\text { Pump } \\
\text { Intake } \\
\text { Depth (ft) }\end{array}$ & $\begin{array}{c}\text { Pump } \\
\text { Intake } \\
\text { Elevation } \\
\text { (ft) }\end{array}$ & $\begin{array}{c}\text { Depth to } \\
\text { Top of } \\
\text { Sump (ft) }\end{array}$ & $\begin{array}{c}\text { Top of } \\
\text { Sump } \\
\text { Elevation } \\
\text { (ft) }\end{array}$ & $\begin{array}{c}\text { Depth to } \\
\text { Sump } \\
\text { Bottom } \\
\text { (ft) }\end{array}$ & $\begin{array}{c}\text { Sump } \\
\text { Length } \\
\text { (ft) }\end{array}$ & $\begin{array}{c}\text { Sump } \\
\text { Volume } \\
\text { (L) }\end{array}$ & Comment \\
\hline 1 & 4.1 & 12.1 & 6560.4 & 6552.4 & 8.0 & & & 12.1 & 6552.4 & 12.0 & 0.0 & 0.0 & Alluvial groundwater \\
\hline
\end{tabular}

\begin{tabular}{|c|c|}
\hline \multicolumn{2}{|c|}{ CDBO-4 Manual Water Levels } \\
\hline Date & Comments \\
\hline $12 / 7 / 2005$ & Dry \\
\hline $3 / 8 / 2006$ & Dry \\
\hline $6 / 26 / 2006$ & Dry \\
\hline $9 / 6 / 2006$ & Dry \\
\hline $10 / 2 / 2006$ & Dry \\
\hline $12 / 8 / 2006$ & Dry \\
\hline $2 / 22 / 2007$ & Dry \\
\hline $3 / 19 / 2007$ & Dry \\
\hline $6 / 5 / 2007$ & Dry \\
\hline $6 / 11 / 2007$ & Dry \\
\hline $9 / 10 / 2007$ & Dry \\
\hline $1 / 24 / 2008$ & Dry \\
\hline $2 / 11 / 2008$ & Dry \\
\hline $4 / 1 / 2008$ & Dry \\
\hline $5 / 22 / 2008$ & Dry \\
\hline $7 / 24 / 2008$ & Dry \\
\hline $8 / 11 / 2008$ & Dry \\
\hline $11 / 3 / 2008$ & Dry \\
\hline $1 / 9 / 2009$ & Dry \\
\hline $2 / 3 / 2009$ & Dry \\
\hline $4 / 27 / 2009$ & Dry \\
\hline $7 / 14 / 2009$ & Dry \\
\hline $8 / 4 / 2009$ & Dry \\
\hline $12 / 14 / 2009$ & Dry \\
\hline & \\
\hline
\end{tabular}




\subsection{CDBO-5}

Location: Alluvial well CDBO- 5 is located in Cañada del Buey, approximately 0.5 miles westnorthwest of CDBO-6.

Period of Record: December 7, 2005, through December 14, 2009.

Remarks: Well has historically been dry during quarterly measurements. A transducer was installed in this well January 12, 2009, and has not yet recorded any water in the well.

\begin{tabular}{|c|c|c|c|c|c|c|c|c|c|c|c|c|c|}
\hline \multicolumn{14}{|c|}{ CDBO-5 Construction Information } \\
\hline Zone & $\begin{array}{c}\text { Screen } \\
\text { Top } \\
\text { Depth (ft) }\end{array}$ & $\begin{array}{c}\text { Screen } \\
\text { Bottom } \\
\text { Depth (ft) }\end{array}$ & $\begin{array}{c}\text { Screen } \\
\text { Top Elev } \\
\text { (ft) }\end{array}$ & $\begin{array}{l}\text { Screen } \\
\text { Bottom } \\
\text { Elev (ft) }\end{array}$ & $\begin{array}{c}\text { Screen } \\
\text { Length } \\
\text { (ft) }\end{array}$ & $\begin{array}{c}\text { Pump } \\
\text { Intake } \\
\text { Depth (ft) }\end{array}$ & $\begin{array}{c}\text { Pump } \\
\text { Intake } \\
\text { Elevation } \\
\text { (ft) }\end{array}$ & $\begin{array}{c}\text { Depth to } \\
\text { Top of } \\
\text { Sump (ft) }\end{array}$ & $\begin{array}{c}\text { Top of } \\
\text { Sump } \\
\text { Elevation } \\
\text { (ft) }\end{array}$ & $\begin{array}{c}\text { Depth to } \\
\text { Sump } \\
\text { Bottom } \\
\text { (ft) }\end{array}$ & $\begin{array}{c}\text { Sump } \\
\text { Length } \\
\text { (ft) }\end{array}$ & $\begin{array}{c}\text { Sump } \\
\text { Volume } \\
\text { (L) }\end{array}$ & Comment \\
\hline 1 & 7.0 & 17.0 & 6872.0 & 6862.0 & 10.0 & & & 17.0 & 6862.0 & 17.0 & 0.0 & 0.0 & Alluvial groundwater \\
\hline
\end{tabular}

\begin{tabular}{|c|c|}
\hline \multicolumn{2}{|c|}{ CDBO-5 Manual Water Levels } \\
\hline Date & Comments \\
\hline $12 / 7 / 2005$ & Dry \\
\hline $10 / 2 / 2006$ & Dry \\
\hline $12 / 8 / 2006$ & Dry \\
\hline $2 / 22 / 2007$ & Dry \\
\hline $3 / 19 / 2007$ & Dry \\
\hline $6 / 5 / 2007$ & Dry \\
\hline $9 / 11 / 2007$ & Dry \\
\hline $1 / 24 / 2008$ & Dry \\
\hline $2 / 11 / 2008$ & Dry \\
\hline $4 / 1 / 2008$ & Dry \\
\hline $5 / 22 / 2008$ & Dry \\
\hline $7 / 24 / 2008$ & Dry \\
\hline $8 / 11 / 2008$ & Dry \\
\hline $11 / 3 / 2008$ & Dry \\
\hline $1 / 12 / 2009$ & Dry \\
\hline $2 / 3 / 2009$ & Dry \\
\hline $4 / 27 / 2009$ & Dry \\
\hline $7 / 14 / 2009$ & Dry \\
\hline $8 / 4 / 2009$ & Dry \\
\hline $12 / 14 / 2009$ & Dry \\
\hline
\end{tabular}




\subsection{CDBO-6}

Location: In Cañada del Buey, a branch of Mortandad Canyon, approximately $420 \mathrm{ft}$ east of production well PM-4.

Period of Record: June 1, 1992, through December 16, 2009.

Remarks: A pressure transducer was installed above the pump until April 30, 2007, when the pump was removed from the well. Transducer data before April 30, 2007, do not represent water levels below $6776.83 \mathrm{ft}$. The dedicated pump was reinstalled November 10, 2009, and the transducer is once again located above the pump.

\begin{tabular}{|c|c|c|c|c|c|c|c|c|c|c|c|c|c|}
\hline \multicolumn{14}{|c|}{ CDBO-6 Construction Information } \\
\hline Zone & $\begin{array}{c}\text { Screen } \\
\text { Top } \\
\text { Depth (ft) }\end{array}$ & $\begin{array}{c}\text { Screen } \\
\text { Bottom } \\
\text { Depth } \\
\text { (ft) }\end{array}$ & $\begin{array}{c}\text { Screen } \\
\text { Top } \\
\text { Elev (ft) }\end{array}$ & $\begin{array}{l}\text { Screen } \\
\text { Bottom } \\
\text { Elev }(\mathrm{ft})\end{array}$ & \begin{tabular}{|c} 
Screen \\
Length \\
(ft)
\end{tabular} & $\begin{array}{c}\text { Pump } \\
\text { Intake } \\
\text { Depth } \\
\text { (ft) }\end{array}$ & $\begin{array}{c}\text { Pump } \\
\text { Intake } \\
\text { Elevation } \\
\text { (ft) }\end{array}$ & $\begin{array}{c}\text { Depth to } \\
\text { Top of } \\
\text { Sump (ft) }\end{array}$ & $\begin{array}{c}\text { Top of } \\
\text { Sump } \\
\text { Elevation } \\
\text { (ft) }\end{array}$ & $\begin{array}{l}\text { Depth to } \\
\text { Sump } \\
\text { Bottom (ft) }\end{array}$ & $\begin{array}{c}\text { Sump } \\
\text { Length } \\
\text { (ft) }\end{array}$ & $\begin{array}{c}\text { Sump } \\
\text { Volume } \\
\text { (L) }\end{array}$ & Comment \\
\hline 1 & 34.0 & 44.0 & 6783.2 & 6773.2 & 10.0 & & & 44.0 & 6773.2 & 49.0 & 5.0 & 3.1 & Alluvial groundwater \\
\hline
\end{tabular}
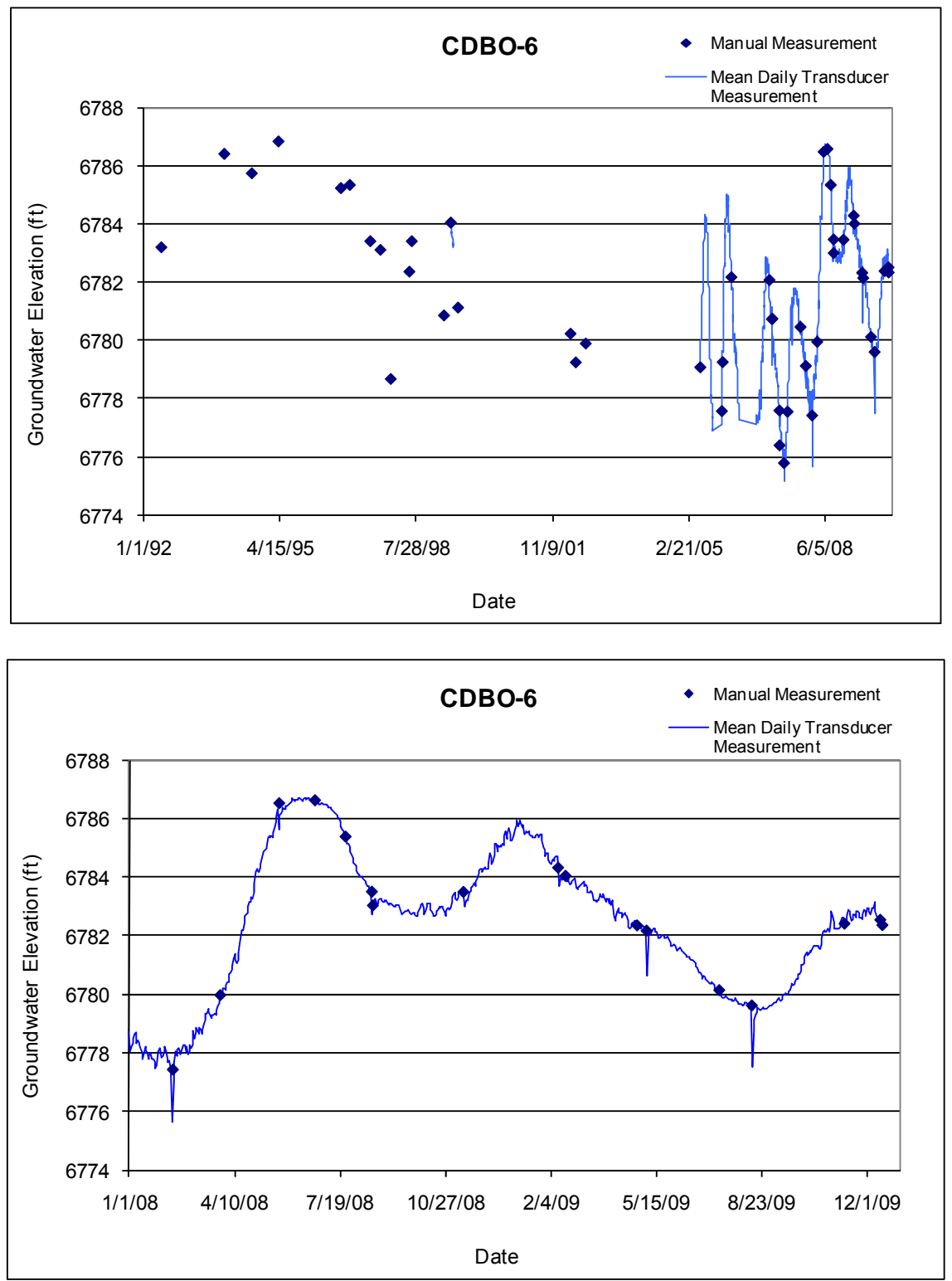


\subsection{CDBO-7}

Location: In Cañada del Buey, a branch of Mortandad Canyon, approximately 0.3 miles southeast of CDBO-6.

Period of Record: June 1,1992, through December 14, 2009.

Remarks: Initially, a pressure transducer was installed above the well's bladder pump at an elevation of $6737.14 \mathrm{ft}$. The transducer was lowered in the well after removal of the pump on April 2, 2007. Data before April 2, 2007, do not represent water levels below $6737.14 \mathrm{ft}$. The water level rose above the sump from August 2008 through June 2009.

\begin{tabular}{|c|c|c|c|c|c|c|c|c|c|c|c|c|c|}
\hline \multicolumn{14}{|c|}{ CDBO-7 Construction Information } \\
\hline Zone & $\begin{array}{l}\text { Screen } \\
\text { Top } \\
\text { Depth (ft) }\end{array}$ & $\begin{array}{c}\text { Screen } \\
\text { Bottom } \\
\text { Depth } \\
\text { (ft) }\end{array}$ & $\begin{array}{c}\text { Screen } \\
\text { Top } \\
\text { Elev (ft) }\end{array}$ & $\begin{array}{l}\text { Screen } \\
\text { Bottom } \\
\text { Elev (ft) }\end{array}$ & $\begin{array}{c}\text { Screen } \\
\text { Length } \\
\text { (ft) }\end{array}$ & $\begin{array}{l}\text { Pump } \\
\text { Intake } \\
\text { Depth } \\
\text { (ft) }\end{array}$ & $\begin{array}{c}\text { Pump } \\
\text { Intake } \\
\text { Elevation } \\
\text { (ft) }\end{array}$ & $\begin{array}{l}\text { Depth to } \\
\text { Top of } \\
\text { Sump (ft) }\end{array}$ & $\begin{array}{c}\text { Top of } \\
\text { Sump } \\
\text { Elevation } \\
\text { (ft) }\end{array}$ & \begin{tabular}{|c|} 
Depth to \\
Sump \\
Bottom (ft)
\end{tabular} & $\begin{array}{c}\text { Sump } \\
\text { Length } \\
(\mathrm{ft})\end{array}$ & $\begin{array}{c}\text { Sump } \\
\text { Volume } \\
\text { (L) }\end{array}$ & Comment \\
\hline 1 & 29.0 & 39.0 & 6742.8 & 6732.8 & 10.0 & & & 39.0 & 6732.8 & 44.0 & 5.0 & 3.1 & Alluvial groundwater \\
\hline
\end{tabular}
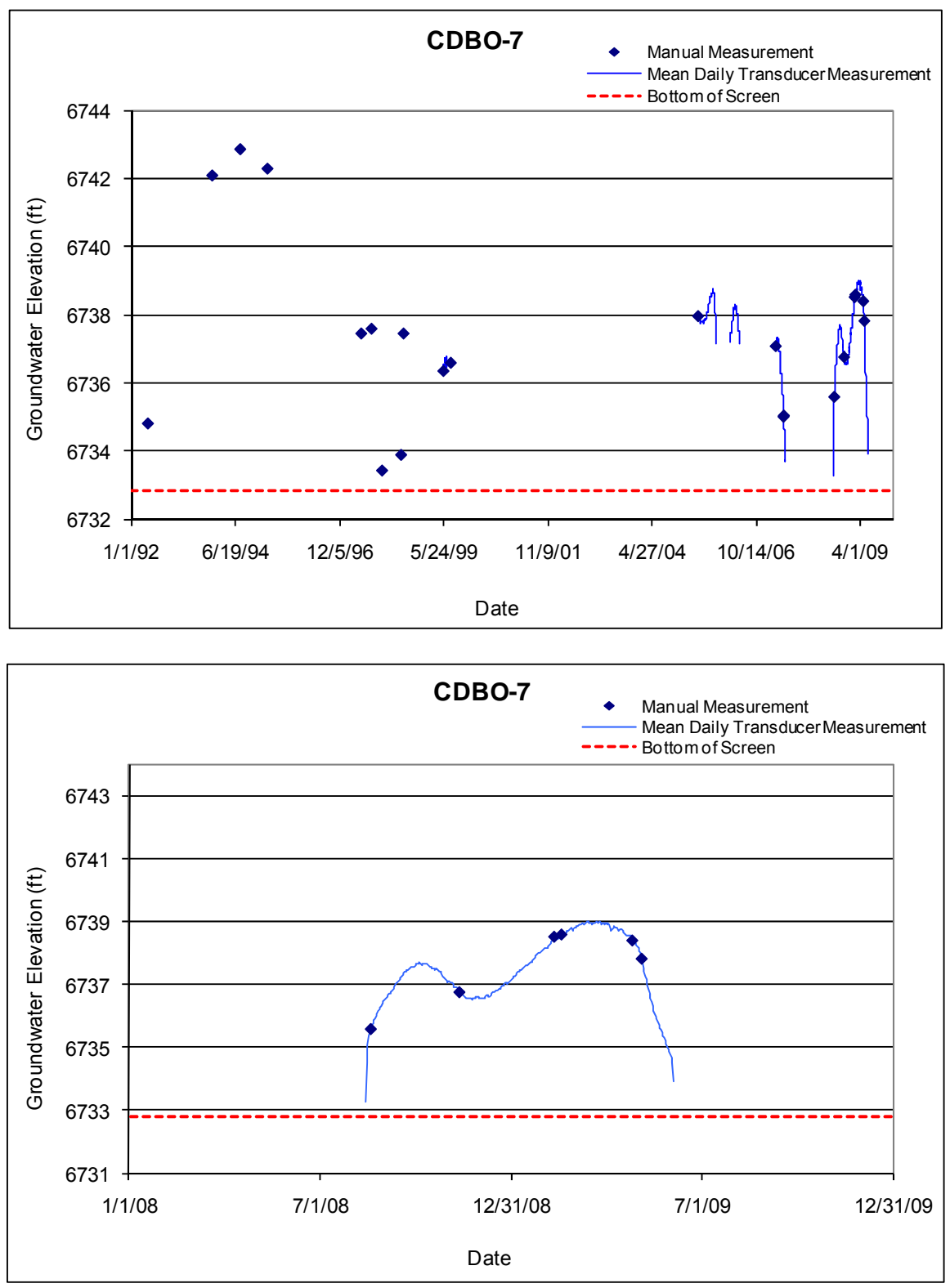


\subsection{CDBO-8}

Location: Alluvial well CDBO-8 is located in Cañada del Buey, approximately 0.4 miles southeast of CDBO-7.

Period of Record: July 2, 2001, through December 14, 2009.

Remarks: Well has historically been dry during quarterly measurements. A transducer was installed in this well January 9, 2009, and has not yet recorded any water in the well.

\begin{tabular}{|c|c|c|c|c|c|c|c|c|c|c|c|c|c|}
\hline \multicolumn{14}{|c|}{ CDBO-8 Construction Information } \\
\hline Zone & $\begin{array}{c}\text { Screen } \\
\text { Top } \\
\text { Depth (ft) }\end{array}$ & $\begin{array}{c}\text { Screen } \\
\text { Bottom } \\
\text { Depth (ft) }\end{array}$ & $\begin{array}{c}\text { Screen } \\
\text { Top Elev } \\
\text { (ft) }\end{array}$ & $\begin{array}{l}\text { Screen } \\
\text { Bottom } \\
\text { Elev (ft) }\end{array}$ & $\begin{array}{l}\text { Screen } \\
\text { Length } \\
\text { (ft) }\end{array}$ & $\begin{array}{c}\text { Pump } \\
\text { Intake } \\
\text { Depth (ft) }\end{array}$ & $\begin{array}{c}\text { Pump } \\
\text { Intake } \\
\text { Elevation } \\
\text { (ft) }\end{array}$ & $\begin{array}{c}\text { Depth to } \\
\text { Top of } \\
\text { Sump (ft) }\end{array}$ & $\begin{array}{c}\text { Top of } \\
\text { Sump } \\
\text { Elevation } \\
\text { (ft) }\end{array}$ & $\begin{array}{l}\text { Depth to } \\
\text { Sump } \\
\text { Bottom } \\
\text { (ft) }\end{array}$ & $\begin{array}{l}\text { Sump } \\
\text { Length } \\
\text { (ft) }\end{array}$ & $\begin{array}{c}\text { Sump } \\
\text { Volume } \\
\text { (L) }\end{array}$ & Comment \\
\hline 1 & 3.0 & 13.0 & 6719.5 & 6709.5 & 10.0 & & & 13.0 & 6709.5 & 23.0 & 10.0 & 6.2 & Alluvial groundwater \\
\hline
\end{tabular}

\begin{tabular}{|c|c|c|c|c|}
\hline \multicolumn{4}{|c|}{ CDBO-8 Manual Water Levels } \\
\hline Date & Comments & Date & Comments \\
\cline { 1 - 1 } $7 / 2 / 2001$ & Dry & & $6 / 8 / 2007$ & Dry \\
\hline $8 / 22 / 2001$ & Dry & & $9 / 10 / 2007$ & Dry \\
\hline $10 / 18 / 2001$ & Dry & & $1 / 24 / 2008$ & Dry \\
\hline $4 / 16 / 2002$ & Dry & & $2 / 11 / 2008$ & Dry \\
\hline $8 / 27 / 2002$ & Dry & & $4 / 1 / 2008$ & Dry \\
\hline $11 / 15 / 2002$ & Dry & & $5 / 22 / 2008$ & Dry \\
\hline $2 / 19 / 2003$ & Dry & & $7 / 24 / 2008$ & Dry \\
\hline $12 / 7 / 2005$ & Dry & & $8 / 11 / 2008$ & Dry \\
\hline $3 / 8 / 2006$ & Dry & & $11 / 3 / 2008$ & Dry \\
\hline $6 / 26 / 2006$ & Dry & & $1 / 12 / 2009$ & Dry \\
\hline $9 / 7 / 2006$ & Dry & & $2 / 3 / 2009$ & Dry \\
\hline $10 / 2 / 2006$ & Dry & $4 / 27 / 2009$ & Dry \\
\hline $12 / 8 / 2006$ & Dry & $7 / 14 / 2009$ & Dry \\
\hline $2 / 22 / 2007$ & Dry & $8 / 4 / 2009$ & Dry \\
\hline $3 / 19 / 2007$ & Dry & $12 / 14 / 2009$ & Dry \\
\hline $6 / 5 / 2007$ & Dry & & \\
\hline
\end{tabular}




\subsection{CDBO-9}

Location: Alluvial well CDBO-9 is located in Cañada del Buey, approximately 0.7 miles southeast of CDBO-8.

Period of Record: July 2, 2001, through December 14, 2009.

Remarks: Well has historically been dry during quarterly measurements. A transducer was installed in this well January 9, 2009, and has not yet recorded any water in the well.

\begin{tabular}{|c|c|c|c|c|c|c|c|c|c|c|c|c|c|}
\hline \multicolumn{14}{|c|}{ CDBO-9 Construction Information } \\
\hline Zone & $\begin{array}{c}\text { Screen } \\
\text { Top } \\
\text { Depth (ft) }\end{array}$ & $\begin{array}{c}\text { Screen } \\
\text { Bottom } \\
\text { Depth }(\mathrm{ft})\end{array}$ & $\begin{array}{c}\text { Screen } \\
\text { Top Elev } \\
\text { (ft) }\end{array}$ & $\begin{array}{l}\text { Screen } \\
\text { Bottom } \\
\text { Elev (ft) }\end{array}$ & $\begin{array}{l}\text { Screen } \\
\text { Length } \\
\text { (ft) }\end{array}$ & $\begin{array}{c}\text { Pump } \\
\text { Intake } \\
\text { Depth (ft) }\end{array}$ & $\begin{array}{c}\text { Pump } \\
\text { Intake } \\
\text { Elevation } \\
\text { (ft) }\end{array}$ & $\begin{array}{c}\text { Depth to } \\
\text { Top of } \\
\text { Sump (ft) }\end{array}$ & $\begin{array}{c}\text { Top of } \\
\text { Sump } \\
\text { Elevation } \\
\text { (ft) }\end{array}$ & $\begin{array}{l}\text { Depth to } \\
\text { Sump } \\
\text { Bottom } \\
\text { (ft) }\end{array}$ & $\begin{array}{c}\text { Sump } \\
\text { Length } \\
\text { (ft) }\end{array}$ & $\begin{array}{c}\text { Sump } \\
\text { Volume } \\
\text { (L) }\end{array}$ & Comment \\
\hline 1 & 19.0 & 29.0 & 6614.0 & 6604.0 & 10.0 & & & 29.0 & 6604.0 & 34.0 & 5.0 & 3.1 & Alluvial groundwater \\
\hline
\end{tabular}

\begin{tabular}{|c|c|c|c|c|}
\hline \multicolumn{4}{|c|}{ CDBO-9 Manual Water Levels } \\
\hline Date & Comments & & Date & Comments \\
\cline { 1 - 1 } $7 / 2 / 2001$ & Dry & $6 / 5 / 2007$ & Dry \\
\hline $8 / 22 / 2001$ & Dry & & $6 / 8 / 2007$ & Dry \\
\hline $10 / 18 / 2001$ & Dry & & $9 / 10 / 2007$ & Dry \\
\hline $4 / 16 / 2002$ & Dry & & $1 / 24 / 2008$ & Dry \\
\hline $8 / 27 / 2002$ & Dry & & $2 / 11 / 2008$ & Dry \\
\hline $11 / 15 / 2002$ & Dry & & $4 / 1 / 2008$ & Dry \\
\hline $2 / 19 / 2003$ & Dry & & $5 / 22 / 2008$ & Dry \\
\hline $6 / 3 / 2003$ & Dry & & $7 / 24 / 2008$ & Dry \\
\hline $12 / 6 / 2005$ & Dry & & $8 / 11 / 2008$ & Dry \\
\hline $3 / 8 / 2006$ & Dry & & $11 / 3 / 2008$ & Dry \\
\hline $6 / 26 / 2006$ & Dry & & $1 / 9 / 2009$ & Dry \\
\hline $9 / 6 / 2006$ & Dry & & $2 / 3 / 2009$ & Dry \\
\hline $10 / 2 / 2006$ & Dry & $4 / 27 / 2009$ & Dry \\
\hline $12 / 8 / 2006$ & Dry & $7 / 14 / 2009$ & Dry \\
\hline $2 / 22 / 2007$ & Dry & $8 / 4 / 2009$ & Dry \\
\hline $3 / 19 / 2007$ & Dry & & $12 / 14 / 2009$ & Dry \\
\hline
\end{tabular}




\subsection{CDV-16-02655}

Location: Westernmost upper Cañon de Valle in TA-16, approximately $800 \mathrm{ft}$ east of Anchor Ranch Road.

Period of Record: May 15, 1998, through October 27, 2009.

Remarks: None.

\begin{tabular}{|c|c|c|c|c|c|c|c|c|c|c|c|c|c|}
\hline \multicolumn{14}{|c|}{ CDV-16-02655 Construction Information } \\
\hline Zone & $\begin{array}{l}\text { Screen } \\
\text { Top } \\
\text { Depth (ft) }\end{array}$ & $\begin{array}{c}\text { Screen } \\
\text { Bottom } \\
\text { Depth } \\
\text { (ft) }\end{array}$ & $\begin{array}{c}\text { Screen } \\
\text { Top } \\
\text { Elev (ft) }\end{array}$ & $\begin{array}{l}\text { Screen } \\
\text { Bottom } \\
\text { Elev (ft) }\end{array}$ & $\begin{array}{c}\text { Screen } \\
\text { Length } \\
\text { (ft) }\end{array}$ & $\begin{array}{l}\text { Pump } \\
\text { Intake } \\
\text { Depth } \\
\text { (ft) }\end{array}$ & $\begin{array}{c}\text { Pump } \\
\text { Intake } \\
\text { Elevation } \\
\text { (ft) }\end{array}$ & $\begin{array}{l}\text { Depth to } \\
\text { Top of } \\
\text { Sump (ft) }\end{array}$ & $\begin{array}{c}\text { Top of } \\
\text { Sump } \\
\text { Elevation } \\
\text { (ft) }\end{array}$ & \begin{tabular}{|c|} 
Depth to \\
Sump \\
Bottom (ft)
\end{tabular} & $\begin{array}{l}\text { Sump } \\
\text { Length } \\
\text { (ft) }\end{array}$ & $\begin{array}{c}\text { Sump } \\
\text { Volume } \\
\text { (L) }\end{array}$ & Comment \\
\hline 1 & 2.3 & 7.3 & 7580.91 & 7575.91 & 5.0 & & & 7.3 & 7575.91 & 7.6 & 0.3 & 0.7 & Alluvial groundwater \\
\hline
\end{tabular}

Note: Aluminum cap elevation: $7583.70 ;$ Ground Elevation: $7583.21 \mathrm{ft}$; all depth measurements are from this elevation
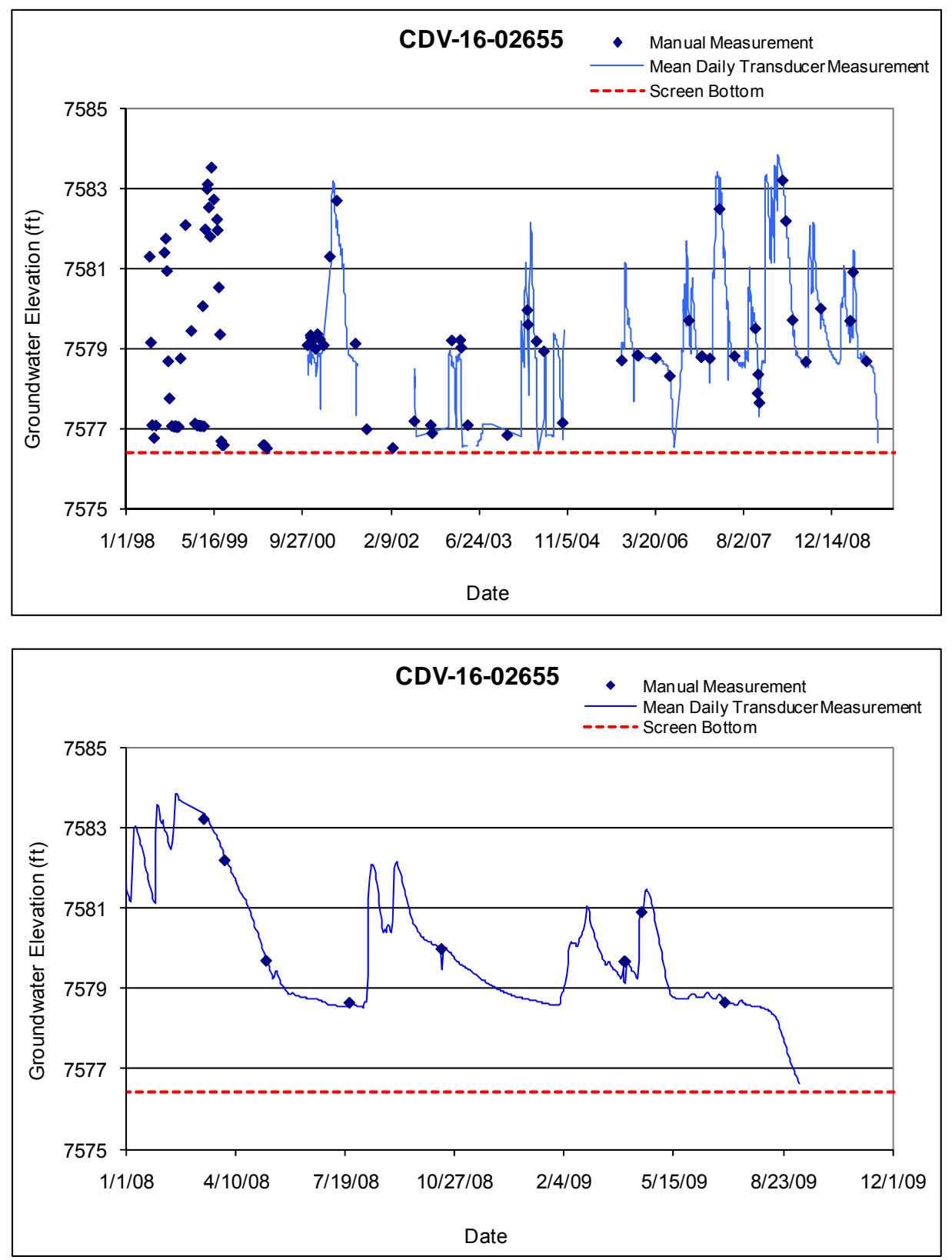


\subsection{CDV-16-02656}

Location: In upper Cañon de Valle at the northern boundary of TA-16.

Period of Record: May 15, 1998, through October 27, 2009.

Remarks: None.

\begin{tabular}{|c|c|c|c|c|c|c|c|c|c|c|c|c|c|}
\hline \multicolumn{14}{|c|}{ CDV-16-02656 Construction Information } \\
\hline Zone & $\begin{array}{l}\text { Screen } \\
\text { Top } \\
\text { Depth (ft) }\end{array}$ & $\begin{array}{c}\text { Screen } \\
\text { Bottom } \\
\text { Depth } \\
\text { (ft) }\end{array}$ & $\begin{array}{c}\text { Screen } \\
\text { Top } \\
\text { Elev (ft) }\end{array}$ & $\begin{array}{l}\text { Screen } \\
\text { Bottom } \\
\text { Elev (ft) }\end{array}$ & $\begin{array}{c}\text { Screen } \\
\text { Length } \\
\text { (ft) }\end{array}$ & $\begin{array}{l}\text { Pump } \\
\text { Intake } \\
\text { Depth } \\
\text { (ft) }\end{array}$ & $\begin{array}{c}\text { Pump } \\
\text { Intake } \\
\text { Elevation } \\
\text { (ft) }\end{array}$ & $\begin{array}{l}\text { Depth to } \\
\text { Top of } \\
\text { Sump (ft) }\end{array}$ & $\begin{array}{c}\text { Top of } \\
\text { Sump } \\
\text { Elevation } \\
\text { (ft) }\end{array}$ & $\begin{array}{l}\text { Depth to } \\
\text { Sump } \\
\text { Bottom (ft) }\end{array}$ & $\begin{array}{c}\text { Sump } \\
\text { Length } \\
\text { (ft) }\end{array}$ & $\begin{array}{c}\text { Sump } \\
\text { Volume } \\
\text { (L) }\end{array}$ & Comment \\
\hline 1 & 3.0 & 8.0 & 7439.69 & 7434.69 & 5.0 & & & 8.0 & 7434.69 & 8.3 & 0.3 & 0.7 & Alluvial groundwater \\
\hline
\end{tabular}

Note: Aluminum cap Elevaton: $7443.18 \mathrm{ft}$; Ground Elevation: $7442.69 \mathrm{ft}$; all depths are from this elevation
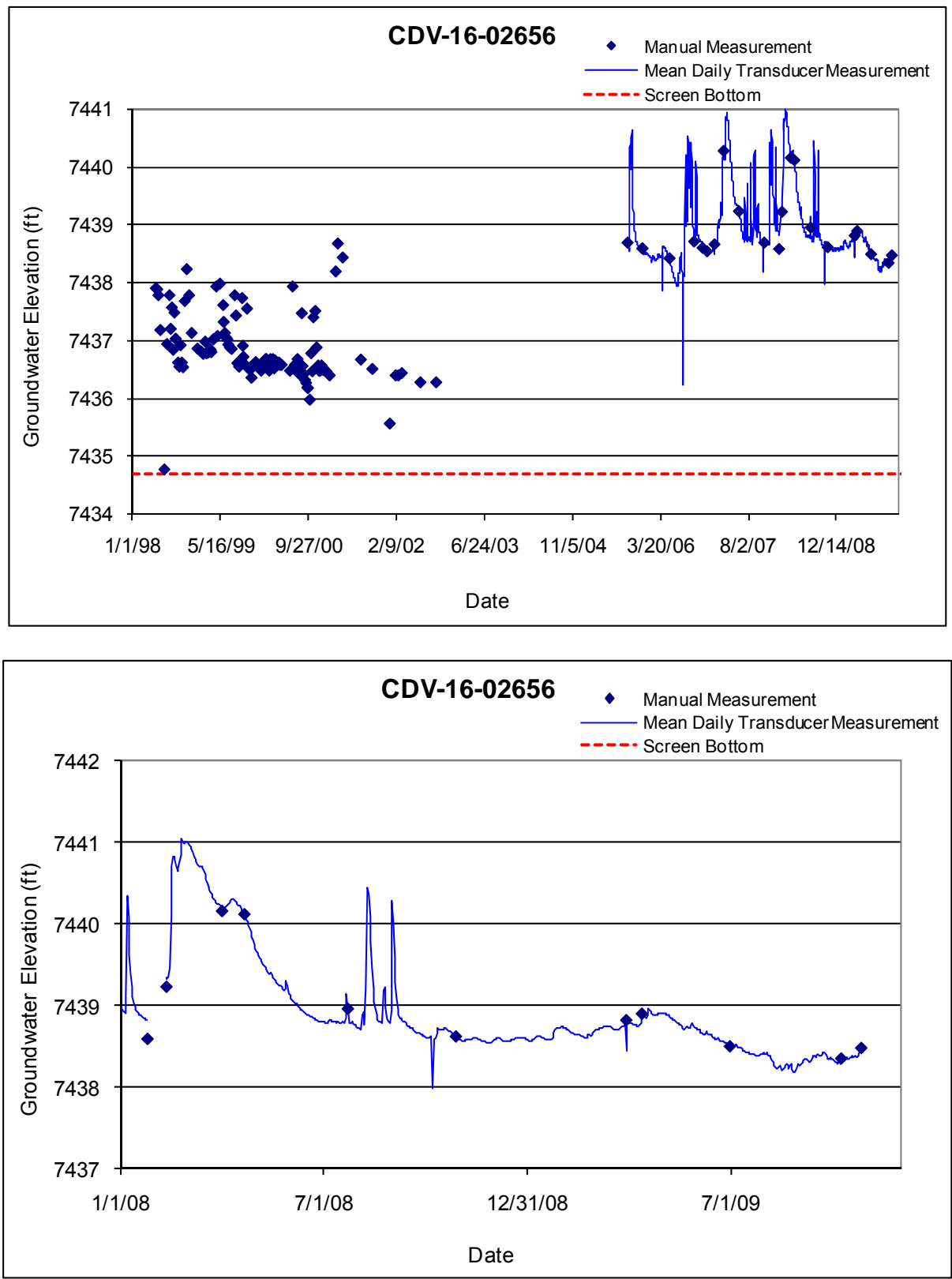


\subsection{CDV-16-02657}

Location: Upper Cañon de Valle at northern boundary of TA-16, approximately $200 \mathrm{ft}$ east-southeast of well CDV-16-02656.

Period of Record: May 15, 1998, through October 27, 2009.

Remarks: Transducer began to malfunction around April 21, 2008; replaced October 31, 2008. This well is closed by a manhole cover, and the cable often cannot vent, resulting in mean daily transducer measurements that differ from the corresponding manual measurements.

\begin{tabular}{|c|c|c|c|c|c|c|c|c|c|c|c|c|c|}
\hline \multicolumn{14}{|c|}{ CDV-16-02657 Construction Information } \\
\hline Zone & $\begin{array}{l}\text { Screen } \\
\text { Top } \\
\text { Depth (ft) }\end{array}$ & $\begin{array}{c}\text { Screen } \\
\text { Bottom } \\
\text { Depth } \\
\text { (ft) }\end{array}$ & $\begin{array}{c}\text { Screen } \\
\text { Top } \\
\text { Elev (ft) }\end{array}$ & $\begin{array}{l}\text { Screen } \\
\text { Bottom } \\
\text { Elev (ft) }\end{array}$ & $\begin{array}{c}\text { Screen } \\
\text { Length } \\
\text { (ft) }\end{array}$ & $\begin{array}{c}\text { Pump } \\
\text { Intake } \\
\text { Depth } \\
\text { (ft) }\end{array}$ & $\begin{array}{c}\text { Pump } \\
\text { Intake } \\
\text { Elevation } \\
\text { (ft) }\end{array}$ & $\begin{array}{l}\text { Depth to } \\
\text { Top of } \\
\text { Sump (ft) }\end{array}$ & $\begin{array}{c}\text { Top of } \\
\text { Sump } \\
\text { Elevation } \\
\text { (ft) }\end{array}$ & \begin{tabular}{|} 
Depth to \\
Sump \\
Bottom (ft)
\end{tabular} & $\begin{array}{c}\text { Sump } \\
\text { Length } \\
\text { (ft) }\end{array}$ & $\begin{array}{c}\text { Sump } \\
\text { Volume } \\
\text { (L) }\end{array}$ & Comment \\
\hline 1 & 0.4 & 5.4 & 7432.85 & 7427.85 & 5.0 & & & 5.4 & 7427.85 & 5.7 & 0.3 & 0.7 & Alluvial groundwater \\
\hline
\end{tabular}
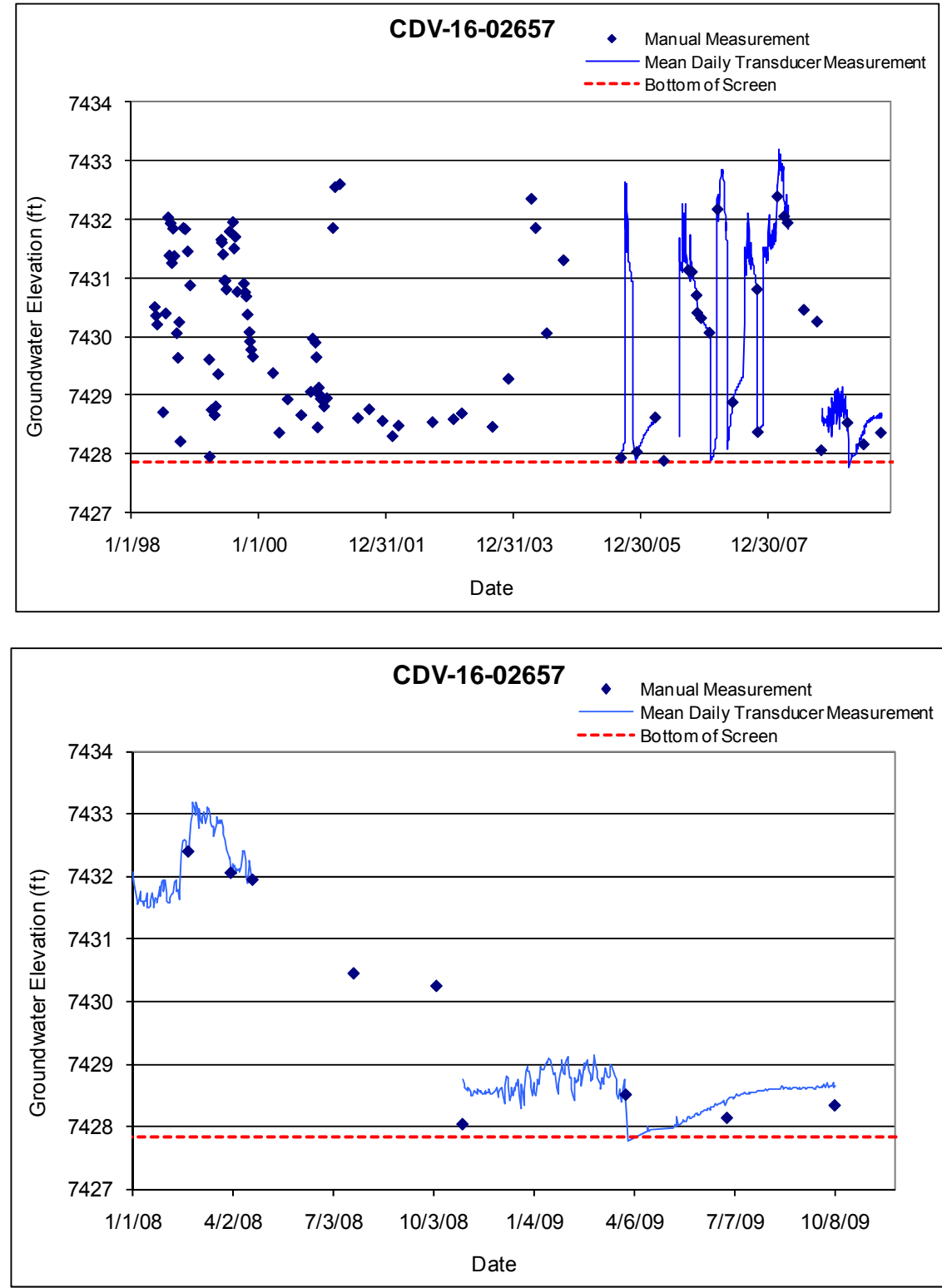


\subsection{CDV-16-02658}

Location: Upper Cañon de Valle at northern boundary of TA-16, approximately $200 \mathrm{ft}$ east-southeast of well CDV-16-02657 and approximately $800 \mathrm{ft}$ east-southeast of Burning Ground Spring.

Period of Record: September 15, 1997, through October 27, 2009.

Remarks: None.

\begin{tabular}{|c|c|c|c|c|c|c|c|c|c|c|c|c|c|}
\hline \multicolumn{14}{|c|}{ CDV-16-02658 Construction Information } \\
\hline Zone & $\begin{array}{c}\text { Screen } \\
\text { Top } \\
\text { Depth (ft) }\end{array}$ & $\begin{array}{c}\text { Screen } \\
\text { Bottom } \\
\text { Depth } \\
\text { (ft) }\end{array}$ & $\begin{array}{c}\text { Screen } \\
\text { Top } \\
\text { Elev (ft) }\end{array}$ & $\begin{array}{l}\text { Screen } \\
\text { Bottom } \\
\text { Elev (ft) }\end{array}$ & $\begin{array}{c}\text { Screen } \\
\text { Length } \\
\text { (ft) }\end{array}$ & $\begin{array}{l}\text { Pump } \\
\text { Intake } \\
\text { Depth } \\
\text { (ft) }\end{array}$ & \begin{tabular}{|c|} 
Pump \\
Intake \\
Elevation \\
(ft)
\end{tabular} & $\begin{array}{c}\text { Depth to } \\
\text { Top of } \\
\text { Sump (ft) }\end{array}$ & $\begin{array}{c}\text { Top of } \\
\text { Sump } \\
\text { Elevation } \\
\text { (ft) }\end{array}$ & \begin{tabular}{|c|} 
Depth to \\
Sump \\
Bottom (ft)
\end{tabular} & $\begin{array}{l}\text { Sump } \\
\text { Length } \\
\text { (ft) }\end{array}$ & $\begin{array}{c}\text { Sump } \\
\text { Volume } \\
\text { (L) }\end{array}$ & Comment \\
\hline 1 & 1.9 & 6.9 & 7373.26 & 7368.26 & 5.0 & & & 6.9 & 7368.26 & 7.2 & 0.3 & 0.7 & Alluvial groundwater \\
\hline
\end{tabular}
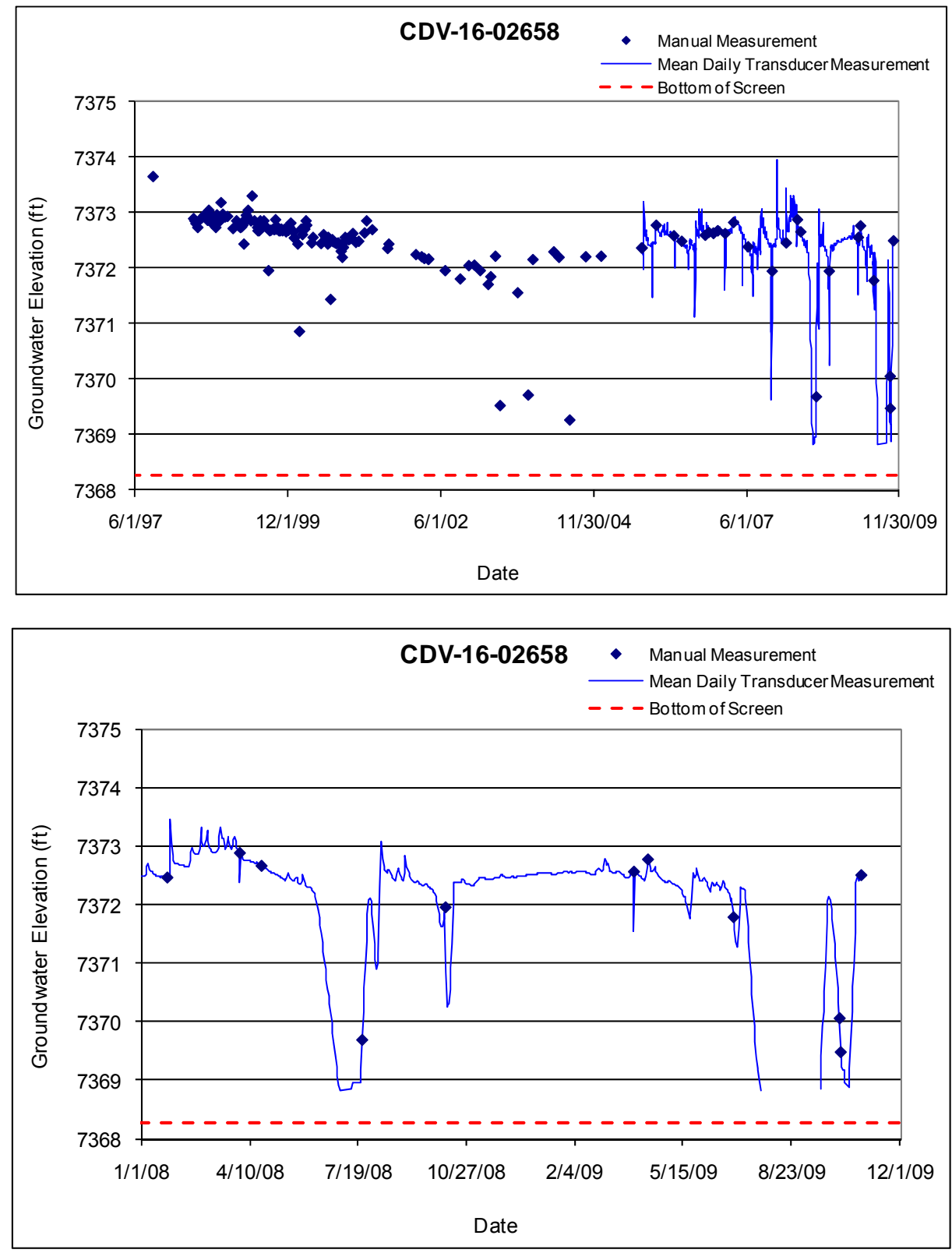


\subsection{CDV-16-02659}

Location: Upper Cañon de Valle at northern boundary of TA-16, approximately $1800 \mathrm{ft}$ east-northeast of well CDV-16-02657.

Period of Record: September 17, 1997, through October 27, 2009.

Remarks: None.

\begin{tabular}{|c|c|c|c|c|c|c|c|c|c|c|c|c|c|}
\hline \multicolumn{14}{|c|}{ CDV-16-02659 Construction Information } \\
\hline Zone & $\begin{array}{c}\text { Screen } \\
\text { Top } \\
\text { Depth (ft) }\end{array}$ & $\begin{array}{c}\text { Screen } \\
\text { Bottom } \\
\text { Depth } \\
\text { (ft) }\end{array}$ & $\begin{array}{c}\text { Screen } \\
\text { Top } \\
\text { Elev (ft) }\end{array}$ & $\begin{array}{l}\text { Screen } \\
\text { Bottom } \\
\text { Elev (ft) }\end{array}$ & \begin{tabular}{|c|} 
Screen \\
Length \\
(ft)
\end{tabular} & $\begin{array}{l}\text { Pump } \\
\text { Intake } \\
\text { Depth } \\
\text { (ft) }\end{array}$ & \begin{tabular}{|c|} 
Pump \\
Intake \\
Elevation \\
(ft)
\end{tabular} & $\begin{array}{c}\text { Depth to } \\
\text { Top of } \\
\text { Sump (ft) }\end{array}$ & $\begin{array}{c}\text { Top of } \\
\text { Sump } \\
\text { Elevation } \\
\text { (ft) }\end{array}$ & $\begin{array}{c}\text { Depth to } \\
\text { Sump } \\
\text { Bottom (ft) }\end{array}$ & $\begin{array}{l}\text { Sump } \\
\text { Length } \\
\text { (ft) }\end{array}$ & $\begin{array}{c}\text { Sump } \\
\text { Volume } \\
\text { (L) }\end{array}$ & Comment \\
\hline 1 & 1.7 & 6.7 & 7298.32 & 7293.32 & 5.0 & & & 6.7 & 7293.32 & 7.0 & 0.3 & 0.7 & Alluvial groundwater \\
\hline
\end{tabular}
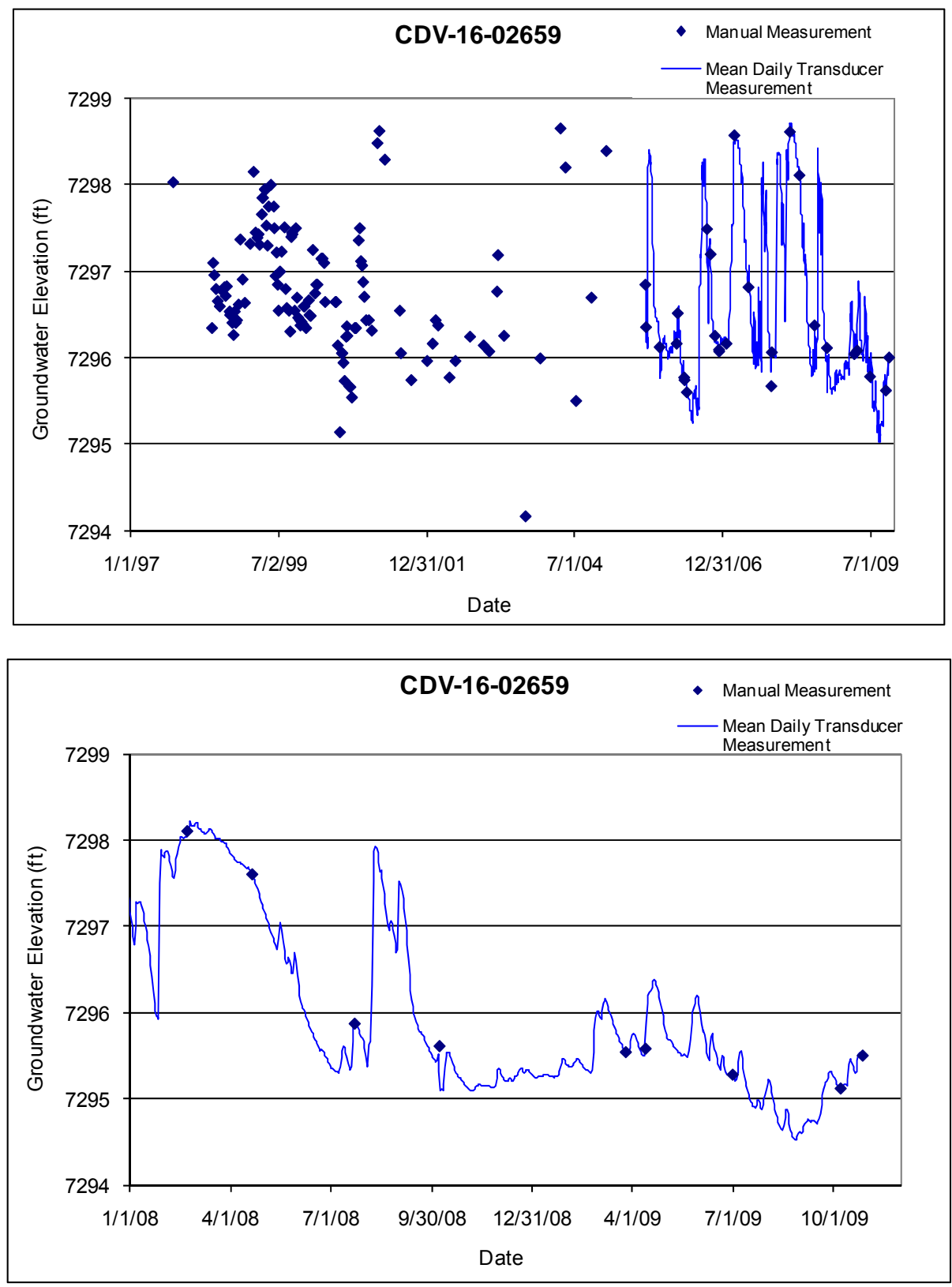


\subsection{FCO-1}

Location: Fence Canyon, approximately 0.1 miles northwest of SR-4.

Period of Record: June 9, 1997, through October 7, 2009.

Remarks: Well has been dry since completion. A transducer was installed January 16, 2008. Water levels have remained below the screen since installation.

\begin{tabular}{|c|c|c|c|c|c|c|c|c|c|c|c|c|c|}
\hline \multicolumn{14}{|c|}{ FCO-1 Construction Information } \\
\hline Zone & $\begin{array}{c}\text { Screen } \\
\text { Top } \\
\text { Depth (ft) }\end{array}$ & $\begin{array}{c}\text { Screen } \\
\text { Bottom } \\
\text { Depth } \\
\text { (ft) }\end{array}$ & $\begin{array}{c}\text { Screen } \\
\text { Top } \\
\text { Elev }(\mathrm{ft})\end{array}$ & $\begin{array}{l}\text { Screen } \\
\text { Bottom } \\
\text { Elev (ft) }\end{array}$ & $\begin{array}{c}\text { Screen } \\
\text { Length } \\
\text { (ft) }\end{array}$ & $\begin{array}{c}\text { Pump } \\
\text { Intake } \\
\text { Depth } \\
\text { (ft) }\end{array}$ & $\begin{array}{c}\text { Pump } \\
\text { Intake } \\
\text { Elevation } \\
\text { (ft) }\end{array}$ & $\begin{array}{c}\text { Depth to } \\
\text { Top of } \\
\text { Sump (ft) }\end{array}$ & $\begin{array}{c}\text { Top of } \\
\text { Sump } \\
\text { Elevation } \\
\text { (ft) }\end{array}$ & \begin{tabular}{|c|} 
Depth to \\
Sump \\
Bottom (ft)
\end{tabular} & $\begin{array}{c}\text { Sump } \\
\text { Length } \\
\text { (ft) }\end{array}$ & $\begin{array}{c}\text { Sump } \\
\text { Volume } \\
\text { (L) }\end{array}$ & Comment \\
\hline 1 & 2.4 & 12.4 & 6506.8 & 6496.8 & 10.0 & & & 2.4 & 6506.8 & 12.4 & 0.0 & 0.0 & Alluvial groundwater \\
\hline
\end{tabular}

\begin{tabular}{|c|c|c|c|}
\hline \multicolumn{4}{|c|}{ FCO-1 Manual Water Levels } \\
\hline Date & Comments & Date & Comments \\
\hline 6/9/1997 & Dry & $9 / 14 / 2005$ & Dry \\
\hline 10/13/1997 & Dry & $6 / 23 / 2006$ & Dry \\
\hline $3 / 25 / 1998$ & Dry & $9 / 8 / 2006$ & Dry \\
\hline $5 / 29 / 1998$ & Dry & $12 / 15 / 2006$ & Dry \\
\hline $7 / 28 / 1998$ & Dry & $1 / 24 / 2007$ & Dry \\
\hline $3 / 3 / 1999$ & Dry & $3 / 15 / 2007$ & Dry \\
\hline $6 / 23 / 1999$ & Dry & $5 / 24 / 2007$ & Dry \\
\hline 8/30/1999 & Dry & $6 / 6 / 2007$ & Dry \\
\hline $11 / 15 / 1999$ & Dry & $9 / 5 / 2007$ & Dry \\
\hline $3 / 26 / 2000$ & Dry & $10 / 17 / 2007$ & Dry \\
\hline $5 / 16 / 2000$ & Dry & $1 / 16 / 2008$ & Dry \\
\hline $8 / 30 / 2000$ & Dry & $4 / 8 / 2008$ & Dry \\
\hline $10 / 8 / 2000$ & Dry & $4 / 25 / 2008$ & Dry \\
\hline $4 / 16 / 2002$ & Dry & $7 / 18 / 2008$ & Dry \\
\hline $8 / 19 / 2002$ & Dry & $10 / 7 / 2008$ & Dry \\
\hline $11 / 13 / 2002$ & Dry & $3 / 23 / 2009$ & Dry \\
\hline $2 / 19 / 2003$ & Dry & $7 / 2 / 2009$ & Dry \\
\hline $5 / 18 / 2003$ & Dry & $10 / 7 / 2009$ & Dry \\
\hline $4 / 7 / 2004$ & Dry & & \\
\hline
\end{tabular}




\subsection{FLC-16-25278}

Location: Fish Ladder Canyon, approximately 0.1 miles southeast of the TA-16 Burning Grounds. Period of Record: June 9, 1997, through October 7, 2009.

Remarks: Water levels frequently drop below the screen.

\begin{tabular}{|c|c|c|c|c|c|c|c|c|c|c|c|c|c|}
\hline \multicolumn{14}{|c|}{ FLC-16-25278 Construction Information } \\
\hline Zone & \begin{tabular}{|c} 
Screen \\
Top \\
Depth (ft)
\end{tabular} & $\begin{array}{c}\text { Screen } \\
\text { Bottom } \\
\text { Depth } \\
\text { (ft) }\end{array}$ & $\begin{array}{c}\text { Screen } \\
\text { Top } \\
\text { Elev (ft) }\end{array}$ & $\begin{array}{l}\text { Screen } \\
\text { Bottom } \\
\text { Elev (ft) }\end{array}$ & $\begin{array}{c}\text { Screen } \\
\text { Length } \\
\text { (ft) }\end{array}$ & $\begin{array}{l}\text { Pump } \\
\text { Intake } \\
\text { Depth } \\
\text { (ft) }\end{array}$ & $\begin{array}{c}\text { Pump } \\
\text { Intake } \\
\text { Elevation } \\
\text { (ft) }\end{array}$ & $\begin{array}{c}\text { Depth to } \\
\text { Top of } \\
\text { Sump (ft) }\end{array}$ & $\begin{array}{c}\text { Top of } \\
\text { Sump } \\
\text { Elevation } \\
\text { (ft) }\end{array}$ & \begin{tabular}{|c|} 
Depth to \\
Sump \\
Bottom (ft)
\end{tabular} & $\begin{array}{c}\text { Sump } \\
\text { Length } \\
\text { (ft) }\end{array}$ & $\begin{array}{c}\text { Sump } \\
\text { Volume } \\
\text { (L) }\end{array}$ & Comment \\
\hline 1 & 1.6 & 3.2 & 7270.6 & 7269.0 & 1.6 & & & 3.2 & 7269 & 3.4 & 0.2 & 0.12 & Alluvial groundwater \\
\hline
\end{tabular}

Note: Ground Elevation: $7272.20 \mathrm{ft}$; all measurements are from this elevation
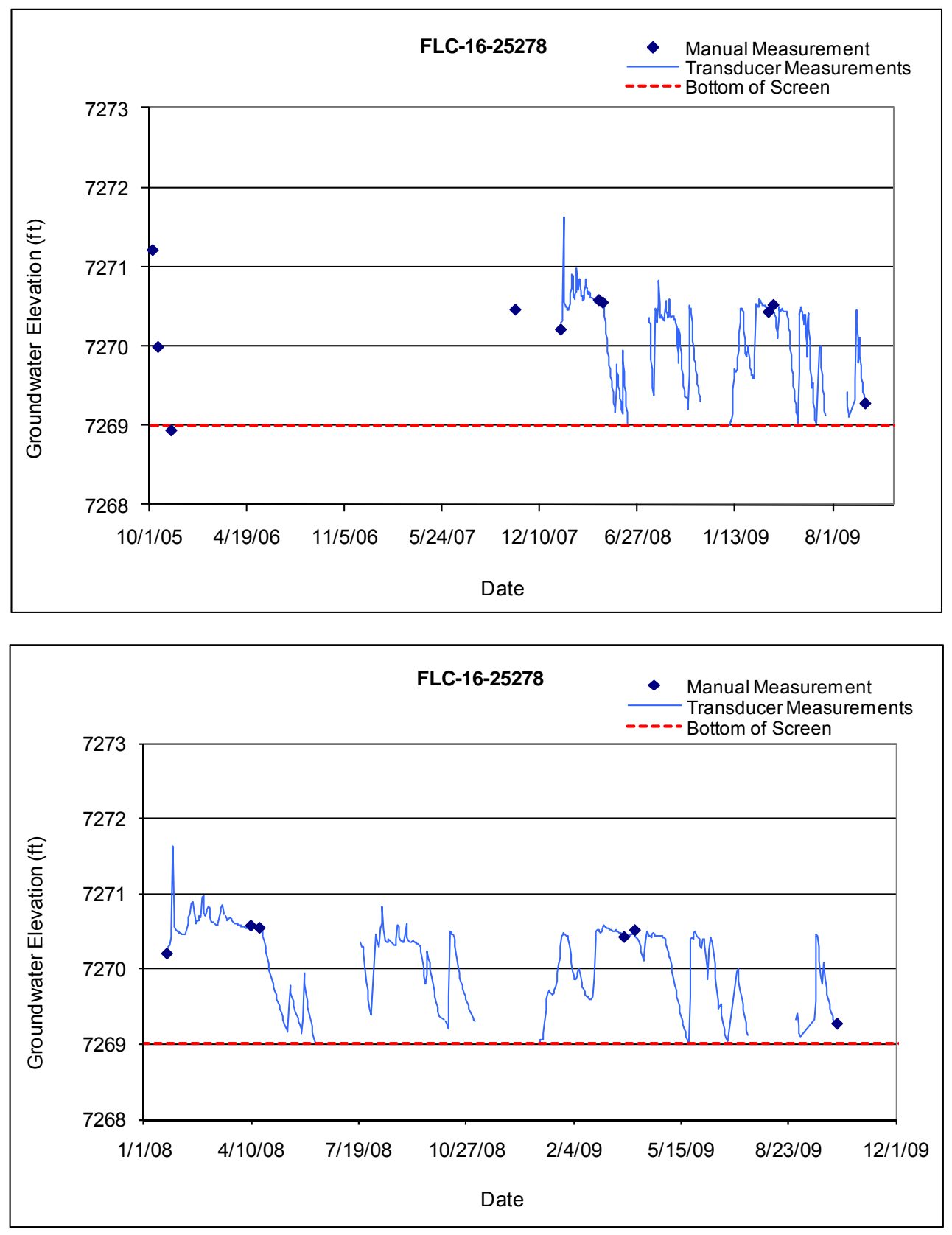


\subsection{FLC-16-25279}

Location: Fish Ladder Canyon, approximately 0.2 miles east of the FLC-16-25278.

Period of Record: June 9, 1997, through October 7, 2009.

Remarks: Water levels frequently drop below the screen. Bottom of screen is calculated to be at $7304.29 \mathrm{ft}$, rather than what was originally reported.

\begin{tabular}{|c|c|c|c|c|c|c|c|c|c|c|c|c|c|}
\hline \multicolumn{14}{|c|}{ FLC-16-25279 Construction Information } \\
\hline Zone & $\begin{array}{c}\text { Screen } \\
\text { Top } \\
\text { Depth (ft) }\end{array}$ & $\begin{array}{c}\text { Screen } \\
\text { Bottom } \\
\text { Depth } \\
\text { (ft) }\end{array}$ & $\begin{array}{c}\text { Screen } \\
\text { Top } \\
\text { Elev (ft) }\end{array}$ & $\begin{array}{l}\text { Screen } \\
\text { Bottom } \\
\text { Elev (ft) }\end{array}$ & $\begin{array}{c}\text { Screen } \\
\text { Length } \\
\text { (ft) }\end{array}$ & $\begin{array}{l}\text { Pump } \\
\text { Intake } \\
\text { Depth } \\
\text { (ft) }\end{array}$ & $\begin{array}{c}\text { Pump } \\
\text { Intake } \\
\text { Elevation } \\
\text { (ft) }\end{array}$ & $\begin{array}{c}\text { Depth to } \\
\text { Top of } \\
\text { Sump (ft) }\end{array}$ & $\begin{array}{c}\text { Top of } \\
\text { Sump } \\
\text { Elevation } \\
\text { (ft) }\end{array}$ & \begin{tabular}{|} 
Depth to \\
Sump \\
Bottom (ft)
\end{tabular} & $\begin{array}{c}\text { Sump } \\
\text { Length } \\
\text { (ft) }\end{array}$ & $\begin{array}{c}\text { Sump } \\
\text { Volume } \\
\text { (L) }\end{array}$ & Comment \\
\hline 1 & 2.7 & 4.3 & 7306.60 & 7305.00 & 1.6 & & & 4.3 & 7305 & 4.5 & 0.2 & 0.12 & Alluvial groundwater \\
\hline
\end{tabular}

Note: Ground Elevation: $7309.30 \mathrm{ft}$; all measurements are from this elevation
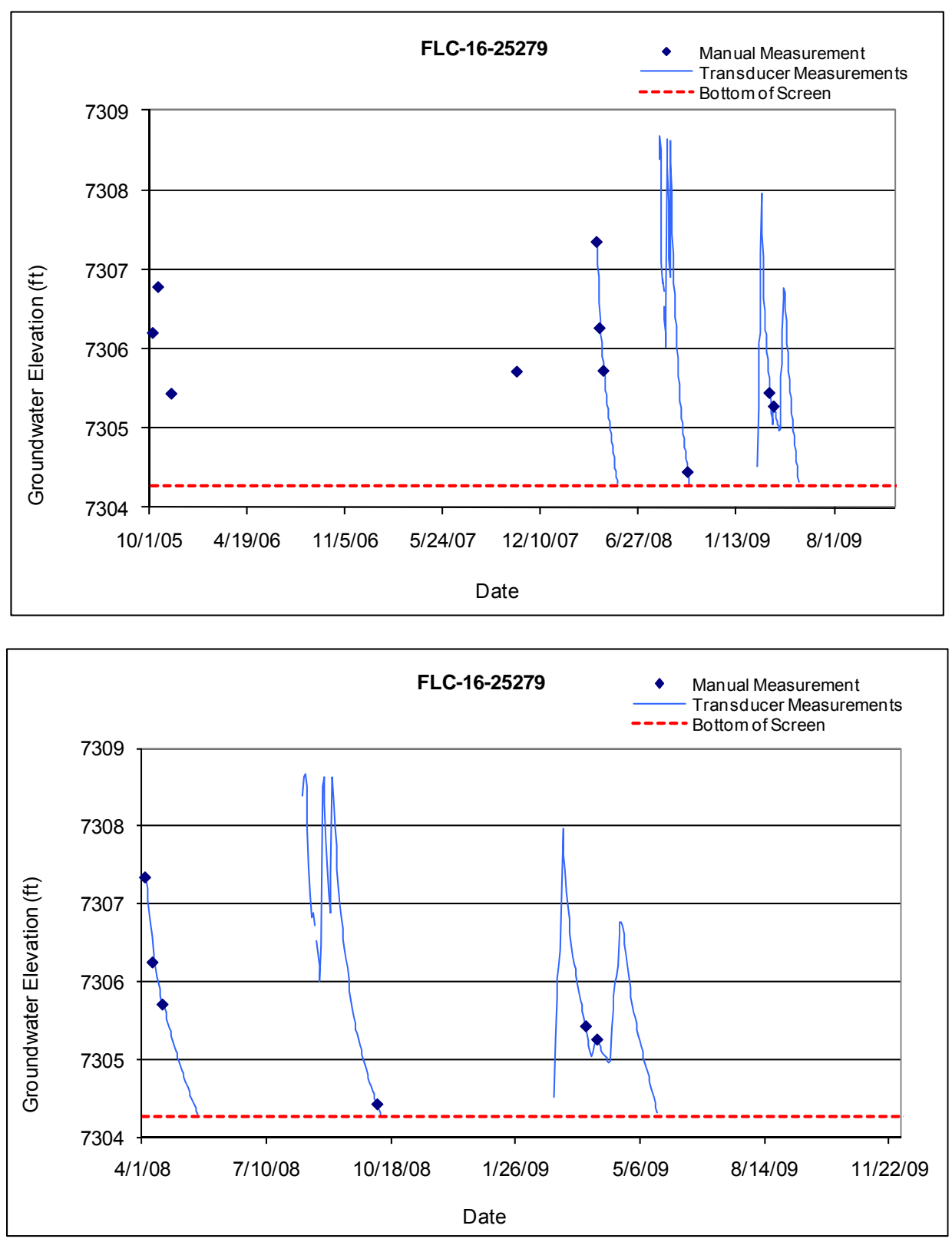


\subsection{FLC-16-25280}

Location: Fish Ladder Canyon, approximately 0.2 miles east of the FLC-16-25279.

Period of Record: June 9, 1997, through October 7, 2009.

Remarks: Water levels frequently drop below the screen.

\begin{tabular}{|c|c|c|c|c|c|c|c|c|c|c|c|c|c|}
\hline \multicolumn{14}{|c|}{ FLC-16-25280 Construction Information } \\
\hline Zone & $\begin{array}{c}\text { Screen } \\
\text { Top } \\
\text { Depth (ft) }\end{array}$ & $\begin{array}{c}\text { Screen } \\
\text { Bottom } \\
\text { Depth } \\
\text { (ft) }\end{array}$ & $\begin{array}{c}\text { Screen } \\
\text { Top } \\
\text { Elev }(\mathrm{ft})\end{array}$ & $\begin{array}{l}\text { Screen } \\
\text { Bottom } \\
\text { Elev (ft) }\end{array}$ & $\begin{array}{c}\text { Screen } \\
\text { Length } \\
\text { (ft) }\end{array}$ & $\begin{array}{l}\text { Pump } \\
\text { Intake } \\
\text { Depth } \\
\text { (ft) }\end{array}$ & $\begin{array}{c}\text { Pump } \\
\text { Intake } \\
\text { Elevation } \\
\text { (ft) }\end{array}$ & $\begin{array}{c}\text { Depth to } \\
\text { Top of } \\
\text { Sump (ft) }\end{array}$ & $\begin{array}{c}\text { Top of } \\
\text { Sump } \\
\text { Elevation } \\
\text { (ft) }\end{array}$ & \begin{tabular}{|c|} 
Depth to \\
Sump \\
Bottom (ft)
\end{tabular} & $\begin{array}{c}\text { Sump } \\
\text { Length } \\
\text { (ft) }\end{array}$ & $\begin{array}{c}\text { Sump } \\
\text { Volume } \\
\text { (L) }\end{array}$ & Comment \\
\hline 1 & 2.6 & 4.2 & 7350.3 & 7348.7 & 1.6 & & & 4.2 & 7348.7 & 4.4 & 0.2 & 0.12 & Alluvial groundwater \\
\hline
\end{tabular}

Note: Ground Elevation: $7352.90 \mathrm{ft}$; all measurements are from this elevation
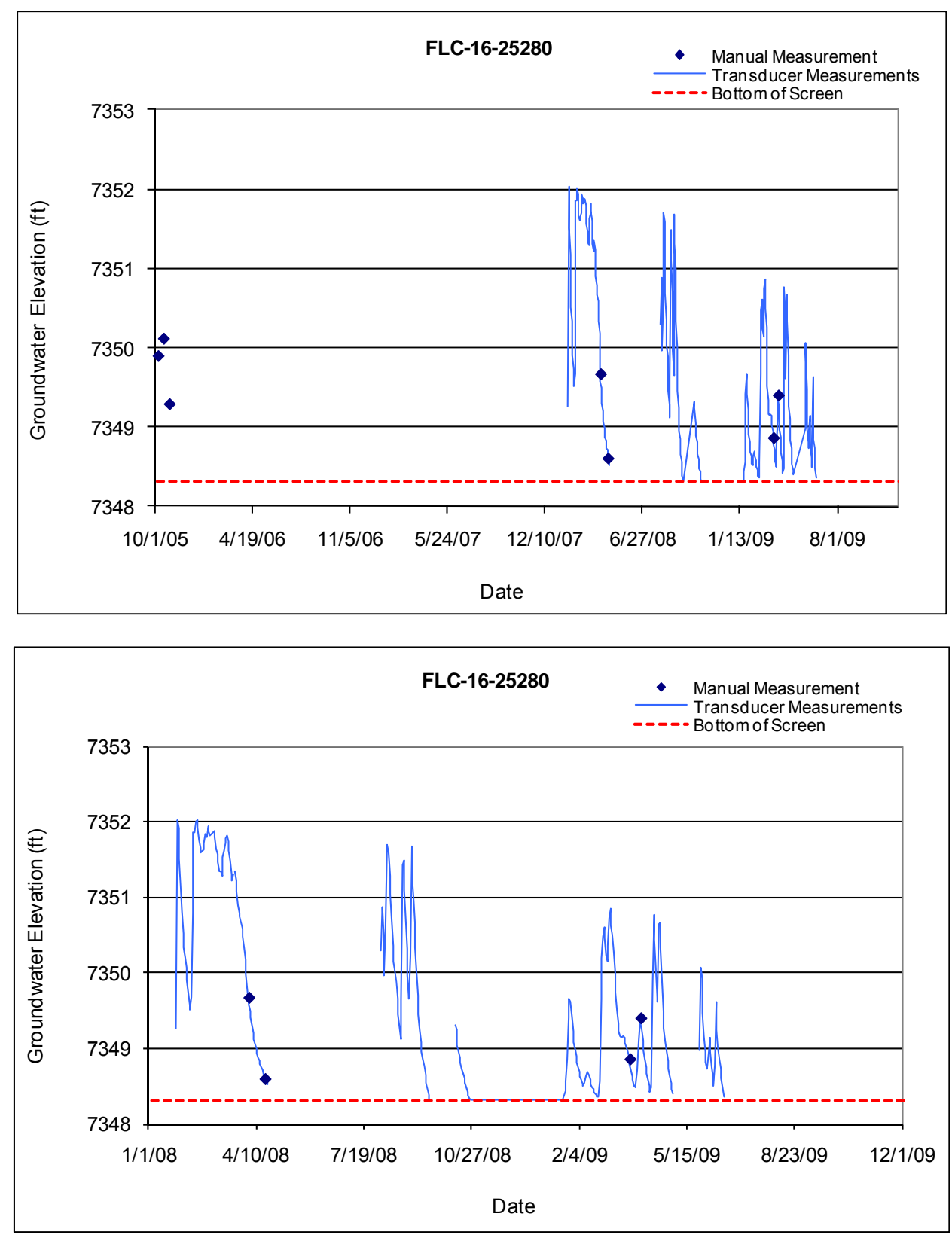


\subsection{LAO-B}

Location: Upper Los Alamos Canyon, approximately $3000 \mathrm{ft}$ west of the Diamond Drive bridge.

Period of Record: April 28, 1994, through January 12, 2010.

Remarks: None.

\begin{tabular}{|c|c|c|c|c|c|c|c|c|c|c|c|c|c|}
\hline \multicolumn{14}{|c|}{ LAO-B Construction Information } \\
\hline Zone & $\begin{array}{l}\text { Screen } \\
\text { Top } \\
\text { Depth (ft) }\end{array}$ & $\begin{array}{c}\text { Screen } \\
\text { Bottom } \\
\text { Depth } \\
\text { (ft) }\end{array}$ & $\begin{array}{c}\text { Screen } \\
\text { Top } \\
\text { Elev (ft) }\end{array}$ & $\begin{array}{l}\text { Screen } \\
\text { Bottom } \\
\text { Elev (ft) }\end{array}$ & $\begin{array}{c}\text { Screen } \\
\text { Length } \\
\text { (ft) }\end{array}$ & $\begin{array}{c}\text { Pump } \\
\text { Intake } \\
\text { Depth } \\
\text { (ft) }\end{array}$ & $\begin{array}{c}\text { Pump } \\
\text { Intake } \\
\text { Elevation } \\
\text { (ft) }\end{array}$ & $\begin{array}{c}\text { Depth to } \\
\text { Top of } \\
\text { Sump (ft) }\end{array}$ & $\begin{array}{c}\text { Top of } \\
\text { Sump } \\
\text { Elevation } \\
\text { (ft) }\end{array}$ & $\begin{array}{c}\text { Depth to } \\
\text { Sump } \\
\text { Bottom (ft) }\end{array}$ & $\begin{array}{c}\text { Sump } \\
\text { Length } \\
\text { (ft) }\end{array}$ & $\begin{array}{c}\text { Sump } \\
\text { Volume } \\
\text { (L) }\end{array}$ & Comment \\
\hline 1 & 11.8 & 26.8 & 7311.8 & 7296.8 & 15.0 & & & 26.8 & 7296.8 & 27.2 & 0.4 & 0.9 & Alluvial groundwater \\
\hline
\end{tabular}

Note: Ground elevation is $7323.59 \mathrm{ft}$; all depths are from this elevation
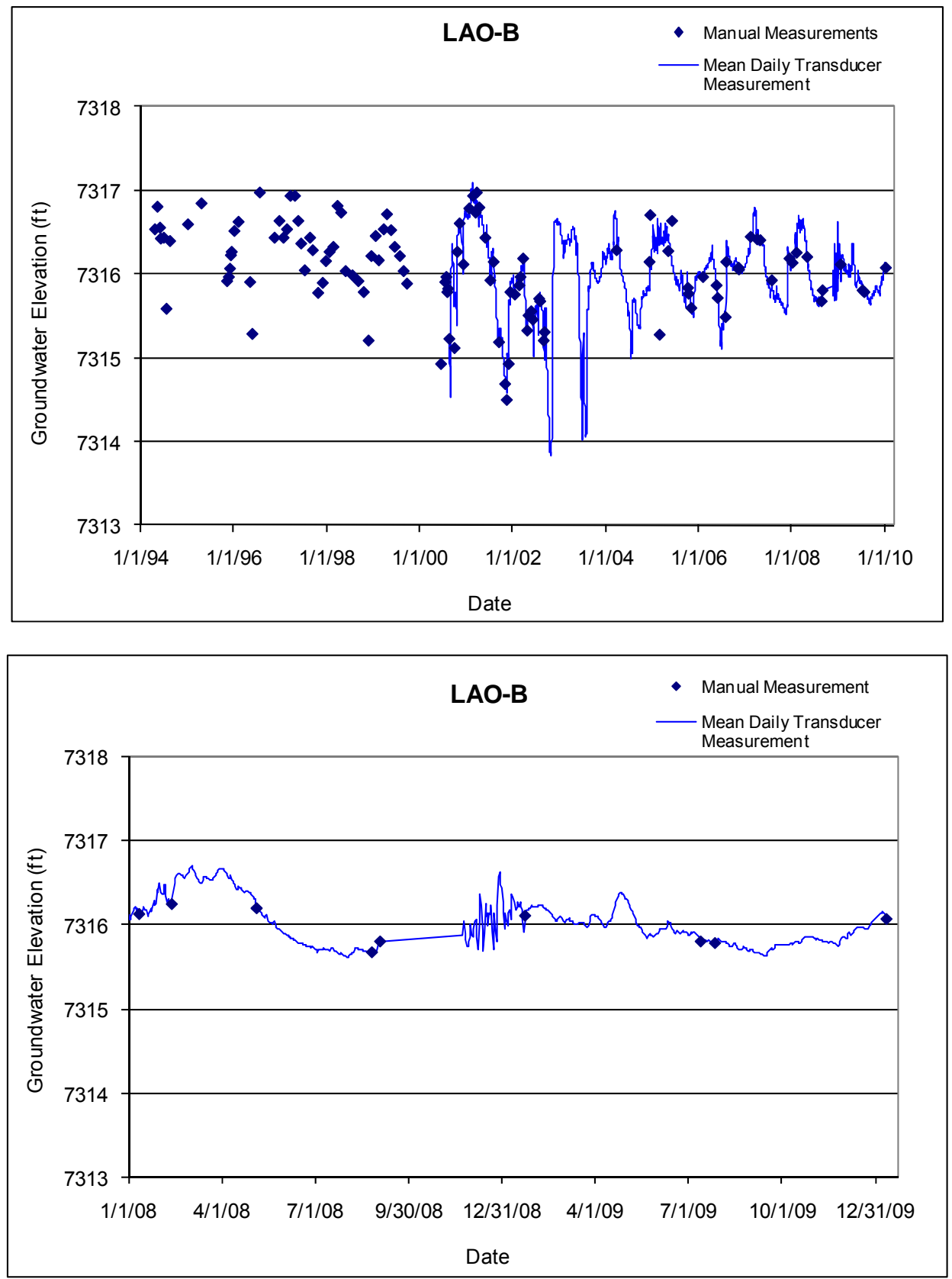


\subsection{LAO-0.3}

Location: Upper Los Alamos Canyon, approximately $5700 \mathrm{ft}$ east of the Diamond Drive bridge. Period of Record: June 1, 1994, through December 2, 2009.

Remarks: Transducer readings were not valid from July 7, 2005, through October 12, 2005; the pressure sensor was in the mud at the bottom of the well.

\begin{tabular}{|c|c|c|c|c|c|c|c|c|c|c|c|c|c|}
\hline \multicolumn{14}{|c|}{ LAO-0.3 Construction Information } \\
\hline Zone & $\begin{array}{l}\text { Screen } \\
\text { Top } \\
\text { Depth (ft) }\end{array}$ & $\begin{array}{c}\text { Screen } \\
\text { Bottom } \\
\text { Depth } \\
\text { (ft) }\end{array}$ & $\begin{array}{c}\text { Screen } \\
\text { Top } \\
\text { Elev (ft) }\end{array}$ & $\begin{array}{l}\text { Screen } \\
\text { Bottom } \\
\text { Elev (ft) }\end{array}$ & $\begin{array}{c}\text { Screen } \\
\text { Length } \\
\text { (ft) }\end{array}$ & $\begin{array}{c}\text { Pump } \\
\text { Intake } \\
\text { Depth } \\
\text { (ft) }\end{array}$ & $\begin{array}{c}\text { Pump } \\
\text { Intake } \\
\text { Elevation } \\
\text { (ft) }\end{array}$ & $\begin{array}{l}\text { Depth to } \\
\text { Top of } \\
\text { Sump (ft) }\end{array}$ & $\begin{array}{c}\text { Top of } \\
\text { Sump } \\
\text { Elevation } \\
\text { (ft) }\end{array}$ & $\begin{array}{l}\text { Depth to } \\
\text { Sump } \\
\text { Bottom (ft) }\end{array}$ & $\begin{array}{c}\text { Sump } \\
\text { Length } \\
\text { (ft) }\end{array}$ & $\begin{array}{c}\text { Sump } \\
\text { Volume } \\
\text { (L) }\end{array}$ & Comment \\
\hline 1 & 5.9 & 10.9 & 6962.23 & 6957.23 & 5.0 & & & 10.9 & 6957.23 & 11.25 & 0.35 & 0.86 & Alluvial groundwater \\
\hline
\end{tabular}

Note: LAO-0.3 Ground elevation is $6968.13 \mathrm{ft}$; all depths are from this elevation
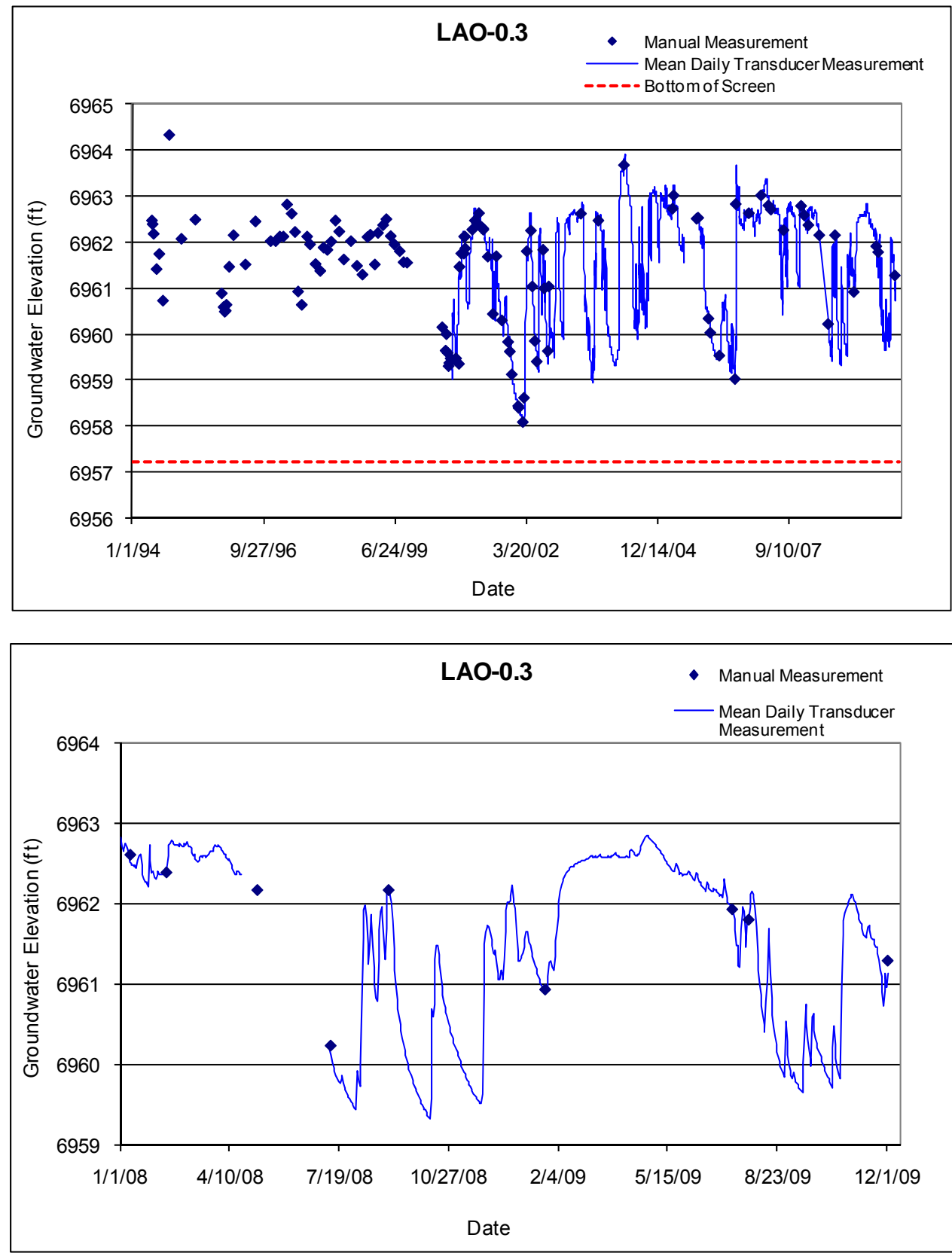


\subsection{LAO-0.6}

Location: Los Alamos Canyon, approximately $7500 \mathrm{ft}$ east of the Diamond Drive bridge.

Period of Record: May 6, 1994, through January 12, 2010.

Remarks: None.

\begin{tabular}{|c|c|c|c|c|c|c|c|c|c|c|c|c|c|}
\hline \multicolumn{14}{|c|}{ LAO-0.6 Construction Information } \\
\hline Zone & $\begin{array}{l}\text { Screen } \\
\text { Top } \\
\text { Depth (ft) }\end{array}$ & $\begin{array}{c}\text { Screen } \\
\text { Bottom } \\
\text { Depth } \\
\text { (ft) }\end{array}$ & $\begin{array}{c}\text { Screen } \\
\text { Top } \\
\text { Elev (ft) }\end{array}$ & $\begin{array}{l}\text { Screen } \\
\text { Bottom } \\
\text { Elev (ft) }\end{array}$ & $\begin{array}{c}\text { Screen } \\
\text { Length } \\
\text { (ft) }\end{array}$ & $\begin{array}{l}\text { Pump } \\
\text { Intake } \\
\text { Depth } \\
\text { (ft) }\end{array}$ & \begin{tabular}{|c|} 
Pump \\
Intake \\
Elevation \\
(ft)
\end{tabular} & $\begin{array}{l}\text { Depth to } \\
\text { Top of } \\
\text { Sump (ft) }\end{array}$ & $\begin{array}{c}\text { Top of } \\
\text { Sump } \\
\text { Elevation } \\
\text { (ft) }\end{array}$ & $\begin{array}{c}\text { Depth to } \\
\text { Sump } \\
\text { Bottom (ft) }\end{array}$ & $\begin{array}{l}\text { Sump } \\
\text { Length } \\
\text { (ft) }\end{array}$ & $\begin{array}{c}\text { Sump } \\
\text { Volume } \\
\text { (L) }\end{array}$ & Comment \\
\hline 1 & 8.0 & 13.0 & 6902.34 & 6897.34 & 5 & & & 13.0 & 6897.34 & 13.35 & 0.35 & 0.86 & Alluvial Groundwater \\
\hline
\end{tabular}

Note: Aluminum Cap Elevation: $6910.74 \mathrm{ft}$; Ground elevation is $6910.34 \mathrm{ft}$; all depths are from this elevation
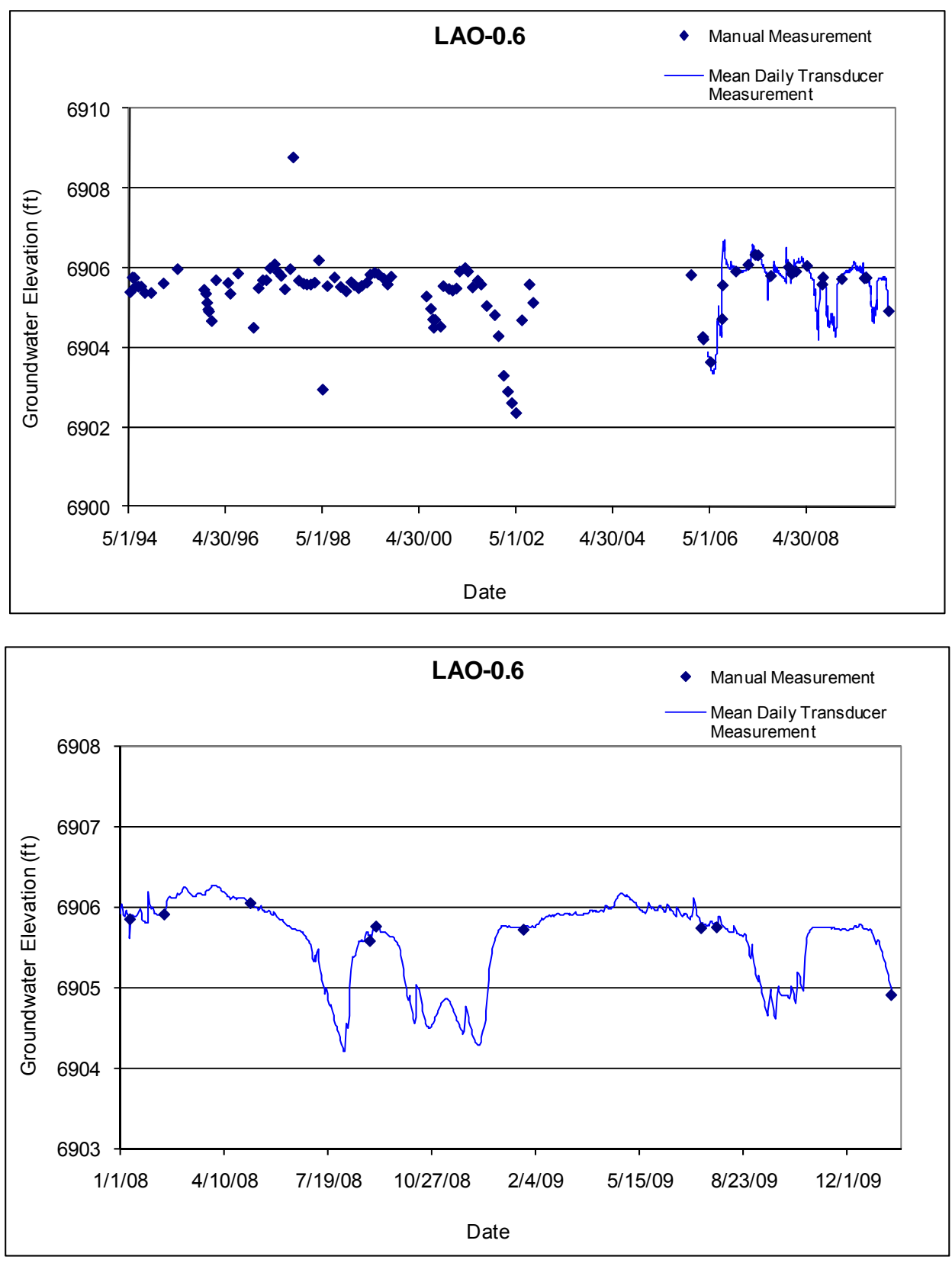


\subsection{LAO-0.91}

Location: Los Alamos Canyon approximately 10,200 ft east of the Diamond Drive bridge and approximately $100 \mathrm{ft}$ east of the eastern boundary of TA-2.

Period of Record: June 1, 1994, through February 21, 2007.

Remarks: Monitoring of this well was discontinued February 21, 2007.

\begin{tabular}{|c|c|c|c|c|c|c|c|c|c|c|c|c|c|}
\hline \multicolumn{14}{|c|}{ LAO-0.91 Construction Information } \\
\hline Zone & $\begin{array}{c}\text { Screen } \\
\text { Top } \\
\text { Depth (ft) }\end{array}$ & $\begin{array}{c}\text { Screen } \\
\text { Bottom } \\
\text { Depth } \\
\text { (ft) }\end{array}$ & $\begin{array}{c}\text { Screen } \\
\text { Top } \\
\text { Elev (ft) }\end{array}$ & $\begin{array}{l}\text { Screen } \\
\text { Bottom } \\
\text { Elev (ft) }\end{array}$ & $\begin{array}{c}\text { Screen } \\
\text { Length } \\
\text { (ft) }\end{array}$ & $\begin{array}{c}\text { Pump } \\
\text { Intake } \\
\text { Depth } \\
\text { (ft) }\end{array}$ & $\begin{array}{c}\text { Pump } \\
\text { Intake } \\
\text { Elevation } \\
\text { (ft) }\end{array}$ & $\begin{array}{c}\text { Depth to } \\
\text { Top of } \\
\text { Sump (ft) }\end{array}$ & \begin{tabular}{|c} 
Top of \\
Sump \\
Elevation \\
(ft)
\end{tabular} & $\begin{array}{c}\text { Depth to } \\
\text { Sump } \\
\text { Bottom (ft) }\end{array}$ & $\begin{array}{c}\text { Sump } \\
\text { Length } \\
\text { (ft) }\end{array}$ & $\begin{array}{c}\text { Sump } \\
\text { Volume } \\
\text { (L) }\end{array}$ & Comment \\
\hline 1 & 9.5 & 14.5 & 6851.66 & 6846.66 & 5.0 & $\overline{\mathrm{NA}}$ & $\overline{N A}$ & 14.5 & 6846.66 & 14.9 & 0.4 & 0.9 & Alluvial groundwater \\
\hline
\end{tabular}
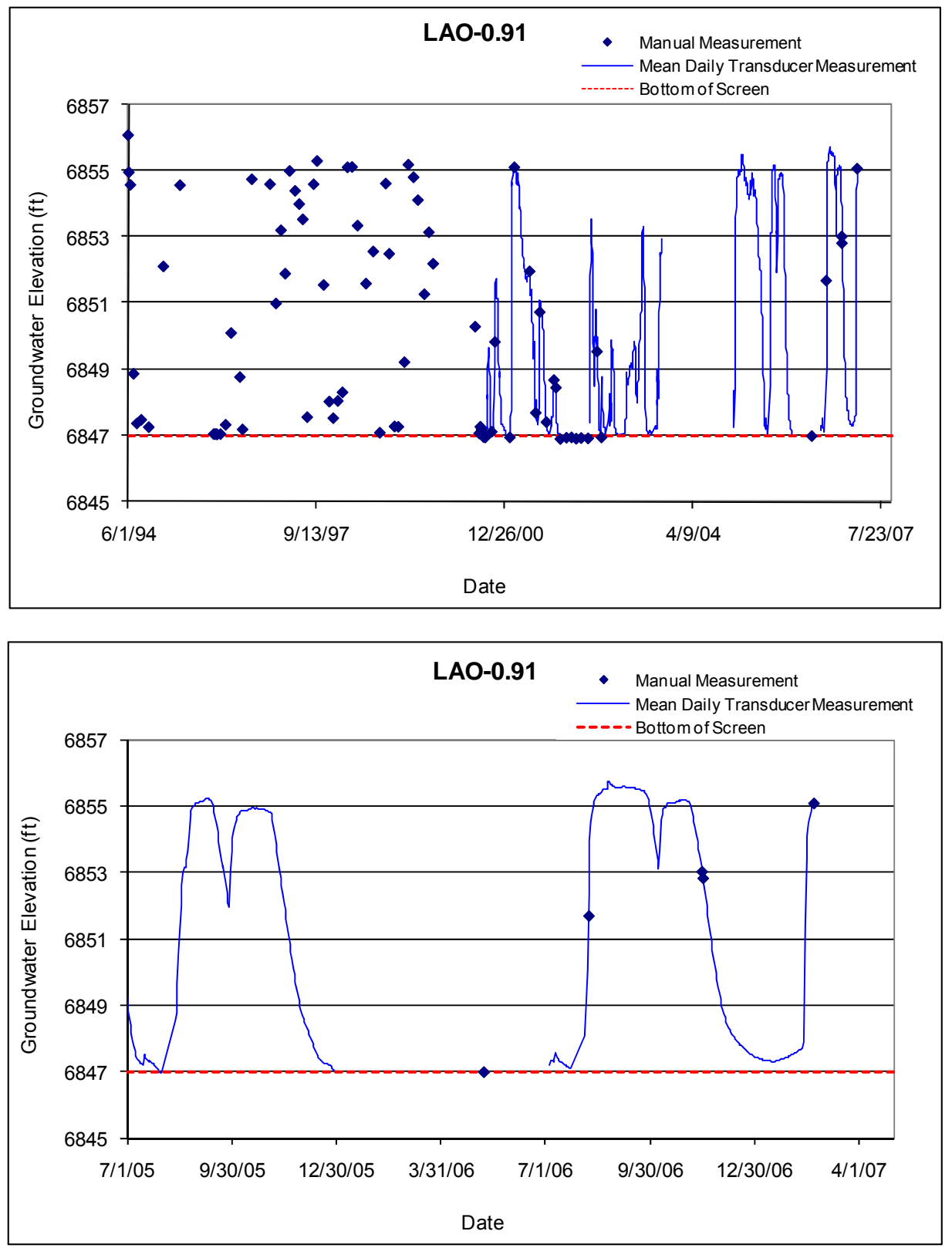


\subsection{LAO-1}

Location: Los Alamos Canyon, near the eastern border of TA-2.

Period of Record: February 15, 1966, through January 12, 2010.

Remarks: LAO-1 is a 2-in.-diameter well with a dedicated bladder pump. The transducer is sitting on top of the pump. Water levels were below the transducer in December 2008 and January 2009.

\begin{tabular}{|c|c|c|c|c|c|c|c|c|c|c|c|c|c|}
\hline \multicolumn{14}{|c|}{ LAO-1 Construction Information } \\
\hline Zone & $\begin{array}{c}\text { Screen } \\
\text { Top } \\
\text { Depth (ft) }\end{array}$ & $\begin{array}{c}\text { Screen } \\
\text { Bottom } \\
\text { Depth } \\
\text { (ft) }\end{array}$ & $\begin{array}{c}\text { Screen } \\
\text { Top } \\
\text { Elev (ft) }\end{array}$ & $\begin{array}{l}\text { Screen } \\
\text { Bottom } \\
\text { Elev (ft) }\end{array}$ & $\begin{array}{c}\text { Screen } \\
\text { Length } \\
\text { (ft) }\end{array}$ & $\begin{array}{l}\text { Pump } \\
\text { Intake } \\
\text { Depth } \\
\text { (ft) }\end{array}$ & $\begin{array}{c}\text { Pump } \\
\text { Intake } \\
\text { Elevation } \\
\text { (ft) }\end{array}$ & $\begin{array}{c}\text { Depth to } \\
\text { Top of } \\
\text { Sump (ft) }\end{array}$ & $\begin{array}{c}\text { Top of } \\
\text { Sump } \\
\text { Elevation } \\
\text { (ft) }\end{array}$ & $\begin{array}{l}\text { Depth to } \\
\text { Sump } \\
\text { Bottom (ft) }\end{array}$ & $\begin{array}{c}\text { Sump } \\
\text { Length } \\
\text { (ft) }\end{array}$ & $\begin{array}{c}\text { Sump } \\
\text { Volume } \\
\text { (L) }\end{array}$ & Comment \\
\hline 1 & 8 & 28 & 6828.24 & 6808.24 & 20 & & & 28 & 6808.24 & 28 & 0 & 0 & Alluvial groundwater \\
\hline
\end{tabular}

Note: Ground elevation is $6836.24 \mathrm{ft}$; all depths are from this elevation
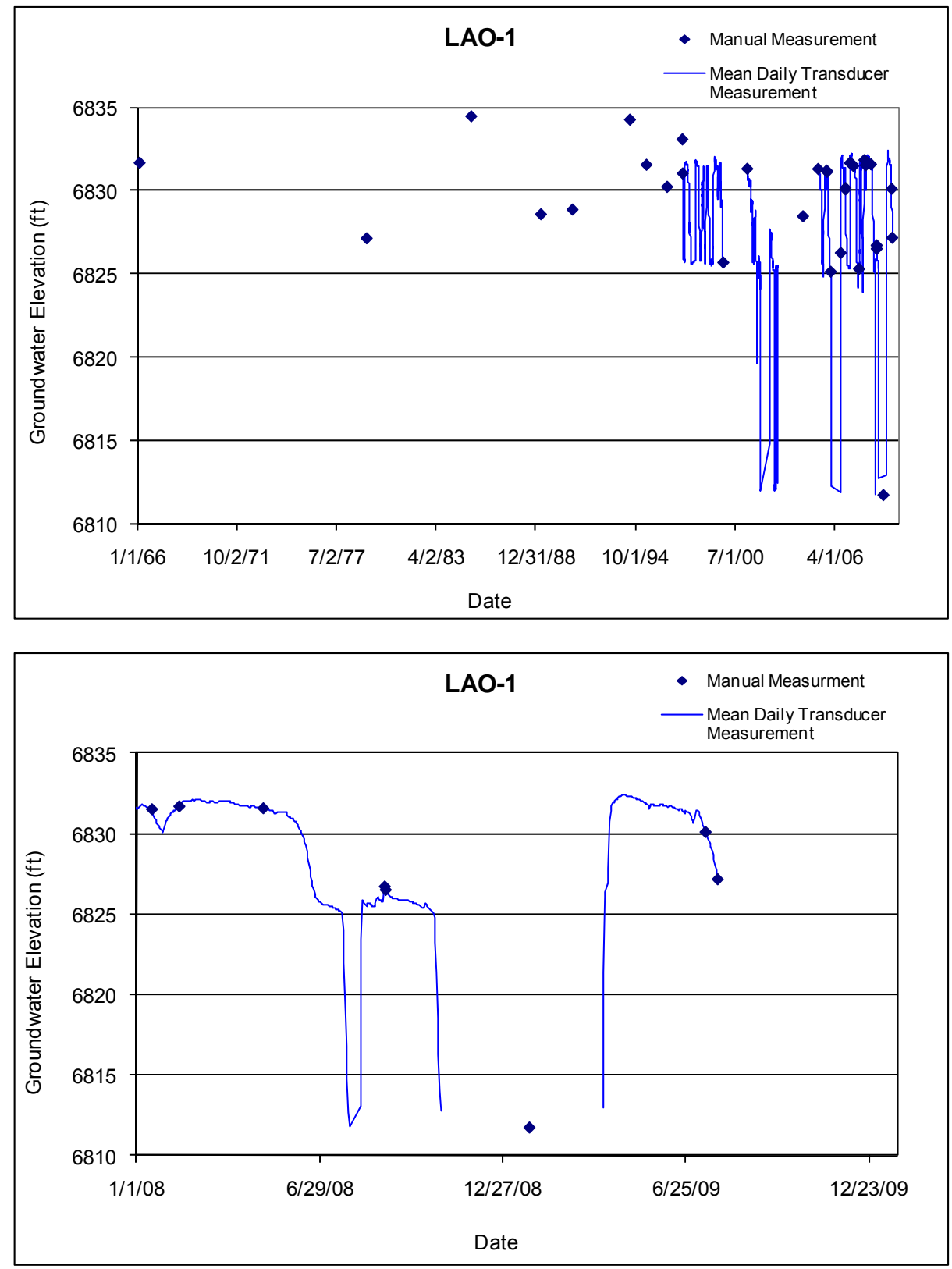


\subsection{LAO-1.6g}

Location: Los Alamos Canyon, approximately $400 \mathrm{ft}$ west of the confluence with DP Canyon. Period of Record: November 22, 1996, through January 12, 2010.

Remarks: None.

\begin{tabular}{|c|c|c|c|c|c|c|c|c|c|c|c|c|c|}
\hline \multicolumn{14}{|c|}{ LAO-1.6G Construction Information } \\
\hline Zone & $\begin{array}{c}\text { Screen } \\
\text { Top } \\
\text { Depth (ft) }\end{array}$ & $\begin{array}{c}\text { Screen } \\
\text { Bottom } \\
\text { Depth } \\
\text { (ft) }\end{array}$ & $\begin{array}{c}\text { Screen } \\
\text { Top } \\
\text { Elev (ft) }\end{array}$ & $\begin{array}{l}\text { Screen } \\
\text { Bottom } \\
\text { Elev (ft) }\end{array}$ & $\begin{array}{c}\text { Screen } \\
\text { Length } \\
\text { (ft) }\end{array}$ & $\begin{array}{c}\text { Pump } \\
\text { Intake } \\
\text { Depth } \\
\text { (ft) }\end{array}$ & $\begin{array}{c}\text { Pump } \\
\text { Intake } \\
\text { Elevation } \\
\text { (ft) }\end{array}$ & $\begin{array}{c}\text { Depth to } \\
\text { Top of } \\
\text { Sump (ft) }\end{array}$ & $\begin{array}{c}\text { Top of } \\
\text { Sump } \\
\text { Elevation } \\
\text { (ft) }\end{array}$ & \begin{tabular}{|l} 
Depth to \\
Sump \\
Bottom (ft)
\end{tabular} & $\begin{array}{c}\text { Sump } \\
\text { Length } \\
\text { (ft) }\end{array}$ & $\begin{array}{c}\text { Sump } \\
\text { Volume } \\
\text { (L) }\end{array}$ & Comment \\
\hline 1 & 10.5 & 25.5 & 6647.5 & 6632.5 & 15.0 & & 6658.0 & 25.5 & 6632.5 & 30.82 & 5.4 & 13.2 & Alluvial well \\
\hline
\end{tabular}

Note: Ground elevation is $6658.01 \mathrm{ft}$; all depths are from this elevation
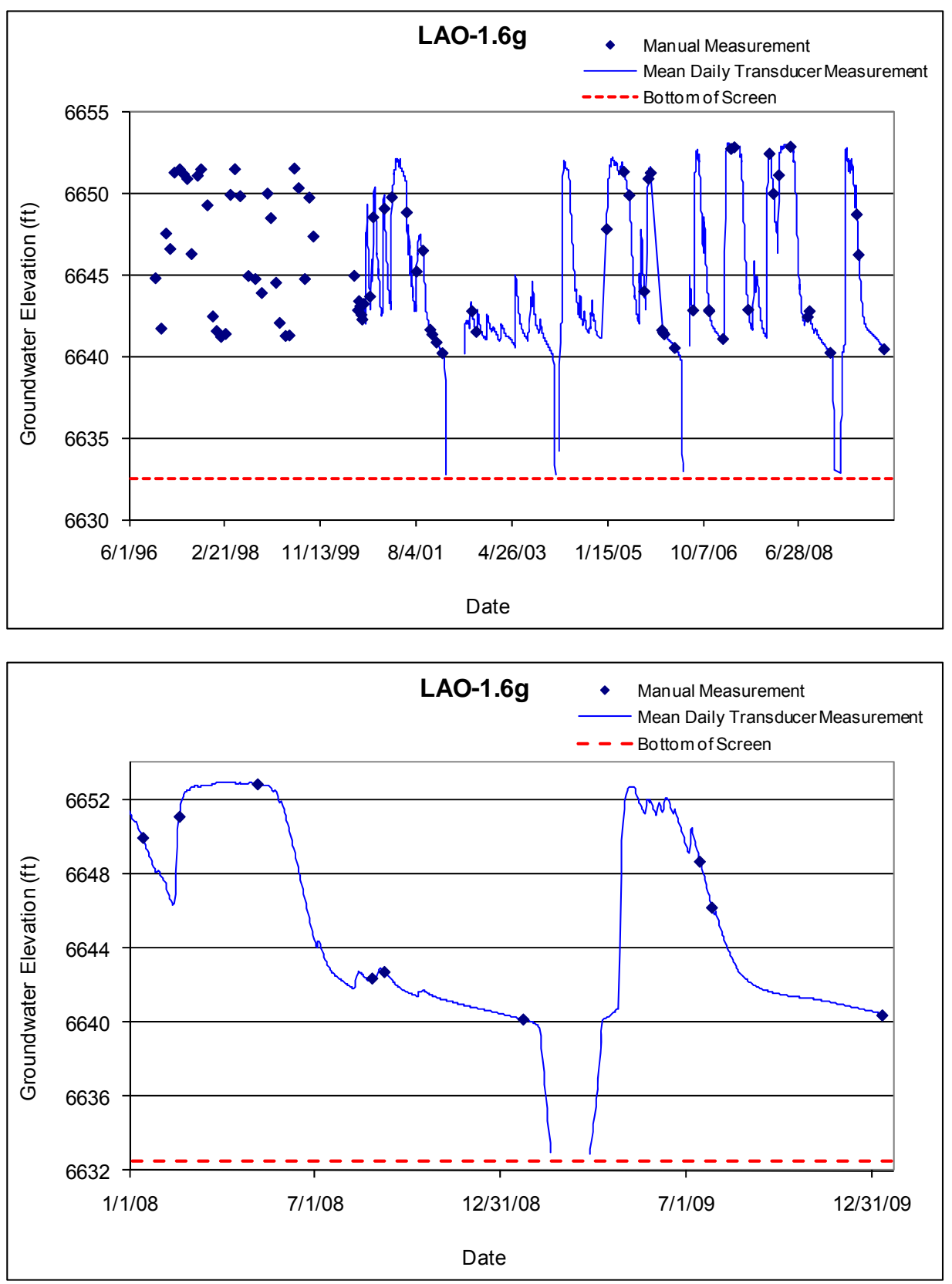


\subsection{LAO-1.8}

Location: Los Alamos Canyon, approximately $650 \mathrm{ft}$ west of LAO-1.6g.

Period of Record: January 8, 2001, through January 7, 2010.

Remarks: This well frequently runs dry. The total depth of the well has changed over the years as it silts in, and is currently around $6665.6 \mathrm{ft}$. Monitoring in this well ceased on January 7, 2010.

\begin{tabular}{|c|c|c|c|c|c|c|c|c|c|c|c|c|c|}
\hline \multicolumn{14}{|c|}{ LAO-1.8 Construction Information } \\
\hline Zone & $\begin{array}{c}\text { Screen } \\
\text { Top } \\
\text { Depth (ft) }\end{array}$ & $\begin{array}{c}\text { Screen } \\
\text { Bottom } \\
\text { Depth } \\
\text { (ft) }\end{array}$ & $\begin{array}{c}\text { Screen } \\
\text { Top } \\
\text { Elev (ft) }\end{array}$ & $\begin{array}{l}\text { Screen } \\
\text { Bottom } \\
\text { Elev (ft) }\end{array}$ & $\begin{array}{c}\text { Screen } \\
\text { Length } \\
\text { (ft) }\end{array}$ & $\begin{array}{c}\text { Pump } \\
\text { Intake } \\
\text { Depth } \\
\text { (ft) }\end{array}$ & $\begin{array}{c}\text { Pump } \\
\text { Intake } \\
\text { Elevation } \\
\text { (ft) }\end{array}$ & $\begin{array}{c}\text { Depth to } \\
\text { Top of } \\
\text { Sump (ft) }\end{array}$ & $\begin{array}{c}\text { Top of } \\
\text { Sump } \\
\text { Elevation } \\
\text { (ft) }\end{array}$ & $\begin{array}{l}\text { Depth to } \\
\text { Sump } \\
\text { Bottom (ft) }\end{array}$ & $\begin{array}{l}\text { Sump } \\
\text { Length } \\
\text { (ft) }\end{array}$ & $\begin{array}{c}\text { Sump } \\
\text { Volume } \\
\text { (L) }\end{array}$ & Comment \\
\hline 1 & 8 & 18 & 6672.00 & 6662.00 & 10 & & & 18 & 6662.00 & 18 & 0 & 0 & Alluvial Groundwater \\
\hline
\end{tabular}

Note: Brass Cap Elevation: $6680.00 \mathrm{ft}$; all depths are from this elevation
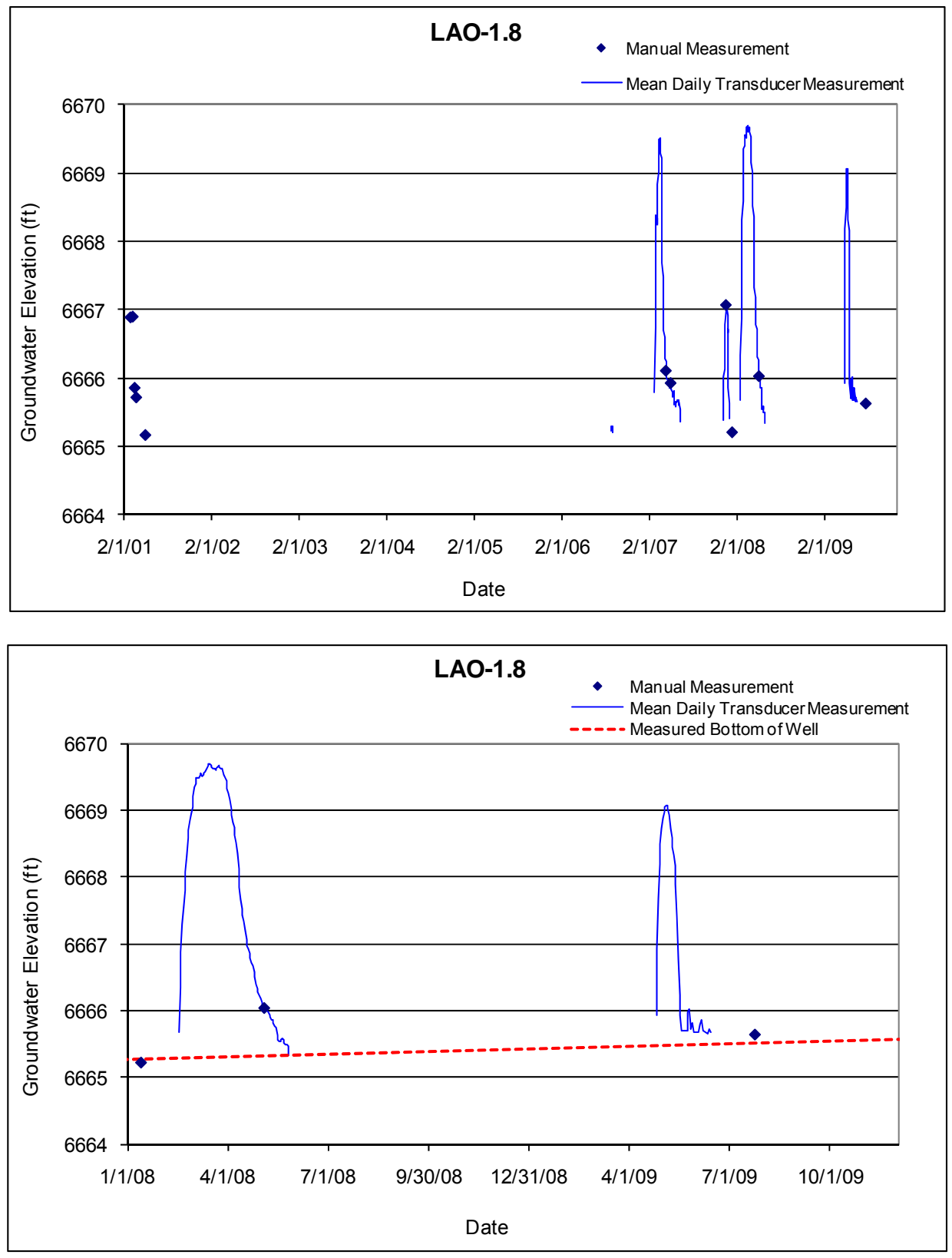


\subsection{LAO-2}

Location: Los Alamos Canyon, approximately $75 \mathrm{ft}$ north of the confluence with DP Canyon.

Period of Record: February 1, 1966, through January 12, 2010.

Remarks: The transducer in this well is installed above the top of the pump with the transducer sensor at $6563.88 \mathrm{ft}$. Water level elevations below $6563.88 \mathrm{ft}$ are not represented by transducer data.

\begin{tabular}{|c|c|c|c|c|c|c|c|c|c|c|c|c|c|}
\hline \multicolumn{14}{|c|}{ LAO-2 Construction Information } \\
\hline Zone & $\begin{array}{c}\text { Screen } \\
\text { Top } \\
\text { Depth (ft) }\end{array}$ & $\begin{array}{c}\text { Screen } \\
\text { Bottom } \\
\text { Depth } \\
\text { (ft) }\end{array}$ & $\begin{array}{c}\text { Screen } \\
\text { Top } \\
\text { Elev (ft) }\end{array}$ & $\begin{array}{l}\text { Screen } \\
\text { Bottom } \\
\text { Elev (ft) }\end{array}$ & $\begin{array}{c}\text { Screen } \\
\text { Length } \\
\text { (ft) }\end{array}$ & $\begin{array}{c}\text { Pump } \\
\text { Intake } \\
\text { Depth } \\
\text { (ft) }\end{array}$ & $\begin{array}{c}\text { Pump } \\
\text { Intake } \\
\text { Elevation } \\
\text { (ft) }\end{array}$ & $\begin{array}{c}\text { Depth to } \\
\text { Top of } \\
\text { Sump (ft) }\end{array}$ & $\begin{array}{c}\text { Top of } \\
\text { Sump } \\
\text { Elevation } \\
\text { (ft) }\end{array}$ & $\begin{array}{l}\text { Depth to } \\
\text { Sump } \\
\text { Bottom (ft) }\end{array}$ & $\begin{array}{l}\text { Sump } \\
\text { Length } \\
\text { (ft) }\end{array}$ & $\begin{array}{c}\text { Sump } \\
\text { Volume } \\
\text { (L) }\end{array}$ & Comment \\
\hline 1 & 12 & 32 & 6580.97 & 6560.97 & 20 & & & 32 & 6560.97 & 32 & 0 & 0 & Alluvial Groundwater \\
\hline
\end{tabular}
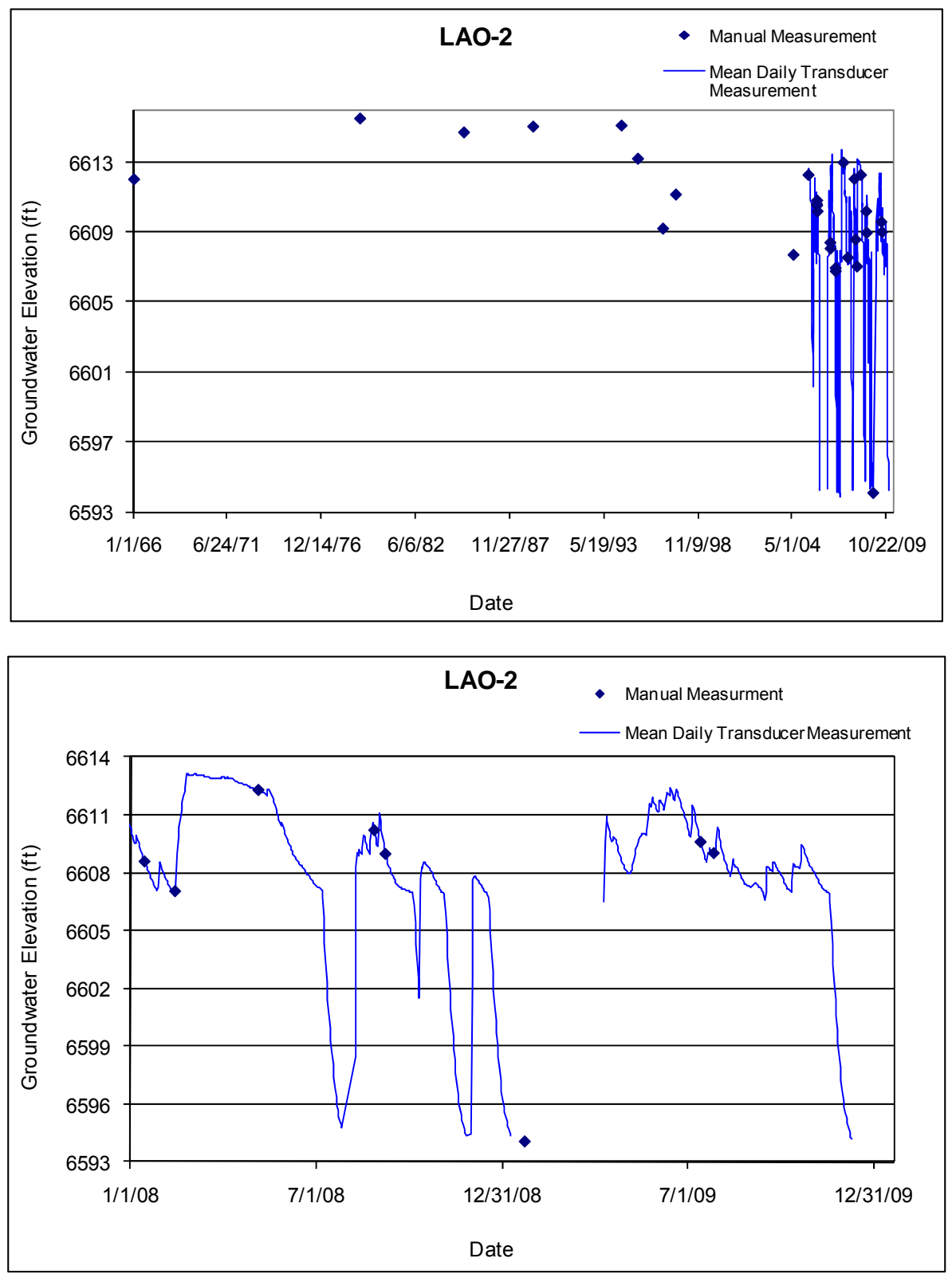


\subsection{LAO-3a}

Location: Los Alamos Canyon, approximately $1000 \mathrm{ft}$ east of the confluence with DP Canyon. Period of Record: September 15,1989, through January 12, 2010.

Remarks: None.

\begin{tabular}{|c|c|c|c|c|c|c|c|c|c|c|c|c|c|}
\hline \multicolumn{14}{|c|}{ LAO-3a Construction Information } \\
\hline Zone & $\begin{array}{c}\text { Screen } \\
\text { Top } \\
\text { Depth (ft) }\end{array}$ & $\begin{array}{c}\text { Screen } \\
\text { Bottom } \\
\text { Depth } \\
\text { (ft) }\end{array}$ & $\begin{array}{c}\text { Screen } \\
\text { Top } \\
\text { Elev (ft) }\end{array}$ & $\begin{array}{l}\text { Screen } \\
\text { Bottom } \\
\text { Elev (ft) }\end{array}$ & $\begin{array}{c}\text { Screen } \\
\text { Length } \\
\text { (ft) }\end{array}$ & $\begin{array}{c}\text { Pump } \\
\text { Intake } \\
\text { Depth } \\
\text { (ft) }\end{array}$ & $\begin{array}{c}\text { Pump } \\
\text { Intake } \\
\text { Elevation } \\
\text { (ft) }\end{array}$ & \begin{tabular}{|c|} 
Depth to \\
Top of \\
Sump (ft)
\end{tabular} & $\begin{array}{c}\text { Top of } \\
\text { Sump } \\
\text { Elevation } \\
\text { (ft) }\end{array}$ & \begin{tabular}{|} 
Depth to \\
Sump \\
Bottom (ft)
\end{tabular} & $\begin{array}{c}\text { Sump } \\
\text { Length } \\
\text { (ft) }\end{array}$ & $\begin{array}{c}\text { Sump } \\
\text { Volume } \\
\text { (L) }\end{array}$ & Comment \\
\hline 1 & 4.7 & 14.7 & 6574.7 & 6564.7 & 10.0 & & & 14.7 & 6564.7 & 15 & 0.3 & 0.2 & Alluvial groundwater \\
\hline
\end{tabular}
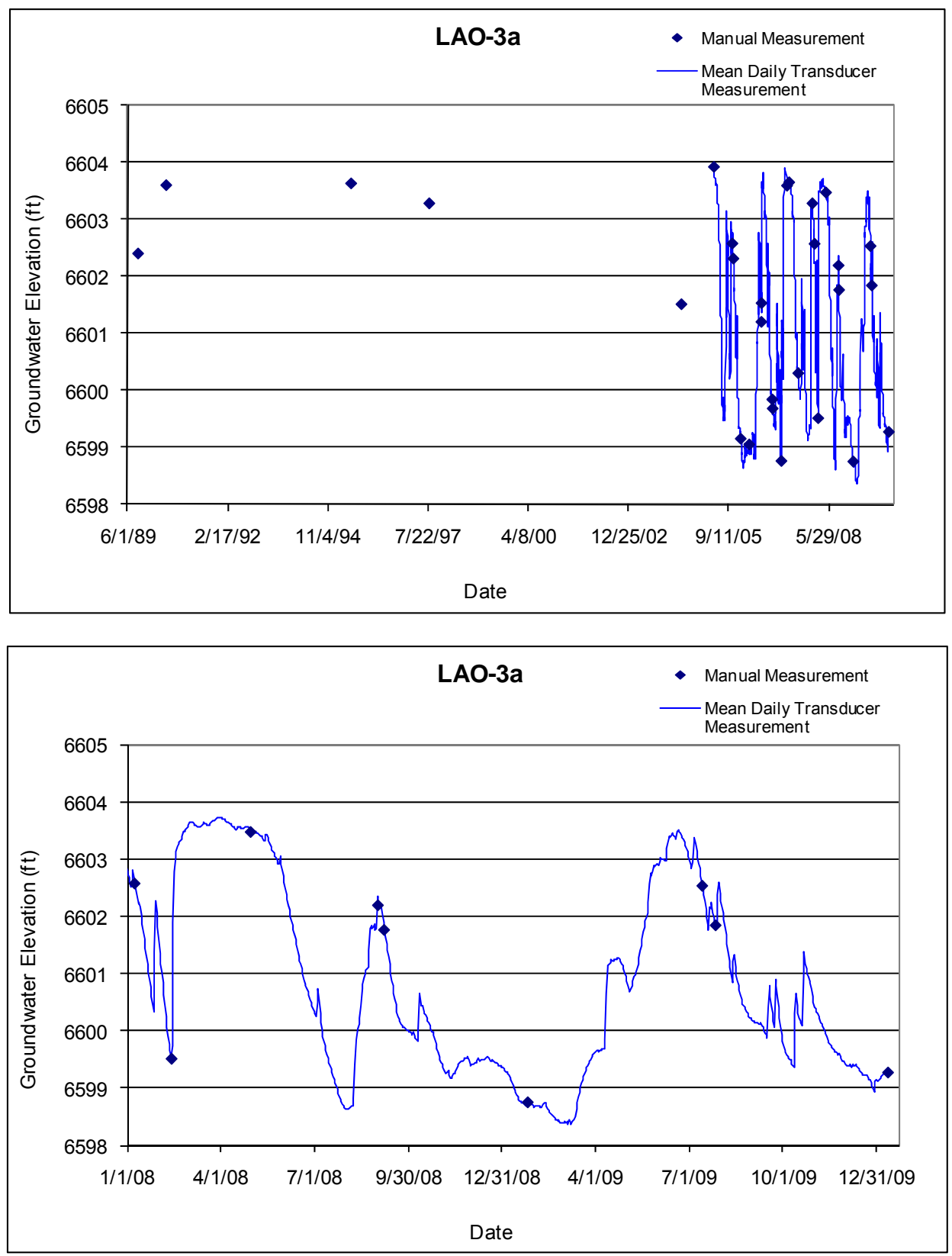


\subsection{LAO-4.5c}

Location: Los Alamos Canyon, approximately 1.25 miles east of the confluence with DP Canyon.

Period of Record: November 22, 1989, through January 12, 2010.

Remarks: The transducer is resting on top of the bladder pump; water levels below $6438.34 \mathrm{ft}$ are not recorded by the transducer. This well also tends to run dry.

\begin{tabular}{|c|c|c|c|c|c|c|c|c|c|c|c|c|c|}
\hline \multicolumn{14}{|c|}{ LAO-4.5c Construction Information } \\
\hline Zone & $\begin{array}{l}\text { Screen } \\
\text { Top } \\
\text { Depth (ft) }\end{array}$ & $\begin{array}{c}\text { Screen } \\
\text { Bottom } \\
\text { Depth } \\
\text { (ft) }\end{array}$ & $\begin{array}{c}\text { Screen } \\
\text { Top } \\
\text { Elev (ft) }\end{array}$ & $\begin{array}{l}\text { Screen } \\
\text { Bottom } \\
\text { Elev (ft) }\end{array}$ & $\begin{array}{c}\text { Screen } \\
\text { Length } \\
\text { (ft) }\end{array}$ & $\begin{array}{c}\text { Pump } \\
\text { Intake } \\
\text { Depth } \\
\text { (ft) }\end{array}$ & $\begin{array}{c}\text { Pump } \\
\text { Intake } \\
\text { Elevation } \\
\text { (ft) }\end{array}$ & \begin{tabular}{|} 
Depth to \\
Top of \\
Sump (ft)
\end{tabular} & $\begin{array}{c}\text { Top of } \\
\text { Sump } \\
\text { Elevation } \\
\text { (ft) }\end{array}$ & \begin{tabular}{|c|} 
Depth to \\
Sump \\
Bottom (ft)
\end{tabular} & $\begin{array}{l}\text { Sump } \\
\text { Length } \\
\text { (ft) }\end{array}$ & $\begin{array}{c}\text { Sump } \\
\text { Volume } \\
\text { (L) }\end{array}$ & Comment \\
\hline 1 & 13.3 & 23.3 & 6444.33 & 6434.33 & 10.0 & & & 23.3 & 6434.33 & 23.3 & 0.0 & 0.0 & Alluvial groundwater \\
\hline
\end{tabular}
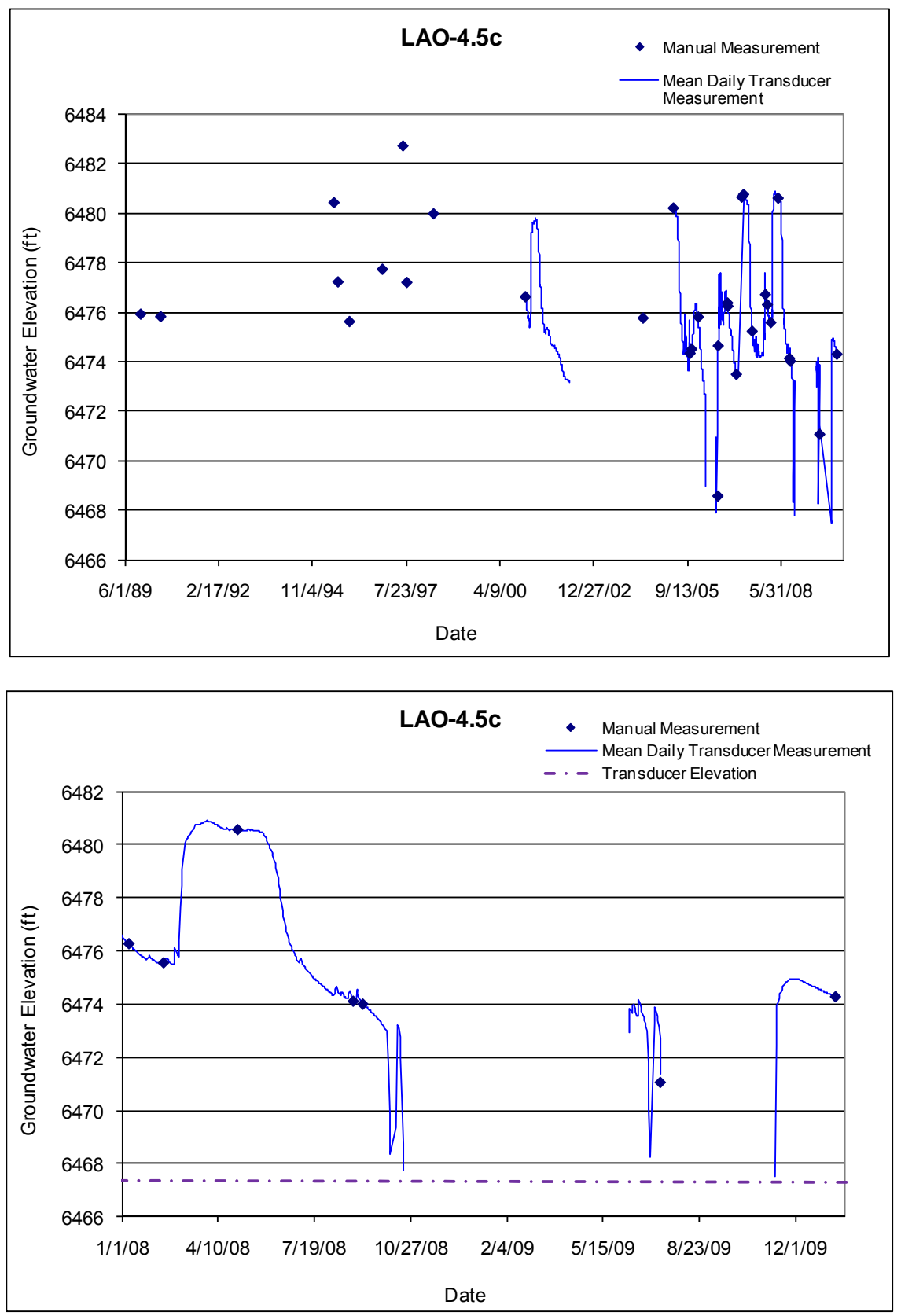


\subsection{LAO-5}

Location: Los Alamos Canyon, approximately 1 mile west of SR-4.

Period of Record: December 14, 2005, through January 7, 2010.

Remarks: LAO-5 was not installed with a pressure transducer and was measured manually on a quarterly schedule. Regular monitoring of the well was discontinued January 9, 2008, and manual water levels are currently only taken for sampling events.

\begin{tabular}{|c|c|c|c|c|c|c|c|c|c|c|c|c|c|}
\hline \multicolumn{14}{|c|}{ LAO-5 Construction Information } \\
\hline Zone & $\begin{array}{c}\text { Screen } \\
\text { Top } \\
\text { Depth (ft) }\end{array}$ & $\begin{array}{c}\text { Screen } \\
\text { Bottom } \\
\text { Depth } \\
\text { (ft) }\end{array}$ & $\begin{array}{c}\text { Screen } \\
\text { Top } \\
\text { Elev (ft) }\end{array}$ & $\begin{array}{l}\text { Screen } \\
\text { Bottom } \\
\text { Elev }(\mathrm{ft})\end{array}$ & $\begin{array}{l}\text { Screen } \\
\text { Length } \\
\text { (ft) }\end{array}$ & $\begin{array}{c}\text { Pump } \\
\text { Intake } \\
\text { Depth } \\
\text { (ft) }\end{array}$ & \begin{tabular}{|c|} 
Pump \\
Intake \\
Elevation \\
(ft)
\end{tabular} & $\begin{array}{l}\text { Depth to } \\
\text { Top of } \\
\text { Sump (ft) }\end{array}$ & $\begin{array}{c}\text { Top of } \\
\text { Sump } \\
\text { Elevation } \\
\text { (ft) }\end{array}$ & \begin{tabular}{|c|} 
Depth to \\
Sump \\
Bottom $(\mathrm{ft})$
\end{tabular} & $\begin{array}{c}\text { Sump } \\
\text { Length } \\
\text { (ft) }\end{array}$ & $\begin{array}{c}\text { Sump } \\
\text { Volume } \\
\text { (L) }\end{array}$ & Comment \\
\hline 1 & 5.0 & 25.0 & 6393.3 & 6373.3 & 20.0 & & & 25.0 & 6373.3 & 25.0 & 0.0 & 0.0 & Alluvial groundwater \\
\hline
\end{tabular}

Note: Ground elevation is $6398.3 \mathrm{ft}$; all depths are from this elevation

\begin{tabular}{|c|c|}
\hline \multicolumn{2}{|c|}{ LAO-5 Manual Water Levels } \\
\hline Date & $\begin{array}{c}\text { Manual Water } \\
\text { Level (ft) }\end{array}$ \\
\hline $12 / 14 / 05$ & Dry \\
\hline $3 / 14 / 06$ & 6409.12 \\
\hline $6 / 13 / 06$ & Dry \\
\hline $8 / 2 / 06$ & Dry \\
\hline $8 / 3 / 06$ & Dry \\
\hline $9 / 7 / 06$ & Dry \\
\hline $12 / 8 / 06$ & 6414.92 \\
\hline $3 / 13 / 07$ & Dry \\
\hline $6 / 7 / 07$ & 6417.22 \\
\hline $8 / 3 / 07$ & 6415.1 \\
\hline $9 / 5 / 07$ & 6409.23 \\
\hline $1 / 9 / 08$ & 6407.6 \\
\hline $8 / 25 / 08$ & 6408.08 \\
\hline $1 / 6 / 09$ & Dry \\
\hline $7 / 8 / 09$ & Dry \\
\hline $1 / 7 / 2010$ & Dry \\
\hline
\end{tabular}

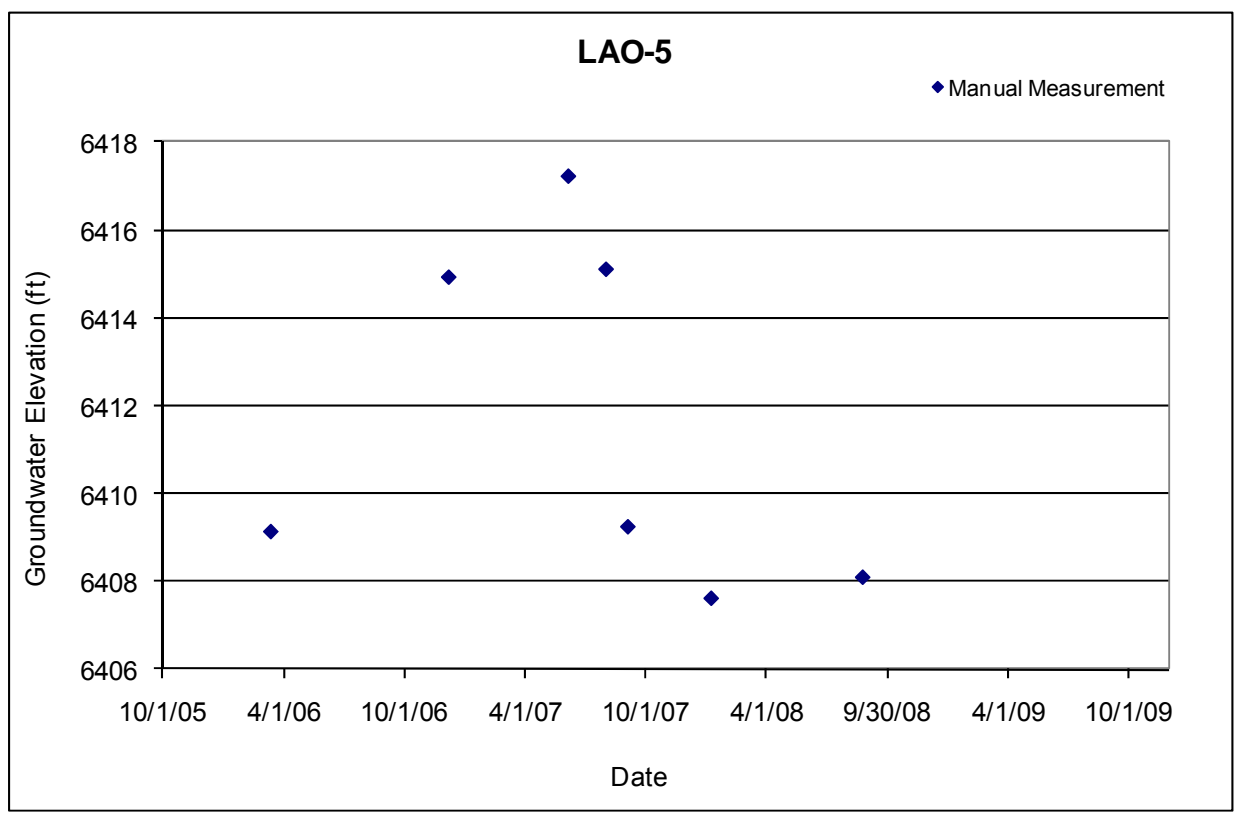




\subsection{LAO-6}

Location: Los Alamos Canyon, approximately 1 mile west of SR-4.

Period of Record: June 26, 1995, through January 28, 2009.

Remarks: Regular monitoring of this well was discontinued January 2, 2008, and manual water levels were obtained for sampling events only. All monitoring of this well was discontinued as of December 2009.

\begin{tabular}{|c|c|c|c|c|c|c|c|c|c|c|c|c|c|}
\hline \multicolumn{14}{|c|}{ LAO-6 Construction Information } \\
\hline Zone & $\begin{array}{l}\text { Screen } \\
\text { Top } \\
\text { Depth (ft) }\end{array}$ & $\begin{array}{c}\text { Screen } \\
\text { Bottom } \\
\text { Depth } \\
\text { (ft) }\end{array}$ & $\begin{array}{c}\text { Screen } \\
\text { Top } \\
\text { Elev (ft) }\end{array}$ & $\begin{array}{l}\text { Screen } \\
\text { Bottom } \\
\text { Elev (ft) }\end{array}$ & $\begin{array}{c}\text { Screen } \\
\text { Length } \\
\text { (ft) }\end{array}$ & $\begin{array}{c}\text { Pump } \\
\text { Intake } \\
\text { Depth } \\
\text { (ft) }\end{array}$ & $\begin{array}{c}\text { Pump } \\
\text { Intake } \\
\text { Elevation } \\
\text { (ft) }\end{array}$ & $\begin{array}{c}\text { Depth to } \\
\text { Top of } \\
\text { Sump (ft) }\end{array}$ & $\begin{array}{c}\text { Top of } \\
\text { Sump } \\
\text { Elevation } \\
\text { (ft) }\end{array}$ & \begin{tabular}{|c|} 
Depth to \\
Sump \\
Bottom (ft)
\end{tabular} & $\begin{array}{c}\text { Sump } \\
\text { Length } \\
\text { (ft) }\end{array}$ & $\begin{array}{c}\text { Sump } \\
\text { Volume } \\
\text { (L) }\end{array}$ & Comment \\
\hline 1 & 6.0 & 16.0 & 6389.3 & 6379.3 & 10.0 & & & 16.0 & 6379.3 & 16.0 & 0.0 & 0.0 & Alluvial groundwater \\
\hline
\end{tabular}

\begin{tabular}{|c|c|}
\hline Date & $\begin{array}{c}\text { Manual Water } \\
\text { Level (ft) }\end{array}$ \\
\hline $6 / 26 / 1995$ & 6385.6 \\
\hline $8 / 8 / 1995$ & 6385.1 \\
\hline $12 / 7 / 1995$ & 6383.5 \\
\hline $3 / 14 / 2006$ & Dry \\
\hline $4 / 19 / 2006$ & Dry \\
\hline $6 / 13 / 2006$ & Dry \\
\hline $7 / 27 / 2006$ & Dry \\
\hline $9 / 7 / 2006$ & Dry \\
\hline $12 / 8 / 2006$ & Dry \\
\hline $3 / 13 / 2007$ & Dry \\
\hline $6 / 7 / 2007$ & 6383.47 \\
\hline $9 / 5 / 2007$ & Dry \\
\hline $1 / 9 / 2008$ & Dry \\
\hline $1 / 7 / 2009$ & Dry \\
\hline
\end{tabular}




\subsection{LAO-6a}

Location: Los Alamos Canyon, approximately 1 mile west of SR-4.

Period of Record: August 17, 1989, through January 7, 2010.

Remarks: Well is seasonally dry.

\begin{tabular}{|c|c|c|c|c|c|c|c|c|c|c|c|c|c|}
\hline \multicolumn{14}{|c|}{ LAO-6a Construction Information } \\
\hline Zone & $\begin{array}{c}\text { Screen } \\
\text { Top } \\
\text { Depth (ft) }\end{array}$ & $\begin{array}{c}\text { Screen } \\
\text { Bottom } \\
\text { Depth } \\
\text { (ft) }\end{array}$ & $\begin{array}{c}\text { Screen } \\
\text { Top } \\
\text { Elev (ft) }\end{array}$ & $\begin{array}{l}\text { Screen } \\
\text { Bottom } \\
\text { Elev (ft) }\end{array}$ & $\begin{array}{c}\text { Screen } \\
\text { Length } \\
\text { (ft) }\end{array}$ & $\begin{array}{c}\text { Pump } \\
\text { Intake } \\
\text { Depth } \\
\text { (ft) }\end{array}$ & $\begin{array}{c}\text { Pump } \\
\text { Intake } \\
\text { Elevation } \\
\text { (ft) }\end{array}$ & $\begin{array}{l}\text { Depth to } \\
\text { Top of } \\
\text { Sump (ft) }\end{array}$ & $\begin{array}{c}\text { Top of } \\
\text { Sump } \\
\text { Elevation } \\
\text { (ft) }\end{array}$ & \begin{tabular}{|c|} 
Depth to \\
Sump \\
Bottom (ft)
\end{tabular} & $\begin{array}{c}\text { Sump } \\
\text { Length } \\
\text { (ft) }\end{array}$ & $\begin{array}{c}\text { Sump } \\
\text { Volume } \\
\text { (L) }\end{array}$ & Comment \\
\hline 1 & 4.2 & 14.2 & 6391.68 & 6381.68 & 10.0 & & & 14.2 & 6381.68 & 14.2 & 0.0 & 0.0 & Alluvial groundwater \\
\hline
\end{tabular}

Note: Ground elevation is $6395.88 \mathrm{ft}$; all depths are from this elevation
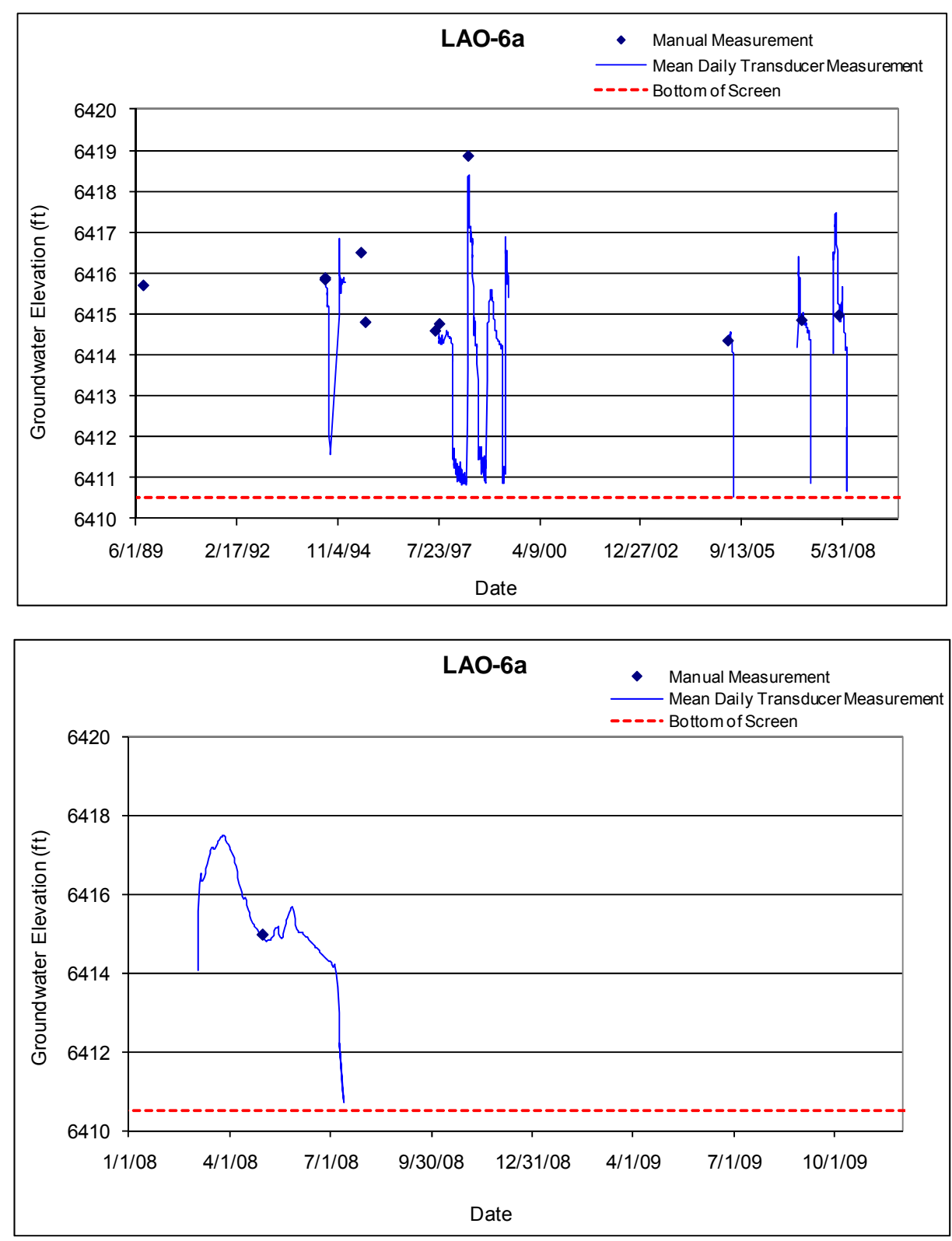


\subsection{LAUZ-1}

Location: DP Canyon, north of TA-21.

Period of Record: August 20, 1997, through January 11, 2010.

Remarks: None.

\begin{tabular}{|c|c|c|c|c|c|c|c|c|c|c|c|c|c|}
\hline \multicolumn{14}{|c|}{ LAUZ-1 Construction Information } \\
\hline Zone & $\begin{array}{c}\text { Screen } \\
\text { Top } \\
\text { Depth (ft) }\end{array}$ & $\begin{array}{c}\text { Screen } \\
\text { Bottom } \\
\text { Depth } \\
\text { (ft) }\end{array}$ & $\begin{array}{c}\text { Screen } \\
\text { Top } \\
\text { Elev (ft) }\end{array}$ & $\begin{array}{l}\text { Screen } \\
\text { Bottom } \\
\text { Elev (ft) }\end{array}$ & $\begin{array}{c}\text { Screen } \\
\text { Length } \\
\text { (ft) }\end{array}$ & $\begin{array}{c}\text { Pump } \\
\text { Intake } \\
\text { Depth } \\
\text { (ft) }\end{array}$ & $\begin{array}{c}\text { Pump } \\
\text { Intake } \\
\text { Elevation } \\
\text { (ft) }\end{array}$ & $\begin{array}{c}\text { Depth to } \\
\text { Top of } \\
\text { Sump (ft) }\end{array}$ & $\begin{array}{c}\text { Top of } \\
\text { Sump } \\
\text { Elevation } \\
\text { (ft) }\end{array}$ & \begin{tabular}{|c|} 
Depth to \\
Sump \\
Bottom (ft)
\end{tabular} & $\begin{array}{l}\text { Sump } \\
\text { Length } \\
\text { (ft) }\end{array}$ & $\begin{array}{c}\text { Sump } \\
\text { Volume } \\
\text { (L) }\end{array}$ & Comment \\
\hline 1 & 5.35 & 10.35 & 7027.07 & 7022.07 & 5.00 & & & 10.35 & 7022.07 & 10.55 & 0.20 & 0.49 & Alluvial groundwater \\
\hline
\end{tabular}

Note: Ground elevation is $7032.42 \mathrm{ft}$; all depths are from this elevation
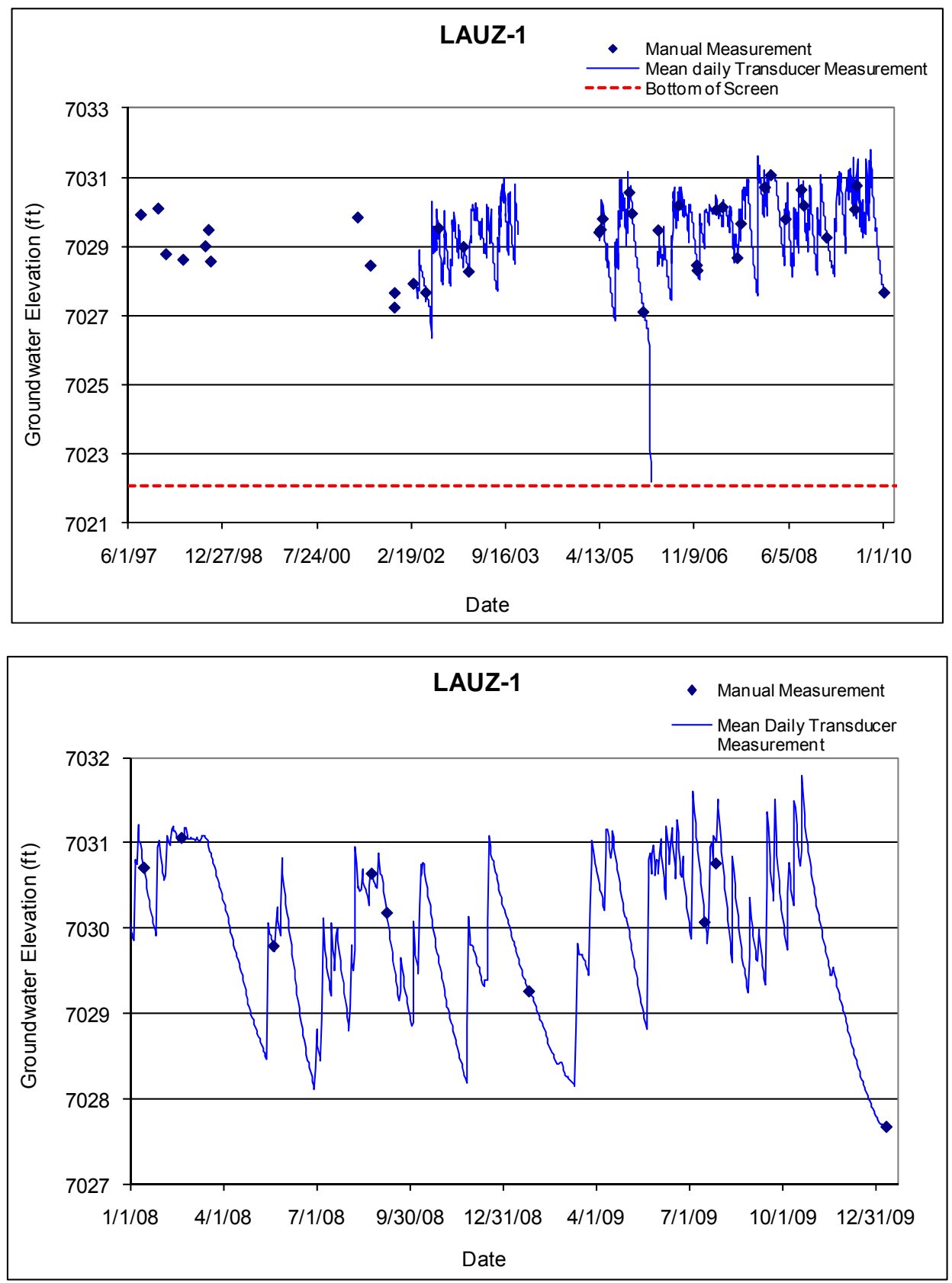


\subsection{LLAO-1b}

Location: Lower Los Alamos Canyon, approximately $3000 \mathrm{ft}$ southwest of Totavi on San Ildefonso Pueblo land.

Period of Record: August 27, 1997, through January 7, 2010.

Remarks: Well has mostly remained dry since June 1,2008 , with the exception of a brief rise in June 2009.

\begin{tabular}{|c|c|c|c|c|c|c|c|c|c|c|c|c|c|}
\hline \multicolumn{14}{|c|}{ LLAO-1b Construction Information } \\
\hline Zone & $\begin{array}{c}\text { Screen } \\
\text { Top } \\
\text { Depth (ft) }\end{array}$ & $\begin{array}{c}\text { Screen } \\
\text { Bottom } \\
\text { Depth } \\
\text { (ft) }\end{array}$ & $\begin{array}{c}\text { Screen } \\
\text { Top } \\
\text { Elev (ft) }\end{array}$ & $\begin{array}{l}\text { Screen } \\
\text { Bottom } \\
\text { Elev (ft) }\end{array}$ & $\begin{array}{c}\text { Screen } \\
\text { Length } \\
\text { (ft) }\end{array}$ & $\begin{array}{l}\text { Pump } \\
\text { Intake } \\
\text { Depth } \\
\text { (ft) }\end{array}$ & $\begin{array}{c}\text { Pump } \\
\text { Intake } \\
\text { Elevation } \\
\text { (ft) }\end{array}$ & $\begin{array}{c}\text { Depth to } \\
\text { Top of } \\
\text { Sump (ft) }\end{array}$ & $\begin{array}{c}\text { Top of } \\
\text { Sump } \\
\text { Elevation } \\
\text { (ft) }\end{array}$ & $\begin{array}{l}\text { Depth to } \\
\text { Sump } \\
\text { Bottom (ft) }\end{array}$ & $\begin{array}{c}\text { Sump } \\
\text { Length } \\
\text { (ft) }\end{array}$ & $\begin{array}{c}\text { Sump } \\
\text { Volume } \\
\text { (L) }\end{array}$ & Comment \\
\hline 1 & 11.32 & 21.32 & 5837.52 & 5827.52 & 10.00 & & & 21.32 & 5827.52 & 24.17 & 2.85 & 7.04 & Alluvial groundwater \\
\hline
\end{tabular}

Note: Ground elevation is $5850.34 \mathrm{ft}$; all measurements are from this elevation
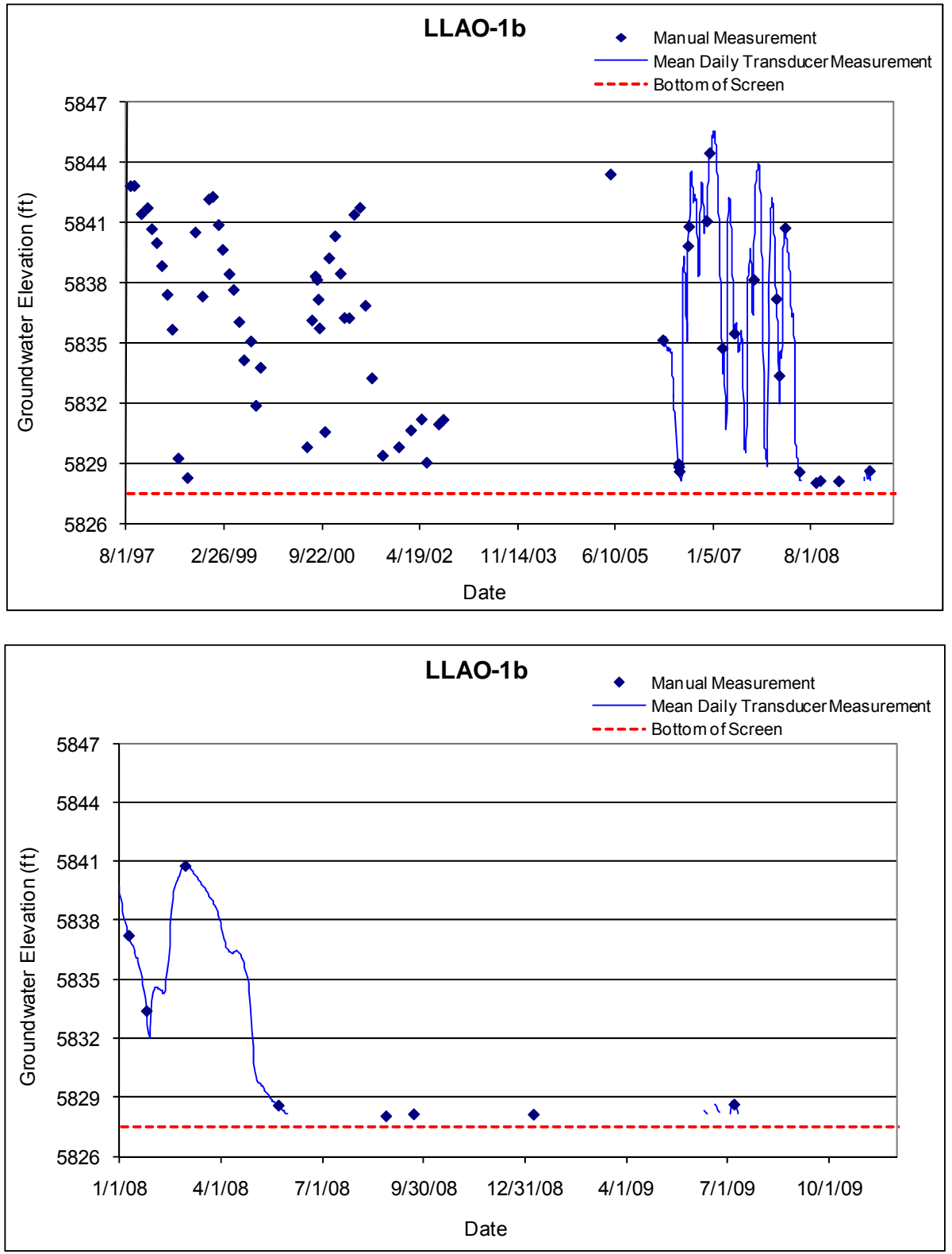


\subsection{LLAO-4}

Location: Lower Los Alamos Canyon, approximately $700 \mathrm{ft}$ northwest of the Rio Grande at SR-502 on San Ildefonso Pueblo land.

Period of Record: November 22, 1996, through January 7, 2010.

Remarks: None.

\begin{tabular}{|c|c|c|c|c|c|c|c|c|c|c|c|c|c|}
\hline \multicolumn{14}{|c|}{ LLAO-4 Construction Information } \\
\hline Zone & $\begin{array}{l}\text { Screen } \\
\text { Top } \\
\text { Depth (ft) }\end{array}$ & $\begin{array}{c}\text { Screen } \\
\text { Bottom } \\
\text { Depth } \\
\text { (ft) }\end{array}$ & $\begin{array}{c}\text { Screen } \\
\text { Top } \\
\text { Elev }(\mathrm{ft})\end{array}$ & $\begin{array}{l}\text { Screen } \\
\text { Bottom } \\
\text { Elev (ft) }\end{array}$ & $\begin{array}{c}\text { Screen } \\
\text { Length } \\
\text { (ft) }\end{array}$ & $\begin{array}{l}\text { Pump } \\
\text { Intake } \\
\text { Depth } \\
\text { (ft) }\end{array}$ & $\begin{array}{c}\text { Pump } \\
\text { Intake } \\
\text { Elevation } \\
\text { (ft) }\end{array}$ & $\begin{array}{l}\text { Depth to } \\
\text { Top of } \\
\text { Sump (ft) }\end{array}$ & $\begin{array}{c}\text { Top of } \\
\text { Sump } \\
\text { Elevation } \\
\text { (ft) }\end{array}$ & \begin{tabular}{|c} 
Depth to \\
Sump \\
Bottom (ft)
\end{tabular} & $\begin{array}{c}\text { Sump } \\
\text { Length } \\
\text { (ft) }\end{array}$ & $\begin{array}{c}\text { Sump } \\
\text { Volume } \\
\text { (L) }\end{array}$ & Comment \\
\hline 1 & 5.24 & 15.24 & 5509.97 & 5499.97 & 10.00 & & & 15.24 & 5499.97 & 18.09 & 2.85 & 7.04 & Alluvial groundwater \\
\hline
\end{tabular}

Note: Ground elevation is $5515.46 \mathrm{ft}$; all depths are from this elevation
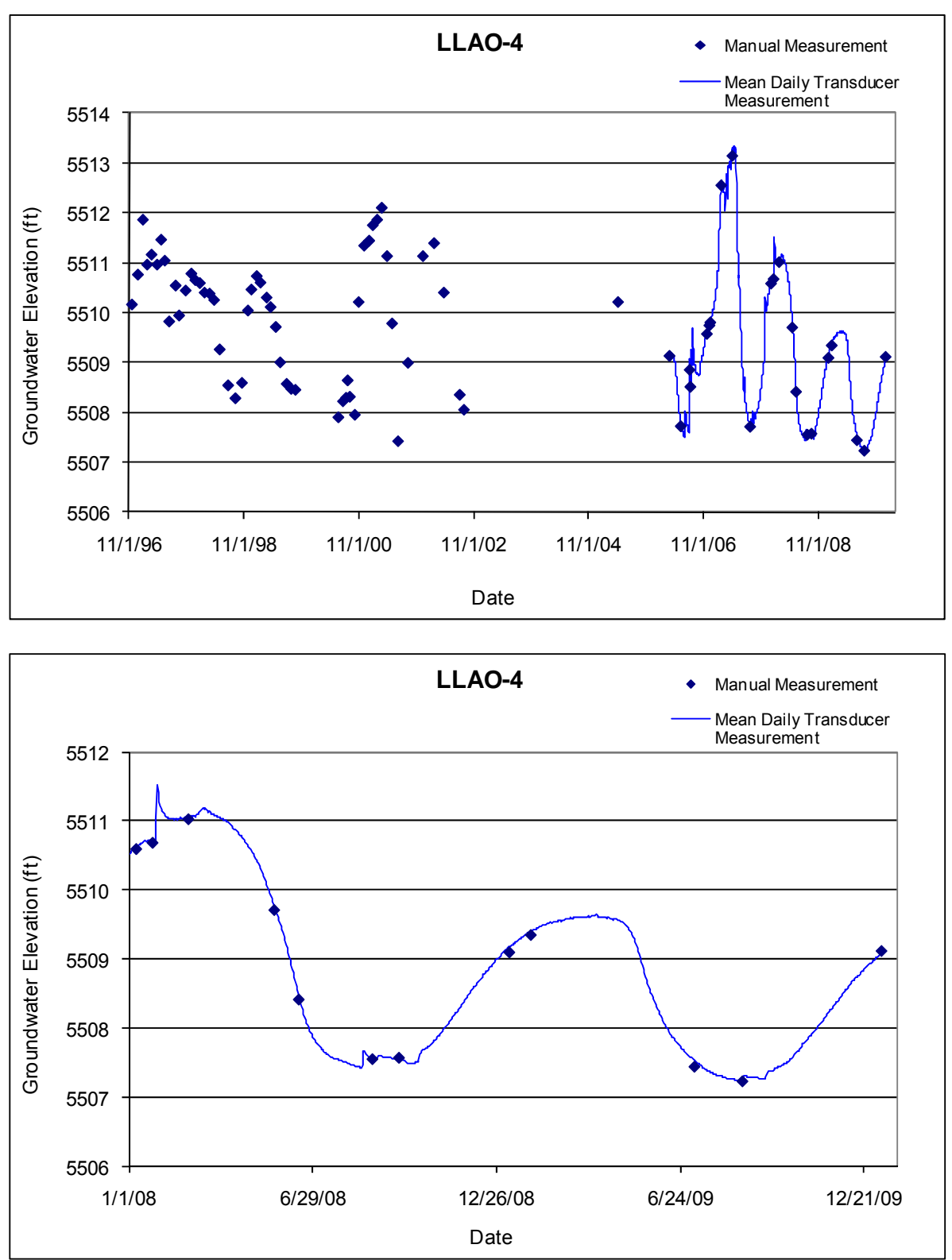


\subsection{MCA-1}

Location: Upper Mortandad Canyon, approximately $700 \mathrm{ft}$ northeast of the TA-50 outfall. Period of Record: April 20, 2005, through November 18, 2009.

Remarks: None.

\begin{tabular}{|c|c|c|c|c|c|c|c|c|c|c|c|c|c|}
\hline \multicolumn{14}{|c|}{ MCA-1 Construction Information } \\
\hline Zone & $\begin{array}{c}\text { Screen } \\
\text { Top } \\
\text { Depth (ft) }\end{array}$ & $\begin{array}{c}\text { Screen } \\
\text { Bottom } \\
\text { Depth } \\
\text { (ft) }\end{array}$ & $\begin{array}{c}\text { Screen } \\
\text { Top } \\
\text { Elev (ft) }\end{array}$ & $\begin{array}{l}\text { Screen } \\
\text { Bottom } \\
\text { Elev (ft) }\end{array}$ & $\begin{array}{c}\text { Screen } \\
\text { Length } \\
\text { (ft) }\end{array}$ & $\begin{array}{c}\text { Pump } \\
\text { Intake } \\
\text { Depth } \\
\text { (ft) }\end{array}$ & $\begin{array}{c}\text { Pump } \\
\text { Intake } \\
\text { Elevation } \\
\text { (ft) }\end{array}$ & $\begin{array}{c}\text { Depth to } \\
\text { Top of } \\
\text { Sump (ft) }\end{array}$ & $\begin{array}{c}\text { Top of } \\
\text { Sump } \\
\text { Elevation } \\
\text { (ft) }\end{array}$ & \begin{tabular}{|c} 
Depth to \\
Sump \\
Bottom (ft)
\end{tabular} & $\begin{array}{c}\text { Sump } \\
\text { Length } \\
\text { (ft) }\end{array}$ & $\begin{array}{c}\text { Sump } \\
\text { Volume } \\
\text { (L) }\end{array}$ & Comment \\
\hline 1 & 2.4 & 5.4 & 7068.2 & 7065.2 & 3.0 & & & 5.4 & 7065.2 & 5.9 & 0.5 & 0.1 & Alluvial groundwater \\
\hline
\end{tabular}
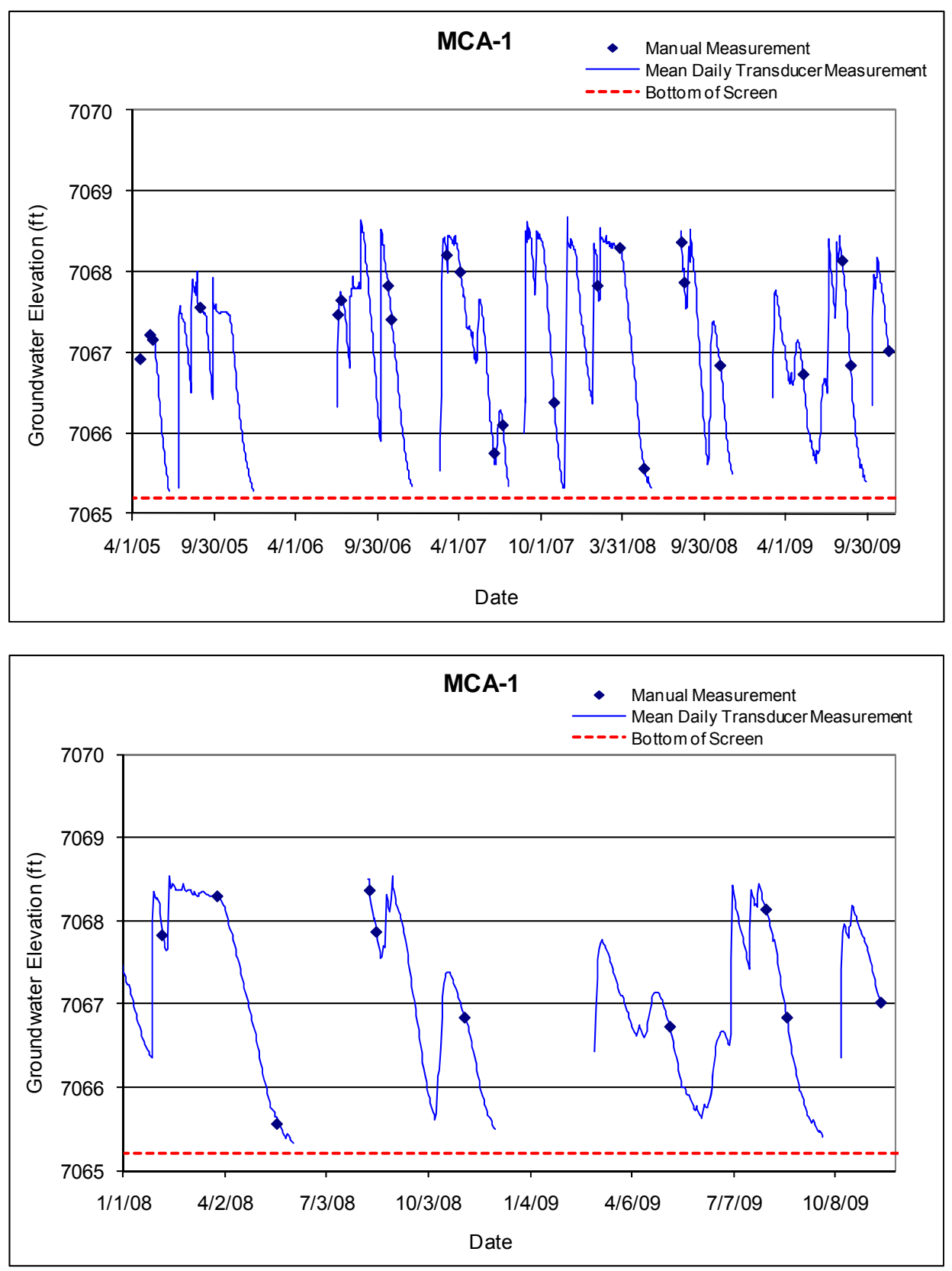


\subsection{MCA-2}

Location: Mortandad Canyon, approximately $400 \mathrm{ft}$ up canyon of the upper sediment trap.

Period of Record: May 18, 2005, through November 28, 2007.

Remarks: Monitoring of this well was discontinued November 28, 2007.

\begin{tabular}{|c|c|c|c|c|c|c|c|c|c|c|c|c|c|}
\hline \multicolumn{14}{|c|}{ MCA-2 Construction Information } \\
\hline Zone & $\begin{array}{c}\text { Screen } \\
\text { Top } \\
\text { Depth (ft) }\end{array}$ & $\begin{array}{c}\text { Screen } \\
\text { Bottom } \\
\text { Depth } \\
\text { (ft) }\end{array}$ & $\begin{array}{c}\text { Screen } \\
\text { Top } \\
\text { Elev (ft) }\end{array}$ & $\begin{array}{l}\text { Screen } \\
\text { Bottom } \\
\text { Elev (ft) }\end{array}$ & $\begin{array}{c}\text { Screen } \\
\text { Length } \\
\text { (ft) }\end{array}$ & $\begin{array}{c}\text { Pump } \\
\text { Intake } \\
\text { Depth } \\
\text { (ft) }\end{array}$ & $\begin{array}{c}\text { Pump } \\
\text { Intake } \\
\text { Elevation } \\
\text { (ft) }\end{array}$ & $\begin{array}{c}\text { Depth to } \\
\text { Top of } \\
\text { Sump (ft) }\end{array}$ & $\begin{array}{c}\text { Top of } \\
\text { Sump } \\
\text { Elevation } \\
\text { (ft) }\end{array}$ & $\begin{array}{l}\text { Depth to } \\
\text { Sump } \\
\text { Bottom (ft) }\end{array}$ & $\begin{array}{c}\text { Sump } \\
\text { Length } \\
\text { (ft) }\end{array}$ & $\begin{array}{c}\text { Sump } \\
\text { Volume } \\
\text { (L) }\end{array}$ & Comment \\
\hline 1 & 45.0 & 60.0 & 6792.2 & 6777.2 & 15.0 & & & 60.0 & 6777.2 & 65.0 & 5.0 & 3.1 & Alluvial groundwater \\
\hline
\end{tabular}

Note: Ground Elevation: $6837.2 \mathrm{ft}$; all depths are from this elevation
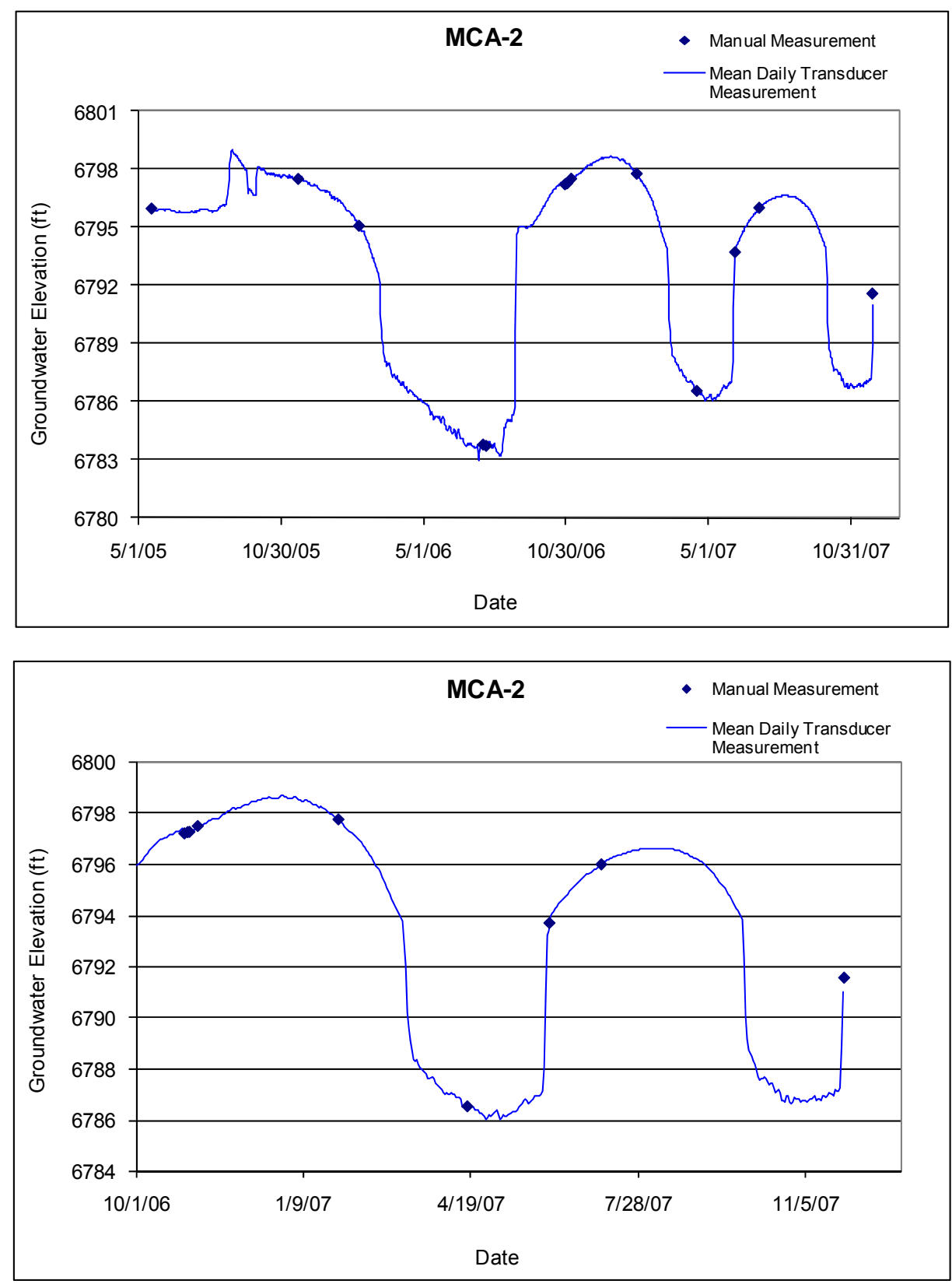


\subsection{MCA-3ac \& MCA-3b}

Location: Middle Mortandad Canyon

Period of Record: MCA-3ac: November 30, 2004, through November 28, 2007.

MCA-3b: November 22, 2004, through November 28, 2007.

Remarks: MCA-3ac was a nested piezometer located about $5 \mathrm{ft}$ south of MCA-3b. Valid manual measurements were not possible to obtain in these wells due to the 1 -in. casing and presence of transducers, until 2006 when a small-diameter water level tape was purchased. Monitoring of both wells was discontinued November 28, 2007.

\begin{tabular}{|c|c|c|c|c|c|c|c|c|c|c|c|c|c|c|}
\hline \multicolumn{15}{|c|}{ MCA-3abc Construction Information } \\
\hline Zone & \begin{tabular}{|c|}
$\begin{array}{c}\text { Screen } \\
\text { Top } \\
\text { Depth } \\
\text { (ft) }\end{array}$ \\
\end{tabular} & \begin{tabular}{|c|c|}
$\begin{array}{c}\text { Screen } \\
\text { Bottom } \\
\text { Depth } \\
\text { (ft) }\end{array}$ \\
\end{tabular} & $\begin{array}{c}\text { Screen } \\
\text { Top } \\
\text { Elev (ft) }\end{array}$ & $\begin{array}{l}\text { Screen } \\
\text { Bottom } \\
\text { Elev (ft) }\end{array}$ & $\begin{array}{c}\text { Screen } \\
\text { Length } \\
\text { (ft) }\end{array}$ & $\begin{array}{c}\text { Pump } \\
\text { Intake } \\
\text { Depth } \\
\text { (ft) }\end{array}$ & \begin{tabular}{|c|} 
Pump \\
Intake \\
Elevation \\
(ft)
\end{tabular} & $\begin{array}{c}\text { Depth to } \\
\text { Top of } \\
\text { Sump (ft) }\end{array}$ & \begin{tabular}{|c|} 
Top of \\
Sump \\
Elevation \\
(ft)
\end{tabular} & \begin{tabular}{|c|} 
Depth to \\
Sump \\
Bottom (ft)
\end{tabular} & $\begin{array}{c}\text { Well T.D. } \\
\text { Elevation } \\
\text { (ft) }\end{array}$ & $\begin{array}{c}\text { Sump } \\
\text { Length } \\
\text { (ft) }\end{array}$ & $\begin{array}{c}\text { Sump } \\
\text { Volume } \\
\text { (L) }\end{array}$ & Comment \\
\hline MCA-3a & 42.9 & 43.4 & 6809.7 & 6809.2 & 0.5 & & & 43.4 & 6809.2 & 44.0 & 6808.6 & 0.6 & 0.23723 & Alluvial groundwater \\
\hline MCA-3b & 40.9 & 41.4 & 6811.7 & 6811.2 & 0.5 & & & 41.4 & 6811.2 & 42.1 & 6810.5 & 0.7 & 0.27677 & Alluvial groundwater \\
\hline MCA-3c & 38.4 & 38.9 & 6814.2 & 6813.7 & 0.5 & & & 38.9 & 6813.7 & 39.5 & 6813.1 & 0.6 & 0.23723 & Alluvial groundwater \\
\hline
\end{tabular}
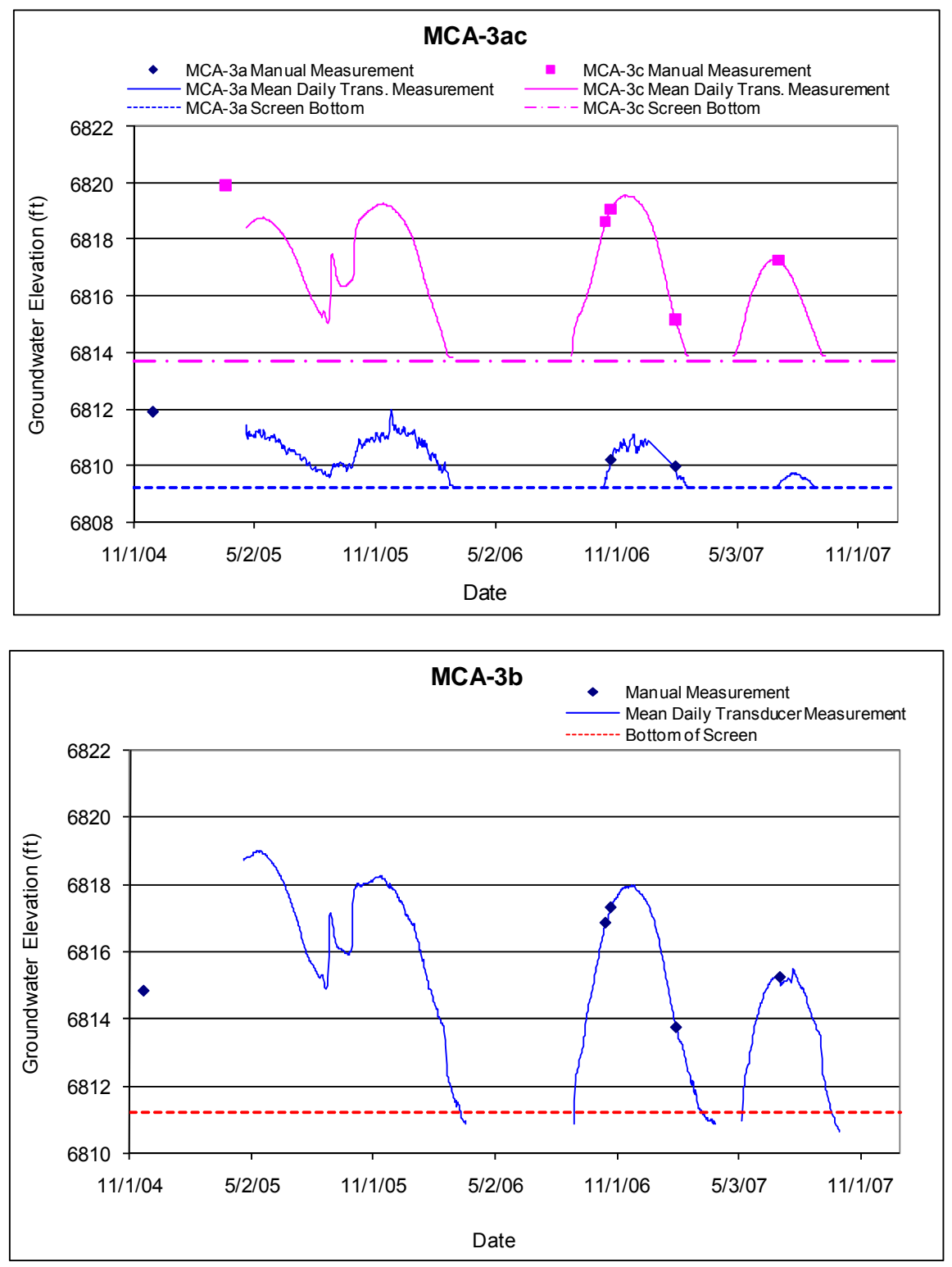


\subsection{MCA-3def}

Location: Middle Mortandad Canyon, south of the sediment traps.

Period of Record: MCA-3d: March 25, 2005, through November 28, 2007,

MCA-3e: March 30, 2005, through November 28, 2007,

MCA-3f: April 5, 2005, through November 28, 2007.

Remarks: MCA-3def is a nested piezometer. Faulty transducers in MCA-3e and MCA-3f were replaced on October 16, 2006. Monitoring of this well was discontinued November 28, 2007.

\begin{tabular}{|c|c|c|c|c|c|c|c|c|c|c|c|c|c|c|}
\hline \multicolumn{15}{|c|}{ MCA-3def Construction Information } \\
\hline Zone & \begin{tabular}{|c|} 
Screen \\
Top \\
Depth \\
(ft)
\end{tabular} & \begin{tabular}{|c|} 
Screen \\
Bottom \\
Depth \\
(ft)
\end{tabular} & $\begin{array}{l}\text { Screen } \\
\text { Top } \\
\text { Elev (ft) }\end{array}$ & $\begin{array}{l}\text { Screen } \\
\text { Bottom } \\
\text { Elev (ft) }\end{array}$ & $\begin{array}{c}\text { Screen } \\
\text { Length } \\
\text { (ft) }\end{array}$ & $\begin{array}{c}\text { Pump } \\
\text { Intake } \\
\text { Depth } \\
\text { (ft) }\end{array}$ & \begin{tabular}{|c|} 
Pump \\
Intake \\
Elevation \\
(ft)
\end{tabular} & $\begin{array}{c}\text { Depth to } \\
\text { Top of } \\
\text { Sump (ft) }\end{array}$ & \begin{tabular}{|c|} 
Top of \\
Sump \\
Elevation \\
(ft)
\end{tabular} & $\begin{array}{l}\text { Depth to } \\
\text { Sump } \\
\text { Bottom } \\
\text { (ft) }\end{array}$ & $\begin{array}{c}\text { Well T.D. } \\
\text { Elevation } \\
\text { (ft) }\end{array}$ & $\begin{array}{l}\text { Sump } \\
\text { Length } \\
\text { (ft) }\end{array}$ & $\begin{array}{c}\text { Sump } \\
\text { Volume } \\
\text { (L) }\end{array}$ & Comment \\
\hline MCA-3d & 54.6 & 55.1 & 6764.9 & 6764.4 & 0.5 & & & 55.1 & 6764.4 & 55.8 & 6763.7 & 0.7 & 0.27677 & Alluvial groundwater \\
\hline MCA-3e & 51.0 & 51.5 & 6768.5 & 6768.0 & 0.5 & & & 51.5 & 6768.0 & 52.2 & 6767.3 & 0.7 & 0.27677 & Alluvial groundwater \\
\hline MCA-3f & 47.5 & 48.0 & 6772.0 & 6771.5 & 0.5 & & & 48.0 & 6771.5 & 48.7 & 6770.8 & 0.7 & 0.27677 & Alluvial groundwater \\
\hline
\end{tabular}
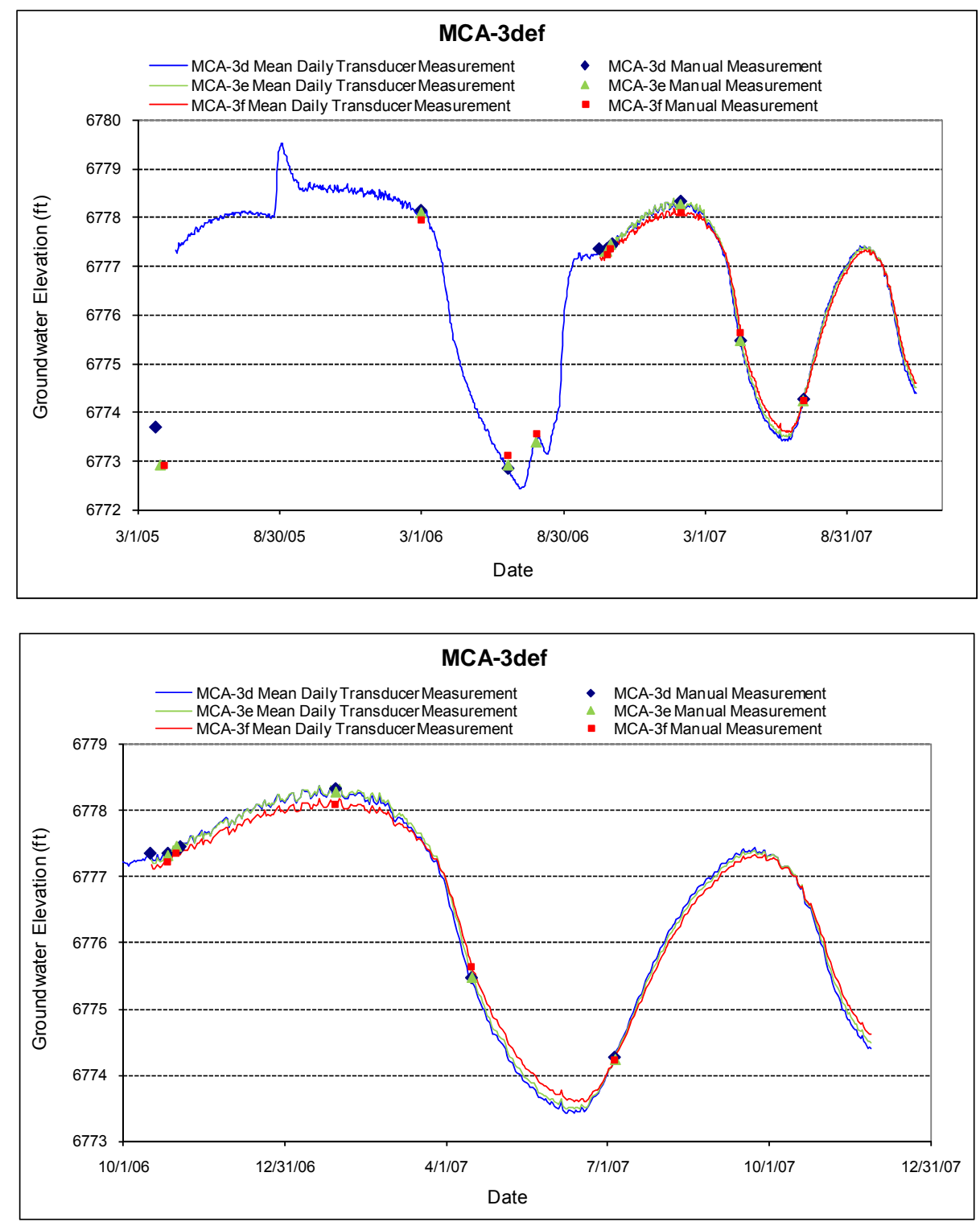


\subsection{MCA-4}

Location: Upper Effluent Canyon, approximately $200 \mathrm{ft}$ west of TA-50 outfall.

Period of Record: April 18, 2005, through November 29, 2007.

Remarks: Monitoring of this well was discontinued November 29, 2007.

\begin{tabular}{|c|c|c|c|c|c|c|c|c|c|c|c|c|c|}
\hline \multicolumn{14}{|c|}{ MCA-4 Construction Information } \\
\hline Zone & $\begin{array}{l}\text { Screen } \\
\text { Top } \\
\text { Depth (ft) }\end{array}$ & $\begin{array}{c}\text { Screen } \\
\text { Bottom } \\
\text { Depth } \\
\text { (ft) }\end{array}$ & $\begin{array}{c}\text { Screen } \\
\text { Top } \\
\text { Elev (ft) }\end{array}$ & $\begin{array}{l}\text { Screen } \\
\text { Bottom } \\
\text { Elev (ft) }\end{array}$ & $\begin{array}{c}\text { Screen } \\
\text { Length } \\
\text { (ft) }\end{array}$ & $\begin{array}{c}\text { Pump } \\
\text { Intake } \\
\text { Depth } \\
\text { (ft) }\end{array}$ & $\begin{array}{c}\text { Pump } \\
\text { Intake } \\
\text { Elevation } \\
\text { (ft) }\end{array}$ & \begin{tabular}{|} 
Depth to \\
Top of \\
Sump (ft)
\end{tabular} & $\begin{array}{c}\text { Top of } \\
\text { Sump } \\
\text { Elevation } \\
\text { (ft) }\end{array}$ & \begin{tabular}{|} 
Depth to \\
Sump \\
Bottom (ft)
\end{tabular} & $\begin{array}{c}\text { Sump } \\
\text { Length } \\
\text { (ft) }\end{array}$ & $\begin{array}{c}\text { Sump } \\
\text { Volume } \\
\text { (L) }\end{array}$ & Comment \\
\hline 1 & 3.3 & 5.3 & 7131.80 & 7129.80 & 2.0 & & & 5.3 & 7129.80 & 5.4 & 0.1 & 0.0 & Alluvial groundwater \\
\hline
\end{tabular}

Note: Ground Elevation: $7135.1 \mathrm{ft}$; all depths are from this elevation
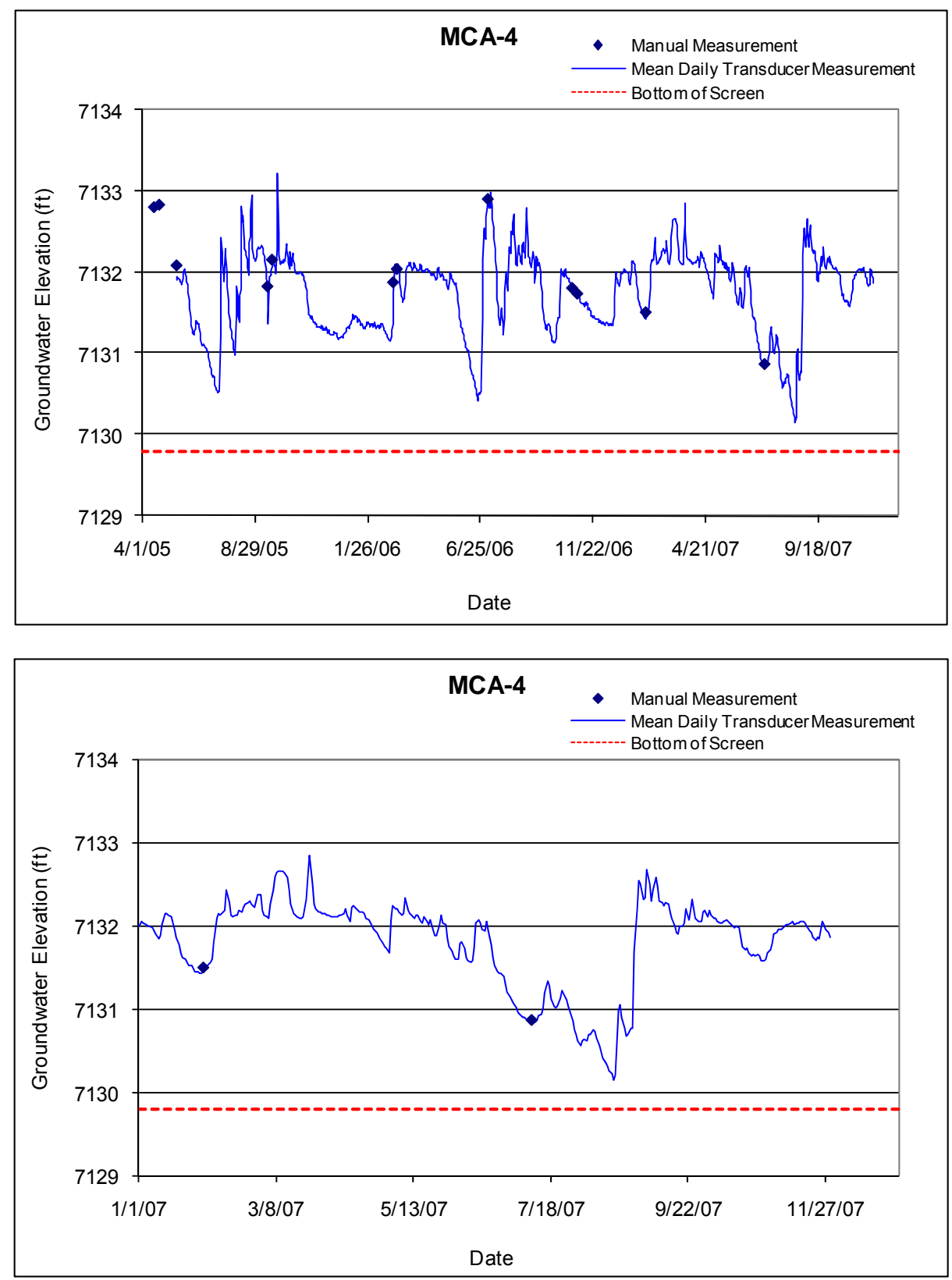


\subsection{MCA-5}

Location: Upper Mortandad Canyon, approximately $1250 \mathrm{ft}$ downstream of TA-50 outfall. Period of Record: April 25, 2005, through November 18, 2009.

Remarks: This well is intermittently dry.

\begin{tabular}{|c|c|c|c|c|c|c|c|c|c|c|c|c|c|}
\hline \multicolumn{14}{|c|}{ MCA-5 Construction Information } \\
\hline Zone & $\begin{array}{c}\text { Screen } \\
\text { Top } \\
\text { Depth (ft) }\end{array}$ & $\begin{array}{c}\text { Screen } \\
\text { Bottom } \\
\text { Depth } \\
\text { (ft) }\end{array}$ & $\begin{array}{c}\text { Screen } \\
\text { Top } \\
\text { Elev (ft) }\end{array}$ & $\begin{array}{l}\text { Screen } \\
\text { Bottom } \\
\text { Elev (ft) }\end{array}$ & $\begin{array}{c}\text { Screen } \\
\text { Length } \\
\text { (ft) }\end{array}$ & $\begin{array}{c}\text { Pump } \\
\text { Intake } \\
\text { Depth } \\
\text { (ft) }\end{array}$ & $\begin{array}{c}\text { Pump } \\
\text { Intake } \\
\text { Elevation } \\
\text { (ft) }\end{array}$ & $\begin{array}{c}\text { Depth to } \\
\text { Top of } \\
\text { Sump (ft) }\end{array}$ & $\begin{array}{c}\text { Top of } \\
\text { Sump } \\
\text { Elevation } \\
\text { (ft) }\end{array}$ & $\begin{array}{l}\text { Depth to } \\
\text { Sump } \\
\text { Bottom (ft) }\end{array}$ & $\begin{array}{c}\text { Sump } \\
\text { Length } \\
\text { (ft) }\end{array}$ & $\begin{array}{c}\text { Sump } \\
\text { Volume } \\
\text { (L) }\end{array}$ & Comment \\
\hline 1 & 1.75 & 5.75 & 7052.05 & 7048.05 & 4.0 & & & 5.75 & 7048.05 & 6.0 & 0.25 & 0.04 & Alluvial groundwater \\
\hline
\end{tabular}

Note: Ground elevation is $7053.8 \mathrm{ft}$; all depths are from this elevation
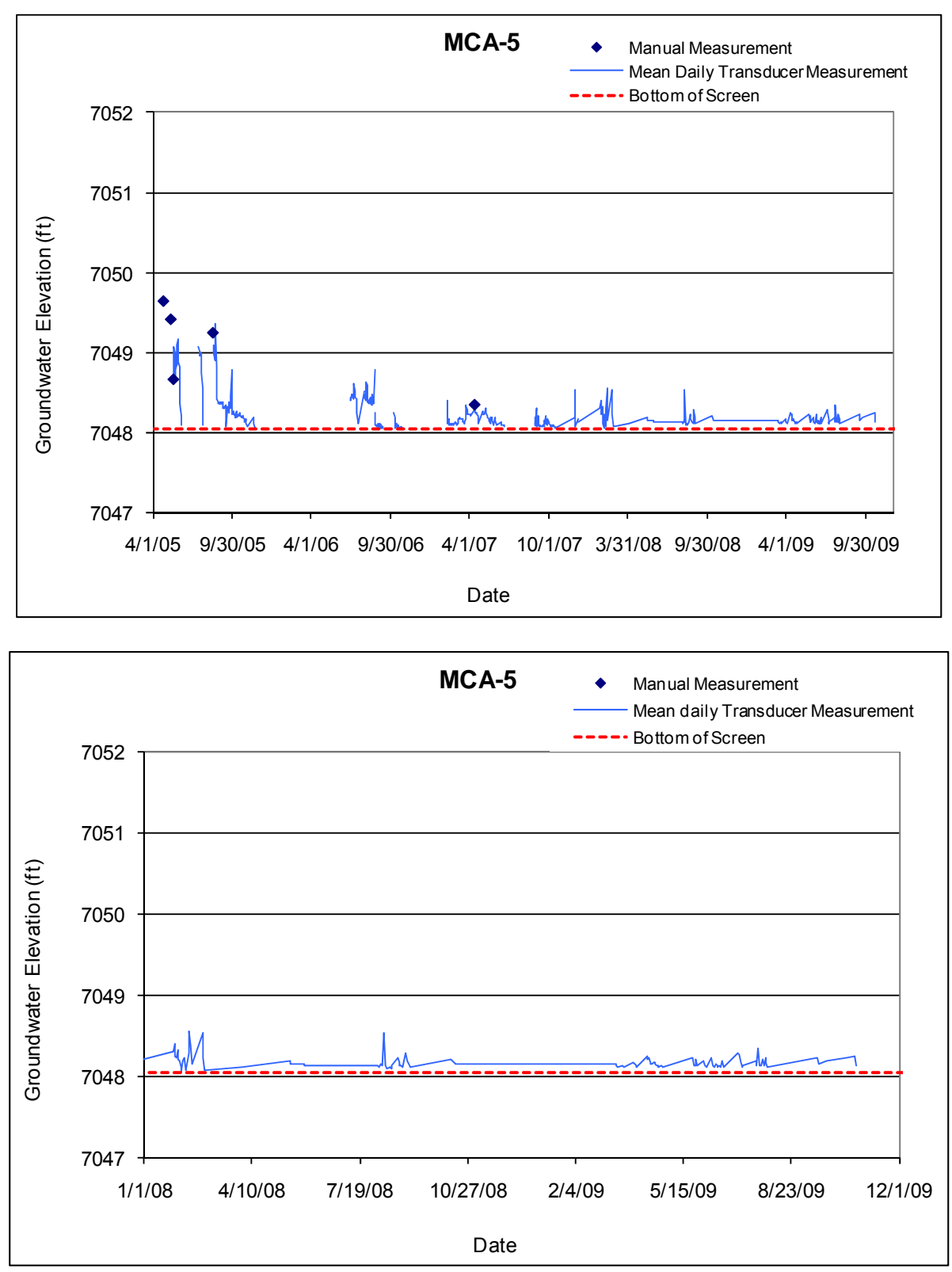


\subsection{MCA-8}

Location: Lower Mortandad Canyon.

Period of Record: October 3, 2005, through November 18, 2009.

Remarks: No valid water level data exist for this well. Water has occurred only in the sump since completion on September 29, 2004.

\begin{tabular}{|c|c|c|c|c|c|c|c|c|c|c|c|c|c|}
\hline \multicolumn{14}{|c|}{ MCA-8 Construction Information } \\
\hline Zone & $\begin{array}{c}\text { Screen Top } \\
\text { Depth (ft) }\end{array}$ & $\begin{array}{c}\text { Screen } \\
\text { Bottom } \\
\text { Depth } \\
\text { (ft) }\end{array}$ & $\begin{array}{c}\text { Screen } \\
\text { Top } \\
\text { Elev (ft) }\end{array}$ & $\begin{array}{l}\text { Screen } \\
\text { Bottom } \\
\text { Elev (ft) }\end{array}$ & $\begin{array}{c}\text { Screen } \\
\text { Length } \\
\text { (ft) }\end{array}$ & $\begin{array}{c}\text { Pump } \\
\text { Intake } \\
\text { Depth } \\
\text { (ft) }\end{array}$ & \begin{tabular}{|c|} 
Pump \\
Intake \\
Elevation \\
(ft)
\end{tabular} & \begin{tabular}{|c} 
Depth to \\
Top of \\
Sump (ft)
\end{tabular} & $\begin{array}{c}\text { Top of } \\
\text { Sump } \\
\text { Elevation } \\
\text { (ft) }\end{array}$ & $\begin{array}{c}\text { Depth to } \\
\text { Sump } \\
\text { Bottom (ft) }\end{array}$ & $\begin{array}{c}\text { Sump } \\
\text { Length } \\
\text { (ft) }\end{array}$ & $\begin{array}{c}\text { Sump } \\
\text { Volume } \\
\text { (L) }\end{array}$ & Comment \\
\hline 1 & 66 & 81 & 6602.7 & 6587.7 & 15 & & & 81 & 6587.7 & 86.3 & 5.3 & 14.4 & Alluvial groundwater \\
\hline
\end{tabular}

\begin{tabular}{|c|c|c|}
\hline \multicolumn{3}{|c|}{ MCA-8 Manual Water Levels } \\
\hline Date & Water Level (ft) & Comments \\
\hline $10 / 3 / 2005$ & 6582.43 & Sump water \\
\hline $1 / 4 / 2006$ & 6583.52 & Sump water \\
\hline $4 / 13 / 2006$ & 6584.09 & Sump water \\
\hline $7 / 18 / 2006$ & 6584.14 & Sump water \\
\hline $10 / 30 / 2006$ & 6584.17 & Sump water \\
\hline $9 / 5 / 2006$ & 6584.16 & Sump water \\
\hline $1 / 26 / 2007$ & 6584.12 & Sump water \\
\hline $4 / 12 / 2007$ & 6584.11 & Sump water \\
\hline $7 / 3 / 2007$ & 6584.1 & Sump water \\
\hline $11 / 29 / 2007$ & 6584.11 & Sump water \\
\hline $12 / 5 / 2007$ & 6583.94 & Sump water \\
\hline $3 / 26 / 2008$ & 6583.99 & Sump water \\
\hline $6 / 19 / 2008$ & 6584.09 & Sump water \\
\hline $8 / 11 / 2008$ & 6584.1 & Sump water \\
\hline $8 / 19 / 2008$ & 6584.01 & Sump water \\
\hline $2 / 19 / 2009$ & 6584.01 & Sump water \\
\hline $5 / 19 / 2009$ & 6584.13 & Sump water \\
\hline $8 / 25 / 2009$ & 6584.11 & Sump water \\
\hline $11 / 18 / 2009$ & 6584.11 & Sump water \\
\hline
\end{tabular}




\subsection{MCA-9}

Location: Lower Mortandad Canyon.

Period of Record: August 17, 2005, through November 29, 2007.

Remarks: No valid water level data exist for this well. Water has occurred only in the sump since completion on December 4, 2004. Monitoring of this well was discontinued November 29, 2007, but a manual water level was taken August 11, 2008.

\begin{tabular}{|c|c|c|c|c|c|c|c|c|c|c|c|c|c|}
\hline \multicolumn{14}{|c|}{ MCA-9 Construction Information } \\
\hline Zone & $\begin{array}{l}\text { Screen } \\
\text { Top } \\
\text { Depth (ft) }\end{array}$ & $\begin{array}{c}\text { Screen } \\
\text { Bottom } \\
\text { Depth } \\
\text { (ft) }\end{array}$ & $\begin{array}{c}\text { Screen } \\
\text { Top } \\
\text { Elev (ft) }\end{array}$ & $\begin{array}{l}\text { Screen } \\
\text { Bottom } \\
\text { Elev (ft) }\end{array}$ & $\begin{array}{c}\text { Screen } \\
\text { Length } \\
\text { (ft) }\end{array}$ & $\begin{array}{c}\text { Pump } \\
\text { Intake } \\
\text { Depth } \\
\text { (ft) }\end{array}$ & $\begin{array}{c}\text { Pump } \\
\text { Intake } \\
\text { Elevation } \\
\text { (ft) }\end{array}$ & $\begin{array}{l}\text { Depth to } \\
\text { Top of } \\
\text { Sump (ft) }\end{array}$ & $\begin{array}{c}\text { Top of } \\
\text { Sump } \\
\text { Elevation } \\
\text { (ft) }\end{array}$ & \begin{tabular}{|l} 
Depth to \\
Sump \\
Bottom (ft)
\end{tabular} & $\begin{array}{c}\text { Sump } \\
\text { Length } \\
\text { (ft) }\end{array}$ & $\begin{array}{c}\text { Sump } \\
\text { Volume } \\
\text { (L) }\end{array}$ & Comment \\
\hline 1 & 92.80 & 107.8 & 6578.9 & 6563.9 & 15.0 & & & 107.8 & 6563.9 & 113.0 & 5.2 & 3.5 & Alluvial groundwater \\
\hline
\end{tabular}

Note: Ground elevation is $6671.7 \mathrm{ft}$; all depths are from this elevation

\begin{tabular}{|c|c|c|}
\hline \multicolumn{3}{|c|}{ MCA-9 Manual Water Levels } \\
\hline Date & Water Elevation (ft) & Comments \\
\hline $12 / 4 / 2004$ & & Dry \\
\hline $8 / 17 / 2005$ & 6558.59 & Sump water \\
\hline $2 / 23 / 2006$ & 6558.76 & Sump water \\
\hline $5 / 16 / 2006$ & 6558.74 & Sump water \\
\hline $5 / 16 / 2006$ & 6558.77 & Sump water \\
\hline $7 / 18 / 2006$ & 6558.76 & Sump water \\
\hline $10 / 30 / 2006$ & 6558.95 & Sump water \\
\hline $10 / 31 / 2006$ & 6558.72 & Sump water \\
\hline $1 / 26 / 2007$ & 6559.13 & Sump water \\
\hline $4 / 12 / 2007$ & 6559.42 & Sump water \\
\hline $7 / 3 / 2007$ & 6559.46 & Sump water \\
\hline $11 / 29 / 2007$ & 6559.35 & Sump water \\
\hline $8 / 11 / 2008$ & 6559.36 & Sump water \\
\hline
\end{tabular}




\subsection{MCO-0.6}

Location: Upper Mortandad Canyon, north of TA-48.

Period of Record: March 31, 1999, through November 18, 2009.

Remarks: None.

\begin{tabular}{|c|c|c|c|c|c|c|c|c|c|c|c|c|c|}
\hline \multicolumn{14}{|c|}{ MCO-0.6 Construction Information } \\
\hline Zone & $\begin{array}{l}\text { Screen } \\
\text { Top } \\
\text { Depth (ft) }\end{array}$ & $\begin{array}{c}\text { Screen } \\
\text { Bottom } \\
\text { Depth } \\
\text { (ft) }\end{array}$ & $\begin{array}{c}\text { Screen } \\
\text { Top } \\
\text { Elev (ft) }\end{array}$ & $\begin{array}{l}\text { Screen } \\
\text { Bottom } \\
\text { Elev (ft) }\end{array}$ & $\begin{array}{c}\text { Screen } \\
\text { Length } \\
\text { (ft) }\end{array}$ & $\begin{array}{l}\text { Pump } \\
\text { Intake } \\
\text { Depth } \\
\text { (ft) }\end{array}$ & $\begin{array}{c}\text { Pump } \\
\text { Intake } \\
\text { Elevation } \\
\text { (ft) }\end{array}$ & $\begin{array}{l}\text { Depth to } \\
\text { Top of } \\
\text { Sump (ft) }\end{array}$ & $\begin{array}{c}\text { Top of } \\
\text { Sump } \\
\text { Elevation } \\
\text { (ft) }\end{array}$ & \begin{tabular}{|} 
Depth to \\
Sump \\
Bottom (ft)
\end{tabular} & $\begin{array}{c}\text { Sump } \\
\text { Length } \\
\text { (ft) }\end{array}$ & $\begin{array}{c}\text { Sump } \\
\text { Volume } \\
\text { (L) }\end{array}$ & Comment \\
\hline 1 & 1.05 & 3.05 & 7186.68 & 7184.68 & 2.00 & & & 3.05 & 7184.68 & 3.10 & 0.05 & 0.04 & Alluvial groundwater \\
\hline
\end{tabular}

Note: Brass Cap Ground elevation: $7188.28 \mathrm{ft}$; Ground Elevatoin: $7187.73 \mathrm{ft}$; all depths are from this elevation
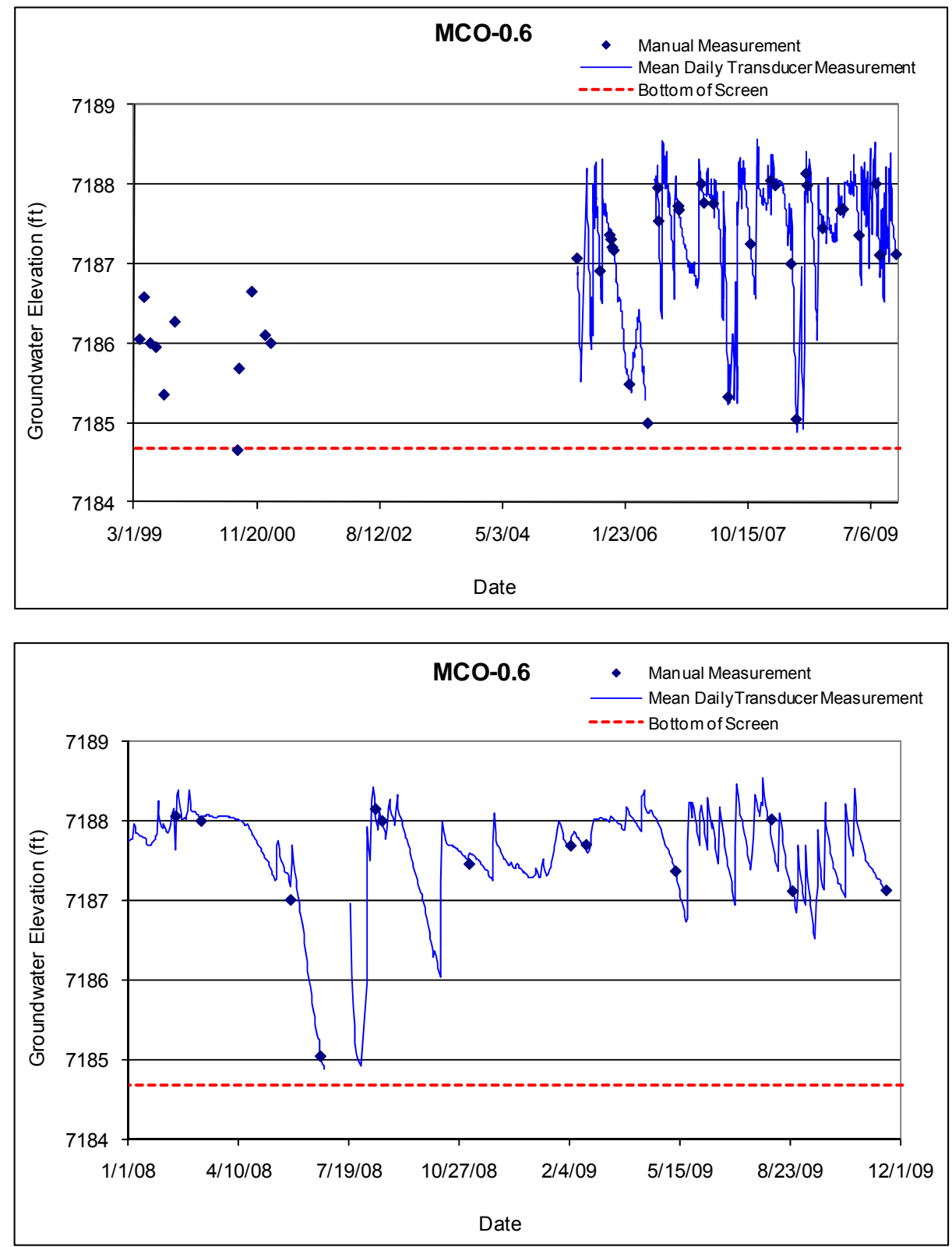


\subsection{MCO-2}

Location: Upper Effluent Canyon, approximately $200 \mathrm{ft}$ west of TA-50 outfall.

Period of Record: November 1, 1960, through November 11, 2009.

Remarks: The transducer was sitting on top of the bladder pump in a 2-in.-diameter well at an elevation of $7133.8 \mathrm{ft}$ until April 12, 2007. The pump was removed from the well on April 12, 2007, and the transducer was lowered to a more functional level.

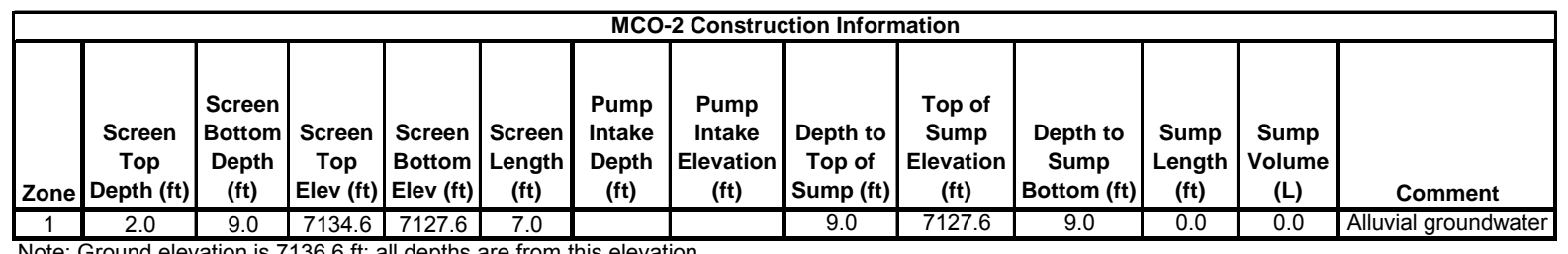

Note: Ground elevation is $7136.6 \mathrm{ft}$; all depths are from this elevation
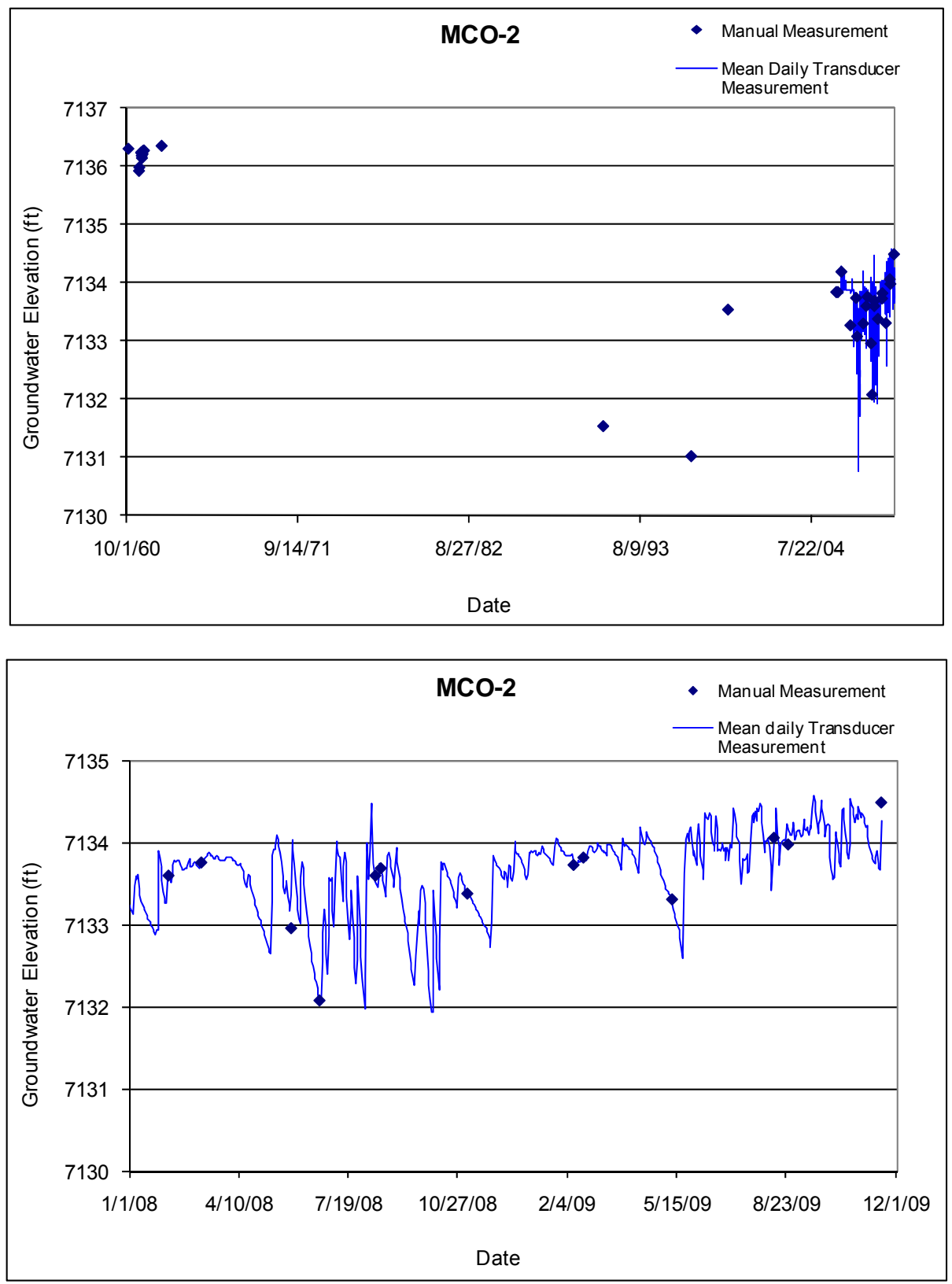


\subsection{MCO-3}

Location: Upper Mortandad Canyon, approximately $1250 \mathrm{ft}$ downstream of TA-50 outfall.

Period of Record: March 27, 1961, through November 5, 2009.

Remarks: There is no transducer installed in this well.

\begin{tabular}{|c|c|c|c|c|c|c|c|c|c|c|c|c|c|}
\hline \multicolumn{14}{|c|}{ MCO-3 Construction Information } \\
\hline Zone & $\begin{array}{c}\text { Screen } \\
\text { Top } \\
\text { Depth (ft) }\end{array}$ & $\begin{array}{c}\text { Screen } \\
\text { Bottom } \\
\text { Depth } \\
\text { (ft) }\end{array}$ & $\begin{array}{c}\text { Screen } \\
\text { Top } \\
\text { Elev (ft) }\end{array}$ & $\begin{array}{l}\text { Screen } \\
\text { Bottom } \\
\text { Elev (ft) }\end{array}$ & $\begin{array}{c}\text { Screen } \\
\text { Length } \\
\text { (ft) }\end{array}$ & $\begin{array}{c}\text { Pump } \\
\text { Intake } \\
\text { Depth } \\
\text { (ft) }\end{array}$ & $\begin{array}{c}\text { Pump } \\
\text { Intake } \\
\text { Elevation } \\
\text { (ft) }\end{array}$ & $\begin{array}{c}\text { Depth to } \\
\text { Top of } \\
\text { Sump (ft) }\end{array}$ & $\begin{array}{c}\text { Top of } \\
\text { Sump } \\
\begin{array}{c}\text { Elevation } \\
\text { (ft) }\end{array}\end{array}$ & \begin{tabular}{|c|} 
Depth to \\
Sump \\
Bottom (ft)
\end{tabular} & $\begin{array}{c}\text { Sump } \\
\text { Length } \\
\text { (ft) }\end{array}$ & $\begin{array}{c}\text { Sump } \\
\text { Volume } \\
\text { (L) }\end{array}$ & Comment \\
\hline 1 & 2.0 & 12.0 & 7050.6 & 7040.6 & 10.0 & & & 12.0 & 7040.6 & 12.0 & 0.0 & 0.0 & Alluvial groundwater \\
\hline
\end{tabular}
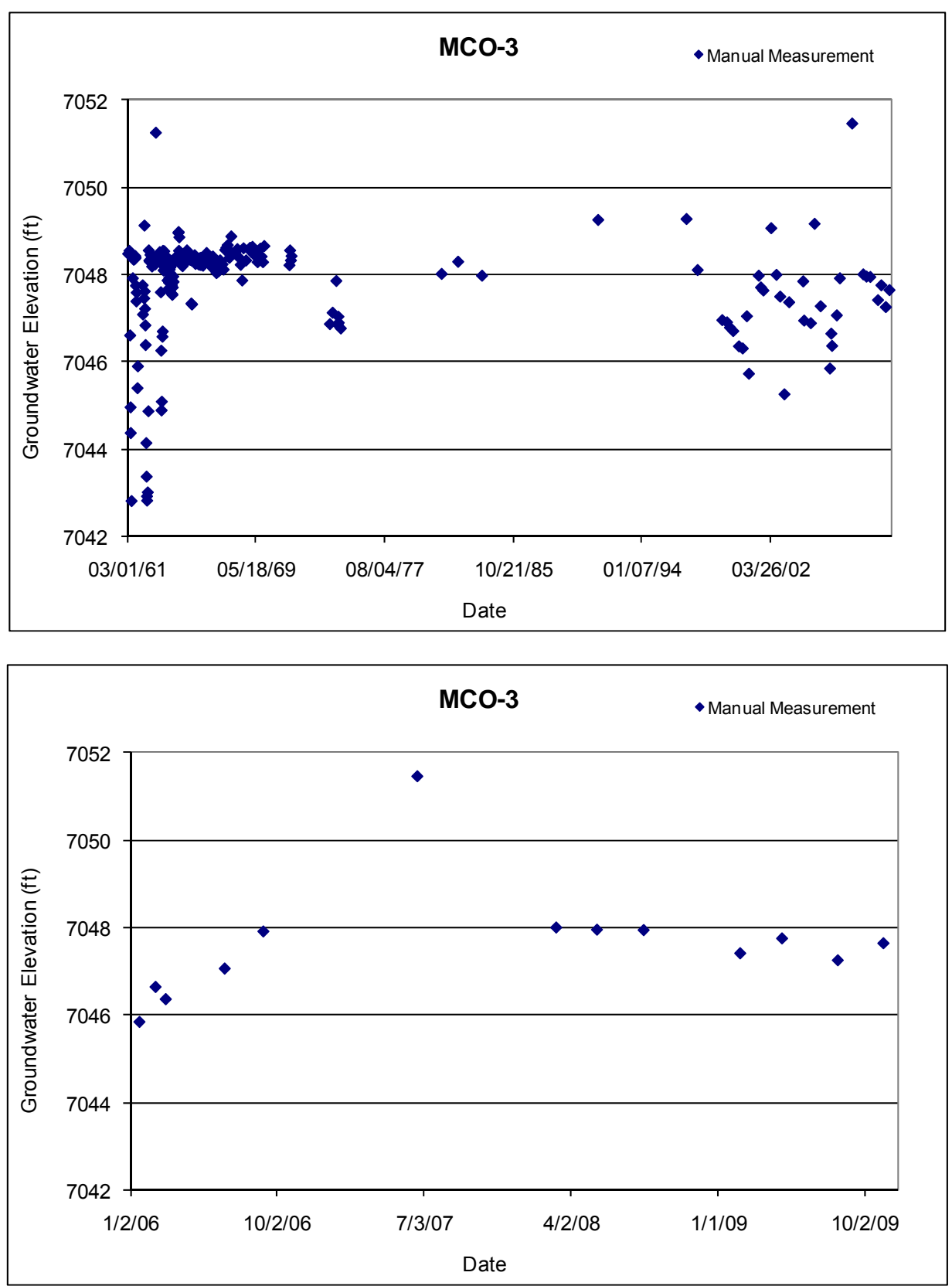


\subsection{MCO-4b}

Location: Middle Mortandad Canyon, approximately $3000 \mathrm{ft}$ up canyon from sediment traps.

Period of Record: August 21, 1990, through November 18, 2009.

Remarks: None.

\begin{tabular}{|c|c|c|c|c|c|c|c|c|c|c|c|c|c|}
\hline \multicolumn{14}{|c|}{ MCO-4b Construction Information } \\
\hline Zone & $\begin{array}{l}\text { Screen } \\
\text { Top } \\
\text { Depth (ft) }\end{array}$ & $\begin{array}{c}\text { Screen } \\
\text { Bottom } \\
\text { Depth } \\
\text { (ft) }\end{array}$ & $\begin{array}{c}\text { Screen } \\
\text { Top } \\
\text { Elev (ft) }\end{array}$ & $\begin{array}{l}\text { Screen } \\
\text { Bottom } \\
\text { Elev (ft) }\end{array}$ & $\begin{array}{c}\text { Screen } \\
\text { Length } \\
\text { (ft) }\end{array}$ & $\begin{array}{l}\text { Pump } \\
\text { Intake } \\
\text { Depth } \\
\text { (ft) }\end{array}$ & $\begin{array}{c}\text { Pump } \\
\text { Intake } \\
\text { Elevation } \\
\text { (ft) }\end{array}$ & $\begin{array}{l}\text { Depth to } \\
\text { Top of } \\
\text { Sump (ft) }\end{array}$ & $\begin{array}{c}\text { Top of } \\
\text { Sump } \\
\text { Elevation } \\
\text { (ft) }\end{array}$ & \begin{tabular}{|} 
Depth to \\
Sump \\
Bottom (ft)
\end{tabular} & $\begin{array}{l}\text { Sump } \\
\text { Length } \\
\text { (ft) }\end{array}$ & $\begin{array}{l}\text { Sump } \\
\text { Volume } \\
\text { (L) }\end{array}$ & Comment \\
\hline 1 & 8.9 & 28.9 & 6877.9 & 6857.9 & 20.0 & & & 28.9 & 6857.9 & 33.9 & 5.0 & 3.1 & Alluvial groundwater \\
\hline
\end{tabular}

Note: Ground elevation is $6886.75 \mathrm{ft}$; all depths are from this elevation
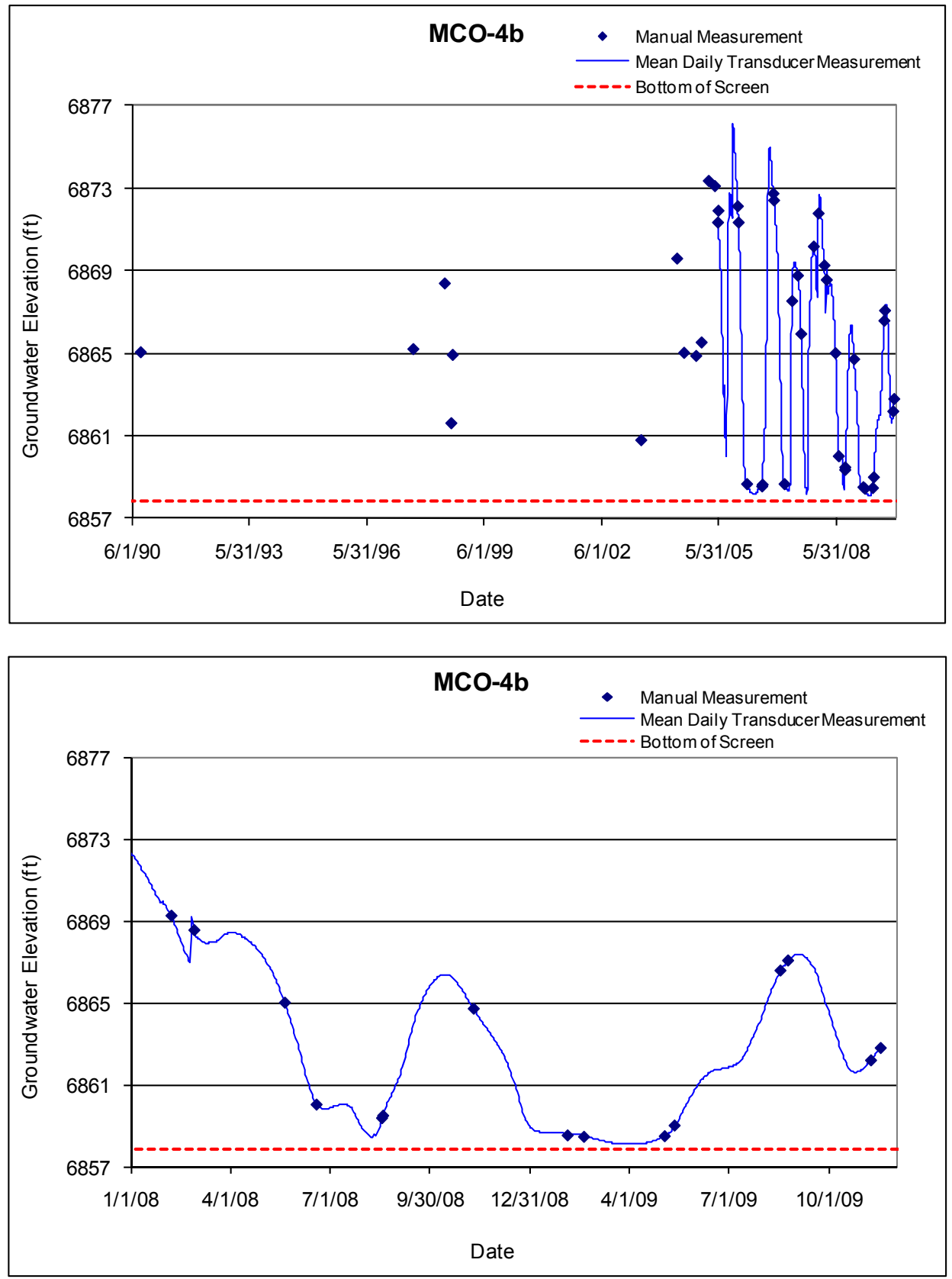


\subsection{MCO-5}

Location: Middle Mortandad Canyon, approximately $2300 \mathrm{ft}$ up canyon from sediment traps.

Period of Record: October 1, 1960, through November 18, 2009.

Remarks: None.

\begin{tabular}{|c|c|c|c|c|c|c|c|c|c|c|c|c|c|}
\hline \multicolumn{14}{|c|}{ MCO-5 Construction Information } \\
\hline Zone & $\begin{array}{l}\text { Screen } \\
\text { Top } \\
\text { Depth (ft) }\end{array}$ & $\begin{array}{c}\text { Screen } \\
\text { Bottom } \\
\text { Depth } \\
\text { (ft) }\end{array}$ & $\begin{array}{c}\text { Screen } \\
\text { Top } \\
\text { Elev }(\mathrm{ft})\end{array}$ & $\begin{array}{l}\text { Screen } \\
\text { Bottom } \\
\text { Elev (ft) }\end{array}$ & $\begin{array}{c}\text { Screen } \\
\text { Length } \\
\text { (ft) }\end{array}$ & $\begin{array}{c}\text { Pump } \\
\text { Intake } \\
\text { Depth } \\
\text { (ft) }\end{array}$ & $\begin{array}{c}\text { Pump } \\
\text { Intake } \\
\text { Elevation } \\
\text { (ft) }\end{array}$ & $\begin{array}{c}\text { Depth to } \\
\text { Top of } \\
\text { Sump (ft) }\end{array}$ & $\begin{array}{c}\text { Top of } \\
\text { Sump } \\
\text { Elevation } \\
\text { (ft) }\end{array}$ & $\begin{array}{l}\text { Depth to } \\
\text { Sump } \\
\text { Bottom (ft) }\end{array}$ & $\begin{array}{c}\text { Sump } \\
\text { Length } \\
\text { (ft) }\end{array}$ & $\begin{array}{c}\text { Sump } \\
\text { Volume } \\
\text { (L) }\end{array}$ & Comment \\
\hline 1 & 21.0 & 46.0 & 6854.66 & 6829.66 & 25.0 & & & 46.0 & 6829.66 & 46.0 & 0.0 & 0.0 & Alluvial groundwater \\
\hline
\end{tabular}
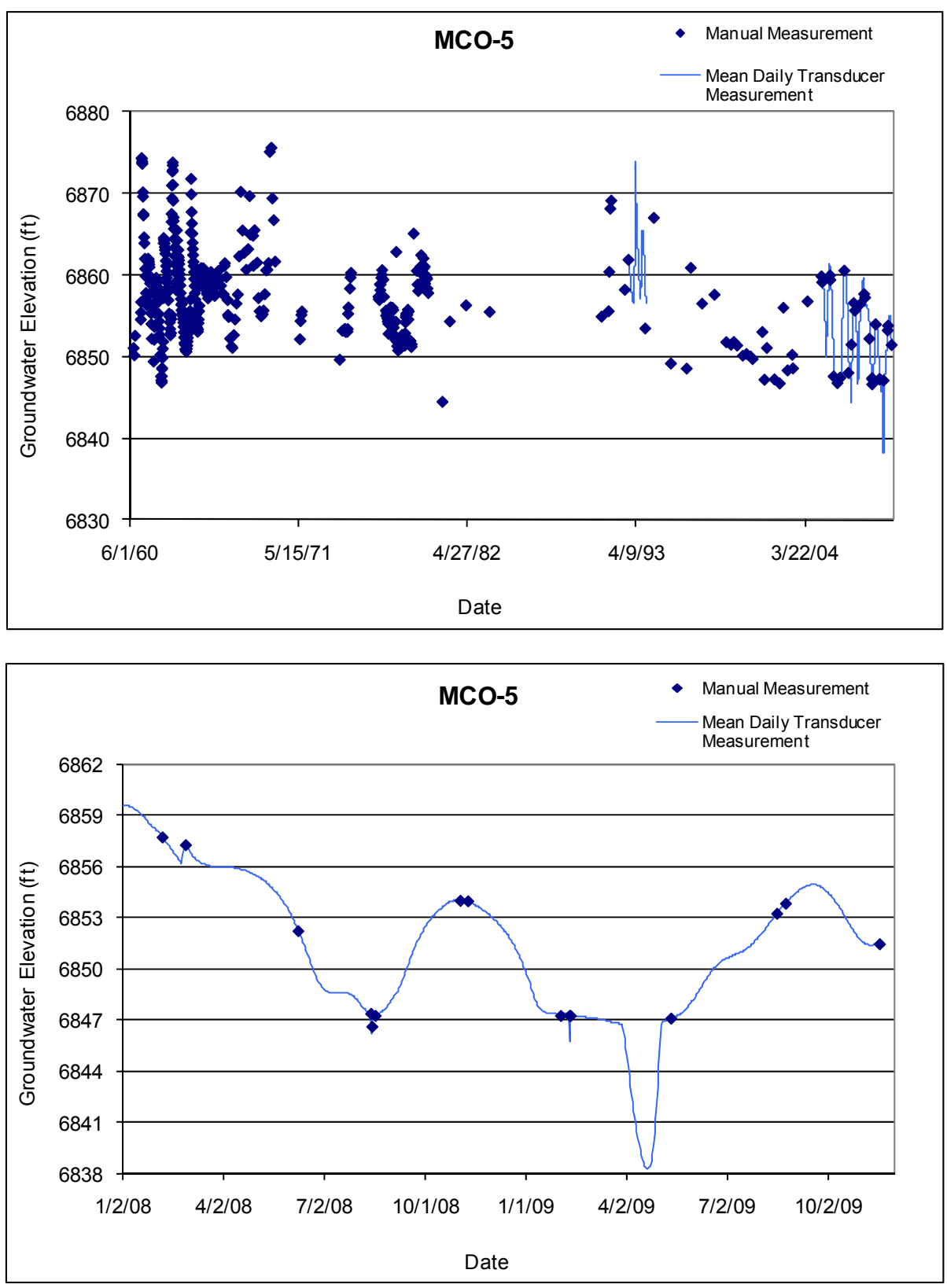


\subsection{MCO-6}

Location: Middle Mortandad Canyon, approximately 0.25 miles east of MCO-5.

Period of Record: August 25, 1961, through November 18, 2009.

Remarks: The transducer was removed from the well October 30, 2007, and replaced February 28, 2008.

\begin{tabular}{|c|c|c|c|c|c|c|c|c|c|c|c|c|c|}
\hline \multicolumn{14}{|c|}{ MCO-6 Construction Information } \\
\hline Zone & $\begin{array}{c}\text { Screen } \\
\text { Top } \\
\text { Depth (ft) }\end{array}$ & $\begin{array}{c}\text { Screen } \\
\text { Bottom } \\
\text { Depth } \\
\text { (ft) }\end{array}$ & $\begin{array}{c}\text { Screen } \\
\text { Top } \\
\text { Elev (ft) }\end{array}$ & $\begin{array}{l}\text { Screen } \\
\text { Bottom } \\
\text { Elev (ft) }\end{array}$ & $\begin{array}{c}\text { Screen } \\
\text { Length } \\
\text { (ft) }\end{array}$ & $\begin{array}{l}\text { Pump } \\
\text { Intake } \\
\text { Depth } \\
\text { (ft) }\end{array}$ & $\begin{array}{c}\text { Pump } \\
\text { Intake } \\
\text { Elevation } \\
\text { (ft) }\end{array}$ & $\begin{array}{l}\text { Depth to } \\
\text { Top of } \\
\text { Sump (ft) }\end{array}$ & $\begin{array}{c}\text { Top of } \\
\text { Sump } \\
\text { Elevation } \\
\text { (ft) }\end{array}$ & $\begin{array}{l}\text { Depth to } \\
\text { Sump } \\
\text { Bottom (ft) }\end{array}$ & $\begin{array}{c}\text { Sump } \\
\text { Length } \\
\text { (ft) }\end{array}$ & $\begin{array}{c}\text { Sump } \\
\text { Volume } \\
\text { (L) }\end{array}$ & Comment \\
\hline 1 & 27.0 & 47.0 & 6822.5 & 6802.5 & 20.0 & & & 47.0 & 6802.5 & 47.0 & 0.0 & 0.0 & Alluvial groundwater \\
\hline
\end{tabular}
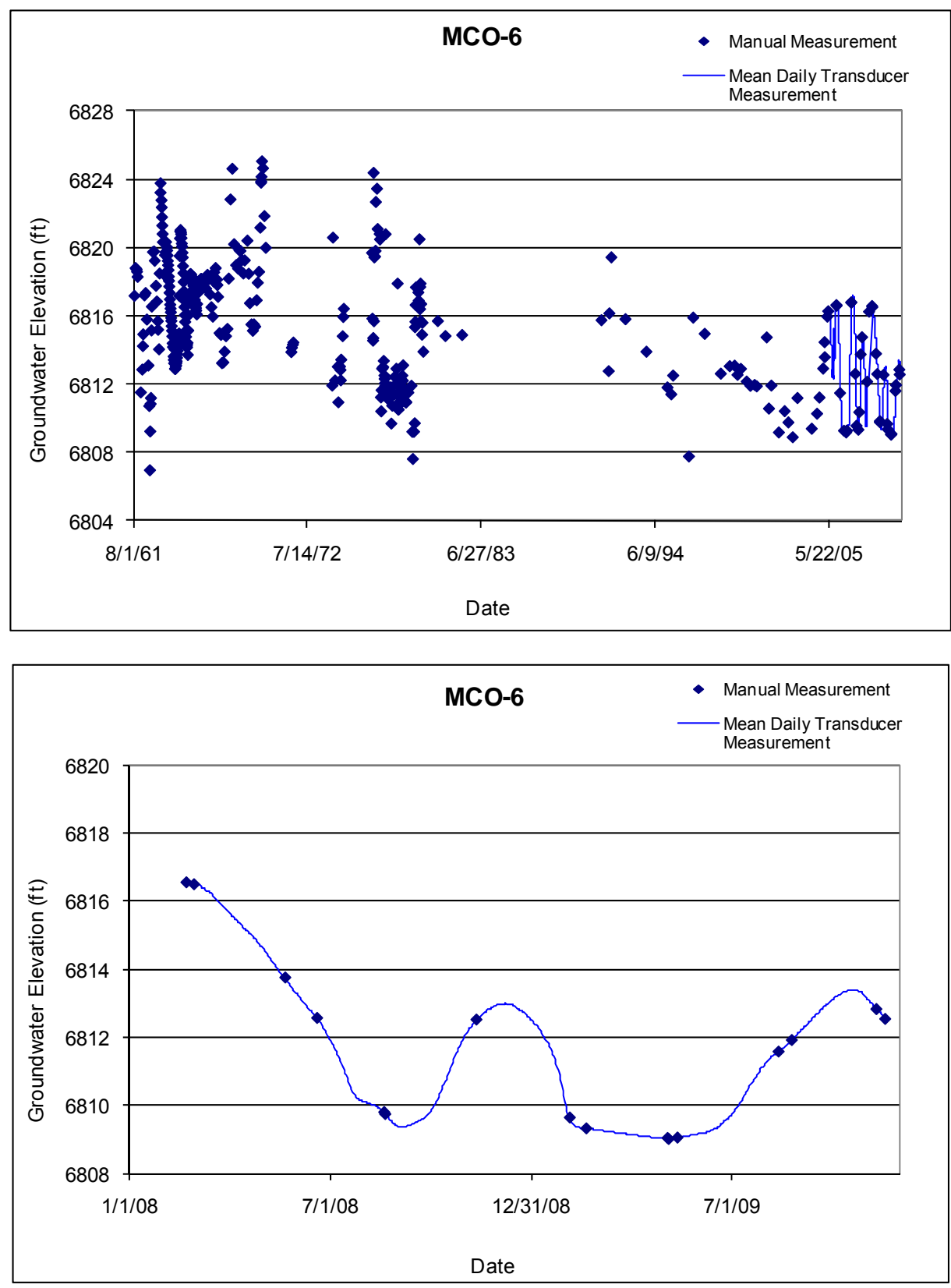


\subsection{MCO-7}

Location: Middle Mortandad Canyon, approximately 0.2 miles east of MCO-6.

Period of Record: October 1, 1960, through November 18, 2009.

Remarks: None.

\begin{tabular}{|c|c|c|c|c|c|c|c|c|c|c|c|c|c|}
\hline \multicolumn{14}{|c|}{ MCO-7 Construction Information } \\
\hline Zone & $\begin{array}{c}\text { Screen } \\
\text { Top } \\
\text { Depth (ft) }\end{array}$ & $\begin{array}{c}\text { Screen } \\
\text { Bottom } \\
\text { Depth } \\
\text { (ft) }\end{array}$ & $\begin{array}{c}\text { Screen } \\
\text { Top } \\
\text { Elev (ft) }\end{array}$ & $\begin{array}{l}\text { Screen } \\
\text { Bottom } \\
\text { Elev (ft) }\end{array}$ & $\begin{array}{c}\text { Screen } \\
\text { Length } \\
\text { (ft) }\end{array}$ & $\begin{array}{c}\text { Pump } \\
\text { Intake } \\
\text { Depth } \\
\text { (ft) }\end{array}$ & $\begin{array}{c}\text { Pump } \\
\text { Intake } \\
\text { Elevation } \\
\text { (ft) }\end{array}$ & $\begin{array}{l}\text { Depth to } \\
\text { Top of } \\
\text { Sump (ft) }\end{array}$ & $\begin{array}{c}\text { Top of } \\
\text { Sump } \\
\text { Elevation } \\
\text { (ft) }\end{array}$ & \begin{tabular}{|c|} 
Depth to \\
Sump \\
Bottom (ft)
\end{tabular} & $\begin{array}{c}\text { Sump } \\
\text { Length } \\
\text { (ft) }\end{array}$ & $\begin{array}{c}\text { Sump } \\
\text { Volume } \\
\text { (L) }\end{array}$ & Comment \\
\hline 1 & 39 & 69 & 6788.31 & 6758.31 & 30 & & & 69 & 6758.31 & 69 & 0 & 0 & Alluvial groundwater \\
\hline
\end{tabular}
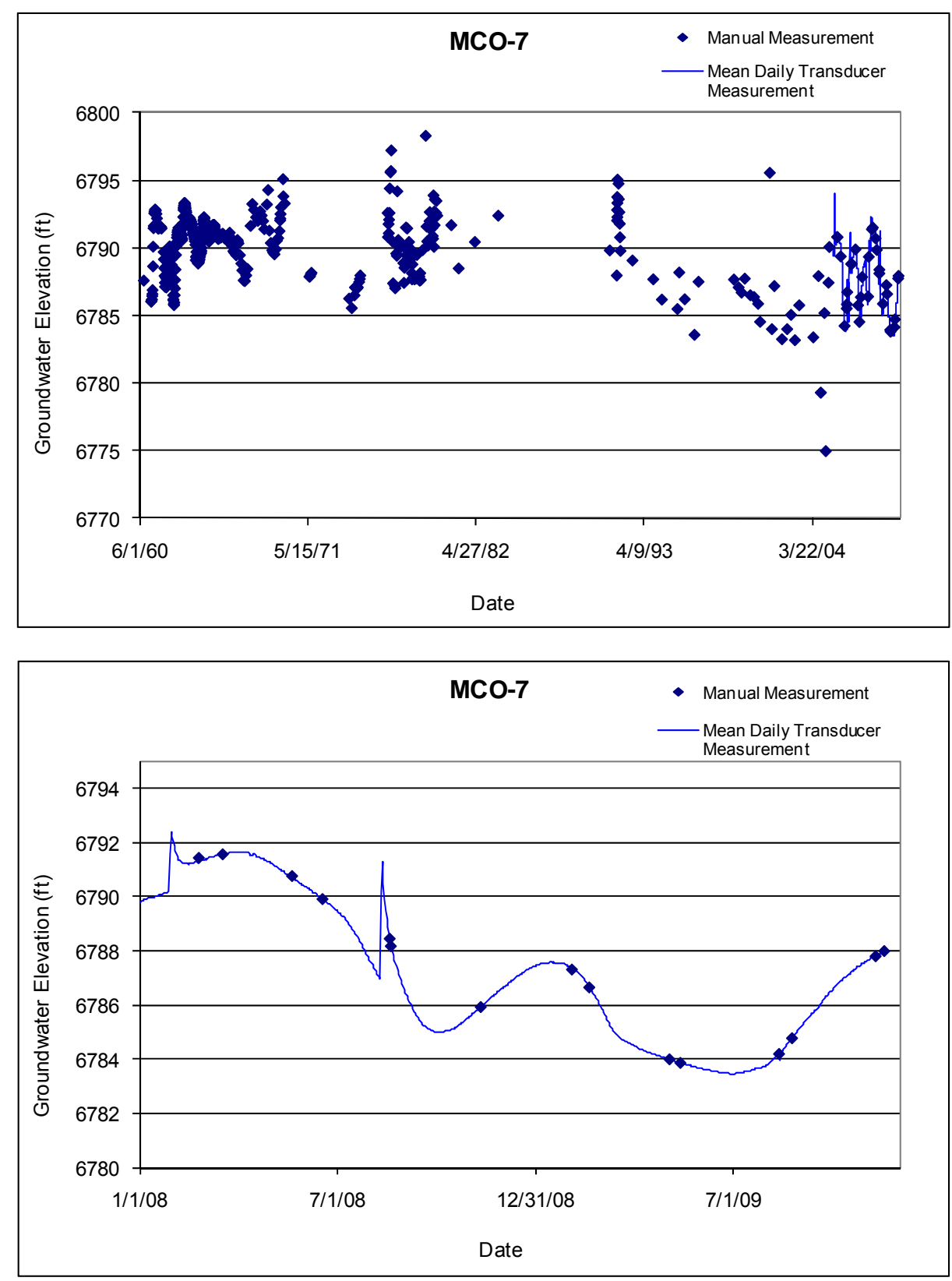


\subsection{MCO-7.5}

Location: Middle Mortandad Canyon, approximately 0.2 miles east of MCO-7.

Period of Record: November 1, 1961, through November 18, 2009.

Remarks: None.

\begin{tabular}{|c|c|c|c|c|c|c|c|c|c|c|c|c|c|}
\hline \multicolumn{14}{|c|}{ MCO-7.5 Construction Information } \\
\hline Zone & $\begin{array}{c}\text { Screen } \\
\text { Top } \\
\text { Depth (ft) }\end{array}$ & $\begin{array}{c}\text { Screen } \\
\text { Bottom } \\
\text { Depth } \\
\text { (ft) }\end{array}$ & $\begin{array}{c}\text { Screen } \\
\text { Top } \\
\text { Elev (ft) }\end{array}$ & $\begin{array}{l}\text { Screen } \\
\text { Bottom } \\
\text { Elev (ft) } \\
\end{array}$ & $\begin{array}{c}\text { Screen } \\
\text { Length } \\
\text { (ft) }\end{array}$ & $\begin{array}{c}\text { Pump } \\
\text { Intake } \\
\text { Depth } \\
\text { (ft) }\end{array}$ & $\begin{array}{c}\text { Pump } \\
\text { Intake } \\
\text { Elevation } \\
\text { (ft) }\end{array}$ & $\begin{array}{c}\text { Depth to } \\
\text { Top of } \\
\text { Sump (ft) }\end{array}$ & $\begin{array}{c}\text { Top of } \\
\text { Sump } \\
\text { Elevation } \\
\text { (ft) }\end{array}$ & $\begin{array}{c}\text { Depth to } \\
\text { Sump } \\
\text { Bottom (ft) }\end{array}$ & $\begin{array}{c}\text { Sump } \\
\text { Length } \\
\text { (ft) }\end{array}$ & $\begin{array}{c}\text { Sump } \\
\text { Volume } \\
\text { (L) }\end{array}$ & Comment \\
\hline 1 & 35 & 60 & 6773.88 & 6748.88 & 25 & & & 60 & 6748.88 & 60 & 0 & 0 & Alluvial groundwater \\
\hline
\end{tabular}
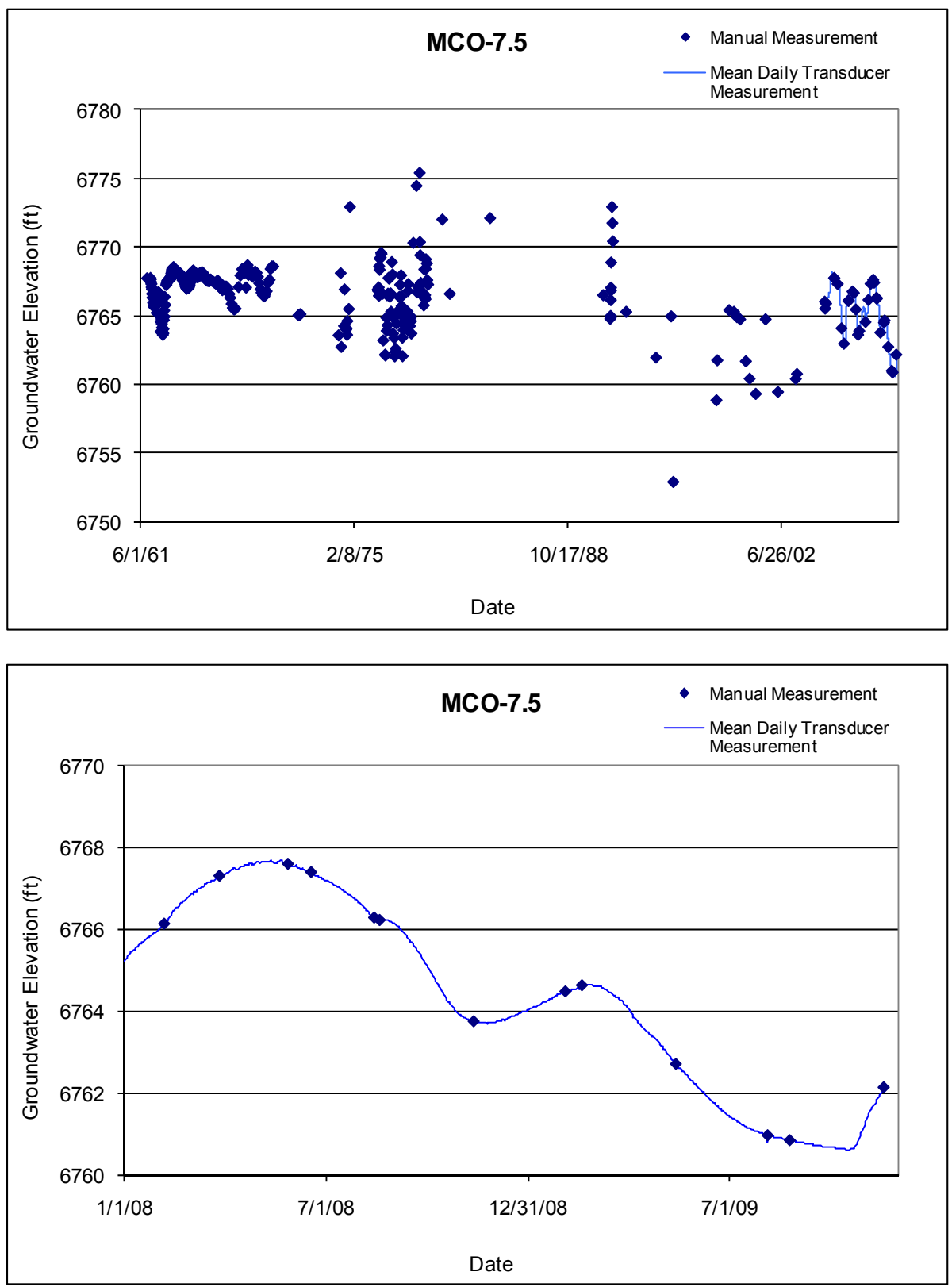


\subsection{MCWB-5}

Location: Middle Mortandad Canyon, up canyon from the sediment traps.

Period of Record: January 9, 1995, through November 18, 2009.

Remarks: Water in the sump is not considered invalid as it appears to respond to groundwater level fluctuations. Transducer hangs above bottom of well; groundwater elevations below $6847 \mathrm{ft}$ are not recorded by the transducer.

\begin{tabular}{|c|c|c|c|c|c|c|c|c|c|c|c|c|c|}
\hline \multicolumn{14}{|c|}{ MCWB-5 Construction Information } \\
\hline Zone & $\begin{array}{c}\text { Screen } \\
\text { Top } \\
\text { Depth (ft) }\end{array}$ & $\begin{array}{c}\text { Screen } \\
\text { Bottom } \\
\text { Depth } \\
\text { (ft) }\end{array}$ & $\begin{array}{c}\text { Screen } \\
\text { Top } \\
\text { Elev (ft) }\end{array}$ & $\begin{array}{l}\text { Screen } \\
\text { Bottom } \\
\text { Elev (ft) }\end{array}$ & $\begin{array}{c}\text { Screen } \\
\text { Length } \\
\text { (ft) }\end{array}$ & $\begin{array}{l}\text { Pump } \\
\text { Intake } \\
\text { Depth } \\
\text { (ft) }\end{array}$ & $\begin{array}{c}\text { Pump } \\
\text { Intake } \\
\text { Elevation } \\
\text { (ft) }\end{array}$ & $\begin{array}{l}\text { Depth to } \\
\text { Top of } \\
\text { Sump (ft) }\end{array}$ & $\begin{array}{c}\text { Top of } \\
\text { Sump } \\
\text { Elevation } \\
\text { (ft) }\end{array}$ & \begin{tabular}{|c|} 
Depth to \\
Sump \\
Bottom (ft)
\end{tabular} & $\begin{array}{c}\text { Sump } \\
\text { Length } \\
\text { (ft) }\end{array}$ & $\begin{array}{c}\text { Sump } \\
\text { Volume } \\
\text { (L) }\end{array}$ & Comment \\
\hline 1 & 17.0 & 27.0 & 6859.2 & 6849.2 & 10.0 & & & 27.0 & 6849.2 & 32.0 & 5.0 & 7.0 & Alluvial groundwater \\
\hline
\end{tabular}
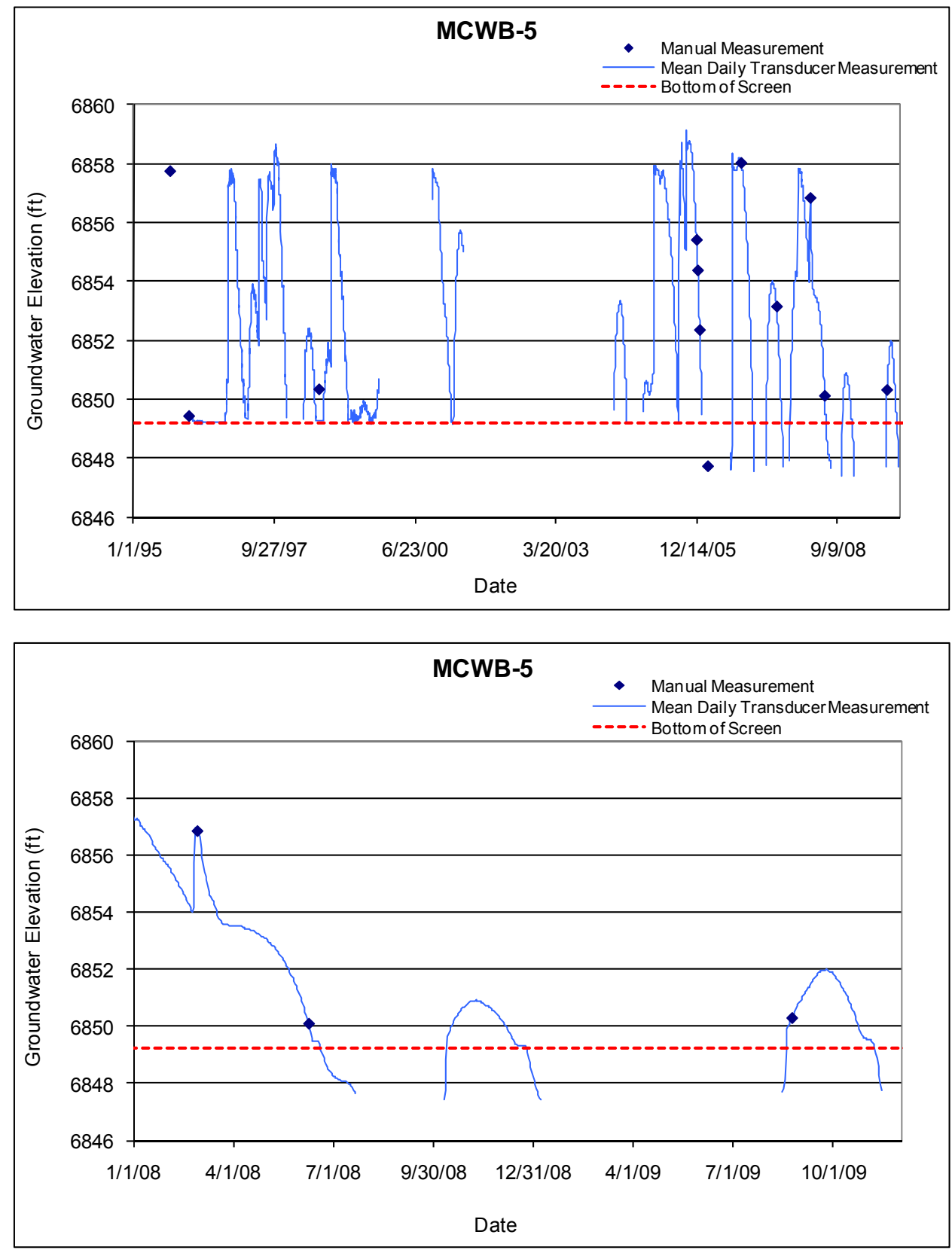


\subsection{MCWB-5.5b}

Location: Middle Mortandad Canyon, up canyon from sediment traps.

Period of Record: January 9, 1995, through November 18, 2009.

Remarks: Water in sump is not invalidated as it appears to represent formation water.

\begin{tabular}{|c|c|c|c|c|c|c|c|c|c|c|c|c|c|}
\hline \multicolumn{14}{|c|}{ MCWB-5.5b Construction Information } \\
\hline Zone & $\begin{array}{c}\text { Screen } \\
\text { Top } \\
\text { Depth (ft) }\end{array}$ & $\begin{array}{c}\text { Screen } \\
\text { Bottom } \\
\text { Depth } \\
\text { (ft) }\end{array}$ & $\begin{array}{c}\text { Screen } \\
\text { Top } \\
\text { Elev (ft) }\end{array}$ & $\begin{array}{l}\text { Screen } \\
\text { Bottom } \\
\text { Elev (ft) }\end{array}$ & $\begin{array}{c}\text { Screen } \\
\text { Length } \\
\text { (ft) }\end{array}$ & $\begin{array}{l}\text { Pump } \\
\text { Intake } \\
\text { Depth } \\
\text { (ft) }\end{array}$ & $\begin{array}{c}\text { Pump } \\
\text { Intake } \\
\text { Elevation } \\
\text { (ft) }\end{array}$ & $\begin{array}{c}\text { Depth to } \\
\text { Top of } \\
\text { Sump (ft) }\end{array}$ & $\begin{array}{c}\text { Top of } \\
\text { Sump } \\
\text { Elevation } \\
\text { (ft) }\end{array}$ & \begin{tabular}{|c|} 
Depth to \\
Sump \\
Bottom (ft)
\end{tabular} & $\begin{array}{l}\text { Sump } \\
\text { Length } \\
\text { (ft) }\end{array}$ & $\begin{array}{c}\text { Sump } \\
\text { Volume } \\
\text { (L) }\end{array}$ & Comment \\
\hline 1 & 22.5 & 32.5 & 6834.4 & 6824.4 & 10.0 & & & 32.5 & 6824.4 & 37.5 & 5.0 & 7.0 & Alluvial groundwater \\
\hline
\end{tabular}

Note: Ground elevation is $6856.89 \mathrm{ft}$; all depths are from this elevation
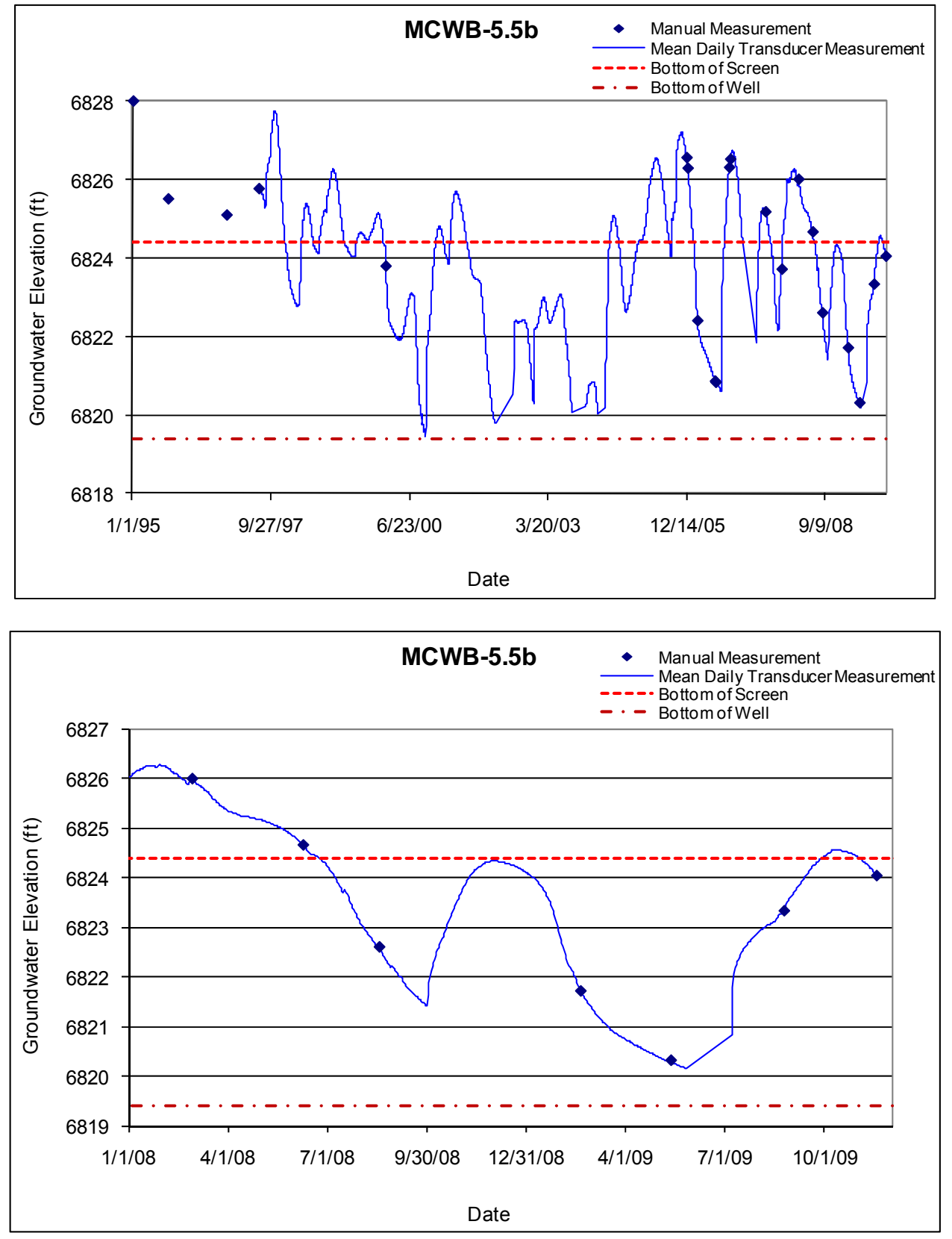


\subsection{MCWB-6.2a}

Location: Middle Mortandad Canyon, up canyon from sediment traps.

Period of Record: January 9, 1995, through November 18, 2009.

Remarks: Water in the sump is not invalidated, as it appears to respond to groundwater level fluctuations. Transducer data indicate that the bottom of the well is at $6801.2 \mathrm{ft}$.

\begin{tabular}{|c|c|c|c|c|c|c|c|c|c|c|c|c|c|}
\hline \multicolumn{14}{|c|}{ MCWB-6.2a Construction Information } \\
\hline Zone & $\begin{array}{l}\text { Screen } \\
\text { Top } \\
\text { Depth (ft) }\end{array}$ & $\begin{array}{c}\text { Screen } \\
\text { Bottom } \\
\text { Depth } \\
\text { (ft) }\end{array}$ & $\begin{array}{c}\text { Screen } \\
\text { Top } \\
\text { Elev (ft) }\end{array}$ & $\begin{array}{l}\text { Screen } \\
\text { Bottom } \\
\text { Elev (ft) }\end{array}$ & $\begin{array}{c}\text { Screen } \\
\text { Length } \\
\text { (ft) }\end{array}$ & $\begin{array}{c}\text { Pump } \\
\text { Intake } \\
\text { Depth } \\
\text { (ft) }\end{array}$ & $\begin{array}{c}\text { Pump } \\
\text { Intake } \\
\text { Elevation } \\
\text { (ft) }\end{array}$ & $\begin{array}{c}\text { Depth to } \\
\text { Top of } \\
\text { Sump (ft) }\end{array}$ & \begin{tabular}{|c} 
Top of \\
Sump \\
Elevation \\
(ft)
\end{tabular} & \begin{tabular}{|c|} 
Depth to \\
Sump \\
Bottom (ft)
\end{tabular} & $\begin{array}{c}\text { Sump } \\
\text { Length } \\
\text { (ft) }\end{array}$ & $\begin{array}{c}\text { Sump } \\
\text { Volume } \\
\text { (L) }\end{array}$ & Comment \\
\hline 1 & 30.5 & 40.5 & 6817.8 & 6807.8 & 10.0 & & & 40.5 & 6807.8 & 45.5 & 5.0 & 7.0 & Alluvial groundwater \\
\hline
\end{tabular}
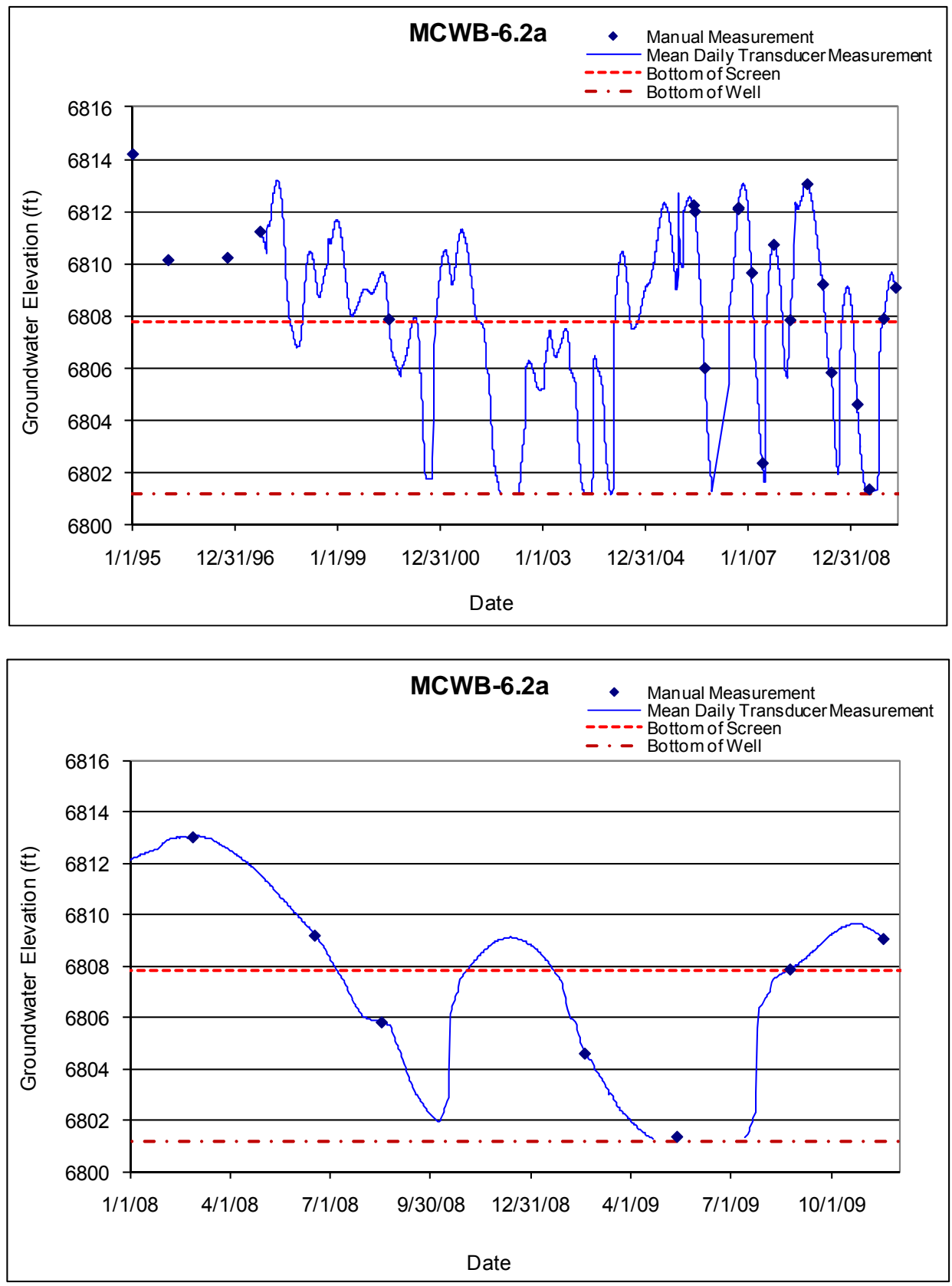


\subsection{MCWB-6.5e}

Location: Middle Mortandad Canyon, up canyon of the sediment traps.

Period of Record: January 9, 1995, through November 18, 2009.

Remarks: Water in sump is not invalidated, as it appears to respond to groundwater level fluctuations. Water is below transducer from March 23, 2007, to May 4, 2008, and from August 26, 2008, to October 8, 2008.

\begin{tabular}{|c|c|c|c|c|c|c|c|c|c|c|c|c|c|}
\hline \multicolumn{14}{|c|}{ MCWB-6.5e Construction Information } \\
\hline Zone & $\begin{array}{c}\text { Screen } \\
\text { Top } \\
\text { Depth }(\mathrm{ft})\end{array}$ & $\begin{array}{c}\text { Screen } \\
\text { Bottom } \\
\text { Depth } \\
\text { (ft) }\end{array}$ & $\begin{array}{c}\text { Screen } \\
\text { Top } \\
\text { Elev (ft) }\end{array}$ & $\begin{array}{l}\text { Screen } \\
\text { Bottom } \\
\text { Elev (ft) }\end{array}$ & $\begin{array}{c}\text { Screen } \\
\text { Length } \\
\text { (ft) }\end{array}$ & $\begin{array}{c}\text { Pump } \\
\text { Intake } \\
\text { Depth } \\
\text { (ft) }\end{array}$ & $\begin{array}{c}\text { Pump } \\
\text { Intake } \\
\text { Elevation } \\
\text { (ft) }\end{array}$ & $\begin{array}{c}\text { Depth to } \\
\text { Top of } \\
\text { Sump (ft) }\end{array}$ & $\begin{array}{c}\text { Top of } \\
\text { Sump } \\
\text { Elevation } \\
\text { (ft) }\end{array}$ & $\begin{array}{l}\text { Depth to } \\
\text { Sump } \\
\text { Bottom (ft) }\end{array}$ & $\begin{array}{c}\text { Sump } \\
\text { Length } \\
\text { (ft) }\end{array}$ & $\begin{array}{c}\text { Sump } \\
\text { Volume } \\
\text { (L) }\end{array}$ & Comment \\
\hline 1 & 35.0 & 45 & 6808.8 & 6798.8 & 10.0 & & & 45.0 & 6798.8 & 50.0 & 5.0 & 7.0 & Alluvial groundwater \\
\hline
\end{tabular}
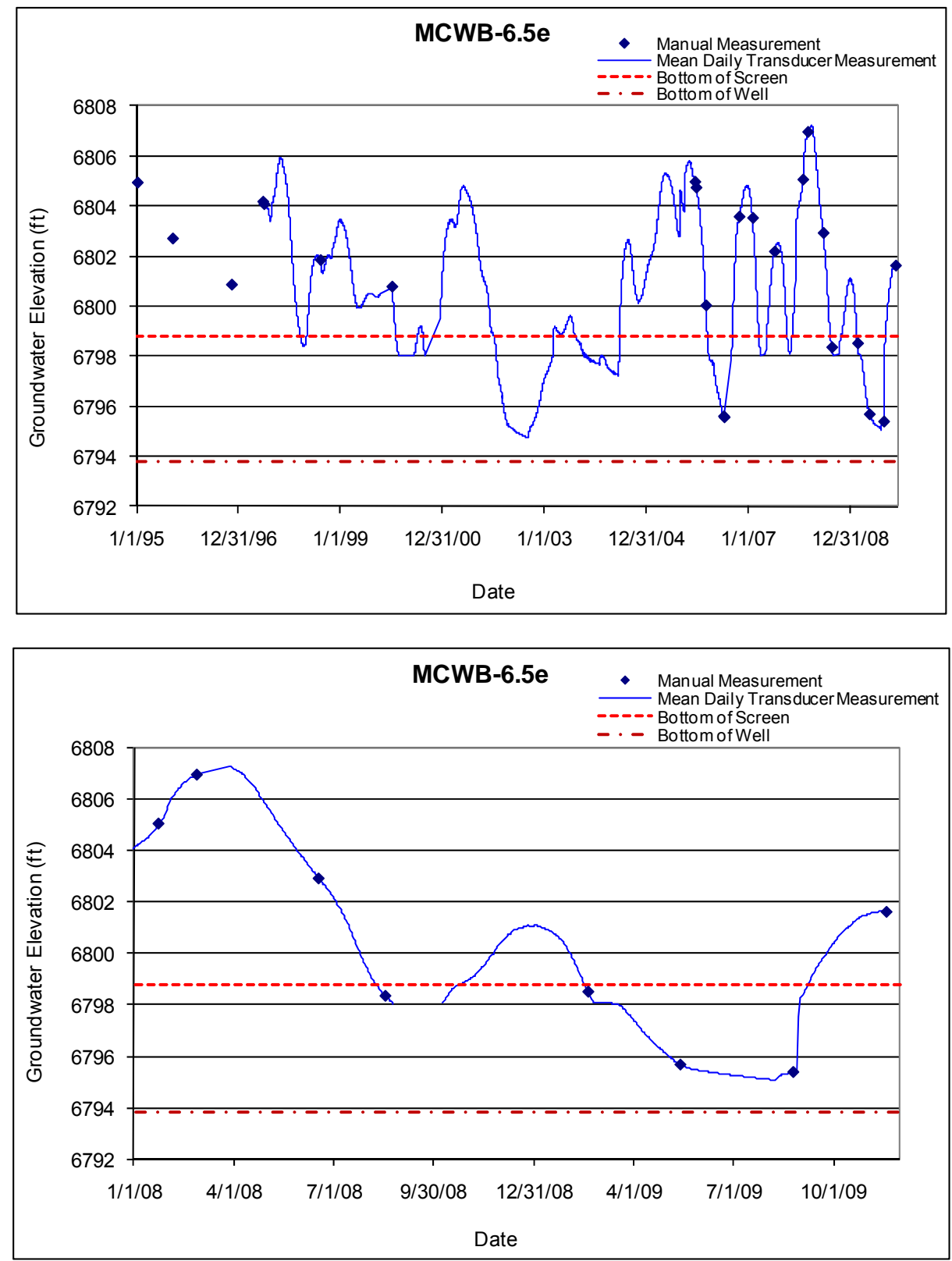


\subsection{MCWB-7a}

Location: Middle Mortandad Canyon, near sediment traps.

Period of Record: January 9, 1995, through November 18, 2009.

Remarks: Water in sump is not invalidated, as it appears to respond to groundwater level fluctuations.

\begin{tabular}{|c|c|c|c|c|c|c|c|c|c|c|c|c|c|}
\hline \multicolumn{14}{|c|}{ MCWB-7a Construction Information } \\
\hline Zone & $\begin{array}{c}\text { Screen } \\
\text { Top } \\
\text { Depth (ft) }\end{array}$ & $\begin{array}{c}\text { Screen } \\
\text { Bottom } \\
\text { Depth } \\
\text { (ft) }\end{array}$ & $\begin{array}{l}\text { Screen } \\
\text { Top } \\
\text { Elev (ft) }\end{array}$ & $\begin{array}{l}\text { Screen } \\
\text { Bottom } \\
\text { Elev }(\mathrm{ft})\end{array}$ & $\begin{array}{c}\text { Screen } \\
\text { Length } \\
\text { (ft) }\end{array}$ & $\begin{array}{c}\text { Pump } \\
\text { Intake } \\
\text { Depth } \\
\text { (ft) }\end{array}$ & $\begin{array}{c}\text { Pump } \\
\text { Intake } \\
\text { Elevation } \\
\text { (ft) }\end{array}$ & $\begin{array}{l}\text { Depth to } \\
\text { Top of } \\
\text { Sump (ft) }\end{array}$ & $\begin{array}{c}\text { Top of } \\
\text { Sump } \\
\text { Elevation } \\
\text { (ft) }\end{array}$ & \begin{tabular}{|} 
Depth to \\
Sump \\
Bottom (ft)
\end{tabular} & $\begin{array}{c}\text { Sump } \\
\text { Length } \\
\text { (ft) }\end{array}$ & $\begin{array}{c}\text { Sump } \\
\text { Volume } \\
\text { (L) }\end{array}$ & Comment \\
\hline 1 & 37.0 & 47.0 & 6794.17 & 6784.17 & 10.0 & & & 47.0 & 6784.2 & 52.0 & 5.0 & 7.0 & Alluvial groundwater \\
\hline
\end{tabular}

Note: Ground elevation is $6831.17 \mathrm{ft}$; all depths are from this elevation
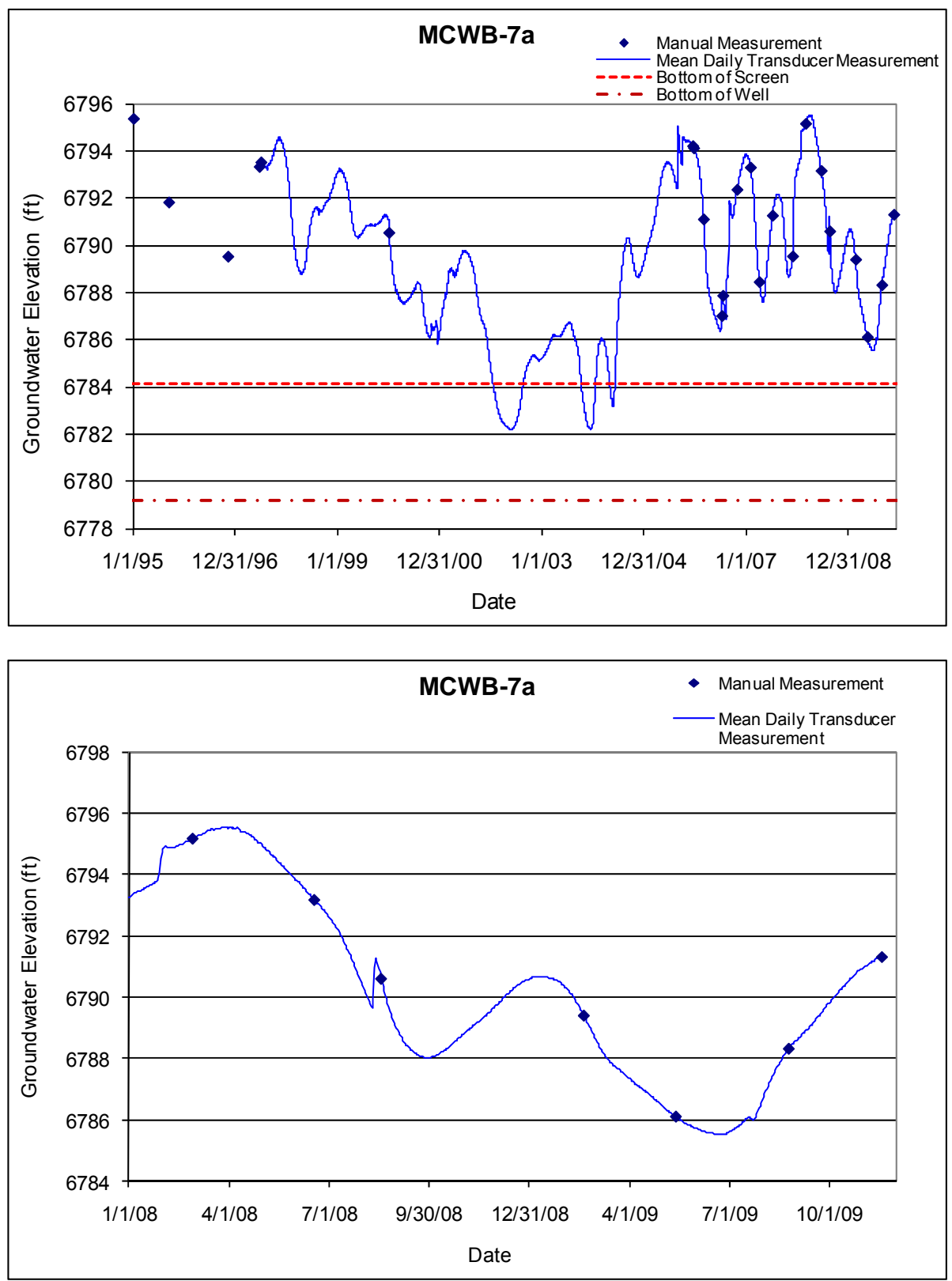


\subsection{MCWB-7.4b}

Location: Middle Mortandad Canyon, down canyon from sediment traps.

Period of Record: January 9, 1995, through November 18, 2009.

Remarks: None.

\begin{tabular}{|c|c|c|c|c|c|c|c|c|c|c|c|c|c|}
\hline \multicolumn{14}{|c|}{ MCWB-7.4b Construction Information } \\
\hline Zone & $\begin{array}{l}\text { Screen } \\
\text { Top } \\
\text { Depth (ft) }\end{array}$ & $\begin{array}{c}\text { Screen } \\
\text { Bottom } \\
\text { Depth } \\
\text { (ft) }\end{array}$ & $\begin{array}{c}\text { Screen } \\
\text { Top } \\
\text { Elev (ft) }\end{array}$ & $\begin{array}{l}\text { Screen } \\
\text { Bottom } \\
\text { Elev (ft) }\end{array}$ & $\begin{array}{c}\text { Screen } \\
\text { Length } \\
\text { (ft) }\end{array}$ & $\begin{array}{c}\text { Pump } \\
\text { Intake } \\
\text { Depth } \\
\text { (ft) }\end{array}$ & $\begin{array}{c}\text { Pump } \\
\text { Intake } \\
\text { Elevation } \\
\text { (ft) }\end{array}$ & $\left|\begin{array}{c}\text { Depth to } \\
\text { Top of } \\
\text { Sump (ft) }\end{array}\right|$ & $\begin{array}{c}\text { Top of } \\
\text { Sump } \\
\text { Elevation } \\
\text { (ft) }\end{array}$ & $\begin{array}{c}\text { Depth to } \\
\text { Sump } \\
\text { Bottom (ft) }\end{array}$ & $\begin{array}{c}\text { Sump } \\
\text { Length } \\
\text { (ft) }\end{array}$ & $\begin{array}{c}\text { Sump } \\
\text { Volume } \\
\text { (L) }\end{array}$ & Comment \\
\hline 1 & 45.0 & 65.0 & 6768.07 & 6748.07 & 20.0 & & & 65.0 & 6748.1 & 70.0 & 5.0 & 7.0 & Alluvial groundwater \\
\hline
\end{tabular}

Note: Ground elevation is $6813.07 \mathrm{ft}$; all depths are from this elevation
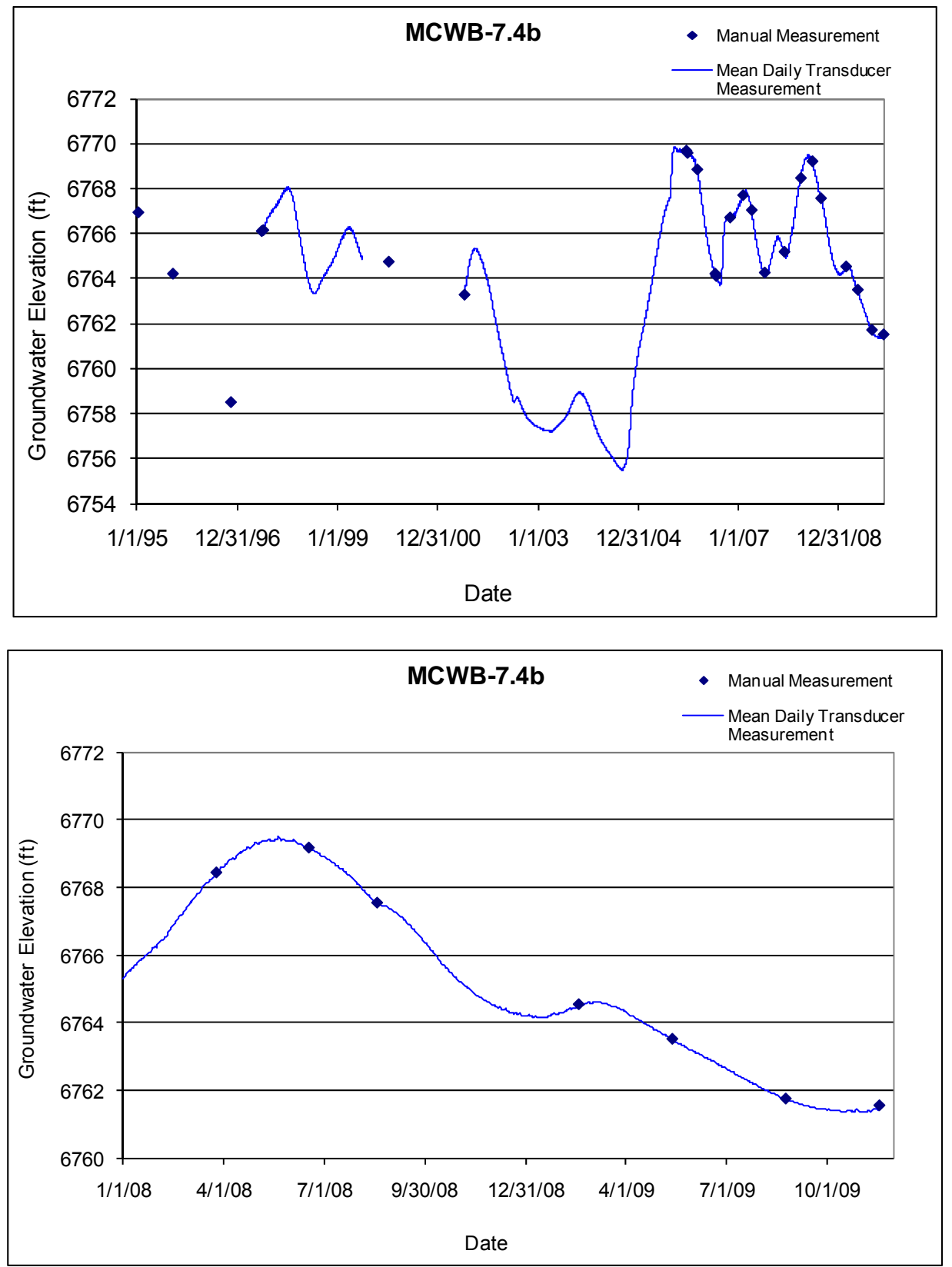


\subsection{MCWB-7.7b}

Location: Middle Mortandad Canyon, down canyon from sediment traps.

Period of Record: January 9, 1995, through November 18, 2009.

Remarks: None.

\begin{tabular}{|c|c|c|c|c|c|c|c|c|c|c|c|c|c|}
\hline \multicolumn{14}{|c|}{ MCWB-7.7b Construction Information } \\
\hline Zone & $\begin{array}{c}\text { Screen } \\
\text { Top } \\
\text { Depth (ft) }\end{array}$ & $\begin{array}{c}\text { Screen } \\
\text { Bottom } \\
\text { Depth } \\
\text { (ft) }\end{array}$ & $\begin{array}{c}\text { Screen } \\
\text { Top } \\
\text { Elev (ft) }\end{array}$ & $\begin{array}{l}\text { Screen } \\
\text { Bottom } \\
\text { Elev (ft) }\end{array}$ & $\begin{array}{c}\text { Screen } \\
\text { Length } \\
\text { (ft) }\end{array}$ & $\begin{array}{c}\text { Pump } \\
\text { Intake } \\
\text { Depth } \\
\text { (ft) }\end{array}$ & $\begin{array}{c}\text { Pump } \\
\text { Intake } \\
\text { Elevation } \\
\text { (ft) }\end{array}$ & $\begin{array}{l}\text { Depth to } \\
\text { Top of } \\
\text { Sump (ft) }\end{array}$ & $\begin{array}{c}\text { Top of } \\
\text { Sump } \\
\text { Elevation } \\
\text { (ft) }\end{array}$ & \begin{tabular}{|c|} 
Depth to \\
Sump \\
Bottom (ft)
\end{tabular} & $\begin{array}{c}\text { Sump } \\
\text { Length } \\
\text { (ft) }\end{array}$ & $\begin{array}{c}\text { Sump } \\
\text { Volume } \\
\text { (L) }\end{array}$ & Comment \\
\hline 1 & 55.0 & 65 & 6744.0 & 6734.0 & 10.0 & & & 65.0 & 6734.0 & 70 & 5.0 & 7.0 & Alluvial groundwater \\
\hline
\end{tabular}
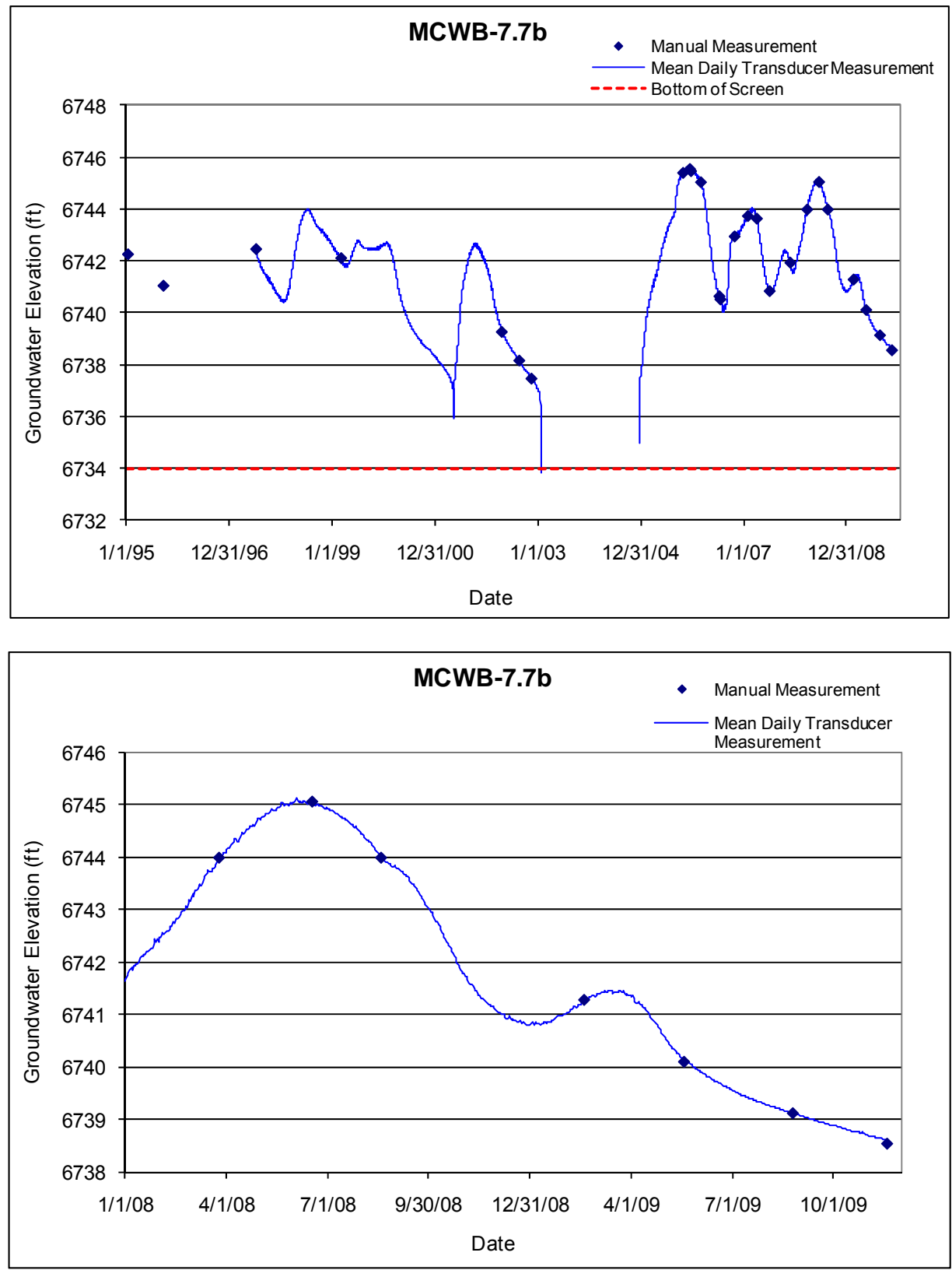


\subsection{MSC-16-06293}

Location: Martin Spring Canyon, about $1600 \mathrm{ft}$ downstream from the Martin Spring outlet. Period of Record: November 6, 2000, through October 30, 2009.

Remarks: This well periodically runs dry.

\begin{tabular}{|c|c|c|c|c|c|c|c|c|c|c|c|c|c|}
\hline \multicolumn{14}{|c|}{ MSC-16-06293 Construction Information } \\
\hline Zone & $\begin{array}{l}\text { Screen } \\
\text { Top } \\
\text { Depth (ft) }\end{array}$ & $\begin{array}{c}\text { Screen } \\
\text { Bottom } \\
\text { Depth } \\
\text { (ft) }\end{array}$ & $\begin{array}{c}\text { Screen } \\
\text { Top } \\
\text { Elev (ft) }\end{array}$ & $\begin{array}{l}\text { Screen } \\
\text { Bottom } \\
\text { Elev (ft) }\end{array}$ & $\begin{array}{c}\text { Screen } \\
\text { Length } \\
\text { (ft) }\end{array}$ & $\begin{array}{c}\text { Pump } \\
\text { Intake } \\
\text { Depth } \\
\text { (ft) }\end{array}$ & $\begin{array}{c}\text { Pump } \\
\text { Intake } \\
\text { Elevation } \\
\text { (ft) }\end{array}$ & \begin{tabular}{|c|} 
Depth to \\
Top of \\
Sump (ft)
\end{tabular} & $\begin{array}{c}\text { Top of } \\
\text { Sump } \\
\text { Elevation } \\
\text { (ft) }\end{array}$ & \begin{tabular}{|c|} 
Depth to \\
Sump \\
Bottom (ft)
\end{tabular} & $\begin{array}{c}\text { Sump } \\
\text { Length } \\
\text { (ft) }\end{array}$ & $\begin{array}{c}\text { Sump } \\
\text { Volume } \\
\text { (L) }\end{array}$ & Comment \\
\hline 1 & 2.3 & 7.3 & 7368.14 & 7363.14 & 5.0 & & & 7.30 & 7363.14 & 7.84 & 0.54 & 1.33 & Alluvial groundwater \\
\hline
\end{tabular}

Note: Brass Cap Elevation: $7370.79 \mathrm{ft}$; Ground elevation: $7370.44 \mathrm{ft}$; all depths are from this elevation
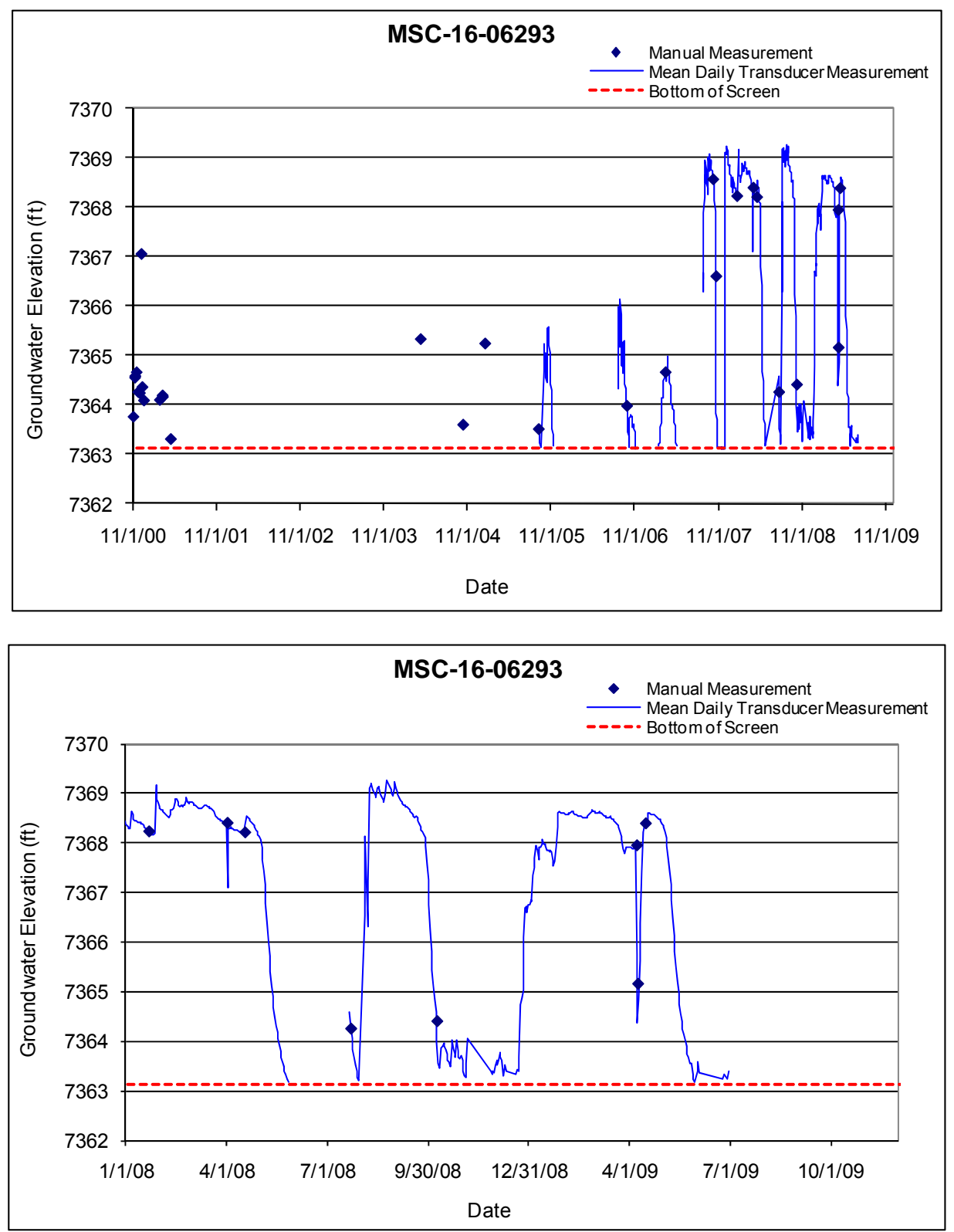


\subsection{MSC-16-06294}

Location: Martin Spring Canyon, about $1600 \mathrm{ft}$ upstream of the K-site wetlands.

Period of Record: November 6, 2000, through October 28, 2009.

Remarks: None.

\begin{tabular}{|c|c|c|c|c|c|c|c|c|c|c|c|c|c|}
\hline \multicolumn{14}{|c|}{ MSC-16-06294 Construction Information } \\
\hline Zone & $\begin{array}{c}\text { Screen } \\
\text { Top } \\
\text { Depth (ft) }\end{array}$ & $\begin{array}{c}\text { Screen } \\
\text { Bottom } \\
\text { Depth } \\
\text { (ft) }\end{array}$ & $\begin{array}{c}\text { Screen } \\
\text { Top } \\
\text { Elev (ft) }\end{array}$ & $\begin{array}{l}\text { Screen } \\
\text { Bottom } \\
\text { Elev (ft) }\end{array}$ & $\begin{array}{c}\text { Screen } \\
\text { Length } \\
\text { (ft) }\end{array}$ & $\begin{array}{l}\text { Pump } \\
\text { Intake } \\
\text { Depth } \\
\text { (ft) }\end{array}$ & $\begin{array}{c}\text { Pump } \\
\text { Intake } \\
\text { Elevation } \\
\text { (ft) }\end{array}$ & \begin{tabular}{|} 
Depth to \\
Top of \\
Sump (ft)
\end{tabular} & $\begin{array}{c}\text { Top of } \\
\text { Sump } \\
\text { Elevation } \\
\text { (ft) }\end{array}$ & \begin{tabular}{|} 
Depth to \\
Sump \\
Bottom (ft)
\end{tabular} & $\begin{array}{c}\text { Sump } \\
\text { Length } \\
\text { (ft) }\end{array}$ & $\begin{array}{l}\text { Sump } \\
\text { Volume } \\
\text { (L) }\end{array}$ & Comment \\
\hline 1 & 2.3 & 7.3 & 7285.84 & 7280.84 & 5.0 & & & 7.3 & 7280.84 & 7.65 & 0.35 & 0.86 & Alluvial groundwater \\
\hline
\end{tabular}
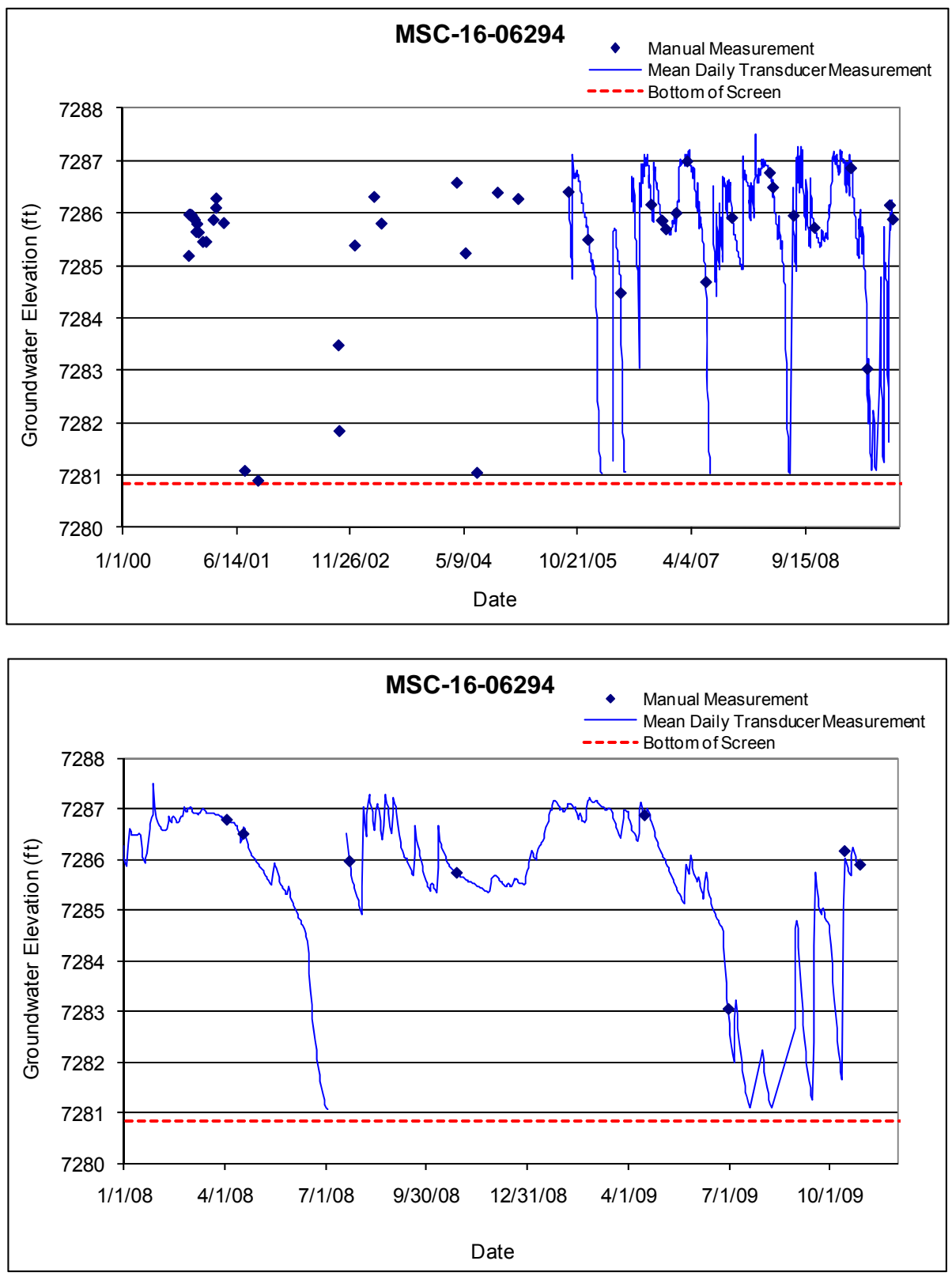


\subsection{MSC-16-06295}

Location: Martin Spring Canyon, just downstream of the K-site wetlands and north of the TA-11 drop tower.

Period of Record: March 10, 2000, through October 28, 2009.

Remarks: Transducer malfunctioned from July 2008 through October 2008.

\begin{tabular}{|c|c|c|c|c|c|c|c|c|c|c|c|c|c|}
\hline \multicolumn{14}{|c|}{ MSC-16-06295 Construction Information } \\
\hline Zone & $\begin{array}{c}\text { Screen } \\
\text { Top } \\
\text { Depth (ft) }\end{array}$ & $\begin{array}{c}\text { Screen } \\
\text { Bottom } \\
\text { Depth } \\
\text { (ft) }\end{array}$ & $\begin{array}{c}\text { Screen } \\
\text { Top } \\
\text { Elev (ft) }\end{array}$ & $\begin{array}{l}\text { Screen } \\
\text { Bottom } \\
\text { Elev (ft) }\end{array}$ & $\begin{array}{c}\text { Screen } \\
\text { Length } \\
\text { (ft) }\end{array}$ & $\begin{array}{l}\text { Pump } \\
\text { Intake } \\
\text { Depth } \\
\text { (ft) }\end{array}$ & $\begin{array}{l}\text { Pump Intake } \\
\text { Elevation (ft) }\end{array}$ & $\begin{array}{l}\text { Depth to } \\
\text { Top of } \\
\text { Sump (ft) }\end{array}$ & $\begin{array}{c}\text { Top of } \\
\text { Sump } \\
\text { Elevation } \\
\text { (ft) }\end{array}$ & $\begin{array}{c}\text { Depth to } \\
\text { Sump } \\
\text { Bottom (ft) }\end{array}$ & $\begin{array}{c}\text { Sump } \\
\text { Length } \\
\text { (ft) }\end{array}$ & $\begin{array}{c}\text { Sump } \\
\text { Volume } \\
\text { (L) }\end{array}$ & Comment \\
\hline 1 & 1.5 & 6.5 & 7254.74 & 7249.74 & 5.0 & & & 6.50 & 7249.74 & 6.85 & 0.35 & 0.86 & Alluvial groundwater \\
\hline
\end{tabular}

Note: Brass Cap Elevation: $7257.03 \mathrm{ft}$; Ground elevation: $7256.24 \mathrm{ft}$; all depths are from this elevation
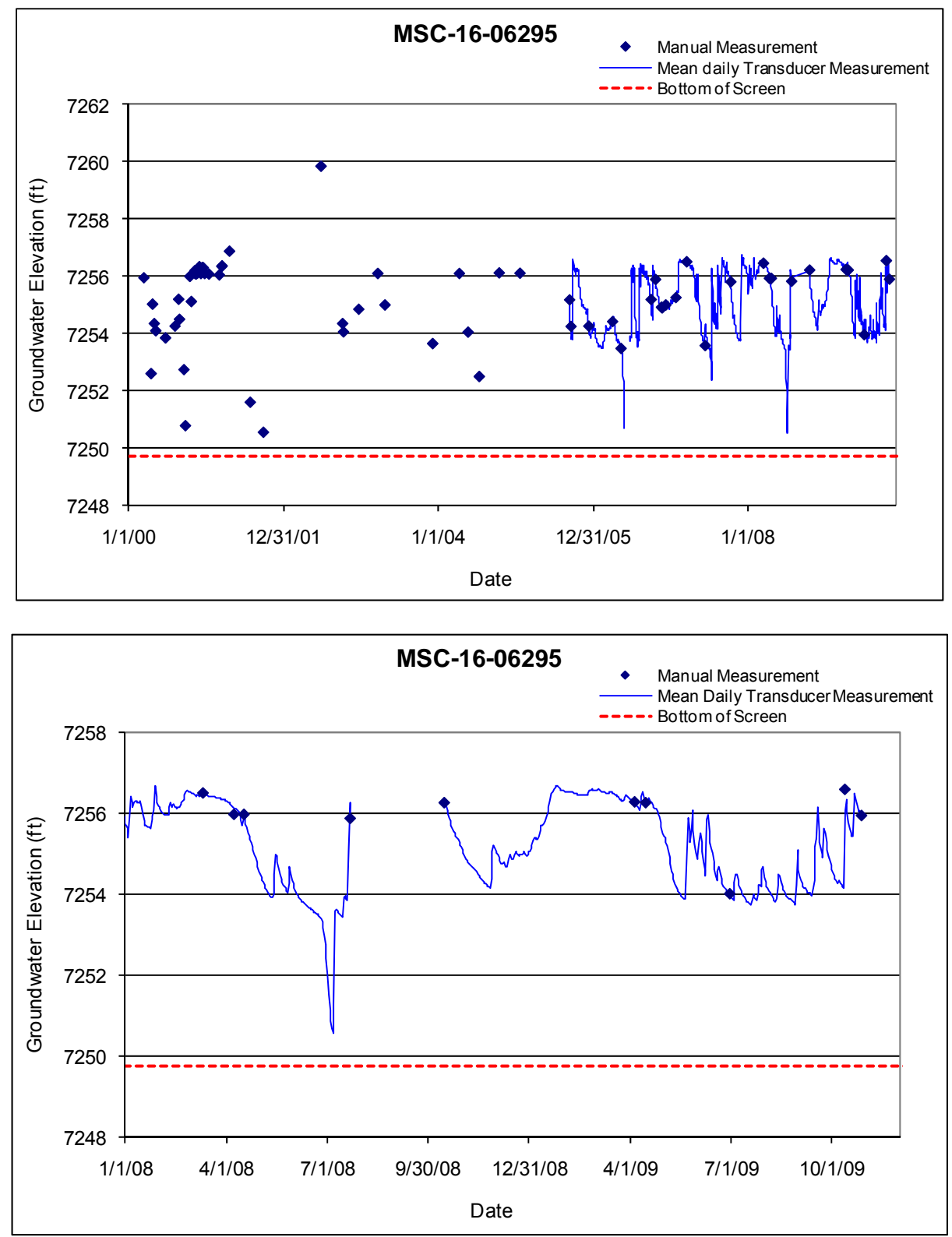


\subsection{MT-1}

Location: Middle Mortandad Canyon, approximately 0.12 miles east of MCO-7.

Period of Record: November 1, 1988, through November 27, 2007.

Remarks: Monitoring of this well was discontinued November 27, 2007.

\begin{tabular}{|c|c|c|c|c|c|c|c|c|c|c|c|c|c|}
\hline \multicolumn{14}{|c|}{ MT-1 Construction Information } \\
\hline Zone & $\begin{array}{c}\text { Screen } \\
\text { Top } \\
\text { Depth (ft) }\end{array}$ & $\begin{array}{c}\text { Screen } \\
\text { Bottom } \\
\text { Depth } \\
\text { (ft) }\end{array}$ & $\begin{array}{c}\text { Screen } \\
\text { Top } \\
\text { Elev (ft) }\end{array}$ & $\begin{array}{l}\text { Screen } \\
\text { Bottom } \\
\text { Elev (ft) }\end{array}$ & $\begin{array}{c}\text { Screen } \\
\text { Length } \\
\text { (ft) }\end{array}$ & $\begin{array}{l}\text { Pump } \\
\text { Intake } \\
\text { Depth } \\
\text { (ft) }\end{array}$ & $\begin{array}{c}\text { Pump } \\
\text { Intake } \\
\text { Elevation } \\
\text { (ft) }\end{array}$ & $\begin{array}{l}\text { Depth to } \\
\text { Top of } \\
\text { Sump (ft) }\end{array}$ & $\begin{array}{c}\text { Top of } \\
\text { Sump } \\
\text { Elevation } \\
\text { (ft) }\end{array}$ & \begin{tabular}{|c|} 
Depth to \\
Sump \\
Bottom (ft)
\end{tabular} & $\begin{array}{c}\text { Sump } \\
\text { Length } \\
\text { (ft) }\end{array}$ & $\begin{array}{c}\text { Sump } \\
\text { Volume } \\
\text { (L) }\end{array}$ & Comment \\
\hline 1 & 39.0 & 59.0 & 6772.6 & 6752.6 & 20.0 & & & 59.0 & 6752.6 & 69.0 & 10.0 & 6.2 & Alluvial groundwater \\
\hline
\end{tabular}

Note: Ground elevation is $6811.63 \mathrm{ft}$; all depths are from this elevation
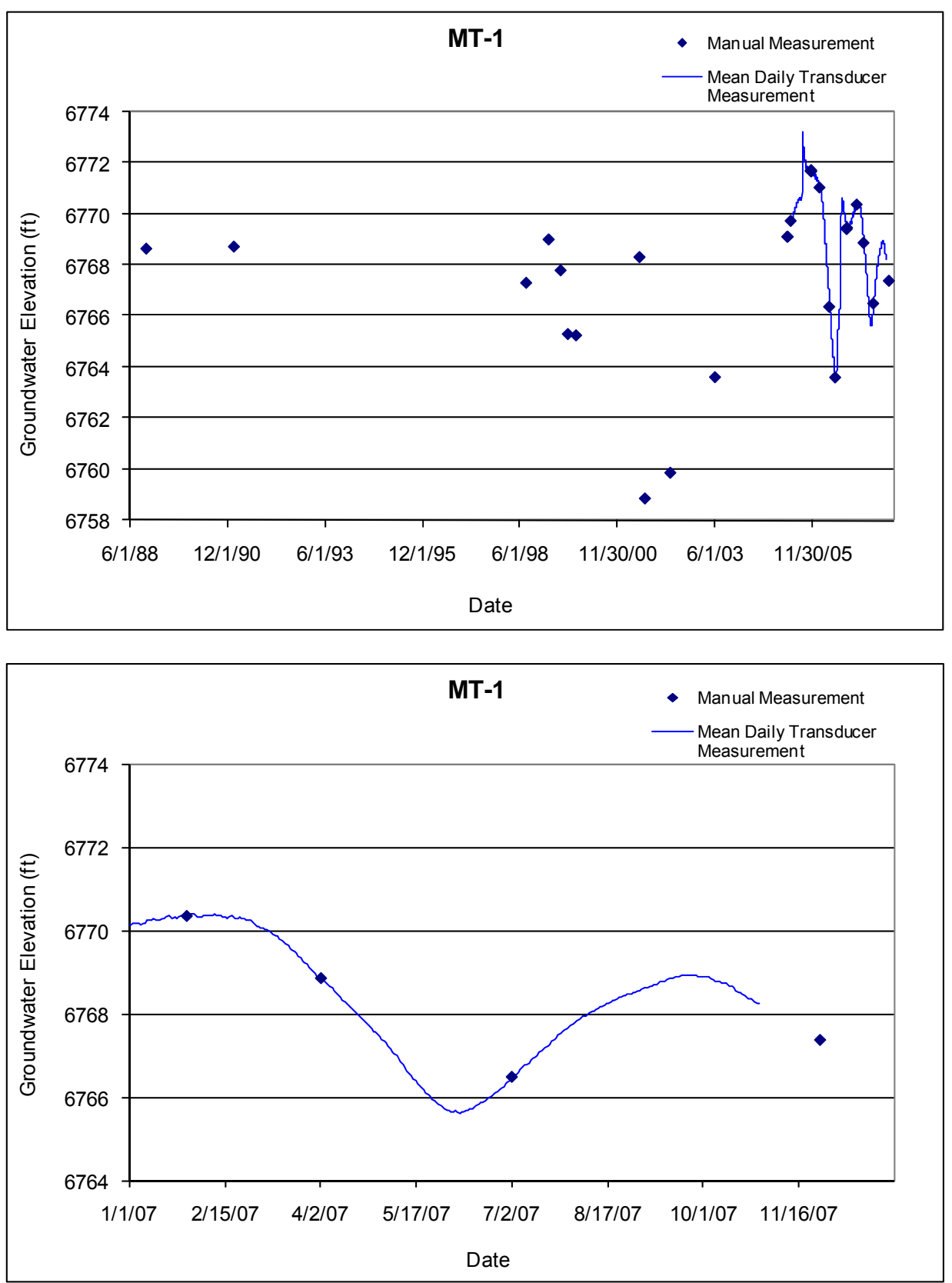


\subsection{MT-2}

Location: Middle Mortandad Canyon, down canyon of sediment traps, approximately 0.12 miles east of MT-1.

Period of Record: November 1, 1988, through November 18, 2009.

Remarks: The transducer was above the pump until April 17, 2007; transducer data before April 17, 2007, do not represent water levels below $6749.3 \mathrm{ft}$. Transducer was removed from well from November 28, 2007, through August 19, 2008.

\begin{tabular}{|c|c|c|c|c|c|c|c|c|c|c|c|c|c|}
\hline \multicolumn{14}{|c|}{ MT-2 Construction Information } \\
\hline Zone & $\begin{array}{l}\text { Screen } \\
\text { Top } \\
\text { Depth (ft) }\end{array}$ & $\begin{array}{c}\text { Screen } \\
\text { Bottom } \\
\text { Depth } \\
\text { (ft) }\end{array}$ & $\begin{array}{l}\text { Screen } \\
\text { Top } \\
\text { Elev (ft) }\end{array}$ & $\begin{array}{l}\text { Screen } \\
\text { Bottom } \\
\text { Elev (ft) }\end{array}$ & $\begin{array}{c}\text { Screen } \\
\text { Length } \\
\text { (ft) }\end{array}$ & $\begin{array}{l}\text { Pump } \\
\text { Intake } \\
\text { Depth } \\
\text { (ft) }\end{array}$ & $\begin{array}{c}\text { Pump } \\
\text { Intake } \\
\text { Elevation } \\
\text { (ft) }\end{array}$ & $\begin{array}{l}\text { Depth to } \\
\text { Top of } \\
\text { Sump (ft) }\end{array}$ & $\begin{array}{c}\text { Top of } \\
\text { Sump } \\
\text { Elevation } \\
\text { (ft) }\end{array}$ & $\begin{array}{l}\text { Depth to } \\
\text { Sump } \\
\text { Bottom (ft) }\end{array}$ & $\begin{array}{c}\text { Sump } \\
\text { Length } \\
\text { (ft) }\end{array}$ & $\begin{array}{c}\text { Sump } \\
\text { Volume } \\
\text { (L) }\end{array}$ & Comment \\
\hline 1 & 44.0 & 64 & 6752.2 & 6732.2 & 20.0 & & & 64.0 & 6732.2 & 64.3 & 0.3 & 0.2 & Alluvial groundwater \\
\hline
\end{tabular}

Note: Ground elevation is $6796.20 \mathrm{ft}$; all depths are from this elevation
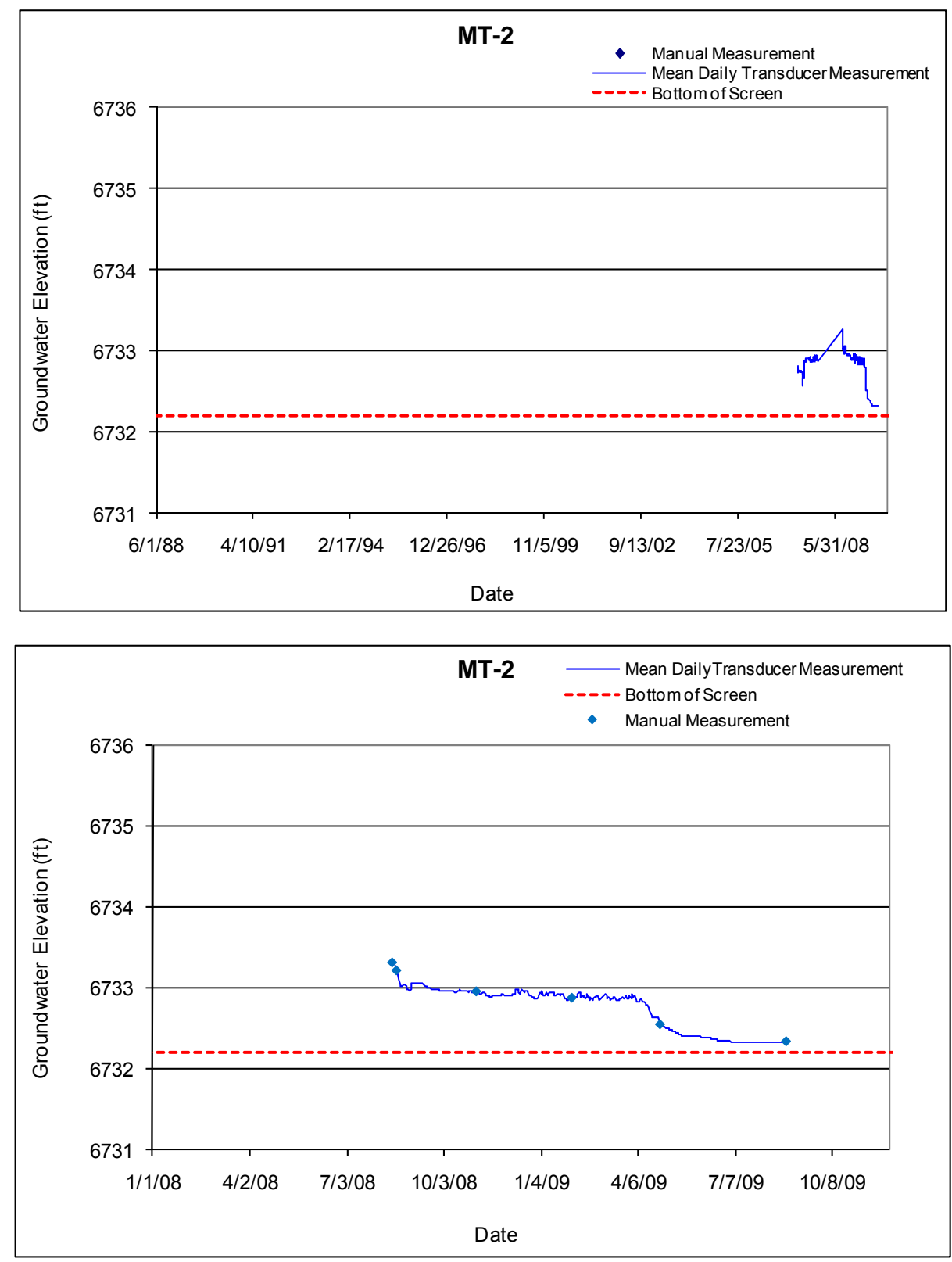


\subsection{MT-3}

Location: Middle Mortandad Canyon, down canyon of sediment traps, approximately 0.12 miles east of MT-1 and approximately $50 \mathrm{ft}$ north of MT-2.

Period of Record: November 1, 1988, through November 2, 2009.

Remarks: None.

\begin{tabular}{|c|c|c|c|c|c|c|c|c|c|c|c|c|c|}
\hline \multicolumn{14}{|c|}{ MT-3 Construction Information } \\
\hline Zone & $\begin{array}{c}\text { Screen } \\
\text { Top } \\
\text { Depth (ft) }\end{array}$ & $\begin{array}{c}\text { Screen } \\
\text { Bottom } \\
\text { Depth } \\
\text { (ft) }\end{array}$ & $\begin{array}{c}\text { Screen } \\
\text { Top } \\
\text { Elev (ft) }\end{array}$ & $\begin{array}{l}\text { Screen } \\
\text { Bottom } \\
\text { Elev (ft) }\end{array}$ & $\begin{array}{c}\text { Screen } \\
\text { Length } \\
\text { (ft) }\end{array}$ & $\begin{array}{c}\text { Pump } \\
\text { Intake } \\
\text { Depth } \\
\text { (ft) }\end{array}$ & $\begin{array}{c}\text { Pump } \\
\text { Intake } \\
\text { Elevation } \\
\text { (ft) }\end{array}$ & $\begin{array}{c}\text { Depth to } \\
\text { Top of } \\
\text { Sump (ft) }\end{array}$ & $\begin{array}{c}\text { Top of } \\
\text { Sump } \\
\text { Elevation } \\
\text { (ft) }\end{array}$ & \begin{tabular}{|c|} 
Depth to \\
Sump \\
Bottom (ft)
\end{tabular} & $\begin{array}{c}\text { Sump } \\
\text { Length } \\
\text { (ft) }\end{array}$ & $\begin{array}{c}\text { Sump } \\
\text { Volume } \\
\text { (L) }\end{array}$ & Comment \\
\hline 1 & 44.0 & 64.0 & 6752.7 & 6732.7 & 20.0 & & & 64.0 & 6732.7 & 74.0 & 10.0 & 6.2 & Alluvial groundwater \\
\hline
\end{tabular}

Note: Ground elevation is $6796.65 \mathrm{ft}$; all depths are from this elevation
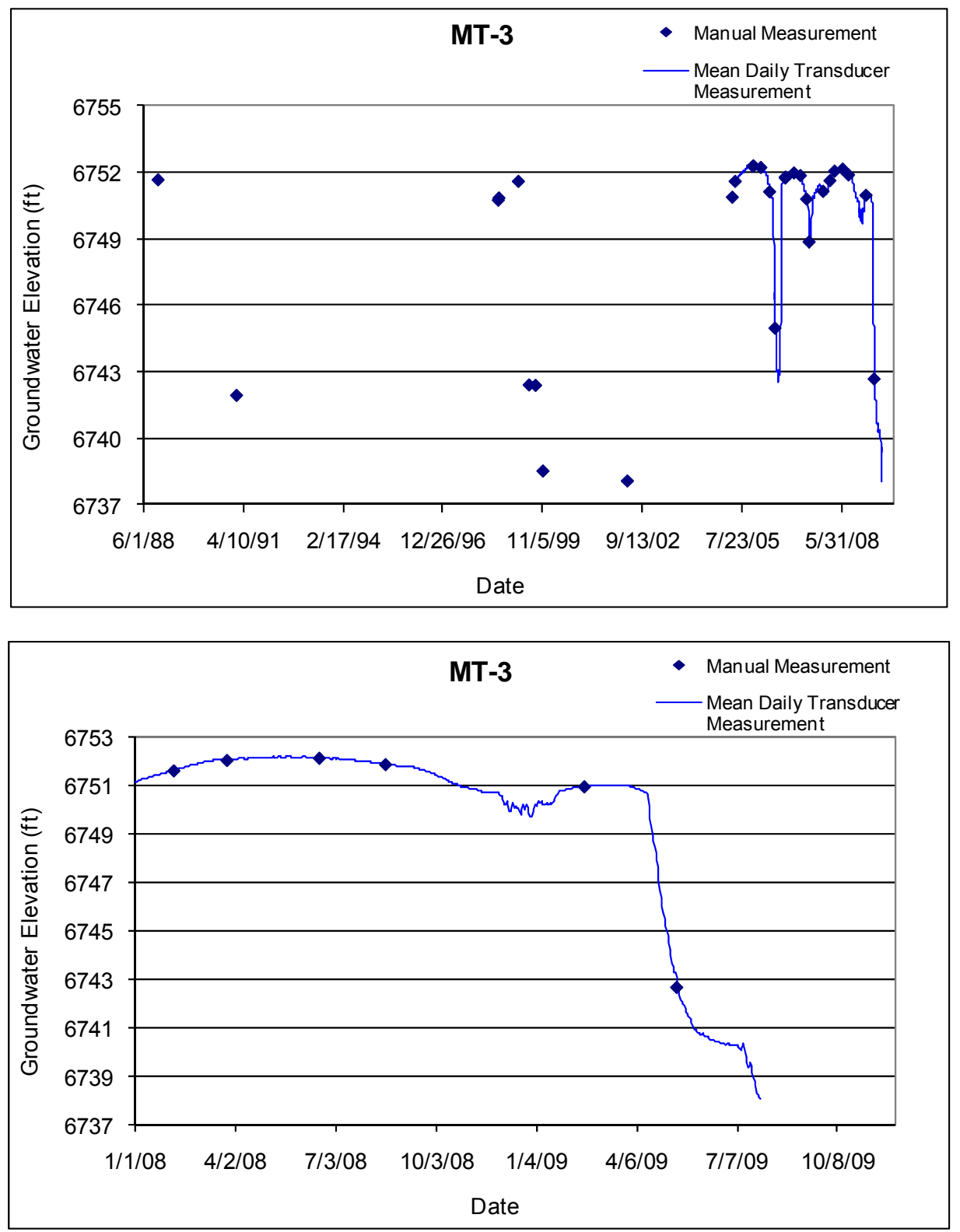


\subsection{MT-4}

Location: Middle Mortandad Canyon, down canyon of the sediment traps, approximately $525 \mathrm{ft}$ east of MT-3.

Period of Record: November 1, 1988, through November 18, 2009.

Remarks: None.

\begin{tabular}{|c|c|c|c|c|c|c|c|c|c|c|c|c|c|}
\hline \multicolumn{14}{|c|}{ MT-4 Construction Information } \\
\hline Zone & $\begin{array}{c}\text { Screen } \\
\text { Top } \\
\text { Depth (ft) }\end{array}$ & $\begin{array}{c}\text { Screen } \\
\text { Bottom } \\
\text { Depth } \\
\text { (ft) }\end{array}$ & $\begin{array}{c}\text { Screen } \\
\text { Top } \\
\text { Elev (ft) }\end{array}$ & $\begin{array}{l}\text { Screen } \\
\text { Bottom } \\
\text { Elev (ft) }\end{array}$ & $\begin{array}{c}\text { Screen } \\
\text { Length } \\
\text { (ft) }\end{array}$ & $\begin{array}{l}\text { Pump } \\
\text { Intake } \\
\text { Depth } \\
\text { (ft) }\end{array}$ & $\begin{array}{c}\text { Pump } \\
\text { Intake } \\
\text { Elevation } \\
\text { (ft) }\end{array}$ & $\begin{array}{c}\text { Depth to } \\
\text { Top of } \\
\text { Sump (ft) }\end{array}$ & $\begin{array}{c}\text { Top of } \\
\text { Sump } \\
\text { Elevation } \\
\text { (ft) }\end{array}$ & $\begin{array}{l}\text { Depth to } \\
\text { Sump } \\
\text { Bottom (ft) }\end{array}$ & $\begin{array}{c}\text { Sump } \\
\text { Length } \\
\text { (ft) }\end{array}$ & $\begin{array}{c}\text { Sump } \\
\text { Volume } \\
\text { (L) }\end{array}$ & Comment \\
\hline 1 & 54 & 64 & 6729.59 & 6719.59 & 10 & & & 64 & 6719.59 & 74 & 10 & 6 & Alluvial groundwater \\
\hline
\end{tabular}

Note: Ground elevation is $6783.59 \mathrm{ft}$; all depths are from this elevation
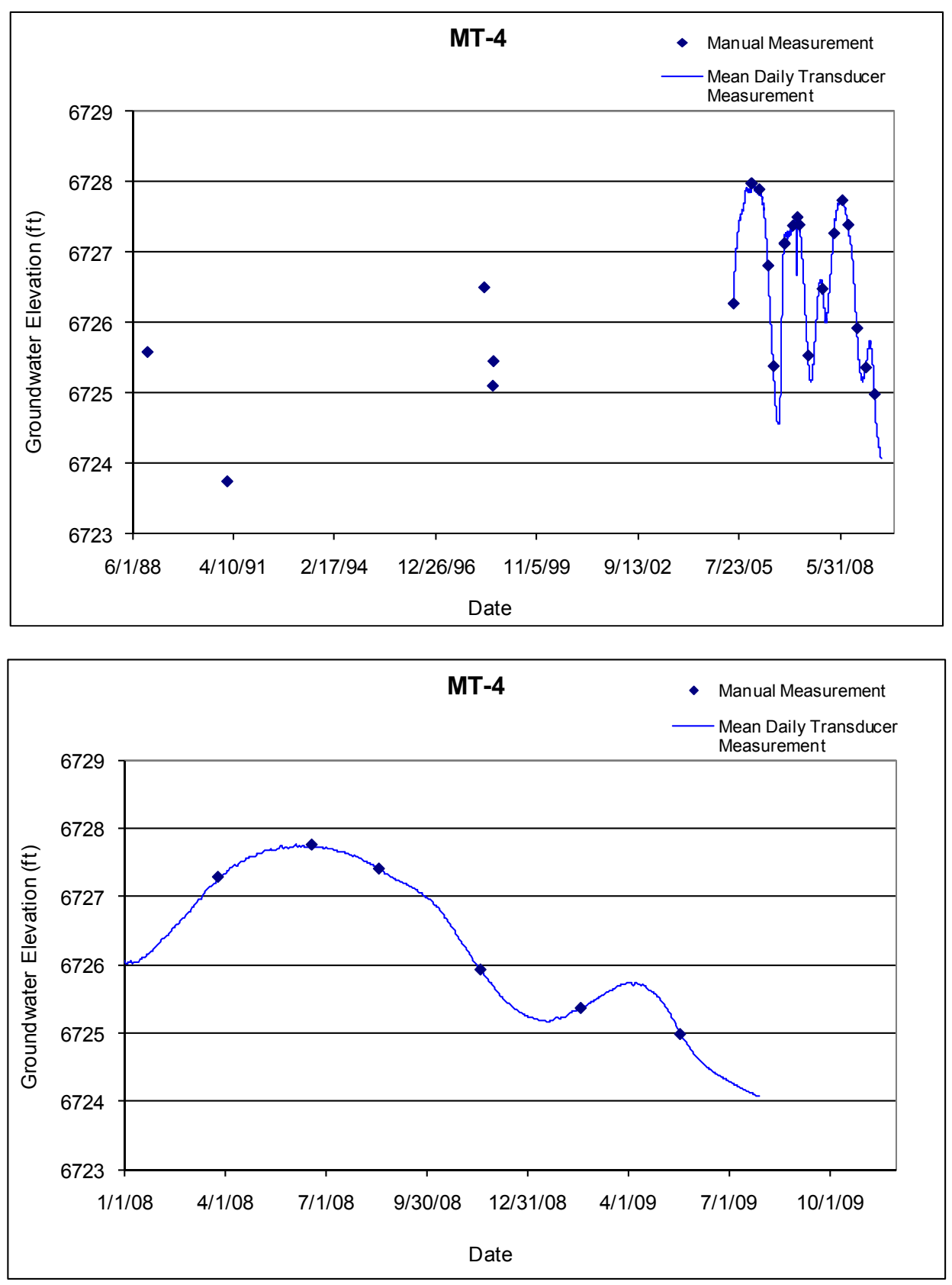


\subsection{PAO-1}

Location: Upper Pueblo Canyon, approximately $1000 \mathrm{ft}$ west of the confluence with Acid Canyon. Period of Record: October 29,1998, through January 26, 2010.

Remarks: The transducer batteries failed on December 3, 2006, and were replaced on February 27 , 2007.

\begin{tabular}{|c|c|c|c|c|c|c|c|c|c|c|c|c|c|}
\hline \multicolumn{14}{|c|}{ PAO-1 Construction Information } \\
\hline Zone & $\begin{array}{l}\text { Screen } \\
\text { Top } \\
\text { Depth (ft) }\end{array}$ & $\begin{array}{c}\text { Screen } \\
\text { Bottom } \\
\text { Depth } \\
\text { (ft) }\end{array}$ & $\begin{array}{c}\text { Screen } \\
\text { Top } \\
\text { Elev (ft) }\end{array}$ & $\begin{array}{l}\text { Screen } \\
\text { Bottom } \\
\text { Elev (ft) }\end{array}$ & $\begin{array}{c}\text { Screen } \\
\text { Length } \\
\text { (ft) }\end{array}$ & $\begin{array}{l}\text { Pump } \\
\text { Intake } \\
\text { Depth } \\
\text { (ft) }\end{array}$ & $\begin{array}{c}\text { Pump } \\
\text { Intake } \\
\text { Elevation } \\
\text { (ft) }\end{array}$ & $\begin{array}{c}\text { Depth to } \\
\text { Top of } \\
\text { Sump (ft) }\end{array}$ & \begin{tabular}{|c} 
Top of \\
Sump \\
Elevation \\
(ft)
\end{tabular} & \begin{tabular}{|c|} 
Depth to \\
Sump \\
Bottom (ft)
\end{tabular} & $\begin{array}{c}\text { Sump } \\
\text { Length } \\
\text { (ft) }\end{array}$ & $\begin{array}{c}\text { Sump } \\
\text { Volume } \\
\text { (L) }\end{array}$ & Comment \\
\hline 1 & 5.89 & 10.89 & 6948.58 & 6943.58 & 5.00 & & & 10.89 & 6944.08 & 13.74 & 2.85 & 7.04 & Alluvial groundwater \\
\hline
\end{tabular}

Note: Brass Cap Elevation: $6954.97 \mathrm{ft}$; Ground elevation is $6954.47 \mathrm{ft}$; all depths are from this elevation
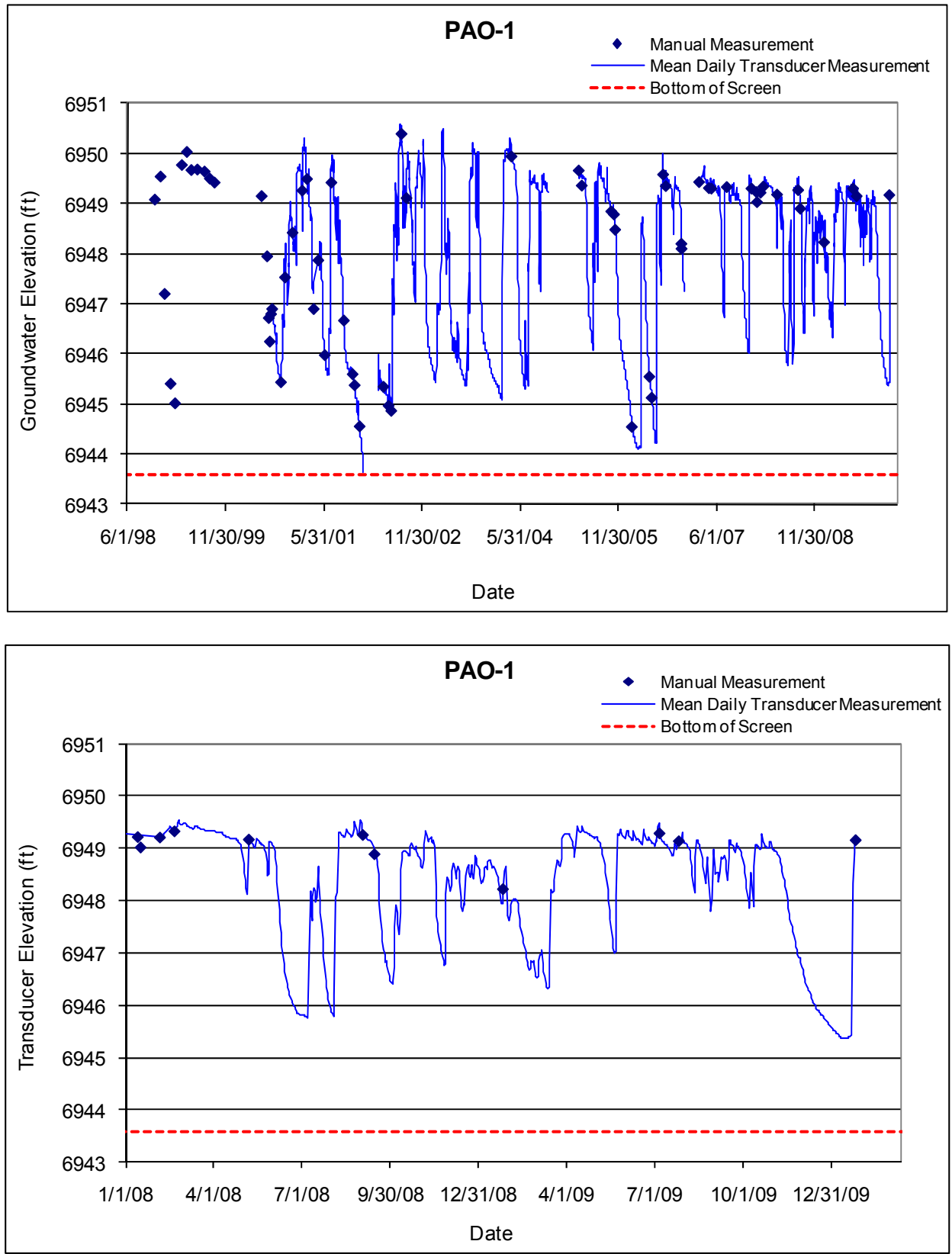


\subsection{PAO-2}

Location: Upper Pueblo Canyon, approximately $500 \mathrm{ft}$ east of the Acid Canyon confluence.

Period of Record: November 30, 1998, through December 2, 2009.

Remarks: The water level frequently drops below the screen.

\begin{tabular}{|c|c|c|c|c|c|c|c|c|c|c|c|c|c|}
\hline \multicolumn{14}{|c|}{ PAO-2 Construction Information } \\
\hline Zone & $\begin{array}{l}\text { Screen } \\
\text { Top } \\
\text { Depth (ft) }\end{array}$ & $\begin{array}{c}\text { Screen } \\
\text { Bottom } \\
\text { Depth } \\
\text { (ft) }\end{array}$ & $\begin{array}{c}\text { Screen } \\
\text { Top } \\
\text { Elev (ft) }\end{array}$ & $\begin{array}{l}\text { Screen } \\
\text { Bottom } \\
\text { Elev (ft) }\end{array}$ & $\begin{array}{c}\text { Screen } \\
\text { Length } \\
\text { (ft) }\end{array}$ & $\begin{array}{c}\text { Pump } \\
\text { Intake } \\
\text { Depth } \\
\text { (ft) }\end{array}$ & $\begin{array}{c}\text { Pump } \\
\text { Intake } \\
\text { Elevation } \\
\text { (ft) }\end{array}$ & $\begin{array}{c}\text { Depth to } \\
\text { Top of } \\
\text { Sump (ft) }\end{array}$ & $\begin{array}{c}\text { Top of } \\
\text { Sump } \\
\text { Elevation } \\
\text { (ft) }\end{array}$ & \begin{tabular}{|c|} 
Depth to \\
Sump \\
Bottom (ft)
\end{tabular} & $\begin{array}{c}\text { Sump } \\
\text { Length } \\
\text { (ft) }\end{array}$ & $\begin{array}{c}\text { Sump } \\
\text { Volume } \\
\text { (L) }\end{array}$ & Comment \\
\hline 1 & 6.06 & 11.06 & 6914.37 & 6919.37 & 5.00 & & & 11.06 & 6919.37 & 13.91 & 2.85 & 7.04 & Alluvial groundwater \\
\hline
\end{tabular}
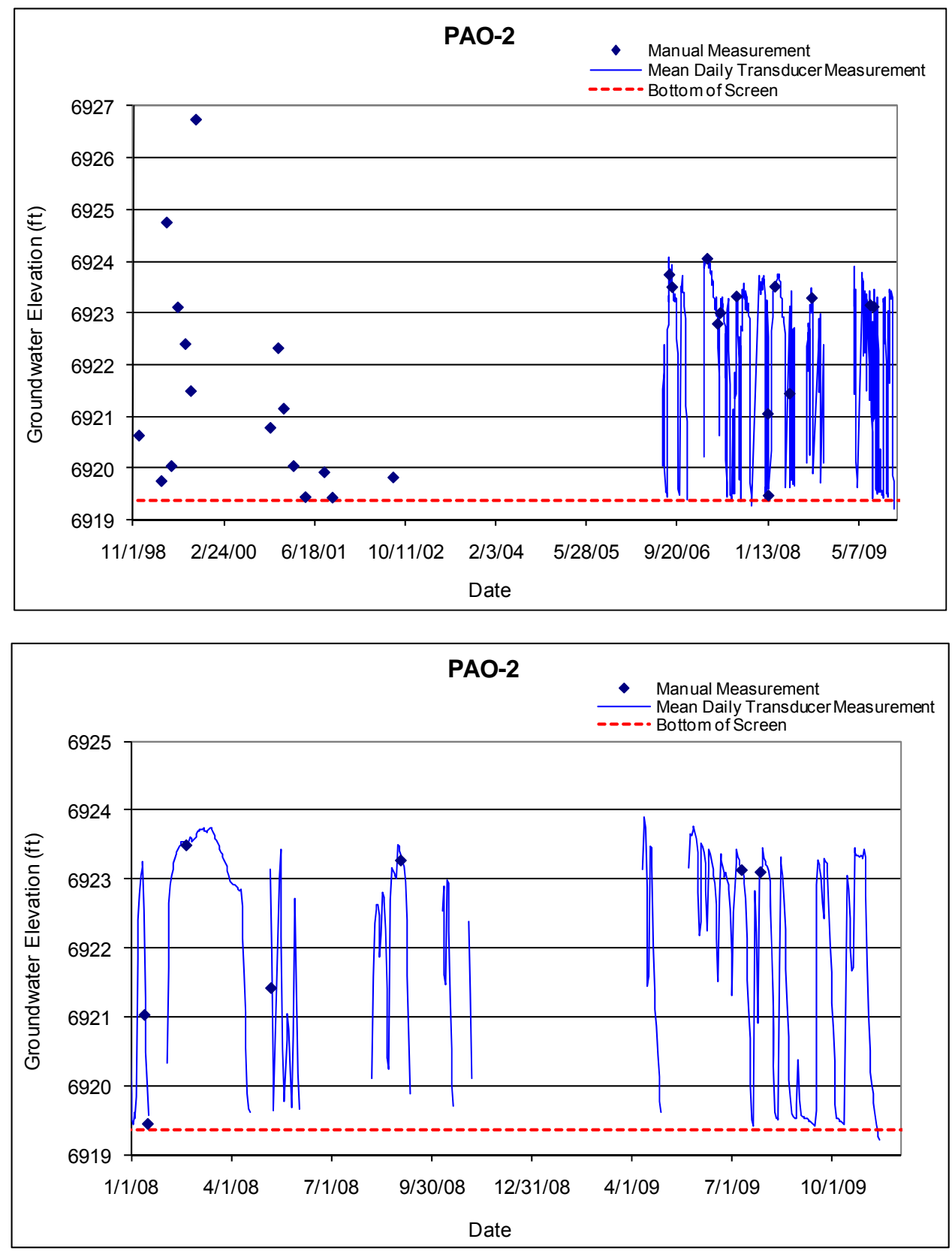


\subsection{PAO-4}

Location: Lower Pueblo Canyon, approximately $3100 \mathrm{ft}$ southeast of the old LAC Sewage Treatment Plant location.

Period of Record: July 24, 1997, through January 11, 2010.

Remarks: Transducer failed from September 2008 through January 2009, and from June 2009 through July 2009.

\begin{tabular}{|c|c|c|c|c|c|c|c|c|c|c|c|c|c|}
\hline \multicolumn{14}{|c|}{ PAO-4 Construction Information } \\
\hline Zone & $\begin{array}{c}\text { Screen } \\
\text { Top } \\
\text { Depth (ft) }\end{array}$ & $\begin{array}{c}\text { Screen } \\
\text { Bottom } \\
\text { Depth } \\
\text { (ft) }\end{array}$ & $\begin{array}{c}\text { Screen } \\
\text { Top } \\
\text { Elev (ft) }\end{array}$ & $\begin{array}{l}\text { Screen } \\
\text { Bottom } \\
\text { Elev (ft) }\end{array}$ & $\begin{array}{c}\text { Screen } \\
\text { Length } \\
\text { (ft) }\end{array}$ & $\begin{array}{c}\text { Pump } \\
\text { Intake } \\
\text { Depth } \\
\text { (ft) }\end{array}$ & $\begin{array}{c}\text { Pump } \\
\text { Intake } \\
\text { Elevation } \\
\text { (ft) }\end{array}$ & \begin{tabular}{|c|} 
Depth to \\
Top of \\
Sump (ft)
\end{tabular} & $\begin{array}{c}\text { Top of } \\
\text { Sump } \\
\text { Elevation } \\
\text { (ft) }\end{array}$ & \begin{tabular}{|c|} 
Depth to \\
Sump \\
Bottom (ft)
\end{tabular} & $\begin{array}{l}\text { Sump } \\
\text { Length } \\
\text { (ft) }\end{array}$ & $\begin{array}{c}\text { Sump } \\
\text { Volume } \\
\text { (L) }\end{array}$ & Comment \\
\hline 1 & 1.97 & 6.97 & 6435.07 & 6430.07 & 5.00 & & & 6.97 & 6430.07 & 9.82 & 2.85 & 7.04 & Alluvial groundwater \\
\hline
\end{tabular}
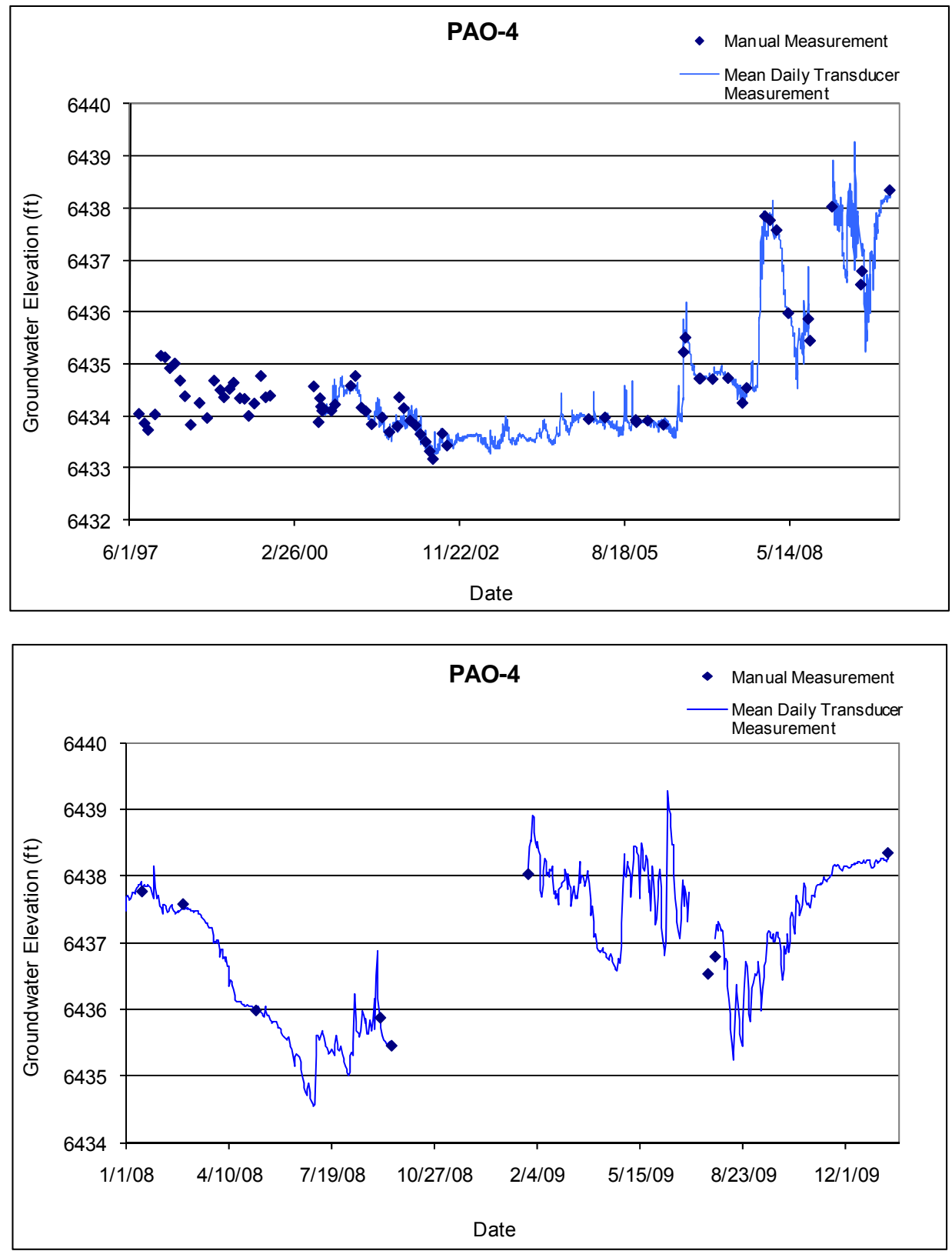


\subsection{PCAO-5}

Location: Middle Pajarito Canyon, adjacent to and on the north side of the stream channel, approximately $100 \mathrm{ft}$ upstream of the flood retention dam.

Period of Record: May 3, 2008, through December 17, 2009.

Remarks: None.

\begin{tabular}{|c|c|c|c|c|c|c|c|c|c|c|c|c|c|}
\hline \multicolumn{14}{|c|}{ PCAO-5 Construction Information } \\
\hline Zone & $\begin{array}{l}\text { Screen } \\
\text { Top } \\
\text { Depth } \\
\text { (ft) }\end{array}$ & $\begin{array}{c}\text { Screen } \\
\text { Bottom } \\
\text { Depth (ft) }\end{array}$ & $\begin{array}{c}\text { Screen } \\
\text { Top Elev } \\
\text { (ft) }\end{array}$ & $\begin{array}{l}\text { Screen } \\
\text { Bottom } \\
\text { Elev (ft) }\end{array}$ & $\begin{array}{l}\text { Screen } \\
\text { Length } \\
\text { (ft) }\end{array}$ & $\begin{array}{c}\text { Pump } \\
\text { Intake } \\
\text { Depth (ft) }\end{array}$ & $\begin{array}{c}\text { Pump } \\
\text { Intake } \\
\text { Elevation } \\
\text { (ft) }\end{array}$ & $\begin{array}{l}\text { Depth to } \\
\text { Top of } \\
\text { Sump (ft) }\end{array}$ & $\begin{array}{c}\text { Top of } \\
\text { Sump } \\
\text { Elevation } \\
\text { (ft) }\end{array}$ & $\begin{array}{c}\text { Depth to } \\
\text { Sump } \\
\text { Bottom } \\
\text { (ft) }\end{array}$ & $\begin{array}{c}\text { Sump } \\
\text { Length } \\
\text { (ft) }\end{array}$ & $\begin{array}{c}\text { Sump } \\
\text { Volume } \\
\text { (L) }\end{array}$ & Comment \\
\hline 1 & 14.7 & 24.7 & 6928.6 & 6918.6 & 10.0 & & & 24.7 & 6918.6 & 30.0 & 5.3 & 13.1 & Alluvial Groundwater \\
\hline
\end{tabular}

Note: Ground elevation is $6943.29 \mathrm{ft}$; all depths from this elevation

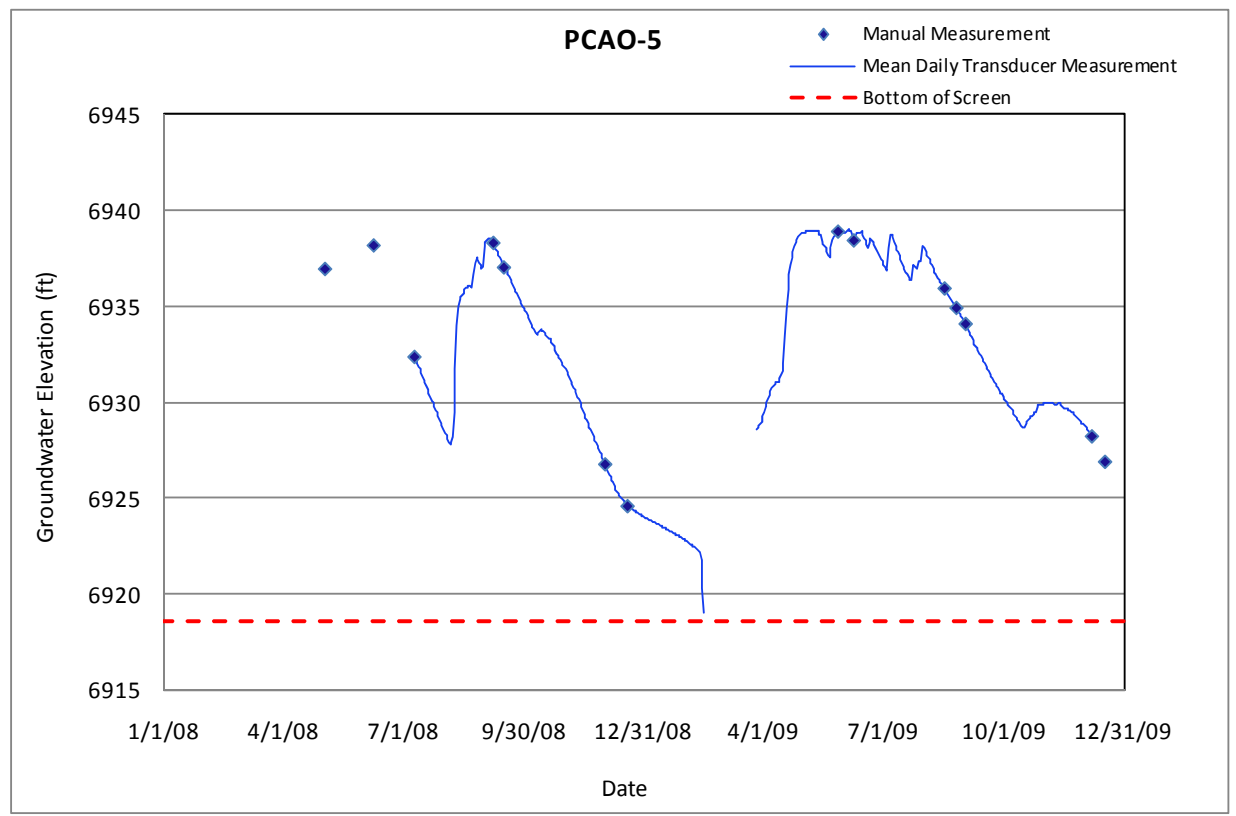




\subsection{PCAO-6}

Location: Middle Pajarito Canyon, on the south side of the stream channel, approximately $300 \mathrm{ft}$ downstream of the flood retention dam, and approximately $100 \mathrm{ft}$ west of regional well R-17.

Period of Record: June 5, 2008, through December 7, 2009.

Remarks: Well was purged dry during drilling (less than one gallon of water). Until April 2009, water did not rise above the sump. Well remained wet during the summer of 2009.

\begin{tabular}{|c|c|c|c|c|c|c|c|c|c|c|c|c|c|}
\hline \multicolumn{14}{|c|}{ PCAO-6 Construction Information } \\
\hline Zone & $\begin{array}{c}\text { Screen } \\
\text { Top } \\
\text { Depth (ft) }\end{array}$ & $\begin{array}{c}\text { Screen } \\
\text { Bottom } \\
\text { Depth (ft) }\end{array}$ & $\begin{array}{c}\text { Screen } \\
\text { Top } \\
\text { Elev (ft) }\end{array}$ & $\begin{array}{l}\text { Screen } \\
\text { Bottom } \\
\text { Elev (ft) }\end{array}$ & $\begin{array}{c}\text { Screen } \\
\text { Length } \\
\text { (ft) }\end{array}$ & $\begin{array}{c}\text { Pump } \\
\text { Intake } \\
\text { Depth } \\
\text { (ft) }\end{array}$ & $\begin{array}{c}\text { Pump } \\
\text { Intake } \\
\text { Elevation } \\
\text { (ft) }\end{array}$ & $\begin{array}{l}\text { Depth to } \\
\text { Top of } \\
\text { Sump (ft) }\end{array}$ & $\begin{array}{c}\text { Top of } \\
\text { Sump } \\
\text { Elevation } \\
\text { (ft) }\end{array}$ & $\begin{array}{l}\text { Depth to } \\
\text { Sump } \\
\text { Bottom } \\
\text { (ft) }\end{array}$ & $\begin{array}{c}\text { Sump } \\
\text { Length } \\
\text { (ft) }\end{array}$ & $\begin{array}{c}\text { Sump } \\
\text { Volume } \\
\text { (L) }\end{array}$ & Comment \\
\hline 1 & 8.0 & 15.0 & 6913.4 & 6906.4 & 7.0 & & & 15.0 & 6906.4 & 20.0 & 5.0 & 12.4 & Alluvial Groundwater \\
\hline
\end{tabular}

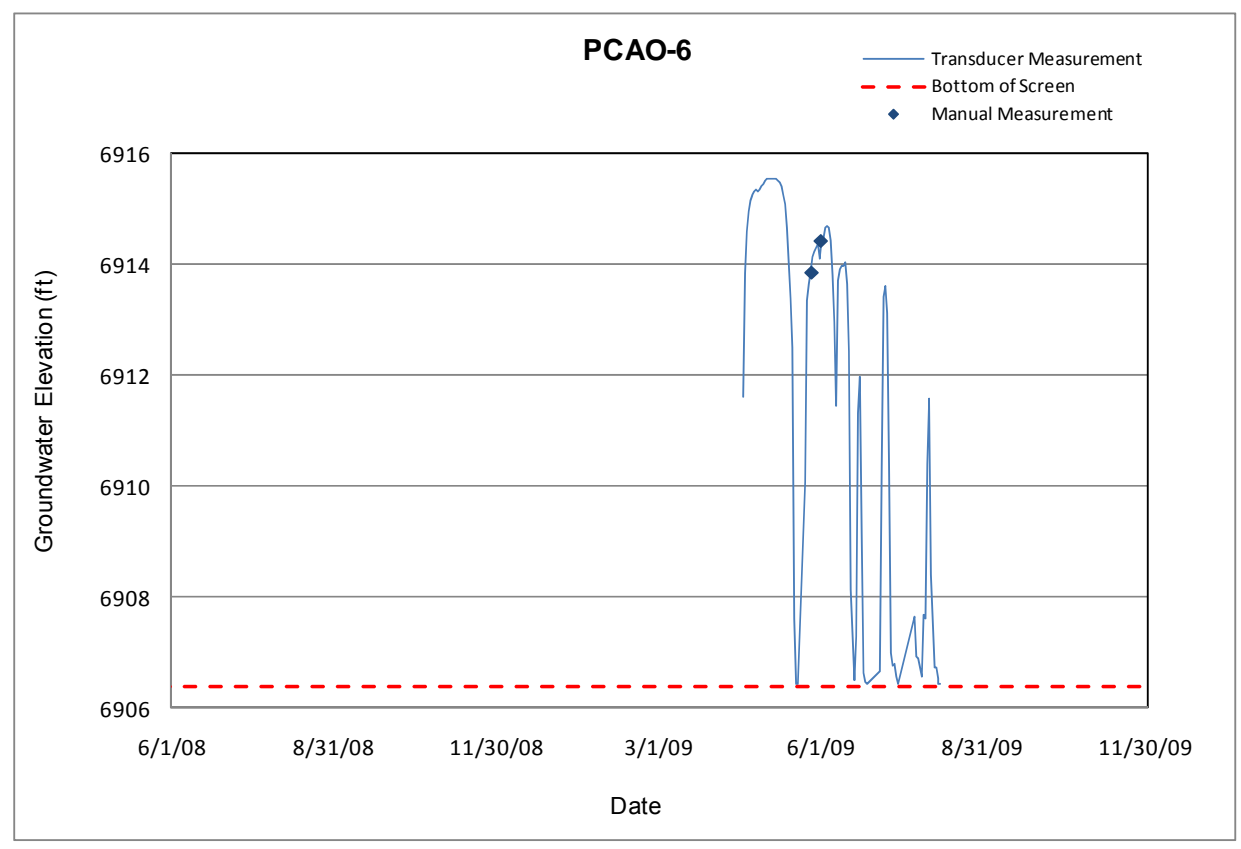




\subsection{PCAO-7a}

Location: In TA-18 in lower Pajarito Canyon on the north side of Pajarito Road, approximately $100 \mathrm{ft}$ from the TA-18 entrance.

Period of Record: June 12, 2008, through December 17, 2009.

Remarks: None.

\begin{tabular}{|c|c|c|c|c|c|c|c|c|c|c|c|c|c|}
\hline \multicolumn{14}{|c|}{ PCAO-7a Construction Information } \\
\hline Zone & $\begin{array}{l}\text { Screen } \\
\text { Top } \\
\text { Depth (ft) }\end{array}$ & $\begin{array}{c}\text { Screen } \\
\text { Bottom } \\
\text { Depth (ft) }\end{array}$ & $\begin{array}{c}\text { Screen } \\
\text { Top Elev } \\
\text { (ft) }\end{array}$ & $\begin{array}{l}\text { Screen } \\
\text { Bottom } \\
\text { Elev (ft) }\end{array}$ & $\begin{array}{c}\text { Screen } \\
\text { Length } \\
\text { (ft) }\end{array}$ & $\begin{array}{c}\text { Pump } \\
\text { Intake } \\
\text { Depth (ft) }\end{array}$ & $\begin{array}{c}\text { Pump } \\
\text { Intake } \\
\text { Elevation } \\
\text { (ft) }\end{array}$ & $\begin{array}{l}\text { Depth to } \\
\text { Top of } \\
\text { Sump (ft) }\end{array}$ & $\begin{array}{c}\text { Top of } \\
\text { Sump } \\
\text { Elevation } \\
\text { (ft) }\end{array}$ & $\begin{array}{l}\text { Depth to } \\
\text { Sump } \\
\text { Bottom } \\
\text { (ft) }\end{array}$ & $\begin{array}{c}\text { Sump } \\
\text { Length } \\
\text { (ft) }\end{array}$ & $\begin{array}{c}\text { Sump } \\
\text { Volume } \\
\text { (L) }\end{array}$ & Comment \\
\hline$\overline{1}$ & 9.7 & 19.7 & 6702.3 & 6692.3 & 10.0 & & & 19.7 & 6692.3 & 24.7 & 5.0 & 12.4 & Alluvial Groundwater \\
\hline
\end{tabular}

Note: Ground elevation is $6711.97 \mathrm{ft}$; all depths are from this elevation.

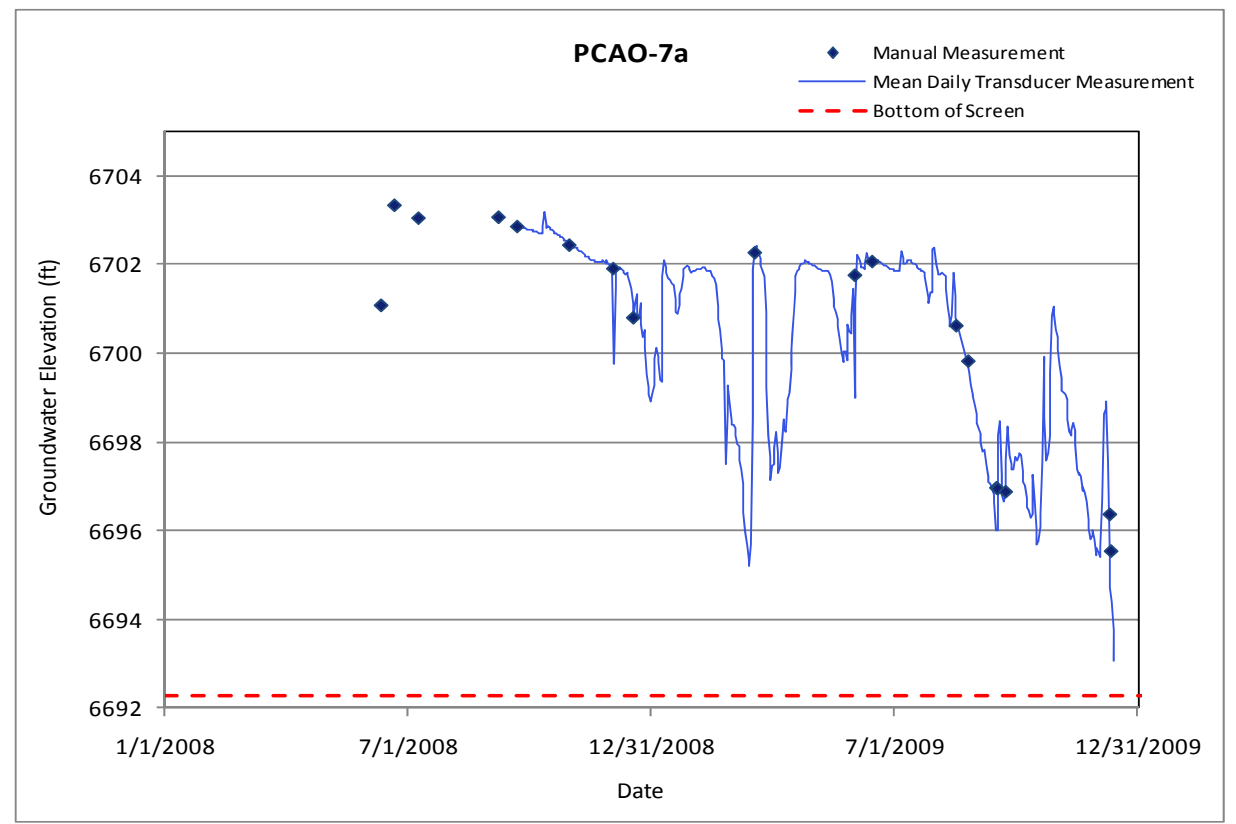




\subsection{PCAO-7b1}

Location: In lower Pajarito Canyon, in TA-18, on the north side of Pajarito Road directly across from the TA-18 entrance. PCAO-7b1 and PCAO-7b2 are approximately $10 \mathrm{ft}$ apart.

Period of Record: May 21, 2008, through December 17, 2009.

Remarks: Well was bailed dry during drilling, and water has not risen above the sump since.

\begin{tabular}{|c|c|c|c|c|c|c|c|c|c|c|c|c|c|}
\hline \multicolumn{14}{|c|}{ PCAO-7b(1) Construction Information } \\
\hline Zone & $\begin{array}{c}\text { Screen } \\
\text { Top } \\
\text { Depth (ft) }\end{array}$ & $\begin{array}{c}\text { Screen } \\
\text { Bottom } \\
\text { Depth (ft) }\end{array}$ & $\begin{array}{c}\text { Screen } \\
\text { Top Elev } \\
\text { (ft) }\end{array}$ & $\begin{array}{l}\text { Screen } \\
\text { Bottom } \\
\text { Elev (ft) }\end{array}$ & $\begin{array}{c}\text { Screen } \\
\text { Length } \\
\text { (ft) }\end{array}$ & $\begin{array}{c}\text { Pump } \\
\text { Intake } \\
\text { Depth } \\
\text { (ft) }\end{array}$ & $\begin{array}{c}\text { Pump } \\
\text { Intake } \\
\text { Elevation } \\
\text { (ft) }\end{array}$ & \begin{tabular}{|c|} 
Depth to \\
Top of \\
Sump \\
(ft)
\end{tabular} & $\begin{array}{c}\text { Top of } \\
\text { Sump } \\
\text { Elevation } \\
\text { (ft) }\end{array}$ & $\begin{array}{c}\text { Depth to } \\
\text { Sump } \\
\text { Bottom } \\
\text { (ft) }\end{array}$ & $\begin{array}{c}\text { Sump } \\
\text { Length } \\
\text { (ft) }\end{array}$ & $\begin{array}{c}\text { Sump } \\
\text { Volume } \\
\text { (L) }\end{array}$ & Comment \\
\hline 1 & 44.0 & 54 & 6669.6 & 6659.6 & 10.0 & & & 54.0 & 6659.6 & 59.3 & 5.3 & 13.1 & Alluvial groundwater \\
\hline
\end{tabular}

\begin{tabular}{|c|c|c|}
\hline \multicolumn{3}{|c|}{ PCAO-7b1 Manual Water Levels } \\
\hline Date & Water Level (ft) & Comments \\
\hline $5 / 21 / 2008$ & 6656.7 & Sump water \\
\hline $5 / 28 / 2008$ & 6657.34 & Sump water \\
\hline $6 / 13 / 2008$ & & Dry \\
\hline $6 / 24 / 2008$ & & Dry \\
\hline $7 / 11 / 2008$ & 6653.82 & Sump water \\
\hline $7 / 11 / 2008$ & 6653.82 & Sump water \\
\hline $9 / 8 / 2008$ & 6653.86 & Sump water \\
\hline $12 / 1 / 2008$ & 6653.85 & Sump water \\
\hline $3 / 3 / 2009$ & 6653.85 & Sump water \\
\hline $5 / 28 / 2009$ & 6653.83 & Sump water \\
\hline $9 / 23 / 2009$ & 6653.85 & Sump water \\
\hline $12 / 17 / 2009$ & 6653.83 & Sump water \\
\hline \multicolumn{2}{|c}{} \\
\hline
\end{tabular}




\subsection{PCAO-7b2}

Location: In lower Pajarito Canyon, in TA-18, on the north side of Pajarito Road directly across from the TA-18 entrance. PCAO-7b1 and PCAO-7b2 are approximately $10 \mathrm{ft}$ apart.

Period of Record: May 27, 2008, through December 17, 2009.

Remarks: None.

\begin{tabular}{|c|c|c|c|c|c|c|c|c|c|c|c|c|c|}
\hline \multicolumn{14}{|c|}{ PCAO-7b(2) Construction Information } \\
\hline Zone & $\begin{array}{c}\text { Screen } \\
\text { Top } \\
\text { Depth (ft) }\end{array}$ & $\begin{array}{c}\text { Screen } \\
\text { Bottom } \\
\text { Depth (ft) }\end{array}$ & $\begin{array}{c}\text { Screen } \\
\text { Top } \\
\text { Elevation } \\
\text { (ft) }\end{array}$ & $\begin{array}{c}\text { Screen } \\
\text { Bottom } \\
\text { Elevation } \\
\text { (ft) }\end{array}$ & $\begin{array}{c}\text { Screen } \\
\text { Length } \\
\text { (ft) }\end{array}$ & $\begin{array}{c}\text { Pump } \\
\text { Intake } \\
\text { Depth } \\
\text { (ft) }\end{array}$ & $\begin{array}{c}\text { Pump } \\
\text { Intake } \\
\text { Elevation } \\
\text { (ft) }\end{array}$ & $\begin{array}{c}\text { Depth to } \\
\text { Top of } \\
\text { Sump } \\
\text { (ft) }\end{array}$ & $\begin{array}{c}\text { Top of } \\
\text { Sump } \\
\text { Elevation } \\
\text { (ft) }\end{array}$ & $\begin{array}{l}\text { Depth to } \\
\text { Sump } \\
\text { Bottom } \\
\text { (ft) }\end{array}$ & $\begin{array}{c}\text { Sump } \\
\text { Length } \\
\text { (ft) }\end{array}$ & $\begin{array}{c}\text { Sump } \\
\text { Volume } \\
\text { (L) }\end{array}$ & Comment \\
\hline 1 & 10.0 & 20 & 6703.4 & 6693.4 & 10.0 & & & 20.0 & 6693.4 & 25.0 & 5.0 & 12.4 & Alluvial groundwater \\
\hline
\end{tabular}

Note: Ground elevation is $6713.39 \mathrm{ft}$; all depths are from this elevation

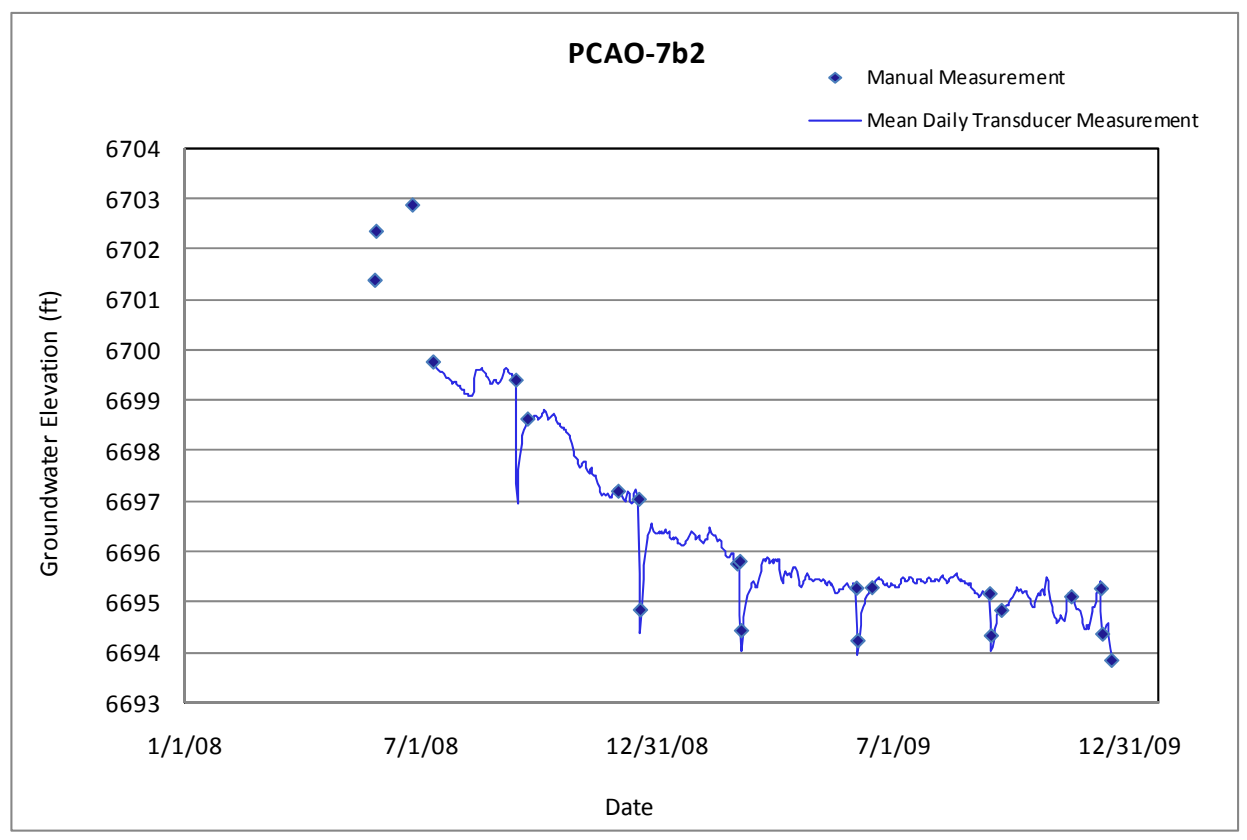




\subsection{PCAO-7c}

Location: Lower Pajarito Canyon, in TA-18 on the south side of Pajarito Road, approximately $50 \mathrm{ft}$ from the TA-18 entrance.

Period of Record: May 16, 2008, through December 17, 2009.

Remarks: None.

\begin{tabular}{|c|c|c|c|c|c|c|c|c|c|c|c|c|c|}
\hline \multicolumn{14}{|c|}{ PCAO-7c Construction Information } \\
\hline Zone & $\begin{array}{l}\text { Screen } \\
\text { Top } \\
\text { Depth (ft) }\end{array}$ & $\begin{array}{c}\text { Screen } \\
\text { Bottom } \\
\text { Depth (ft) }\end{array}$ & $\begin{array}{c}\text { Screen } \\
\text { Top } \\
\text { Elevation } \\
\text { (ft) }\end{array}$ & $\begin{array}{c}\text { Screen } \\
\text { Bottom } \\
\text { Elevation } \\
\text { (ft) }\end{array}$ & $\begin{array}{c}\text { Screen } \\
\text { Length } \\
\text { (ft) }\end{array}$ & \begin{tabular}{|c|} 
Pump \\
Intake \\
Depth (ft)
\end{tabular} & $\begin{array}{c}\text { Pump } \\
\text { Intake } \\
\text { Elevation } \\
\text { (ft) }\end{array}$ & $\begin{array}{l}\text { Depth to } \\
\text { Top of } \\
\text { Sump (ft) }\end{array}$ & $\begin{array}{c}\text { Top of } \\
\text { Sump } \\
\text { Elevation } \\
\text { (ft) }\end{array}$ & $\begin{array}{l}\text { Depth to } \\
\text { Sump } \\
\text { Bottom } \\
\text { (ft) }\end{array}$ & $\begin{array}{c}\text { Sump } \\
\text { Length } \\
\text { (ft) }\end{array}$ & $\begin{array}{c}\text { Sump } \\
\text { Volume } \\
\text { (L) }\end{array}$ & Comment \\
\hline 1 & 9.7 & 19.7 & 6704.9 & 6694.9 & 10.0 & & & 19.7 & 6694.9 & 25.0 & 5.3 & 13.1 & Alluvial groundwater \\
\hline
\end{tabular}

Note: Ground elevation is $6714.57 \mathrm{ft}$; all depths from this elevation

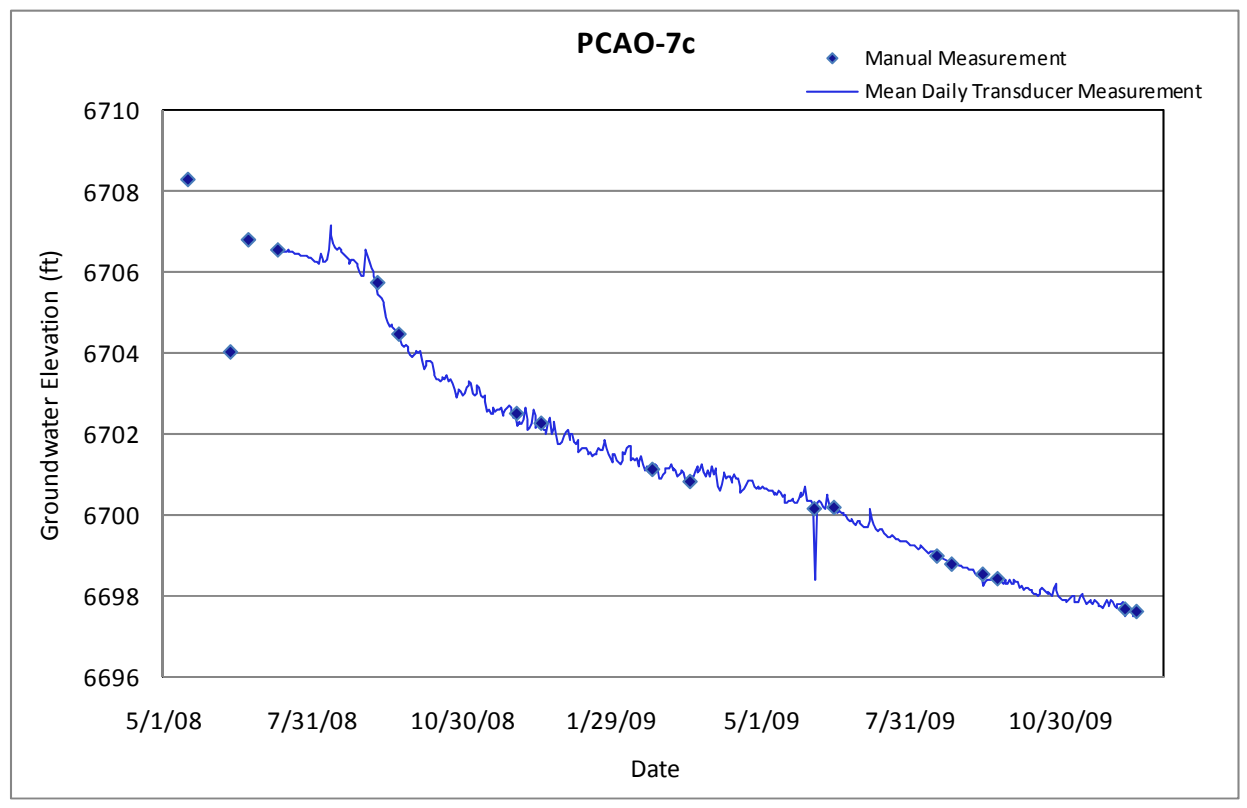




\subsection{PCAO-8}

Location: In lower Pajarito Canyon, on the south side of Pajarito Road in TA-36, approximately a quarter mile west of PCAO-9.

Period of Record: June 2, 2008, through December 11, 2009.

Remarks: None.

\begin{tabular}{|c|c|c|c|c|c|c|c|c|c|c|c|c|c|}
\hline \multicolumn{14}{|c|}{ PCAO-8 Construction Information } \\
\hline Zone & $\begin{array}{c}\text { Screen } \\
\text { Top } \\
\text { Depth (ft) }\end{array}$ & $\begin{array}{c}\text { Screen } \\
\text { Bottom } \\
\text { Depth (ft) }\end{array}$ & $\begin{array}{c}\text { Screen } \\
\text { Top } \\
\text { Elevation } \\
\text { (ft) }\end{array}$ & $\begin{array}{c}\text { Screen } \\
\text { Bottom } \\
\text { Elevation } \\
\text { (ft) }\end{array}$ & $\begin{array}{c}\text { Screen } \\
\text { Length } \\
\text { (ft) }\end{array}$ & $\begin{array}{c}\text { Pump } \\
\text { Intake } \\
\text { Depth } \\
\text { (ft) }\end{array}$ & $\begin{array}{c}\text { Pump } \\
\text { Intake } \\
\text { Elevation } \\
\text { (ft) }\end{array}$ & \begin{tabular}{|} 
Depth to \\
Top of \\
Sump \\
(ft)
\end{tabular} & $\begin{array}{c}\text { Top of } \\
\text { Sump } \\
\text { Elevation } \\
\text { (ft) }\end{array}$ & $\begin{array}{l}\text { Depth to } \\
\text { Sump } \\
\text { Bottom } \\
\text { (ft) }\end{array}$ & $\begin{array}{c}\text { Sump } \\
\text { Length } \\
\text { (ft) }\end{array}$ & $\begin{array}{c}\text { Sump } \\
\text { Volume } \\
\text { (L) }\end{array}$ & Comment \\
\hline 1 & 9.7 & 19.7 & 6574.8 & 6564.8 & 10.0 & & & 19.7 & 6564.8 & 25.0 & 5.3 & 13.1 & Alluvial groundwater \\
\hline
\end{tabular}

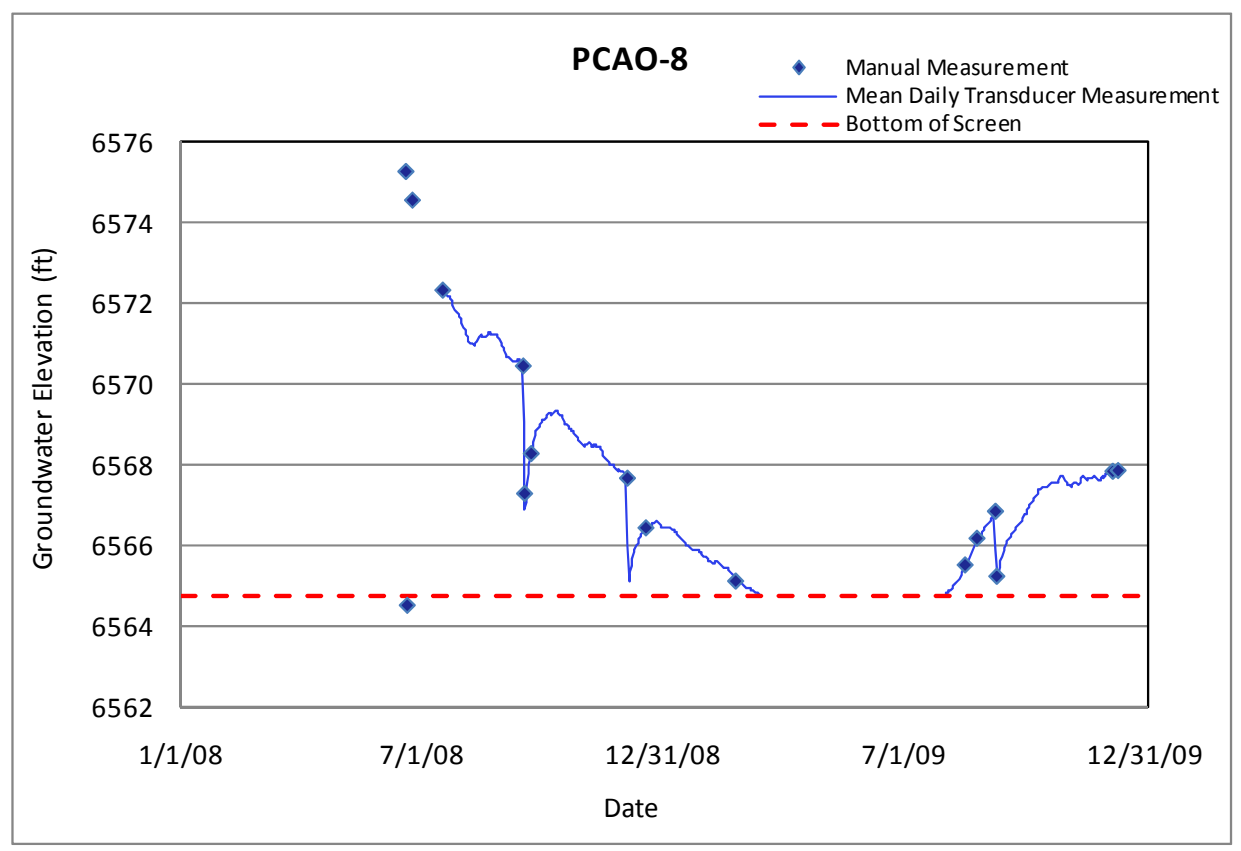




\subsection{PCAO-9}

Location: In lower Pajarito Canyon on the south side of Pajarito Road in TA-36, approximately a quarter mile west of the security check point, and quarter mile east of PCAO-8.

Period of Record: June 12, 2008, through December 9, 2009.

Remarks: Water level dropped below screen on November 1, 2008 and has not again risen above the screen.

\begin{tabular}{|c|c|c|c|c|c|c|c|c|c|c|c|c|c|}
\hline \multicolumn{14}{|c|}{ PCAO-9 Construction Information } \\
\hline Zone & $\begin{array}{c}\text { Screen } \\
\text { Top } \\
\text { Depth (ft) }\end{array}$ & $\begin{array}{c}\text { Screen } \\
\text { Bottom } \\
\text { Depth (ft) }\end{array}$ & $\begin{array}{c}\text { Screen } \\
\text { Top } \\
\text { Elevation } \\
\text { (ft) }\end{array}$ & \begin{tabular}{|c|} 
Screen \\
Bottom \\
Elevation \\
(ft)
\end{tabular} & $\begin{array}{c}\text { Screen } \\
\text { Length } \\
\text { (ft) }\end{array}$ & $\begin{array}{c}\text { Pump } \\
\text { Intake } \\
\text { Depth } \\
\text { (ft) }\end{array}$ & $\begin{array}{c}\text { Pump } \\
\text { Intake } \\
\text { Elevation } \\
\text { (ft) }\end{array}$ & \begin{tabular}{|c} 
Depth to \\
Top of \\
Sump \\
(ft)
\end{tabular} & \begin{tabular}{|c|} 
Top of \\
Sump \\
Elevation \\
(ft)
\end{tabular} & \begin{tabular}{|c} 
Depth to \\
Sump \\
Bottom \\
(ft)
\end{tabular} & $\begin{array}{c}\text { Sump } \\
\text { Length } \\
\text { (ft) }\end{array}$ & $\begin{array}{c}\text { Sump } \\
\text { Volume } \\
\text { (L) }\end{array}$ & Comment \\
\hline 1 & 6.0 & 16.0 & 6552.6 & 6542.6 & 10.0 & & & 16.0 & 6542.6 & 21.0 & 5.0 & 12.4 & Alluvial groundwater \\
\hline
\end{tabular}

Note: Ground elevation is $6558.60 \mathrm{ft}$; all depths from this elevation

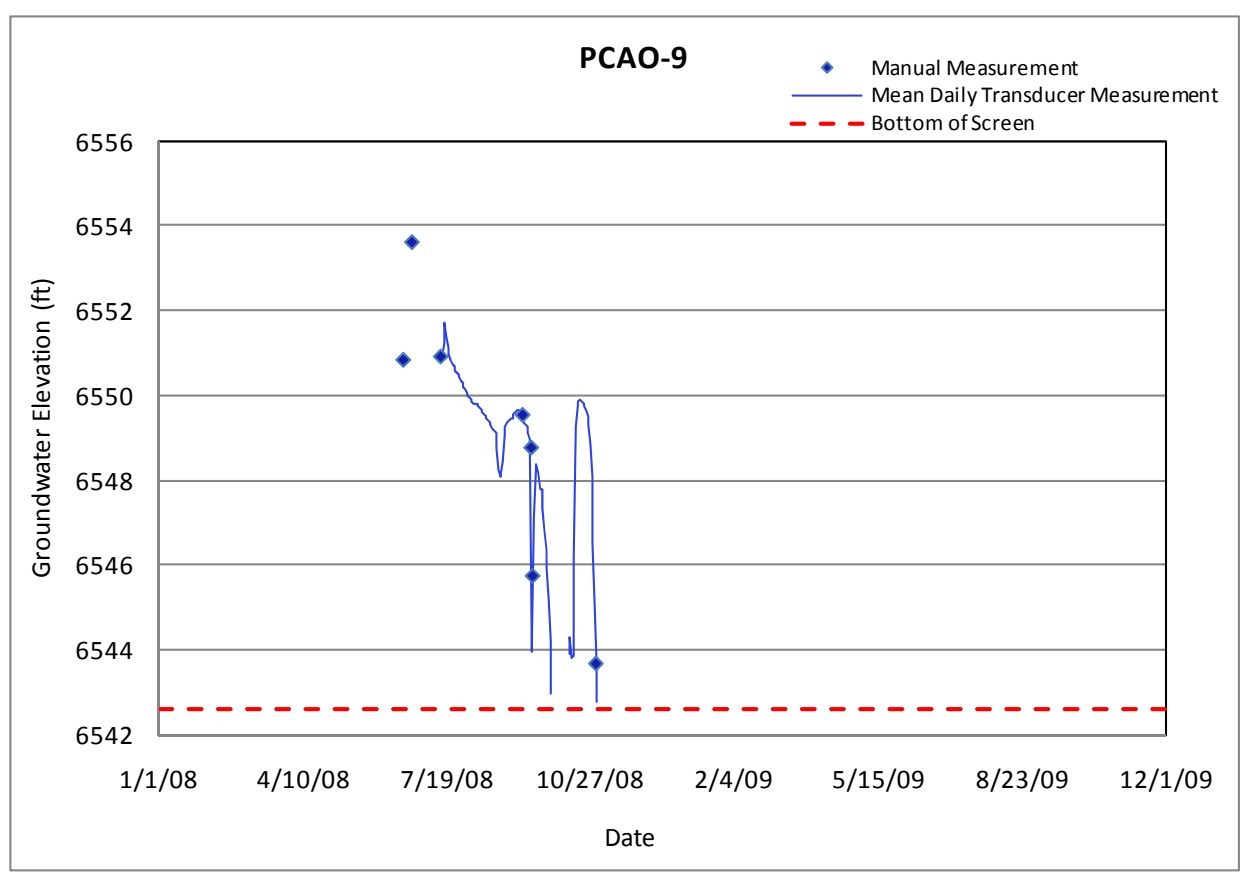




\subsection{PCO-1}

Location: Pajarito Canyon, approximately $200 \mathrm{ft}$ north of R-20.

Period of Record: June 11, 1985, through May 7, 2008.

Remarks: Monitoring of this well was discontinued May 7, 2008.

\begin{tabular}{|c|c|c|c|c|c|c|c|c|c|c|c|c|c|}
\hline \multicolumn{14}{|c|}{ PCO-1 Construction Information } \\
\hline Zone & $\begin{array}{l}\text { Screen } \\
\text { Top } \\
\text { Depth (ft) }\end{array}$ & $\begin{array}{c}\text { Screen } \\
\text { Bottom } \\
\text { Depth } \\
\text { (ft) }\end{array}$ & $\begin{array}{l}\text { Screen } \\
\text { Top } \\
\text { Elev (ft) }\end{array}$ & $\begin{array}{l}\text { Screen } \\
\text { Bottom } \\
\text { Elev (ft) }\end{array}$ & $\begin{array}{c}\text { Screen } \\
\text { Length } \\
\text { (ft) }\end{array}$ & $\begin{array}{l}\text { Pump } \\
\text { Intake } \\
\text { Depth } \\
\text { (ft) }\end{array}$ & $\begin{array}{c}\text { Pump } \\
\text { Intake } \\
\text { Elevation } \\
\text { (ft) }\end{array}$ & $\begin{array}{l}\text { Depth to } \\
\text { Top of } \\
\text { Sump (ft) }\end{array}$ & $\begin{array}{c}\text { Top of } \\
\text { Sump } \\
\text { Elevation } \\
\text { (ft) }\end{array}$ & $\begin{array}{c}\text { Depth to } \\
\text { Sump } \\
\text { Bottom (ft) }\end{array}$ & $\begin{array}{c}\text { Sump } \\
\text { Length } \\
\text { (ft) }\end{array}$ & $\begin{array}{l}\text { Sump } \\
\text { Volume } \\
\text { (L) }\end{array}$ & Comment \\
\hline 1 & 4.3 & 12.3 & 6682.7 & 6674.7 & 8.0 & & & 12.3 & 6674.7 & 12.3 & 0.0 & 0.0 & Alluvial groundwater \\
\hline
\end{tabular}

Note: Ground elevation is $6687.0 \mathrm{ft}$; all depths are from this elevation
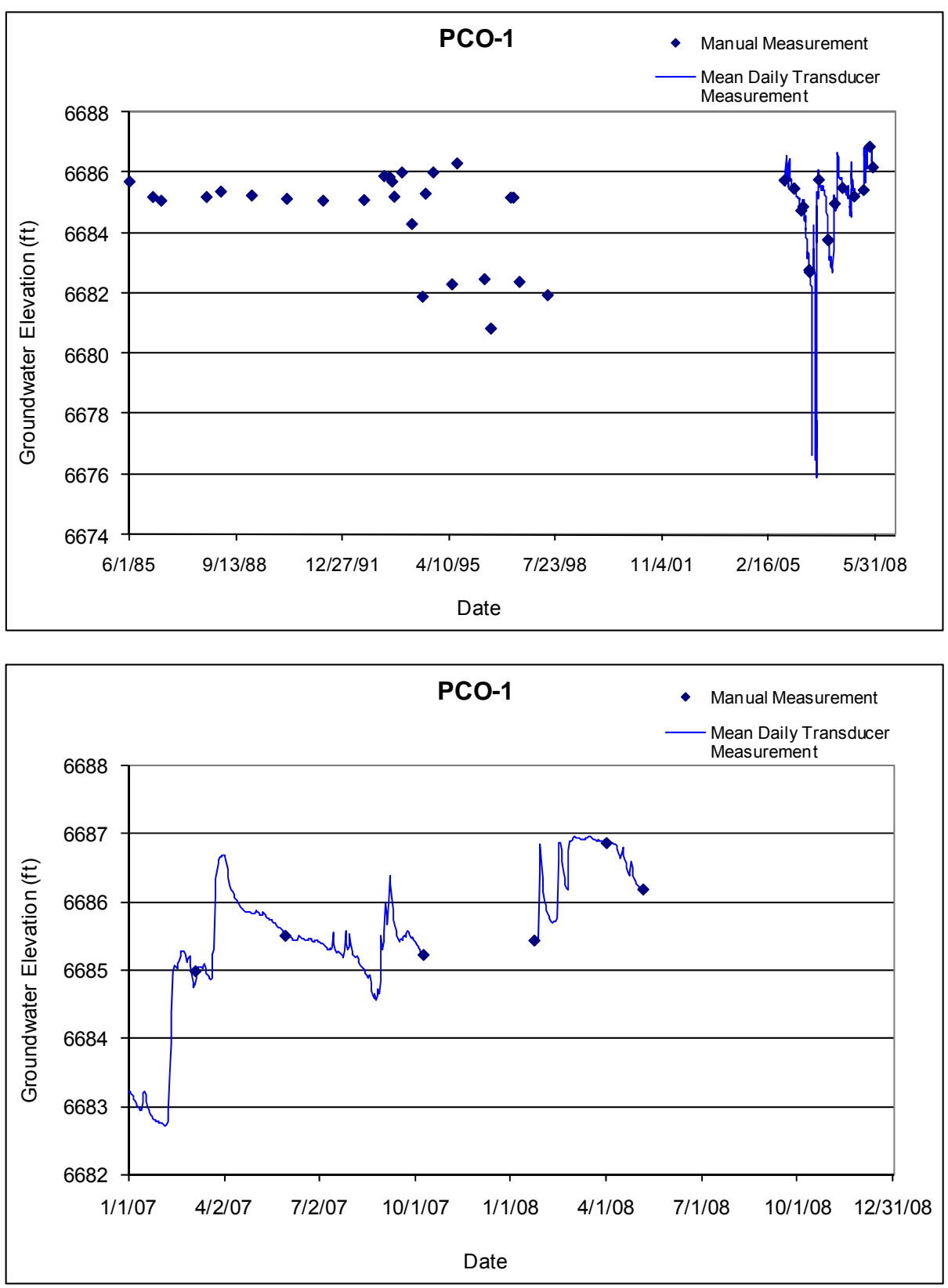


\subsection{PCO-2}

Location: In lower Pajarito Canyon on the north side of Pajarito Road, approximately 0.1 miles east of R-32.

Period of Record: June 11, 1985, through December 7, 2009.

Remarks: Well has been dry since February 2009.

\begin{tabular}{|c|c|c|c|c|c|c|c|c|c|c|c|c|c|}
\hline \multicolumn{14}{|c|}{ PCO-2 Construction Information } \\
\hline Zone & $\begin{array}{c}\text { Screen } \\
\text { Top } \\
\text { Depth (ft) }\end{array}$ & $\begin{array}{c}\text { Screen } \\
\text { Bottom } \\
\text { Depth } \\
\text { (ft) }\end{array}$ & $\begin{array}{c}\text { Screen } \\
\text { Top } \\
\text { Elev (ft) }\end{array}$ & $\begin{array}{l}\text { Screen } \\
\text { Bottom } \\
\text { Elev (ft) }\end{array}$ & $\begin{array}{c}\text { Screen } \\
\text { Length } \\
\text { (ft) }\end{array}$ & $\begin{array}{c}\text { Pump } \\
\text { Intake } \\
\text { Depth } \\
\text { (ft) }\end{array}$ & $\begin{array}{c}\text { Pump } \\
\text { Intake } \\
\text { Elevation } \\
\text { (ft) }\end{array}$ & $\begin{array}{l}\text { Depth to } \\
\text { Top of } \\
\text { Sump (ft) }\end{array}$ & $\begin{array}{c}\text { Top of } \\
\text { Sump } \\
\text { Elevation } \\
\text { (ft) }\end{array}$ & $\begin{array}{l}\text { Depth to } \\
\text { Sump } \\
\text { Bottom } \\
\text { (ft) }\end{array}$ & $\begin{array}{c}\text { Sump } \\
\text { Length } \\
\text { (ft) }\end{array}$ & $\begin{array}{c}\text { Sump } \\
\text { Volume } \\
\text { (L) }\end{array}$ & Comment \\
\hline 1 & 1.5 & 9.5 & 6616.8 & 6608.8 & 8 & & & 9.5 & 6608.8 & 9.5 & 0 & 0 & Alluvial groundwater \\
\hline
\end{tabular}

Note: Ground Elevation: $6618.3 \mathrm{ft}$; all depths are from this elevation
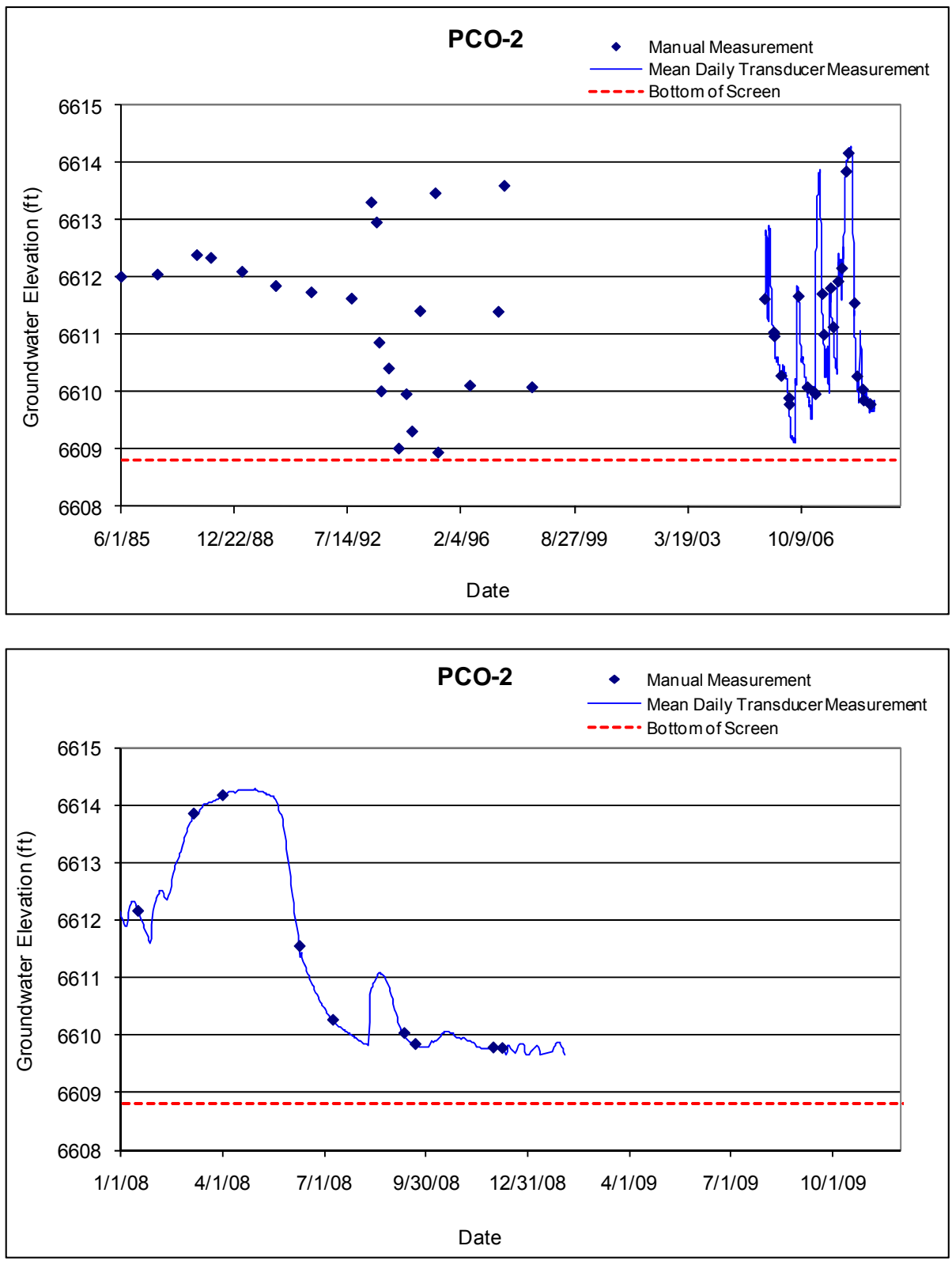


\subsection{PCO-3}

Location: Lower Pajarito Canyon, approximately 1 mile east of R-32, in wetlands on the south side of Pajarito Road.

Period of Record: June 11, 1985, through December 9, 2009.

Remarks: The water level was below the bottom of the screen from July 2, 2007, to September 3, 2007, and since July 2008.

\begin{tabular}{|c|c|c|c|c|c|c|c|c|c|c|c|c|c|}
\hline \multicolumn{14}{|c|}{ PCO-3 Construction Information } \\
\hline Zone & $\begin{array}{c}\text { Screen } \\
\text { Top } \\
\text { Depth (ft) }\end{array}$ & \begin{tabular}{|c|} 
Screen \\
Bottom \\
Depth (ft)
\end{tabular} & \begin{tabular}{|c|} 
Screen \\
Top \\
Elevation \\
(ft)
\end{tabular} & $\begin{array}{c}\text { Screen } \\
\text { Bottom } \\
\text { Elevation } \\
\text { (ft) }\end{array}$ & $\begin{array}{c}\text { Screen } \\
\text { Length } \\
\text { (ft) }\end{array}$ & $\begin{array}{c}\text { Pump } \\
\text { Intake } \\
\text { Depth } \\
\text { (ft) }\end{array}$ & $\begin{array}{c}\text { Pump } \\
\text { Intake } \\
\text { Elevation } \\
\text { (ft) }\end{array}$ & $\begin{array}{l}\text { Depth to } \\
\text { Top of } \\
\text { Sump } \\
\text { (ft) }\end{array}$ & $\begin{array}{c}\text { Top of } \\
\text { Sump } \\
\text { Elevation } \\
\text { (ft) }\end{array}$ & $\begin{array}{l}\text { Depth to } \\
\text { Sump } \\
\text { Bottom } \\
\text { (ft) }\end{array}$ & $\begin{array}{c}\text { Sump } \\
\text { Length } \\
\text { (ft) }\end{array}$ & $\begin{array}{c}\text { Sump } \\
\text { Volume } \\
\text { (L) }\end{array}$ & Comment \\
\hline 1 & 5.7 & 17.7 & 6540.6 & 6528.6 & 12.0 & & & 17.7 & 6528.6 & 17.7 & 0.0 & 0.0 & Alluvial groundwater \\
\hline
\end{tabular}

Note: Ground Elevation: $6546.30 \mathrm{ft}$; all depths are from this elevation
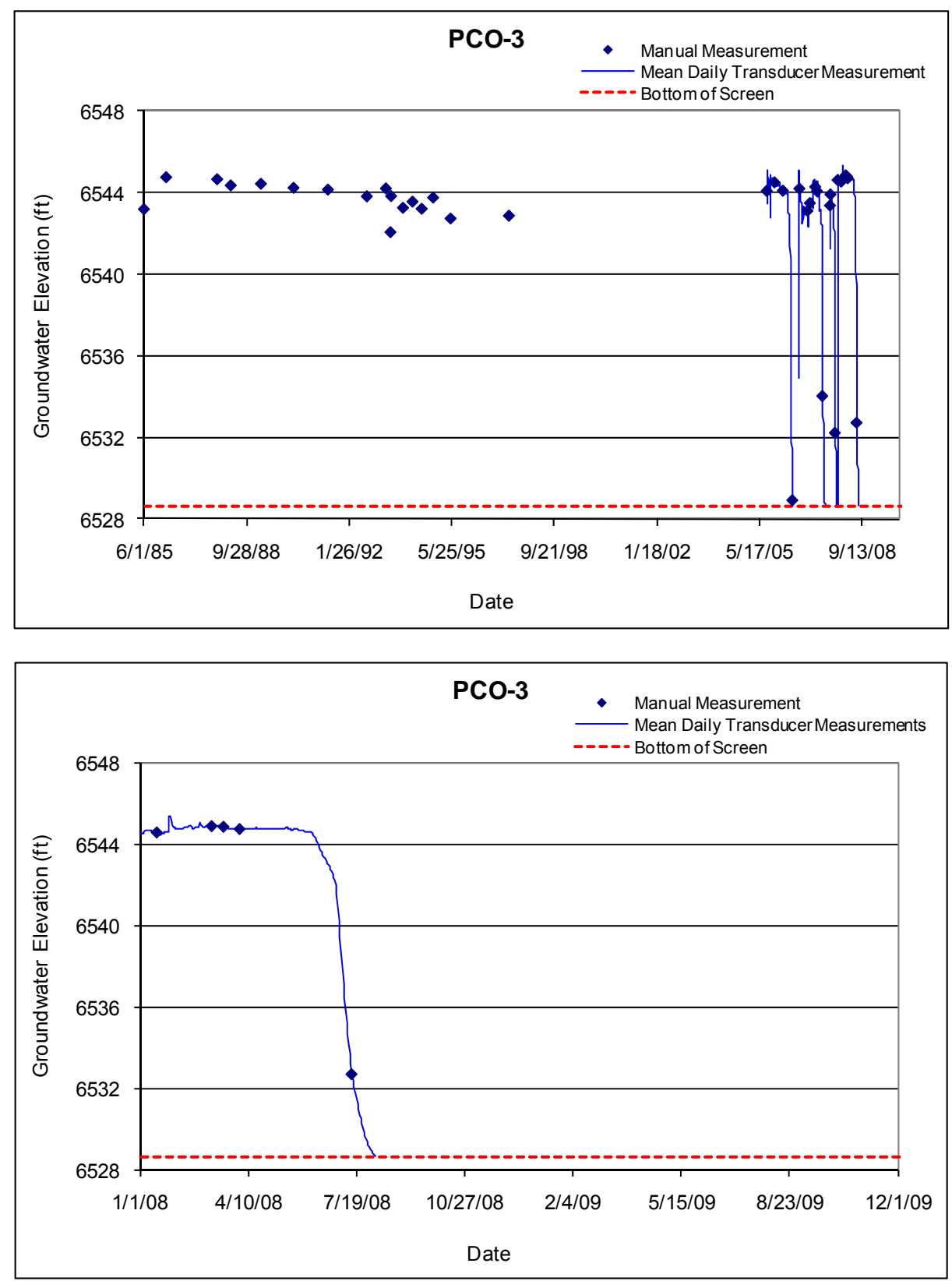


\subsection{SCA-1 and SCA-1-DP}

Location: In upper Sandia Canyon, in the wetlands approximately $350 \mathrm{ft}$ upstream from gaging station E123. SCA-1-DP is located approximately $15 \mathrm{ft}$ west of SCA-1.

Period of Record: October 13, 2006, through December 22, 2009.

Remarks: SCA-1 is a shallow alluvial well located in a wetland. Recent sampling events have moved to temporary drive point well SCA-1-DP due to silting-in of the screen in SCA-1. Continuous water levels are monitored at SCA-1, and manual measurements are taken in conjunction at SCA-1-DP.

\begin{tabular}{|c|c|c|c|c|c|c|c|c|c|c|c|c|c|}
\hline \multicolumn{14}{|c|}{ SCA-1 Construction Information } \\
\hline Zone & $\begin{array}{c}\text { Screen } \\
\text { Top } \\
\text { Depth (ft) }\end{array}$ & $\begin{array}{c}\text { Screen } \\
\text { Bottom } \\
\text { Depth } \\
\text { (ft) }\end{array}$ & $\begin{array}{c}\text { Screen } \\
\text { Top } \\
\text { Elev (ft) }\end{array}$ & $\begin{array}{l}\text { Screen } \\
\text { Bottom } \\
\text { Elev (ft) }\end{array}$ & $\begin{array}{c}\text { Screen } \\
\text { Length } \\
\text { (ft) }\end{array}$ & $\begin{array}{l}\text { Pump } \\
\text { Intake } \\
\text { Depth } \\
\text { (ft) }\end{array}$ & $\begin{array}{c}\text { Pump } \\
\text { Intake } \\
\text { Elevation } \\
\text { (ft) }\end{array}$ & $\begin{array}{c}\text { Depth to } \\
\text { Top of } \\
\text { Sump (ft) }\end{array}$ & $\begin{array}{c}\text { Top of } \\
\text { Sump } \\
\text { Elevation } \\
\text { (ft) }\end{array}$ & $\begin{array}{l}\text { Depth to } \\
\text { Sump } \\
\text { Bottom (ft) }\end{array}$ & $\begin{array}{c}\text { Sump } \\
\text { Length } \\
\text { (ft) }\end{array}$ & $\begin{array}{c}\text { Sump } \\
\text { Volume } \\
\text { (L) }\end{array}$ & Comment \\
\hline 1 & 1.3 & 1.9 & 7209.9 & 7209.3 & 0.6 & & & 1.9 & 7209.3 & 2.1 & 0.2 & 0.1 & Alluvial groundwater \\
\hline
\end{tabular}

Note: Ground elevation is $7211.22 \mathrm{ft}$; all depths are from this elevation
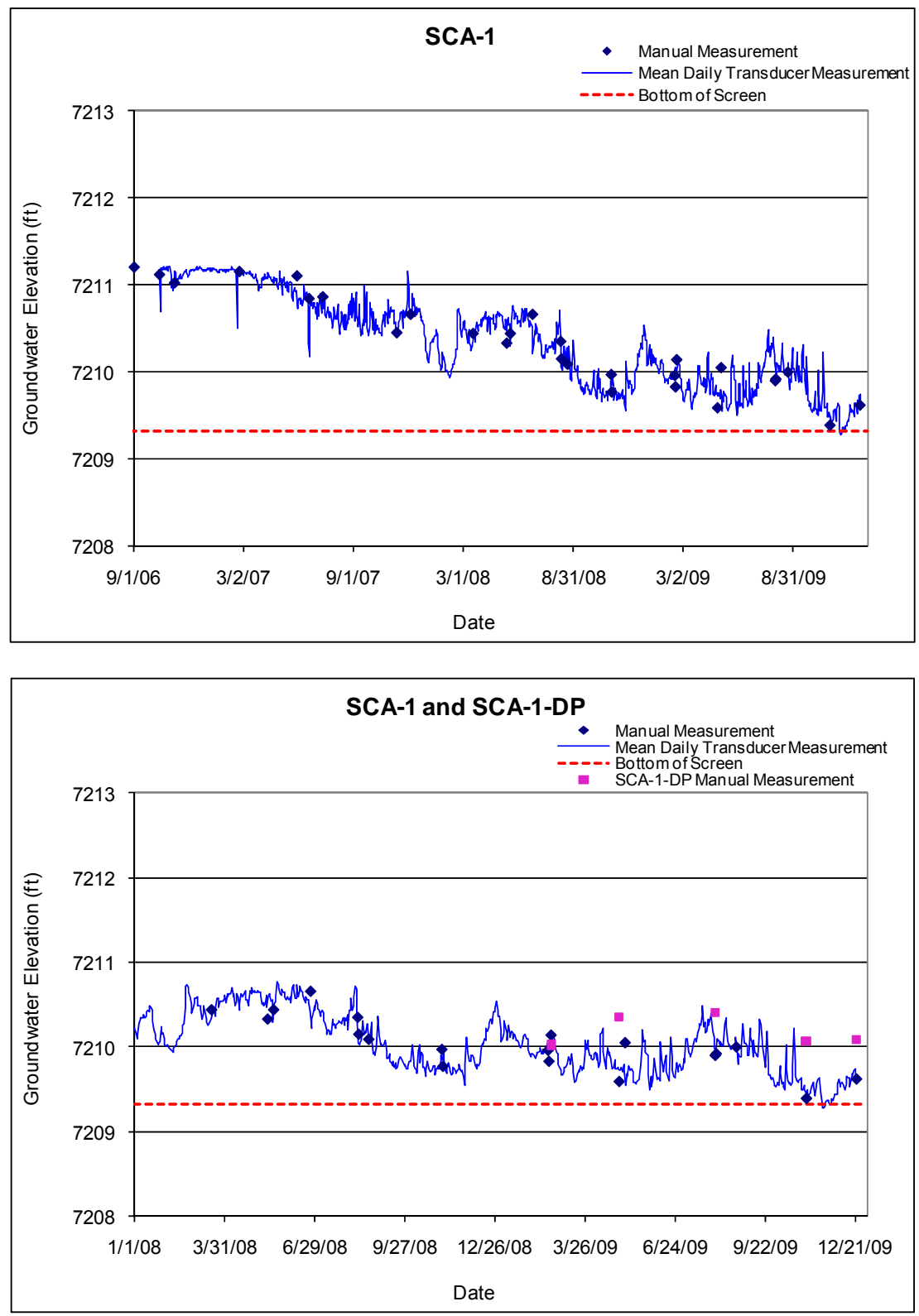


\subsection{SCA-2}

Location: Middle Sandia Canyon, approximately $700 \mathrm{ft}$ upstream of gaging station E124.

Period of Record: October 13, 2006, through November 2, 2009.

Remarks: SCA-2 responds to the sewer treatment plant discharge in upper Sandia Canyon. Water levels frequently drop below the screen. From August 22, 2008, though March 11, 2009, the transducer was set too high in the well, not recording water levels below $6735.7 \mathrm{ft}$, and not matching manual measurements. Transducer has since been lowered to record all water level data.

\begin{tabular}{|c|c|c|c|c|c|c|c|c|c|c|c|c|c|}
\hline \multicolumn{14}{|c|}{ SCA-2 Construction Information } \\
\hline Zone & $\begin{array}{c}\text { Screen } \\
\text { Top } \\
\text { Depth (ft) }\end{array}$ & $\begin{array}{c}\text { Screen } \\
\text { Bottom } \\
\text { Depth } \\
\text { (ft) }\end{array}$ & $\begin{array}{c}\text { Screen } \\
\text { Top } \\
\text { Elev (ft) }\end{array}$ & $\begin{array}{l}\text { Screen } \\
\text { Bottom } \\
\text { Elev (ft) }\end{array}$ & $\begin{array}{c}\text { Screen } \\
\text { Length } \\
\text { (ft) }\end{array}$ & $\begin{array}{c}\text { Pump } \\
\text { Intake } \\
\text { Depth } \\
\text { (ft) }\end{array}$ & $\begin{array}{c}\text { Pump } \\
\text { Intake } \\
\text { Elevation } \\
\text { (ft) }\end{array}$ & \begin{tabular}{|} 
Depth to \\
Top of \\
Sump (ft)
\end{tabular} & $\begin{array}{c}\text { Top of } \\
\text { Sump } \\
\text { Elevation } \\
\text { (ft) }\end{array}$ & \begin{tabular}{|l} 
Depth to \\
Sump \\
Bottom (ft)
\end{tabular} & $\begin{array}{c}\text { Sump } \\
\text { Length } \\
\text { (ft) }\end{array}$ & $\begin{array}{c}\text { Sump } \\
\text { Volume } \\
\text { (L) }\end{array}$ & Comment \\
\hline 1 & 10.3 & 15.0 & 6738.8 & 6734.1 & 4.7 & & & 15.0 & 6733.8 & 15.6 & 0.6 & 0.4 & Alluvial groundwater \\
\hline
\end{tabular}
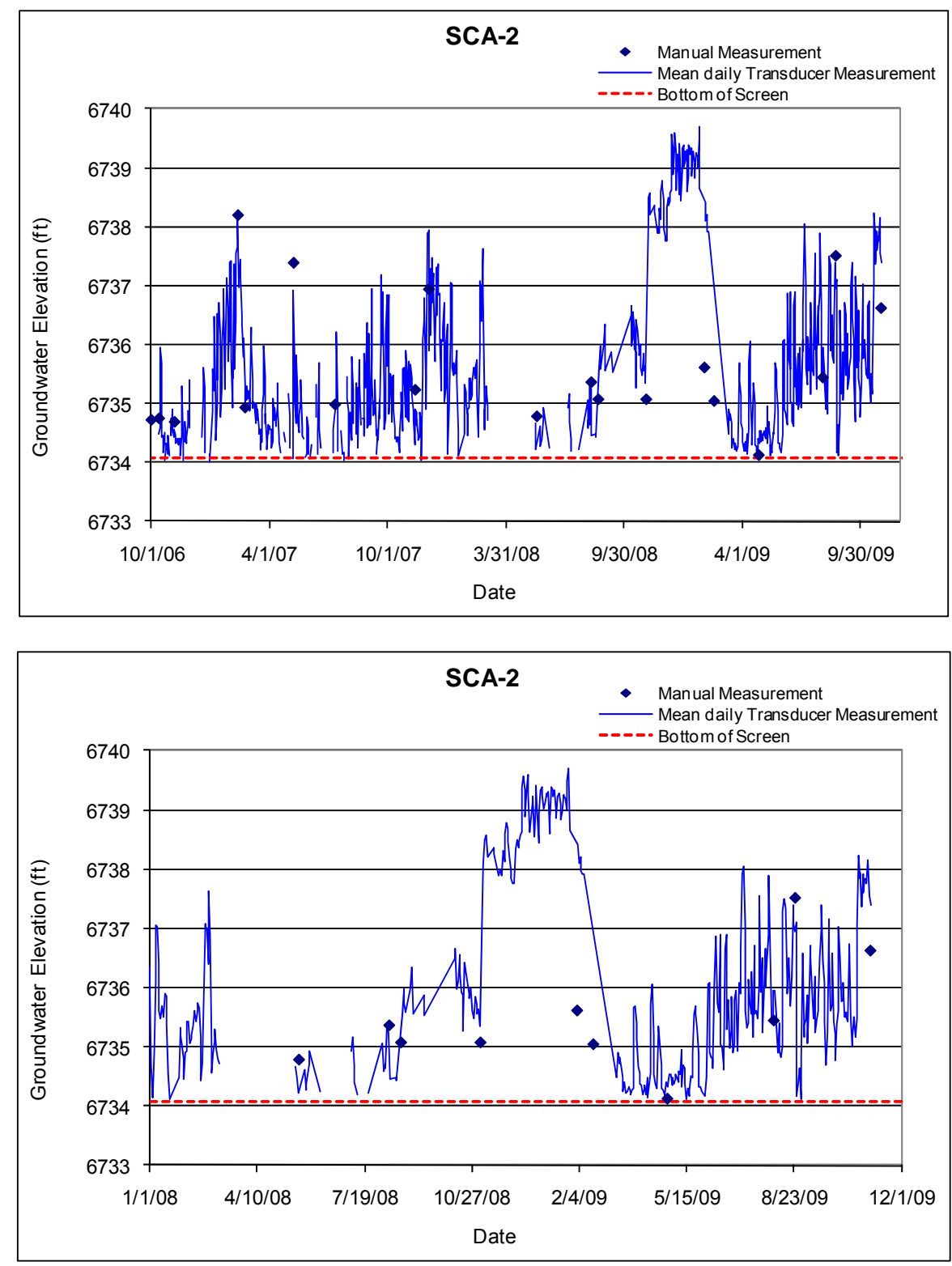


\subsection{SCA-3}

Location: Middle Sandia Canyon, approximately $700 \mathrm{ft}$ downstream of gaging station E124.

Period of Record: October 13, 2006, through November 2, 2009.

Remarks: Water rose above the sump for the first time on December 10, 2007. Since then the well has periodically run dry.

\begin{tabular}{|c|c|c|c|c|c|c|c|c|c|c|c|c|c|}
\hline \multicolumn{14}{|c|}{ SCA-3 Construction Information } \\
\hline Zone & $\begin{array}{c}\text { Screen } \\
\text { Top } \\
\text { Depth (ft) }\end{array}$ & $\begin{array}{c}\text { Screen } \\
\text { Bottom } \\
\text { Depth } \\
\text { (ft) }\end{array}$ & $\begin{array}{c}\text { Screen } \\
\text { Top } \\
\text { Elev (ft) }\end{array}$ & $\begin{array}{l}\text { Screen } \\
\text { Bottom } \\
\text { Elev (ft) }\end{array}$ & $\begin{array}{c}\text { Screen } \\
\text { Length } \\
\text { (ft) }\end{array}$ & $\begin{array}{c}\text { Pump } \\
\text { Intake } \\
\text { Depth } \\
\text { (ft) }\end{array}$ & $\begin{array}{c}\text { Pump } \\
\text { Intake } \\
\text { Elevation } \\
\text { (ft) }\end{array}$ & $\begin{array}{c}\text { Depth to } \\
\text { Top of } \\
\text { Sump (ft) }\end{array}$ & $\begin{array}{c}\text { Top of } \\
\text { Sump } \\
\text { Elevation } \\
\text { (ft) }\end{array}$ & \begin{tabular}{|} 
Depth to \\
Sump \\
Bottom \\
(ft)
\end{tabular} & $\begin{array}{c}\text { Sump } \\
\text { Length } \\
\text { (ft) }\end{array}$ & $\begin{array}{c}\text { Sump } \\
\text { Volume } \\
\text { (L) }\end{array}$ & Comment \\
\hline 1 & 27.6 & 32.0 & 6695.6 & 6691.2 & 4.4 & & & 32.0 & 6691.2 & 32.6 & 0.6 & 4.4 & Alluvial groundwater \\
\hline
\end{tabular}

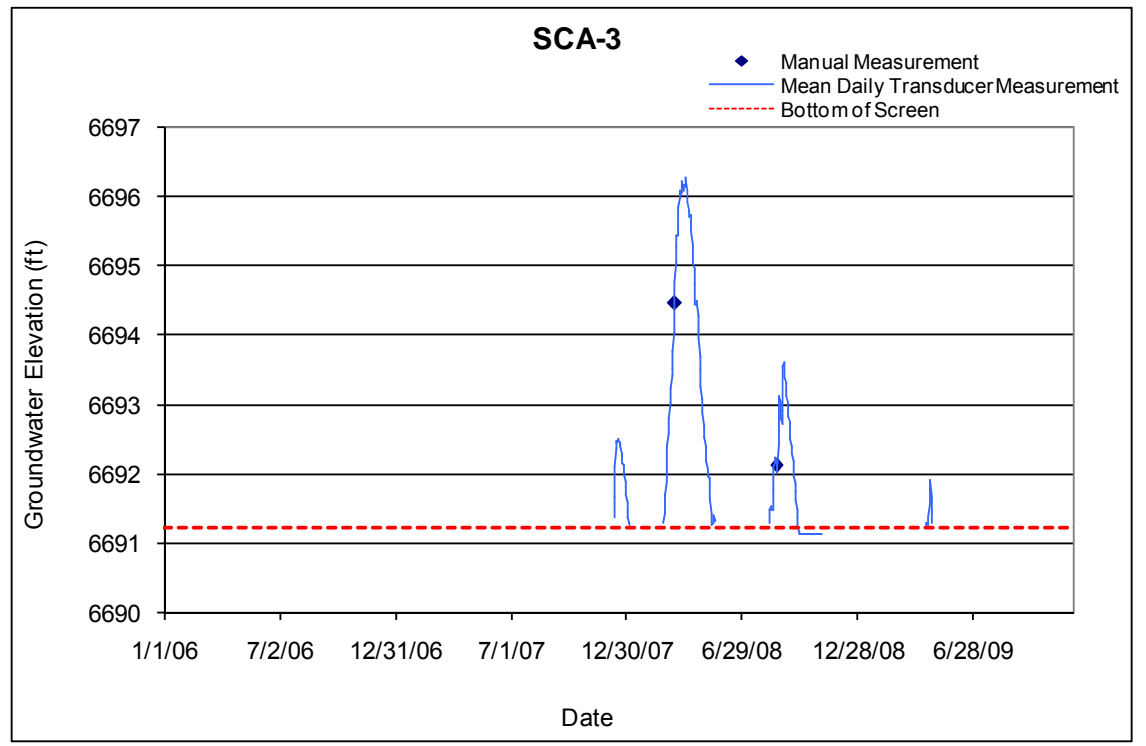




\subsection{SCA-4}

Location: Middle Sandia Canyon, approximately $700 \mathrm{ft}$ downstream from SCA-3.

Period of Record: October 3, 2006, through November 2, 2009.

Remarks: The transducer was installed on October 3,2006 , above the top of the pump at an elevation of $6665.28 \mathrm{ft}$. The pump was removed on October 31, 2006, to allow for complete water level monitoring.

\begin{tabular}{|c|c|c|c|c|c|c|c|c|c|c|c|c|c|}
\hline \multicolumn{14}{|c|}{ SCA-4 Construction Information } \\
\hline Zone & $\begin{array}{c}\text { Screen } \\
\text { Top } \\
\text { Depth (ft) }\end{array}$ & $\begin{array}{c}\text { Screen } \\
\text { Bottom } \\
\text { Depth } \\
\text { (ft) }\end{array}$ & $\begin{array}{c}\text { Screen } \\
\text { Top } \\
\text { Elev (ft) }\end{array}$ & $\begin{array}{l}\text { Screen } \\
\text { Bottom } \\
\text { Elev (ft) }\end{array}$ & $\begin{array}{c}\text { Screen } \\
\text { Length } \\
\text { (ft) }\end{array}$ & $\begin{array}{l}\text { Pump } \\
\text { Intake } \\
\text { Depth } \\
\text { (ft) }\end{array}$ & $\begin{array}{c}\text { Pump } \\
\text { Intake } \\
\text { Elevation } \\
\text { (ft) }\end{array}$ & $\begin{array}{c}\text { Depth to } \\
\text { Top of } \\
\text { Sump (ft) }\end{array}$ & $\begin{array}{c}\text { Top of } \\
\text { Sump } \\
\text { Elevation } \\
\text { (ft) }\end{array}$ & $\begin{array}{c}\text { Depth to } \\
\text { Sump } \\
\text { Bottom (ft) }\end{array}$ & $\begin{array}{c}\text { Sump } \\
\text { Length } \\
\text { (ft) }\end{array}$ & $\begin{array}{c}\text { Sump } \\
\text { Volume } \\
\text { (L) }\end{array}$ & Comment \\
\hline 1 & 37.0 & 41.5 & 6666.2 & 6661.7 & 4.5 & & & 41.5 & 6661.7 & 42.0 & 0.5 & 3.7 & Alluvial groundwater \\
\hline
\end{tabular}

Note: Brass Cap Elevation: $6703.58 \mathrm{ft}$; Ground elevation: $6703.20 \mathrm{ft}$; all depths are from this elevation
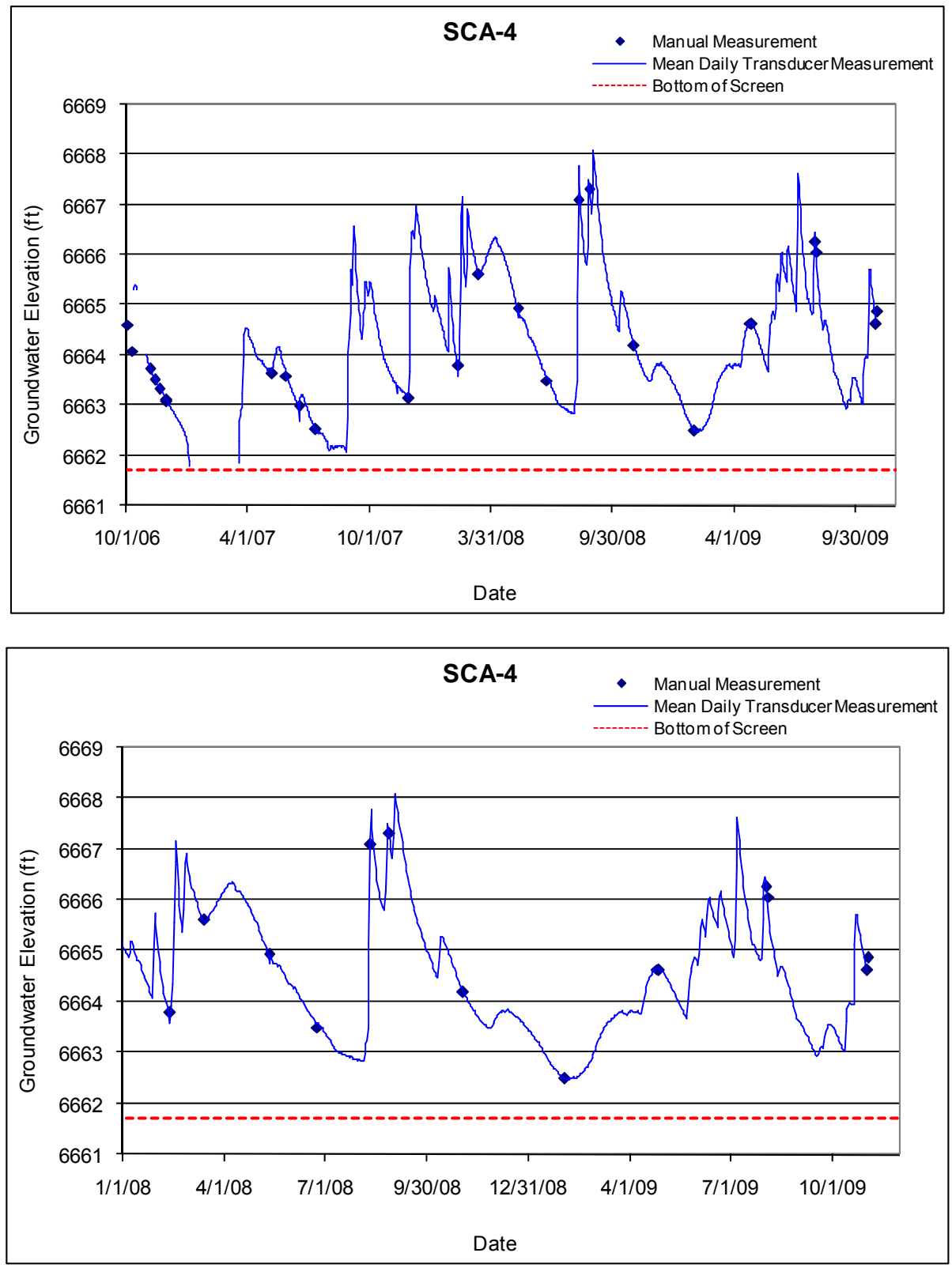


\subsection{SCA-5}

Location: Middle Sandia Canyon, approximately $650 \mathrm{ft}$ upstream from the firing range at TA-72 and about $325 \mathrm{ft}$ north of R-11.

Period of Record: October 3, 2006, through November 2, 2009.

Remarks: Until spring 2008, the transducer was installed above the pump in the 2-in. casing and the transducer data did not represent water levels below $6608.1 \mathrm{ft}$. Since spring 2008, the transducer has recorded all water in the well. This well has run dry frequently since installation of the pressure transducer.

\begin{tabular}{|c|c|c|c|c|c|c|c|c|c|c|c|c|c|}
\hline \multicolumn{14}{|c|}{ SCA-5 Construction Information } \\
\hline Zone & $\begin{array}{l}\text { Screen } \\
\text { Top } \\
\text { Depth (ft) }\end{array}$ & $\begin{array}{c}\text { Screen } \\
\text { Bottom } \\
\text { Depth } \\
\text { (ft) }\end{array}$ & $\begin{array}{c}\text { Screen } \\
\text { Top } \\
\text { Elev (ft) }\end{array}$ & $\begin{array}{l}\text { Screen } \\
\text { Bottom } \\
\text { Elev (ft) }\end{array}$ & $\begin{array}{c}\text { Screen } \\
\text { Length } \\
\text { (ft) }\end{array}$ & $\begin{array}{c}\text { Pump } \\
\text { Intake } \\
\text { Depth } \\
\text { (ft) }\end{array}$ & $\begin{array}{c}\text { Pump } \\
\text { Intake } \\
\text { Elevation } \\
\text { (ft) }\end{array}$ & $\begin{array}{l}\text { Depth to } \\
\text { Top of } \\
\text { Sump (ft) }\end{array}$ & $\begin{array}{c}\text { Top of } \\
\text { Sump } \\
\text { Elevation } \\
\text { (ft) }\end{array}$ & \begin{tabular}{|l} 
Depth to \\
Sump \\
Bottom (ft)
\end{tabular} & $\begin{array}{l}\text { Sump } \\
\text { Length } \\
\text { (ft) }\end{array}$ & $\begin{array}{c}\text { Sump } \\
\text { Volume } \\
\text { (L) }\end{array}$ & Comment \\
\hline 1 & 55.00 & 64.4 & 6614.0 & 6604.6 & 9.4 & & & 64.4 & 6604.6 & 64.9 & 0.5 & 0.3 & Alluvial groundwater \\
\hline
\end{tabular}
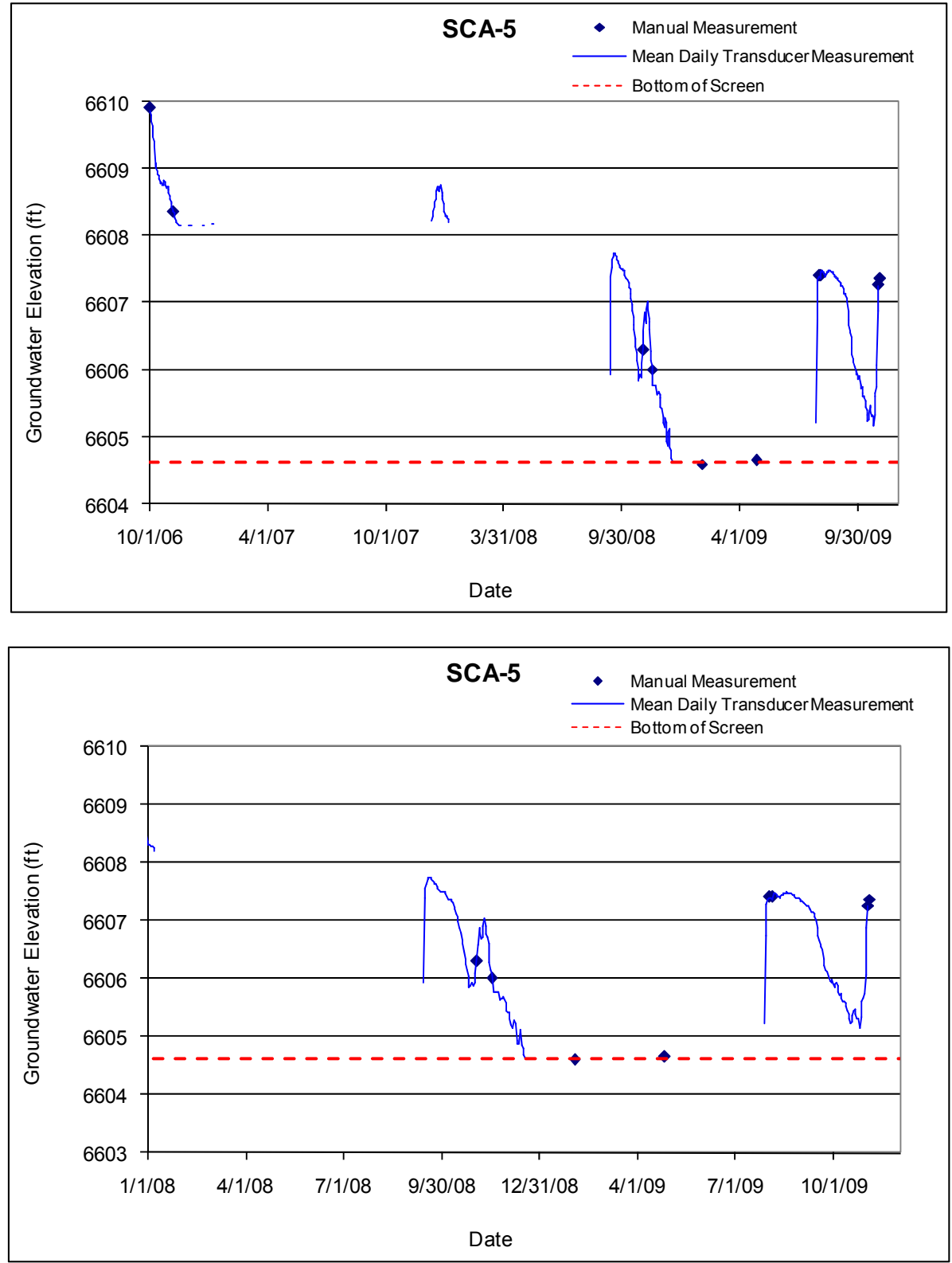


\subsection{SCO-1}

Location: Sandia Canyon, approximately 0.1 miles east of R-11.

Period of Record: June 7, 1997, through August 24, 2009.

Remarks: No valid data; well has been dry for every measurement event. There is no transducer installed in this well. Monitoring ceased in August 2009.

\begin{tabular}{|c|c|c|c|c|c|c|c|c|c|c|c|c|c|}
\hline \multicolumn{14}{|c|}{ SCO-1 Construction Information } \\
\hline Zone & $\begin{array}{c}\text { Screen } \\
\text { Top } \\
\text { Depth (ft) }\end{array}$ & $\begin{array}{c}\text { Screen } \\
\text { Bottom } \\
\text { Depth (ft) }\end{array}$ & $\begin{array}{c}\text { Screen } \\
\text { Top Elev } \\
\text { (ft) }\end{array}$ & $\begin{array}{l}\text { Screen } \\
\text { Bottom } \\
\text { Elev (ft) }\end{array}$ & $\begin{array}{l}\text { Screen } \\
\text { Length } \\
\text { (ft) }\end{array}$ & $\begin{array}{c}\text { Pump } \\
\text { Intake } \\
\text { Depth } \\
\text { (ft) }\end{array}$ & \begin{tabular}{|c|} 
Pump \\
Intake \\
Elevation \\
(ft)
\end{tabular} & $\begin{array}{c}\text { Depth to } \\
\text { Top of } \\
\text { Sump (ft) }\end{array}$ & \begin{tabular}{|c|} 
Top of \\
Sump \\
Elevation \\
(ft)
\end{tabular} & $\begin{array}{l}\text { Depth to } \\
\text { Sump } \\
\text { Bottom } \\
\text { (ft) }\end{array}$ & $\begin{array}{c}\text { Sump } \\
\text { Length } \\
\text { (ft) }\end{array}$ & $\begin{array}{c}\text { Sump } \\
\text { Volume } \\
\text { (L) }\end{array}$ & Comment \\
\hline 1 & 9.3 & 19.3 & 6609.4 & 6599.4 & 10.0 & & & 19.3 & 6599.4 & 19.3 & 0.0 & 0.0 & Alluvial groundwater \\
\hline
\end{tabular}

\begin{tabular}{|c|c|c|c|}
\hline \multicolumn{4}{|c|}{ SCO-1 Manual Water Levels } \\
\hline Date & Comments & Date & Comments \\
\hline $8 / 14 / 1989$ & Dry & $10 / 18 / 2005$ & Dry \\
\hline $6 / 9 / 1997$ & Dry & $12 / 8 / 2005$ & Dry \\
\hline $10 / 13 / 1997$ & Dry & $3 / 7 / 2006$ & Dry \\
\hline $3 / 25 / 1998$ & Dry & $6 / 13 / 2006$ & Dry \\
\hline $5 / 29 / 1998$ & Dry & $8 / 28 / 2006$ & Dry \\
\hline $7 / 28 / 1998$ & Dry & $9 / 7 / 2006$ & Dry \\
\hline $3 / 3 / 1999$ & Dry & $10 / 3 / 2006$ & Dry \\
\hline $6 / 23 / 1999$ & Dry & $12 / 8 / 2006$ & Dry \\
\hline $8 / 30 / 1999$ & Dry & $2 / 12 / 2007$ & Dry \\
\hline $11 / 15 / 1999$ & Dry & $3 / 13 / 2007$ & Dry \\
\hline $3 / 26 / 2000$ & Dry & $6 / 7 / 2007$ & Dry \\
\hline $5 / 16 / 2000$ & Dry & $6 / 12 / 2007$ & Dry \\
\hline $8 / 30 / 2000$ & Dry & $9 / 5 / 2007$ & Dry \\
\hline $10 / 8 / 2000$ & Dry & $11 / 12 / 2007$ & Dry \\
\hline $7 / 2 / 2001$ & Dry & $1 / 24 / 2008$ & Dry \\
\hline $8 / 22 / 2001$ & Dry & $2 / 12 / 2008$ & Dry \\
\hline $10 / 18 / 2001$ & Dry & $4 / 3 / 2008$ & Dry \\
\hline $1 / 27 / 2002$ & Dry & $5 / 12 / 2008$ & Dry \\
\hline $4 / 19 / 2002$ & Dry & $7 / 22 / 2008$ & Dry \\
\hline $8 / 27 / 2002$ & Dry & $8 / 11 / 2008$ & Dry \\
\hline $2 / 19 / 2003$ & Dry & $11 / 3 / 2008$ & Dry \\
\hline $5 / 18 / 2003$ & Dry & $2 / 2 / 2009$ & Dry \\
\hline $2 / 28 / 2005$ & Dry & $4 / 27 / 2009$ & Dry \\
\hline $6 / 7 / 2005$ & Dry & $8 / 24 / 2009$ & Dry \\
\hline $6 / 14 / 2005$ & Dry & & \\
\hline
\end{tabular}




\subsection{SCO-2}

Location: Sandia Canyon, approximately $300 \mathrm{ft}$ west of R-12.

Period of Record: June 9, 1997, through August 24, 2009.

Remarks: No valid data; well has been dry for every measurement event. There is no transducer installed in this well. Monitoring ceased in August 2009.

\begin{tabular}{|c|c|c|c|c|c|c|c|c|c|c|c|c|c|}
\hline \multicolumn{14}{|c|}{ SCO-2 Construction Information } \\
\hline Zone & $\begin{array}{l}\text { Screen } \\
\text { Top } \\
\text { Depth (ft) }\end{array}$ & $\begin{array}{c}\text { Screen } \\
\text { Bottom } \\
\text { Depth (ft) }\end{array}$ & $\begin{array}{l}\text { Screen } \\
\text { Top Elev } \\
\text { (ft) }\end{array}$ & $\begin{array}{l}\text { Screen } \\
\text { Bottom } \\
\text { Elev (ft) }\end{array}$ & $\begin{array}{l}\text { Screen } \\
\text { Length } \\
\text { (ft) }\end{array}$ & $\begin{array}{c}\text { Pump } \\
\text { Intake } \\
\text { Depth } \\
\text { (ft) }\end{array}$ & $\begin{array}{c}\text { Pump } \\
\text { Intake } \\
\text { Elevation } \\
\text { (ft) }\end{array}$ & $\begin{array}{c}\text { Depth to } \\
\text { Top of } \\
\text { Sump (ft) }\end{array}$ & $\begin{array}{c}\text { Top of } \\
\text { Sump } \\
\text { Elevation } \\
\text { (ft) }\end{array}$ & $\begin{array}{l}\text { Depth to } \\
\text { Sump } \\
\text { Bottom } \\
\text { (ft) }\end{array}$ & $\begin{array}{c}\text { Sump } \\
\text { Length } \\
\text { (ft) }\end{array}$ & $\begin{array}{c}\text { Sump } \\
\text { Volume } \\
\text { (L) }\end{array}$ & Comment \\
\hline 1 & 9.4 & 19.4 & 6491.3 & 6481.3 & 10.0 & & & 19.4 & 6481.3 & 19.4 & 0.0 & 0.0 & Alluvial groundwater \\
\hline
\end{tabular}

\begin{tabular}{|c|c|c|c|}
\hline \multicolumn{4}{|c|}{ SCO-2 Manual Water Levels } \\
\hline Date & Comments & Date & Comments \\
\hline $8 / 16 / 1989$ & Dry & $10 / 18 / 2005$ & Dry \\
\hline $6 / 9 / 1997$ & Dry & $12 / 8 / 2005$ & Dry \\
\hline $10 / 13 / 1997$ & Dry & $3 / 7 / 2006$ & Dry \\
\hline $3 / 25 / 1998$ & Dry & $6 / 13 / 2006$ & Dry \\
\hline $5 / 29 / 1998$ & Dry & $8 / 28 / 2006$ & Dry \\
\hline \begin{tabular}{|l|}
$7 / 28 / 1998$ \\
\end{tabular} & Dry & $9 / 7 / 2006$ & Dry \\
\hline $3 / 3 / 1999$ & Dry & $10 / 3 / 2006$ & Dry \\
\hline 6/23/1999 & Dry & $12 / 8 / 2006$ & Dry \\
\hline $8 / 30 / 1999$ & Dry & $2 / 12 / 2007$ & Dry \\
\hline $11 / 15 / 1999$ & Dry & $3 / 13 / 2007$ & Dry \\
\hline $3 / 26 / 2000$ & Dry & $6 / 7 / 2007$ & Dry \\
\hline $5 / 16 / 2000$ & Dry & $6 / 12 / 2007$ & Dry \\
\hline $8 / 30 / 2000$ & Dry & $9 / 5 / 2007$ & Dry \\
\hline $10 / 8 / 2000$ & Dry & $11 / 12 / 2007$ & Dry \\
\hline $7 / 2 / 2001$ & Dry & $1 / 24 / 2008$ & Dry \\
\hline $8 / 22 / 2001$ & Dry & $2 / 12 / 2008$ & Dry \\
\hline $10 / 18 / 2001$ & Dry & $4 / 3 / 2008$ & Dry \\
\hline $4 / 19 / 2002$ & Dry & $5 / 12 / 2008$ & Dry \\
\hline $8 / 27 / 2002$ & Dry & $7 / 22 / 2008$ & Dry \\
\hline \begin{tabular}{|l|}
$10 / 27 / 2002$ \\
\end{tabular} & Dry & $8 / 11 / 2008$ & Dry \\
\hline $2 / 19 / 2003$ & Dry & $11 / 3 / 2008$ & Dry \\
\hline \begin{tabular}{|l|}
$5 / 18 / 2003$ \\
\end{tabular} & Dry & $2 / 2 / 2009$ & Dry \\
\hline $6 / 7 / 2005$ & Dry & $4 / 27 / 2009$ & Dry \\
\hline $6 / 14 / 2005$ & Dry & $8 / 24 / 2009$ & Dry \\
\hline
\end{tabular}




\subsection{SCP-1abc}

Location: Middle Sandia Canyon, approximately $5 \mathrm{ft}$ west of SCA-4.

Period of Record: October 13, 2006, through November 20, 2009.

Remarks: SCP-1abc is a triple-nested piezometer.

\begin{tabular}{|c|c|c|c|c|c|c|c|c|c|c|c|c|c|}
\hline \multicolumn{14}{|c|}{ SCP-1abc Construction Information } \\
\hline Zone & $\begin{array}{c}\text { Screen } \\
\text { Top } \\
\text { Depth (ft) }\end{array}$ & $\begin{array}{c}\text { Screen } \\
\text { Bottom } \\
\text { Depth } \\
\text { (ft) }\end{array}$ & $\begin{array}{c}\text { Screen } \\
\text { Top } \\
\text { Elev (ft) }\end{array}$ & $\begin{array}{l}\text { Screen } \\
\text { Bottom } \\
\text { Elev (ft) }\end{array}$ & $\begin{array}{l}\text { Screen } \\
\text { Length } \\
\text { (ft) }\end{array}$ & $\begin{array}{l}\text { Pump } \\
\text { Intake } \\
\text { Depth } \\
\text { (ft) }\end{array}$ & $\begin{array}{c}\text { Pump } \\
\text { Intake } \\
\text { Elevation } \\
\text { (ft) }\end{array}$ & \begin{tabular}{|c|} 
Depth to \\
Top of \\
Sump (ft)
\end{tabular} & $\begin{array}{c}\text { Top of } \\
\text { Sump } \\
\text { Elevation } \\
\text { (ft) }\end{array}$ & \begin{tabular}{|c|} 
Depth to \\
Sump \\
Bottom (ft)
\end{tabular} & $\begin{array}{c}\text { Sump } \\
\text { Length } \\
\text { (ft) }\end{array}$ & $\begin{array}{c}\text { Sump } \\
\text { Volume } \\
\text { (L) }\end{array}$ & Comment \\
\hline$a$ & 37.80 & 38.3 & 6665.44 & 6664.94 & 0.5 & & & 38.3 & 6664.9 & 38.4 & 0.1 & 0.004 & Alluvial groundwater \\
\hline $\mathrm{b}$ & 39.4 & 39.9 & 6663.84 & 6663.34 & 0.5 & & & 39.9 & 6663.34 & 40.0 & 0.1 & 0.004 & Alluvial groundwater \\
\hline C & 41.2 & 41.7 & 6662.04 & 6661.54 & 0.5 & & & 41.7 & 6661.54 & 41.8 & 0.1 & 0.004 & Alluvial groundwater \\
\hline
\end{tabular}
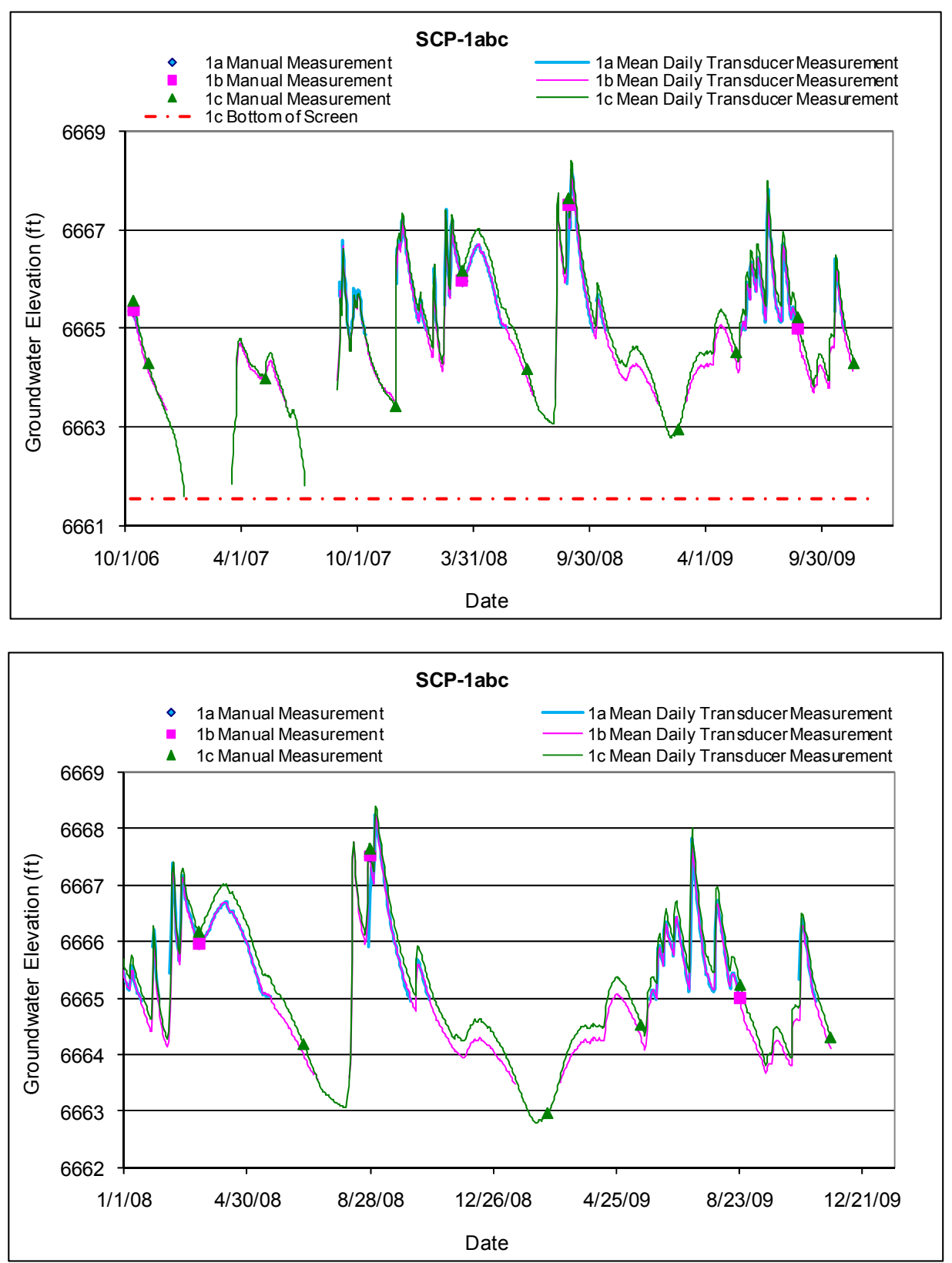


\subsection{SCP-2a}

Location: Middle Sandia Canyon, approximately $10 \mathrm{ft}$ east of SCA-3 and $5 \mathrm{ft}$ east of SCP-2b.

Period of Record: October 13, 2006, through November 20, 2009.

Remarks: None.

\begin{tabular}{|c|c|c|c|c|c|c|c|c|c|c|c|c|c|}
\hline \multicolumn{14}{|c|}{ SCP-2a Construction Information } \\
\hline Zone & $\begin{array}{c}\text { Screen } \\
\text { Top } \\
\text { Depth (ft) }\end{array}$ & $\begin{array}{c}\text { Screen } \\
\text { Bottom } \\
\text { Depth } \\
\text { (ft) }\end{array}$ & $\begin{array}{c}\text { Screen } \\
\text { Top Elev } \\
\text { (ft) }\end{array}$ & $\begin{array}{l}\text { Screen } \\
\text { Bottom } \\
\text { Elev (ft) }\end{array}$ & $\begin{array}{c}\text { Screen } \\
\text { Length } \\
\text { (ft) }\end{array}$ & $\begin{array}{l}\text { Pump } \\
\text { Intake } \\
\text { Depth } \\
\text { (ft) }\end{array}$ & $\begin{array}{c}\text { Pump } \\
\text { Intake } \\
\text { Elevation } \\
\text { (ft) }\end{array}$ & $\begin{array}{c}\text { Depth to } \\
\text { Top of } \\
\text { Sump (ft) }\end{array}$ & \begin{tabular}{|} 
Top of \\
Sump \\
Elevation \\
(ft)
\end{tabular} & \begin{tabular}{|c|} 
Depth to \\
Sump \\
Bottom (ft)
\end{tabular} & $\begin{array}{c}\text { Sump } \\
\text { Length } \\
\text { (ft) }\end{array}$ & $\begin{array}{c}\text { Sump } \\
\text { Volume } \\
\text { (L) }\end{array}$ & Comment \\
\hline $2 a$ & 44.5 & 45.0 & 6678.1 & 6677.6 & 0.5 & & & 45.0 & 6678.0 & 45.1 & 0.1 & 0.02 & Alluvial groundwater \\
\hline
\end{tabular}

Note: Brass Cap Elevation: $6722.95 \mathrm{ft}$; Ground elevation: $6722.57 \mathrm{ft}$; all depths are from this elevation
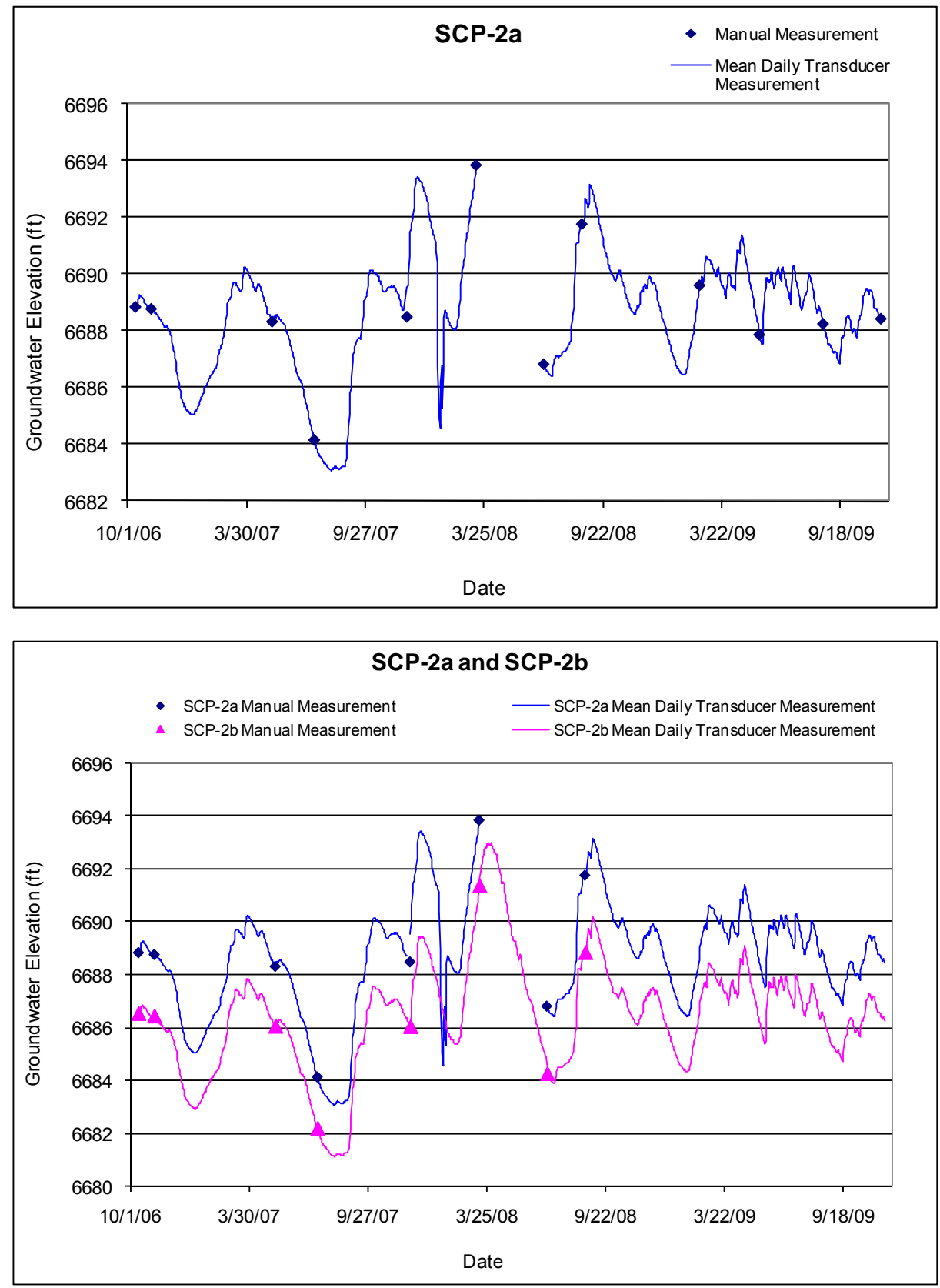


\subsection{SCP-2b}

Location: Middle Sandia Canyon, approximately $5 \mathrm{ft}$ east of SCA-3 and $5 \mathrm{ft}$ west of SCP-2a.

Period of Record: October 13, 2006, through November 20, 2009.

Remarks: None.

\begin{tabular}{|c|c|c|c|c|c|c|c|c|c|c|c|c|c|}
\hline \multicolumn{14}{|c|}{ SCP-2b Construction Information } \\
\hline Zone & $\begin{array}{l}\text { Screen } \\
\text { Top } \\
\text { Depth (ft) }\end{array}$ & $\begin{array}{c}\text { Screen } \\
\text { Bottom } \\
\text { Depth } \\
\text { (ft) }\end{array}$ & $\begin{array}{c}\text { Screen } \\
\text { Top } \\
\text { Elev (ft) }\end{array}$ & $\begin{array}{l}\text { Screen } \\
\text { Bottom } \\
\text { Elev (ft) }\end{array}$ & $\begin{array}{c}\text { Screen } \\
\text { Length } \\
\text { (ft) }\end{array}$ & $\begin{array}{c}\text { Pump } \\
\text { Intake } \\
\text { Depth } \\
\text { (ft) }\end{array}$ & $\begin{array}{c}\text { Pump } \\
\text { Intake } \\
\text { Elevation } \\
\text { (ft) }\end{array}$ & $\begin{array}{l}\text { Depth to } \\
\text { Top of } \\
\text { Sump (ft) }\end{array}$ & $\begin{array}{c}\text { Top of } \\
\text { Sump } \\
\text { Elevation } \\
\text { (ft) }\end{array}$ & \begin{tabular}{|} 
Depth to \\
Sump \\
Bottom (ft)
\end{tabular} & $\begin{array}{l}\text { Sump } \\
\text { Length } \\
\text { (ft) }\end{array}$ & $\begin{array}{l}\text { Sump } \\
\text { Volume } \\
\text { (L) }\end{array}$ & Comment \\
\hline $2 b$ & 49.5 & 50.0 & 6673.1 & 6672.6 & 0.5 & & & 50.0 & 6673.1 & 50.1 & 0.1 & 0.02 & Alluvial groundwater \\
\hline
\end{tabular}
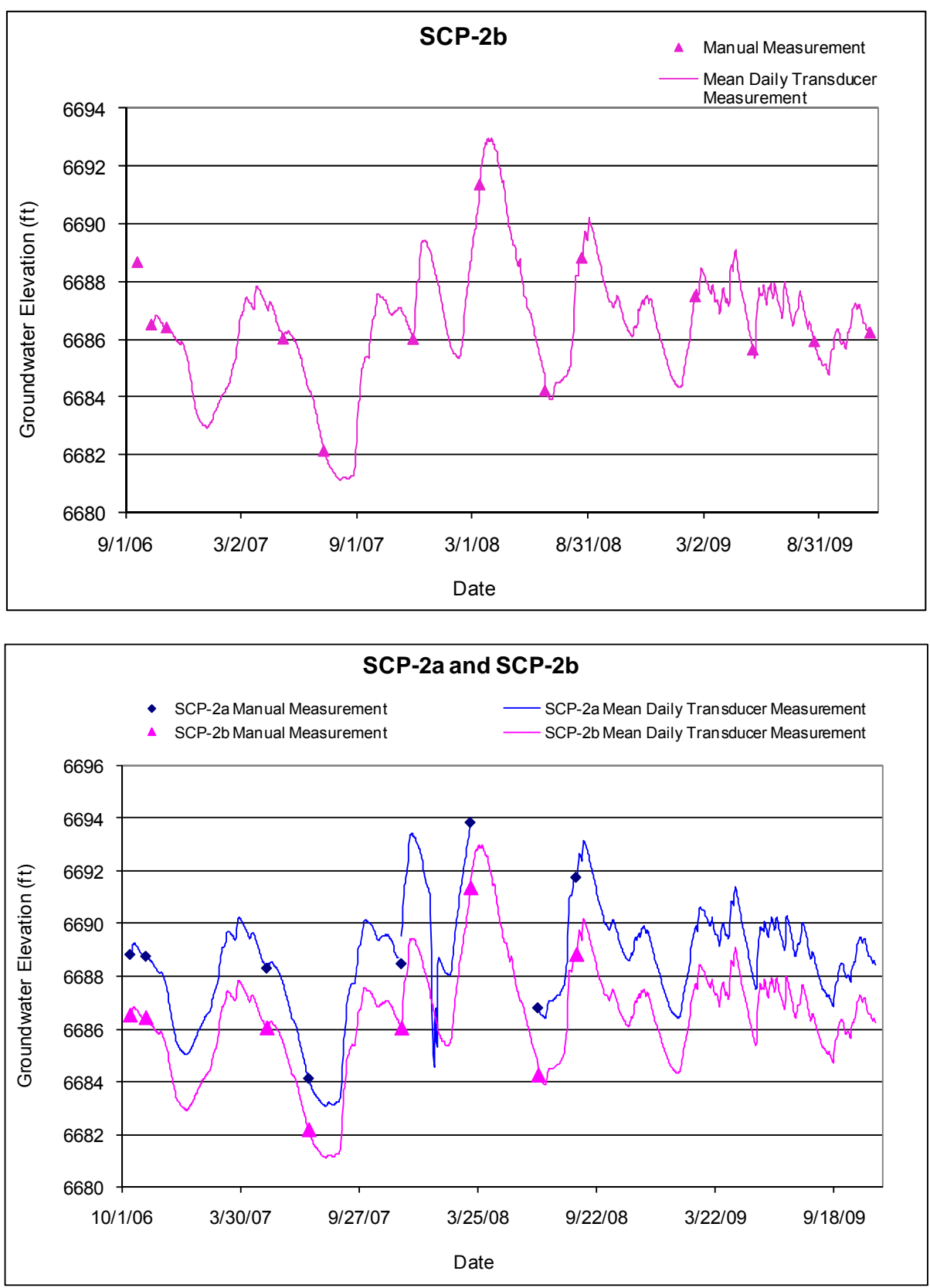


\subsection{TMO-1}

Location: In lower Two Mile Canyon, just above the confluence with Pajarito Canyon; approximately $500 \mathrm{ft}$ upstream of PCAO-5 and the flood retention dam.

Period of Record: July 17, 2008, through December 12, 2009.

Remarks: Data from July 17, 2008, through August 9, 2008, were invalidated because transducer was hanging above level of water. The transducer was lowered to the bottom of the well on December 12, 2009.

\begin{tabular}{|c|c|c|c|c|c|c|c|c|c|c|c|c|c|}
\hline \multicolumn{14}{|c|}{ TMO-1 Construction Information } \\
\hline Zone & $\begin{array}{c}\text { Screen } \\
\text { Top } \\
\text { Depth (ft) }\end{array}$ & \begin{tabular}{|c|} 
Screen \\
Bottom \\
Depth (ft)
\end{tabular} & $\begin{array}{c}\text { Screen } \\
\text { Top } \\
\text { Elevation } \\
\text { (ft) }\end{array}$ & $\begin{array}{c}\text { Screen } \\
\text { Bottom } \\
\text { Elevation } \\
\text { (ft) }\end{array}$ & $\begin{array}{c}\text { Screen } \\
\text { Length } \\
\text { (ft) }\end{array}$ & $\begin{array}{l}\text { Pump } \\
\text { Intake } \\
\text { Depth } \\
\text { (ft) }\end{array}$ & $\begin{array}{c}\text { Pump } \\
\text { Intake } \\
\text { Elevation } \\
\text { (ft) }\end{array}$ & $\begin{array}{l}\text { Depth to } \\
\text { Top of } \\
\text { Sump } \\
\text { (ft) }\end{array}$ & $\begin{array}{c}\text { Top of } \\
\text { Sump } \\
\text { Elevation } \\
\text { (ft) }\end{array}$ & $\begin{array}{l}\text { Depth to } \\
\text { Sump } \\
\text { Bottom } \\
\text { (ft) }\end{array}$ & $\begin{array}{c}\text { Sump } \\
\text { Length } \\
\text { (ft) }\end{array}$ & $\begin{array}{c}\text { Sump } \\
\text { Volume } \\
\text { (L) }\end{array}$ & Comments \\
\hline 1 & 3.5 & 6.5 & 6941.7 & 6938.7 & 3.0 & & & 6.5 & 6938.7 & 6.5 & 0.0 & 0.0 & Hand-augered well \\
\hline
\end{tabular}

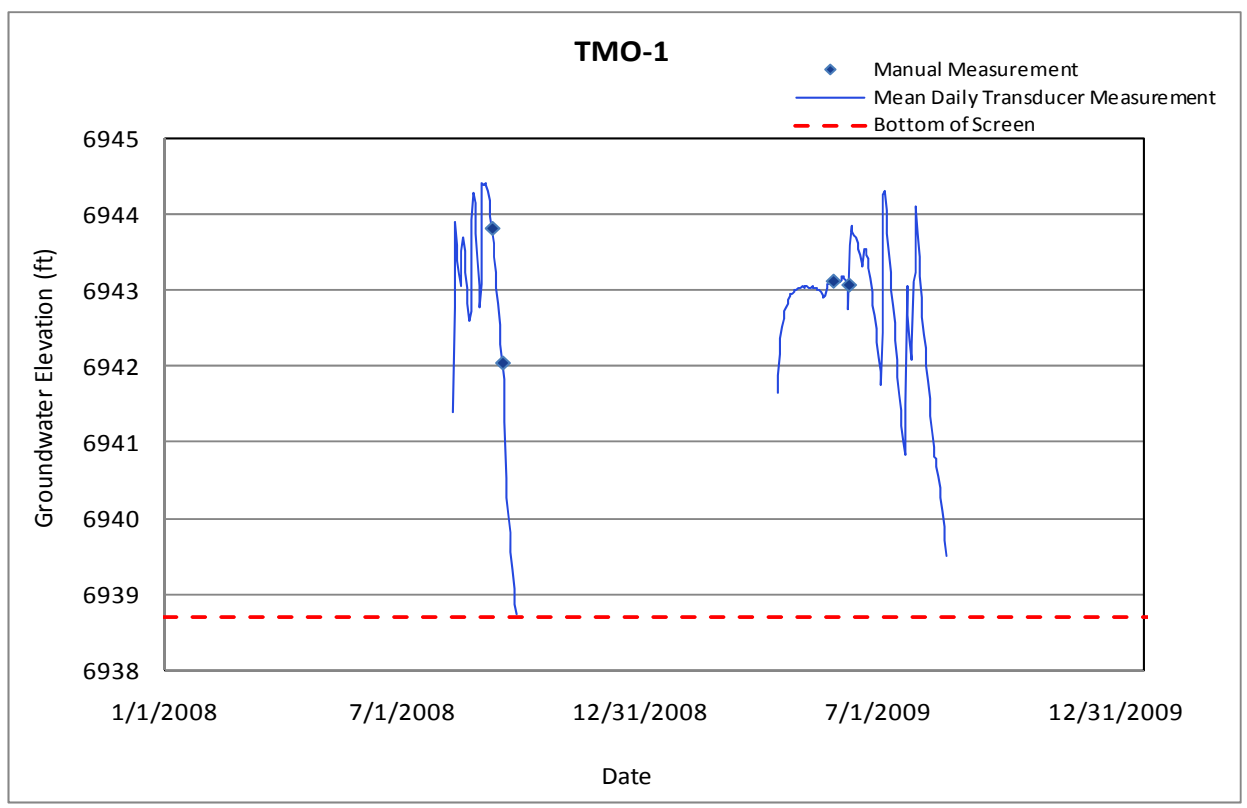




\subsection{TSCA-6}

Location: Ten Site Canyon, approximately $600 \mathrm{ft}$ west of Mortandad Canyon confluence.

Period of Record: April 18, 2005, through November 2, 2009.

Remarks: This well tends to run dry seasonally, and has been dry since May 2009.

\begin{tabular}{|c|c|c|c|c|c|c|c|c|c|c|c|c|c|}
\hline \multicolumn{14}{|c|}{ TSCA-6 Construction Information } \\
\hline Zone & $\begin{array}{l}\text { Screen } \\
\text { Top } \\
\text { Depth (ft) }\end{array}$ & $\begin{array}{c}\text { Screen } \\
\text { Bottom } \\
\text { Depth } \\
\text { (ft) }\end{array}$ & $\begin{array}{c}\text { Screen } \\
\text { Top } \\
\text { Elev (ft) }\end{array}$ & $\begin{array}{l}\text { Screen } \\
\text { Bottom } \\
\text { Elev (ft) }\end{array}$ & $\begin{array}{c}\text { Screen } \\
\text { Length } \\
\text { (ft) }\end{array}$ & $\begin{array}{c}\text { Pump } \\
\text { Intake } \\
\text { Depth } \\
\text { (ft) }\end{array}$ & $\begin{array}{c}\text { Pump } \\
\text { Intake } \\
\text { Elevation } \\
\text { (ft) }\end{array}$ & $\begin{array}{c}\text { Depth to } \\
\text { Top of } \\
\text { Sump (ft) }\end{array}$ & $\begin{array}{c}\text { Top of } \\
\text { Sump } \\
\text { Elevation } \\
\text { (ft) }\end{array}$ & $\begin{array}{l}\text { Depth to } \\
\text { Sump } \\
\text { Bottom (ft) }\end{array}$ & $\begin{array}{c}\text { Sump } \\
\text { Length } \\
\text { (ft) }\end{array}$ & $\begin{array}{c}\text { Sump } \\
\text { Volume } \\
\text { (L) }\end{array}$ & Comment \\
\hline 1 & 16.20 & 20.9 & 6847.0 & 6842.3 & 4.7 & & & 20.9 & 6842.3 & 21.3 & 0.4 & 0.2 & Alluvial groundwater \\
\hline
\end{tabular}

Note: Ground elevation is $6863.2 \mathrm{ft}$; all depths are from this elevation
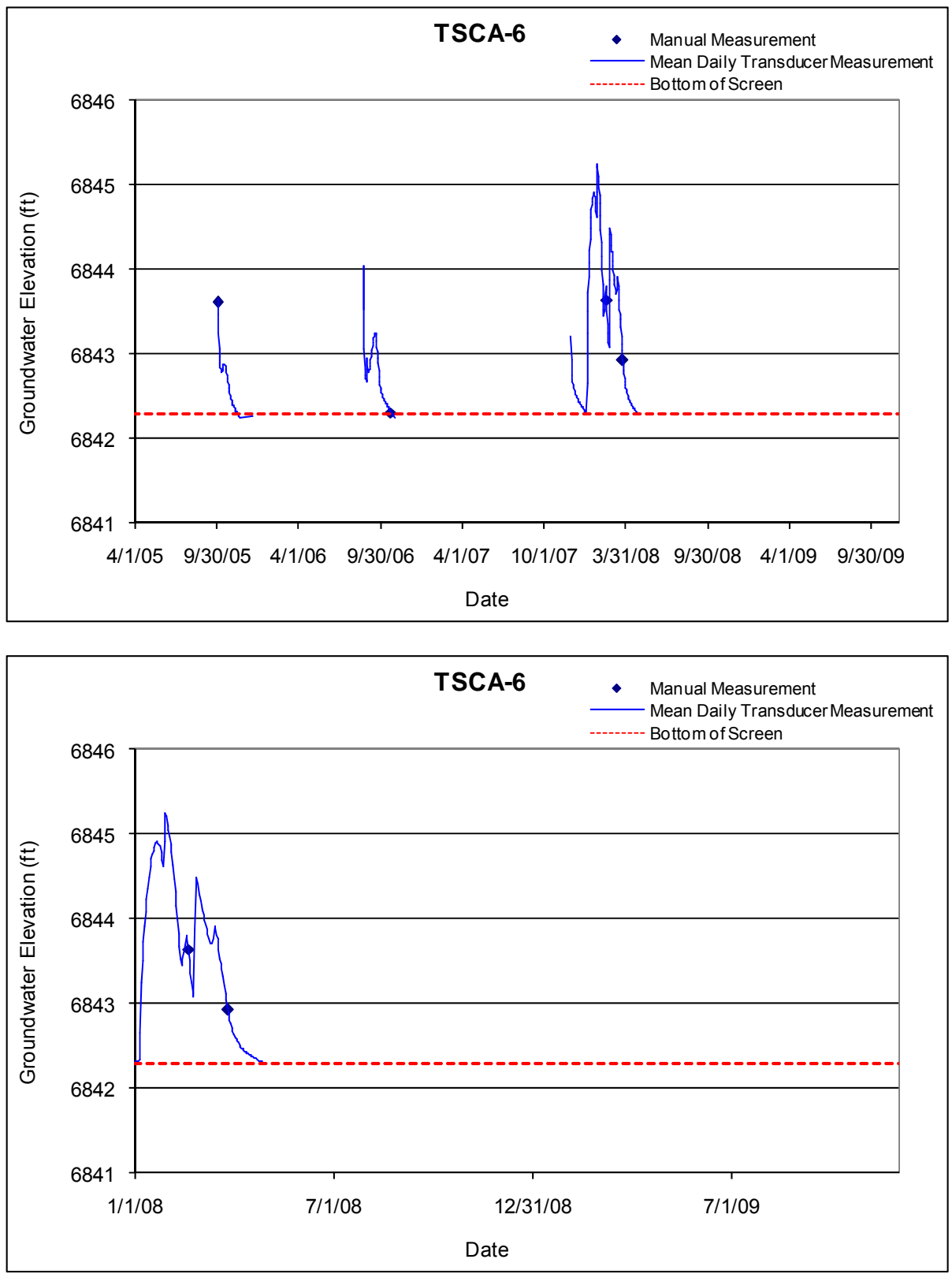


\subsection{TSWB-6}

Location: Ten Site Canyon, approximately $300 \mathrm{ft}$ west of confluence with Mortandad Canyon. Period of Record: January 9, 1995, through February 7, 2008.

Remarks: No valid groundwater level data exist for TSWB-6. Well has been dry during every measurement event. A transducer was installed July 5, 2006, and removed on January 24, 2008; the transducer never recorded water in the well. Monitoring ceased when the transducer was removed.

\begin{tabular}{|c|c|c|c|c|c|c|c|c|c|c|c|c|c|}
\hline \multicolumn{14}{|c|}{ TSWB-6 Construction Information } \\
\hline Zone & $\begin{array}{c}\text { Screen } \\
\text { Top } \\
\text { Depth (ft) }\end{array}$ & $\begin{array}{c}\text { Screen } \\
\text { Bottom } \\
\begin{array}{c}\text { Depth } \\
\text { (ft) }\end{array}\end{array}$ & $\begin{array}{c}\text { Screen } \\
\text { Top } \\
\text { Elev (ft) }\end{array}$ & $\begin{array}{l}\text { Screen } \\
\text { Bottom } \\
\text { Elev (ft) }\end{array}$ & $\begin{array}{c}\text { Screen } \\
\text { Length } \\
\text { (ft) }\end{array}$ & $\begin{array}{c}\text { Pump } \\
\text { Intake } \\
\text { Depth } \\
\text { (ft) }\end{array}$ & $\begin{array}{c}\text { Pump } \\
\text { Intake } \\
\text { Elevation } \\
\text { (ft) }\end{array}$ & $\begin{array}{c}\text { Depth to } \\
\text { Top of } \\
\text { Sump (ft) }\end{array}$ & $\begin{array}{c}\text { Top of } \\
\text { Sump } \\
\text { Elevation } \\
\text { (ft) }\end{array}$ & \begin{tabular}{|c|} 
Depth to \\
Sump \\
Bottom (ft)
\end{tabular} & $\begin{array}{c}\text { Sump } \\
\text { Length } \\
\text { (ft) }\end{array}$ & $\begin{array}{c}\text { Sump } \\
\text { Volume } \\
\text { (L) }\end{array}$ & Comment \\
\hline 1 & 25.0 & 35.0 & 6828.21 & 6818.21 & 10.0 & & & 35.0 & 6818.2 & 40.0 & 5.0 & 7.0 & Alluvial groundwater \\
\hline
\end{tabular}

\begin{tabular}{|c|c|c|c|}
\hline \multicolumn{4}{|c|}{ TSWB-6 Manual Water Levels } \\
\hline Date & Comment & Date & Comment \\
\hline $1 / 9 / 1995$ & Dry & $11 / 14 / 2002$ & Dry \\
\hline 9/18/1995 & Dry & $2 / 21 / 2003$ & Dry \\
\hline $11 / 13 / 1996$ & Dry & $6 / 11 / 2003$ & Dry \\
\hline $6 / 25 / 1997$ & Dry & $12 / 14 / 2005$ & Dry \\
\hline $7 / 7 / 1997$ & Dry & $7 / 5 / 2006$ & Dry \\
\hline $2 / 9 / 2000$ & Dry & $7 / 10 / 2006$ & Dry \\
\hline $3 / 27 / 2000$ & Dry & $9 / 26 / 2006$ & Dry \\
\hline $6 / 23 / 2000$ & Dry & $10 / 26 / 2006$ & Dry \\
\hline $9 / 28 / 2000$ & Dry & $10 / 30 / 2006$ & Dry \\
\hline $11 / 15 / 2000$ & Dry & $11 / 1 / 2006$ & Dry \\
\hline $12 / 11 / 2000$ & Dry & $1 / 30 / 2007$ & Dry \\
\hline $6 / 11 / 2001$ & Dry & $3 / 7 / 2007$ & Dry \\
\hline $7 / 2 / 2001$ & Dry & $4 / 16 / 2007$ & Dry \\
\hline $8 / 22 / 2001$ & Dry & $7 / 5 / 2007$ & Dry \\
\hline $10 / 18 / 2001$ & Dry & $11 / 1 / 2007$ & Dry \\
\hline $4 / 17 / 2002$ & Dry & $1 / 24 / 2008$ & Dry \\
\hline $7 / 2 / 2002$ & Dry & $2 / 7 / 2008$ & Dry \\
\hline $8 / 19 / 2002$ & Dry & & \\
\hline
\end{tabular}




\subsection{WCO-1}

Location: Water Canyon, near western border of TA-68.

Period of Record: October 31,1989, through October 7, 2009.

Remarks: This well is usually dry. There are only two records indicating water in well. This well was plugged and abandoned in December 2009. Monitoring will move to WCO-1a.

\begin{tabular}{|c|c|c|c|c|c|c|c|c|c|c|c|c|c|}
\hline \multicolumn{14}{|c|}{ WCO-1 Construction Information } \\
\hline Zone & $\begin{array}{c}\text { Screen } \\
\text { Top } \\
\text { Depth (ft) }\end{array}$ & $\begin{array}{c}\text { Screen } \\
\text { Bottom } \\
\text { Depth } \\
\text { (ft) }\end{array}$ & $\begin{array}{c}\text { Screen } \\
\text { Top } \\
\text { Elev }(\mathrm{ft})\end{array}$ & $\begin{array}{l}\text { Screen } \\
\text { Bottom } \\
\text { Elev (ft) }\end{array}$ & $\begin{array}{c}\text { Screen } \\
\text { Length } \\
\text { (ft) }\end{array}$ & $\begin{array}{c}\text { Pump } \\
\text { Intake } \\
\text { Depth } \\
\text { (ft) }\end{array}$ & $\begin{array}{c}\text { Pump } \\
\text { Intake } \\
\text { Elevation } \\
\text { (ft) }\end{array}$ & $\begin{array}{c}\text { Depth to } \\
\text { Top of } \\
\text { Sump (ft) }\end{array}$ & $\begin{array}{c}\text { Top of } \\
\text { Sump } \\
\text { Elevation } \\
\text { (ft) }\end{array}$ & \begin{tabular}{|c|} 
Depth to \\
Sump \\
Bottom (ft)
\end{tabular} & $\begin{array}{c}\text { Sump } \\
\text { Length } \\
\text { (ft) }\end{array}$ & $\begin{array}{c}\text { Sump } \\
\text { Volume } \\
\text { (L) }\end{array}$ & Comment \\
\hline 1 & 24.4 & 34.4 & 6592.0 & 6582.0 & 10.0 & & & 34.4 & 6582.0 & 34.4 & 0.0 & 0.0 & Alluvial groundwater \\
\hline
\end{tabular}

\begin{tabular}{|c|c|c|c|}
\hline \multicolumn{4}{|c|}{ WCO-1 Manual Water Levels } \\
\hline Date & $\begin{array}{l}\text { Groundwater } \\
\text { Elevation }(\mathrm{ft})\end{array}$ & Date & $\begin{array}{l}\text { Groundwater } \\
\text { Elevation (ft) }\end{array}$ \\
\hline $10 / 31 / 1989$ & Dry & $6 / 19 / 2003$ & Dry \\
\hline $11 / 1 / 1989$ & Dry & 9/14/2005 & Dry \\
\hline $8 / 24 / 1990$ & Dry & $12 / 22 / 2005$ & Dry \\
\hline 6/23/1997 & 6582.75 & $3 / 13 / 2006$ & Dry \\
\hline $10 / 13 / 1997$ & Dry & $6 / 23 / 2006$ & Dry \\
\hline $3 / 25 / 1998$ & Dry & 9/13/2006 & Dry \\
\hline $5 / 29 / 1998$ & 6582.75 & $12 / 15 / 2006$ & Dry \\
\hline $7 / 28 / 1998$ & Dry & $1 / 24 / 2007$ & Dry \\
\hline $3 / 3 / 1999$ & Dry & $3 / 15 / 2007$ & Dry \\
\hline $6 / 23 / 1999$ & Dry & $5 / 24 / 2007$ & Dry \\
\hline $8 / 30 / 1999$ & Dry & 6/6/2007 & Dry \\
\hline $11 / 15 / 1999$ & Dry & 9/5/2007 & Dry \\
\hline $3 / 26 / 2000$ & Dry & \begin{tabular}{|l|}
$10 / 17 / 2007$ \\
\end{tabular} & Dry \\
\hline $5 / 16 / 2000$ & Dry & $1 / 16 / 2008$ & Dry \\
\hline $8 / 30 / 2000$ & Dry & $4 / 8 / 2008$ & Dry \\
\hline $10 / 8 / 2000$ & Dry & $4 / 25 / 2008$ & Dry \\
\hline $7 / 2 / 2001$ & Dry & $7 / 18 / 2008$ & Dry \\
\hline $8 / 22 / 2001$ & Dry & $10 / 7 / 2008$ & Dry \\
\hline $10 / 18 / 2001$ & Dry & $2 / 6 / 2009$ & Dry \\
\hline $4 / 19 / 2002$ & Dry & $3 / 23 / 2009$ & Dry \\
\hline $8 / 19 / 2002$ & Dry & $7 / 2 / 2009$ & Dry \\
\hline $11 / 13 / 2002$ & Dry & $10 / 7 / 2009$ & Dry \\
\hline $2 / 18 / 2003$ & Dry & & \\
\hline
\end{tabular}




\subsection{WCO-2}

Location: Water Canyon, about 0.9 miles west of gate 9 on SR-4.

Period of Record: October 26, 1989, through October 7, 2009.

Remarks: The transducer malfunctioned on August 23, 2008, and was fixed February 6, 2009.

\begin{tabular}{|c|c|c|c|c|c|c|c|c|c|c|c|c|c|}
\hline \multicolumn{14}{|c|}{ WCO-2 Construction Information } \\
\hline Zone & $\begin{array}{c}\text { Screen } \\
\text { Top } \\
\text { Depth (ft) }\end{array}$ & $\begin{array}{c}\text { Screen } \\
\text { Bottom } \\
\text { Depth } \\
\text { (ft) }\end{array}$ & $\begin{array}{c}\text { Screen } \\
\text { Top } \\
\text { Elev (ft) }\end{array}$ & $\begin{array}{l}\text { Screen } \\
\text { Bottom } \\
\text { Elev (ft) }\end{array}$ & $\begin{array}{c}\text { Screen } \\
\text { Length } \\
\text { (ft) }\end{array}$ & $\begin{array}{l}\text { Pump } \\
\text { Intake } \\
\text { Depth } \\
\text { (ft) }\end{array}$ & $\begin{array}{c}\text { Pump } \\
\text { Intake } \\
\text { Elevation } \\
\text { (ft) }\end{array}$ & $\begin{array}{c}\text { Depth to } \\
\text { Top of } \\
\text { Sump (ft) }\end{array}$ & $\begin{array}{c}\text { Top of } \\
\text { Sump } \\
\text { Elevation } \\
\text { (ft) }\end{array}$ & $\begin{array}{c}\text { Depth to } \\
\text { Sump } \\
\text { Bottom (ft) }\end{array}$ & $\begin{array}{c}\text { Sump } \\
\text { Length } \\
\text { (ft) }\end{array}$ & $\begin{array}{c}\text { Sump } \\
\text { Volume } \\
\text { (L) }\end{array}$ & Comment \\
\hline 1 & 13.5 & 23.5 & 6511.1 & 6501.1 & 10.0 & & & 23.5 & 6501.1 & 23.5 & 0.0 & 0.0 & Alluvial groundwater \\
\hline
\end{tabular}

Note: Ground elevation is $6524.57 \mathrm{ft}$; all measurements are from this elevation
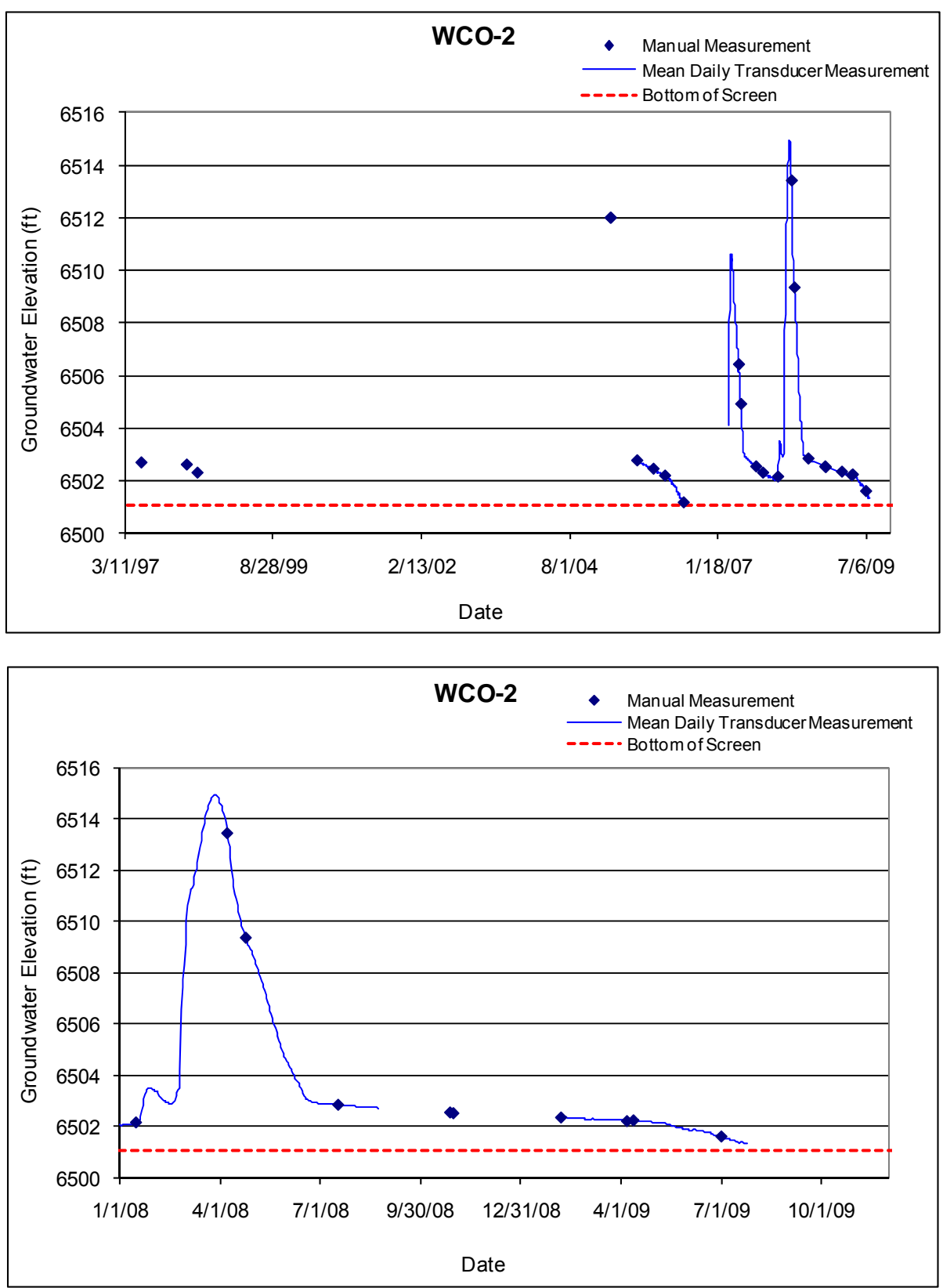


\subsection{WCO-3}

Location: Water Canyon, approximately 0.1 miles west of gate 9 on SR-4.

Period of Record: October 25, 1989, through October 7, 2009.

Remarks: Well is typically dry. A transducer was installed January 16,2008 , and never recorded any water in the well. This well was plugged and abandoned in December 2009. Monitoring will move to WCO-3a.

\begin{tabular}{|c|c|c|c|c|c|c|c|c|c|c|c|c|c|}
\hline \multicolumn{14}{|c|}{ WCO-3 Construction Information } \\
\hline Zone & $\begin{array}{c}\text { Screen } \\
\text { Top } \\
\text { Depth (ft) }\end{array}$ & $\begin{array}{c}\text { Screen } \\
\text { Bottom } \\
\text { Depth } \\
\text { (ft) }\end{array}$ & $\begin{array}{c}\text { Screen } \\
\text { Top } \\
\text { Elev (ft) }\end{array}$ & $\begin{array}{l}\text { Screen } \\
\text { Bottom } \\
\text { Elev (ft) }\end{array}$ & $\begin{array}{c}\text { Screen } \\
\text { Length } \\
\text { (ft) }\end{array}$ & $\begin{array}{c}\text { Pump } \\
\text { Intake } \\
\text { Depth } \\
\text { (ft) }\end{array}$ & $\begin{array}{c}\text { Pump } \\
\text { Intake } \\
\text { Elevation } \\
\text { (ft) }\end{array}$ & $\begin{array}{c}\text { Depth to } \\
\text { Top of } \\
\text { Sump (ft) }\end{array}$ & $\begin{array}{c}\text { Top of } \\
\text { Sump } \\
\text { Elevation } \\
\text { (ft) }\end{array}$ & \begin{tabular}{|c|} 
Depth to \\
Sump \\
Bottom (ft)
\end{tabular} & $\begin{array}{c}\text { Sump } \\
\text { Length } \\
\text { (ft) }\end{array}$ & $\begin{array}{c}\text { Sump } \\
\text { Volume } \\
\text { (L) }\end{array}$ & Comment \\
\hline 1 & 7.4 & 12.4 & 6429.0 & 6424.0 & 5.0 & & & 12.4 & 6424.0 & 12.4 & 0.0 & 0.0 & Alluvial groundwater \\
\hline
\end{tabular}

\begin{tabular}{|r|c|r|r|c|}
\hline \multicolumn{4}{|c|}{ WCO-3 Manual Water Levels } \\
\hline \multicolumn{1}{|c|}{ Date } & Water level (ft) & \multicolumn{1}{|c|}{ Date } & Water level (ft) \\
\hline $10 / 25 / 1989$ & Dry & & $6 / 19 / 2003$ & Dry \\
\hline $8 / 24 / 1990$ & Dry & & $9 / 14 / 2004$ & Dry \\
\hline $6 / 23 / 1997$ & 6424.6 & & $12 / 22 / 2005$ & Dry \\
\hline $3 / 25 / 1998$ & Dry & & $3 / 13 / 2006$ & Dry \\
\hline $5 / 29 / 1998$ & Dry & $6 / 23 / 2006$ & Dry \\
\hline $7 / 28 / 1998$ & Dry & & $9 / 13 / 2006$ & Dry \\
\hline $3 / 3 / 1999$ & Dry & $12 / 15 / 2006$ & Dry \\
\hline $6 / 23 / 1999$ & Dry & $1 / 24 / 2007$ & Dry \\
\hline $8 / 30 / 1999$ & Dry & & $3 / 15 / 2007$ & Dry \\
\hline $11 / 15 / 1999$ & Dry & $5 / 24 / 2007$ & Dry \\
\hline $3 / 26 / 2000$ & Dry & $6 / 6 / 2007$ & Dry \\
\hline $5 / 16 / 2000$ & Dry & $9 / 5 / 2007$ & Dry \\
\hline $8 / 30 / 2000$ & Dry & $10 / 17 / 2007$ & Dry \\
\hline $10 / 8 / 2000$ & Dry & $1 / 16 / 2008$ & Dry \\
\hline $7 / 2 / 2001$ & Dry & $4 / 8 / 2008$ & Dry \\
\hline $8 / 22 / 2001$ & Dry & $7 / 18 / 2008$ & Dry \\
\hline $10 / 18 / 2001$ & Dry & $10 / 7 / 2008$ & Dry \\
\hline $4 / 19 / 2002$ & Dry & $2 / 6 / 2009$ & Dry \\
\hline $8 / 19 / 2002$ & Dry & $3 / 23 / 2009$ & Dry \\
\hline $11 / 13 / 2002$ & Dry & $7 / 2 / 2009$ & Dry \\
\hline $2 / 18 / 2003$ & Dry & $10 / 7 / 2009$ & Dry \\
\hline
\end{tabular}




\subsection{Groundwater Level Data from Water Supply Wells}

Table 6-1 lists the LAC water supply wells; all supply wells were monitored for groundwater levels in 2009 after transducers were installed at G-1A and O-4. The table provides the well name, date of completion, well depth, surveyed location coordinates, ground surface elevation, and the screen top and bottom depths for each well. See Figure 3-1 for the locations of the wells.

The LANL GWLM Project integrated the water supply wells in the monitoring project beginning in 2007 with the cooperation of LAC Utility personnel. Recently obtained groundwater level data for the supply wells are provided in the following sections. Historical groundwater level data for the supply wells were summarized by Koch and Rogers (2003) and other preceding Water Supply Reports for Los Alamos.

Table 6-1. General Information for Los Alamos County Water Supply Wells

\begin{tabular}{|c|r|r|r|r|r|r|r|}
\hline $\begin{array}{c}\text { Well } \\
\text { Name }\end{array}$ & $\begin{array}{c}\text { Date } \\
\text { Completed }\end{array}$ & $\begin{array}{c}\text { Completed } \\
\text { Depth (ft) }\end{array}$ & $\begin{array}{c}\text { Easting } \\
\text { (ft) }\end{array}$ & $\begin{array}{c}\text { Northing } \\
\text { (ft) }\end{array}$ & $\begin{array}{c}\text { Surface } \\
\text { Elevation } \\
\text { (ft) }\end{array}$ & $\begin{array}{c}\text { Screen } \\
\text { Top } \\
\text { Depth (ft) }\end{array}$ & $\begin{array}{c}\text { Screen } \\
\text { Bottom } \\
\text { Depth (ft) }\end{array}$ \\
\hline G-1A & $12 / 15 / 1954$ & 1519 & 1655240.9 & 1784353.3 & 6014 & 272 & 1513 \\
\hline G-2A & $3 / 21 / 1998$ & 2000 & 1651973.8 & 1786166.3 & 6138 & 565 & 1980 \\
\hline G-3 & $8 / 25 / 1999$ & 1800 & 1651676.4 & 1786218.3 & 6139 & 441 & 1100 \\
\hline G-3A & $5 / 9 / 1998$ & 2000 & 1649661.5 & 1786585.3 & 6212 & 590 & 1980 \\
\hline G-4A & $4 / 1 / 1998$ & 2000 & 1647318.2 & 1787112.9 & 6299 & 655 & 1980 \\
\hline G-5A & $5 / 20 / 1998$ & 2000 & 1644877.2 & 1789636.0 & 6414 & 765 & 1980 \\
\hline O-1 & $8 / 1 / 1990$ & 2497 & 1649396.3 & 1772232.1 & 6396 & 1017 & 2477 \\
\hline O-4 & $3 / 1 / 1990$ & 2617 & 1637337.4 & 1772995.1 & 6627 & 1115 & 2596 \\
\hline PM-1 & $2 / 1 / 1965$ & 2499 & 1647734.3 & 1768112.1 & 6520 & 945 & 2479 \\
\hline PM-2 & $7 / 15 / 1965$ & 2300 & 1636697.5 & 1760406.4 & 6715 & 1004 & 2280 \\
\hline PM-3 & $11 / 1 / 1966$ & 2552 & 1642590.0 & 1769530.0 & 6610 & 956 & 2532 \\
\hline PM-4 & $8 / 15 / 1981$ & 2874 & 1635623.0 & 1764740.0 & 6920 & 1260 & 2854 \\
\hline PM-5 & $9 / 1 / 1982$ & 3092 & 1632110.0 & 1767790.0 & 7095 & 1440 & 3072 \\
\hline
\end{tabular}

All LAC water supply wells are powered by electric motors except for PM-4, which has a natural-gaspowered motor. The electric-powered wells are typically operated at night and on weekends when electricity rates are lower. Thus these wells usually cycle on and off daily, in contrast to PM-4, which usually runs continuously when in use, which is usually just during the summer months when water demand is highest. Thus, due to the operational characteristics of the electric-powered wells, the data displayed in the following sections for these wells are the maximum daily water level, or the "nonpumping" water level, and the minimum daily or "pumping" water level. The difference between the non-pumping and the pumping water level is the drawdown for each well. The data shown for the wells that aren't operated cyclically, which are PM-4 and O-1 (which hasn't been used in recent years), are mean daily water levels. Because of the short period of transducer data for G-1A and O-4, the hourly transducer data are shown for these wells. 


\section{$6.1 \quad$ G-1A}

Location: G-1A is located in Guaje Canyon and is the easternmost well in the Guaje well field.

Completion Type: Single completion in the Santa Fe Group.

Period of Record: Well completed in 1954, periodic manual measurements (Koch and Rogers 2003).

Transducer installed in bubbler pressure line October 29, 2008; data through June 2009.

Remarks: G-1A was constructed without gage lines so manual measurements are not possible while the pump is installed. Drawdown during pumping is about $45 \mathrm{ft}$.

\begin{tabular}{|c|c|c|c|c|c|c|c|c|c|c|c|c|c|c|}
\hline \multicolumn{15}{|c|}{ G-1A Construction Information } \\
\hline Screen & $\begin{array}{c}\text { Screen } \\
\text { Top } \\
\text { Depth } \\
\text { (ft) }\end{array}$ & $\begin{array}{c}\text { Screen } \\
\text { Bottom } \\
\text { Depth } \\
\text { (ft) }\end{array}$ & $\begin{array}{l}\text { Screen } \\
\text { Top } \\
\text { Elev (ft) }\end{array}$ & $\begin{array}{l}\text { Screen } \\
\text { Bottom } \\
\text { Elev (ft) }\end{array}$ & $\begin{array}{c}\text { Screen } \\
\text { Length } \\
\text { (ft) }\end{array}$ & $\begin{array}{c}\text { Pump } \\
\text { Intake } \\
\text { Depth } \\
\text { (ft) }\end{array}$ & $\begin{array}{c}\text { Pump } \\
\text { Intake } \\
\text { Elev } \\
\text { (ft) }\end{array}$ & $\begin{array}{c}\text { Depth to } \\
\text { Top of } \\
\text { Sump } \\
\text { (ft) }\end{array}$ & $\begin{array}{c}\text { Top of } \\
\text { Sump } \\
\text { Elev } \\
\text { (ft) }\end{array}$ & $\begin{array}{l}\text { Depth to } \\
\text { Sump } \\
\text { Bottom } \\
\text { (ft) }\end{array}$ & $\begin{array}{l}\text { Sump } \\
\text { Length } \\
\text { (ft) }\end{array}$ & $\begin{array}{l}\text { Sump } \\
\text { Volume } \\
\text { (L) }\end{array}$ & $\begin{array}{c}\text { Hydro } \\
\text { Zone } \\
\text { Code }\end{array}$ & $\begin{array}{c}\text { Geo } \\
\text { Unit } \\
\text { Code }\end{array}$ \\
\hline 1 & 272 & 1513 & 5742 & 4501 & 1241 & 496 & 5518 & 1513 & 4501 & 1519 & 6 & $\overline{93}$ & $\mathrm{RT}$ & $\overline{T s f}$ \\
\hline
\end{tabular}

Note: Ground Elevation: $6014.0 \mathrm{ft}$; all measurements from this elevation

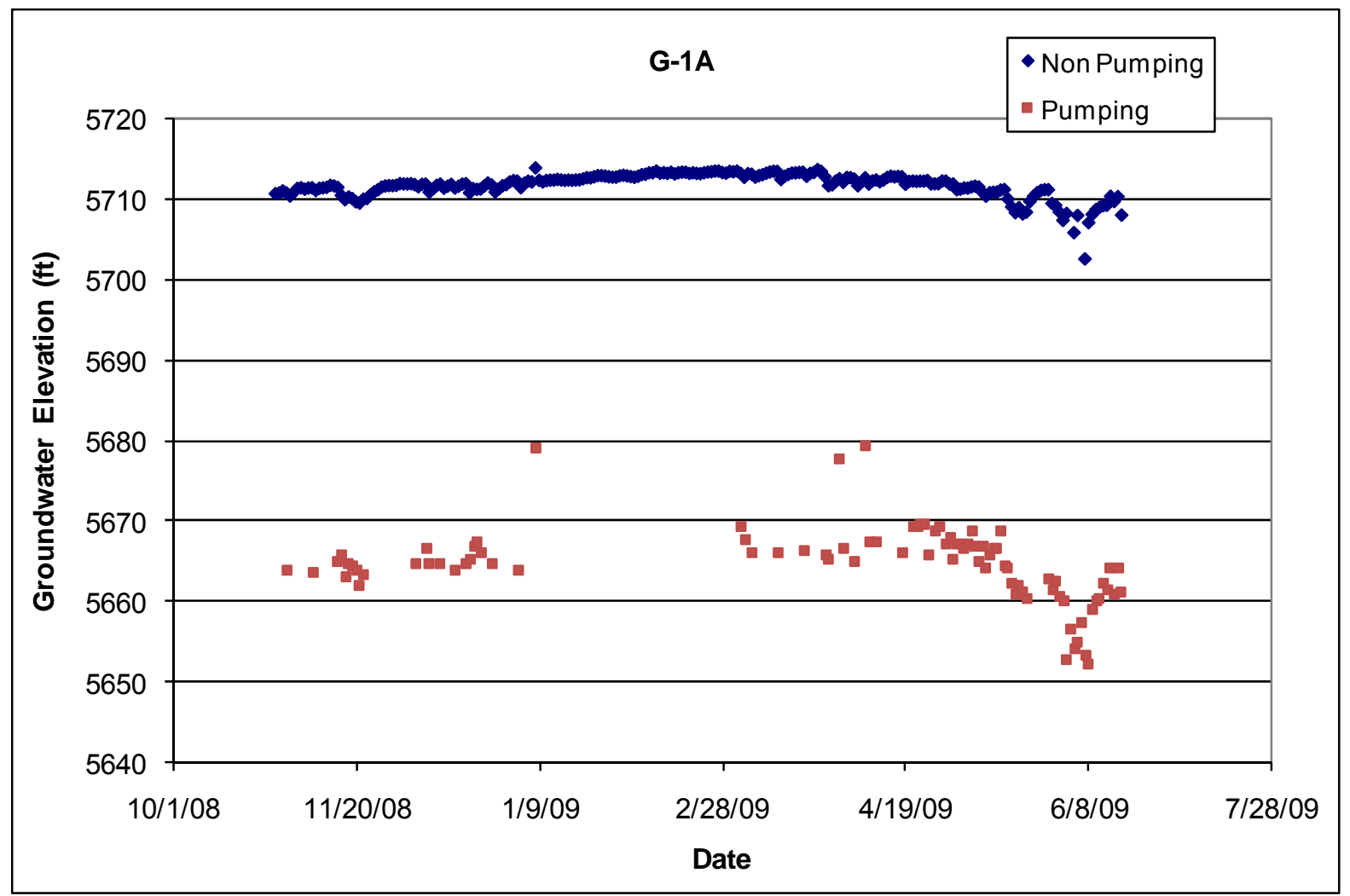




\section{$6.2 \quad$ G-2A}

Location: G-2A is located in Guaje Canyon about $300 \mathrm{ft}$ east of monitoring well G-3.

Completion Type: Single completion in the Santa Fe Group.

Period of Record: Well completed in 1998, transducer installed December 2003; data through June 2009.

Remarks: The pumping and non-pumping water levels overlap depending on pumping stress to the aquifer. The drawdown is about $40 \mathrm{ft}$.

\begin{tabular}{|c|c|c|c|c|c|c|c|c|c|c|c|c|c|c|}
\hline \multicolumn{15}{|c|}{ G-2A Construction Information } \\
\hline Screen & $\begin{array}{l}\text { Screen } \\
\text { Top } \\
\text { Depth } \\
\text { (ft) }\end{array}$ & $\begin{array}{c}\text { Screen } \\
\text { Bottom } \\
\text { Depth } \\
\text { (ft) }\end{array}$ & $\begin{array}{c}\text { Screen } \\
\text { Top } \\
\text { Elev } \\
\text { (ft) }\end{array}$ & $\begin{array}{c}\text { Screen } \\
\text { Bottom } \\
\text { Elev } \\
\text { (ft) }\end{array}$ & $\begin{array}{l}\text { Screen } \\
\text { Length } \\
\text { (ft) }\end{array}$ & $\begin{array}{c}\text { Pump } \\
\text { Intake } \\
\text { Depth } \\
\text { (ft) }\end{array}$ & $\begin{array}{c}\text { Pump } \\
\text { Intake } \\
\text { Elev } \\
\text { (ft) }\end{array}$ & $\begin{array}{l}\text { Depth to } \\
\text { Top of } \\
\text { Sump } \\
\text { (ft) }\end{array}$ & $\begin{array}{c}\text { Top of } \\
\text { Sump } \\
\text { Elev } \\
\text { (ft) }\end{array}$ & $\begin{array}{l}\text { Depth to } \\
\text { Sump } \\
\text { Bottom } \\
\text { (ft) }\end{array}$ & $\begin{array}{c}\text { Sump } \\
\text { Length } \\
\text { (ft) }\end{array}$ & $\begin{array}{l}\text { Sump } \\
\text { Volume } \\
\text { (L) }\end{array}$ & $\begin{array}{c}\text { Hydro } \\
\text { Zone } \\
\text { Code }\end{array}$ & $\begin{array}{l}\text { Geo } \\
\text { Unit } \\
\text { Code }\end{array}$ \\
\hline 1 & 565 & 1980 & 5573 & 4158 & 1415 & 540 & 5598 & 1980 & 4158 & 2000 & 20 & 444.8 & RT & Tsf \\
\hline
\end{tabular}

Note: Ground Elevation: $6138.0 \mathrm{ft}$; all depths are from this elevation

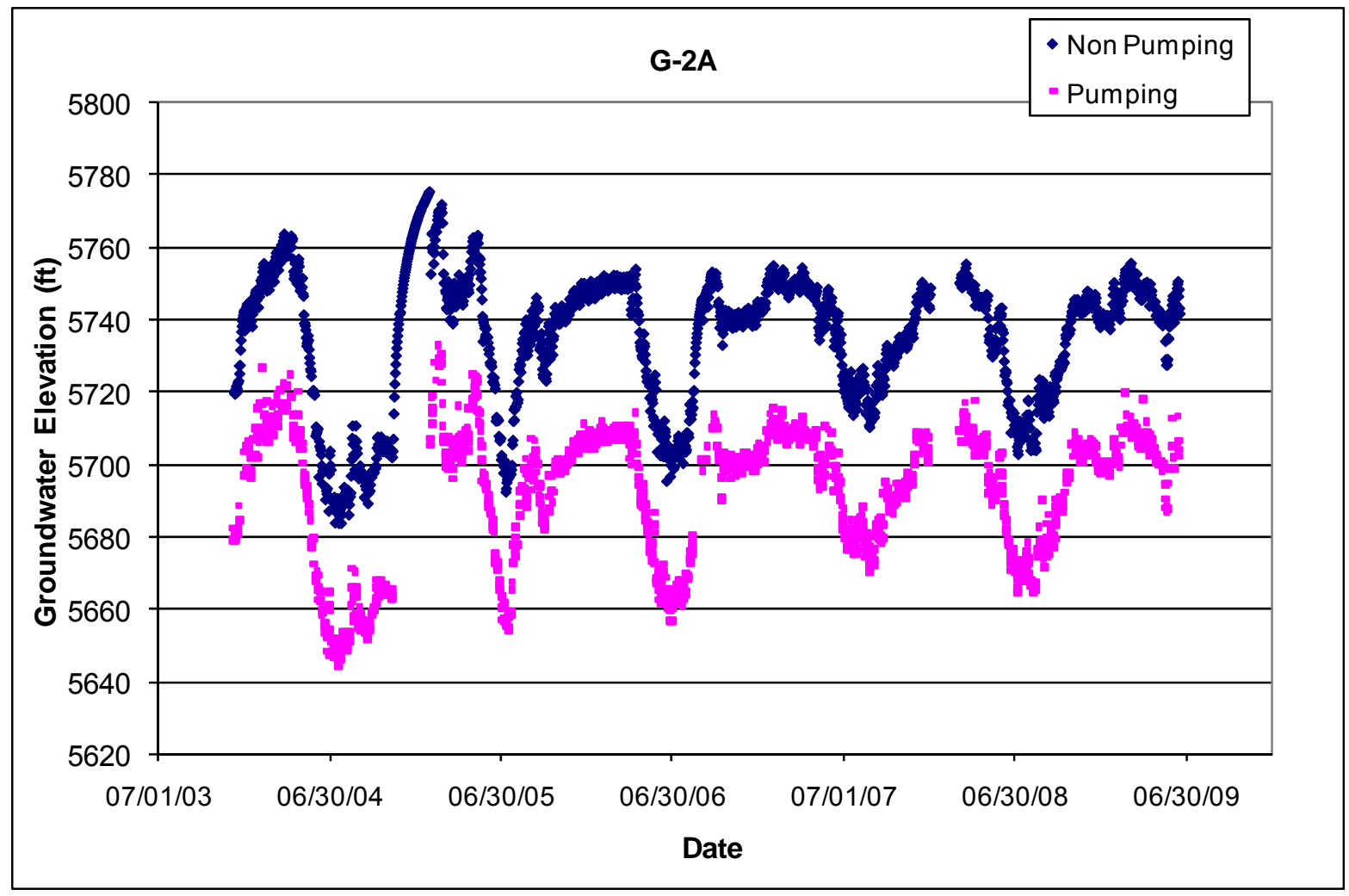




\section{$6.3 \quad$ G-3}

Location: G-3 is located in Guaje Canyon about $300 \mathrm{ft}$ west of supply well G-2A.

Completion Type: Single completion in the Santa Fe Group.

Period of Record: Well originally completed as a supply well in July 1951; plugged back to $1103 \mathrm{ft}$ and converted to a monitoring well in 1998, transducer installed June 2002; data through 2009.

Remarks: G-3 responds primarily to pumping at supply well G-2A; daily water level fluctuation is about $8 \mathrm{ft}$. The aquifer in the Guaje well field fluctuates seasonally 40 to $70 \mathrm{ft}$ depending on pumping stresses.

\begin{tabular}{|c|c|c|c|c|c|c|c|c|c|c|c|c|c|c|}
\hline \multicolumn{15}{|c|}{ G-3 Construction Information } \\
\hline Screen & $\begin{array}{l}\text { Screen } \\
\text { Top } \\
\text { Depth } \\
\text { (ft) }\end{array}$ & $\begin{array}{c}\text { Screen } \\
\text { Bottom } \\
\text { Depth } \\
\text { (ft) }\end{array}$ & $\begin{array}{c}\text { Screen } \\
\text { Top } \\
\text { Elev } \\
\text { (ft) }\end{array}$ & $\begin{array}{l}\text { Screen } \\
\text { Bottom } \\
\text { Elev (ft) }\end{array}$ & $\begin{array}{l}\text { Screen } \\
\text { Length } \\
\text { (ft) }\end{array}$ & $\begin{array}{c}\text { Pump } \\
\text { Intake } \\
\text { Depth } \\
\text { (ft) }\end{array}$ & $\begin{array}{c}\text { Pump } \\
\text { Intake } \\
\text { Elev } \\
\text { (ft) }\end{array}$ & \begin{tabular}{|} 
Depth to \\
Top of \\
Sump \\
(ft)
\end{tabular} & $\begin{array}{c}\text { Top of } \\
\text { Sump } \\
\text { Elev } \\
\text { (ft) }\end{array}$ & \begin{tabular}{|} 
Depth to \\
Sump \\
Bottom \\
(ft)
\end{tabular} & $\begin{array}{c}\text { Sump } \\
\text { Length } \\
\text { (ft) }\end{array}$ & $\begin{array}{c}\text { Sump } \\
\text { Volume } \\
\text { (L) }\end{array}$ & $\begin{array}{l}\text { Hydro } \\
\text { Zone } \\
\text { Code }\end{array}$ & $\begin{array}{l}\text { Geo } \\
\text { Unit } \\
\text { Code }\end{array}$ \\
\hline$\overline{1}$ & $\overline{441}$ & 1100 & 5698 & 5039 & 659 & $\overline{\text { None }}$ & None & 1100 & 5039 & 1103 & $\overline{3}$ & 66.7 & $\overline{\mathrm{RT}}$ & $\overline{T s f}$ \\
\hline
\end{tabular}

Note: Ground Elevation: $6139.0 \mathrm{ft}$; all depths are from this elevation

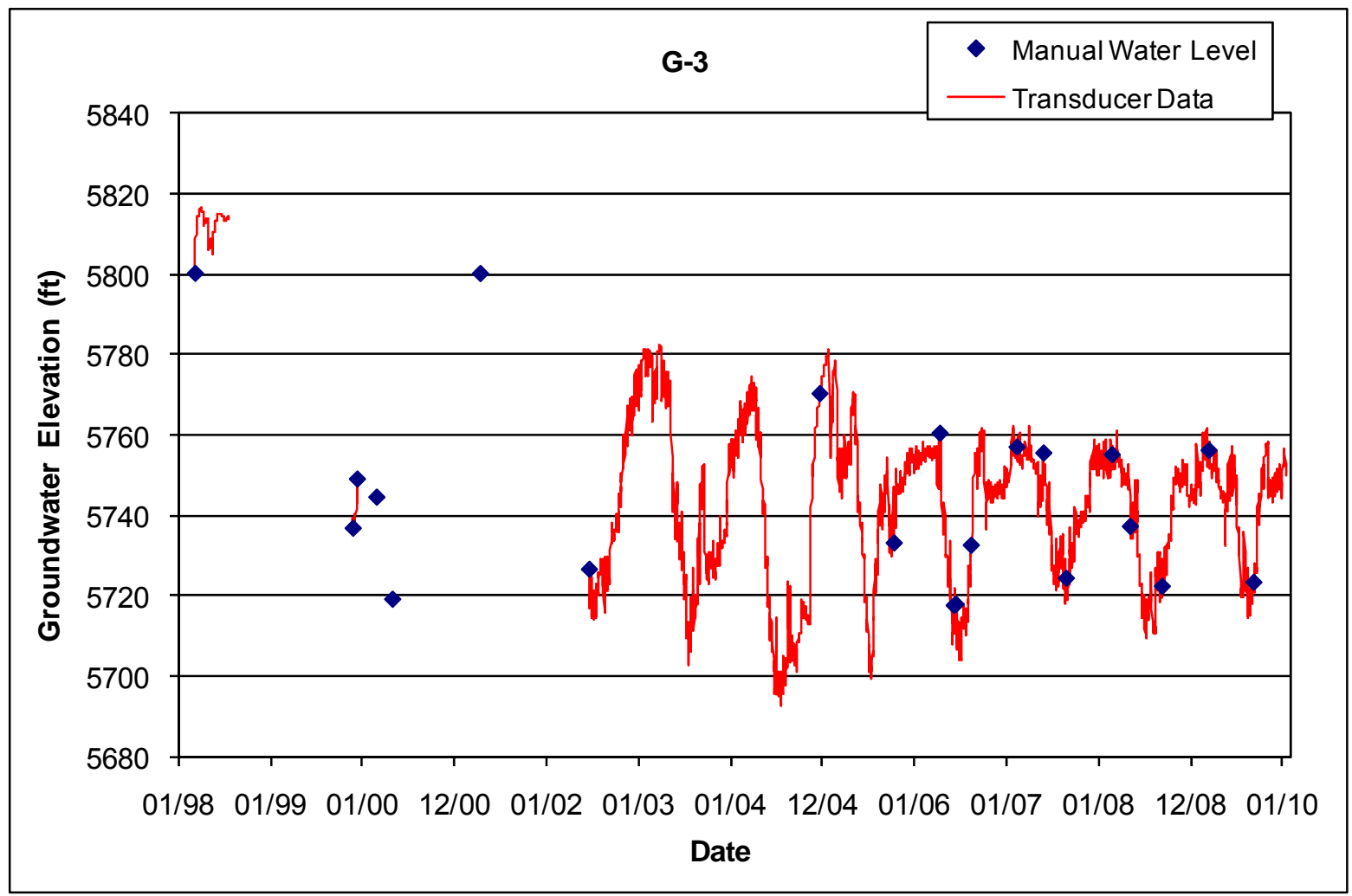

Note: mean daily water level values displayed 


\subsection{G-3A}

Location: G-3A is located in Guaje Canyon about 1.5 miles west of monitoring well G-3.

Completion Type: Single completion in the Santa Fe Group.

Period of Record: Well completed as a supply well in May 1998; transducer installed December 2003; intermittent data through June 2009.

Remarks: Drawdown is 60 to $65 \mathrm{ft}$.

\begin{tabular}{|c|c|c|c|c|c|c|c|c|c|c|c|c|c|c|}
\hline \multicolumn{15}{|c|}{ G-3A Construction Information } \\
\hline Screen & $\begin{array}{l}\text { Screen } \\
\text { Top } \\
\text { Depth } \\
\text { (ft) }\end{array}$ & $\begin{array}{c}\text { Screen } \\
\text { Bottom } \\
\text { Depth } \\
\text { (ft) }\end{array}$ & $\begin{array}{c}\text { Screen } \\
\text { Top } \\
\text { Elev } \\
\text { (ft) }\end{array}$ & $\begin{array}{l}\text { Screen } \\
\text { Bottom } \\
\text { Elev (ft) }\end{array}$ & $\begin{array}{l}\text { Screen } \\
\text { Length } \\
\text { (ft) }\end{array}$ & $\begin{array}{c}\text { Pump } \\
\text { Intake } \\
\text { Depth } \\
\text { (ft) }\end{array}$ & $\begin{array}{c}\text { Pump } \\
\text { Intake } \\
\text { Elev } \\
\text { (ft) }\end{array}$ & $\begin{array}{c}\text { Depth to } \\
\text { Top of } \\
\text { Sump } \\
\text { (ft) }\end{array}$ & $\begin{array}{c}\text { Top of } \\
\text { Sump } \\
\text { Elev } \\
\text { (ft) }\end{array}$ & $\begin{array}{l}\text { Depth to } \\
\text { Sump } \\
\text { Bottom } \\
\text { (ft) }\end{array}$ & $\begin{array}{c}\text { Sump } \\
\text { Length } \\
\text { (ft) }\end{array}$ & $\begin{array}{c}\text { Sump } \\
\text { Volume } \\
\text { (L) }\end{array}$ & $\begin{array}{l}\text { Hydro } \\
\text { Zone } \\
\text { Code }\end{array}$ & $\begin{array}{l}\text { Geo } \\
\text { Unit } \\
\text { Code }\end{array}$ \\
\hline 1 & 590 & 1980 & 5622 & 4232 & 1390 & 560 & 5652 & 1980 & 4232 & 2000 & 20 & 853.7 & $\mathrm{RT}$ & Tsf \\
\hline
\end{tabular}

Note: Ground Elevation: $6212.0 \mathrm{ft}$; all measurements are from this elevation

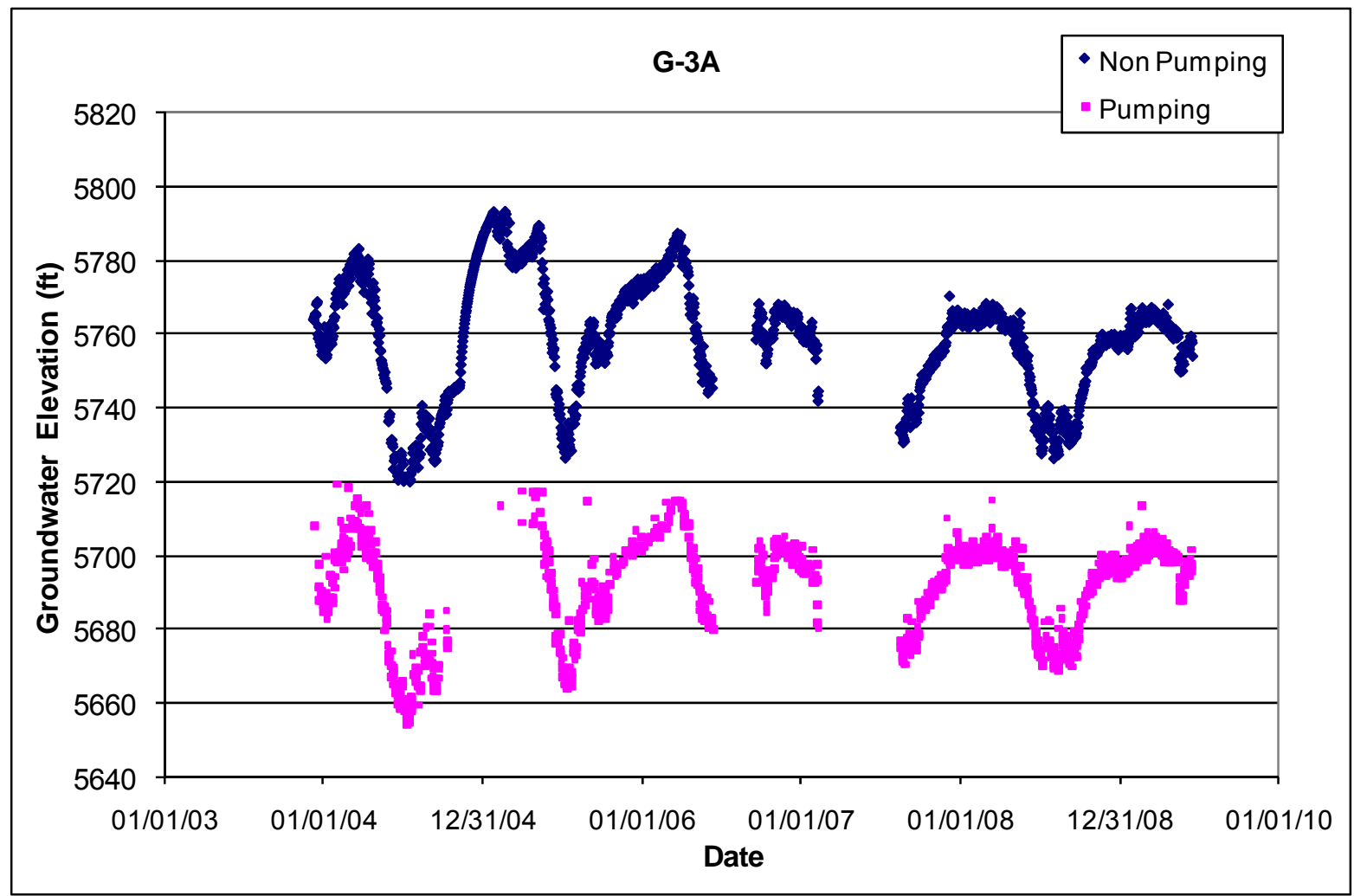




\section{$6.5 \quad G-4 A$}

Location: G-4A is located in lower Rendija Canyon near the confluence with Guaje Canyon and about 0.5 miles west of supply well G-3A.

Completion Type: Single completion in the Santa Fe Group.

Period of Record: Well completed as a supply well in April 1998; transducer installed December 2003; intermittent data through June 2009.

Remarks: Drawdown is 80 to $85 \mathrm{ft}$.

\begin{tabular}{|c|c|c|c|c|c|c|c|c|c|c|c|c|c|c|}
\hline \multicolumn{15}{|c|}{ G-4A Construction Information } \\
\hline Screen & $\begin{array}{c}\text { Screen } \\
\text { Top } \\
\text { Depth } \\
\text { (ft) }\end{array}$ & $\begin{array}{c}\text { Screen } \\
\text { Bottom } \\
\text { Depth } \\
\text { (ft) }\end{array}$ & $\begin{array}{c}\text { Screen } \\
\text { Top } \\
\text { Elev } \\
\text { (ft) }\end{array}$ & $\begin{array}{c}\text { Screen } \\
\text { Bottom } \\
\text { Elev } \\
\text { (ft) }\end{array}$ & $\begin{array}{l}\text { Screen } \\
\text { Length } \\
\text { (ft) }\end{array}$ & $\begin{array}{c}\text { Pump } \\
\text { Intake } \\
\text { Depth } \\
\text { (ft) }\end{array}$ & $\begin{array}{c}\text { Pump } \\
\text { Intake } \\
\text { Elev } \\
\text { (ft) }\end{array}$ & $\begin{array}{l}\text { Depth to } \\
\text { Top of } \\
\text { Sump } \\
\text { (ft) }\end{array}$ & $\begin{array}{c}\text { Top of } \\
\text { Sump } \\
\text { Elev } \\
\text { (ft) }\end{array}$ & $\begin{array}{l}\text { Depth to } \\
\text { Sump } \\
\text { Bottom } \\
\text { (ft) }\end{array}$ & $\begin{array}{c}\text { Sump } \\
\text { Length } \\
\text { (ft) }\end{array}$ & $\begin{array}{l}\text { Sump } \\
\text { Volume } \\
\text { (L) }\end{array}$ & $\begin{array}{c}\text { Hydro } \\
\text { Zone } \\
\text { Code }\end{array}$ & $\begin{array}{c}\text { Geo } \\
\text { Unit } \\
\text { Code }\end{array}$ \\
\hline 1 & 655 & 1980 & 5644 & 4319 & 1325 & 630 & 5669 & 1980 & 4319 & 2000 & 20.0 & 853.7 & RT & Tsf \\
\hline
\end{tabular}

Note: Ground Elevation: $6299.0 \mathrm{ft}$; all measurements are from this elevation

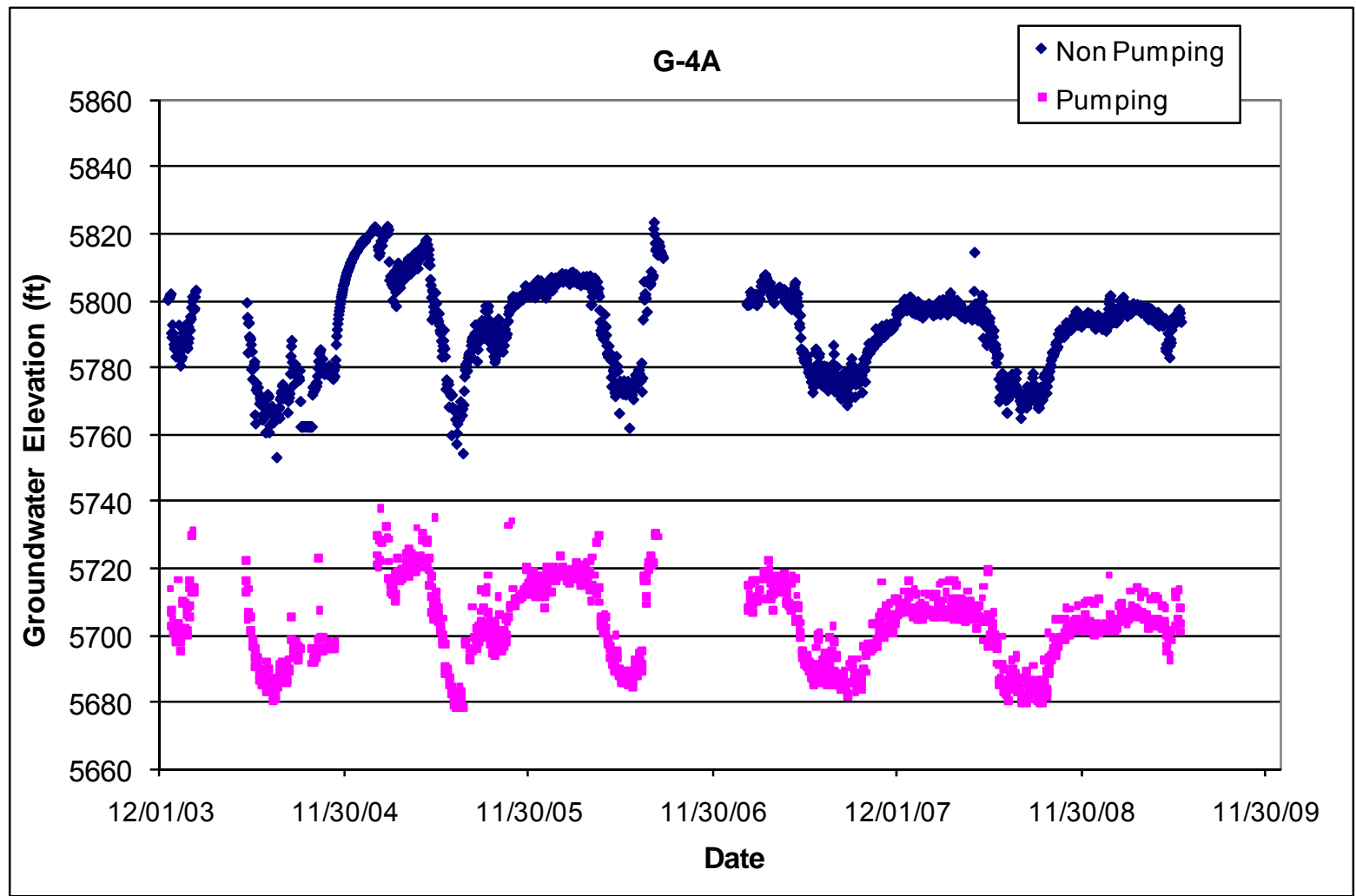




\section{$6.6 \quad$ G-5A}

Location: G-5A is located in Guaje Canyon upstream of Rendija Canyon and about 1.9 miles northwest of supply well G-4A.

Completion Type: Single completion in the Santa Fe Group.

Period of Record: Well completed as a supply well in May 1998; transducer installed January 2004; intermittent data through June 2009.

Remarks: G-5A is not used on a regular basis. Drawdown is 140 to $150 \mathrm{ft}$.

\begin{tabular}{|c|c|c|c|c|c|c|c|c|c|c|c|c|c|c|c|}
\hline \multicolumn{16}{|c|}{ G-5A Construction Information } \\
\hline Screen & $\begin{array}{c}\text { Screen } \\
\text { Top } \\
\text { Depth } \\
\text { (ft) }\end{array}$ & $\begin{array}{c}\text { Screen } \\
\text { Bottom } \\
\text { Depth } \\
\text { (ft) }\end{array}$ & $\begin{array}{c}\text { Screen } \\
\text { Top } \\
\text { Elev } \\
\text { (ft) }\end{array}$ & $\begin{array}{c}\text { Screen } \\
\text { Bottom } \\
\text { Elev } \\
\text { (ft) }\end{array}$ & $\begin{array}{c}\text { Screen } \\
\text { Length } \\
\text { (ft) }\end{array}$ & $\begin{array}{c}\text { Pump } \\
\text { Intake } \\
\text { Depth } \\
\text { (ft) }\end{array}$ & $\begin{array}{c}\text { Pump } \\
\text { Intake } \\
\text { Elev } \\
\text { (ft) }\end{array}$ & $\begin{array}{l}\text { Depth to } \\
\text { Top of } \\
\text { Sump } \\
\text { (ft) }\end{array}$ & $\begin{array}{c}\text { Top of } \\
\text { Sump } \\
\text { Elev } \\
\text { (ft) }\end{array}$ & $\begin{array}{l}\text { Depth to } \\
\text { Sump } \\
\text { Bottom } \\
\text { (ft) }\end{array}$ & $\begin{array}{c}\text { Sump } \\
\text { Length } \\
\text { (ft) }\end{array}$ & $\begin{array}{c}\text { Sump } \\
\text { Volume } \\
\text { (L) }\end{array}$ & $\begin{array}{c}\text { Hydro } \\
\text { Zone } \\
\text { Code }\end{array}$ & $\begin{array}{l}\text { Geo } \\
\text { Unit } \\
\text { Code }\end{array}$ & Comment \\
\hline 1 & 765 & 1980 & 5649 & 4434 & 1215 & $\overline{740}$ & 5674 & 1980 & 4434 & 2000 & 20 & 853.7 & RT & Tsf & Supply Well \\
\hline
\end{tabular}

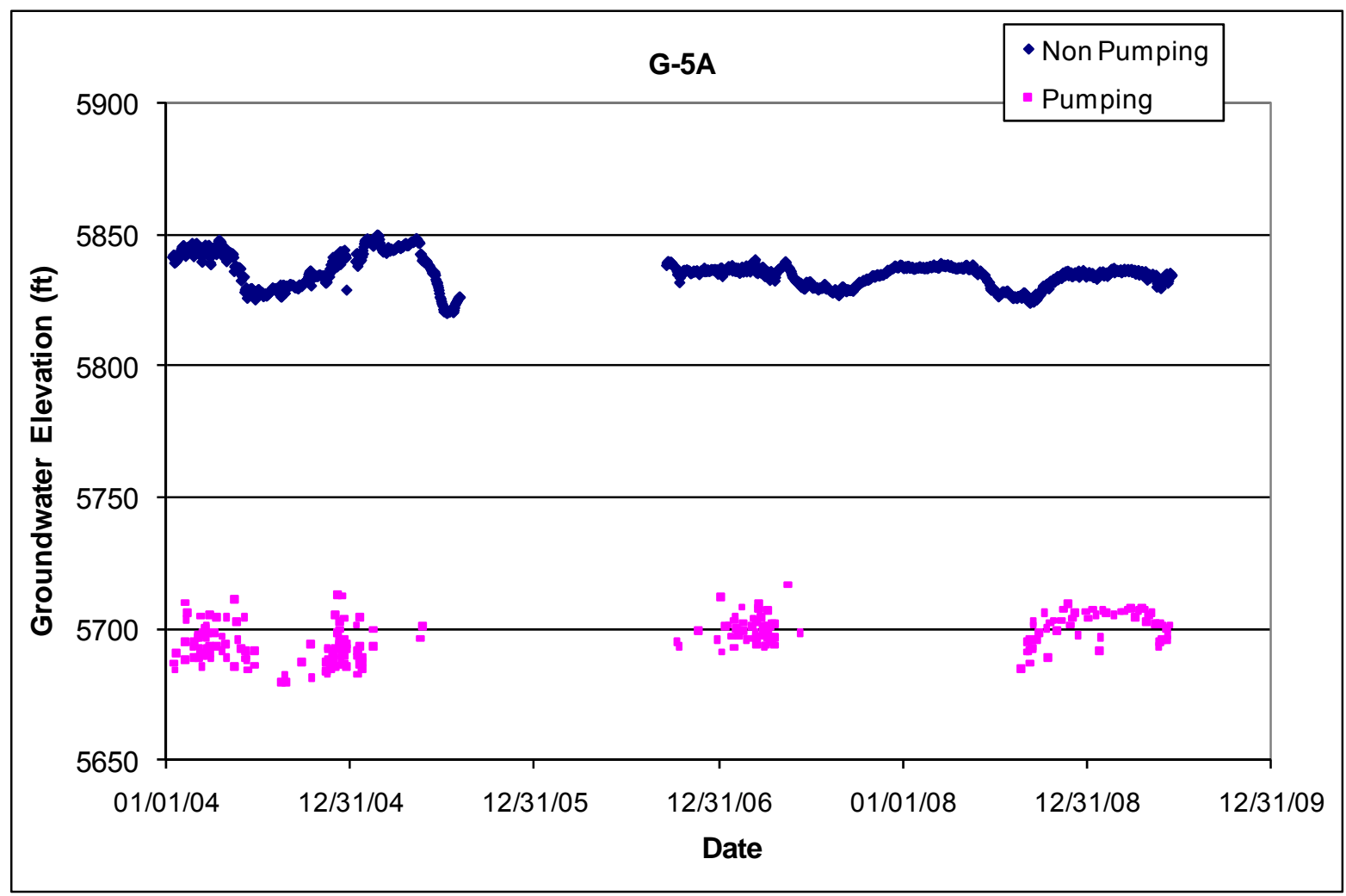




\section{$6.7 \quad 0-1$}

Location: O-1 is located in lower Pueblo Canyon about 0.5 miles downstream of monitoring well R-5. Completion Type: Single completion in the Santa Fe Group.

Period of Record: Well completed as a supply well in August 1990; transducer installed June 2007; data through June 2009.

Remarks: O-1 has not been used on a regular basis except for periodic groundwater sampling. Drawdown is about $100 \mathrm{ft}$. O-1 responds to pumping of supply well PM-1.

\begin{tabular}{|c|c|c|c|c|c|c|c|c|c|c|c|c|c|c|}
\hline \multicolumn{15}{|c|}{ O-1 Construction Information } \\
\hline Screen & $\begin{array}{l}\text { Screen } \\
\text { Top } \\
\text { Depth } \\
\text { (ft) }\end{array}$ & $\begin{array}{c}\text { Screen } \\
\text { Bottom } \\
\text { Depth } \\
\text { (ft) }\end{array}$ & $\begin{array}{c}\text { Screen } \\
\text { Top } \\
\text { Elev } \\
\text { (ft) }\end{array}$ & $\begin{array}{l}\text { Screen } \\
\text { Bottom } \\
\text { Elev (ft) }\end{array}$ & $\begin{array}{c}\text { Screen } \\
\text { Length } \\
(\mathrm{ft})\end{array}$ & $\begin{array}{l}\text { Pump } \\
\text { Intake } \\
\text { Depth } \\
\text { (ft) }\end{array}$ & $\begin{array}{c}\text { Pump } \\
\text { Intake } \\
\text { Elev } \\
\text { (ft) }\end{array}$ & $\begin{array}{c}\text { Depth to } \\
\text { Top of } \\
\text { Sump (ft) }\end{array}$ & $\begin{array}{c}\text { Top of } \\
\text { Sump } \\
\text { Elev } \\
\text { (ft) }\end{array}$ & $\begin{array}{l}\text { Depth to } \\
\text { Sump } \\
\text { Bottom } \\
\text { (ft) }\end{array}$ & $\begin{array}{c}\text { Sump } \\
\text { Length } \\
\text { (ft) }\end{array}$ & $\begin{array}{c}\text { Sump } \\
\text { Volume } \\
\text { (L) }\end{array}$ & \begin{tabular}{|c} 
Hydro \\
Zone \\
Code
\end{tabular} & $\begin{array}{c}\text { Geo } \\
\text { Unit } \\
\text { Code }\end{array}$ \\
\hline 1 & 1017 & 2477 & 5379 & 3919 & 1460 & 877 & 5519 & 2477 & 2477 & 2497 & 20 & 790.8 & RT & Tsf \\
\hline
\end{tabular}

Note: Ground Elevation: $6396 \mathrm{ft}$; all measurements are from this elevation

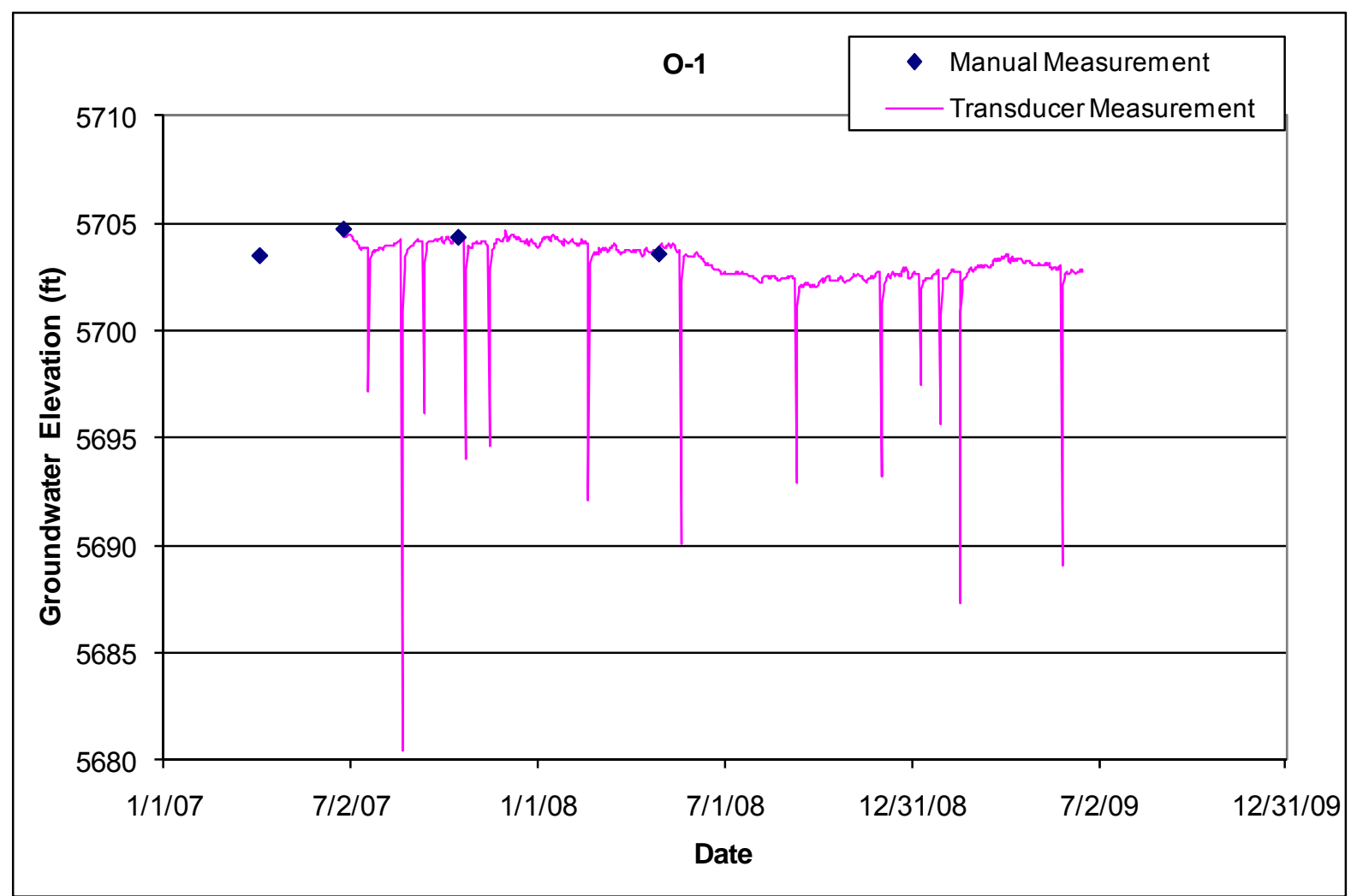

Note: Hydrograph shows mean daily values 


\section{$6.8 \quad 0-4$}

Location: O-4 is located in Los Alamos Canyon above the confluence with DP Canyon and about $1500 \mathrm{ft}$ southeast of monitoring well R-6.

Completion Type: Single completion in the Santa Fe Group.

Period of Record: Well completed as a supply well in March 1990; transducer installed August 2008, intermittent data through 2009.

Remarks: $\mathrm{O}-4$ drawdown is about $25 \mathrm{ft}$.

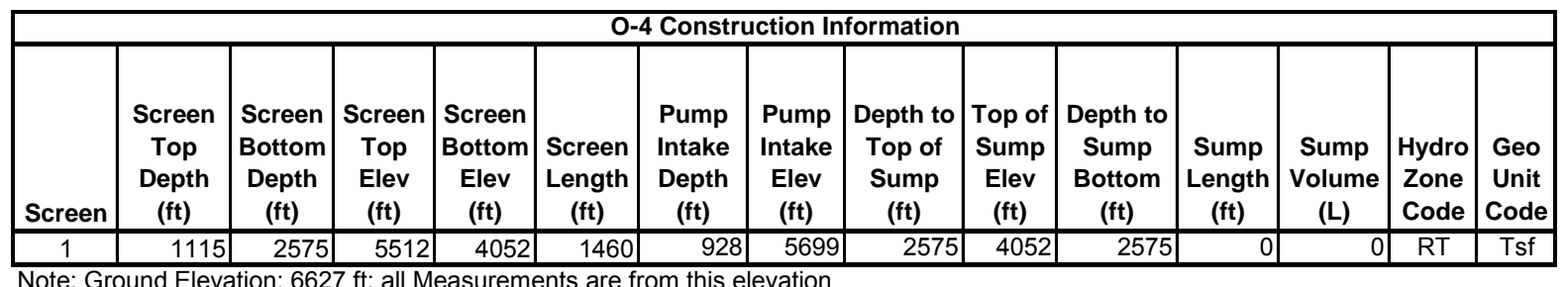

Note: Ground Elevation: $6627 \mathrm{ft}$; all Measurements are from this elevation

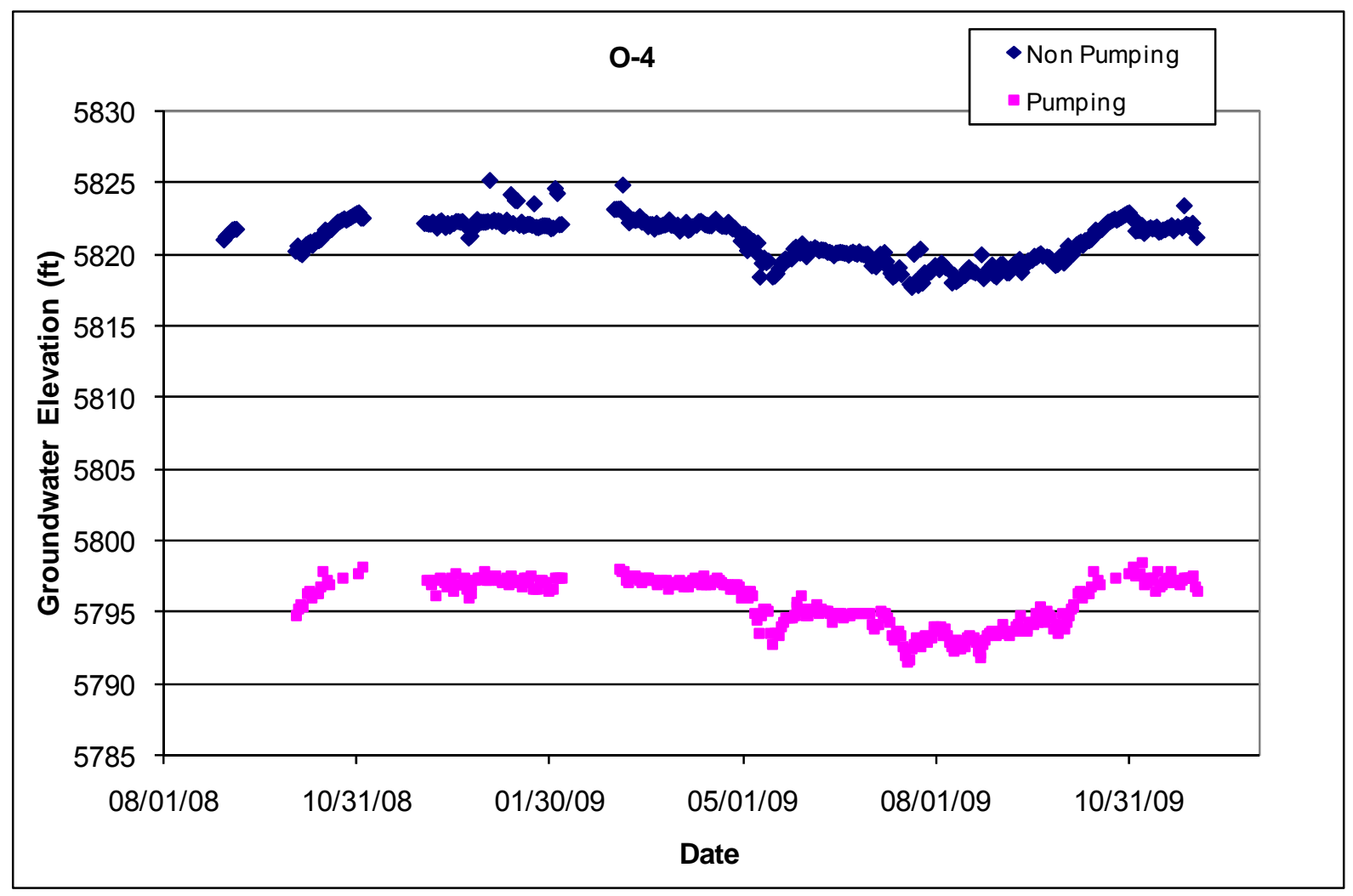




\section{$6.9 \quad$ PM-1}

Location: PM-1 is located in lower Sandia Canyon near the eastern Laboratory boundary and about $360 \mathrm{ft}$ northeast of monitoring well R-12.

Completion Type: Single completion in the Santa Fe Group.

Period of Record: Well completed as a supply well in February 1965; transducer installed December 2006; data through June 2009.

Remarks: Drawdown is about $30 \mathrm{ft}$.

\begin{tabular}{|c|c|c|c|c|c|c|c|c|c|c|c|c|c|c|}
\hline \multicolumn{15}{|c|}{ PM-1 Construction Information } \\
\hline Screen & $\begin{array}{l}\text { Screen } \\
\text { Top } \\
\text { Depth } \\
\text { (ft) }\end{array}$ & $\begin{array}{c}\text { Screen } \\
\text { Bottom } \\
\text { Depth } \\
\text { (ft) }\end{array}$ & $\begin{array}{c}\text { Screen } \\
\text { Top } \\
\text { Elev } \\
\text { (ft) }\end{array}$ & $\begin{array}{c}\text { Screen } \\
\text { Bottom } \\
\text { Elev } \\
\text { (ft) }\end{array}$ & $\begin{array}{c}\text { Screen } \\
\text { Length } \\
\text { (ft) }\end{array}$ & $\begin{array}{c}\text { Pump } \\
\text { Intake } \\
\text { Depth } \\
\text { (ft) }\end{array}$ & $\begin{array}{c}\text { Pump } \\
\text { Intake } \\
\text { Elev } \\
\text { (ft) }\end{array}$ & \begin{tabular}{|} 
Depth to \\
Top of \\
Sump \\
(ft)
\end{tabular} & $\begin{array}{c}\text { Top of } \\
\text { Sump } \\
\text { Elev } \\
\text { (ft) }\end{array}$ & $\begin{array}{l}\text { Depth to } \\
\text { Sump } \\
\text { Bottom } \\
\text { (ft) }\end{array}$ & $\begin{array}{c}\text { Sump } \\
\text { Length } \\
\text { (ft) }\end{array}$ & $\begin{array}{c}\text { Sump } \\
\text { Volume } \\
\text { (L) }\end{array}$ & $\begin{array}{l}\text { Hydro } \\
\text { Zone } \\
\text { Code }\end{array}$ & $\begin{array}{l}\text { Geo } \\
\text { Unit } \\
\text { Code }\end{array}$ \\
\hline 1 & 945 & 2479 & 5575 & 4041 & 1534 & 877 & 5643 & 2479 & 2479 & 2499 & 20.0 & 790.8 & RT & Tsf \\
\hline
\end{tabular}

Note: Ground Elevation: $6520 \mathrm{ft}$; all measurements are from this elevation

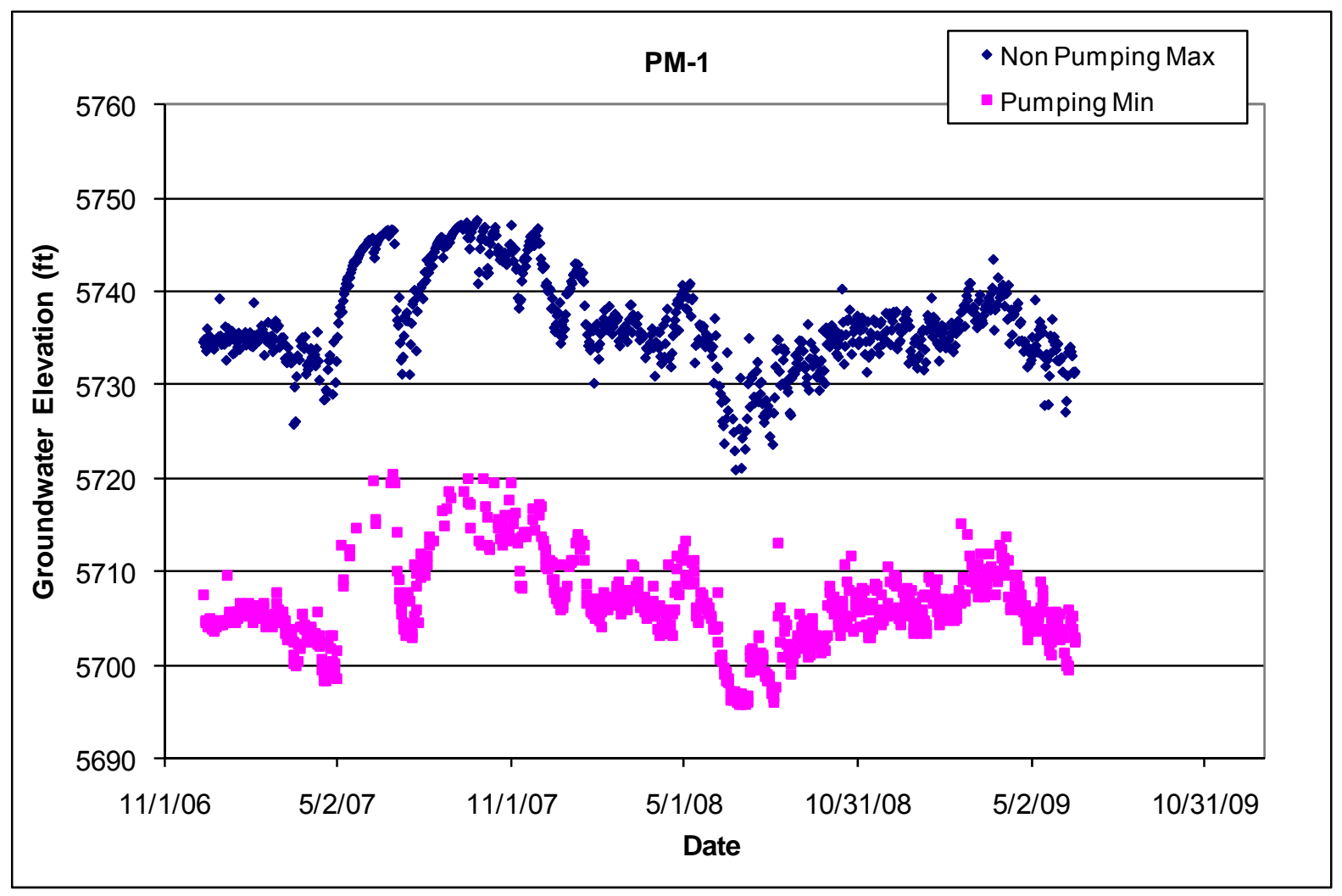




\subsection{PM-2}

Location: PM-2 is located in Pajarito Canyon about 0.25 miles west of monitoring well R-20 and about $220 \mathrm{ft}$ southwest of recently installed monitoring well R-40.

Completion Type: Single completion in the Puye Formation and Santa Fe Group.

Period of Record: Well completed as a supply well in July 1965; transducer installed December 2004; data to October 23, 2007. The transducer was removed in October 2007 during pump removal and well rehabilitation. Data during April and May 2008 during pump testing.

Transducer removed May 30, 2008, for well repairs.

Remarks: Drawdown is about $70 \mathrm{ft}$. PM-2 responds to pumping at PM-4 (McLin 2006). PM-2 was not operated for most of 2008 and 2009 because of well maintenance and repairs.

\begin{tabular}{|c|c|c|c|c|c|c|c|c|c|c|c|c|c|c|}
\hline \multicolumn{15}{|c|}{ PM-2 Construction Information } \\
\hline Screen & \begin{tabular}{|c} 
Screen \\
Top \\
Depth \\
(ft)
\end{tabular} & \begin{tabular}{|c|} 
Screen \\
Bottom \\
Depth \\
(ft)
\end{tabular} & \begin{tabular}{|c} 
Screen \\
Top \\
Elev \\
(ft)
\end{tabular} & $\begin{array}{c}\text { Screen } \\
\text { Bottom } \\
\text { Elev } \\
\text { (ft) }\end{array}$ & $\begin{array}{c}\text { Screen } \\
\text { Length } \\
\text { (ft) }\end{array}$ & $\begin{array}{c}\text { Pump } \\
\text { Intake } \\
\text { Depth } \\
\text { (ft) }\end{array}$ & $\begin{array}{c}\text { Pump } \\
\text { Intake } \\
\text { Elev } \\
\text { (ft) }\end{array}$ & $\mid \begin{array}{c}\text { Depth to } \\
\text { Top of } \\
\text { Sump (ft) }\end{array}$ & \begin{tabular}{|c|} 
Top of \\
Sump \\
Elev \\
(ft)
\end{tabular} & $\begin{array}{l}\text { Depth to } \\
\text { Sump } \\
\text { Bottom } \\
\text { (ft) }\end{array}$ & $\begin{array}{c}\text { Sump } \\
\text { Length } \\
\text { (ft) }\end{array}$ & $\begin{array}{c}\text { Sump } \\
\text { Volume } \\
\text { (L) }\end{array}$ & $\begin{array}{l}\text { Hydro } \\
\text { Zone } \\
\text { Code }\end{array}$ & \begin{tabular}{|l|} 
Geo \\
Unit \\
Code
\end{tabular} \\
\hline 1 & 1004 & 2280 & 5711 & 4435 & 1276 & 980 & 5735 & 2280 & 4435 & 2300 & 20.0 & 790.8 & RT & $\mathrm{Tp}$ \\
\hline
\end{tabular}

Note: Ground Elevation: $6715 \mathrm{ft}$; all measurements are from this elevation

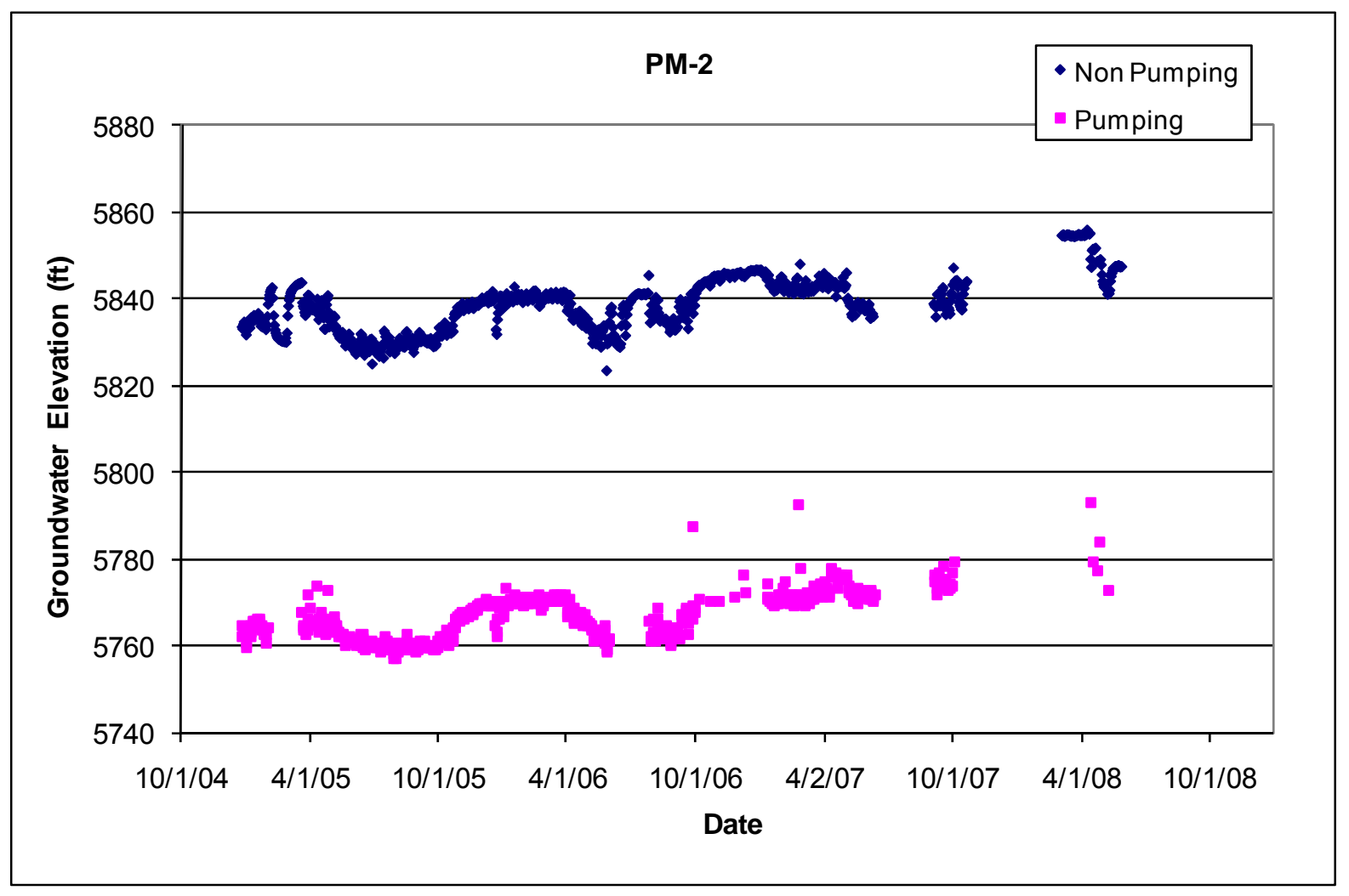




\subsection{PM-3}

Location: PM-3 is located in Sandia Canyon about 1 mile west of PM-1 and about $330 \mathrm{ft}$ northeast of monitoring well R-35a.

Completion Type: Single completion in Santa Fe Group.

Period of Record: Well completed as a supply well in November 1966; transducer installed October 2006; data through June 2009.

Remarks: Drawdown is about $27 \mathrm{ft}$. PM-3 responds to pumping at O-4.

\begin{tabular}{|c|c|c|c|c|c|c|c|c|c|c|c|c|c|c|}
\hline \multicolumn{15}{|c|}{ PM-3 Construction Information } \\
\hline Screen & $\begin{array}{l}\text { Screen } \\
\text { Top } \\
\text { Depth } \\
\text { (ft) }\end{array}$ & $\begin{array}{c}\text { Screen } \\
\text { Bottom } \\
\text { Depth } \\
\text { (ft) }\end{array}$ & $\begin{array}{c}\text { Screen } \\
\text { Top } \\
\text { Elev } \\
\text { (ft) }\end{array}$ & \begin{tabular}{|c|} 
Screen \\
Bottom \\
Elev \\
$(\mathrm{ft})$
\end{tabular} & $\begin{array}{l}\text { Screen } \\
\text { Length } \\
\text { (ft) }\end{array}$ & $\begin{array}{l}\text { Pump } \\
\text { Intake } \\
\text { Depth } \\
\text { (ft) }\end{array}$ & $\begin{array}{c}\text { Pump } \\
\text { Intake } \\
\text { Elev } \\
\text { (ft) }\end{array}$ & \begin{tabular}{|} 
Depth to \\
Top of \\
Sump \\
(ft)
\end{tabular} & $\begin{array}{c}\text { Top of } \\
\text { Sump } \\
\text { Elev } \\
\text { (ft) }\end{array}$ & $\begin{array}{l}\text { Depth to } \\
\text { Sump } \\
\text { Bottom } \\
\text { (ft) }\end{array}$ & $\begin{array}{l}\text { Sump } \\
\text { Length } \\
\text { (ft) }\end{array}$ & $\begin{array}{c}\text { Sump } \\
\text { Volume } \\
\text { (L) }\end{array}$ & $\mid \begin{array}{c}\text { Hydro } \\
\text { Zone } \\
\text { Code }\end{array}$ & $\begin{array}{l}\text { Geo } \\
\text { Unit } \\
\text { Code }\end{array}$ \\
\hline 1 & 956 & 2532 & 5654 & 4078 & 1576 & 830 & 5780 & 2532 & 4078 & 2552 & 20 & 605.4 & RT & $\overline{T s f}$ \\
\hline
\end{tabular}

Note: Ground Elevation: $6610 \mathrm{ft}$; all measurements are from this elevation

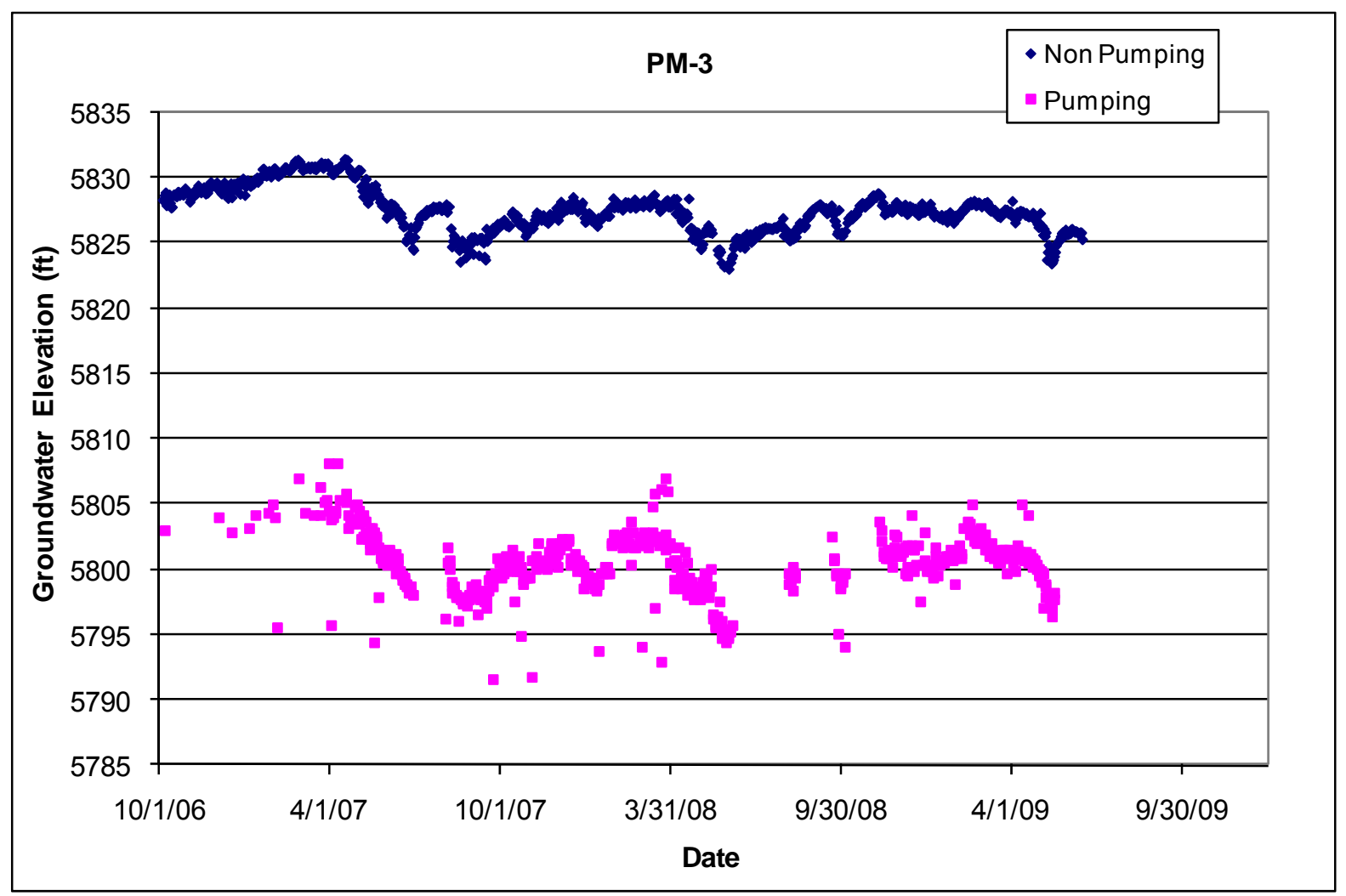




\subsection{PM-4}

Location: PM-4 is located on Mesita del Buey about midway between supply wells PM-2 and PM-5. The nearest monitoring well is R-15 in Mortandad Canyon, about 0.67 miles to the north.

Completion Type: Single completion in the Puye Formation and Santa Fe Group.

Period of Record: Well completed as a supply well in August 1981; transducer installed August 2004. The transducer failed in November 2006 and was replaced in April 2007, failed again June 2008, replaced September 2008; intermittent data through 2009.

Remarks: Well is powered by a natural gas motor and when used is operated continuously. Drawdown in 2008 was about $48 \mathrm{ft}$. PM-4 responds to pumping at PM-2.

\begin{tabular}{|c|c|c|c|c|c|c|c|c|c|c|c|c|c|c|}
\hline \multicolumn{15}{|c|}{ PM-4 Construction Information } \\
\hline Screen & $\begin{array}{c}\text { Screen } \\
\text { Top } \\
\text { Depth } \\
\text { (ft) }\end{array}$ & $\begin{array}{c}\text { Screen } \\
\text { Bottom } \\
\text { Depth } \\
\text { (ft) }\end{array}$ & \begin{tabular}{|c} 
Screen \\
Top \\
Elev \\
(ft)
\end{tabular} & \begin{tabular}{|c|} 
Screen \\
Bottom \\
Elev \\
(ft)
\end{tabular} & $\begin{array}{c}\text { Screen } \\
\text { Length } \\
\text { (ft) }\end{array}$ & $\begin{array}{l}\text { Pump } \\
\text { Intake } \\
\text { Depth } \\
\text { (ft) }\end{array}$ & $\begin{array}{c}\text { Pump } \\
\text { Intake } \\
\text { Elev } \\
\text { (ft) }\end{array}$ & $\begin{array}{l}\text { Depth to } \\
\text { Top of } \\
\text { Sump } \\
\text { (ft) }\end{array}$ & $\begin{array}{c}\text { Top of } \\
\text { Sump } \\
\text { Elev } \\
\text { (ft) }\end{array}$ & $\begin{array}{l}\text { Depth to } \\
\text { Sump } \\
\text { Bottom } \\
\text { (ft) }\end{array}$ & $\begin{array}{c}\text { Sump } \\
\text { Length } \\
\text { (ft) }\end{array}$ & $\begin{array}{c}\text { Sump } \\
\text { Volume } \\
\text { (L) }\end{array}$ & $\begin{array}{l}\text { Hydro } \\
\text { Zone } \\
\text { Code }\end{array}$ & $\begin{array}{c}\text { Geo } \\
\text { Unit } \\
\text { Code }\end{array}$ \\
\hline 1 & 1260 & 2854 & 5660 & 4066 & 1594 & 1210 & 5710 & 2854 & 4066 & 2874 & 20 & 790.8 & RT & Tp \\
\hline
\end{tabular}

Note: Ground Elevation: $6920 \mathrm{ft}$; all measurements are from this elevation

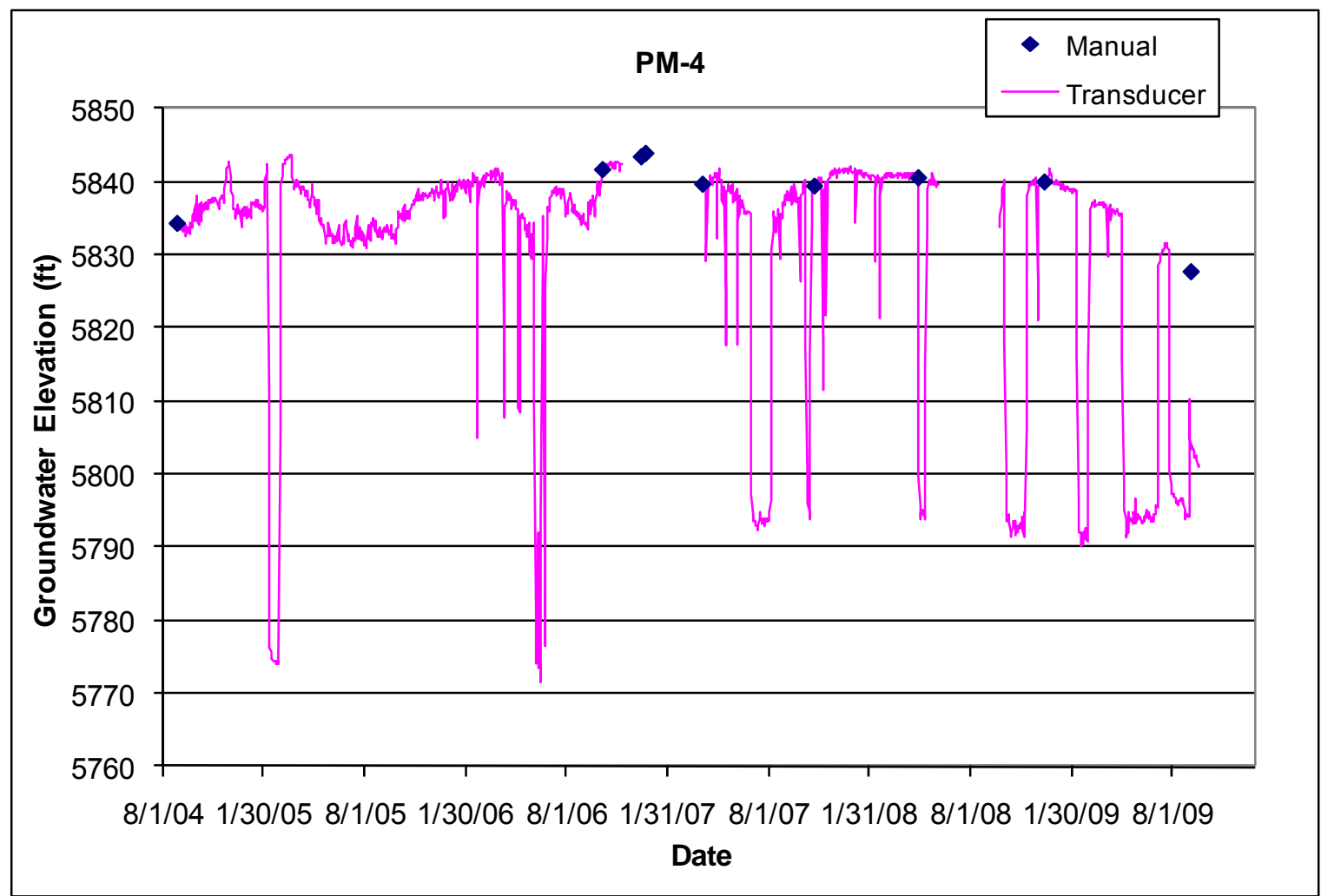

Note: mean daily water level values shown 


\subsection{PM-5}

Location: PM-5 is located on a mesa south of Ten Site and Mortandad canyons. The nearest monitoring well is R-33 in Ten Site Canyon about $1500 \mathrm{ft}$ to the northeast.

Completion Type: Single completion in the Puye Formation and Santa Fe Group.

Period of Record: Well completed as a supply well in September 1982; transducer installed December 2004. The transducer failed in October 2006 and was replaced in April 2007; data through 2008.

Remarks: PM-5 responds to pumping PM-4. Drawdown is about $80 \mathrm{ft}$. Transducer equipment problems prevented data collection in 2009.

\begin{tabular}{|c|c|c|c|c|c|c|c|c|c|c|c|c|c|c|}
\hline \multicolumn{15}{|c|}{ PM-5 Construction Information } \\
\hline Screen & $\begin{array}{c}\text { Screen } \\
\text { Top } \\
\text { Depth } \\
\text { (ft) }\end{array}$ & $\begin{array}{c}\text { Screen } \\
\text { Bottom } \\
\text { Depth } \\
\text { (ft) }\end{array}$ & $\begin{array}{c}\text { Screen } \\
\text { Top } \\
\text { Elev } \\
\text { (ft) }\end{array}$ & $\begin{array}{c}\text { Screen } \\
\text { Bottom } \\
\text { Elev } \\
\text { (ft) }\end{array}$ & $\begin{array}{c}\text { Screen } \\
\text { Length } \\
\text { (ft) }\end{array}$ & $\begin{array}{c}\text { Pump } \\
\text { Intake } \\
\text { Depth } \\
\text { (ft) }\end{array}$ & $\begin{array}{c}\text { Pump } \\
\text { Intake } \\
\text { Elev } \\
\text { (ft) }\end{array}$ & $\begin{array}{c}\text { Depth to } \\
\text { Top of } \\
\text { Sump (ft) }\end{array}$ & $\begin{array}{c}\text { Top of } \\
\text { Sump } \\
\text { Elev } \\
\text { (ft) }\end{array}$ & $\begin{array}{c}\text { Depth to } \\
\text { Sump } \\
\text { Bottom } \\
\text { (ft) }\end{array}$ & $\begin{array}{l}\text { Sump } \\
\text { Length } \\
\text { (ft) }\end{array}$ & $\begin{array}{c}\text { Sump } \\
\text { Volume } \\
\text { (L) }\end{array}$ & $\begin{array}{c}\text { Hydro } \\
\text { Zone } \\
\text { Code }\end{array}$ & $\begin{array}{l}\text { Geo } \\
\text { Unit } \\
\text { Code }\end{array}$ \\
\hline 1 & 1440 & 3072 & 5655 & 4023 & 1632 & & 7095 & 3072 & 3072 & 3092 & 20 & 790.8 & RT & $\overline{T p}$ \\
\hline
\end{tabular}

Note: Ground Elevation: $7095 \mathrm{ft}$; all measurements are from this elevation

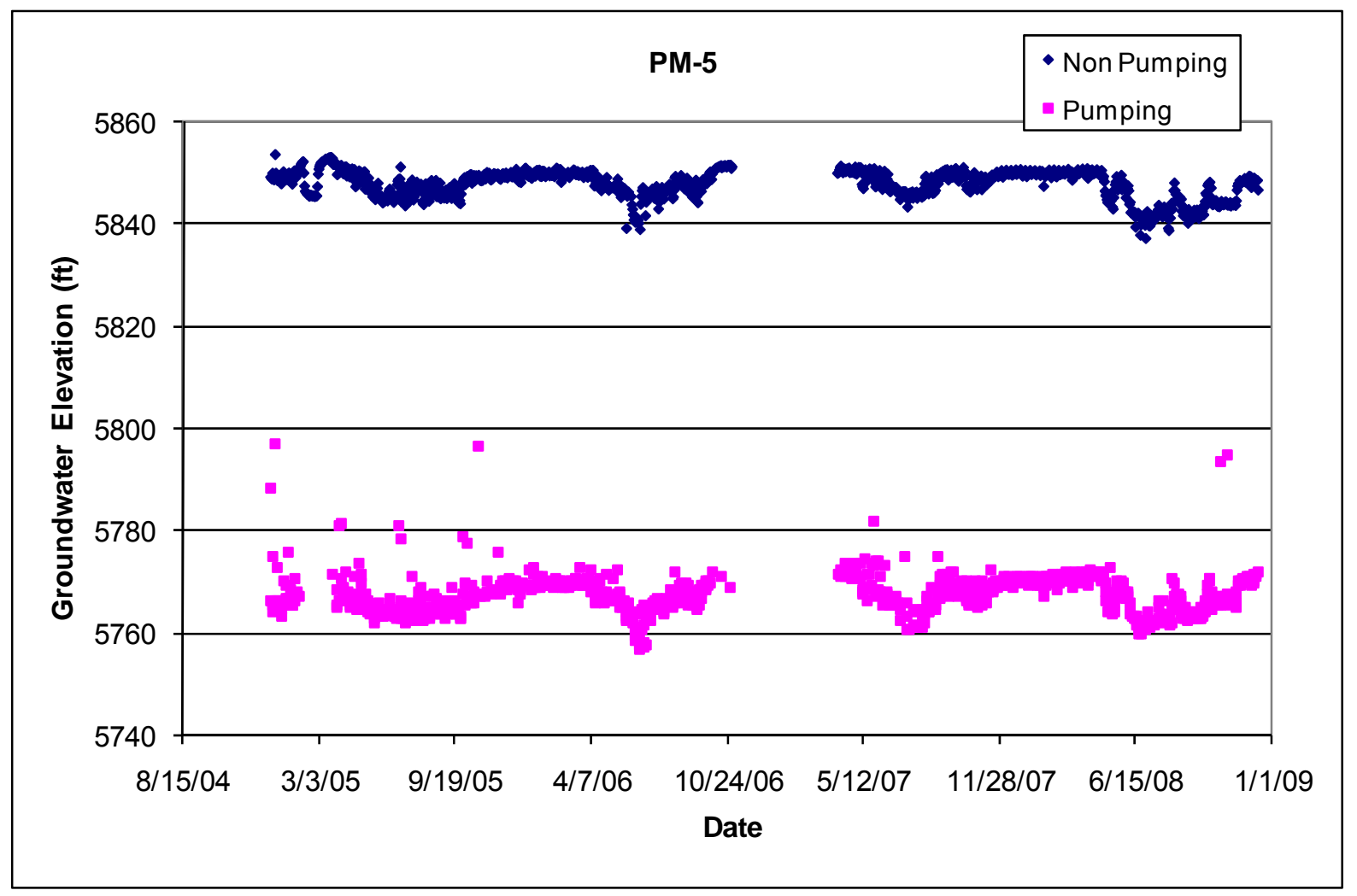




\subsection{Acknowledgments}

The authors would like to acknowledge all those whose work contributed to this report, especially the Water Stewardship Program Field Operations Team members who collected most of the groundwater level data: Consuelo Montoya, Jackie Carr, Lisa Ansay, Jesse Berryhill, William Shaw, David Woody, Harold Wershow, Nathan Wales, Jayson Romero, and others. Thanks also to Danny Katzman, Tim Goering, Steve Paris, Mike Alexander, and Paul Huber for programmatic support for the Groundwater Monitoring Project.

Thanks and acknowledgment are extended to the LAC Water Utilities Department personnel, Wayne Witten, Daryl Hastings, John Fesser, Rick Herrera, Brian Montoya, and others, whose help, cooperation, and patience have been invaluable in obtaining water level data for the water supply wells.

Tim Goering, Hai Shen, Hector Hinojosa, and Danny Katzman provided helpful reviews of the report. Many thanks also to Hector Hinojosa for editing and compositional support.

\subsection{References and Bibliography}

The following reports and documents contain groundwater level data for wells at LANL.

Allen, S.A., and R.J. Koch, 2006, "Groundwater Level Status Report for 2005, Los Alamos National Laboratory," Los Alamos National Laboratory report LA-14292-PR, Los Alamos, New Mexico.

Allen, S.A., and R.J. Koch, 2007, "Groundwater Level Status Report for Fiscal Year 2006, Los Alamos National Laboratory," Los Alamos National Laboratory report LA-14331-PR, Los Alamos, New Mexico.

Allen, S.A., and R.J. Koch, 2008, "Groundwater Level Status Report for Fiscal Year 2007, Los Alamos National Laboratory," Los Alamos National Laboratory report LA-14358-PR, Los Alamos, New Mexico.

Ball, T., M. Everett, P. Longmire, D. Vaniman, W. Stone, D. Larssen, K. Greene, N. Clayton, and S. McLin, February 2002, "Characterization Well R-22 Completion Report," Los Alamos National Laboratory report LA-13893-MS, Los Alamos, New Mexico.

Broxton, D.E., R. Warren, D. Vaniman, B. Newman, A. Crowder, M. Everett, R. Gilkeson, P. Longmire, J. Marin, W. Stone, S. McLin, and D. Rogers, 2001, "Characterization Well R-12

Completion Report," Los Alamos National Laboratory report LA-13822-MS, Los Alamos, New Mexico.

Broxton, D., R. Gilkeson, P. Longmire, J. Marin, R. Warren, D. Vaniman, A. Crowder, B. Newman, B. Lowry, D. Rogers, W. Stone, S. McLin, G. WoldeGabriel, D. Daymon, and D. Wycoff, 2001, "Characterization Well R-9 Completion Report," Los Alamos National Laboratory report LA-13742MS, Los Alamos, New Mexico.

Broxton, D., D. Vaniman, W. Stone, S. McLin, J. Marin, R. Koch, R. Warren, P. Longmire, D. Rogers, and N. Tapia, 2001, "Characterization Well R-19 Completion Report," Los Alamos National Laboratory report LA-13823-MS, Los Alamos, New Mexico.

Broxton, D., R. Warren, P. Longmire, R. Gilkeson, S. Johnson, D. Rogers, W. Stone, B. Newman, M. Everett, D. Vaniman, S. McLin, J. Skalski, and D. Larssen, 2002, "Characterization Well R-25 Completion Report," Los Alamos National Laboratory report LA-13909-MS, Los Alamos, New Mexico. 
Gray, R.N., 2001, "Report on Alluvial Well Completions 1994-2001," Prepared for the Environmental Restoration Project, Los Alamos National Laboratory, 56 pages with appendices.

Keating, E., and R. Kelley, 2005, "Groundwater Elevation Contour Map of the Top of the Regional Aquifer in the Vicinity of LANL," Los Alamos National Laboratory report LA-UR-05-0455, Los Alamos, New Mexico.

Kleinfelder, March 19, 2004, "Final Completion Report, Characterization Well R-11 Los Alamos National Laboratory, Los Alamos, New Mexico," Project No. 37151. Prepared for the United States Department of Energy and the National Nuclear Security Administration through the United States Army Corps of Engineers, Sacramento District. Prepared by Kleinfelder, Inc., 8300 Jefferson NE, Ste B, Albuquerque, NM 87113, 27 pages, with appendices.

Kleinfelder, March 23, 2004, "Final Completion Report, Characterization Well R-4, Los Alamos National Laboratory, Los Alamos, New Mexico," Project No. 37151/7.12. Prepared for the United States Department of Energy and the National Nuclear Security Administration through the United States Army Corps of Engineers, Sacramento District. Prepared by Kleinfelder, Inc., 8300 Jefferson NE, Ste B, Albuquerque, NM 87113, 29 pages, with appendices.

Kleinfelder, April 5, 2004, "Final, Well R-2 Completion Report, Los Alamos National Laboratory, Los Alamos, New Mexico," Project No. 37151/Task 11, Document No. ALB04RP001. Prepared for the United States Department of Energy and the National Nuclear Security Administration through the United States Army Corps of Engineers, Sacramento District. Prepared by Kleinfelder, Inc., 8300 Jefferson NE, Ste B, Albuquerque, NM 87113, 17 pages, with appendices.

Kleinfelder, April 19, 2004, "Final Well R-1 Completion Report, Los Alamos National Laboratory, Los Alamos, New Mexico," Project No. 37151/17.12. Prepared for the United States Department of Energy and the National Nuclear Security Administration through the United States Army Corps of Engineers, Sacramento District. Prepared by Kleinfelder, Inc., 8300 Jefferson NE, Ste B, Albuquerque, NM 87113, 20 pages, with appendices.

Kleinfelder, April 28, 2004, "Final Well R-28 Completion Report, Los Alamos National Laboratory, Los Alamos, New Mexico," Project No. 37151/16.12. Prepared for the United States Department of Energy and the National Nuclear Security Administration through the United States Army Corps of Engineers, Sacramento District. Prepared by Kleinfelder, Inc., 8300 Jefferson NE, Ste B, Albuquerque, NM 87113, 22 pages, with appendices.

Kleinfelder, May 7, 2004, "Final, Well CdV-16-1(i) Completion Report, Los Alamos National Laboratory, Los Alamos, New Mexico," Project No. 37151/9.12. Prepared for the United States Department of Energy and the National Nuclear Security Administration through the United States Army Corps of Engineers, Sacramento District. Prepared by Kleinfelder, Inc., 8300 Jefferson NE, Ste B, Albuquerque, NM 87113, 22 pages, with appendices.

Kleinfelder, May 14, 2004, "Final, Well CdV-16-2(i) Completion Report, Los Alamos National Laboratory, Los Alamos, New Mexico," Project No. 37151/10.12. Prepared for the United States Department of Energy and the National Nuclear Security Administration through the United States Army Corps of Engineers, Sacramento District. Prepared by Kleinfelder, Inc., 8300 Jefferson NE, Ste B, Albuquerque, NM 87113, 20 pages, with appendices.

Kleinfelder, May 18, 2004, "Final, Borehole CdV-16-3(i) Completion Report, Los Alamos National Laboratory, Los Alamos, New Mexico," Project No. 37151/11.12. Prepared for the United States Department of Energy and the National Nuclear Security Administration through the United States Army Corps of Engineers, Sacramento District. Prepared by Kleinfelder, Inc., 8300 Jefferson NE, Ste B, Albuquerque, NM 87113, 17 pages, with appendices. 
Kleinfelder, November 2004, "Final Completion Report, Characterization Well R-34, Los Alamos National Laboratory, Los Alamos, New Mexico," Project No. 37151. Prepared for the United States Department of Energy and the National Nuclear Security Administration through the United States Army Corps of Engineers, Sacramento District. Prepared by Kleinfelder, Inc., 8300 Jefferson NE, Ste B, Albuquerque, NM 87113, 27 pages, with appendices.

Kleinfelder, January 2006a, "Final Completion Report, Characterization Wells R-10a/R-10, Los Alamos National Laboratory, Los Alamos, New Mexico," Project No. 49436. Prepared for the United States Department of Energy and the National Nuclear Security Administration through the United States Army Corps of Engineers, Sacramento District. Prepared by Kleinfelder, Inc., 8300 Jefferson NE, Ste B, Albuquerque, NM 87113, 32 pages, with appendices.

Kleinfelder, January 2006b, "Final Completion Report, Intermediate Well LAOI-7, Los Alamos National Laboratory, Los Alamos, New Mexico," Project No. 49436. Prepared for the United States Department of Energy and the National Nuclear Security Administration through the United States Army Corps of Engineers, Sacramento District. Prepared by Kleinfelder, Inc., 8300 Jefferson NE, Ste B, Albuquerque, NM 87113, 32 pages, with appendices. Kleinfelder 2006a.

Koch, R.J., and D.B. Rogers, 2003, "Water Supply at Los Alamos, 1998-2001," Los Alamos National Laboratory report LA-13985-PR, Los Alamos, New Mexico, 28 pp.

Koch, R.J., D.B. Rogers, N.J. Tapia, and S.G. McLin, 2004, "Manual and Transducer Groundwater Levels from Test Wells at Los Alamos National Laboratory, 1992-2003," Los Alamos National Laboratory report LA-14132, Los Alamos, New Mexico, 36 pp.

Koch, R.J., and S. Schmeer, 2009, "Groundwater Level Status Report for 2008, Los Alamos National Laboratory," Los Alamos National Laboratory report LA-14397-PR, Los Alamos, New Mexico.

Kopp, H.W., A.J. Crowder, M.C. Everett, D.T. Vaniman, D.D. Hickmott, W.J. Stone, N. Clayton, S.G. Pearson, and D.E. Larssen, 2002, "Well CdV-R-15-3 Completion Report," Los Alamos National Laboratory report LA-13906-MS, Los Alamos, New Mexico.

LANL (Los Alamos National Laboratory), May 22, 1998, "Hydrogeologic Workplan," Los Alamos, New Mexico.

LANL (Los Alamos National Laboratory), 2003, "Phase III RFI Report for SWMU 16-021(c)-99," Los Alamos National Laboratory report LA-UR-03-5248, Los Alamos, New Mexico.

LANL (Los Alamos National Laboratory), April 2004, "Los Alamos and Pueblo Canyons Investigation Report," Los Alamos National Laboratory report LA-UR-04-2714, Los Alamos, New Mexico.

LANL (Los Alamos National Laboratory), 2005, "Groundwater Level Data Submittal to NMED," Los Alamos National Laboratory report LA-UR-05-0457, Los Alamos, New Mexico.

LANL (Los Alamos National Laboratory), March 2005, "Groundwater Level Monitoring Plan and Field Implementation Plan for the Groundwater Level Monitoring Project, 2005," draft unpublished monitoring plan, Water Quality and Hydrology Group, Environmental Stewardship Division, Los Alamos National Laboratory, Los Alamos, New Mexico.

LANL (Los Alamos National Laboratory), June 2006, "2006 Hydrogeologic Site Atlas," Los Alamos National Laboratory report LA-UR-06-3058, Los Alamos, New Mexico.

LANL (Los Alamos National Laboratory), 2006, "Quality Assurance Project Plan for the Groundwater Level Monitoring Project," Environmental Remediation and Support Services quality document EPERSS-WSP-1003, available online at http://erinternal.lanl.gov/procedures/water procedures.shtml. 
LANL (Los Alamos National Laboratory), March 2007, "General Facility Information," Los Alamos National Laboratory report LA-UR-07-1837, Los Alamos, New Mexico.

LANL (Los Alamos National Laboratory), 2007, "Completion Report for Regional Aquifer Wells R-35a and R-35b," Los Alamos National Laboratory report LA-UR-07-5324, Los Alamos, New Mexico.

LANL (Los Alamos National Laboratory), December 2007, "Well R-32 Rehabilitation and Conversion Summary Report, Revision 1," Los Alamos National Laboratory report LA-UR-07-8074, Los Alamos, New Mexico.

LANL (Los Alamos National Laboratory), January 2008, "Well R-20 Rehabilitation and Conversion Summary Report," Los Alamos National Laboratory report LA-UR-08-0056, Los Alamos, New Mexico.

LANL (Los Alamos National Laboratory), August 2008, "Well R-33 Rehabilitation and Conversion Summary Report," Los Alamos National Laboratory report LA-UR-08-4696, Los Alamos, New Mexico.

LANL (Los Alamos National Laboratory), September 2008, "Completion Report for Well R-25c," Los Alamos National Laboratory report LA-UR-08-5878, Los Alamos, New Mexico.

LANL (Los Alamos National Laboratory), December 2008, "Completion Report for Well R-25b, Revision 1," Los Alamos National Laboratory report LA-UR-08-7831, Los Alamos, New Mexico.

LANL (Los Alamos National Laboratory), 2009, "2009 Interim Facility-Wide Groundwater Monitoring Plan," Los Alamos National Laboratory report LA-UR-09-1340, Los Alamos, New Mexico.

LANL (Los Alamos National Laboratory), March 2009, "Completion Report for Well R46," Los Alamos National Laboratory report LA-UR-09-1338, Los Alamos, New Mexico.

LANL (Los Alamos National Laboratory), August 2009a, "R-22 Well Redevelopment Phase I Summary Report," Los Alamos National Laboratory report LA-UR-09-4936, Los Alamos, New Mexico.

LANL (Los Alamos National Laboratory), August 2009b, "Plugging and Abandonment Summary Report for Well CdV-16-2(i)," Los Alamos National Laboratory report LA-UR-09-4672, Los Alamos, New Mexico.

LANL (Los Alamos National Laboratory), September 2009a, "Rehabilitation and Conversion Summary Report for R-16," Los Alamos National Laboratory report LA-UR-09-5372, Los Alamos, New Mexico.

LANL (Los Alamos National Laboratory), September 2009b, "Plugging and Abandonment Summary Report for Well MCOBT-4.4," Los Alamos National Laboratory report LA-UR-09-5374, Los Alamos, New Mexico.

LANL (Los Alamos National Laboratory), September 2009c, "Completion Report for Intermediate Aquifer Well PCI-2," Los Alamos National Laboratory report LA-UR-09-5489, Los Alamos, New Mexico.

LANL (Los Alamos National Laboratory), October 2009, "Plugging and Abandonment Summary Report for Wells 03-B-9 and 03-B-10," Los Alamos National Laboratory report LA-UR-09-6791, Los Alamos, New Mexico.

Longmire, P., D. Broxton, W. Stone, B. Newman, R. Gilkeson, J. Marin, D. Vaniman, D. Counce, D. Rogers, R. Hull, S. McLin, and R. Warren, 2001, "Characterization Well R-15 Completion Report," Los Alamos National Laboratory report LA-13749-MS, Los Alamos, New Mexico. 
McLin, S.G., 1996, "Analysis of Water Level Fluctuations in Pajarito Plateau Wells," in New Mexico Geological Society Guidebook, 47th Field Conference, Jemez Mountains Region, New Mexico, pp. 421-426.

McLin, S.G., W.D. Purtymun, and M.N. Maes, 1997, "Water Supply at Los Alamos during 1995," Los Alamos National Laboratory report LA-13216-PR, Los Alamos, New Mexico.

McLin, S.G., W.D. Purtymun, and M.N. Maes, 1998, "Water Supply at Los Alamos during 1997," Los Alamos National Laboratory report LA-13548-PR, Los Alamos, New Mexico.

McLin, S.G., 2005, "Analyses of the PM-2 Aquifer Test Using Multiple Observation Wells," Los Alamos National Laboratory report LA-14225-MS, Los Alamos, New Mexico.

McLin, S.G., 2006, "Analyses of the PM-4 Aquifer Test Using Multiple Observation Wells," Los Alamos National Laboratory report LA-14252-MS, Los Alamos, New Mexico.

Nylander, C., T. Ball, K. Bitner, K. Henning, E. Keating, P. Longmire, B. Robinson, D. Rogers, W. Stone, and D. Vaniman, 2002, "Groundwater Annual Status Report for Fiscal Year 2001," Los Alamos National Laboratory report LA-13931-SR, Los Alamos, New Mexico.

Purtymun, W.D., and J.W. Herceg, 1972, "Summary of the Los Alamos Municipal Well-Field Characteristics, 1947-1971," Los Alamos Scientific Laboratory report LA-5040-MS, Los Alamos, New Mexico.

Purtymun, W.D., and J.W. Herceg, 1976, "Water Supply at Los Alamos during 1975," Los Alamos Scientific Laboratory report LA-6461-MS, Los Alamos, New Mexico.

Purtymun, W.D., 1984, "Hydrologic Characteristics of the Main Aquifer in the Los Alamos Area: Development of Groundwater Supplies," Los Alamos National Laboratory report LA-9957-MS, Los Alamos, New Mexico.

Purtymun, W.D., and A.K. Stoker, 1988, "Current Status of Wells and Future Water Supply," Los Alamos National Laboratory report LA-11332-MS, Los Alamos, New Mexico.

Purtymun, W.D., 1995, "Geologic and Hydrologic Records of Observation Wells, Test Holes, Test Wells, Supply Wells, Springs, and Surface Water Stations in the Los Alamos Area," Los Alamos National Laboratory report LA-12883-MS, Los Alamos, New Mexico.

Reid, K.D., R.J. Koch, D. Katzman, K.H. Birdsell, D.E. Broxton, and V.V. Vesselinov, 2008, "Rapid Recharge to Perched-Intermediate Groundwater Zones, Pajarito Plateau, Los Alamos, New Mexico," Poster presented at American Geophysical Union Fall Meeting, December 2008, Los Alamos National Laboratory report LA-UR-08-05882, Los Alamos, New Mexico.

Rogers, D.B., and R.J. Koch, 2005, "Revised Preliminary Map of Annual Water Level Decline Rate at LANL," Los Alamos National Laboratory report LA-UR-05-4456, Los Alamos, New Mexico.

Shomaker \& Associates, January 1999, "Well Report: Construction and Testing, Guaje Replacement Wells GR-1, GR-2, GR-3, and GR-4, Santa Fe County, New Mexico," John Shomaker \& Associates, Inc., report prepared for University of California, Los Alamos National Laboratory, Los Alamos, New Mexico, and Chavez-Grieves Consulting Engineers, Inc., Albuquerque, New Mexico.

Stone, W.J., D.T. Vaniman, P. Longmire, D.E. Broxton, M.C. Everett, R. Lawrence, and D.E. Larssen, 2002, "Characterization Well R-7 Completion Report," Los Alamos National Laboratory report LA13932-MS, Los Alamos, New Mexico. 
Stone, W., D. Levitt, P. Stauffer, D. Wykoff, P. Longmire, D. Newell, Jr., C. Jones, A. Groffman, and R. Roback, 2004. "Results of Monitoring at the Los Alamos Canyon Low-Head Weir, 2002-2003," Los Alamos National Laboratory report LA-14103-MS, Los Alamos, New Mexico.

Vaniman, D., J. Marin, W. Stone, B. Newman, P. Longmire, N. Clayton, R. Lewis, R. Koch, S. McLin, G. WoldeGabriel, D. Counce, D. Rogers, R. Warren, E. Kluk, S. Chipera, D. Larssen, and W. Kopp, March 2002, "Characterization Well R-31 Completion Report," Los Alamos National Laboratory report LA-13910-MS, Los Alamos, New Mexico. 


\section{Appendix A. Geologic Unit Codes}

Table A-1. Geologic Unit Codes

\begin{tabular}{|c|c|}
\hline $\begin{array}{c}\text { Geologic Unit } \\
\text { Code }\end{array}$ & Geologic Unit Description \\
\hline $\mathrm{P}$ & Polvadera Group \\
\hline Qal & Quaternary alluvium \\
\hline $\mathrm{Qb}$ & Bandelier Tuff, undivided \\
\hline Qbo & Otowi Member of the Bandelier Tuff, undivided \\
\hline Qbof & Otowi Member of the Bandelier Tuff, ash flows \\
\hline Qbog & Otowi Member of the Bandelier Tuff, Guaje Pumice Bed \\
\hline Qbt & Tshirege Member of the Bandelier Tuff, undivided \\
\hline Qbt1 & Tshirege Member of the Bandelier Tuff, Unit 1, undivided \\
\hline Qbt1g & Tshirege Member of the Bandelier Tuff, Unit 1, glassy \\
\hline Qbt1v & Tshirege Member of the Bandelier Tuff, Unit 1, vapor phase \\
\hline Qbt2 & Tshirege Member of the Bandelier Tuff, Unit 2 \\
\hline Qbt3 & Tshirege Member of the Bandelier Tuff, Unit 3 \\
\hline Qbt3nw & Tshirege Member of the Bandelier Tuff, Unit 3, nonwelded \\
\hline Qbt3t & Tshirege Member of the Bandelier Tuff, Unit 3, transitional \\
\hline Qbt4 & Tshierge Member of the Bandelier Tuff , Unit 4 \\
\hline Qbt5 & Tshierge Member of the Bandelier Tuff , Unit 5 \\
\hline Qbtt & Tshierge Member of the Bandelier Tuff, Tsankawi Pumice Bed \\
\hline Qct & Cerro Toledo Interval \\
\hline$T$ & Tewa Group \\
\hline $\mathrm{Tb}$ & Tertiary Basalts \\
\hline Tb1 & Middle Miocene Basalts, 12.8 - $12.9 \mathrm{Ma}$ \\
\hline Tb2 & Late Miocene Basalts, 8.4 - 11.4 Ma \\
\hline Tb4 & Cerros del Rio Basaltic Rocks, Pliocene Lavas and associated tephra of the Cerro \\
\hline Tf & Puye Formation, Older fanglomerate \\
\hline Tk & Keres Group, undivided \\
\hline $\mathrm{Tp}$ & Puye Formation, undivided \\
\hline Tpf & Puye Formation, fanglomerates \\
\hline Tpp & Puye Formation, pumiceous fanglomerates \\
\hline Tpt & Puye Formation, Totavi river gravels \\
\hline Tsf & Santa Fe Group, undivided \\
\hline Tsfb & Santa Fe Group basalt \\
\hline Tsfu & Santa Fe Group, excluding Tsfuv \\
\hline Tsfuv & Santa Fe Group, upper unit with volcanic detritus \\
\hline $\mathrm{Tt}$ & Tschicoma Formation, undivided \\
\hline Tt1 & Tschicoma Formation, older flows \\
\hline Tt2 & Tschicoma Formation, younger flows \\
\hline
\end{tabular}


Appendix B. Mean Annual Water Level Data

Table B-1. Mean Annual Groundwater Levels at the Top of the Regional Aquifer in 2009

\begin{tabular}{|c|c|c|c|c|}
\hline Well Name & $\begin{array}{c}\text { Top of } \\
\text { Regional } \\
\text { Aquifer (ft) }\end{array}$ & $\begin{array}{c}\text { No. of } \\
\text { Data } \\
\text { Values }\end{array}$ & $\begin{array}{c}\text { Std. Dev. } \\
(\mathrm{ft})\end{array}$ & $\begin{array}{c}\text { Last Data } \\
\text { Date }\end{array}$ \\
\hline
\end{tabular}

CDV-R-15-3

CDV-R-37-2

G-3

$\mathrm{R}-1$

R-10a

R-11

R-13

R-14

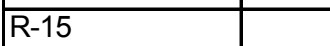

\begin{tabular}{|l|r|}
\hline R-16r & \\
\hline R-17 & 58 \\
\hline$R-18$
\end{tabular}

$\mathrm{R}-17$
$\mathrm{R}-18$
$\mathrm{R}-19$

\begin{tabular}{|l|r|}
\hline R-19 & \\
\hline R-2 & \\
R-20 & 58 \\
\hline
\end{tabular}

\begin{tabular}{|l|l|}
\hline R-20 & \\
\hline R-21 & 20 \\
\hline R-22 & -58 \\
\hline
\end{tabular}

R-21

R-22

R-23

R-24

R-25

R-26

R-28

R-31

R-32

R-33

R-34

R-35b

R-36

\begin{tabular}{ll}
$\mathrm{R}-37$ \\
$\mathrm{R}-38$ \\
\hline
\end{tabular}

R-38

R-3

R-4

R-40

R-41

R-42

R-43

R-44

\begin{tabular}{ll}
$\mathrm{R}-45$ \\
$\mathrm{R}-46$ \\
\hline $\mathrm{R}-48$
\end{tabular}

\begin{tabular}{ll}
$\mathrm{R}-46$ \\
$\mathrm{R}-48$ \\
\hline $\mathrm{R}-49$ \\
\hline
\end{tabular}

R-4

R-5

R-6

\begin{tabular}{|l|}
\hline$R-6$ \\
\hline$R-7$ \\
\hline$R-8$ \\
\hline
\end{tabular}

\begin{aligned} $\mathrm{R}-8 \\ \mathrm{R}-\mathrm{\theta} \\$\hline\end{aligned}

R-9

Test Well DT-10

Test Well DT-5A

Test Well DT-9

6019.4

6136.9

5743.8

5877.7

5740.0

5836.8

5835.0

\begin{tabular}{|l|l|l|l|}
\hline 5879.2 & 7761 & 0.30 & $11 / 20 / 09$ \\
\hline 5692.3 & 7718 & 0.72 & $11 / 18 / 09$ \\
\hline
\end{tabular}

\begin{tabular}{|l|l|l|l|}
\hline 5692.3 & 7761 & 0.17 & $11 / 20 / 09$ \\
\hline
\end{tabular}

\begin{tabular}{|l|l|l|l|}
\hline 5884.5 & 8412 & 0.25 & $12 / 17 / 09$ \\
\hline
\end{tabular}

$6116.9 \quad 8505$

$5887.4 \quad 5749$

$5869.8 \quad 8756$

5864.3

\begin{tabular}{r|r|}
5854.1 & 8435 \\
\hline
\end{tabular}

\begin{tabular}{l|r|}
5761.6 & 3403 \\
\hline
\end{tabular}

\begin{tabular}{|l|r|}
5696.9 & 8409 \\
\hline
\end{tabular}

\begin{tabular}{l|r|}
5828.3 & 8758 \\
\hline
\end{tabular}

\begin{tabular}{|r|r|}
\hline 6231.7 & 7175 \\
\hline
\end{tabular}

\begin{tabular}{r|r|}
\hline 6533.5 & 6106 \\
\hline 5898.3 & 7260 \\
\hline 5837.2 & 9491 \\
\hline
\end{tabular}

5837.2

5827.3

\begin{tabular}{r|r}
5870.9 & 14797 \\
\hline
\end{tabular}

\begin{tabular}{r|r|}
\hline 5870.9 & 9361 \\
\hline 5833.7 & 8384 \\
\hline 5836.1 & 7762
\end{tabular}

5836.1

$5840.2-7762$

\begin{tabular}{r|r}
5855.9 & 11117 \\
\hline
\end{tabular}

5857.7

5753.7

5829.7

5864.7

5699.5

5838.8

5838.1

5835.5

5835.3

5884.7

6130.9

5770.1

5766.0

5837.2

5876.7

5852.

5691.2

5918.4

5957.7

5914.8
6431

\begin{tabular}{|l|l|l|}
\hline 7046 & 0.36 & $12 / 17 / 09$ \\
\hline
\end{tabular}

\begin{tabular}{|l|l|l|}
\hline 8758 & 0.75 & $12 / 31 / 09$ \\
\hline
\end{tabular}

\begin{tabular}{|l|l|l|}
\hline 7118 & 1.01 & $12 / 17 / 09$ \\
\hline
\end{tabular}

\begin{tabular}{l|l|l|}
\hline 4268 & 0.16 & $11 / 20 / 09$ \\
\hline
\end{tabular}

\begin{tabular}{ll|l|}
7150 & 0.28 & $11 / 20 / 09$ \\
\hline
\end{tabular}

\begin{tabular}{|l|l|l|}
\hline 5936 & 0.28 & $11 / 20 / 09$ \\
\hline
\end{tabular}

\begin{tabular}{l|l|l|}
7057 & 0.14 & $12 / 18 / 09$ \\
\hline
\end{tabular}

\begin{tabular}{|l|l|l|}
\hline 7332 & 0.15 & $12 / 18 / 09$ \\
\hline
\end{tabular}

\begin{tabular}{ll|l|}
4017 & 0.30 & $11 / 20 / 09$ \\
\hline
\end{tabular}

\begin{tabular}{l|r|r|}
\hline 9093 & 10.01 & $12 / 04 / 09$ \\
\hline 6321 & 10.84 & $12 / 17 / 09$ \\
\hline
\end{tabular}

\begin{tabular}{r|r|r|}
\hline 6321 & 10.84 & $12 / 17 / 09$ \\
\hline 8268 & 0.16 & $12 / 31 / 09$ \\
\hline
\end{tabular}

\begin{tabular}{|l|l|l|}
\hline 8268 & 0.16 & $12 / 31 / 09$ \\
\hline
\end{tabular}

\begin{tabular}{|l|l|l|}
\hline 8758 & 0.43 & $12 / 31 / 09$ \\
\hline
\end{tabular}

\begin{tabular}{|l|l|l|}
\hline 4742 & 0.10 & $07 / 28 / 09$ \\
\hline
\end{tabular}

\begin{tabular}{l|l|l|}
\hline 7879 & 0.43 & $12 / 31 / 09$ \\
\hline
\end{tabular}

\begin{tabular}{|l|l|l|}
\hline 8750 & 0.16 & $12 / 31 / 09$ \\
\hline
\end{tabular}

\begin{tabular}{|l|l|l|}
\hline 8385 & 0.11 & $12 / 16 / 09$ \\
\hline
\end{tabular}

\begin{tabular}{|l|l|l|}
\hline 8387 & 0.19 & $12 / 16 / 09$ \\
\hline
\end{tabular}

5951

\begin{tabular}{ll}
0.12 & $12 / 16 / 09$ \\
\hline
\end{tabular} 
Table B-2. Mean Annual Groundwater Levels in Intermediate Wells in 2009

\begin{tabular}{|c|c|c|c|c|c|}
\hline Well Name & Screen & $\begin{array}{l}\text { Average } \\
2009 \text { Water } \\
\text { Level (ft) }\end{array}$ & $\begin{array}{c}\text { No. Data } \\
\text { Points }\end{array}$ & $\begin{array}{c}\text { Std. Dev. } \\
\text { (ft) }\end{array}$ & $\begin{array}{c}\text { Date Last } \\
\text { Data }\end{array}$ \\
\hline $16-26644$ & Single & 7456.7 & 1 & & $10 / 13 / 09$ \\
\hline 90LP-SE-16-02669 & Single & Dry & 1 & & $03 / 23 / 09$ \\
\hline CdV-16-1(i) & Single & 6804.1 & 8758 & 1.09 & $12 / 31 / 09$ \\
\hline CdV-16-2(i)r & Single & 6618.5 & 7185 & 0.45 & $10 / 27 / 09$ \\
\hline LADP-3 & Single & 6434.5 & 6618 & 0.67 & $12 / 31 / 09$ \\
\hline LAOI(A)-1.1 & Single & 6542.3 & 11452 & 0.30 & $12 / 31 / 09$ \\
\hline LAOI-3.2 & Single & 6498.1 & 8758 & 0.21 & $12 / 31 / 09$ \\
\hline LAOI-3.2a & Single & 6440.8 & 8759 & 0.26 & $12 / 31 / 09$ \\
\hline LAOI-7 & Single & 6241.1 & 6059 & 0.76 & $09 / 10 / 09$ \\
\hline MCOI-4 & Single & 6316.6 & 7656 & 0.40 & $11 / 18 / 09$ \\
\hline \begin{tabular}{|l|} 
MCOI-5 \\
\end{tabular} & Single & 6138.6 & 7717 & 0.77 & $11 / 18 / 09$ \\
\hline MCOI-6 & Single & 6156.6 & 7718 & 1.05 & $11 / 18 / 09$ \\
\hline MSC-16-02665 & Single & Dry & 1 & & $03 / 23 / 09$ \\
\hline $\mathrm{PCl}-2$ & Single & 6408.0 & 4200 & 0.17 & $12 / 17 / 09$ \\
\hline$\overline{\mathrm{POI}-4}$ & Single & 6213.2 & 8759 & 0.36 & $12 / 31 / 09$ \\
\hline $\mathrm{R}-12$ & 1 & 6072.5 & 8431 & 0.49 & $12 / 18 / 09$ \\
\hline R-12 & 2 & 6072.7 & 8430 & 0.42 & $12 / 18 / 09$ \\
\hline R-19 & 2 & 6169.6 & 5316 & 0.10 & $12 / 21 / 09$ \\
\hline \begin{tabular}{|l|}
$R-23 i$ \\
\end{tabular} & 1 & 6121.8 & 6180 & 0.15 & $12 / 07 / 09$ \\
\hline R-23i & 2 & 6079.1 & 5213 & 0.46 & $12 / 07 / 09$ \\
\hline R-23i & 3 & 6071.1 & 4708 & 0.61 & $12 / 02 / 09$ \\
\hline R-25 & 1 & 6781.6 & 7175 & 0.46 & $10 / 21 / 09$ \\
\hline R-25 & 2 & 6743.5 & 7175 & 0.28 & $10 / 21 / 09$ \\
\hline R-25 & 4 & 6345.2 & 7175 & 0.11 & $10 / 21 / 09$ \\
\hline R-25b & Single & 6767.1 & 9 & 1.45 & $10 / 09 / 09$ \\
\hline R-25c & Single & Dry & 4 & & $12 / 16 / 09$ \\
\hline R-26 & 1 & 7034.1 & 6598 & 0.07 & $10 / 19 / 09$ \\
\hline R-37 & 1 & 5961.5 & 10434 & 1.42 & $12 / 17 / 09$ \\
\hline R-3i & Single & 6204.7 & 8758 & 1.56 & $12 / 31 / 09$ \\
\hline R-40 & $R-40 i$ & 6079.7 & 2693 & 0.17 & $12 / 17 / 09$ \\
\hline R-40 & 1 & 5950.7 & 8515 & 6.57 & $12 / 17 / 09$ \\
\hline R-5 & 2 & 6134.4 & 8268 & 0.56 & $12 / 31 / 09$ \\
\hline R-6i & Single & 6403.4 & 8758 & 0.17 & $12 / 31 / 09$ \\
\hline R-9i & 1 & 6240.6 & 6707 & 0.94 & $12 / 31 / 09$ \\
\hline R-9i & 2 & 6131.3 & 6707 & 0.32 & $12 / 31 / 09$ \\
\hline $\mathrm{SCl}-1$ & Single & 6369.6 & 7766 & 0.34 & $11 / 20 / 09$ \\
\hline \begin{tabular}{|l|}
$\mathrm{SCl}-2$ \\
\end{tabular} & Single & 6205.3 & 6788 & 0.50 & $11 / 20 / 09$ \\
\hline TA-53i & Single & 6386.6 & 5077 & 0.17 & $12 / 31 / 09$ \\
\hline Test Well 2A & Single & 6545.0 & 8288 & 0.82 & $12 / 12 / 09$ \\
\hline
\end{tabular}


Appendix C. Summary of Transient Responses

Table C-1. Summary of Transient Responses to Supply Well Pumping in LANL Monitoring Wells

\begin{tabular}{|c|c|c|c|c|c|c|c|c|c|c|c|}
\hline Well & Screen & $\begin{array}{l}\text { Seasonal } \\
\text { Response }\end{array}$ & Guaje & $0-1$ & $0-4$ & PM-1 & PM-2 & PM-3 & PM-4 & PM-5 & Comment \\
\hline CdV-R-15-3 & 4 & Yes & NE & NE & $\mathrm{NE}$ & $\mathrm{NE}$ & No & NE & No & No & Seasonal response not related to pumping \\
\hline CdV-R-15-3 & 5 & Yes & $\mathrm{NE}$ & $\mathrm{NE}$ & $\mathrm{NE}$ & $\mathrm{NE}$ & No & $\mathrm{NE}$ & No & No & Seasonal response not related to pumping \\
\hline CdV-R-15-3 & 6 & Yes & NE & NE & NE & $\mathrm{NE}$ & No & NE & No & Possible & Seasonal response not related to pumping \\
\hline CdV-R-37-2 & 2 & Yes & $\mathrm{NE}$ & NE & NE & $\mathrm{NE}$ & No & NE & No & No & Seasonal response not related to pumping \\
\hline CdV-R-37-2 & 3 & Yes & $\mathrm{NE}$ & $\mathrm{NE}$ & $\mathrm{NE}$ & $\mathrm{NE}$ & No & NE & No & No & Seasonal response not related to pumping \\
\hline CdV-R-37-2 & 4 & Yes & $\mathrm{NE}$ & $\mathrm{NE}$ & $\mathrm{NE}$ & $\mathrm{NE}$ & No & $\mathrm{NE}$ & No & No & Seasonal response not related to pumping \\
\hline G-3 & Single & Yes & Yes & $\mathrm{NE}$ & NE & NE & $\mathrm{NE}$ & $\mathrm{NE}$ & $\mathrm{NE}$ & $\mathrm{NE}$ & Guaje well field monitoring well \\
\hline $\mathrm{R}-1$ & Single & Yes & $\mathrm{NE}$ & $\mathrm{NE}$ & Possible & $\mathrm{NE}$ & No & No & Possible & Yes & Primarily responds to PM-5 \\
\hline R-2 & Single & No & No & $\mathrm{NE}$ & No & $\mathrm{NE}$ & $\mathrm{NE}$ & $\mathrm{NE}$ & $\mathrm{NE}$ & $\mathrm{NE}$ & Gradual decline of about $0.5 \mathrm{ft} / \mathrm{yr}$ \\
\hline $\mathrm{R}-4$ & Single & Yes & Possible & No & Possible & $\mathrm{NE}$ & $\mathrm{NE}$ & Yes & $\mathrm{NE}$ & $\mathrm{NE}$ & Seasonal response but not to a specific well \\
\hline R-5 & 3 & No & No & No & No & No & $\mathrm{NE}$ & No & $\mathrm{NE}$ & $\mathrm{NE}$ & Gradual decline of about $0.6 \mathrm{ft} / \mathrm{yr}$ \\
\hline R-5 & 4 & Yes & No & Possible & No & Yes & $\mathrm{NE}$ & No & $\mathrm{NE}$ & $\mathrm{NE}$ & Seasonal response but not to a specific well \\
\hline R-6 & Single & Yes & No & No & Possible & $\mathrm{NE}$ & $\mathrm{NE}$ & Yes & $\mathrm{NE}$ & No & Seasonal response but not to a specific well \\
\hline R-7 & 3 & No & No & No & No & NE & $\mathrm{NE}$ & No & $\mathrm{NE}$ & $\mathrm{NE}$ & Gradual decline of about $0.5 \mathrm{ft} / \mathrm{yr}$ \\
\hline R-8 & 1 & Yes & No & $\mathrm{NE}$ & Possible & No & $\mathrm{NE}$ & Yes & $\mathrm{NE}$ & $\mathrm{NE}$ & Responds primarily to pumping at PM-3 \\
\hline R-8 & 2 & Yes & No & $\mathrm{NE}$ & Possible & No & $\mathrm{NE}$ & Yes & $\mathrm{NE}$ & $\mathrm{NE}$ & Responds primarily to pumping at PM-3 \\
\hline R-9 & Single & Yes & No & No & $\mathrm{NE}$ & No & $\mathrm{NE}$ & No & $\mathrm{NE}$ & $\mathrm{NE}$ & Gradual decline of about $0.4 \mathrm{ft} / \mathrm{yr}$ \\
\hline $\mathrm{R}-10$ & 1 & ID & $\mathrm{NE}$ & $\mathrm{NE}$ & $\mathrm{NE}$ & Yes & $\mathrm{NE}$ & NE & $\mathrm{NE}$ & $\mathrm{NE}$ & Responds primarily to PM-1 \\
\hline $\mathrm{R}-10$ & 2 & ID & ID & ID & ID & ID & ID & ID & ID & ID & No water level data as of $01 / 08$ \\
\hline R-10a & Single & No & $\mathrm{NE}$ & $\mathrm{NE}$ & $\mathrm{NE}$ & No & $\mathrm{NE}$ & No & NE & $\mathrm{NE}$ & No apparent response to pumping \\
\hline $\mathrm{R}-11$ & Single & Yes & $\mathrm{NE}$ & $\mathrm{NE}$ & No & $\mathrm{NE}$ & Possible & No & No & Possible & Seasonal response but not to a specific well \\
\hline $\mathrm{R}-12$ & 3 & No & No & No & No & No & $\mathrm{NE}$ & No & No & No & No apparent response to nearby well PM-1 \\
\hline $\mathrm{R}-13$ & Single & Yes & $\mathrm{NE}$ & $\mathrm{NE}$ & No & No & Possible & No & Yes & Possible & Seasonal response but not to a specific well \\
\hline $\mathrm{R}-14$ & 1 & Yes & $\mathrm{NE}$ & $\mathrm{NE}$ & Possible & NE & Possible & NE & No & Yes & Responds primarily to PM-5 \\
\hline $\mathrm{R}-14$ & 2 & Yes & $\mathrm{NE}$ & $\mathrm{NE}$ & Possible & $\mathrm{NE}$ & Possible & $\mathrm{NE}$ & No & Yes & Responds primarily to $\mathrm{PM}-5$ \\
\hline R-15 & Single & Yes & $\mathrm{NE}$ & NE & Possible & $\mathrm{NE}$ & No & No & Yes & Yes & Responds primarily to pumping at $\mathrm{PM}-4$ and $\mathrm{PM}-5$ \\
\hline R-16 & 2 & No & $\mathrm{NE}$ & $\mathrm{NE}$ & NE & No & No & NE & NE & $\mathrm{NE}$ & No apparent response to Buckman pumping \\
\hline R-16 & 3 & No & $\mathrm{NE}$ & $\mathrm{NE}$ & NE & No & No & $\mathrm{NE}$ & $\mathrm{NE}$ & $\mathrm{NE}$ & No apparent response to Buckman pumping \\
\hline R-16 & 4 & No & $\mathrm{NE}$ & $\mathrm{NE}$ & $\mathrm{NE}$ & No & No & NE & NE & $\mathrm{NE}$ & No apparent response to Buckman pumping \\
\hline R-16r & Single & No & No & No & No & No & No & No & No & No & No apparent response to Buckman pumping \\
\hline $\mathrm{R}-17$ & 1 & Yes & $\mathrm{NE}$ & $\mathrm{NE}$ & $\mathrm{NE}$ & $\mathrm{NE}$ & No & $\mathrm{NE}$ & No & No & Seasonal response but not to a specific well \\
\hline $\mathrm{R}-17$ & 2 & Yes & $\mathrm{NE}$ & $\mathrm{NE}$ & $\mathrm{NE}$ & $\mathrm{NE}$ & Possible & $\mathrm{NE}$ & Possible & Yes & Responds primarily to pumping at PM-5 \\
\hline $\mathrm{R}-18$ & Single & No & $\mathrm{NE}$ & $\mathrm{NE}$ & $\mathrm{NE}$ & $\mathrm{NE}$ & No & $\mathrm{NE}$ & No & No & No apparent response to pumping \\
\hline $\mathrm{R}-19$ & 3 & Yes & $\mathrm{NE}$ & $\mathrm{NE}$ & $\mathrm{NE}$ & $\mathrm{NE}$ & Possible & $\mathrm{NE}$ & No & Possible & Muted response \\
\hline $\mathrm{R}-19$ & 4 & Yes & $\mathrm{NE}$ & $\mathrm{NE}$ & $\mathrm{NE}$ & $\mathrm{NE}$ & Yes & $\mathrm{NE}$ & Yes & Possible & Responds primarily to $\mathrm{PM}-2$ \\
\hline $\mathrm{R}-19$ & 5 & Yes & $\mathrm{NE}$ & $\mathrm{NE}$ & $\mathrm{NE}$ & $\mathrm{NE}$ & Yes & $\mathrm{NE}$ & Yes & Possible & Responds primarily to $\mathrm{PM}-2$ \\
\hline $\mathrm{R}-19$ & 6 & Yes & $\mathrm{NE}$ & $\mathrm{NE}$ & $\mathrm{NE}$ & $\mathrm{NE}$ & Yes & $\mathrm{NE}$ & Yes & Possible & Responds primarily to $\mathrm{PM}-2$ \\
\hline $\mathrm{R}-19$ & 7 & Yes & $\mathrm{NE}$ & $\mathrm{NE}$ & $\mathrm{NE}$ & $\mathrm{NE}$ & Yes & $\mathrm{NE}$ & Yes & Possible & Responds primarily to $\mathrm{PM}-2$ \\
\hline $\mathrm{R}-20$ & 1 & Yes & $\mathrm{NE}$ & NE & $\mathrm{NE}$ & $\mathrm{NE}$ & Yes & $\mathrm{NE}$ & Yes & $\mathrm{NE}$ & Highly muted response \\
\hline R-20 & 2 & Yes & $\mathrm{NE}$ & $\mathrm{NE}$ & $\mathrm{NE}$ & $\mathrm{NE}$ & Yes & $\mathrm{NE}$ & Yes & $\mathrm{NE}$ & Muted response \\
\hline R-20 & 3 & Yes & $\mathrm{NE}$ & $\mathrm{NE}$ & $\mathrm{NE}$ & $\mathrm{NE}$ & Yes & $\mathrm{NE}$ & Yes & $\mathrm{NE}$ & Responds primarily to PM-2 but also to PM-4 \\
\hline R-21 & Single & Yes & $\mathrm{NE}$ & $\mathrm{NE}$ & $\mathrm{NE}$ & No & Yes & No & Possible & $\mathrm{NE}$ & Seasonal response but not to a specific well \\
\hline
\end{tabular}


Table C-1. Summary of Transient Responses to Supply Well Pumping in LANL Monitoring Wells (Continued)

\begin{tabular}{|c|c|c|c|c|c|c|c|c|c|c|c|}
\hline Well & Screen & $\begin{array}{l}\text { Seasonal } \\
\text { Response }\end{array}$ & Guaje & $0-1$ & $0-4$ & PM-1 & PM-2 & PM-3 & PM-4 & PM-5 & Comment \\
\hline R-22 & 1 & Yes & $\mathrm{NE}$ & $\mathrm{NE}$ & $\mathrm{NE}$ & No & No & No & No & $\mathrm{NE}$ & Seasonal response but not to a specific well \\
\hline R-22 & 2 & Yes & $\mathrm{NE}$ & $\mathrm{NE}$ & $\mathrm{NE}$ & No & No & No & No & $\mathrm{NE}$ & Seasonal response but not to a specific well \\
\hline R-22 & 3 & Yes & $\mathrm{NE}$ & $\mathrm{NE}$ & NE & No & No & No & No & $\mathrm{NE}$ & Seasonal response but not to a specific well \\
\hline R-22 & 4 & Yes & $\mathrm{NE}$ & $\mathrm{NE}$ & $\mathrm{NE}$ & No & No & No & No & $\mathrm{NE}$ & Seasonal response but not to a specific well \\
\hline R-22 & 5 & Yes & $\mathrm{NE}$ & $\mathrm{NE}$ & $\mathrm{NE}$ & No & No & No & No & $\mathrm{NE}$ & Seasonal response but not to a specific well \\
\hline R-23 & Single & No & $\mathrm{NE}$ & $\mathrm{NE}$ & NE & No & No & $\mathrm{NE}$ & $\mathrm{NE}$ & $\mathrm{NE}$ & No apparent response to pumping \\
\hline R-24 & Single & Yes & Possible & No & Possible & No & $\mathrm{NE}$ & Yes & $\mathrm{NE}$ & $\mathrm{NE}$ & Responds primarily to pumping at PM-3 \\
\hline R-25 & 5 & No & $\mathrm{NE}$ & $\mathrm{NE}$ & $\mathrm{NE}$ & $\mathrm{NE}$ & No & No & No & No & No apparent response to pumping \\
\hline R-25 & 6 & No & $\mathrm{NE}$ & $\mathrm{NE}$ & $\mathrm{NE}$ & $\mathrm{NE}$ & No & No & No & No & No apparent response to pumping \\
\hline R-25 & 7 & No & $\mathrm{NE}$ & $\mathrm{NE}$ & $\mathrm{NE}$ & $\mathrm{NE}$ & No & No & No & No & No apparent response to pumping \\
\hline $\mathrm{R}-25$ & 8 & No & $\mathrm{NE}$ & $\mathrm{NE}$ & $\mathrm{NE}$ & $\mathrm{NE}$ & No & No & No & No & No apparent response to pumping \\
\hline R-26 & 2 & No & $\mathrm{NE}$ & $\mathrm{NE}$ & $\mathrm{NE}$ & $\mathrm{NE}$ & No & No & No & No & No apparent response to pumping \\
\hline R-27 & Single & Yes & $\mathrm{NE}$ & $\mathrm{NE}$ & $\mathrm{NE}$ & $\mathrm{NE}$ & $\mathrm{NE}$ & $\mathrm{NE}$ & $\mathrm{NE}$ & $\mathrm{NE}$ & Seasonal response but not to a specific well \\
\hline R-28 & Single & Yes & $\mathrm{NE}$ & $\mathrm{NE}$ & $\mathrm{NE}$ & $\mathrm{NE}$ & Possible & No & Yes & Possible & Seasonal response but not to a specific well \\
\hline R-31 & 2 & No & $\mathrm{NE}$ & $\mathrm{NE}$ & $\mathrm{NE}$ & No & No & No & No & $\mathrm{NE}$ & No apparent response to pumping \\
\hline R-31 & 3 & No & $\mathrm{NE}$ & $\mathrm{NE}$ & $\mathrm{NE}$ & No & No & No & No & $\mathrm{NE}$ & No apparent response to pumping \\
\hline R-31 & 4 & No & $\mathrm{NE}$ & $\mathrm{NE}$ & NE & No & Possible & No & No & $\mathrm{NE}$ & Limited data for evaluation \\
\hline R-31 & 5 & Yes & $\mathrm{NE}$ & $\mathrm{NE}$ & $\mathrm{NE}$ & No & Yes & No & Possible & $\mathrm{NE}$ & Appears to respond seasonally like PM-2 \\
\hline R-32 & 1 & No & $\mathrm{NE}$ & $\mathrm{NE}$ & $\mathrm{NE}$ & $\mathrm{NE}$ & No & No & No & $\mathrm{NE}$ & No apparent response to pumping \\
\hline R-32 & 2 & Yes & $\mathrm{NE}$ & $\mathrm{NE}$ & $\mathrm{NE}$ & No & Yes & No & Yes & $\mathrm{NE}$ & Responds primarily to pumping at PM-2 and PM-4 \\
\hline R-32 & 3 & Yes & $\mathrm{NE}$ & $\mathrm{NE}$ & $\mathrm{NE}$ & No & Yes & No & Yes & $\mathrm{NE}$ & Responds primarily to pumping at PM-2 and PM-4 \\
\hline R-33 & 1 & No & $\mathrm{NE}$ & $\mathrm{NE}$ & $\mathrm{NE}$ & $\mathrm{NE}$ & $\mathrm{NE}$ & NE & $\mathrm{NE}$ & No & No apparent response to PM-5 \\
\hline R-33 & 2 & Yes & $\mathrm{NE}$ & $\mathrm{NE}$ & $\mathrm{NE}$ & $\mathrm{NE}$ & $\mathrm{NE}$ & No & Yes & Yes & Responds primarily to pumping at PM-5 \\
\hline R-34 & Single & Yes & $\mathrm{NE}$ & $\mathrm{NE}$ & $\mathrm{NE}$ & No & No & No & No & $\mathrm{NE}$ & Seasonal response but not to a specific well \\
\hline R-35a & Single & Yes & $\mathrm{NE}$ & $\mathrm{NE}$ & Yes & $\mathrm{NE}$ & $\mathrm{NE}$ & Yes & NE & $\mathrm{NE}$ & Responds primarily to nearby supply well PM-3 \\
\hline R-35b & Single & Yes & $\mathrm{NE}$ & $\mathrm{NE}$ & $\mathrm{NE}$ & $\mathrm{NE}$ & $\mathrm{NE}$ & No & $\mathrm{NE}$ & $\mathrm{NE}$ & Gradual decline of about $0.6 \mathrm{ft} / \mathrm{yr}$ \\
\hline R-36 & Single & No & $\mathrm{NE}$ & $\mathrm{NE}$ & $\mathrm{NE}$ & $\mathrm{NE}$ & $\mathrm{NE}$ & $\mathrm{NE}$ & $\mathrm{NE}$ & $\mathrm{NE}$ & Gradual decline of about $0.5 \mathrm{ft} / \mathrm{yr}$ \\
\hline R-37 & 1 & ID & ID & ID & ID & ID & ID & ID & ID & ID & Insufficient data for analysis \\
\hline R-38 & Single & ID & ID & ID & ID & ID & ID & ID & ID & ID & Insufficient data for analysis \\
\hline R-39 & Single & ID & ID & ID & ID & ID & ID & ID & ID & ID & Insufficient data for analysis \\
\hline $\mathrm{R}-40$ & 2 & ID & ID & ID & ID & ID & ID & ID & ID & ID & Insufficient data for analysis \\
\hline $\mathrm{R}-41$ & 1 & ID & ID & ID & ID & ID & ID & ID & ID & ID & Insufficient data for analysis \\
\hline R-42 & 1 & Yes & $\mathrm{NE}$ & $\mathrm{NE}$ & ID & $\mathrm{NE}$ & ID & ID & Possible & Possible & Insufficient data for analysis \\
\hline$R-43$ & 1 & ID & ID & ID & ID & ID & ID & ID & ID & ID & Insufficient data for analysis \\
\hline $\mathrm{R}-43$ & 2 & ID & ID & ID & ID & ID & ID & ID & ID & ID & Insufficient data for analysis \\
\hline R-44 & 1 & ID & ID & ID & ID & ID & ID & ID & ID & ID & Insufficient data for analysis \\
\hline $\mathrm{R}-44$ & 2 & ID & ID & ID & ID & ID & ID & ID & Possible & ID & Insufficient data for analysis \\
\hline R-45 & 1 & ID & ID & ID & ID & ID & ID & ID & ID & ID & Insufficient data for analysis \\
\hline R-45 & 2 & ID & ID & ID & ID & ID & ID & ID & Possible & ID & Insufficient data for analysis \\
\hline R-46 & Single & ID & ID & ID & ID & ID & ID & ID & ID & Possible & Insufficient data for analysis \\
\hline $\mathrm{R}-48$ & Single & ID & ID & ID & ID & ID & ID & ID & ID & ID & Insufficient data for analysis \\
\hline R-49 & 1 & ID & ID & ID & ID & ID & ID & ID & ID & ID & Insufficient data for analysis \\
\hline R-49 & 2 & ID & ID & ID & ID & ID & ID & ID & Possible & ID & Insufficient data for analysis \\
\hline TW-1 & Single & No & No & No & $\mathrm{NE}$ & No & $\mathrm{NE}$ & $\mathrm{NE}$ & $\mathrm{NE}$ & $\mathrm{NE}$ & Water level impacted by surface water near well \\
\hline TW-2 & Single & Yes & $\mathrm{NE}$ & $\mathrm{NE}$ & $\mathrm{NE}$ & $\mathrm{NE}$ & $\mathrm{NE}$ & $\mathrm{NE}$ & $\mathrm{NE}$ & $\mathrm{NE}$ & No recent valid water level data \\
\hline TW-3 & Single & Yes & No & $\mathrm{NE}$ & No & $\mathrm{NE}$ & $\mathrm{NE}$ & No & NE & $\mathrm{NE}$ & Gradual decline of about $0.8 \mathrm{ft} / \mathrm{yr}$ \\
\hline TW-4 & Single & Yes & No & $\mathrm{NE}$ & No & $\mathrm{NE}$ & $\mathrm{NE}$ & $\mathrm{NE}$ & $\mathrm{NE}$ & $\mathrm{NE}$ & Seasonal fluctuations not related to pumping \\
\hline
\end{tabular}

$\mathrm{NE}=$ not evaluated; ID = insufficient Data 


\section{Appendix D. Summary of Intermediate Groundwater Level Responses to Runoff}

\section{D.1. Intermediate Groundwater Responses in Cerros del Rio Basalt (Tb4)}

Figure D-1 shows the intermediate groundwater hydrographs for wells completed in the Cerros del Rio basalt. These wells are located in lower Los Alamos Canyon, lower Pueblo Canyon, middle Mortandad Canyon, and lower Pajarito Canyon (see Figure 4-1). Note the water levels in R-12 and R$23 i$ are lower than in the other wells (scale on the right side of the hydrograph). Perched intermediate groundwater levels in the Cerros del Rio basalt in some wells show seasonal variations that are evaluated as possible response to large runoff events in Los Alamos Canyon.

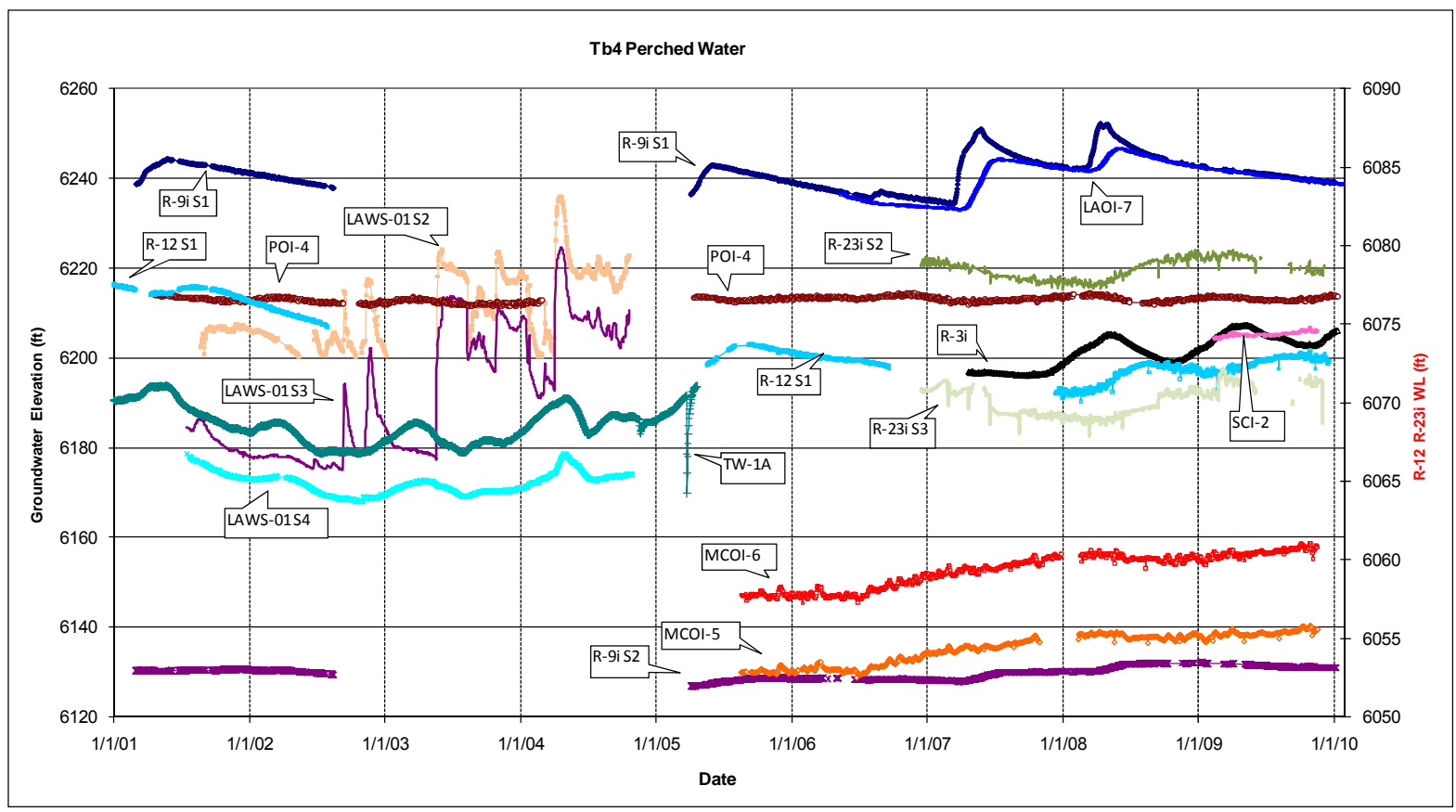

Figure D-1. Intermediate groundwater levels in Cerros del Rio basalt.

Figure D-2 shows the intermediate groundwater level in Cerros del Rio basalt in wells in lower Los Alamos Canyon and lower Pueblo Canyon and the mean daily flow at gaging station E042 in lower Los Alamos Canyon. From 2001 to 2004 screens 2 and 3 in LAWS-01 in lower Los Alamos Canyon (Stone et al. 2004) show responses to small and large runoff events. During this period LAWS-01 screen 4 and nearby well TW-1A in lower Pueblo Canyon show similar responses, generally higher water levels in the winter and lower levels in the summer. From 2006 through 2009, similar seasonal responses are observed in $\mathrm{POI}-4$ and $\mathrm{R}-3 \mathrm{i}$.

Large snowmelt runoff events occurred in Los Alamos Canyon in the spring of 2001, 2005, 2007, and 2008, as observed in lower Los Alamos Canyon at stream gage E042 (Figure D-2). No significant snowmelt runoff occurred in 2009. Concurrent with the large snowmelt runoff in lower Los Alamos Canyon, intermediate groundwater levels in wells R-9i, R-12, and LAOI-7 show groundwater level rises that appear to be related to the snowmelt runoff events. 


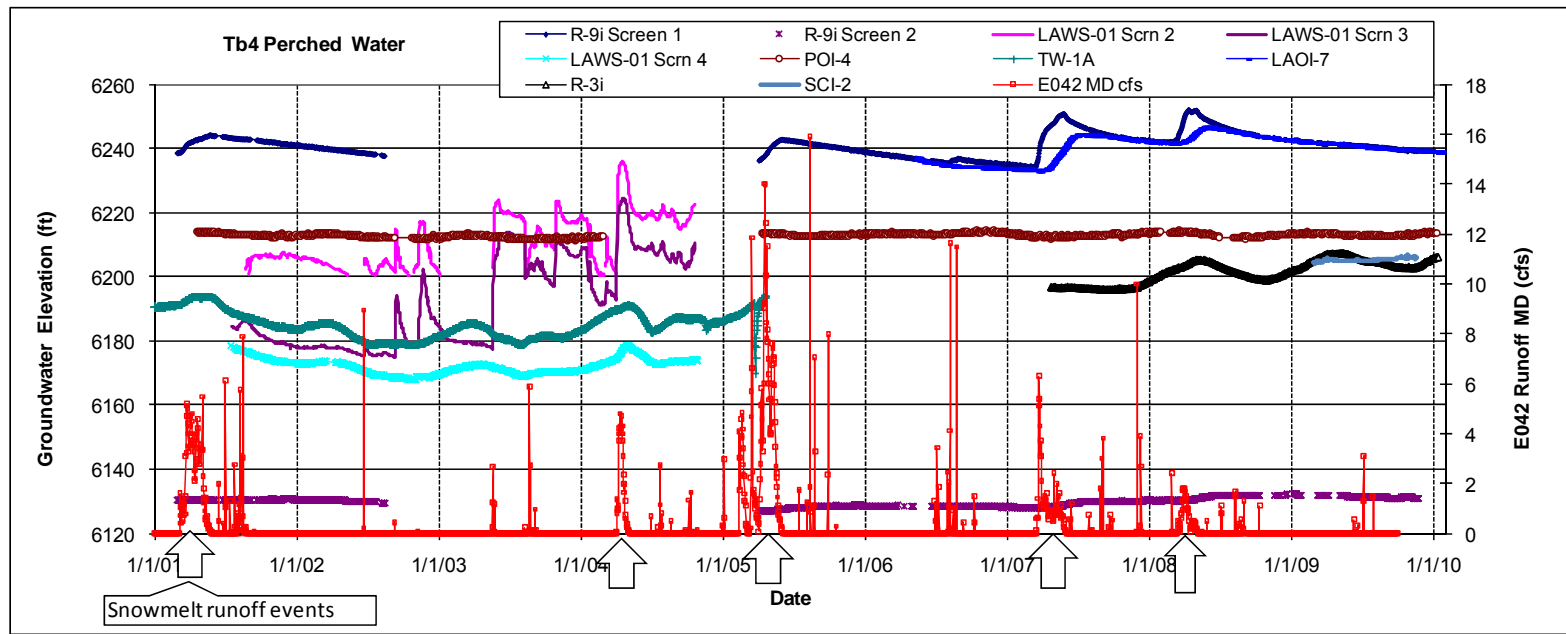

Figure D-2. Intermediate groundwater levels in Cerros del Rio basalt in Los Alamos and Pueblo canyons and mean daily flow at Gaging Station E042.

Figure D-3 shows the runoff at gage E042 during 2007 and 2008 and the water level responses in the Cerros del Rio basalt in wells R-9i screen 1, LAOI-7, and R-12 screen 1. The earliest water level response to snowmelt runoff is at R-9i screen 1 , followed by LAOI-7 with a slightly reduced total response, and then followed possibly by a much subdued response at $R-12$ screen 1 ; again, note that the groundwater elevation at screen 1 in R-12 is about $170 \mathrm{ft}$ lower than R-9i and LAOI-7. A significantly smaller and delayed response is also observed in R-9i screen 2. Additionally, two large storm runoff events in the summer of 2006 caused a rise in the groundwater level at R-9i screen 1 but little if any response at LAOI-7. With no snowmelt runoff in 2009 , the groundwater levels at R-9i and LAOI-7 show a continued decline through 2009. However, the groundwater at R-12 screen 1 showed a rising trend in 2009 , suggesting that the groundwater at $R-12$ is not responding to large runoff events in lower Los Alamos Canyon, or possibly is responding at a lag period greater than a few months. Additional monitoring is needed to understand the groundwater level fluctuations at R-12.

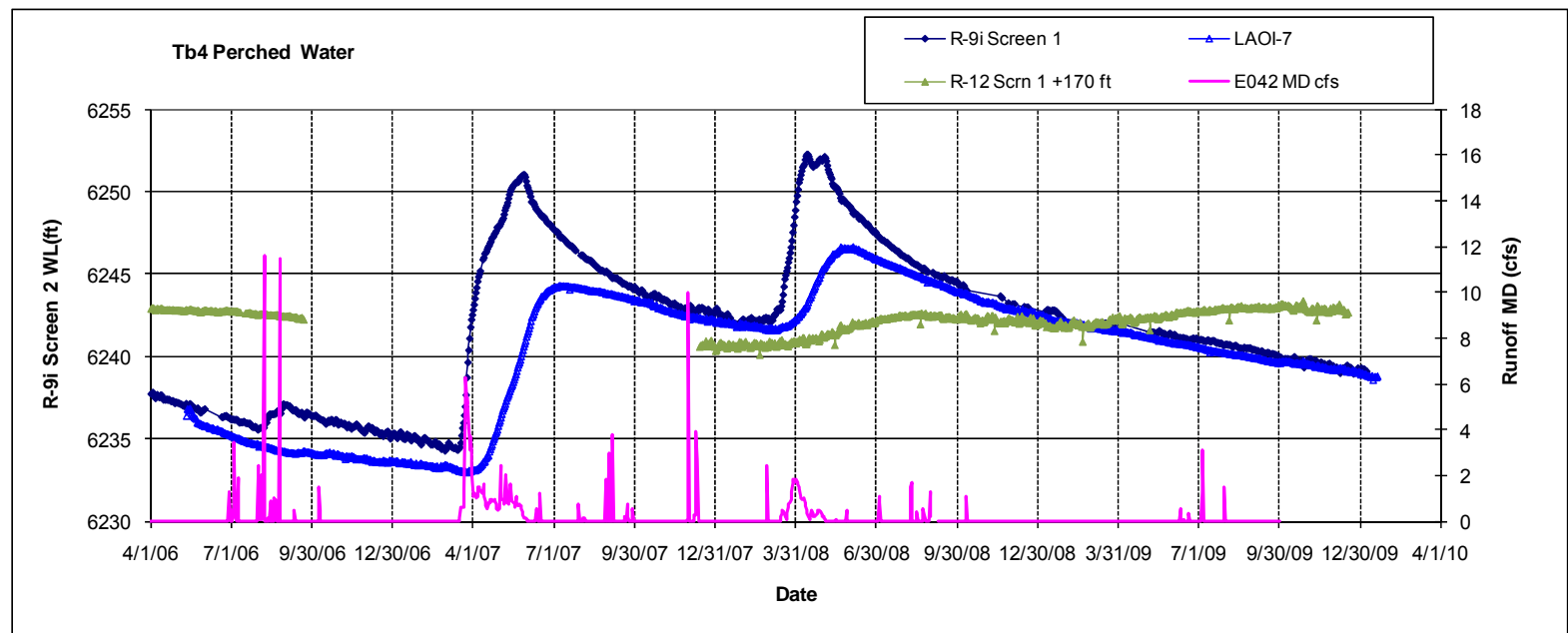

Figure D-3. Intermediate groundwater responses to snowmelt runoff in 2008 and 2009 in Cerros del Rio basalt and mean daily flow at Gaging Station E042.

Figure D-4 shows the hydrographs for intermediate perched groundwater in R-12 and R-23i and the runoff at stream gages E042 in Los Alamos Canyon and E250 in lower Pajarito Canyon. As indicated 
above, the groundwater level fluctuations at R-12 may not be the result of snowmelt runoff infiltration below Los Alamos Canyon. The groundwater level rise in R-23i in 2008 follows a large snowmelt runoff period in the spring of 2008 and may similarly be associated with snowmelt runoff in Pajarito Canyon (or possibly with runoff in Los Alamos Canyon). Following no runoff in lower Pajarito Canyon in 2009, the water levels in R-23i showed a declining trend. Additional runoff monitoring in lower Pajarito Canyon and groundwater level data from R-23i are necessary to determine if groundwater at $\mathrm{R}-23 \mathrm{i}$ responds to runoff events.

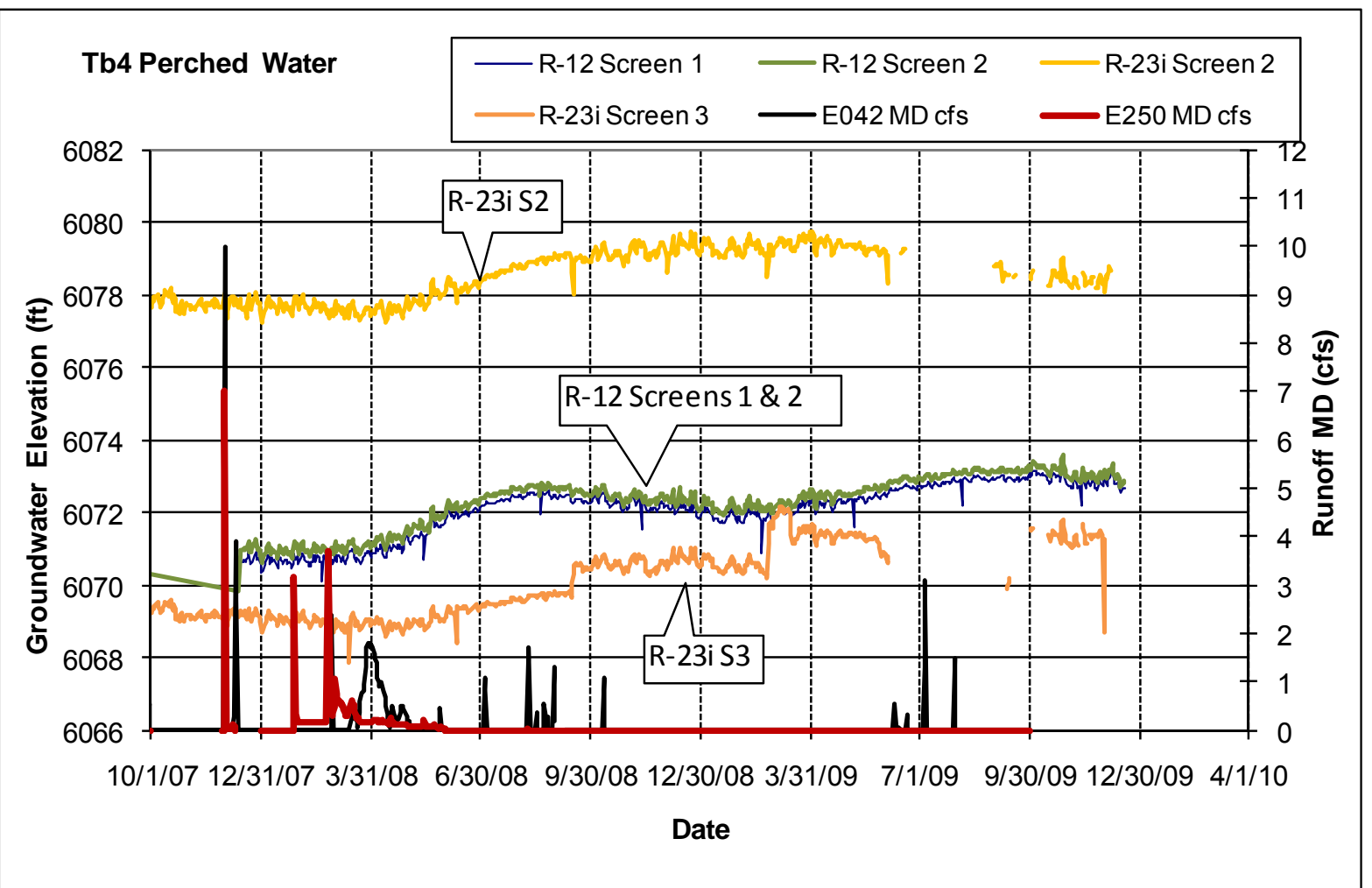

Figure D-4. Intermediate groundwater levels at R-12 and R-23i and mean daily flow at Gaging Stations E042 and E250.

Perched intermediate groundwater in the Cerros del Rio basalt beneath Mortandad Canyon in wells MCOI-5 and MCOI-6 (Figure D-1) shows a rising trend from mid 2006 to early 2008 when the water levels in both wells rose about $10 \mathrm{ft}$. A small rising trend continued at these wells in 2009. The trends in the groundwater levels in these wells do not appear to be related to specific runoff events; additional monitoring is needed to determine if the intermediate groundwater in these wells is influenced by runoff.

\section{D.2. Intermediate Groundwater in Guaje Pumice Bed (Qbog)}

Figure D-5 shows the hydrographs of perched intermediate groundwater in wells screened in the Guaje pumice bed and the mean daily runoff recorded in lower Los Alamos Canyon at stream gage E042. These wells are located in middle Los Alamos Canyon where the intermediate groundwater in the Guaje Pumice bed is 100 to $300 \mathrm{ft}$ below the canyon floor and is stratigraphically higher than the intermediate groundwater in the Puye Formation and Cerros del Rio basalts. The Guaje Pumice bed is about $100 \mathrm{ft}$ above the Cerros del Rio basalt in this area. There is no apparent correlation between trends in the groundwater levels in the Guaje pumice bed and runoff in Los Alamos Canyon. 


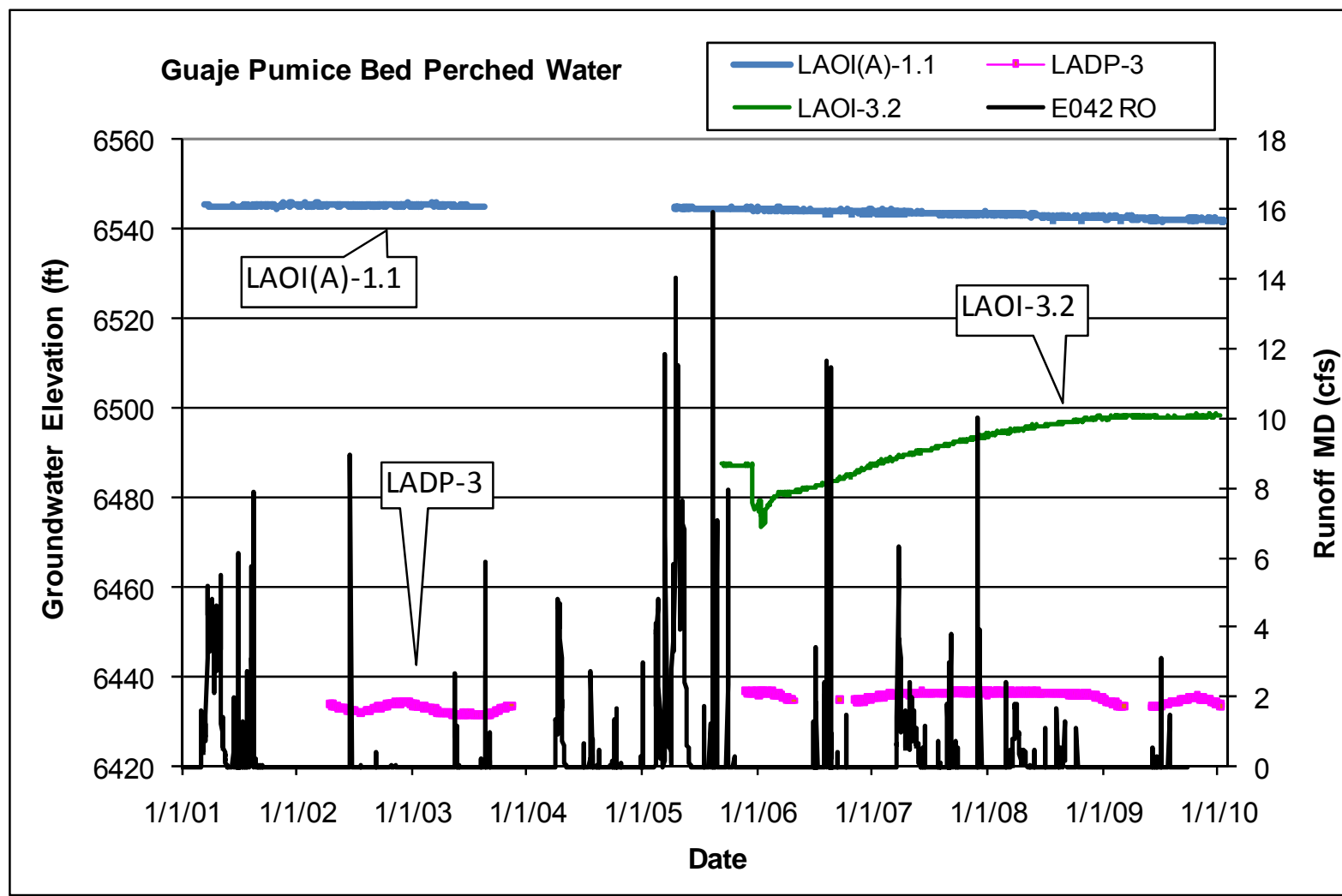

Figure D-5. Intermediate groundwater levels in the Guaje pumice bed at LAOI(A)-1.1, LADP-3, and LAOI-3.2 and mean daily flow at Gaging Station E042.

\section{D.3. Intermediate Groundwater in the Puye Formation (Tp)}

Screens in monitoring wells LAOI-3.2a, SCI-1, MCOI-4, MCOBT-4.4, R-5 screen 2, R-6i, and TA-53i monitor perched intermediate groundwater in the Puye Formation (see Section 4). There is no apparent relationship between runoff and groundwater levels in these wells.

\section{D.4. Intermediate Groundwater at TA-16}

Intermediate groundwater is monitored in the TA-16 area at wells CdV-16(i)-1, R-25 screens 1, 2, and 4 , and CdV-16-2(i)r. Figure D-6 shows the groundwater levels from these wells and the mean daily runoff at gage E252 in upper Water Canyon. Snowmelt runoff occurred at gage E252 in 2005, 2007, and 2008, but significant runoff occurred in 2009. The groundwater in CdV-16-1(i) and R-25 screens 1 and 2 show an apparent response to snowmelt runoff in 2007 and 2008, ranging (in 2007) from a few tenths of a foot at R-25 screen 1 up to about $3 \mathrm{ft}$ at CdV-16-1(i). There is no apparent response to snowmelt runoff at CdV-16-2(i)r in 2007, but there was a possible response in 2008. R-25 screen 4 may have showed a slight response to runoff in 2007, but there was no apparent response in 2008. Note that R-25 screens 1 and 2 and CdV-16-1(i) showed water level responses to drilling and installing monitoring wells R-25b and R-25c in August and September 2008.

The groundwater levels at R-25 screens 1 and 2 and CdV-16-1(i) showed a continued declining trend through 2009, apparently due to the lack of runoff recharge. The groundwater level at CdV-16-2(i)r began to rise after plugging and abandonment of nearby dry well CdV-16-2(i) (see Section 3). 

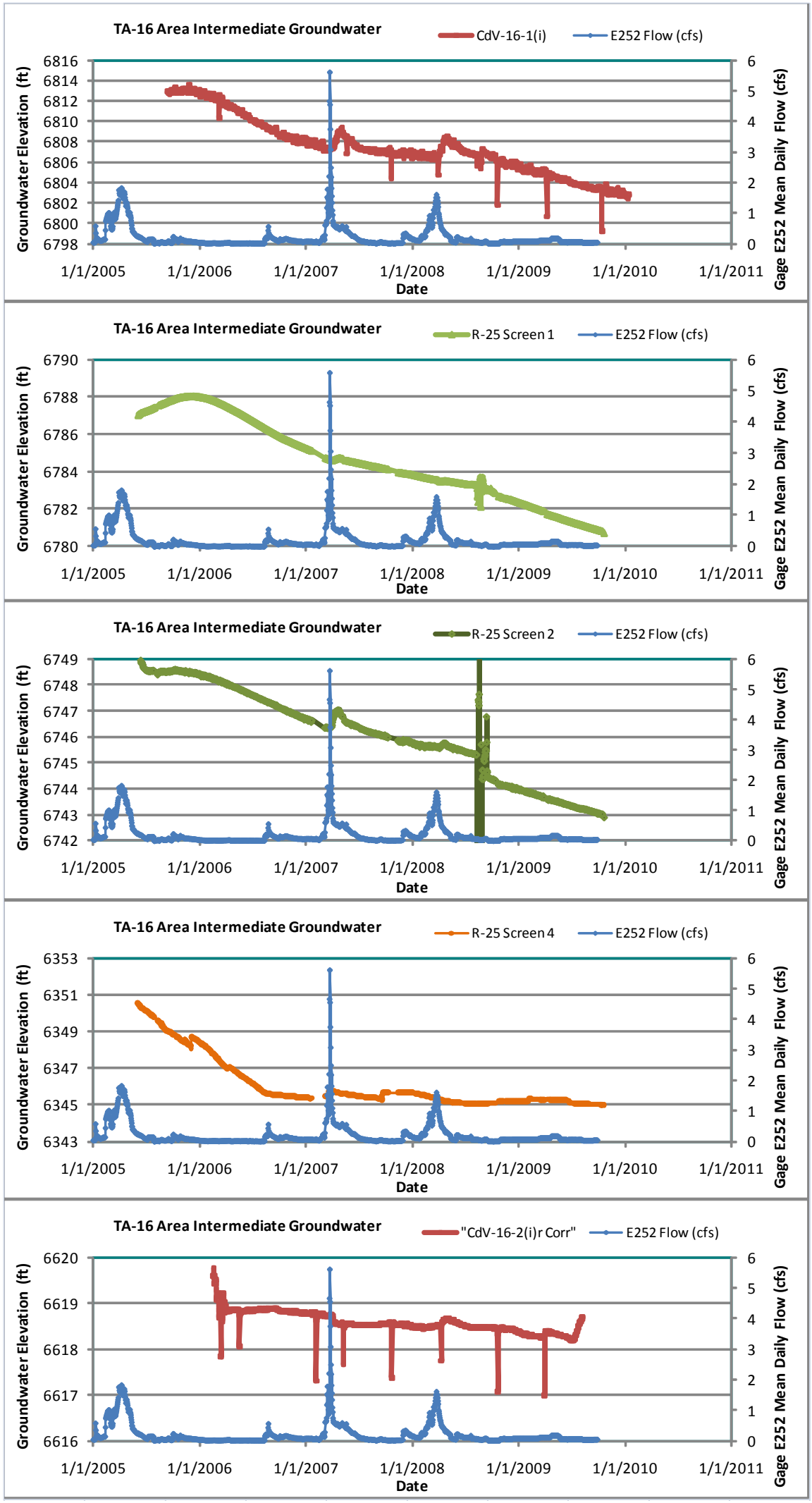

Figure D-6. Intermediate groundwater levels in TA-16 wells and mean daily flow at Gaging Station E252. 


\section{D.5. Summary of Runoff Impacts to Intermediate Perched Groundwater}

Large snowmelt and storm runoff events in Los Alamos Canyon that extend eastward as far as the LANL boundary appear to infiltrate into subsurface units and impact groundwater levels in wells completed in the Cerros del Rio basalt. Intermediate perched groundwater in other geologic units beneath the middle part of Los Alamos Canyon and the surrounding Pajarito Plateau does not appear to be impacted by runoff events.

Similarly, intermediate perched groundwater at TA-16 appears to respond to large snowmelt runoff events. With no significant runoff events in 2009 , the intermediate groundwater levels in the TA-16 area showed a continued decline. Reid et al. (2008) observed that the rapid infiltration to intermediate zones occurred at both the eastern and western side of the plateau in two contrasting hydrogeologic settings: runoff over fractured basalt in lower Los Alamos Canyon and possibly in lower Pajarito Canyon, and runoff crossing the Pajarito fault and associated fractured bedrock in the western part of the Pajarito Plateau. Reid et al. (2008) concluded that the key feature associated with the large runoff events and response in intermediate groundwater zones was persistent runoff and brittle bedrock near the surface that provided a conduit for infiltration. 


\section{Appendix E. Summary of Regional and Intermediate Groundwater Temperature}

Table E-1. Groundwater Temperature in Regional Aquifer and Intermediate Groundwater Wells

\begin{tabular}{|c|c|c|c|}
\hline \multicolumn{4}{|c|}{ Regional Aquifer Temperature } \\
\hline Well & Screen & $\mathrm{T}(\mathrm{C})$ & Geo Unit \\
\hline CDV-R-15-3 & 4 & 16.5 & $\mathrm{Tp}$ \\
\hline CDV-R-15-3 & 5 & 17.0 & $T p$ \\
\hline CDV-R-15-3 & 6 & 19.0 & $\mathrm{Tp}$ \\
\hline CDV-R-37-2 & 2 & 20.1 & $\mathrm{Tt}$ \\
\hline CDV-R-37-2 & 3 & 20.7 & $\mathrm{Tt}$ \\
\hline CDV-R-37-2 & 4 & 21.7 & $\mathrm{Tt}$ \\
\hline G-2A & Single & 27.1 & Tsf \\
\hline G-3 & Single & 24.8 & Tsf \\
\hline G-3A & Single & 26.5 & Tsf \\
\hline O-1 & Single & 23.0 & Tsf \\
\hline PM-1 & Single & 27.7 & Tsf \\
\hline PM-2 & Single & 21.0 & $\mathrm{Tp}$ \\
\hline PM-3 & Single & 25.3 & Tsf \\
\hline PM-4 & Single & 24.1 & $T p$ \\
\hline PM-5 & Single & 23.9 & $\mathrm{Tp}$ \\
\hline R-10a & Single & 20.4 & Tsf \\
\hline R-10 & 1 & 21.3 & Tsf \\
\hline R-10 & 2 & 21.2 & Tsf \\
\hline R-11 & Single & 21.3 & $\mathrm{Tp}$ \\
\hline R-12 & 3 & 23.5 & Tsfb \\
\hline R-13 & Single & 19.9 & $\mathrm{Tp}$ \\
\hline R-14 & 1 & 22.6 & $\mathrm{Tp}$ \\
\hline R-14 & 2 & 23.0 & $\mathrm{Tp}$ \\
\hline R-16r & Single & 19.8 & Tpt \\
\hline R-16 & 2 & 22.4 & Tsf \\
\hline R-16 & 3 & 24.2 & Tsf \\
\hline R-16 & 4 & 26.0 & Tsf \\
\hline R-17 & 1 & 21.5 & Tpf \\
\hline R-18 & Single & 14.8 & Tpf \\
\hline R-19 & 3 & 20.3 & Tpf \\
\hline R-19 & 4 & 21.5 & Tpf \\
\hline R-19 & 5 & 21.5 & Tpf \\
\hline R-19 & 6 & 25.1 & Tpf \\
\hline R-19 & 7 & 26.4 & Tpf \\
\hline R-2 & Single & 23.6 & Tpf \\
\hline R-20 & 1 & 20.7 & Tb4 \\
\hline R-20 & 2 & 21.2 & Tpp \\
\hline R-20 & 3 & 25.0 & Tsf \\
\hline R-21 & Single & 20.3 & $T p$ \\
\hline R-22 & 1 & 21.7 & Tb4 \\
\hline R-22 & 2 & 22.1 & Tb4 \\
\hline R-22 & 3 & 24.2 & Tpf \\
\hline R-22 & 4 & 26.4 & Tb4 \\
\hline R-22 & 5 & 27.1 & Tpf \\
\hline R-23 & Single & 21.6 & Tsf \\
\hline R-24 & Single & 28.4 & Tsf \\
\hline R-25 & 5 & 12.4 & Tpf \\
\hline R-25 & 6 & 13.7 & Tpf \\
\hline R-25 & 7 & 16.6 & Tpf \\
\hline R-25 & 8 & 20.2 & Tpf \\
\hline R-26 & 2 & 26.5 & $\mathrm{Tp}$ \\
\hline R-27 & Single & 17.6 & Tpf \\
\hline R-31 & 2 & 19.3 & Tb4 \\
\hline R-31 & 3 & 20.4 & Tb4 \\
\hline R-31 & 4 & 20.2 & Tbt \\
\hline R-31 & 5 & 23.8 & Tbt \\
\hline R-32 & 1 & 19.7 & Tb4 \\
\hline R-32 & 2 & 20.2 & Tpf \\
\hline R-32 & 3 & 20.8 & Tpf \\
\hline R-33 & 1 & 21.2 & Tpp \\
\hline
\end{tabular}

\begin{tabular}{|l|c|c|c|}
\hline \multicolumn{4}{|c|}{ Regional Aquifer Temperature } \\
\hline WeIl & Screen & T (C) & Geo Unit \\
\hline R-35a & Single & 25.0 & Tsfu \\
\hline R-35b & Single & 23.5 & Tpf \\
\hline R-36 & Single & 22.8 & Tsfu \\
\hline R-37 & 2 & 20.4 & Tpf \\
\hline R-38 & Single & 20.0 & Tb4 \\
\hline R-39 & Single & 21.4 & Tb4 \\
\hline R-4 & Single & 24.5 & Tp \\
\hline R-41 & 2 & 22.4 & Tpf \\
\hline R-42 & Single & 19.6 & Tsfuv \\
\hline R-43 & 1 & 20.6 & Tsfu \\
\hline R-44 & 1 & 19.2 & Tpf \\
\hline R-45 & 1 & 19.6 & Tsfu \\
\hline R-46 & Single & 22.9 & Tpf \\
\hline R-48 & Single & 20.3 & Tt \\
\hline R-49 & 1 & 21.5 & Tb4 \\
\hline R-5 & 3 & 22.8 & Tsf \\
\hline R-5 & 4 & 25.1 & Tsfb \\
\hline R-6 & Single & 21.9 & Tf \\
\hline R-7 & 3 & 16.1 & Tp \\
\hline R-8 & 1 & 20.7 & Tp \\
\hline R-8 & Single & 22.2 & Tsfb \\
\hline R-9 & Single & 18.4 & Tb4 \\
\hline DT-10 & Single & 20.6 & Tb4 \\
\hline DT-5A & 22.9 & Tp \\
\hline DT-9 & Tb4 \\
\hline Not: saded & 20.5 & Th \\
\hline
\end{tabular}

Note: shaded screens are no longer monitored

Intermediate Groundwater Temperature

\begin{tabular}{|c|c|c|c|}
\hline Well & Screen & $\mathrm{T}(\mathrm{C})$ & Geo Unit \\
\hline CdV-16-1(i) & Single & 10.8 & Qbo \\
\hline CdV-16-2(i)r & Single & 11.1 & Tpf \\
\hline LADP-3 & Single & 9.9 & Qbog \\
\hline LAOI(A)-1.1 & Single & 9.6 & Qbog \\
\hline LAOI-3.2 & Single & 11.7 & Qbog \\
\hline LAOI-3.2a & Single & 12.1 & Tpf \\
\hline LAOI-7 & Single & 13.8 & $\mathrm{~Tb} 4$ \\
\hline MCOI-4 & Single & 14.5 & Tpf \\
\hline MCOI-5 & Single & 16.0 & Tb4 \\
\hline MCOI-6 & Single & 15.0 & Tb4 \\
\hline $\mathrm{PCl}-2$ & Single & 14.5 & Tpf \\
\hline POI-4 & Single & 11.6 & Tb4 \\
\hline R-12 & 1 & 18.7 & Tb4 \\
\hline R-12 & 2 & 18.7 & $\mathrm{Tp}$ \\
\hline R-19 & 2 & 18.4 & $T p$ \\
\hline R-23i & 1 & 15.7 & Tb4 \\
\hline R-23i & 2 & 16.4 & $\mathrm{~Tb} 4$ \\
\hline R-25 & 1 & 11.2 & Qbo \\
\hline R-25 & 2 & 10.7 & Tpf \\
\hline R-25 & 4 & 11.1 & Tpf \\
\hline R-26 & 1 & 15.5 & Qct \\
\hline R-3i & Single & 20.0 & Tb4 \\
\hline R-40 & R-40i & 18.1 & Tb4 \\
\hline R-40 & 1 & 19.2 & $\mathrm{~Tb} 4$ \\
\hline R-5 & 2 & 17.7 & $T p$ \\
\hline R-6i & Single & 16.5 & Tpf \\
\hline R-9i & 1 & 9.6 & Tb4 \\
\hline R-9i & 2 & 12.8 & Tb4 \\
\hline $\mathrm{SCl}-1$ & Single & 10.9 & Tpf \\
\hline $\mathrm{SCl}-2$ & Single & 16.0 & Tb4 \\
\hline TA-53i & Single & 14.5 & Tpf \\
\hline Test Well 2A & Single & 11.4 & $\mathrm{Tp}$ \\
\hline
\end{tabular}




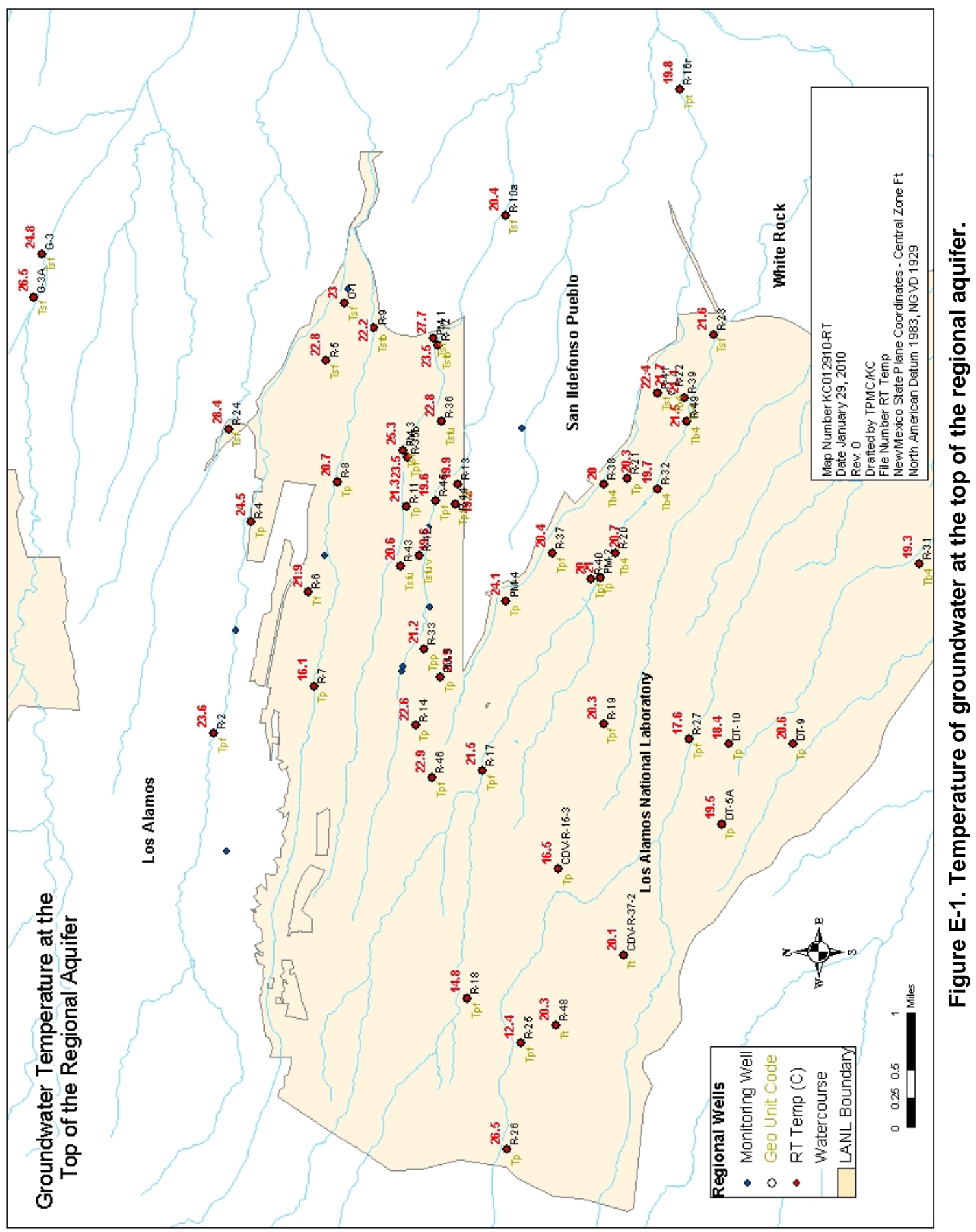




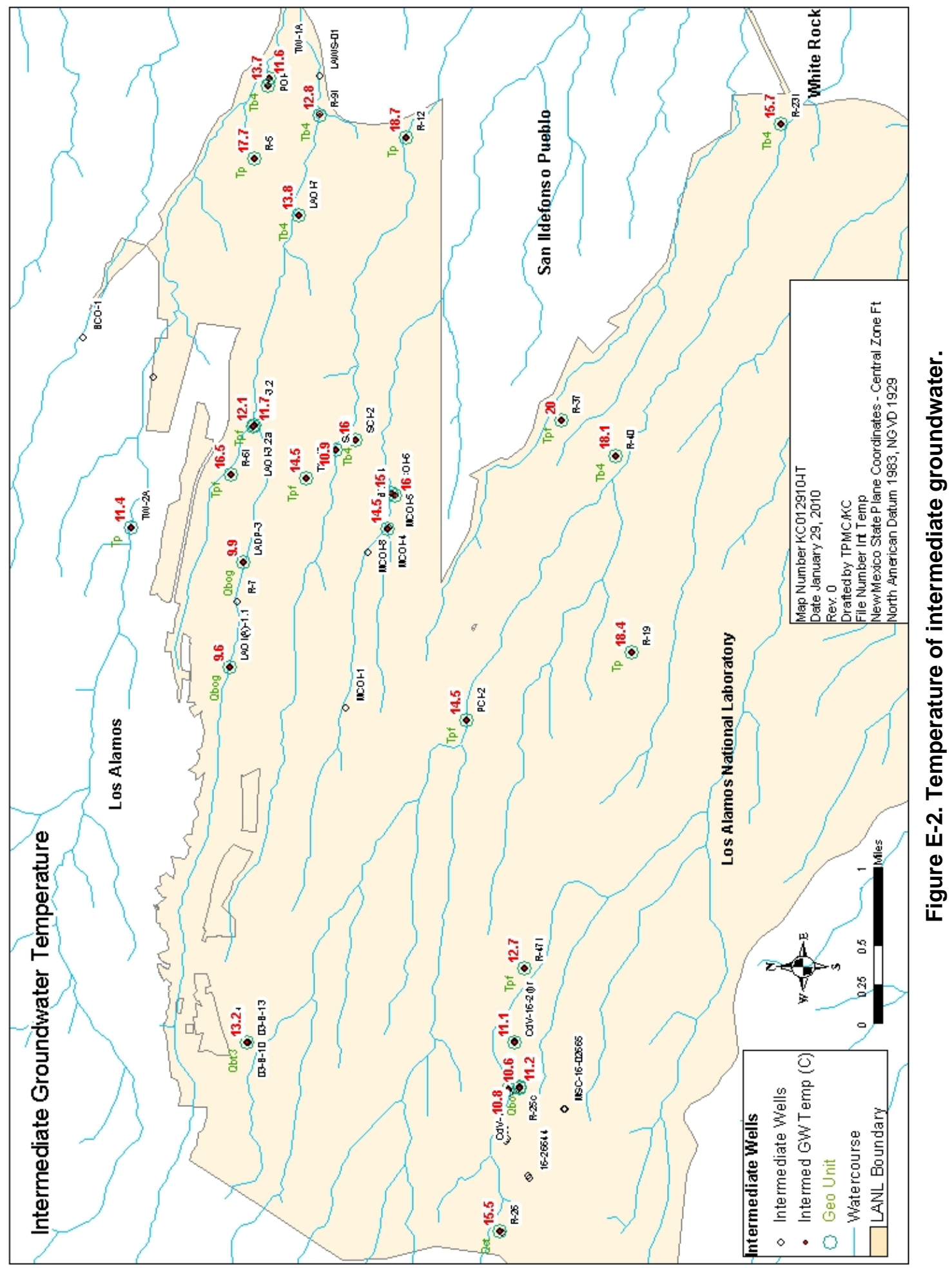


This report has been reproduced directly from the best available copy. It is available electronically on the Web (http://www.doe.gov/bridge).

Copies are available for sale to U.S. Department of Energy employees and contractors from:

Office of Scientific and Technical Information

P.O. Box 62

Oak Ridge, TN 37831

(865) 576-8401

Copies are available for sale to the public from: National Technical Information Service

U.S. Department of Commerce

5285 Port Royal Road

Springfield, VA 22161

(800) 553-6847 
Los Alamos

NATIONAL LABORATORY

EST.1943 